$x^{4}+1, d x$

$(x), x^{2}: 13$

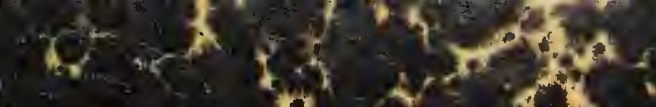

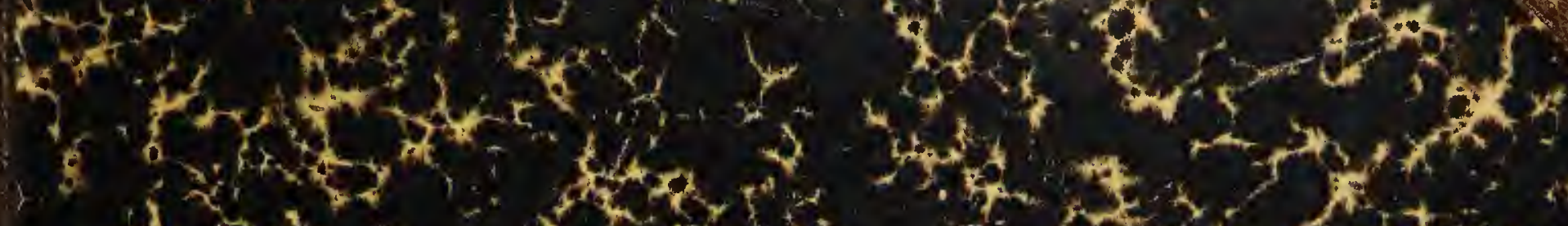

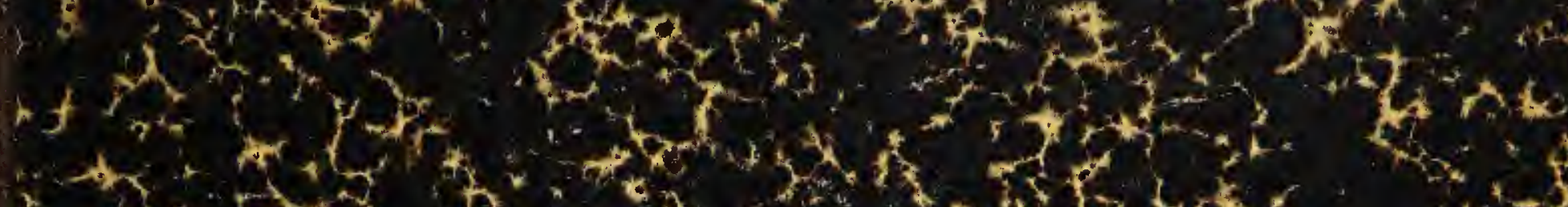

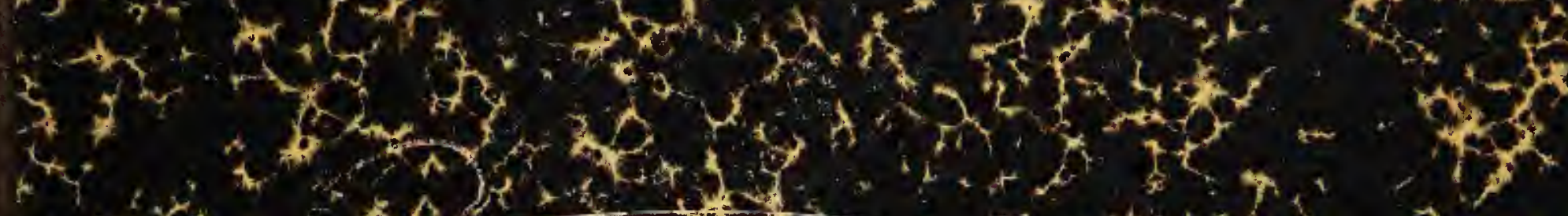

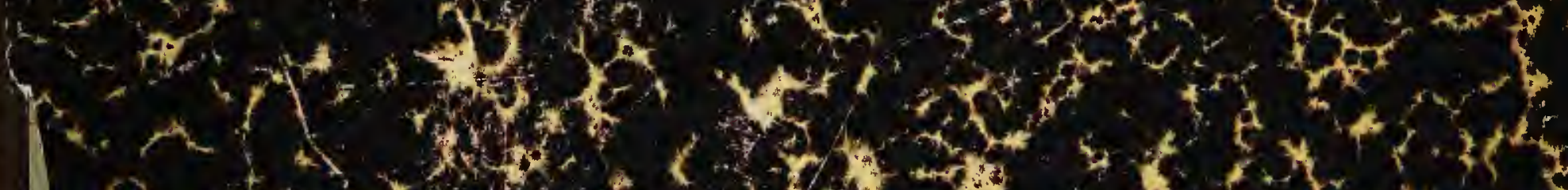

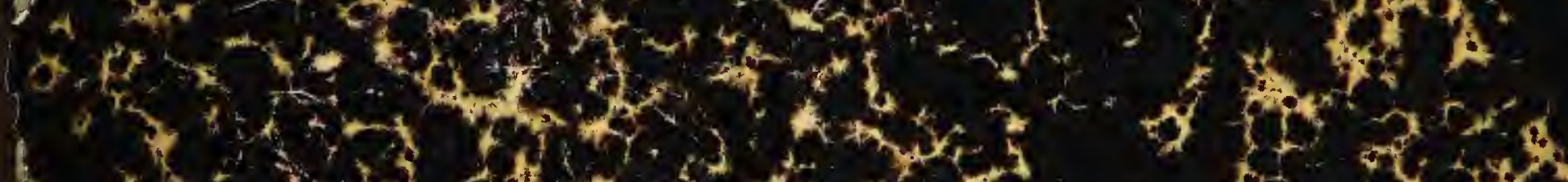

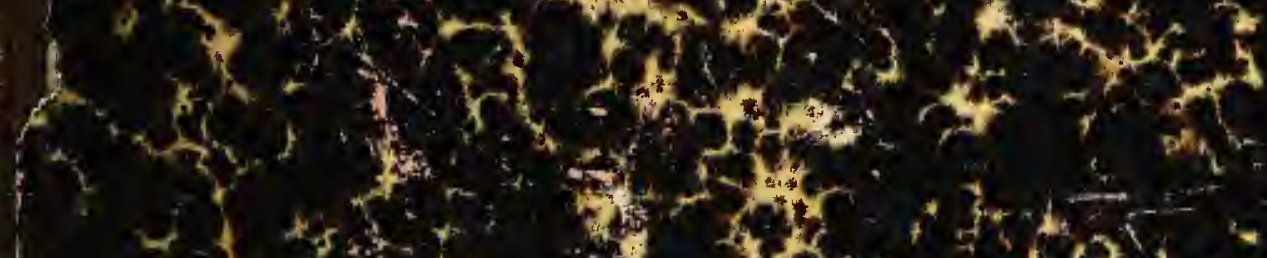

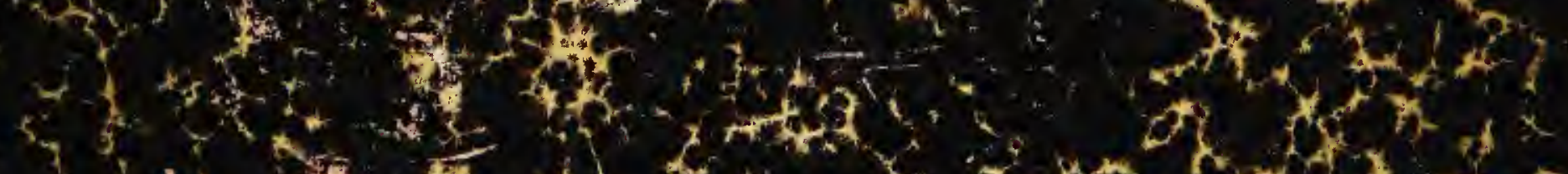

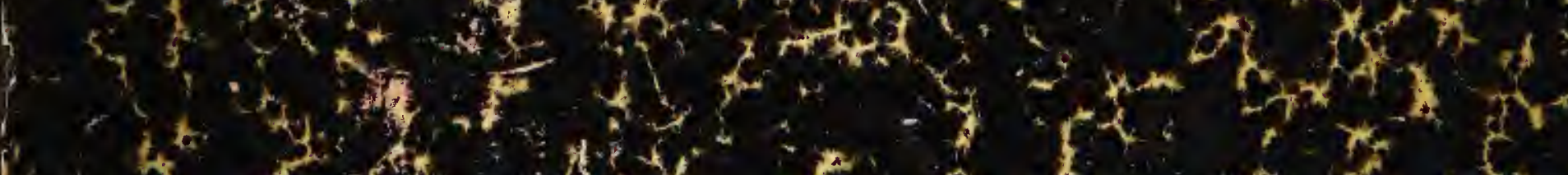

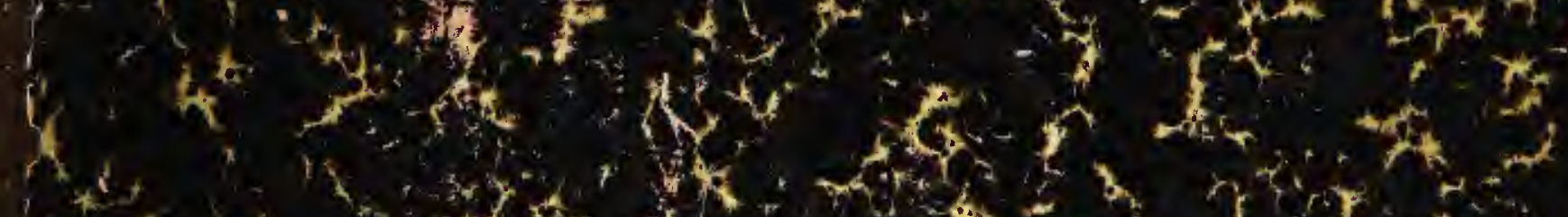

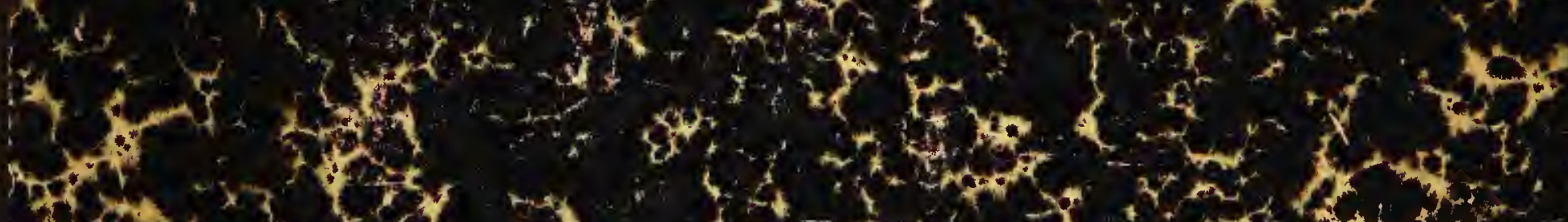

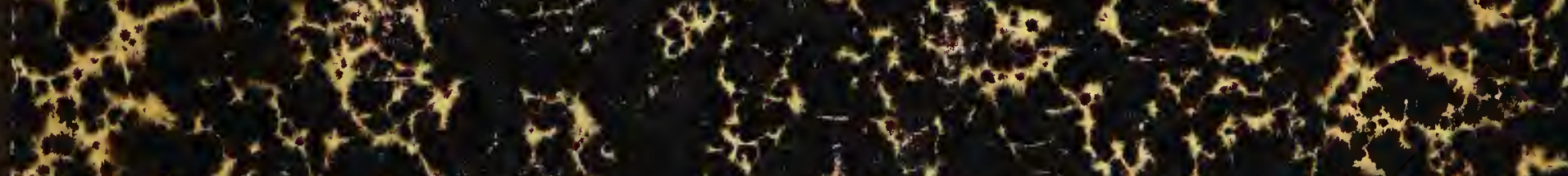

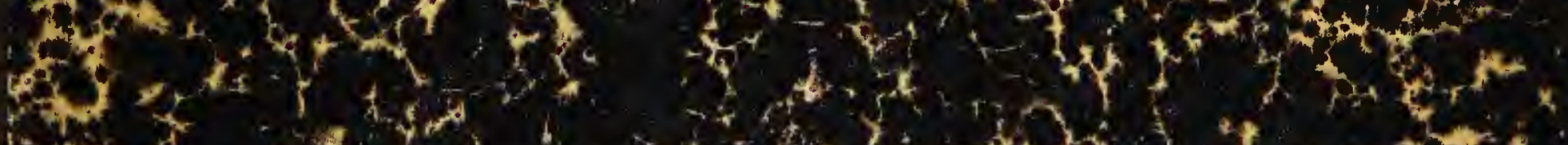

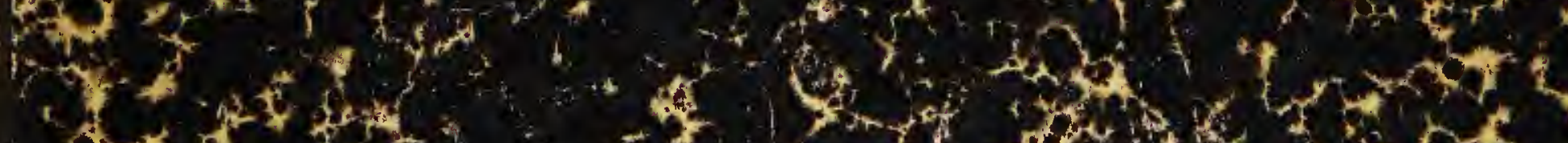

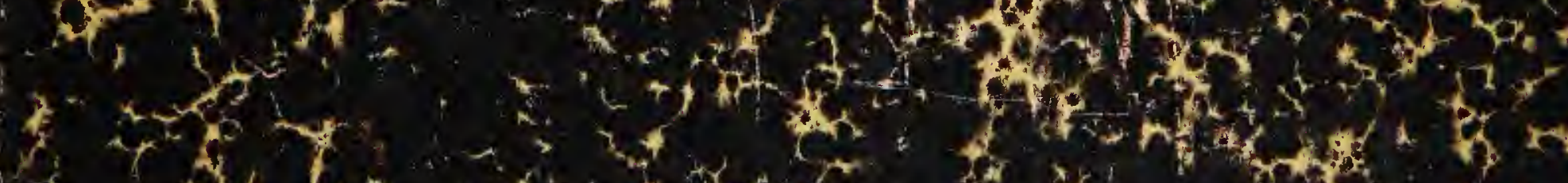

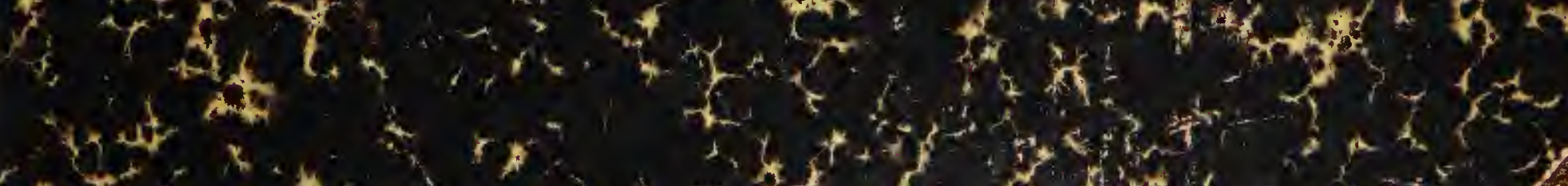

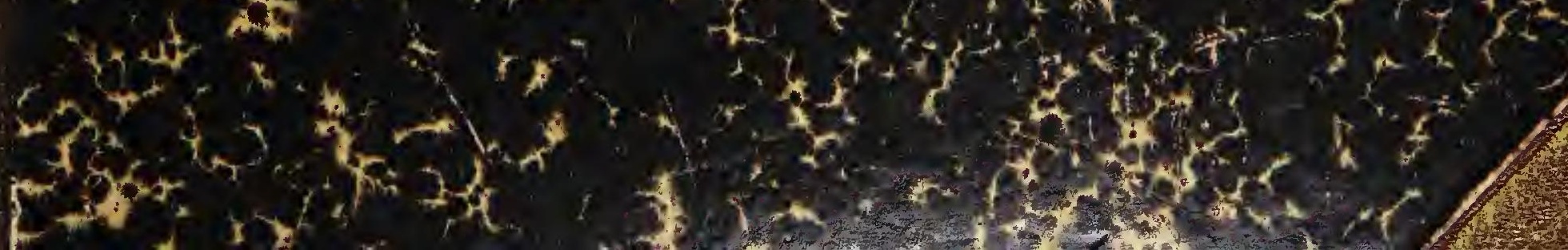




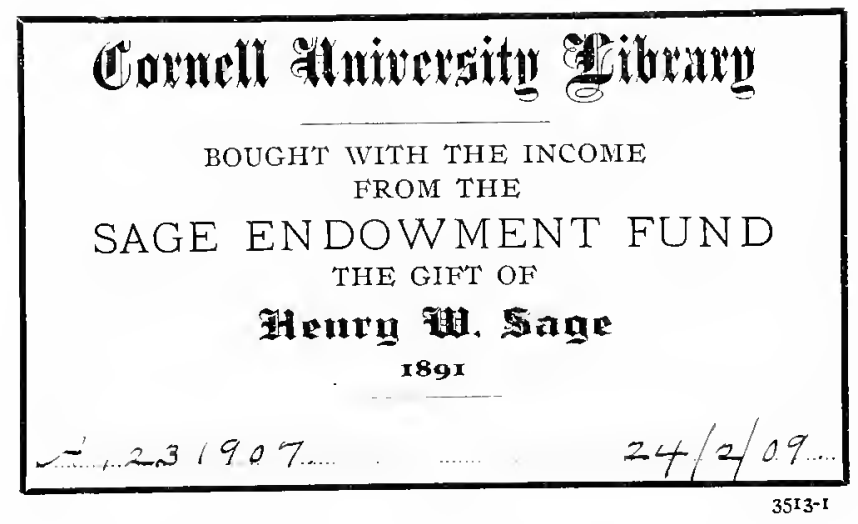

RETURN TO

ALBERT R. MANN LIBRARY

ITHACA, N. Y. 


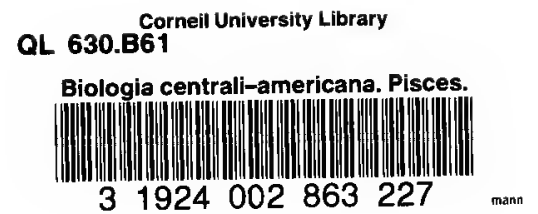




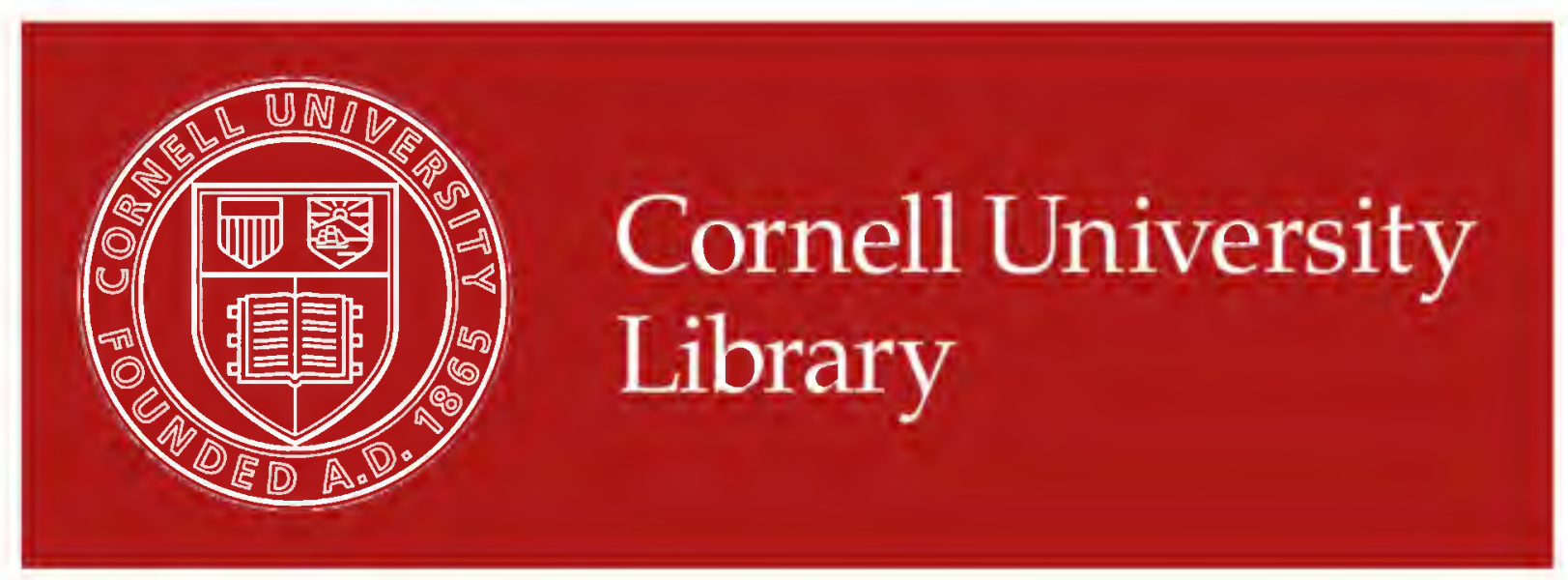

\section{The original of this book is in the Cornell University Library.}

There are no known copyright restrictions in the United States on the use of the text.

http://www.archive.org/details/cu31924002863227 




\section{B I O L O G I A \\ CENTRALI-A MERICANA.}

P I S C E S.

BY

C. TATE REGAN, M.A.

1906-1908. 



\section{CONTENTS.}

Page

Maps showing the Geographical Distribution of Fresh-water Fishes in Mexico and Central America.

List of Plates . . . . . . . . . . . . . . . . . . . . . . . . . xxxiii

Teleostoni.

Teleostei,

ACANthoptertgit . . . . . . . . . . . . . . . . . . . . . . . . . . 1

LOPHOBRANCHII . . . . . . . . . . . . . . . . . . . . . . 54

Percesoces . . . . . . . . . . . . . . . . . . . . . . . . 56

HAPLOMI . . . . . . . . . . . . . . . . . . . . . . . . . 74

Apodes . . . . . . . . . . . . . . . . . . . . . . . . . . 109

Symbranchil . . . . . . . . . . . . . . . . . . . . . . 110

OSTARIOPHYSI . . . . . . . . . . . . . . . . . . . . . . . 110

Malacopterygit . . . . . . . . . . . . . . . . . . 176

GringLYModi . . . . . . . . . . . . . . . . . . . . . 180

SELACHII.

Eusedachit.

Pleurotremata. . . . . . . . . . . . . . . . . . . . . . . 182

Hypotremata . . . . . . . . . . . . . . . . . . . . 183

Cxclostomata.

HYPeroarti . . . . . . . . . . . . . . . . . . . I84

SOPPLEMENT . . . . . . . . . . . . . . . . . . . . 185

Index . . . . . . . . . . . . . . . . . . . . . . . . . 193

Plates. 



\section{INTRODUCTION.}

THERE is a considerable literature dealing with the fresh-water fishes of Mexico and Central America, but our knowledge of them must still be regarded as very incomplete. The fact that not a single fresh-water fish has yet been described from the Republic of Honduras, or from Nicaragua north and east of the Great Lakes, may be instanced in support of this. The following account is based on the material in the British Museum; the diagnoses of the sub-orders and families in the systematic part are intended only to apply to their Mexican and Central-American representatives; in all cases synopses of the genera and species are presented in the form of keys, and sufficient references are given for the verification of determinations thus effected. Detailed descriptions and full synonymies are given only in the case of groups which appear to need revision and which are well represented in the British Museum.

True fresh-water fishes and also marine fishes which are known to ascend rivers beyond the influence of the tides are included: thus, in addition to the problems of the distribution of nearctic and neotropical types in this area, that of the differentiation of the marine faunas of the Atlantic and Pacific coasts is dealt with to a certain extent. The introductory remarks are arranged under the following headings :-

1. Principal Faunal Works on the Fresh-water Fishes of Mexico and Central America.

2. Principal Collections described in this Work.

3. Classification.

4. Geographical Distribution.

5. The Shore-Fishes of the Atlantic and Pacific Coasts of Mexico and Central America. 
1. Principal faunal Works on tile Fresh-water Fishes of Mexico and

\section{Central america.}

The fresh-water fishes of Mexico and Central America are included in Jordan and Evermann's great work on the fishes of Nortl and Middle America (Bull. U.S. Nat. Mus. xlvii. 1896-1900), which is, however, so far as the Central-American fresh-water fish-fauna is concerned, rather a compilation than a critical revision; and necessarily so, seeing that the majority of the types are preserved in the British Museum and a large proportion of the remainder at Vienna. Dr. S. E. Meek has recently made extensive collections in Mexico, and has published an account of the fresh-ivater fishes of Mexico north of the Isthmus of Tehuantepec (Publ. Columbian Mus., Zool. v. 1904) based on his own material. Of other works dealing with Mexican fresh-water fishes we may mention Girard's valuable report on the fishes collected during the United States and Mexico boundary survey, published in 1859, Steindachner's report on a collection from the Lerma Basin and the Valley of Mexico (Denkschr. Ak. Wien, lxii. 1895), and a paper by Jordan and Snyder dealing with fishes from the same region (Bull. U.S. Fish. Comm. xix. 1900).

Dr. Günther's memoir on the Fishes of Central America (Trans. Zool. Soc. Lond. i. IS68) is still the best account of the fresh-water fishes of this region, and it is remarkable how little our knowledge of them has been increased since its publication. It was precerled by Kner and Steindachner's account of a collection from Panama (Abhandl. Bayer. Ak. x. 1864), and the only important contributions since are by Gill and Bransford on the fishes of Lake Nicaragua (Proc. Ac. Philad. 1877), Steindachner on those of the Rio Mamoni, Panama (Denkschr. Ak. Wien, xli. 1879), and two recent papers by Meek, one on the fishes of Lakes Managua and Nicaragna, the other describing collections from Guatemala and Costa Rica (Publ. Columbian Mus., Zool. vii. 1907).

2. Principal Collections described in this Work.

The present account is based on the specimens preserved in the British Museum, including the actual types of a large proportion of the species and co-types or authenticated examples of many others.

First in importance are the large collections made in Central America by Messrs. F. D. Godman and O. Salvin and Capt. J. M. Dow during the years 1859-1865, which formed the basis of $\mathrm{Dr}$. Günther's report.

Next to these must be placed a fine series of Mexican fishes received from the Field Museum of Natural History, Chicago, in 1905, including examples of many of the species recently described by Dr. Meek. 
The remaining collections may be considered in chronological order; they include:-

(1) Fishes from Mexico and Central America collected by A. Sallé in 1850 and following years.

(2) Co-types of some of the species described by Baird and Girard, received from the Smithsonian Institution in 1861.

(3) A collection from Southern Mexico, purchased of A. Boucard in 1868.

(4) A small series from Guatemala, collected by Mr. F. C. Sarg, acquired in 1880.

(5) A collection made by Mr. C. Patrick Geddes in Mexico (Vera Cruz, Puebla, and Mexico) and presented by him in 1880 .

(6) A series from Presidio, Sinaloa, collected by A. Forrer; purchased in 1883.

(7) A collection made by the Rev. J. Robertson in British Honduras; purchased in 1890 and 1891.

(8) Two collections made in Mexico by Dr. A. C. Buller-one from Vera Cruz and Oaxaca, the other from Guanajuato, Jalisco and Michoacan; acquited in 1890 and 1892 respectively.

(9) Series of fishes from the Rio Grande, Chihuahua, Salamanca, and Mexico City, collected by Mr. A. J. Woolman, and including a few co-types of species described by him; purchased in 1892 .

(10) A collection from San Luis Potosi, including several co-types, received from Dr. D. S. Jordan in 1900.

(11) Fishes collected by Dr. H. Gadow in Vera Cruz and Oaxaca in 1902.

(12) Co-types of some of the species described by Gill and Bransford from Lake Nicaragua, sent by the Smithsonian Institution in 1905.

(13) A few co-types of species described by Vaillant and Bocourt, received from the Paris Museum in 1906.

(14) Recently acquired collections made in Costa Rica by H. Pittier, P. Biolley, H. Rogers and C. F. Underwood.

In addition to these, we may mention three collections of marine fishes, containing examples of species new to the British Musenm of Galeichthys, Mugil, Centropomus, and other genera which enter fresh water. 'Two of these are from Panama, one acquired from A. Boucard in 1875 and the other from Dr. Jordan in 1903; the third is from Mazatlan. received from Dr. Jordan in 1895 


\section{Classification.}

The class Pisces, as understood in this work, includes craniate vertebrates with gills, and typically with median and paired fins which are supported by endoskcletal elements. Three sub-classes are recognized, viz. Cyclostomata, Selachii, and Teleostomi, which are, however, separated from each other by characters at least as trenchant as those which serve for the distinction of the classes of higher vertebrates, and which have therefore, with some reason, been considered as separate elasses, in which case the term Pisces has been restricted to the Teleostomi. The Teleostomi approach the Batrachians in that they have typically a lung or its homologue, the air-bladder, and in the development of membrane bones. The Batrachia are well separated, however, by the absence of dermal fin-rays and of endoskeletal supports for the median fins, by the modification of the paired fins into pentadactyle limbs and of the hyomandibular into the stapes, and by the presence of true internal nares.

I especially lay stress on the last character, because the impression is prevalent that the Dipneusti have internal nares, and in this respect show affinity to the Batrachians. As a matter of fact, the Dipneusti, like other Teleostomes, have two external nasal openings on each side; these are situated on the under side of the snout, and when the mouth is closed the posterior and, to a certain extent, the anterior are covered by the lower lip. The posterior nostril is also covered by the lower lip when the mouth is closed in some Eels (e. g. Ophichthys).

True internal nares are quite different in structure and position to the posterior external nares of the Teleostomi, being paired perforations of the palate internal to the præmaxillaries and maxillaries. Their ontogenetic development in the Batrachians, the lowest group in which they occur, supports the view that they are a new formation.

The Cyclostomes and Selachians are represented by only a few species in the fresh waters of Mexico and Central America, the bulk of the fish-fauna belonging to the Teleostomi, or bony fishes.

These may be arranged in two series-Actinopterygian and Crossopterygian. In the fishes of the Actinopterygian series the branchiostegal rays and supports of the paired fins retain their primitive condition or evolve by a simple process of concentration or reduction, whilst the duct connecting the air-bladder with the digestive tract, when persistent, opens dorsally or dorso-laterally into the latter. The fishes of the Crossopterygian series comprise the orders Crossopterygii and Dipneusti; these have 
the branchiostegal rays replaced by a pair of large gular plates (absent in some specialized Dipneusti), the paired fins more or less lobate, their basal supports becoming axial in the more specialized forms, and the duct of the air-bladder opening into the rentral part of the csophagus. The Actinopterygian series includes two main groups which may be given ordinal rank; in the lower (Chondrostei) the clavicles (infra-clavicles) are clistinct from the cleithra (clavicles), the pelvic fins have a welldeveloped series of radials, the median fins have the dermal rays more numerous than their endoskeletal supports, and the caudal fin is typically strongly heterocercal. The living members of this order are the Sturgeons (Acipenseridæ) and Paddle-fishes (Polyodontidx); neither family is represented in Mexico or Central America.

In the more specialized gromp, the Teleostei, the clavicles do not exist as separate elements, the radials of the pelvic fins are absent or vestigial, the dermal rays of the median fins are equal in number to their endoskeletal supports, and the caudal fin is abbreviate heterocercal or homocercal.

The Teleostei are the dominant group to which the great majority of living fishes belong; their classification is by no means an easy matter. The genera Lepidostcus and Amic differ from other living 'Teleosts in the presence of a splenial and of a metapterygium, and in the absence of an endochondral supraoccipital ossification; they have been regarded as belonging to a separate order, Holostei.

Some of the supposed distinctive features of the Holostei have been found in undoubted Teleosts (Elopidæ, Albulidx, Chirocentridæ), and a study of the fossils makes it still more difficult to recognize two orders, annectent forms (e.g. Dapedius, Pholidoplionus) occurring.

Lepidosteus is represented in the fresh waters of Mexico and Central America; it is the type of the sub-order Ginglymodi, characterized by the opisthoccelous vertebræ.

The remaining Teleostei have a well-ossified endochondral supraoccipital, the lower jaw composed of three elements ouly (dentary, articulare, and angulare), and the pectoral radials all directly attached to the scapula and coracoid, the metapterygium. being absent.

The most generalized of these form the sub-order Malacopterygii, soft-rayed fishes with abdominal ventral fins, with a pneumatic duct, and with a mesocoracoid element in the pectoral arch. This sub-order is represented in the fresh waters of Mexico and Central America by a few marine types.

$$
\text { biol. Centr.-Amer., Pisces, February } 1908 .
$$


The fishes of the next sub-order, Ostariophysi, differ from the Malacopterygii in the modification of the superior and lateral elements of the anterior vertebra to form a chain of ossicles connecting the air-bladder with the auditory organ.

This group is almost entirely composed of fresh-water fishes, and five of the six families recognized by Boulenger are represented in Mexico and Central America.

The Ostariophysi agree with the Malacopterygii in having a mesocoracoid bone, but in the other groups to be considered this element has been lost.

Of four groups of more or less anguilliform fishes, Lyomeri, Heteromi, Symbranchii, and Apodes, which appear to be independent offshoots of the Malacopterygii, the last two are represented in the rivers of Mexico and Central America.

In the Symbranchii the body is eel-shaped, the dorsal and anal fins are continuous with the caudal, the ventral fins are absent, the gill-openings are confluent to form a single ventral slit, and the well-cleveloped præmaxillaries exclucle the maxillaries from the border of the mouth.

The Eels of the sub-order Apodes differ in having the small gill-openings usually separate and in having the mouth bordered above by the maxillaries, which are separated in the median line by the ethmo-vomer, to which the priemaxillaries (if present) are suturally united.

The sub-ordinal groups already mentioned appear to be natural and well-defined, but the next sub-order, Haplomi, which differs from the Malacopterygii only in the absence of a mesocoracoid, is less satisfactory, and includes four or five groups which may not be related.

The Cyprinodontidæ are abundant in the rivers of Mexico and Central America. Recent researches have shown that some members of this family are physoclistic*, and that in others the lower pharyngeal bones are suturally united. On this account I would place the physoclistic Scombresocidx, which have the lower pharyngeals completely united, near the Cyprinodontidæ in the sub-order Haplomi. In my opinion they are much more closely related to the Cyprinodontidx than to the Atherinidæ, with which they have recently been associated.

Most of the physoclistic Teleosts with abdominal ventral fins are placed by Boulenger in two sub-orders, Catosteomi and Percesoces, the former being distinguished from the latter by the supposed cnlarged coracoid. In the 'Cambridge Natural History" Boulenger writes:- "The whole question of the arrangement of the

\footnotetext{
* Philippi, Sitzungsb. Gusellsch, naturf. Freund. 1906, p. 232.
} 
physoclists with abdominal ventrals (Catosteomi and Percesoces) is, I feel, much in need of revision, and it may be found advisable to break up this group [Catosteomi] into a greater number of sub-orders."

I have paid a good deal of attention to these groups, and am of opinion that they are unnatural and indefinable.

After removal of the Selenichthyes, which I liave recently been able to show are rclated to the Tæniosomi, and of the Hypostomides, the remainder of the Catosteomi, which corresponds to the Hemibranchii of Smith Woodvard, is still a heterogeneous assemblage which I find incapable of definition, and includes three well-marked but probably related groups which should, in my opinion, be given sub-ordinal rank. These are: (1) Thoracostei *, which have on each side a large dermal plate, which in the adult is co-ossified with the coracoid and suturally united to the clavicle; (2) Solenichrthes (nom. nov.), which have a considerable amount of dermal armour but no plates similar to the ectocoracoids of the Thoracostei-the tnbiform snout, terminal toothless month, pectinate gills, and elongate anterior vertebræ with separate transverse processes further characterize this group; (3) Lophobranchil, differing from the Solenichthyes in the lobate gills and normal anterior vertebræ.

The resemblances between the Centriscidæ and the Solenostomidæ, respectivcly the most generalized of the Solenichthyes and the Lophobranchii, seem to indicate relationship, but are, no doubt, in great part due to similar modes of life.

A few fishes belonging to the sub-order Lophobranchii are found in the rivers of Mexico and Central America.

Adding the Osphromenidæ, which should, in my opinion, be placed with the Anabantidæ, and after removing the Scombresocidæ to the Haplomi, the Ammodytidæ and Champsodontidæ to the Percomorphi, and the Chiasmodontidæ (incertce sedis), the families included by Boulenger in the Percesoces may be arranged thus :-

I. Pelvic bones remote from the clavicles; a separate spinous dorsal; no suprabranchial organ; no osophageal sacs . . . . . . . . Atherinida, Mugilide, Polynemidee, and sphyrcenida.

II. A suprabranchial organ . . . . . . . Ophiocephatida, Anabantidce, and Osphlromenidce. III. Cisophagus with a pair of lateral muscular sacs, with internal papillæ which may be toothed. . . . . . . . . . . . Tetrayonurida, Stromateide.

IV. Pelvic bones remote from the clavicles; no fin-spines; no suprabranchial organ; no csophageal sacs . . . . . . . . . . . . . . Icosteida.

In the second and third of these divisions we see the transition from abdominal * Swinnerton, Quart. Journ. Micr. Sci. slr. 1902, p. 580, and xlix. 1905, pp. 369-380. 
to truly thoracic ventral fins (with the pelvic bones directly attached to the clavicles) in the series Ophiocephalus, Anabas, Osphromenus and Tetragonurus, Centrolophus, Stromateus respectively, and in order to attain precise diagnoses it becomes necessary to regard each of these two groups as of primary, $i$. e. sub-ordinal, rank, and to neglect the character of the attachment of the pelric bones in defining them.

The first and second of these sub-orders have the names Percesoces and Labyrinthici respectively. For the third I propose the name Zenopharyngii, whilst the fourth, comprising fishes with the skeleton in great part cartilaginous, may be termed Malacichthyes. Of these groups ouly the Percesoces is represcuted in the fresh waters of Mexico and Central America.

The sub-order Acanthopterygii, as understood by Bonlenger, is defined by a single character, viz., the direct attachment of the pelvic bones to the pectoral arch. When the systematic portion of the present work was commenced, more than two years ago, the sub-order was accepted by me; but 1 now think that the fact has to be recognized that the pelvic bones have become directly attached to the clavicles in several groups and that a large group defined by this character alone is unnatural.

It has been mentioned above that each of two natural groups, Zenopharyngii and Labyrinthici, includes forms with the pelvic bones remote from the clavicles and others in which they have acquired a direct attachment to the clavicles. In a third group, the Berycoids, the two conditions are also found, Polymixia exemplifying the first and Trachichthys the second. It seems pretty certain that the Cyttidie and the Percoid fishes have erolved independently from the Berycoids, and we cannot lay much stress on the fact that the pelvic bones are directly attiched to the clavicles in the two first-named groups as indicating any special relationship between them.

Enongh has been said to show that the Acanthopterygii should be split up into several sub-orders; two of these are represented in the fresh waters of Mexico and Central America, riz. Percomorphi and Heterosomata, the latter including the single family Pleuronecticla.

\section{Geographical Distribution.}

In discussing the distribution of fresh-water fishes we need not tike notice of marine fishes (Centropomus, Pomadasis, Mugil, \&c.) which ascend rivers for considerablc distances, either in search of food or for breeding-purposes, nor need we consider fishes which descend the rivers to breed in the sea (e. g. Anguilla). Fresh-water species of marine genera (e.g. Chirostoma humboldtiunum) and freshwater genera of marine families (c. g. Xenatherina) have little importance. True 
fresh-water fishes belong to families which are wholly (e.g. Percidæ, Cichlidæ) or chicfly (e.g. Cyprinodontidre, Siluridie) confined to fresh water. In Mexico and Central America these are the following:-Cichlidæ, Percidx, Centrarchidæ, Cyprinodontidæ, Loricariidæ, Siluridæ, Cyprinidic, Gymnotidæ, Claracinidæ, and Lepidosteidx.

The Cichlids are Perciform fishes which bear a considerable resemblance in appearance and anatomy to the most generalized group of Perciformes, the widelydistributed marine family Serranidx, but differ from them in certain features of specialization, such as the presence of but a single nostril on each side, the absence of teeth on the palate, the coalescence or sutural union of the lower pharyugeals, and the reduced number of brarchiostegal rays.

No known fossils can be referred to the Cichlidæ, which inhabit America, from Texas to Montevideo, and Africa, including Madagascar. Seven species occur in Syria, and a single genus with three species inhabits Ceylon and Southern India.

The American Cichlidæ comprise over 150 species which may be arranged in 23 genera; from Africa more than 200 species referred to 35 genera have been described.

Not one of the genera is common to Africa and America, but the Sonth-American Acara is scarcely generically distinct from the African Paratilapia, and there can be no doubt that these are the most generalized of living Cichlidie and very near to the ancestral type of the family.

The Mexican and Central-American Cichlidx are more specialized than the SouthAmerican ones, and have certainly been derived from them; not one of the genera with three anal spines is found north of the Isthmus of Panama, and all the SouthAmerican Cichlidæ have simple conical teeth.

Of the Southern types only Cichlosoma has reached Mexico and Central America, and has there given rise to a variety of more specialized forms.

We have no evidence in farour of dating the origin of the Cichlida before the Eocene. At the same time we have to explain their occurrence in South America, Africa, and India at the present day. Boulenger, in his address to the Zoological Section of the British Association in 1905, whilst adopting a non-committal attitude, put formard the hypothesis that the Cichlidæ were originally a Northern group, and that in the Eocene they ranged over North America and Northern and Eastern Asia, which were then one continent, and that they have attained their present distribution by a sonthward migration and by becoming extinct in their original habitat. This view 
xiv

INTRODUCTION.

is supposed to be supported by the occurrence in the Eocene of Wyoming and Utah of a fish, Priscacara, which has been referred by some authors to the Cichlidic. But Priscacara has neither the reduced number of branchiostegals nor the toothless palate which characterize all living Cichlidie, and it appears to me that it has no bearing on the problem of how two very closely allied genera, Acarc and Paratilapia, differing from it and agreeing with each other in some important features which are obviously due to their near relationship, have come to inhabit South America and Africa respectively.

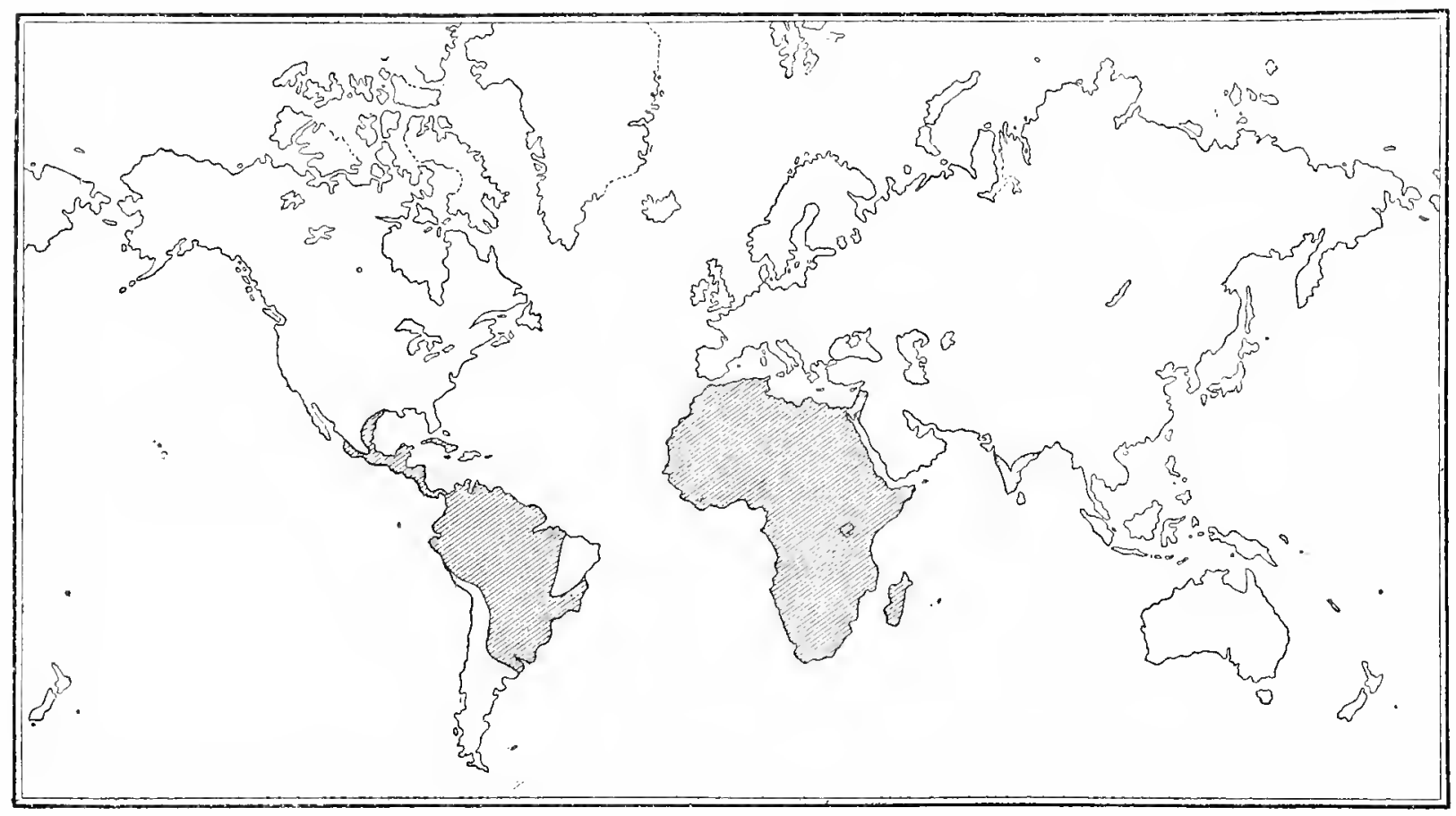

Distribution of Cictilidx.

The Indian Etroplus is an isolated type, more specialized than Paretroplus of Madagascar, which appears to be its nearest relative, and, as has already been stated, a study of the American Cicllidix leaves no possible doubt that the Mexican and Central-American Cichlid fauna has originated with immigrants from South America; consequently the hypothesis of the northern origin of the family should, I think, be rejected. We are therefore led to believe that in early Eocene times Africa was connected by land with South America on the one side and with Inclia, vid Madagascar, on the other.

The Mexican and Contral-Amcrican Cichlidie number about 65 species; they are 
not found on the Mexican Plateau, but in lowland rivers they extend northward to Sinaloa on the West and to the Rio Grande on the East.

The South-American Acarc and Geophagus are each represented by a single species in Panama. Most of the Mexican and Central-American Cichlidr belong to the genus Cichlosoma, but usually to different sections of the genus from the South-American species.

The section Theraps contains 21 species: 16 are from Guatemala and Mexico south of the Balsas, one of them ranging southwards to Panama; the most northern species occurs in the Panuco; whilst 3 are found in Lakes Managua and Nicaragua and 1 in Costa Rica.

Archocentrus comprises 6 species, 5 from Guatemala and Southern Mexico and 1 from Lake Nicaragua. Astatheros is made up of 4 species from Oaxaca, Guatemala, and British Honduras, 9 from the Great Lakes of Nicaragua, and 1 from Costa Rica and Panama. The 3 species of Thorichthys inhabit Guatemala and Southern Mexico.

Parapetenia is the most widely distributed group of the genus Cichlosoma. In addition to the sixteen species known from Mexico and Central America there is one in Cuba and another in Barbados (the latter locality perhaps donbtful), two in Western Ecuador, one in Colombia, and one in the Amazon. The South-American species of this section are probably derived from immigrants from Central America.

The Mexican and Central-American species of Parapetenia are distributed thus:-

C. beani. Lowland streams of Sinaloa and Jalisco.

C. istlanum. Rio Balsas.

C. steindachneri and C. bartoni. Rio Panuco.

C. mento, C. uroplethalmus, C. centrale, C. tenue, C. trimaculatum, C. mojarra, C. salvini, C. multifasciatum, C. friedrichstahli, and C. motaguense. Southern Vera Cruz and Oaxaca to Guatemala.

C. managuense and C. dovii. Lakes Managua and Nicaragua.

Petenia is a monotypic genus, remarkable for the extremely protractile mouth, from Lake Peten. Herichthys, with four species from the Rio Grande to Lake Yzabal, differs from Cichlosoma in having incisor-like teeth. Paraneetroplus, with one species from Southern Vera Cruz and another from Costa Rica and Panama, and Neetroplus and Herotilapia, each with a single species from the Great Lakes of Nicaragna, are allied genera.

The points to be noted in the distribution of the Cichlidie in Mexico and Central America are the following :-The chain of volcanoes which extends from Colima to Vera Cruz has checked the northward migration of the family, which is not represented on the Mexican plateau. The majority of the species are found in Southern 
xvi

INTRODUCTION.

Mexico (i.e. Sonthern Vera Cruz, Oaxaca, Chiapas), British Honduras, and Guatemala. In this area $4 \mathrm{I}$ species occur, and to the north of it the Cichlid fauna is a very poor one, comprising one species from the Balsas, another from the lowland streams of Sinaloa and Jalisco, four from the Pannco (one of which also occurs in the Rio Soto Marina and the Rio Grande), and an additional species from the tributaries of the Rio Grande in Nuero Leon.

The great lakes of Nicaranua, Takes Managua and Nicaragna, have a peculiar Cichlid fauna, consisting of 18 species, all but one of which are cndemic. These include some romarkable types, such as the genera Ilerotitepir and Nectroplus, and specialized forms of the genus Cichlosoma, snch as C. labiatum and C. lobochilus, with thick lips and large blunt tecth, $C$. managuense and $C$. dovii, with very protractile mouth, and $C$. batteatum and $C$. nicaraguense, with the profile of the snout nearly vertical. It is certainly curious that each of the sections Theraps, Archocentrus, Astatheros, and Parrpetenic is represented in the Great Lakes of Nicaragua by its most specialized types.

Nothing is known of the Cichlid fauna of Honduras, Salvador, and Nicaragua north and west of the Great Lakes, but it may be inforred that it is of the same goneral character as that of Guatemala and that many of the species will prove to be the same, seeing that Cichlosoma maculicuda of Guatomala is also found in the Rio Chagres. Except $C$. maculicat $a$ and the two species belonging to the Sonth-American genera Acara and Geophagus, only fom Cichlids have been described from Costa Rica and Panama. These are: (1) Cichlosoma citrincllum, also found in Lake Nicaragua ; (2) Cichlosoma altifions, very close to C. rostratum of Lake Nicaragua; (3) Cichlosoma uffari, allied to C. balteatum of Lake Nicaragua; and (4) Parancetroplus sieboldii, congeneric with $P$. bullori from Southern Mexico, but also noar to Neetroplus ncmatopus of the Great Lakes of Nicaragua.

The PLrcide are fresh-water fishes of North America, east of the Rocky Momntains, and Western Eurasia. Of nearly 100 species about S0 belong to the North-American genera Etheostoma, Percina, Bolcosoma, \&c., comprising the dwarf Perches known as " darters." Only 6 species of these extend southward to the basin of the Rio Grande and the rivers of Chihuahua and Durango. Fossil Percidæe are found in the middle Eocene deposits of $W^{\top}$ yoming.

The Centramcinde are fresh-mater fishes of North America. Of about 30 species, which may be grouped into 8 or 9 genera, all but one, the Californian Ambloplites inlermptus, are found east of the Rodky Mountains. Six species extend southward to the Rio Grande, and one a little further, into Tamaulipas. 


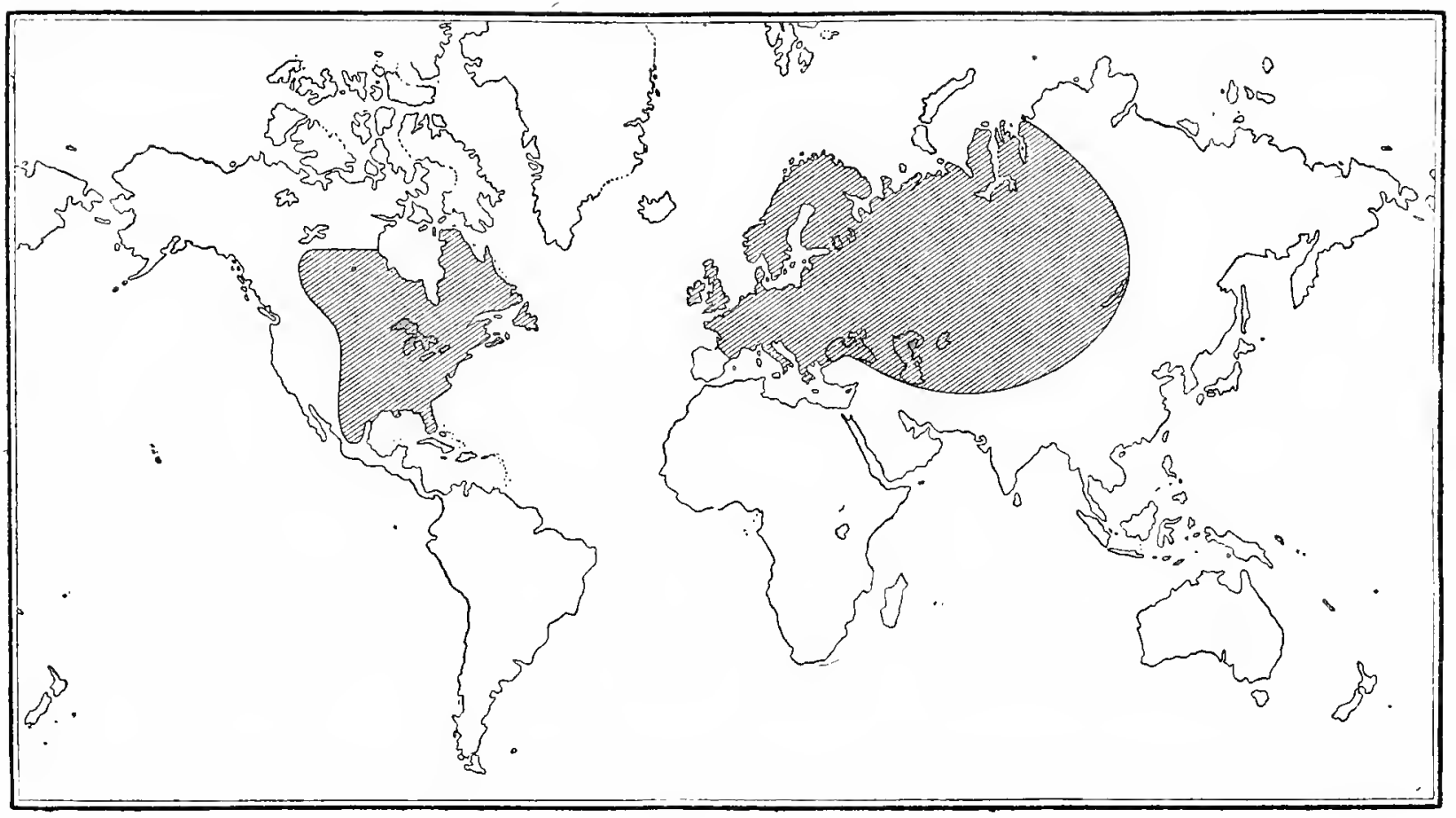

Distribution of Percide.

The Centrarchidæ have probably originated in Eastern North America from marine Perciform fishes with the habit of ascending rivers, as do the Bass (Morone) at the present day. The most generalized Centrarchids (Chcenobryttus and Micropterus) are rery similar to the Serranidx. The Indo-Pacific Kuhlia and its fresh-water allies in Australia have been associated with the Centrarchidæ, but they present no very close affinity to the Nortl-American fishes of the family. Fossil Centrarchidæ are found in the Eocene of North America.

CrPRINodontide.-At the present day many species of this family enter brackish or salt water, but this habit is probably secondary, as in the case of the marine Cat-fishes of the genera Arius, Plotosus, \&c. 'The reasons which may be assigned for regarding the Cyprinodontidæ as primarily a fresh-water family are as follows:-(1) Their absence from the Australian Region, except for a species of Haplochilus in Celebes and Lombok. (2) Several species have been found in European Oligocene and Miocene deposits, and Dr. Smith Woodward has been kind emough to tell me that "all fossil Cyprinodonts known are from fresh-water or estuarine deposits, chiefly lake deposits." (3) The nearest allies of the Cyprinodontidæ appear to be the more generalized Holarctic fresh-water types Esox and Umbra.

biol. Centr.-Amer., Pisces, Februay 1903. 
The Cyprinodontinæ are the oviparons Cyprinodonts, and are found at the present day in America from the Northern United States to Argentina, in Africa, and in Southern and Eastern Enrasia. Of nearly 120 species of this group, abont 60 are North American, 20 South American, and 30 African.

Prolebias, with several species fiom fresh-water deposits of the Oligocene and Miocene of France, Germany, and Sicily, is probably not distinct from Fumlulus, which is in some respects the most generalized of living genera. Fundulus inchudes a large number of species from the coasts and rivers of the United States; a few species occur in Mexico and Central America, Southeru Europe, and Africa.

The North-American Cyprinodon is represented in the Mediterranean district by the living genus or sub-genus Lebias and the extinct Pachylebias of the Upper Niocene; sereral of the species enter brackish or salt water.

The Cyprinodonts of India, the Malay Peninsula and Archipelign, China, and Japan are few in number and belong to genera which differ from Fundulus but little. Some of the African species may be placed in Fundulus or in the allied Indian genus Haplochilus; the rest do not depart widely from this type. The South-American Cyprinodontine are the genera Rimulus, Cynolebias, and Orestias, which differ from Fundulus in having the margins of the eyes not free and in other characters of specialization. Four species of Rivulus are known from Southern Mexico and Central America. A consideration of the distribution of the Cyprinodontinæ leads us to suppose that they were originally a holarctic fresh-water group and that they have spread southwards; the African forms are probably derived from immigrants from Europe and India; the Sonth-Americau genera have evolved from a North-American stock, which probably reached the southern continent by migration along the coast.

The viviparous Cyprinodontidie are exclusively American and may be arranged in three groups - Characodontina, P'ocilina, and Anablepinie. 'The Characodontinie are characteristic of and almost peculiar to the system of the Rio Lerma (including the Valley of Mexico). Zooguncticus comprises four species from the Lerma System, which may be defined as Fumduli of the type of $F$. punctutus, but riviparous and with the anal tin of the male modified, the anterior 5 or 6 rays being short and stiff and separated by a notch from the rest of the tin. Fundulus punctatus is found in all the L'acific coast streams from Oaxaca to Lcuador, and probably enters the sea; it may be regarded as nearly representing the ancestral form from which Zoogoneticus hats erohed.

Limnurgus (one species), Characodon (tive species), and Goodea (seven species) differ from Zoogoneticus in their more specialized dentition. A species of Characolon 
has extended northward to the rivers of Coahuila and Durango, and another has become marine and reached the coast of Lower California. Three species of Gooded have reached the upper tributaries of the neighbouring river-systems of the Balsas and the Panuco.

There can be no doubt that the Lerma System is the original home of the Characodontinæ.

The Pociliinæ start with the genus Gambusia, which differs from Fundulus only in being viviparous and in having the anal fin of the male advanced and modified into an intromittent organ, the anterior rays being thickened and produced. Gambusia comprises about 14 species from the Southern United States, Mexico, Central America, Cuba, and Jamaica. The widely distributed G. gracilis (Atlantic streams from Illinois to Vera Cruz) enters brackish water; the others appear to be strictly fresh-water species. The Central-American Belonesox is a remarkable offshoot from the Gambusia type. Pocilic and Gircrdinus comprise several species which differ from Gambusia in the structure of the mouth and the dentition, which is modified in adaptation to their phytophagous habits. 'These genera have a similar distribution to Gambusia, but in addition are well represented in the Lesser Antilles and in Brazil, a distribution no doubt to be accounted for by the fact that some of the species enter the sea. Allied to Procilic are Mollienisia, with one species from the Surthern United States and Tamaulipas and another from Lake Peten, and Xiphophorus, with five species in Atlantic coast streams from Mexico to British Honduras.

The remarkable Anableps, surface-swimming fishes with the projecting eyes divided horizontally into an upper part adapted for vision in the air and a lower for vision in the water, comprises three species-two from tropical South America, one from Southern Mexico and Central Anerica. The males have the anal fin modified into a scaly conical intromittent organ with terminal orifice. The nearest ally of Analleps appears to be Jemynsia from Argentina.

The points to be noted in the distribution of the Cyprinodontidie in Mexico and Central America are the remarkable development of the Characodontine in the River Lerma System, the presence of some endemic genera of the Pociliinze in the Atlantic coast rivers, the presence of only two genera (Rivulus and Anableps) which may be regarded as probable immigrants from the south, and the absence of peculiar types in the Great Lakes of Nicaragua, which contain only two species, both widely distributed.

The sub-order Ostariopirsi, comprising the families Characinide, Gymnoticle, Cyprinidie, Siluridæ, Aspredinide, and Loricariidæ, is an offshoot of the Malaco- 
pterygii, which were abundant in Cretaceous seas; no prectertiary Ostariophysi have been found, but Silnridæ occur in the earliest Eocene deposits. With the exception of the Silurid genera Arins, Plotosus, and a few allied to them, which have become estuarine or marine, all the members of the group are fresh-water fishes. The Gymnotidxe and Cyprinide are evidently modified Characinidx, whilst the Loricariidæe and Aspredinida have been derived from the Siluridic. The Characinidæ and Siluridæ, however, are by no means closely related, although evidently derived from the same stock, as is shown by the presence in both of the remarkable chain of "Weberian ossicles" connecting the air-bladder with the auditory organ. The origin and distribution of the Mexican and Central-American families of this group may now be discussed.

The family Characinid 2 is very abundant in the fresh waters of South America, where more than 500 species are known to occur and where the genera are numerous and

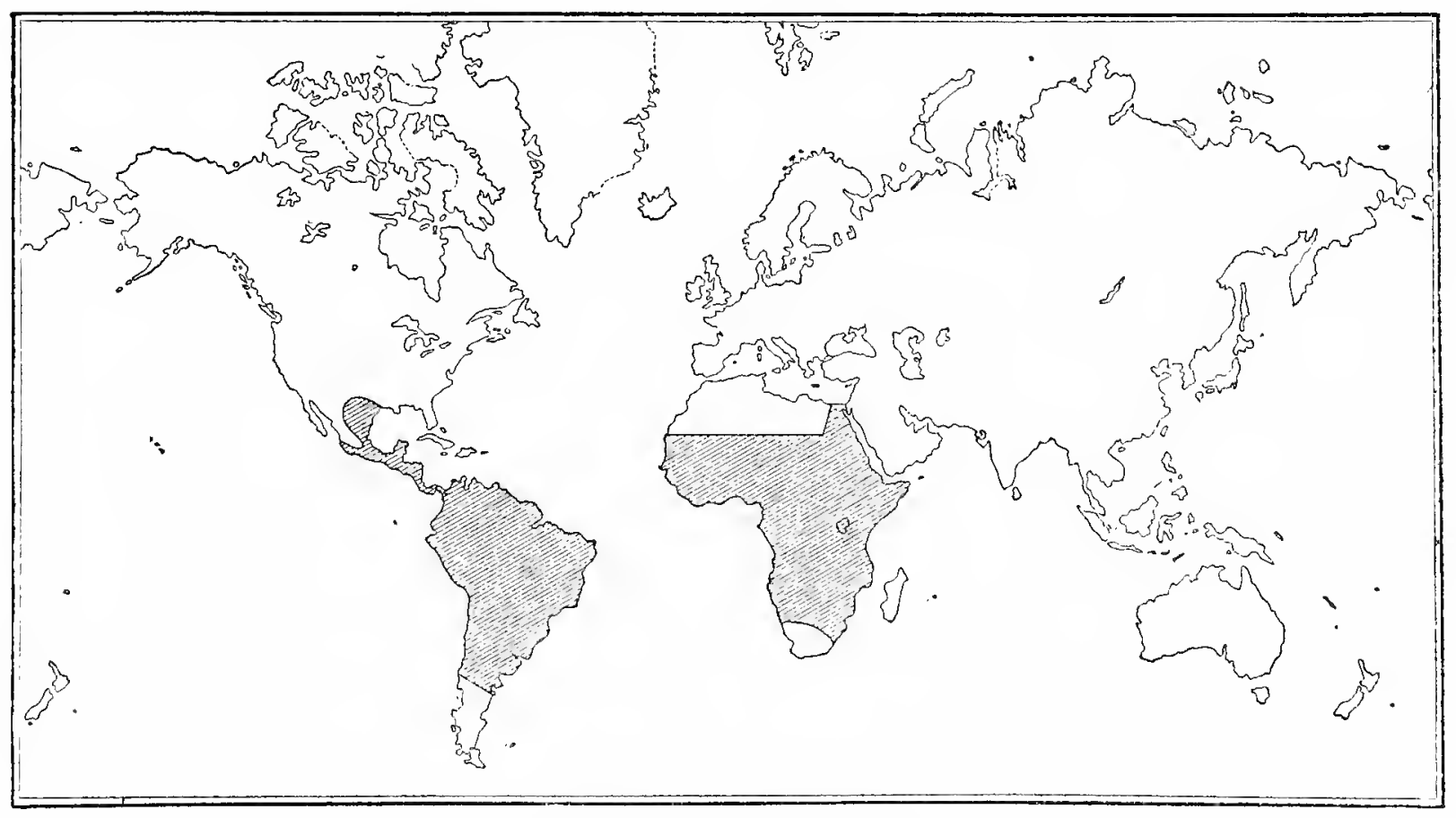

Distarution of Chamacinitiat.

rery diversified. The most genoralized types also occur in this continent, which must be regarded as the original home of the group. In Africa there are abont 100 species, but the family is not represented in Madagascar. None of the genera are common to 
the two continents, but in at least one case (Brycon and Alestes) an American and an African genus are very closely allied.

The Mexican and Central-American Characinidæ are evidently an offshoot from the South-American stock; as in the Cichlidæ, the immigrants have found the volcanic chain of mountains which forms the southern boundary of the Mexican platean an impassable barrier to their northward progress, but in the Eastern lowlands they have made their way as far north as the Rio Grande System.

The Mexican and Central-American Characinidæ may be arranged thus:-

1. Species belonging to South-American genera, the northern limit of which is the Istlumus of Panama: in sevcral cases these species occur also in Colombia or Ecuador. 'To this division may be referred a species of Hoplias, two of Piubuina, one of Luciocharax, one of Gastropelecus, and one of Curimatus.

2. Species belonging to South-American genera which extend further north than the Isthmus of Panama. 'To this division belong two species of Brycon, one from Panama and Costa Rica, the other from Guatemala; a Roboirles, ranging from Oaxaca to Ecuador; a Chirodon from the Rio Papaloapam; and five species of Tetragonopterus, all closely allied to the widely distributed Sonth-American T. rutilus. One species of Tetragonopterus is known only from Panama, a second ranges from Panama to Oaxaca and Vera Cruz, a third from Guatemala to Texas; the other two are found in Southern Mexico.

3. Two species belonging to the endemic genus Bramocharax, which appears to be related to Brycon and which is peculiar to the Great Lakes of Nicaragua.

The Gravotide are specialized eel-like Characiuids, and have evidently evolved from the latter in South America. There are about $\$$ genera and 30 species, one of which (Giton fasciatus) extends from Guatemala to the La Plata, whilst a secourl (Eigenmannia humboldtii) is found in Panama and Colombia.

The Crprinide are fresh-water fishes of North America, Furasia, and Africa. They are absent from Madagascar and do not cross Wallace's Line; the family is well represented in Borneo and a few species are known from the Philippines and from Bali, but none from Celebes or Lombok. In America they extend sonthwarls to the Rio Balsas in Southern Mexico and the Rio Usumacinta in Guatemala.

The family is closely related to and probably derived from the Characinidæ, from which they differ especially in the falciform lower pharyngeals. 
The Cyprinidx may be divided into four sub-families, viz. Cyprininæ, Catostomine, Cobitidine, and Homalopterine, the first having a range nearly co-extensive with that of the family, the second being North American (with 2 or 3 species in Eastern Asia), the third occurring in Eurasia and Abyssinia, the fourth in Sonthern Asia.

The Cyprininæ, in addition to having the widest range, are by far the most diversified and the most numerous in genera and species, and may perhaps be regarded as the most generalized, especially as in some of the genera primitive characters are present (pharyngeal teeth in more than one series, lips normal, gill-membranes free from the isthmus, suborbitals broad) which are not to be found in the other sub-families.

In the Cypriniux the maxillaries are entirely or in great part exclucled by the premaxillaries from the upper border of the mouth. The Catostominæ differ from them in that the margin of the upper jaw is formed in the middle by the small præmaxillaries and at the sides by the maxillaries; these bones are hidden in thick fleshy lips, and the reduction of the pramaxillaries is, in my opinion, probably due to this fact.

'The Cyprinidx may hare originated in some part of the Indian region *, which is at the present day the richest in genera and species and where the most generalized forms occur. Boulenger, regarding the Catostominæ as the most generalized group, considers that the Cyprinidæ may have originated in North America as an offshoot of the Southand Central-American Characinide. He explains the fact that in America they have not extended further south than Guatemala as due to competition with herbivorous Characinids; but as the most northern representative of the latter group (Curimatus magdalene) does not extend further north than Panama, this explanation is scarcely satisfactory, especially as Cyprinidie and herbivorous Characinidæ are by no means mutually exchnsive in Africa.

The Catostomine comprise about serenty species belonging to about ten generi from North and Central America and three species belonging to about two genera from Lastem Asia.

Ictiolus, with the dorsal fin elongate, includes about twelve species, in rivers east of the Rocky Mountains and the Sierra Madre, from the Great Lakes to the Rio Usumacinta in Guatemala. The Mexican species are four in number and are found in the southern tributaries of the Rio Grande and the rivers of Tamaulipas. I. meridionalis from the Usumacinta is the only member of the sub-family in the Neotropical Revion. Cycleptus, with a single species ranging from the Mississippi to Tamanlipas, and a genus with two species in China are allied to Ictiolus.

\footnotetext{
* The present distribution of the Cyjrinide leads to the sulposition that they originated in Indo-China at or before the verrinuing of the Eucene.
} 
The other Catostominæ have the dorsal fin short. Two of the genera are only found west of the Rocky Mountains, viz. Cllasmistes (4 species) and Xyrauchen (2 species). One species of Xyrauchen is recorded from Northern Sonora. Catostomus comprises one species from Eastern Siberia and abont twenty-five from North America, chiefly in the Rocky Mountain region. Two species occur in Mexico, one from Sonora and one from the Rio Grande. Moxostoma includes twenty species from the United States east of the Rocky Mountains, from the Great Lakes to the Rio Grande; in Mexico

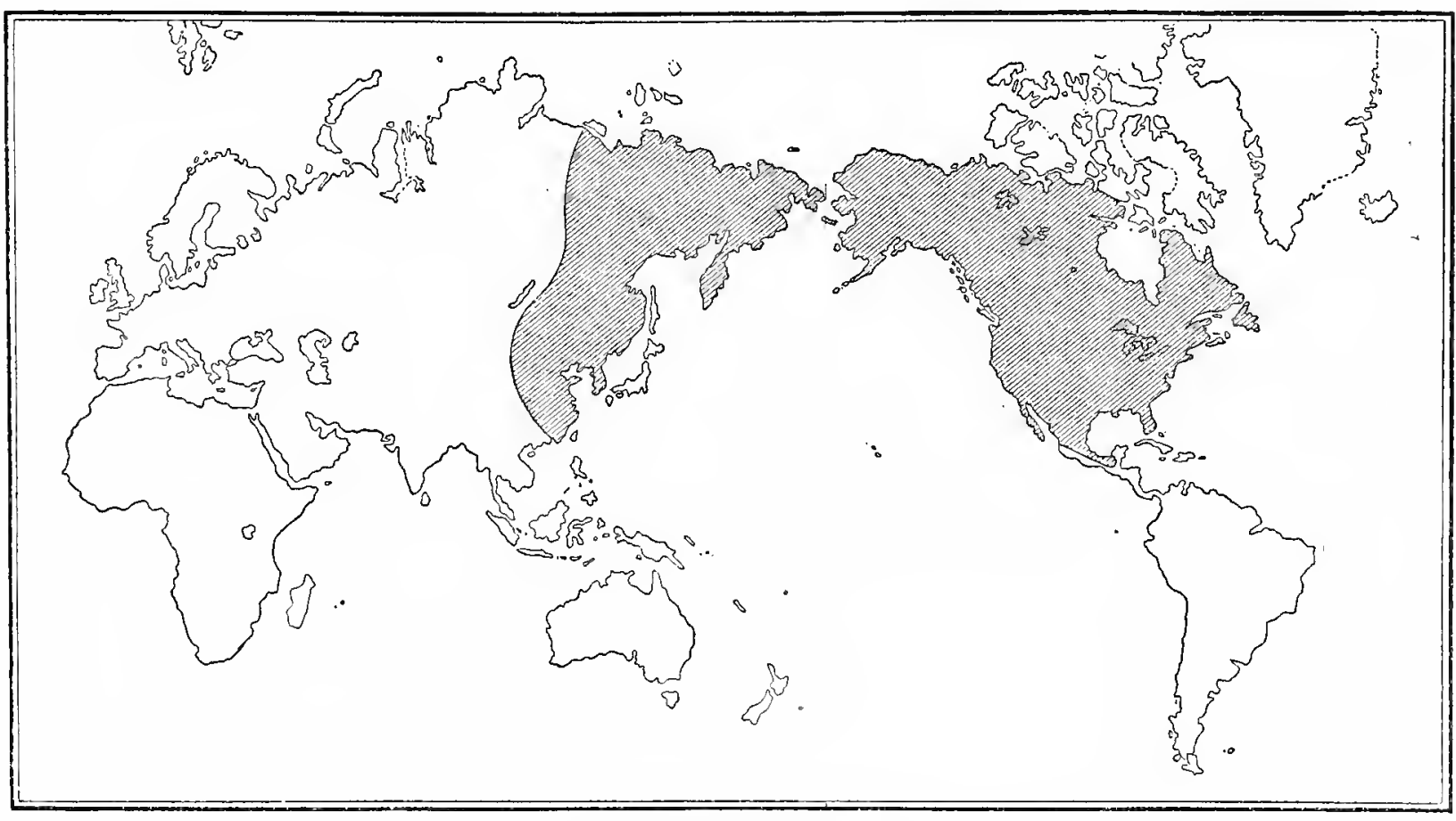

Distribution of Catostonin.

one species is found in the Lerma System and another in the Rio Mascota, a small Pacific coast stream to the south of the Rio Grande de Santiago. Four monotypic genera allied to Moxostoma from the eastern part of the United States complete the count of the Catostominæ.

The Cyprininæ comprise more than 1000 species from all parts of the world excepi the extreme north and the Neotropical and Australian regions. Less than 200 species are known from Africa, and most of these belong to Indian genera; they are absent from Madagascar. The Indian Region is the richest in genera and species and the most generalized types occur there; fossil Cyprinidæ are found in Tertiary deposits of uncertain age in Sumatra. In the Palæarctic Region the Cyprininæ are an important 
element of the fresh-water fish-fauna, but the gencric types are comparatively fow; sume of the existing European genera are represented in Oligocene and Miscene deposits.

The Nearctic Cyprinina number about 225 speeies, most of which belong to the lahaurctic genus Lenciscus or to closely allied generic types, there being, perhaps, less

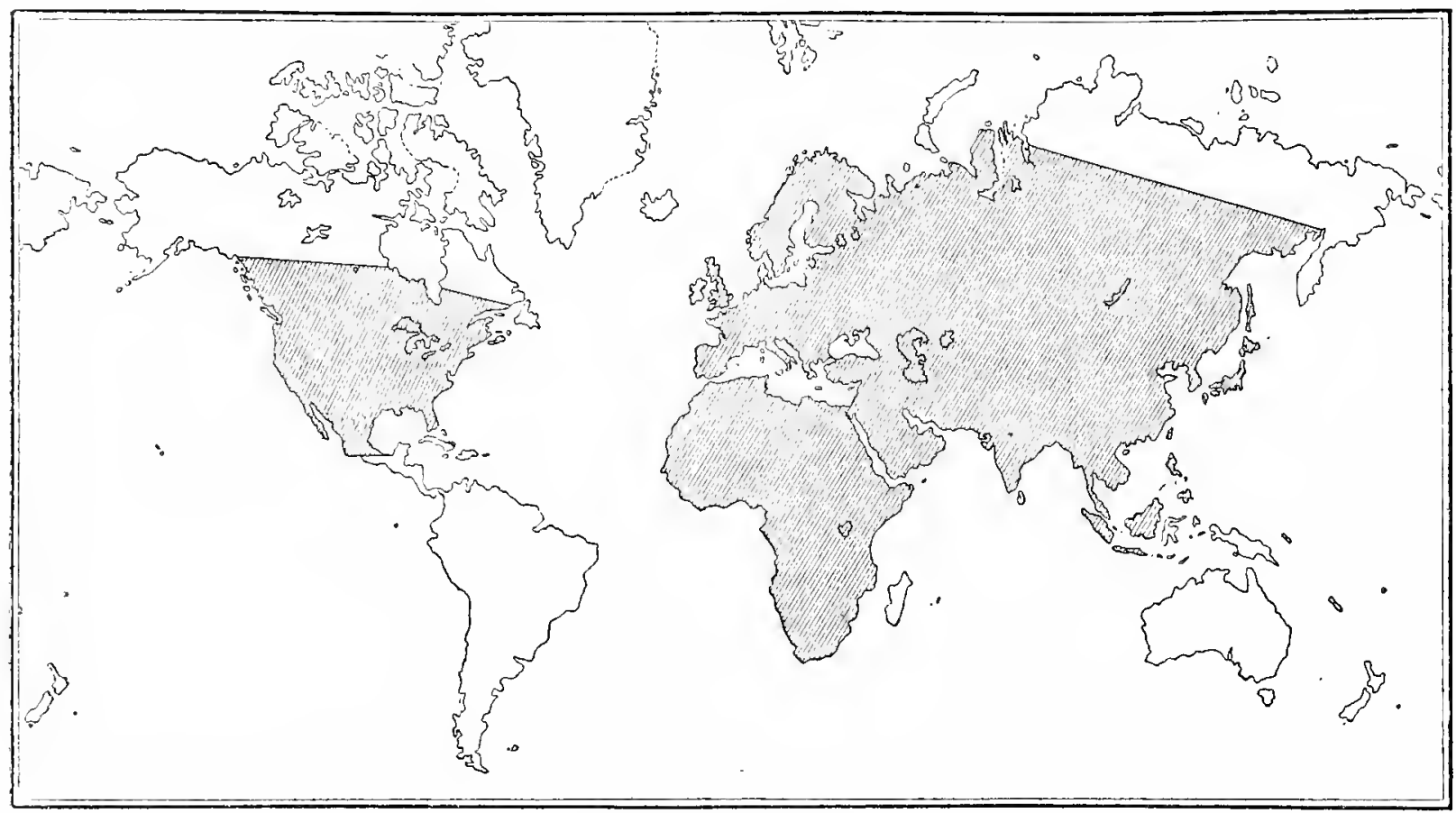

T)istribtion of Crprinin.e.

diversity in this region than in any other. Consequently the generie distinetious are in great part based on vory trivial characters, and slight differences in the form and number of the pharyngeal teeth are considered of importanee.

In America the Cyprininæ range from British Columbia, Saskatchewan, and Quebee 1) the Rio Balsas in Southern Mexico. As in the Catostomine, few genera are common to both sides of the Rocky Mountains, except in the ease of types specially adapted to mountain-streams.

Of the 40 species included in the fauna of Mexico, 10 belong to six endemic genera, of which five, Alyansen (4 species), Falcula (1 species), Divara (2 species), Iystrosus (1 species), and I wriria (1 species), are peculiar to the Lerma System and the other, sfypodon, contains a single species from Coahuila. Notropis, with about 100 species, all from rivers east of the liocky Mountains and the Sierra Madre, is represented by 13 in Mexico; 10 of these are from north of the Lerma and 3 from the Lerma System; 
one of the latter occurs also in the Balsas. In the last-named river is found a species ( $N$. boucrveli) which has so far only been obtained elsewhere in Nuevo Leon, possibly a case of discontinuous distribution.

The other Mexican Cyprinidæ are the representatives in Sonora (5 species) or in Mexico north of the Lerma System and east of the Sierra Madre (13 species) of Westeru and Eastern North-American types respectively.

The family Silurinæ, with about 1000 species, is practically cosmopolitan in tropical and temperate regions and is especially abundant in South America, Africa, India, and the Malay Peninsula and Archipelago. The true fresh-water types do not appear to cross Wallace's Line, the Siluridæ of the Australian Region belonging to the marine Galeichthys, Plotosus, \&c., or to genera which may be regarded as evolved from these. A uumber of genera are common to the Indian and African Regions, but the Neotropical fresh-water types are all generically distinct from, although in some cases closely allied to, those of Africa. Genera related to the existing Galeichthys are found in the Eocene of Europe and North America.

As in the case of the Characinidx, a larger number of genera and species and a greater diversity is found in the Neotropical Region than in any other. This parallelism extends to the fact that of three families peculiar to the Neotropical Region, one (Gymnotidæ) is derived from the Characinidx, the other two (Loricariidæ and Aspredinidæ) from the Siluridæ.

In Mexico and Central America there are about sixty species, nearly half of which are marine Cat-fishes of the genera Arius, Gateichthys, and Elurichthys. The freshwater Silurids belong either to the widely distributed South-American genera Rhamdia, Pimelodus, and Conorhynchichthys, or to the North-American Amiurus and Leptops. Of these Pimelodus is represented only by two or three species in Panama, and Conorhynchichthys by one from the Usumacinta. Rhamdia, however, extends northward to Oaxaca and Southern Vera Cruz, and includes a considerable number of Central-American species.

Leptops comprises a single species from the United States east of the Rocky Mountains, which is also found in the southern tributaries of the Rio Grande. Amiurus includes a species in China and about twenty in America, eleven of which are found in Mexico and Central America. Three of these are widely distributed, ranging from the Great Lakes to Tamaulipas; a fourth is found in Texas and Northbiol. Centr.-AMer., Pisces, February 1908. 
eastern Mexico; and two more are known from the Rio Panuco, one of these extending into Southern Vera Cruz. The southernmost species is Amiurus meridionalis from the Rio Usumacinta. The four remaining species occur respectively in Arizona and Sonora, Chihuahua and Durango, the Rio Lerma, and the Rio Balsas.

The family Loricarimd, with over 200 species, ranges from Panama to Montevideo, and has evidently evolved in South America from the Siluridie.

\section{The Nearctic Region.}

For fresh-water fishes the volcanic chain of mountains which stretches across Mexico from Colima nearly to Vera Cruz may be taken as the boundary between the Nearctic and Neotropical Regions. This range has proved an insuperable obstacle to the northward migration of the neotropical fishes, none of which have surmounted it to reach the Mexican plateau; in the narrow lowland strip near the west coast of Mexico one neotropical type (Cichlosoma beani) has extended nortbwards to the Rio Presidio in Sinaloa, whilst in the plains of Northem Vera Cruz and Tamaulipas on the east some neotropical fishes are found, viz. fire Cichlids* and a Characinid (T'etragonopterus mexicanus), which last has spreal from the Rio Grande on to the platean north of the Lerma System. These only counterbalance the nearctic types which occur south of the Nearctic Region, viz. Goodea whitii, Aminrus balsanus, Notropis boncardi, and N. aztecus in the Rio Balsas, Aminrus meidionalis and Ictiobus meridionalis in the Rio Usumacinta, the latter also in the Rio Papaloapam, and Lepidosteus tropicus, ranging from Guatemala to Panama.

The Nearctic and Neotropical Regions are quite distinct, aud show no affinity whatever. 'The former has much in common witl the Palxarctic Region, whilst the latter shows relationship only to the Ethiopian. In addition to partly marine groups, such as the Salmonidie and Gastrosteidie, there are several families of true fresl-water fishes common to the Paliearctic and Nearctic Regions (e.g., Esocide, Cyprinidie, Percida, \&c.). The latter is characterized by some endemic families (Fiodontidi, Amblyopsidæ, Percopsidre, and Aphredoderidie), by the numerous dwarfed Percida (Etheostome, \&c.) and the great development of the Cyprinodontinix (partly marine), and by three groups of fishes which are almost peculiar to this region, viz. Catostomina, Silurida of the genera Animes, Noturus, \&c., and Centrarchidic. The first two are also found in

* Cichlosoma labridens, C. barloni, O. steindachneri, II'richthys cyanoguttatus, and H. pavonaceus. 
Eastern Asia, whilst to the last-named family has been referred a marine Indo-Pacific genus, with fresh-water representatives in Australia.

The Nearctic Region may be divided into three sub-legions, the first corresponding to the United States west of the Rocky Mountains and Northeru Mexico to the west of the Sierra Madre. This, the Californian sub-region, is especially remarkable for the paucity of true fresh-water fishes. Esocidæ and Percidæ, in addition to the endemic nearctic families, are entirely absent, whilst the Siluridæe and Centrarchidæe are each represented by only a single species. The Cyprinidx are fairly abundant, several peculiar generic types inhabiting this sub-region.

The fish-fauna of the rivers of Sonora and Sinaloa is very little known; the few fishes which have been recorded from the Rio Sonora show that its fauna is similar to that of the Rio Colorado, and the same may be said of that part of the Rio Yaqui which drains the western slope of the Sierra Madre. Only two strictly fresh-water fishes are known from streams of Sinaloa and Jalisco to the west of the Sierra Madre; one of these (Cichlosoma beani) is a neotropical type, the other (Moxostoma mascoter) a nearctic one.

The second sub-region of the Nearctic Region includes Alaska, Canada, the United States east of the Rocky Mountains, and Mexico east of the Sierra Madre and north of the Lerma System. This sub-region may be characterized in nearly the same terms as those used to define the Nearctic Region as a whole: there is a northern zone in which the Salmonida are dominant; further south the Cyprinidæ become well established, and in the Mississippi System attain their maximum, together with the Cyprinodontinæ, Centrarchidæe, and Etheostomatinæ; in the Rio Grande a number of characteristic types disappear. These changes in the character of the fish-fauna render it necessary to divide this sub-region into several provinces, the sonthernmost of which (Rio Grande Province) comprises the Rio Grande System, with the rivers of the Mexican plateau north of the Lerma System and the streams of the Atlantic slope in 'Tamaulipas and Northern Vera Cruz.

A number of streams in Chihuahua and Durango flow in the direction of the Rio Grande, but never reach it, terminating in lakes which vary in magnitude according to the season. As has been pointed out by Dr. Meek, the nature of the fish-fauna justifies the supposition that these rivers were formerly tributaries of the Rio Grande. For a similar reason he considers that the portions of the Yaqui and Mezquital Rivers to the east of the Sierra Madre also at one time belonged to the Rio Grande System, and that 
a cutting back of the western rivers has resulted in their capture, with the result that the castern rivers with which they were formerly connected have diminished in size and fail to reach the main stream.

The Rio Grande Province differs from the Mississippi Province principally in the paucity of types. Not one of the endemic nearctic families is present; the Esocidic are absent, and the Percidic and Centrarchidæ are represented by a few species only. A considerable proportion of the true fresh-water fishes belong to the Cyprinidie, whilst the presence of Cichlida and Characinide is a positive feature which distinguishes this arca from other parts of the Nearctic Region.

The Rio Lerma System (excluding the Rio Grande de Santiago below the falls, and properly including, as Dr. Meek has shown, the Rio San Juan, a tributary of the Panuco, as well as the isolated lakes in the States of Michoacan and Mcxico) has so pecnliar a fish-fauna that it may be regarded as a separate sub-region of the Nearctic Region.

The viviparous Cyprinodontidæe of the sub-family Characondontinæ are characteristic of and nearly peculiar to this, the Lerma, Sub-region, in which the Atherinid genus Chirostoma is represented by a number of species which show a remarkable diversity. Both these groups are probably derived from marine ancestors which entercd the river at a remote epoch; mone of the marine types (Gobiidre, Mugilide, \&c.) which are found at the present day in neighbouring rivers, such as the Balsas and Panuco, have been able to make their way into the Lerma System, from which neotropical fishes are also absent.

'The Cyprinida of this sub-region differ considerably from those of the Rio Grande, as five of the seven genera are endemic. With the exception of a Cat-fish (Amiums) and a Lamprey (Lampetra), all the fishes of the Lerma Sub-region belong to the three groups already mentioned.

Below, in comparing some of the shore-fishes of the Pacitic and Atlantic coasts of Central America, it is shown that in many cases D. S. Jordan's generalization-to the effect that a form occurring in a certain area has as its nearest relative a form inhabiting a neighbouring area separated by some sort of barrier from the first-holds good. In such cases isolation appears to have been a factor in determining specitic: differentiation.

Jordan's gencralization also holds good for many groups of fresh-water fishes, but for many others it does not. As examples of the latter we may instance the Cichlid fauna of Likes Managua and Nicaragua and the greater part of the fish-fauna of the Lerma System. 
All the Cyprinodontilæe and Atherinidæ of the Lerma System appear to have evolved therein, in all probability each from a single prototype.

Of the fourteen species of Chirostoma, at least eleven, and probably all the fourteen, occur together in Lake Chapala; several of these species are vcry closely related and it is by no means easy to distinguish between them; some of the specific characters appear to be adaptive-e.g., the lower jaw is short in C. promeles and strongly projecting in C. ocotlane, whilst C. splyyrana is remarkable for its strong dentition; such characters may have arisen during physiological isolation.

\section{The Neotropical Region.}

The families Lepidosirenidæ, Characinidæ, Cichlidæ, and Polycentridx are either almost or entirely restricted to the Neotropical and Ethiopian Regions, as are the Siluridæ of the groups Pimelodinæe and Doradinæ.

The Neotropical Region is especially characterized by the great development of the Cbaracinidæ and Siluridæ, and by the presence of endemic families derived from them. The Characinidæ are represented by an extraordinary variety of endemic types, and they have given rise to the Gymnotidre; the neotropical Siluridie include several sub-families peculiar to this region, and from them the endemic families Loricariidie and Aspredinidæ have evolved.

The Neotropical Region may be held to include three principal divisions, which may be termed the Patagonian, Brazilian, and Central-American Sub-regions. The fishfauna of Chili and Patagonia is chiefly remarkable for the scarcity of true neotropical types; in Southern Mexico and Central America severil South-American groups are absent, but this sub-region is characterized also by the presence of a few nearctic fishes and by the development of a number of peculiar Cichlidre and Cyprinodontidie.

Our knowledge of the fresh-water fishes of the Central-American Sub-region is so incomplete that any division of this area into provinces can only be provisional. The Rio balsas with its tributaries forms a province defined by the presence of some nearctic types (Goodea, Amiurus, Notropis) and by the scarcity or absence of typical Central-American groups (Cichlidie represented by a single species; Pimelodine, Belonesox and Tiphophorus absent).

The Rio San Juan, with Lakes Managua and Nicaragua, may perhaps be regarded as a province (San Juan Province) characterized by the peculiar Cichlid fauna; the region to the north of these right up to and including the Papaloapam System forms another province, defined by the presence of three nearctic fishes (viz. one species each of Aminurus, Ictiobus, and Lepidosteus), by numerous Cichlidx of the genus Cichlosom, 
and by some peculiar Cyprinodonts, such as Belonesox and Xiphophorus. This may be termed the Guatemalan Province. Costa Rica and Panama comprise a fourth province, in which many of the South-American types attain their northern limit (e.g., Acara and Geophagus of the Cichlidæ, Curimatus, Gastropelecus and some other Characinidx, the Loricariidx). In this, the Isthmian Province, the only nearctic form is Lepitosteus tropicus.

\section{5. 'The Shore-Fishes of tile Atlantic and Pacific Coasts of Mexico and Central America.}

There is a great similarity between the fishes found on the Atlantic and Pacific coasts of Central America. It was formerly stated that a considerable proportion of the species were the samc on both coasts, but in recent years the number of supposed identical species has been greatly rednced by more detailed comparison.

In the present work only those groups of shore-fishes which enter fresh water are considered; as a result of my studies on these I am inclined to think that if we eliminate pelagic or semi-pelagic fishes of wide distribution, very few species will be found to be identical on both coasts, and that these will probably be fishes which enter rivers for considerable distances. Such fishes may have become involved in those geological changes which have led to the occurrence of the same fresh-water species in rivers of the Atlantic and Pacific Slopes.

Many of the species which were formerly considered to be the same on both coasts are now found to be distinguished by slight but constant differences. In such cases, where an Atlantic species is more closely related to a Pacific one than to any on its own side, it is reasonable to suppose that both are derived from a parent species which inhabited the neighbouring parts of the two oceans at the time when there was a connection between them. Such a marine connection appears to have existed in the Eocene orer what is now the Isthmus of Panama, and there are good reasons for believing that it ceased at the beginning of the Miocene.

A comparison of the shore-fishes of the two coasts should therefore give clata as to the nature of the specific characters which may arise during isolation and as to the time required for specific differentiation in certain groups.

The following species are included in the systematic part of the present work and may be paired together, the members of each pair satisfying the definition that they are more closely related than either is to any other species, and that they represent each other on the Atlantic and Pacific coasts :- 


\section{Pacific.}

1. Philypnus maculatus.

2. Eleotris picta.

3. Dormitator latifions.

4. Gobioides peruanus.

5. Gerres simillimus.

6. Gerres californiensis.

7. Gerres peruvianus.

8. Gerres lineatus.

9. Centropomus medius.

10. Centropomus viridis.

11. Centropomus robalito.

12. Centroponues unionensis.

13. Pomadasis bayanus.

14. Mugil thoburni.

15. Alurichthys scutatus.

16. Alurichthys pinnimaculatus.

17. Galeichthys guatcmalcusis.

18. Arius liropus.
Atrantic.

$P$. dormitator.

E. pisonis.

D. maculatus.

G. broussonetii.

$G$. cinereus.

$G$. harengulus.

G. olithostomus.

G. plumieri.

C. pectinatus.

C. undecimalis.

C. ensiferus.

C. altus.

P. crocro.

11. incilis.

E. isthmensis.

A. bagre.

G. assimilis.

A. melanopus.

In several cases there is identity in the number of fin-rays, scales (when present), and gill-rakers between the members of a pair of species. This applies to the following:-Dormitator maculatus and D. latifrons, Gerres lineatus and G. plumieri, Centropomus robalito and C. ensiferus, Centropomus unionensis and $C$. altus, Mugil thoburni and Mr.incilis, Elurichthys scutatus and A. isthmensis, Galeichthys guatemalensis and $G$. assimilis, Arius melanopus and A. liropus.

In other cases there is agreement in the number of fin-rays and of gill-rakers, but not of the scales (e.g., Gerres simillimus and G. cinereus, Gerres peruvianus and G. olithostomus, Centropomus medius and C. pectinatus, Pomadasis bayanus and $P$. crocro). In the last pair the slight difference in the size of the scales is uniform; a longitudinal or transverse count on any part of the body will probably give a larger number for the Pacific form. In Centropomus medius and C.pectinatus the scales differ in number only above the lateral line, especially anteriorly, where they are always smaller in the Atlantic species. Gerres peruvianus is identical in scaling with G. olithostomus, except in the thoracic region, where it has distinctly fewer and larger scales, whilst the only tangible difference in the scaling of Gerres simillimus and G. cinerens is the constant presence in the latter of 5 or $5 \frac{1}{2}$ instead of 4 series of scales above the lateral line.

Gerres californiensis and $G$. havengulus are two species which agree in the number 
of scales and fin-rays, but the latter appears to have constantly $S$ gill-rakers on the lower part of the anterior arch, whilst the former has 7 .

Centropomus viridis and C. undecimalis agree in the number of scales and gill-rakers, but the formex appears to have a ray less in the second dorsal fin. A similar difference is found between Philypme maculatus and $P$. dormitator, the former having a ray more in the anal fin.

The members of each pair of species in all cases differ from each other in at least one more or less tangible "substantive" character, such as the relative depth of the body, length of the head, size of the mouth, length of the fin-rass, or size of the teeth.

When there is agreement in all the characters which can be mumerically expressed and the distinction appears to rest on a single feature, as in the case of Dormitator latifrons, scparated from D. maculatus by the larger head, or Gerres lineatus, differing from G. plumieri in the less elevated dorsal fin, the two forms can scarcely be regarded as more than sub-specifically distinct.

In other cases the Atlantic and Pacific forms differ in two tangible characters, e.g. Gerres olithostomus and G. peruvianus, the latter of which is distinguished by the larger scales in the thoracic region and the somewhat smaller mouth. From such pairs of species we pass to others, the members of which may be separated by three, four, or more tangible characters.

From the data given above we may conclude that a greater or less amount of change may take place in a species when isolated for a considerable period, and that some of the changes which take place may be non-adaptive.

The fact that in so many cases species on opposite coasts may be paired is more in harmony with the view that there has been a gradual modification during isolation than with the supposition that a "mutant" has arisen which has replaced the parent form. 


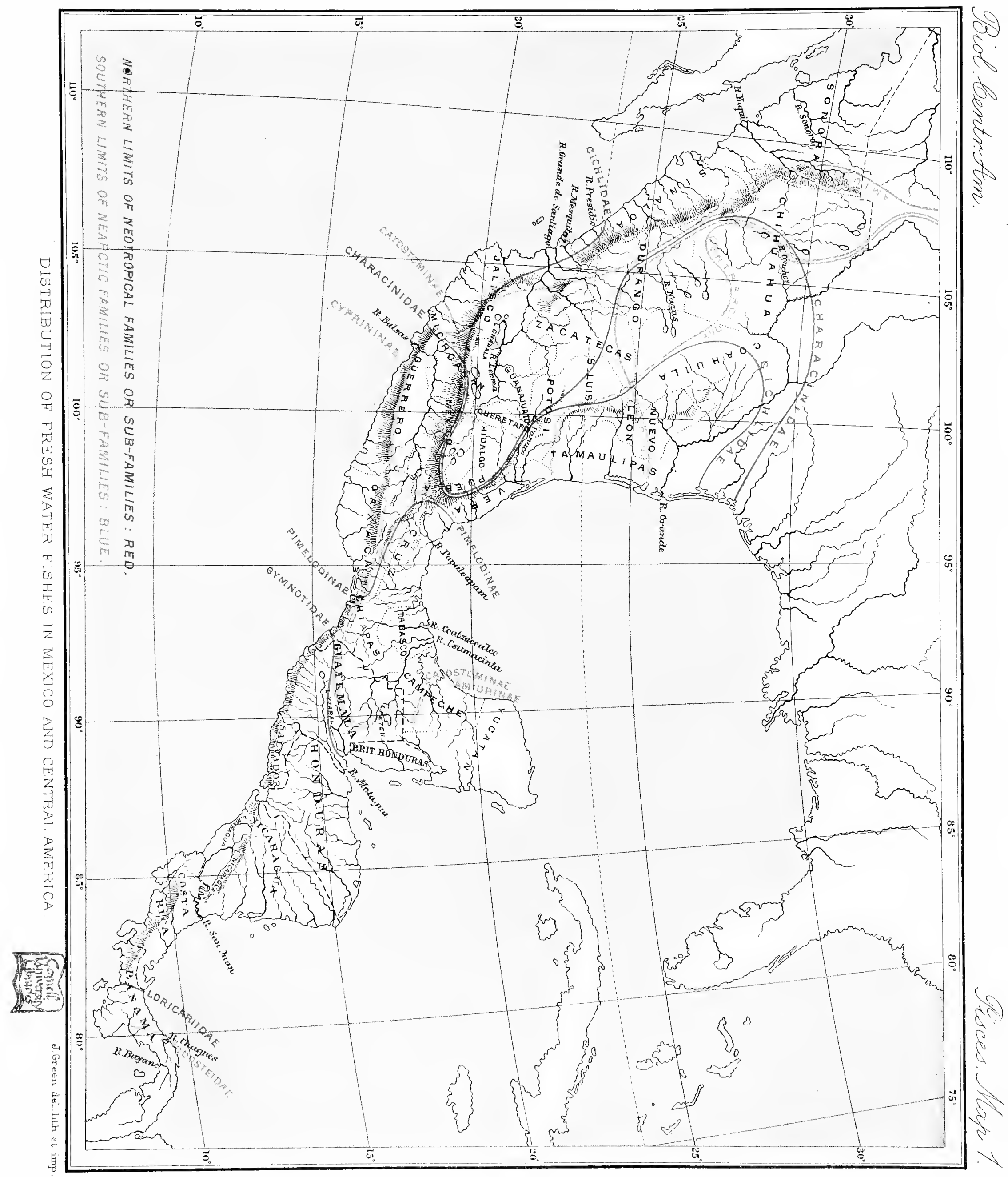




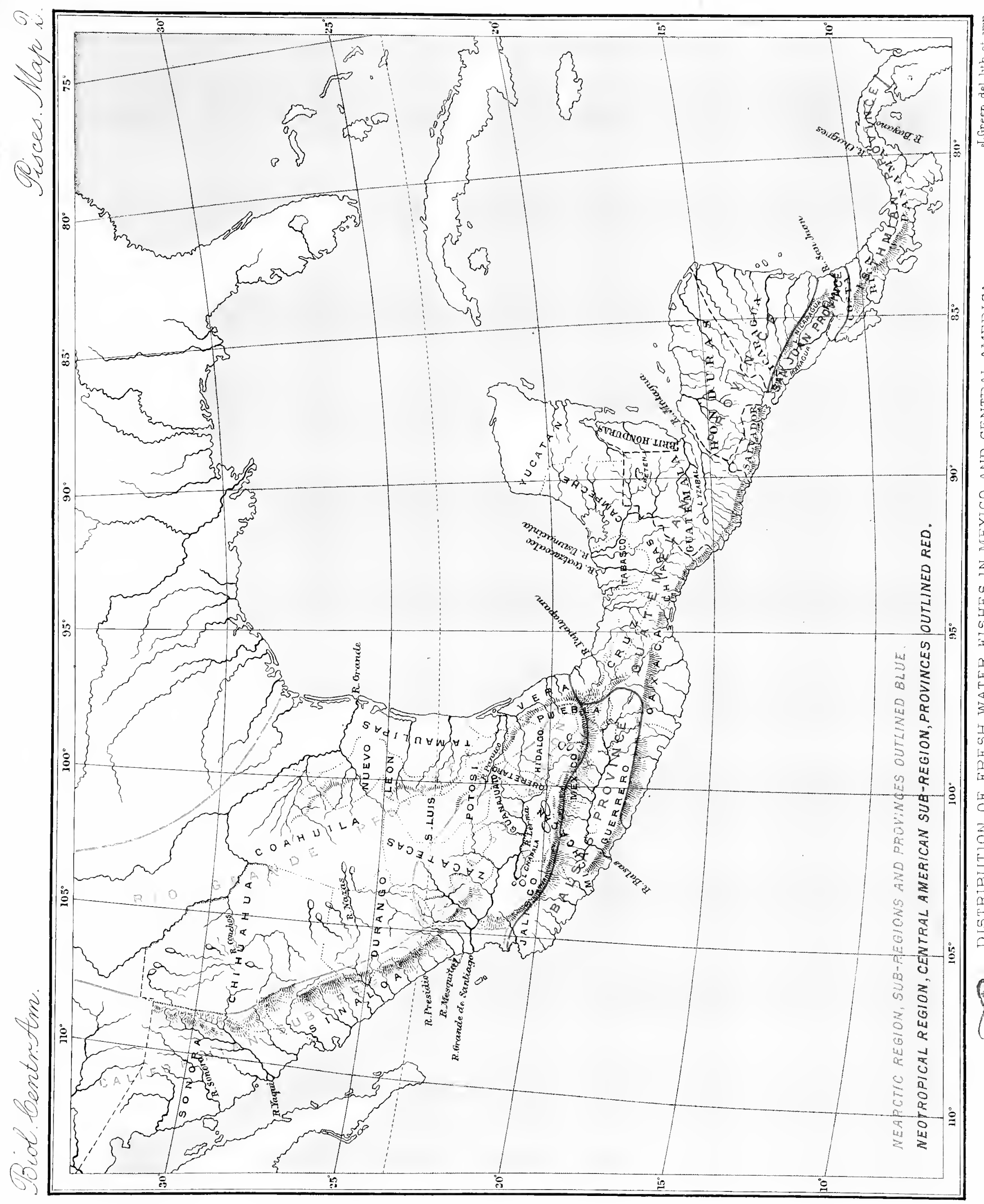





\section{LIST OF PLATES.}

\begin{tabular}{|c|c|c|c|c|c|c|c|}
\hline & Plate. & Fig. & Page. & & Plate. & Fig. & Page. \\
\hline Philypnus maculatus & I. & 2 & 5 & Xipbophorus strigatus & XIV. & 7 & 107 \\
\hline Dormitator latifrons ......... & I. & 3 & 9 & - brevis................. & XIV. & 8,9 & 108 \\
\hline Sicydium multipuuctatum ...... & I. & 1 & 11 & Alyrichthrs seutatu & $X V$ & 2 & 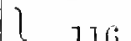 \\
\hline Cichlosoma maculicauda....... & II. & 3 & 19,186 & Acuricatnys sculatus & $X I X$. & 2 & 110 \\
\hline — sexfasciatum .......... & IV. & 2 & 19 & - isthmensis & $\mathrm{XV}$ & 1 & 117 \\
\hline _ microphtbalmus $\ldots \ldots \cdots$ & VII. & 2 & 20,186 & $10 \mathrm{DLTh}$ & XIX. & 1 & \\
\hline 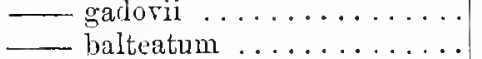 & $\begin{array}{l}\text { V. } \\
\text { II. }\end{array}$ & $\begin{array}{l}2 \\
1\end{array}$ & $\begin{array}{l}20 \\
22\end{array}$ & Galeichthys platypogon & $\begin{array}{l}\text { XVII. } \\
\text { XIX. }\end{array}$ & $\frac{1}{5}$ & 122 \\
\hline — centrarchus ......... & IV. & 1 & 29 & & XVI. & 2 & \\
\hline - robertsoni ........... & III. & 1 & 24 & & XIX. & 4 & 122 \\
\hline - macracanthus $\ldots \ldots \ldots \ldots$ & V. & 1 & 24 & crulescens & XVII. & 2 & 123 \\
\hline _. rostratum $\ldots \ldots \ldots \ldots \ldots$ & VII. & 1 & 25 & certuliscedis & III. & 6 & 120 \\
\hline — callolepis $\ldots \ldots \ldots \ldots \ldots$ & II. & 2 & 20 & - gruentheri & XVI. & 1 & 124 \\
\hline $\begin{array}{l}- \text { beani } \ldots \ldots \ldots \ldots \ldots \ldots \\
\text { multifasciatum } \ldots \ldots \ldots\end{array}$ & III. & $\begin{array}{l}1 \\
3\end{array}$ & 28 & & XVIII. & 3 & \\
\hline — friedrichstali . . . . . . . . & III. & $\because$ & 29 & Arius melanopu & XIX. & 7 & 126 \\
\hline $\left.\begin{array}{r}\text { Paraueetroplus sieboldii } \quad(= \\
\text { Herichthys underwoodi }) \ldots\end{array}\right\}$ & III. & 5\{ & $\begin{array}{c}30,186 \\
185\end{array}$ & — fuerthii & $\begin{array}{l}\text { XVIII. } \\
\text { XIX. }\end{array}$ & $\begin{array}{l}2 \\
8\end{array}$ & 127 \\
\hline Herichthys geddesi........... & III. & 4 & 30,188 & Rhamdia motagueusis & XX. & 1 & 130 \\
\hline Paraneetroplus bulleri ...... & VI. & $\ddot{z}$ & 31 & - nicaragnensis. . . . . . . . & $\mathrm{XX}$ & 2 & 130 \\
\hline Gerres simillimus $\ldots \ldots \ldots \ldots$ & TIII. & 2 & 38 & — boucardi.............. & XX. & 3 & 131 \\
\hline Centropomus altus ........... & VIII. & 1 & $5 \%$ & — petenensis . . . . . . . . & XXII. & 1 & 132 \\
\hline Chirostoma bartoni $\quad \ldots \ldots \ldots$ & $\mathrm{X}$ & 2 & 58 & — godwani............ & XXI. & 1. & 133,191 \\
\hline — patzcuaro...$\ldots \ldots \ldots$ & $\mathrm{I}$ & 1 & 58 & 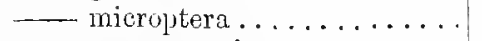 & XXIII. & 3 & 133 \\
\hline - breve ............. & $\mathrm{X}$ & 3 & 59 & — managuensis . . . . . . . & XXI. & 2 & $1: 33$ \\
\hline —ocotlano............ & IX. & 1 & 62 & — hypselura ........ & TXI. & 3 & 134 \\
\hline- sphjrena $\ldots \ldots \ldots \ldots$ & IX. & 2 & 63 & - brachycephala & XXII. & 2 & 135,191 \\
\hline Agonostomus nasutus....... & $\mathrm{X}$. & $t$ & 68 & — underwoudi..... & XIIII. & 4 & 1:35 \\
\hline — salvini $\ldots \ldots \ldots \ldots$ & II. & 2 & 68 & - silviui . ...... & XXIII. & 2 & 135 \\
\hline — macracanthus & II. & 1 & 69 & - polycaulus. & XXII. & 3 & $1: 36$ \\
\hline Rirulus flabcllicauda .... & $X$ & 6 & 81 & — rogersi & XXIII. & 1 & 136,1920 \\
\hline 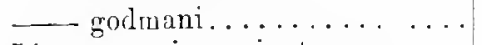 & $\mathrm{X}$. & 5 & 82 & Amiurus meeli & XXIlI. & 5 & 140 \\
\hline Limnurgus innomiuatus. . . . . & XII. & 1 & 87 & Ictiobus meridionalis .... & XXIV. & 1 & $1+4$ \\
\hline Characodon multiradiatus ..... & XII. & 3,4 & 88 & Ioxostoma mascuta $\ldots \ldots \ldots$ & SIIT. & 2 & $1+7$ \\
\hline — furcidens $\ldots \ldots \ldots \ldots$ & XIL. & $\stackrel{2}{2}$ & 90 & - parrinles. $\ldots \ldots \ldots$ & TXIT. & 3 & 147 \\
\hline Goodea multipunctata $\ldots \ldots$ & XII. & 5,6 & 92 & Algansua affinis $\ldots$. & XXV. & 1 & 151 \\
\hline Gambusia annectens $\ldots \ldots \ldots$ & XIV. & 5,6 & 97 & $\longrightarrow$ stigmatura $\ldots \ldots \ldots \ldots \ldots$ & XIV. & 2 & 152 \\
\hline — terrabensis $\ldots \ldots \ldots \ldots$ & XII. & 7 & 97 & Notropis boucirdi .. & XXV. & $t, 5$ & 150 \\
\hline — jonesii ... & XII. & 8 & 97 & _. salloi ... & XXY. & $: 3$ & 157 \\
\hline __ bimaculata & XIT. & 4 & 95 & Hoplius microlepis . . . . . . . & XxY1. & 1 & 167 \\
\hline I'ouilia sphenops & XIII. & $1,3-7$ & 102 & Tetragonopterus macrophthalmus. & XXVI. & + & 171 \\
\hline —_ caucana*. & XIII. & $\stackrel{2}{0}$ & 190 & — mexicanus . . . . . . . . . . & MXIL & $\ddot{2}, \ddot{3}$ & 171 \\
\hline — saivatoris $\ldots \ldots \ldots$ & TIV. & 2,3 & 104 & — angustifrons $\ldots$ & XITI. & $\overline{5}$ & 172 \\
\hline- couchiana $\ldots \ldots \ldots \ldots \ldots$ & NIV. & 1 & 104 & & & & \\
\hline
\end{tabular}

Figured on 'Tab. XIII. tig. 2 as a form of P. whenops.

biol. Centr.-Aher, Pisces, February $\stackrel{7}{908 .}$ 



\title{
BIOLOGIA CENTRALI-AMERICANA.
}

\author{
Z 00 I 0 G I A.
}

\section{Class P I S C E S.}

\section{Sub-class I. TELEOSTOMI.}

\section{Order I. TELEOSTEI.}

\section{Sub-order I. ACANTHOPTERYGII.}

IT has been found convenient to commence an account of the Fresh-water Fishes of Mexico and Central America with the Acanthopterygii, which may be recognized by the thoracic or jugular position of the ventral fins, the pelvic bones being directly attached to the clavicles.

The Acanthopterygian fresh-water fishes of Mexico and Central America may be referred to their families by means of the following key:-

I. Head asymmetrical, with the two eyes on one side; fins without spines. I. Preuronectide. II. Head symmetrical.

A. Gill-openings restrieted, the gill-membranes attaehed to the isthmus.

Ventral fius widely separated, jugular; dorsal and anal fins short, without spinous rays . . . . . . . . . . . . 2. Gobiesocrde.

Ventral fins not widely separated, thoraeie; tro dorsals or the dorsal

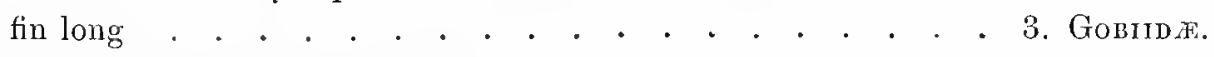

B. Gill-membranes free from the isthmus.

1. Anal fin witl 3 spines, 2 of which are detaehed from the rest of the

$$
\text { fin . . . . . . . . . . . . . . . . 4. Carangide. }
$$

2. Anal fin not preeeded by free spines.

a. A siugle nostril on each side. Dorsal with XIV-XIX $7-15$ * rays. Anal with III-XII 6-12 rass . . . . . . . . . . . . 5. CICILLId

* The Roman numerals indicate the number of spines, the Arabic figures the number of articulated rays. Biol. Centr.-AMer., Pisces, October 1906. 
b. 'Two nostrils on each side.

$\alpha$. Spinous part of the dorsal fin considerably sliorter than the soft-rayed part; anal with 1 or 2 spines . . . . . . . . . . . . . . . 6. Scimnide.

$\beta$. Spinous part of the dorsal fin not shorter or not much shorter than the soft-rayed part. * Ventral fins without scaly axillary processes.

Two dorsals, with VI-XVII, 8-17 rays; anal with I-II 6-12 rays . . . . 7. Percidæ.

A single dorsal, with X-XI 10-13 rays; anal with III 8-12 rays . . . . 8. Centrarchidex.

* A scaly process at the base of the spine of each ventral fin.

A single dorsal with IX 10 rays; anal with II-III 7-9 rays . . . . . . 9. Llognathid * * A single dorsal with X-XIV 10-18 rays; anal with III 7-13 rays . . . 10. Ponadasid 王.

Two dorsals, with VIII, I 9-Iİ rays; anal with III 6-7 rays . . . . . 11. Centroponide.

In all cases the account of the species is based on an examination of the examples in the British Museum Collection; but in the case of groups which have already been adequately described a synopsis only is given, with references to the works in which more details are to be found.

\section{Fam. 1. PLEURONECTID正.}

The Flat-fishes are a large family, at once distinguished from all other fishes by the asymmetrical head, with the two eyes on one side. They are mostly marine, but many ascend rivers for considerable distances. In Mexico and Central America four species have been recorded as occurring in rivers above the regions affected by the tides, and must therefore be included in an account of the fresh-water fishes.

\section{CITHARICHTHYS, Bleeker, 1862.}

Citharichthys, Jord. \& Everm. Bull. U.S. Nat. Mus. xlvii. 1898, p. $26 r 8$.

Eyes on the left side. Mouth moderately large; each jaw with a single scries of small pointed teeth; palate toothless. Scales moderate or small, feebly ctenoid, deciduous; lateral line nearly straight. Dorsal eommeneing just in front of the eye and posteriorly free from the caudal; left rentral median, but not continuous with the anal; pectorals well-developed.

\section{Citharichthys gilberti, Jenkins \& Evermann, $18 \delta 8$.}

Citharichthys gilberti, Jord. \& Everm. Bull. U.S. Nat. Mus. xlvii. 1898, p. 2686.

Depth of body about 2 in the length, length of head $3 \frac{1}{3}$ to $3 \frac{?}{3}$. Snout as long as or a little longer than eye, the diameter of which is $4 \frac{2}{3}$ to $5 \frac{1}{2}$ in the length of head; interorbital region a narrow, shallow groove, bordered by the slightly elcrated orbital margins; maxillary extending to below middle of eye; gill-rakers of moderate length, 12 to 14 on the lower part of the anterior areh. 38 to 45 scales in a longitudinal series. Dorsal 77-85. Anal 57-63. Left pectoral as long or nearly as long as tho postorbital part of head; right pectoral shorter; caudal doubly truncate. Lirit brown, spotted or marbled with darker.

IIab. Pacific Coast from Guaymas, Mexico, to Ecuador, entering rivers.

My description is based on four specimens, 110 to $160 \mathrm{~mm}$. in total length, from

* Usually known as Gerrida, a family narue preoccupied in Homiptera. 
Mazatlan, Chiapas, and the Rio Sapayo, Ecuador. The very closely allied C. spilopterus, Günth., 1862, from the Atlantic coast, differs in having the head somerwat shorter and the eyes a little smaller, whilst the scales are usually more numerous; it appears to be more strictly marine than its Pacific representative.

\section{ACHIRUS, Lacep., 1803.}

Achirus, Jord. \& Everm. Bull. U.S. Nat. Mus. xlvii. 1898, p. 2693.

Eyes on the right side, small, close together. Month small; jaws with small tecth on the left side, but not on the right; palate toothless. Scales small, adherent, strongly ctenoid; lateral line straight. Dorsal commencing on the snout, posteriorly free from the caudal; right ventral median and continuous with the anal; pectorals small or absent; caudal rounded.

The three species known to occur in the rivers of Mexico and Central America are closely allied, and differ little in the size of the scales (65 to 85 in a longitudinal series), the number of fin-rays (dorsal 50-60, anal 36-46), or the coloration (brownish, usually spotted or clouded with darker and with very narrow blackish transverse stripes). Their distinctive features are shown in the following key:-

I. Depth of body $1 \frac{1}{2}$ to $1 \frac{3}{5}$ in the length; right pectoral present . . . . . 1. mazatlanus.

II. Depth of body $1 \frac{3}{4}$ to 2 in the length.

Right pectoral present . . . . . . . . . . . . . 2. fonsecensis.

No pectoral fins . . . . . . . . . . . . . . . . . 3. fasciatus.

1. Achirus mazatlanus, Steind., 1869.

Achirus mazatlanus, Jord. \& Everm. Bull. U.S. Nat. Mus. xlvii. 1898, p. 2698.

Hab. Pacific Coast of Mexico, entering rivers.

I have examined three specimens, 70 to $140 \mathrm{~mm}$. in total length, from Presidio and Mazatlan.

2. Achirus fonsecensis, Günth., 1862.

Solea fonsecensis, Günth. Cat. Fish. iv. p. 475 (1862).

Achirus fonsecensis, Jord. \& Everm. Bull. U.S. Nat. Mus. xlvii. 1898, p. 2699.

$H a b$. Pacific Coast of Mexico and Central America, entering rivers.

I have examined the type, a specimen of $110 \mathrm{~mm}$., from the Gulf of Fonseca, and some small examples from the Rio Presidio.

3. Achirus fasciatus, Lacep., 1803.

Solea achirus, Günth. Cat. Fish. iv. p. 476 (1862).

Achirus fasciatus, Jord. \& Everm. Bull. U.S. Nat. Mus. xlvii. 1898, p. 2700.

Hab. Atlantic Coasts of the Southern United States and Mexico, entering rivers.

I have examined six examples, measuring up to $120 \mathrm{~mm}$. in total length, from various localities. 


\section{Fam. 2. GOBIESOCID IS.}

The Cling-fishes are small marine fishes, easily recognizable by the naked body, the short dorsal and anal fins without spinous rays, the widely separated ventral fins, which are jugnlar in position, and by the small gill-openings. They have an adhesire ventral disc, by means of which they adhere to stones or shells. They are usually found between tide-marks; bnt Pellegrin (Bull. Mus. Paris, vii. 1901, p. 206) has recorded that a species which he identifies with Goliesox adustus, Jord. \& Gilb., originally described from Mazatlan, is common in rapid streams near Tepic, Jalisco, and in the Rio Grande de Santiago.

\section{Fam. 3. GOBIID 耵.}

A large family, cbiefly marine, but with representatives in the fresh waters of all parts of the world. The Gobiidæ may easily be distinguished from other Acanthoptergians found in the rivers of Mexico and Central America by the following peculiarities:- The spinous portion of the dorsal fin is composed of a few slender non-articulated rays; the anal fin is preceded by a single slender spine; the pectoral is symmetrical and has a broad, subvertical base; the ventrals, inserted below the base of the pectorals, consist each of a short feeble spine and of five branched rays; the gill-openings are restricted, the gill-membranes being more or less broadly attached to the isthmus.

Synopsis of the Genera represented in the Fresh Waters of Mexico and Central America.

I. Ventral fins separate.

Jaws with bands of pointed tectlı; vomer with teeth; lower jaw projecting; gill-openings extending forward to below the eye. . . I. Pinlrenus.

Jaws with bands of pointed teeth; palate toothless; lower jaw projecting; gill-openings not extending forward to below the cye . .

Jaws with bands of movable, slender teeth with truncatc apices; palate toothless; jaws equal antcriorly; gill-openings not extending forward to below the cye . . . . . . . . . . . 3. Dormitator.

II. Ventral fins united to form a dise.

A. Two dorsal fins.

1. Each jaw with a series of numcrous slender teeth, those in the lower jaw horizontal and sometimes hidden by the gum; lower jaw witl an inner scries of a few crect conical tcetlı . . . . . . . 4. Sicrorum.

2. Jaws with bands of pointed tectlı.

Two or three fleshy flaps on the anterior edge of pectoral areh, projecting into the gill-cavity . . . . . . . . . 5. Chonophorus.

No dermal flaps on the pectoral arclı. . . . . . . . . 6. Gorius.

B. A single dorsal fin . . . . . . . . . . . . . . . . . 7. Gobromees. 
1. PHILYPNUS, Cuv. \& Val., 1837.

Philypnus, Jord. \& Everm. Bull. U.S. Nat. Mus. xlvii. 1898, p. 2194.

Body elongate, compressed or subcylindrical; head elongate, more or less depressed. Wouth large, oblique; lower jaw projecting; jaws with pointed teeth in bands, the outermost series erect, fixed, somewhat recurved, the inner series depressiblo; vomer with a broad crescentic patch of small pointed teeth. Eyes moderate or rather small; interorbital region rather broad. Gill-openings wide, extending forward to below the eyes. Scales ctenoid, rather small, corering the body and the greater part of the head. Two dorsals, with VI, I 9 rays; anal with I 9-10 rays; caudal rounded; pectoral of moderate length, symmetrical, rounded; rentrals well separated, each with a short concealed spine and 5 branched rass.

This genus consists of two species only, which appear to be principally fluviatile, but enter the sea. In both the development of the soft vertical fins is subject to great sexual variation, the males having these fins larger, the second dorsal especially being much more elevated than in the females.

\section{Philypnus dormitator.}

Gobiomorus dormitor, Lacep. Hist. Nat. Poiss. ii. p. 599 (1798) ${ }^{1}$; Jord. \& Eigenm. Proc. U.S. Nat. Mus. 1886, p. $482^{2}$; Eigenm. \& Eigenm. Proc. Cal. Ac. (2) i. 1888, p. $52^{3}$.

Platycephalus dormitator, Schneider, Bloch's Syst. Ichtlı. p. 60, t. 12 (1801) '.

Eleotris dormitatrix, Cuv. Règne Anim. ed. 2, ii. p. 246 (1829) ${ }^{5}$; Günth. Cat. Fish. iii. p. 119 (1861) $)^{\circ}$.

Philypnus dormitator, Cuv. \& Val. Hist. Nat. Poiss. xii. p. 255 (1837 ${ }^{7}$; Poey, Mem. ii. p. 381 $(1856)^{8}$, and Enum. p. 128 (1875) ${ }^{\text {; }}$; Girard, U.S. \& NLex. Bound. Survey, Ichth. p. 29, t. 12. fig. 13 (1859) ${ }^{10}$; Jord. \& Gilb. Synopsis, p. 631 (1883) ${ }^{11}$; Jord. \& Everm. Buil. U.S. Nat. Mus. xlvii. 1898, p. 2194, fig. $781^{12}$.

Eleotris longiceps, Günth. Proc. Zool. Soc. 1864, p. $151^{13}$, and Trans. Zool. Soc. vi, 1869, p. $440^{14}$. Philypnus dormitor (part.), Mcek, Zool. Pub. Columbian Mus. v. 1904, p. $226^{15}$.

Depth of body 5 to 6 in the length, leugth of head 3 to $3 \frac{1}{4}$. 57 to 68 seales in a longitudinal series, 26 to 31 from interorbital region to origin of anterior dorsal. Dorsal VI, I 9. Anal I 9. Candal peduncle 2 to $2 \frac{1}{2}$ as long as deep. Body marbled with brownish, sometimes with an irregular dark band froin operculum to base of caudal, sometimes with light spots ou the lower part of the sides; fins with series of dark spots.

Hab. Atlantic Coast Rivers from Texas to Surinam, and also in West-Indian Islands:

Rio Grande ${ }^{10}$; Rio Soto la Marina ${ }^{15}$; Rio Panuco ${ }^{15}$; Rio Motagua (Salvin); Lake Yzabal (Salvin); Lake Nicaragua (Salvin ${ }^{1314}$ ).-Cuba ${ }^{89}$; Jamaica ${ }^{6}$; Haiti ${ }^{7}$; Porto Rico ${ }^{7}$; Dominica; Martinique ${ }^{4}$; St. Vincent; Barbados ${ }^{6}$; Trinidad.

Here described from several specimeus, 120 to $330 \mathrm{~mm}$. in total length, including the type of Eleotris longiceps, from Southern Mexico, Lake Yzabal, the Rio Motagua, and Lake Nicaragna.

2. Philypnus maculatus. (Tab. I. fig. 2.)

Lembus maculatus, Güuth. Cat. Fish. i. p. 505 (1859) ${ }^{\text {}}$, and Proc. Zool. Soc. 1860, p. $236^{2}$. Philypnus lateralis, Gill, Proc. Ac. Philad. 1860, p. $123^{3}$; Jord. \& Gilb. Proc. U.S. Nat. Mus. 
1881, p. $232^{4}$, and 1882, pp. $368^{\circ}, 372^{5}, 377^{\top}$, and $380^{\circ}$; Jord. \& Everm. Bull. U.S. Nat. Mus. xlvii. 1898, p. $2195^{\text {? }}$.

Eleatris lembus, Günth. Cat. Fish. iii. p. $121(1861)^{10}$.

Eleotris lateralis, Güntlı. t. c. p. I22 ${ }^{11}$.

Gobiomorus lateralis, Eigenm. \& Fordice, Proc. Ac. Philad. 1885, p. $69^{12}$; Jord. \& Eigenm. Proc.

U.S. Nat. Mus. 1886, p. $482^{13}$; Eigenm. \& Eigenm. Proc. Cal. Ac. (2) i. 1888, p. $51^{14}$.

Gobiomorus maculatus, Eigenm. \& Fordice, t. c. p. $70^{15}$.

Plilypnus dormitor (part.), Meek, Zool. Pub. Columbian Mus. v. 1904, p. $226{ }^{16}$.

Depth of body $3 \frac{2}{3}$ to 5 in the length, length of the head $2 \frac{3}{4}$ to 3 . 55 to 60 scales in a longitudinal series, 20 to 24 from interorbital regrion to origin of anterior dorsal. Dorsal VI, I 9. Aual I 10. Caudal peduncle $1 \frac{1}{2}$ to 2 as long as deep. Body usually spotted or marbled with dark brownish and with a more or less distinct dark longitudinal band from eye to base of caudal; an oblique dark stripe from eye across the præorbital; a vertical stripe from eye to corner of mouth; a dark spot on the upper part of the base of pectoral; soft vertical fins with or without series of small dark spots on the interradial membranes, sometimes with series of light spots.

Hab. Pacific Coast Rivers from California to Ecuador:

Cape St. Lucas ${ }^{345}$.-Rio Presidio ${ }^{9}$; Colima ${ }^{6}$; Tehuantepec ${ }^{16}$; San José $^{8}$; Panama ${ }^{7}$.-Ecuador ${ }^{12} 10$.

Here described from six specimens, 128 to $215 \mathrm{~mm}$. in total length, from Presidio and Ecuador, including the types of the species.

This species has the head and body more compressed than its Atlantic congener, and has constantly a ray more in the anal fin.

\section{ELEOTRIS, Gronow, 1763.}

Guavina and Eleotris, Jord. \& Everm. Bull. U.S. Nat. Mus. xlvii. 1898, pp. 2198 \& 2199.

Body elongate, subcylindrical, more or less compressed posteriorly; head broad, more or less depressed. Mouth large, oblique; lower jaw projecting; jaws with small pointed teeth in bands; palate toothless. Eyes rather small; interorbital region broad. Gill-openings moderately wide, extending forward to below the angle of præoperculum, the gill-membranes attached to the isthmus. Scales small or moderate, ctenoid or cycloid; no lateral line. Two dorsals, with VI-VIl, I 7-13 rays; anal with $I$ 7-13 rays; caudal rounded; pectoral symmetrical, rounded; ventrals well separated, each with a short feeble spine and 5 branched rays.

This widely distributed tropical genus comprises several species, some of which are strictly marine, whilst some enter rivers, and others appear to be permanently fluviatile. The three species which are known to occur in the rivers of Mexico and Central America may be distinguished thus:-

I. D. VII, I 10. A. I 10. 95 to 110 scales in a longitudinal series; no præoper-

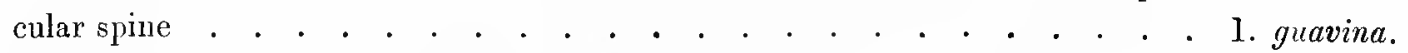

II. D. VI, I 8. A. I 8.55 to 70 scales in a longitudinal series; a small concealed antrorse spine at the angle of the preoperculum.

Deptl of body 4 to $4_{3}^{\circ}$ in the length . . . . . . . . . . . . 2. pisonis.

Depth of body 5 to 6 in the length . . . . . . . . . . . . . 3. picta. 


\section{Eleotris guavina*.}

Eleotris guavina, Cuv. \& Val. Hist. Nat. Poiss. xii. p. 223 (1837) ${ }^{1}$; Günth. Cat. Fish. iii. p. 124 $(1861)^{2}$; Poey, Repert. i. p. 337 (1867) ${ }^{3}$, Syn. p. 395 (1868) ${ }^{4}$, and Enum. p. 127 (1875) ${ }^{5}$. Guavina guavina, Eigcnm. \& Fordice, Proc. Ac. Philad. 1885, p. $73^{6}$; Jord. \& Eigenm. Proc. U.S. Nat. Mus. 1886, p. $483^{7}$; Eigenm. \& Eigenm. Proc. Cal. Ac. (2) i. 1888, p. $54^{8}{ }^{8}$; Jord. \& Everm. Bull. U.S. Nat. Mus. xlvii. 1898, p. $2198^{\circ}$.

Depth of body 4 to 5 in the length, length of head $3 \frac{3}{5}$ to 4 . No præopercular spine. Dorsal VII, I 10. Anal I 10. 95 to 110 scales in a longitudinal series. Uniformly brownish (in spirit).

Hab. Atlantic Coasts and Rivers from Mexico and Cuba to Southern Brazil :

Central America ${ }^{8}$; Turbo $^{8}$; Demerara ${ }^{2}$; Brazil $^{8}$; Cuba ${ }^{345}$; Martinique $^{1}$; Barbados ${ }^{8}$.

Here described from two specimens, 150 and $220 \mathrm{~mm}$. in total length, from Demerara.

\section{Eleotris pisonis.}

Gobius pisonis, Gmelin, Linn. Syst. Nat. p. 1206 (1788) '

Gobius amorea, Walbaum, Artedi Pisc. iii. p. 205 (1792) ${ }^{2}$.

Eleotris pisonis, Scbneid. Bloch's Syst. Ichth. p. $68(1801)^{3}$; Eigenm. \& Fordice, Proc. Ac. Philad. 1885, p. $75^{4}$; Jord. \& Eigenm. Proc. U.S. Nat. Mus. 1886, p. $483^{5}$; Eigenm. \& Eigenm. Proc. Cal. Ac. (2) i. 1888, p. $55^{\circ}$; Jord. \& Everm. Bull. U.S. Nat. Mus. xlvii. 1898, p. $2201^{7}$; Meck, Zool. Pub. Columbian Mus. v. 1904, p. $228^{8}$.

Eleotris gyrinus, Cuv. \& Val. Hist. Nat. Poiss, xii. p. 220, t. $356(1837)^{\circ}$; Girard, U.S. \& Mexico Bound. Survey, Ichth. p. 28, t. 12. figs. 11 \& 12 (1859) ${ }^{10}$; Günth. Cat. Fish. iii. p. $122(1861)^{11}$; Poey, Repert. i. p. $336(1867)^{12}$, Syn. p. $395(1868)^{13}$, and Enum. p. $127(1875)^{14}$; Jord. \& Gilb. Synopsis, p. $631(1883)^{15}$.

Culius perniger, Cope, Proc. Am. Phil. Soc. 1870, p. $473^{16}$.

Culius belizianus, Sauv. Bull. Soc. Philom. 1879, p. $55^{17}$; Eigenm. \& Fordice, 1. c. ${ }^{18}$; Eigenm. \& Eigenm. 1. c. ${ }^{19}$.

Eleotris perniger, Eigenm. \& Eigenm. 1. c. ${ }^{20}$; Jord. \& Everm. t. c. p. $2201{ }^{91}$.

Depth of body 4 to $4 \frac{2}{3}$ in the length, length of head 3 to $3 \frac{1}{2}$. A small concealed antrorse spine at the angle of the præoperculum. Dorsal VI, I 8. Anal I 8. 54 to 67 scales in a longitudinal series.

$H a b$. Atlantic Coasts and Rivers from Florida to Southern Brazil $\uparrow$ :

Florida ${ }^{6}$; Rio Grande ${ }^{10}$; Vera Cruz ${ }^{8}$; Boca del Rio ${ }^{8}$; Belize ${ }^{17}$.- Surinam ${ }^{9}$; Brazil $^{16}$; Cuba ${ }^{6121314}$; Haiti; Dominica ${ }^{69}$; Martinique ${ }^{69}$; St. Viucent ${ }^{6}$; St. Christopher ${ }^{6}$.

Here described from several specimens from Haiti, St. Vincent, Dominica, and Pernambuco, measuring up to $160 \mathrm{~mm}$. in total length. This series of examples includes some with the cheeks wholly or partially naked, corresponding to E. perniger, and others which closely approach $E$. abacu'us, Jord. \& Gilb., in the small number of scales in a longitudinal series.

E. amblyopsis, Cope, is a closely allied species, but appears to have larger scales.

* Eleotris Zrasiliensis, Sauv., 1880, is probably not distinct from E. guavina.

+ This or a very similar species has been recorded from West-Africau rivers. 


\section{Eleotris picta.}

Eleotris picta, Kncr \& Steind. Abhandl. Bayern Ak. 1864, p. 18, t. 3. fig. I ${ }^{1}$.

Culius requidens, Jold. \& Gilb. Proc. U.S. Nat. Mus. 1881, p. $461^{2}$, and 1882, pp. $372^{3} \& 380^{4}$.

Eleotris cquidens, Eigenm. \& Fordice, Proc. Ac. Philad. 1885, p. $76^{5}$; Jord. \& Eigenm. Proc. U.S.

Nat. Mus. 1886, p. 483 ${ }^{6}$; Eigenm. \& Eigenm. Proc. Cal. Ac. (2) i. 1888, p. $55^{7}$.

Eleotris pictus, Jord. \& Evcrm. Bull. U.S. Nat. Mus. xlvii. 1898, p. $2201^{8}$.

Depth of body 5 to 6 in the length, length of head 3 to $3 \frac{1}{3}$. A small concealed antrorse spine at the angle of the preoperculum. Dorsal VI, I S. Anal I 8. 60 to 70 scales in a longitudinal series. Back and sides obscurely spotled or clouded with blackish; lower parts with pale spots; fins with series of small dark spots on the rays and with irregular markings on the iuterradial membranes.

Ilab. Pacific Coasts and Rivers from California to Ecuador:

Cape St. Lucas ${ }^{4}$ - Mazatlan ${ }^{2}$; Presidio (Forrer); Colima ${ }^{3}$; Rio Bayano, Panama ${ }^{1}$.-Ecuador.

Here described from several specimens, measuring up to $380 \mathrm{~mm}$. in total length, from the Rio Presidio and from Ecuador. This species is very close to the Atlantic E. pisonis, which has a deeper body and a shorter and broader head.

\section{DORMTTATOR, Gill, 1862.}

Dormitator, Jord. E Everm. Bull. U.S. Nat. Mus. xlvii. 1898, p. 2195.

Body oblong, compressed; head broad, obtuse. Mouth moderate, wore or less oblique; jaws equal anteriorly, with bands of small, movable, slender tecth with truncate apices; palate toothless. Eyes rather small; interorbital region broad. Gill-openings moderately wide, extending forward nearly to below the angle of preoperculum, the gill-membranes attached to the isthmus. Scales etenoid, rather large, corering the body and the greater part of the head; no lateral line. Two dorsals, the first of 7 flexible spines, the sceond of a slender spine and 8 branched rays; anal similar to the second dorsal, with a slcuder spine and 9 or 10 brauched rays; caudal rounded; pectoral of moderate length, symmetrical, rouncled; ventrals below the base of the pectorals, close together but not united, each with a short concealed spine and 5 branehed rass.

This genus is now usually considered to contain a single species, subject to considerable variation in form and colour. I find, however, that it is always possible to distinguish between specimens from the Atlantic and Pacific, and, although the differences are but slight, the two forms may provisionally be recognized as specifically distinct.

\section{Dormitator maculatus.}

Scicena maculata, Bloch, Ausl. Fische, t. 209. fig. $2\left(\mathbf{1 7 9 0 ) ^ { 1 }}{ }^{\text {; }}\right.$ Schneid. Bloch's Syst. 1chth. p. 80 (1801) ${ }^{2}$.

Eleotris muyiloides, Cuv. \& Val. Hist. Natt. Poiss. xii. p. 226 (183\% ${ }^{3}$.

Eleotris grondistuetuat, Cuv. \& Val. t. c. p. $299^{1}$; Günth. Cat. Fish. iii. p. 113 (1861)

Eleotris sima, Cuv. \& Val. t. c. p. $232^{\circ}$; Günth. 1. c. 7 .

Eleotris somenolentus, Girand, Proc. Ac. Plilad. 1858, p. I69", and U.S. \& Mex. Bouml. Survey,

Fish. 1. 28, t. 12. figs. 1-3 (1859) " ; Günth.t. c. 1. $555^{10}$.

Eleotris omocyaneus, l'ucy, Mcm. ii. p. 269 (1860) ${ }^{11}$. 
Eleotris gundlachi, Poey, t. c. p. $272^{12}$.

Eleotris maculata (part.), Günth. t. c. p. $112^{13}$.

Dormitator lineatus, Gill, Proc. Ac. Philad. 1863, p. $271^{11}$.

Dormitator gundlachi, Poey, Syuopsis, p. 396 (1868) ${ }^{15}$, and Enum. p. 128 (1875) ${ }^{16}$.

Dormitator omocyaneus, Poey, 1. c. ${ }^{17}$ and 1. c. ${ }^{18}$.

Dormitator maculatus (part.), Jord. \& Gilb. Synopsis, p. 632 (1883) ${ }^{19}$; Jord. \& Figcum. Proc. U.S. Nat. Mus. 1886, p. $482^{20}$; Eigenm. \& Eigenm. Proc. Cal. Ac. (2) i. 1888, p. $52^{21}$; Jord. \& Everm. Bull. U.S. Nat. Mus. xlvii. 1898, p. 2196 ${ }^{2 * 2}$; Meek, Zool. Pub. Columbian Mus. v. $190 \mathrm{\&}$, p. $227^{23}$.

Dormitator maculatus, Eigenm. \& Fordice, Proc. Ac. Philad. 1885, p. $71^{24}$.

Depth of body $2 \frac{2}{3}$ to $3 \frac{1}{2}$ in the length, length of head $3 \frac{1}{2}$ (young) to 4 (adult). 33 to 38 scales in a longitudinal series. Dorsal VII, I S. Anal I 9-10. Soft rertical fins, especially the secoud dorsal, more dereloped in males than in females. Body irregularly marbled or with alternate light and dark oblique crass-bars; sometimes a longitudinal band from operculum to base of caudal; sometimes dark longitudinal lines along the scries of scales; a dark, nearly vertical stripe from eye to corner of mouth; usually 3 or 4 dark horizontal stripes across the cheek and operculum; a dark humeral spot; a dark bar at the base of the pectoral; rertical fins duskj, sometimes light-edged, the spinous dorsal, anal and caudal sometimes, the sott dorsal alwajs with series of spots.

Hab. Atlantic Coasts and Rivers of the Atlantic Slope from Carolina to Para, and also in the West-Indian Islands:

Savannah ${ }^{14}$.- Rio Grande ${ }^{8}{ }^{9}$; Vera Cruz ${ }^{6}$; Cordora ${ }^{10}$; Boca del Rio ${ }^{23}$; Rio Papaloapam ${ }^{23}$.CCuba 1112151718 ; Haiti; St. Croix; Martinique ${ }^{3}$; Trinidad ${ }^{13}$; Demerara $^{13}$; Surinam ${ }^{3}$.

Here described from sereral specimens, 100 to $180 \mathrm{~mm}$. in total length, from Southern Mexico, Haiti, and St. Croix.

2. Dormitator latifrons. ('Tab. I. fig. 3.)

Eleotris latifrons, Richards. Voy. 'Sulphur,' Tishes, p. 57, t. 35. figs. 4-5 (1837) '.

Eleotris maculata (part.), Günth. Cat. Fish. iii. p. 112 (1861) .

Dormitator microphthulmus, Gill, Proc. Ac. Philad. 1863, p. $170^{3}$.

Eleotris maculata (non Bloch), Crinth. Trans. Zool. Soc. ri. 1869, p. 440 ".

Dormitator maculatus (nou Bloch), Jord. \& Gill. Proc. U.S. Nat. MLus. 1881, p. 289 ${ }^{5}$, and 1882, pp. $368^{\circ}, 372^{\top}, 37 \sigma^{8}, \& 380^{\circ}$, and Bull. U.S. Fish. Comm. 1882, p. $108^{10}$.

Dornitator maculatus (part.), Jord. \& Gillb. Synopsis, p. 632 (1883) ${ }^{11}$; Jord. \& Eigcnm. Proc. U.S. Nat. Mus. 1886, p. $482^{12}$; Eigenm. \& Eigenm. Proc. Cal. Ac. (2) i. 1888, p. $52^{13}$; Jord. \& Everm. Bull. U.S. Nat. Mus. xlvii. 1898, p. $2190^{14}$; Meck, Zool. Pub. Colnmbian Mus. v. 1904, p. $22 \tau^{15}$.

Durmitator latifrons, Eigenm. \& Fordice, Proc. Ac. l'hilad. 1885̃, p. $72{ }^{16}$.

Length of head 3 (joung) to $3 \frac{1}{3}$ (adult) in the length of the fish; mouth rather less oblique thau in $D$. maculatus, usually entirely below the lerel of the eye; in other characters showing extreme similarity to the preceding species.

IIab. Pacific Coasts and Rivers of the Pacific Stope, from California to Ecuador:

Cape St. Lucas 58.-Presidio (Forrer); Mazatlan ${ }^{9} 1014$; Huamuchal ${ }^{4}$ (Salvin); Panama ${ }^{3}$ 7.-Giuayaquil 2. BIOL. CEnTr.-AMer, Pisces, October 1906. 
I have examined numerous examples of this form from Presidio, Huamuchal, and Guayaquil, measuring from 110 to $280 \mathrm{~mm}$. in total length.

\section{SICYDIUM, Cuv. \& Val., 1837.}

Sicydium and Cotylopus, Jord. \& Ercrm. Bull. U.S. Nat. Mus. xlvii. 1898, pp. 2205 \& 2207. Oreogobius, Bouleng. Ann. Mag. N. II. ( $($ ) iv. 1899, p. 126.

Bedy elongate, subcylindrical. Mouth wide, subterminal, the lower jaw the shorter; lips thick; both jaws with a scries of numerous slender teeth, those in the lower jaw horizontal, sometimes completely hidden by the gum; an inner sories of erect conical teeth in the lower jaw; palate toothless. Eyes small or of moderate size; interorbital region noderatoly broad. Gill-openings of moderate widtl, nearly rertical, not produced forward below. Scales smill, etenoid. Two dorsals, with T1 (V-TI1), 1 10-I2 rays; anal with I 9-11; eaudal rounded; pectoral symmetrical, rounded; rentrals united to form a disc which is free from the body posteriorly, with a basal mombrane which is folded to form a pit auteriorly.

In the males the dorsal fins are more elevated than in the females, whilst the rays of the anterior dorsal are produced into long filaments.

'The genus comprises about thirty species from tropical rivers near the sea, three of which are found in Mexico and Central America.

\section{Sicydium salvini.}

Sicydium salrini, Grant, Proc. Zool. Soc. 1884, p. 159, t. 12. fig. $2^{1}$.

Sicyopterus salvini, Jord. \& Eigenm. Proc. U.S. Nat. Mus. 1886, p. 485 .

Cotylopus salcini, Jord. \& Evcrm. Bull. U.S. Nat. Mus. xlvii. 1898, p. $2208^{3}$.

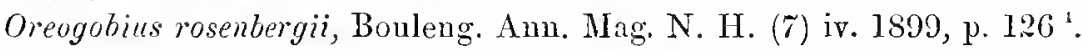

Horizontal tceth of lower jaw consuicnous. Scales cxtending forward on the upper surface of head nearly to the interorbital region; abdomen completely corered with small scales; 68 to 76 scules in a longitudinal series. Dorsal VI, I 10. Anal I 10. Body with broad irregular dark cross-bars and with a more or less distinct dark longitudinal band from pectoral to base of caudal ; each scale with a dark spot at the base; dorsal fins dusky, the second usually with numerous small dark spots, which may unite to form a netrork; anal dusky in tho male, in the fewale pale with a dark intramarginal stripe.

IIab. Panama ${ }^{1}$-- WVestelin Ecuador ${ }^{4}$.

Here described from five specimens, measuring up to $120 \mathrm{~mm}$., including the types of the species and of 0 . rosenbergii.

\section{Sicydium gymnogaster.}

Sicydium gymmogaster, Grimt, Proc. Zool. Soc. 1881, p. 158, t. 11. fig. 2 and t. 12. fig. 6 '.

Siryoptcrus gymmogaster, Jord. \& Eigcum. Proc. U.S. Nat. Mus. 1886, p. I85².

Cotylopus gymnoyaster, Jord. \& Evcrm. Bull. U.S. Nat. Mus, xlvii. 1898, p. 2207³.

Horizontal teeth of lower jaw nsually more or less completely concealed beneath a fleshy pad. Scalos not. exteuling forward on to the head; abdomon with a median naked area; 60 to 74 scales in a longitudinal scries*. Dorsal VT, I 10. Anul I 10. Coloration as iu S. sulvini, but the fius without spots.

* In three specimens the scales extend forwarl abovo to the lovel of the gill-opening, and in these I count 6i; to 74 in a longitudinal series. Usually the scales conmence above the pectoral, and consequeutly this uumber is fewer. 
Hab. Mexico, Michoacan (Mus. Mexico), Hacienda del Hobo, Southern Mexico (Geddes), Misantla*, Vera Cruz ${ }^{1}$ (Irres. Brit.).

I have examined several examples, measuring up to $120 \mathrm{~mm}$. in total length.

3. Sicydium multipunctatum, nom. nov. (Tab. I. fig. 1.)

Cotylorus punctatus $\dagger$, Regan, Ann. Mag. N. H. (7) xvi. 1905, p. $362^{2}$.

Horizontal teeth of lower jaw concealed. Scales not extending forward on to the head; abdomen with a median naked area; 85 scales in a longitudinal series. Dorsal VI, I 10. Anal I 11. Head covercd with small dark spots; a similar spot on each scale of the body; numerous small dark spots on the dorsal fins and on the base of the pectoral.

IIab. Mexico, Tequixistlan in Oaxaca ( Gadow $\left.^{1}\right)$.

This species is known only from the type, a specimen $132 \mathrm{~mm}$. in total length.

\section{CHONOPHORUS, Poey, $186 \mathrm{I}$.}

Awaous, Jord. \& Everm. Bull. U.S. Nat. Mus. xlvii. 1898, p. 2234.

Body elongate, little compressed; head naked, elongate; mouth moderate or large, horizontal; jaws equal anteriorly or the lower tbe shorter, with narrow bands of small pointed teeth and an outer series of more or less distinctly enlarged teeth; palate toothless. Eyes moderate, placed high; interorbital region rather narrow. Gill-opening nearly vertical, placed in front of the base of the pectoral, scarcely produced forward below; 2 or 3 fleshy flaps on the anterior edge of the pectoral arch, projecting into the branchial chamber and covered by the operculum. Scales small or moderate, ctcnoid. Two dorsals, with VI, I 9-12 rays; anal with I $9-13$ rays; caudal ronnded; pectoral symmetrical, rounded; ventrals completely united to form a rounded dise, which is free from the body and has a well-dereloped basal membrane.

This genus comprises about ten species from the Tropics, all of which enter or reside in rivers. The species are variable and difficult to define; the males differ from the females in having the snout more produced and the month larger.

\section{Chonophorus banana.}

? Gobius taiasica, Lichtenstein, Berl. Abhandl. 1822, p. $273^{1}$.

Gobius banana, Cuv. \& Val. Hist. Nat. Poiss. xii. p. 103 (1837) ${ }^{2}$; Günth. Cat. Fish. iii. p. 59 $(\mathbf{1 8 6 1})^{3}$; Steind. Sitzungsb. Ak. Wien, lvi. 1867, p. 351 ${ }^{4}$; Cope, Trans. Am. Phil. Soc. xiv. 1871, p. $473^{5}$; Jord. \& Gilb. Proc. U.S. Nat. Mus. 1882, pp. $368 \& 379^{\circ}$.

Gobius martinicus, Cuv. \& Val. t. c. p. $105^{7}$; Casteln. Anim. Am. Sud, Poiss. p. 26 (1855) ${ }^{8}$.

Gobius mexicanus, Gïnth. t. c. p. $61^{9}$.

Chonophorus bucculentus, Poey, Mem. ii. p. 275 (1861) ${ }^{10}$.

Rhinogobius contractus, Poey, t. c. p. $424^{11}$, and Enum. p. $125(1875)^{12}$.

Rhinogovius bucculentus, Poey, Syn. p. $394(1868)^{13}$, and Enum. p. $125^{14}$.

Gobius dolichocephalus, Cope, Trans. Am. Phil. Soc. 1869, p. $403^{15}$.

* This locality was erroneonsly giren as Mazatlan in the original description.

$\uparrow$ The differences in the form of the upper teeth appear to be too much subject to intergradation to serre for generic distinctions. If Cotylopus be not recognized, the name punctatus must be changed, being preoccupied in Sicydium by S. punctatum, Perugia, 1806. 
Chonophorus taiusica, Jord. \& Eigcnm. Proc. U.S. Nat. Mus. 1886, p. 500 ${ }^{16}$; Eigenm. \& Eigenm. Proc. Cal. Ac. (2) i. 1881, p. $68^{17}$; Meek, Zool. Pub. Columbian Mus. v. 1904, p. $233^{14}$.

Chonophorus mexiconus, Jord. \& Eigenm. t.c. p. $501^{19}$; Eigenm. \& Eigenm. l. c. ${ }^{20}$; Mrcek, l. c. ${ }^{21}$. Awaous taiasica, Jord. Proc. Cal. Ac. (2) v. 1895, 1) 494"2: Jord. \& Everm. Bull. U.S. Nat. M[us. xlvii. 1898, p. $2236^{23}$; Jord. \& Snyd. Bull. U.S. Fish. Comm. 1900, p. 147 ${ }^{24}$; Meek, Zool. Pub. Columbian Mins. iii. 1902, p. $121^{25}$.

twaous mexicanus, Jord. \& Evcrm. t. c. p. $2937^{20}$.

Depth of body 5 to 6 in the length, length of head 3 to $3 \frac{3}{\bar{n}}$. Dorsal VI, 1 10. Anal I 10. 60 to 84 scales in a longitudinal series, 20 to 26 in a transrerse series from origin of second dorsal to that of the anal fin. Olivaeeous; back and sides with irregular dark spots; sides of head with spots or oblique lines; a dark bar on the upper part of base of pectoral; dorsal, caudal, and pectoral fins with serios of dirk spots; rentrals and anal immaculate.

Hal. Coasts and Rivers of Tropical America from Southern California to Panama and from Mexico to Brazil, and also in the West-Indian Islands:

Cape St. Lucas ${ }^{6}$.-Presidio ${ }^{22}$; Puente de Ixtla; Balsas and Cuautla; Rio Balsals ${ }^{18}{ }^{25}$; Valles, San Luis Potosi ${ }^{18}$; San Francisco, La Antigua and Perez, Vera Cruz ${ }^{185}$; Orizaba ${ }^{15}$; San José ${ }^{6}$; Rio Notagua (Salvin); Panama ${ }^{17}$. Cuba ${ }^{1011} 1213$; Haiti ${ }^{2}$; Martinique ${ }^{717}$; St. Vincent, St. Croix ${ }^{17}$; St. Lucia ${ }^{17}$; Barbados ${ }^{17}$; Trinidad (Guppy); Brazil ${ }^{17}$.

Here described from several specimens, measuring up to $300 \mathrm{~mm}$.

\section{Chonophorus transandeanus.}

Gobius transendeams, Günth. Cat. Fish. iii. p. 62 (1861) ${ }^{3}$.

?Awaous nelsoni, Everm. Proc. Biol. Soc. Washington, xii. 1895, p. $3^{2}$; Jord. \& Evcrm. Bull.

U.S. Nat. Mus. xlvii. 1898, p. $2285^{3}$.

Gobius guentheri, Regan, Amı. Mag. N. II. (7) xii. 1903, p. 629 !.

Differs from $C$. banana especially in having only from 15 to 18 scales between the origins of the second dorsal and anal fins.

Mal. Wusterix Mexico, Rosario, Sinaloa 2 3.-TVesters Ecuddor ${ }^{14}$.

G. guentheri was based on male examples, which differ considerably from the females. Probably A. melsoni will prove to be identical with G. transanderme, and the specics will be found to occur in all the Pacific Coast streams from sinaloa to Ecuador.

\section{GOBIUS, Linn.}

Gotins, Jorr. \& Evcrm. Bull. U.S. Nat. MIus, xlvii. 1898, p. 22,10.

budy more or less elongite, compressed posteriorly; month moderate; jaws with sereral series of pointed teeth; pilate toothless. Lyes plined high; interobilal region wot very wide. Gill-opening nearly verticil, in front of the bise of pectoral, not on sancely produced forwarl helow; no theshy flaps on pectoral arch. Seales usually ateniul. 'Two dorsils, the ant rion of live to seren spines. Voutrals completely mited to form a runded disc, which is lree from the budy and has a basal membrane. 
The limits of this large and cosmopolitan genus have never been precisely defined. Most of its representatives are marine, but some are fluviatile. Dr. Meek has recently described two species from fresh and brackish waters near Vera Cruz.

\section{Gobius parvus.}

Gobius parvus, Meek, Zool. Pub. Columbian Mus. v. 1904, p. 230, t. $17^{1}$.

Dorsal VI 11. Anal 12. 30 scales in a longitudinal series.

Hab. Mexico, Vera Cruz ${ }^{1}$.

\section{Gobius claytoni.}

Gobius claytoni, Meek, t. c. p. 231, t. $17^{1}$.

Dorsal VI 12. Anal 13. 42 scales in a longitudinal series.

Hab. Mexico, Vera Cruz ${ }^{1}$.

\section{GOBIOIDES, Lacep., 1798.}

Gobioides, Jord. \& Everm. Bull. U.S. Nat. Mus. xlvii. 1898, p. 2263.

Body very elongate, compressed posteriorly; head comparatively short; mouth large, oblique; lower jaw more or less distinctly projecting; jaws with bands of small pointed teeth and an onter series of strongly enlarged teeth; palate toothless. Eyes small, placed high; interorbital region rather narrow. Gillopening nearly vertical, in front of the base of pectoral, not produced forward below. Scales small, cycloid. A single corsal fin, with V-VII 15-23 rays; anal with I 15-22; caudal pointed; pectoral symmetrical, rounded; ventrals completely united to form a rounded disc, which is frec from the body and has a well-developed basal membrane.

Tropical seas, entering rivers.

\section{Gobioides broussonetii.}

Gobioides broussonetii, Lacep. Hist. Nat. Poiss. ii. p. 580 (1798) ${ }^{1}$; Jord. \& Eigenm. Proc. U.S.

Nat. Mus. 1886, p. $512^{2}$; Bean \& Bean, Proc. U.S. Nat. Mus. 1895, p. $631^{3}$; Eigenm. $\mathbb{\alpha}^{2}$

Eigenm. Proc. Cal. Ac. (2) i. 1888, p. $75^{4}$; Jord. \& Everm. Bull. U.S. Nat. Mus. xlvii. 1898, p. $2263^{\circ}$.

Amblyopus brasiliensis, Sehneid. Bloch's Syst. Ichth. p. 69 (1801) ${ }^{6}$; Cuv. \& Val. Hist. Nat. Poiss. xii. p. 121 (183\% ${ }^{\top}$.

Gobius oblongus, Schneid. t. c. p. $548^{8}$.

Gobioides barreto, Poey, Mem. ii. p. 282 (1861) ${ }^{9}$, Syn. p. 394 (1868) "', and Enum. p. 125 $(\mathrm{I} 8 \pi 6)^{11}$.

Amblyopus broussonetii, Güntl. Cat. Fish. iii. p. 136 (1861) ${ }^{12}$.

Amblyopus mexicanus, O'Shaughnessy, Ann. Mag. N. H. (4) xv. 1875, p. $147^{13}$.

Depth of body 9 or 10 times in the length, length of head 6 to 7 . Dorsal VI 16-17; sixth spine separated by considerable interspaces from the fifth and from the first branched ray; last ray adnate to the caudal. Anal I 15-16. Pectoral more than $\frac{1}{2}$ the length of head, shorter than the ventrals. Caudal $1 \frac{1}{2}$ (young) to twice (adult) as long as the head. Body with dark cross-bars, or with a series of dark syots on each side. 
IIab. Atlantic Coasts and Rivers from Florida to Brazil, and also in the West-Indian Islands :

Mexico ${ }^{13}$; Gulf of Mexico ${ }^{3}$.-Surinam ; Amazons ${ }^{4}$; Rio Janeiro ${ }^{4}$; Cuba ${ }^{910}{ }^{11}$; Martinique.

Here described from six specimens (including the type of A.mexicanns) from Mexico and Surinam, from 230 to $500 \mathrm{~mm}$. in total length.

Gobioides peruanus, Steind., ISS0, from Peru and Ecuador, will probably be found in the Pacific Coast streams of Central America. The body is more slender and the head longer than in G. broussonetii, whilst the outer series of teeth is much stronger.

\section{Fam. 4. CARANGID正.}

A large family of the tropical and temperate seas, represented in the fresh-water fauna of Central America by a single species.

\section{SCOMBROIDES, Lacep., 1800.}

Oligoplites, Jord. \& Everm. Bull. U.S. Nat. Mus. xlvii. 1896, p. 898.

Body ovate or fusiform, compressed; scales lanceolate or linear. M[outh rather larse, oblique, little protractile; teeth somewhat small, pointed, in narrow bands in the jaws; romeriue and palatine teeth present. Spinous dorsal of a few short spines, connected by mcmbrane at the base only; solt dorsal

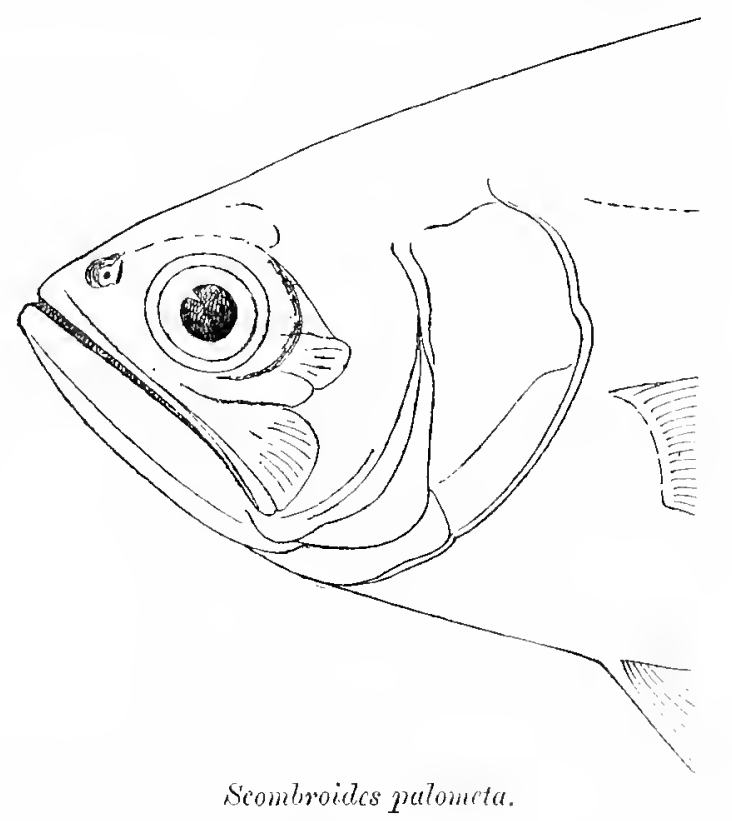

long, more or less elcrated anteriorly and with the posterior rạs much branched and semi-detached as finlets. Anal similar to soft dorsal, preceded by two spines separalu form the rest of the fin. Pectural short, asymmetrical; pentrals with I 5 rays, close together, brew the bise of the pectorals, will the inncr ray attached to the abdomen by membrane. Caudal peducle slender; caudal tiu widely forked.

Mal. Tropical Seas (one speries only from fresll-water lakes of Tropical America). 
The American species belong to the subgenus Oligoplites, Gill, with 4 or 5 dorsal spines and linear scales. They are six in number, viz.: S. saurus, Bl. Schn.; S. refulgens, Gilb. \& Starks; S. altus, Gthr.; S. mundus, Jord. \& Starks ; S. saliens, Bl.; and S. palometa, C. \& V.

The first-named appears to be identical on the Atlantic and Pacific Coasts; the next three are kuown from the Pacific Coast only. S. saliens is an Atlantic species and Pacific records of it should be referred to $S$. mundus.

\section{Scombroides palometa.}

Chorinemus palometa, Cuv. \& Val. Hist. Nat. Poiss. viii. p. 392 (1831) '.

Chorinemus saliens, var. palometa, Günth. Cat. Fish. ii. p. 475 (1860) ${ }^{2}$.

Oligoplites saliens palometa, Jord. \& Everm. Bull. U.S. Nat. Mus. xlvii. 1896, p. $899^{3}$.

Depth of body $3 \frac{2}{3}$ in the length, length of head $4 \frac{3}{4}$. Snout as long as eje, the diameter of which is $4 \frac{1}{2}$ in tho length of head, interorbital width $3 \frac{1}{3}$. Maxillary extending slightly beyond the vertical from the posterior margin of eye. 12 gill-rakers on the lower part of anterior arch. Dorsal 1V, 1 19. Anal II, I 20. Pectoral $\frac{2}{3}$ the length of head. Least depth of caudal peduncle $\frac{1}{4}$ the length of head. Silvery, back brownish; dorsal dusky, other fins yellowish.

IIab. Guatemala, Lake Yzabal (Salvin).-Venezolda, Lake Naracaibo ${ }^{12}$.

Here described from a specimen of $280 \mathrm{~mm}$. from Lake Maracaibo. There is a small example $(90 \mathrm{~mm}$.) from Lake Yzabal in the British Museum. This species has not yet been recorded from other localities, but probably enters the sea.

\section{Fam. 5. CICHLID枓.}

This large family of fresh-water fishes is the dominant perciform group in Tropical America and Africa. In America the Cichlidx extend from Texas to Argentina, and comprise about 150 species, which may be grouped into twenty-three genera. Africa appears to be somewhat richer in both genera and species, whilst a single genus with three representatives occurs in India and Ceylon.

The study of the relationships of the American genera is of considerable interest in connection with their geographical distribution, and leaves no room for doubt that the Mexican and Central-American Cichlid fauma originated with immigrants from the southern continent. The fact that the most generalized South-American genus $A c a r^{\circ} a$ is scarcely generically distinct from the African Paratilapia is also important, and, seeing that there is no reason to believe that the Cichlids have ever been other than a fresh-water group, it lends support to the theory of a land-connection between South America and Africa in Eocene times.

I have recently monographed the American Cichlidr, and, except where some amplification or alteration is necessary, a list of the species only, with keys for their identification, is here given. 
Synopsis of the Cichlid Genera represented in Nexico and Central America.

I. Anal fin with 3 spines.

No lobe on the anterior branchial arcl . . . . . . . . . . 1. Acara.

A compressed lobe on the upper part of the anterior blanchial arch . 2. Geophigus.

II. Anal fin with more than 3 spines.

Teeth all conical or cylindrical; mouth small or moderate, moderately protractile, the promaxillary spines (ascendiug processes) shorter than the head. . . . . . . . . . . . . . .

Teeth all conical or cylindrical; moutli large, very protractile, the priemaxillary spines as long as the head . . . . . . . . t. Perenia.

Several series of small conical teeth and an outcr series of larger tceth, all or most of which arc compressed, incisor-likc . . . . . . 5. Herichthys.

Teeth all compressed, entirc, with pointed or rounded apices . . . . 6. Paraneetroplus.

Teetl all compressed, eutire, with truncate apices . . . . . . . 7. Newrroplus.

Teeth all compressed, mostly tricuspid, only the median ones of the outer series being cutirc, with truncate apices . . . . . . 8. Herotilapia.

\section{ACARA, Heck., 1840.}

Acara, Regan, Amn. Mag. Nat. Hist. ( $\boldsymbol{\tau}$ ) xv. 1905, p. 330.

This, the most generalized genus of American Cichlidx, is rery closely allied to the African Paratilapia, which it resembles not only in external features, but also in the anatomy. The only difference between them is that the maxillary is completely hidden by the proorbital in Acara, whilst it is more or less exposed distally in Paratilapia. Of the nineteen species of Acara, only one is found as far north as the Isthmos of Panama.

\section{Acara ceruleopunctata, Kner \& Steind., 1863.}

Acare cureleupunctata, Regan, Amn. Mag. Nat. Hist. (7) xv. 1905, p. 336.

D. XIV-XV 10-11. A. III 8-9. As. $20-28 \frac{3}{4-4^{\circ}}$ Proporculum scaleless; dorsal and anal fins scaleless; depth of body 2 to $2 \frac{1}{3}$ in the length; 6 gill-rakers on the lower part of anterior arch; dorsal spines increasing in length to the last, whieh is nearly $\frac{1}{2}$ the leugth ol head.

Mab. Panama, Rio Chagres.-N.W. Eceador.

2. GEOPIIAGUS, Heck., 1840.

Geoplatgus, Regan, Mmu. Mag. Nat. Hist. (7) xvii. 1906, p. 50.

Closcly allich to serme, differing only in the structure of the anterior branchial arch. (If the twolve sprecies clevers are fiuntl Americuls.

I. Geophagus crassilabris, Steind., 1877.

Geophrous crossilubris, licyan, Aum. Mag. Nat. Hist. (7) xvii. 1906, p. 58.

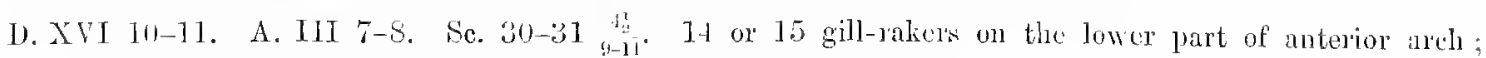
pectoral $\frac{2}{3}$ the lemgth of head, not extendiug to abure the anal.

Ilal. Parims. 


\section{CICHLOSOMA, Swains., 1839.}

Cichlosoma, Regan, Ann. Mag. Nat. Hist. (テ) xvi. 1905, p. 61.

This important genus inchles the American Cichlids with more than three anal spines, with all the teeth conical or cylindrical, and with the mouth not abnormally protractile. There are 68 species-53 in Mexico and Central America, 1 in Cuba, 1 in Barbados, and 13 in South America.

I hare arranged the Mexican and Central-American species in five sections, which appear to be natural groups, but which are not sufficiently sharply defined to rank as subgenera.

Section 1. Timeraps, Günth., 1802.

The tecth of the outer series in the upper jaw are in moderate number (10 to 15 on each side) and regularly increase in size anteriorly; in the lower jaw the teeth are either similar to those in the upper, or the anterior 3 to ; on each side are enlarged, subequal and rather sharply differentiated from the smaller lateral teeth. The mouth is small or of molerate width, the maxillary norer extending beyond the rertical from the anterior margin of eye; the cleft of the mouth is nearly horizontal and entirely below the level of the eye, the preorbital being deep; the jaws are equal anteriorly or the lower is somewhat the shorter; $i$ the adult fish the priemaxillary spines do not extend to above the orbit. The apper profile of the snout is usually slightly convex, and except in two species (C. microplethalmus and C. godmani) the fold of the lower lip is not coutinuous. The dorsal tin has XV-XIX $10-15$ rays and is more or less scaly at the base posteriorly; the anal has IV-VIII $7-12$ rays: the pectoral is usually rather short and only in one species ( $C$. nicuraguense) does it extend beyond the origin of the anal; the caudal is either rounded, truncate, or emarginate with rounded lobes.

This group consists of twenty species from Mexico and Central America, one extending into Colombia.

Heros deppii, Heckel, and Cichlosoma zonatum, Meek, are insufficiently described species, apparently belonging to this section.

\section{Synopsis of the species.}

I. Pectoral not extending to above the anal, which has to to 7 spines.

A. Caudal rounded or truncate.

1. Depth of body $1 \frac{2}{3}$ to 25 in the length.

a. Last dorsal spine 3 to $\frac{a_{5}}{5}$ the length of liead.

a. Lower jaw a little shorter than the upper; depth of body $2 \frac{1}{4}$ to $2 \frac{9}{3}$ in the length; eaudal pedunele nearly as long as or longer than deep. D. XVII-XVIII 12-15.

A. V-VI 8-10.

Length of head $3 \frac{1}{4}$ to $3 \frac{1}{2}$ in the length of the fish . . . . . . . . 1. eigenmanni. Length of heal $3 \frac{2}{3}$ to 4 in the lcugth of the fish . . . . . . . . . . 2. nebuliferum.

$\beta$. Jaws equal anteriorly.

: Caudal peduncle $\frac{1}{2}$ to $\frac{3}{4}$ as loug as deep.

$\dagger$ D. XVI-XVII 12-14. A. VI-VII 9-10. A large dark blotch on the eaudal peduncle. Depth of body $] \frac{2}{3}$ to 2 in the length . . . . . . . . . . . . 3. macnlicauda. DIOL. Cextr.-AMER, Pisces, October 1906. 
†† D. XVII-XVIII 11-13. A. VI-VII 8-9. Dark cross-bars and a dark band from operculum to base of caudal.

Depth of body $I_{3}$ to 2 in the lengtli, length of head 25 (young) to $3 \frac{1}{4}$ (adult).

Last dorsal spine $\frac{1}{2}$, pectoral $\frac{7}{5}$ the length of head . . . . . . 4. fenestratum.

Depth of body $2 \frac{1}{4}$ in the length, length of had $3 \frac{2}{\bar{z}}$ (adult). Last dorsal spine $\frac{9}{5}$, pectoral $\frac{3}{4}$ the length of head . . . . . . . . . . . . 5. seifasciatum.

** Caudal pechuncle from $\frac{3}{4}$ to as long as deep.

† 8 to 10 gill-rakers on the lower part of anterior arch ; a broad dark band from pectoral to base of caudal.

D. XVII 13. A. VI 9. Last dorsal spine $\frac{1}{2}$ the length of head . . . . . 6. bifasciatum.

D. XVI-XVIII 12-14. A. VI-VII 9-10. Last dorsal spine $\frac{2}{50}$ the length of head

7. guttulatum.

†† 7 or 8 gill-rikers on the lowcr part of anterior arch.

$\ddagger$ Fold of the lower lip continuous, or at least with a continuous free edge. D. XVIII 11-13. A. (V) VI 9-11. Dark cross-bars and a dark band ending in a spot on the base of candal more or less distinct.

8. microphthalmus.

ff Fold of the lower lip not continuous, rarely subcontinuous in the young.

Diameter of eye 3 to 5 in the lengtl of lead, interorbital width $2 \%$ to 3 (in specimens of 85 to $260 \mathrm{~mm}$.). D. XVII-XVIII 11. A V-VI 8-9. An interrupted dark longitudinal band or a series of spots above the lateral line, another from middlc of side to caudal; lower parts of head

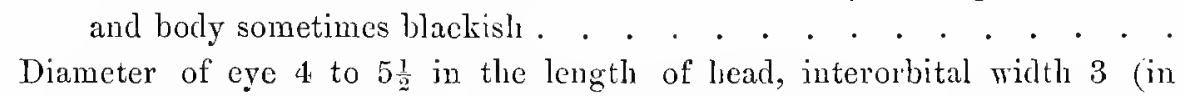

9. melamunu. specimens of 80 to $175 \mathrm{~mm}$.$) . D. XV-XVI 10-11. A. V-VI 8-9.$ Usually 5 or 6 dark cross-bars on the posterior part of the body; lowcr parts of head and body sometimes blackish . . . . . . . . 10. labridens.

Diamcter of eye 4 to $4 \frac{3}{4}$ in the length of head, interorbital width $2 \frac{1}{4}$ to $2 \frac{2}{5}$ (in specimens of 130 to $240 \mathrm{~mm}$.). D. XVI-XVIII 12-13. A. VIVII 8-9. Dark cross-bar's and a dark band from operculum to caudal . . . . . . . . . . . . . . . . . . . .11. gadovii.

Diameter of eye 4 to $4 \frac{2}{5}$ in the length of hearl, interorbital width $2 \frac{1}{3}$ to $2 \frac{2}{5}$ (in specimens of 96 to $177 \mathrm{~mm}$.). D. (XVI-XVII) XV11I 10-12 (13). A. (IV) V-VI 8-10 (1]). A broad blackish angular band from operculum to the middle of side and thence upwards to the spinous dorsal; a dark blotch on the caudal peduncle . . . . . . . . . . . 12. anguliferum.

Diameter of eye $4 \frac{1}{4}$ to $4 \frac{1}{2}$ in the length of head, interorbital width $2 \frac{2}{5}$ to 3 (in specimens of 133 to $155 \mathrm{~mm}$.). D. XVIII 9-11. $\Lambda$. V-VI 8-10. A dark angular band as in C. anguliferum; a narrow longitudinal band from the angle of the broader one to the base of candal, where it forms a vertically cxpanded spot . . . . . . . . . . . . .

D. XVI 12. A. V 8. 10 or 11 obscure dark cross-bars; a series of 4 to 6 13. intermedium. blackish spots, usually ocellated and vertically cxpanded, below the dorsal fin on the posterior part of the body; an ocellus ou the upper part of the base of cauclal

11. pavonaceum. 
$b$. Last dorsal spine $\frac{1}{3}$ the length of head.

Depth of body 21 in the length. D. XVII 11. A. V 8 . . . . . . 15. sieboldii.

Depth of body $2 \frac{1}{2}-2 \frac{3}{4}$ in the length. D. XVI-XVII 12-13. A. V 10 . 16. godmani.

2. Depth of body 3 to $3 \frac{1}{2}$ in the length; last dorsal spine $\frac{1}{3}$ to $\frac{2}{5}$ the

length of head. D. XV-XVII 12-13. A. IV-V 9-10 . . . 17. irregulare.

B. Caudal emarginate, with rounded lobes; depth of body $2 \frac{2}{3}-2 \frac{4}{5}$ in the length; last dorsal spine $\frac{1}{2}$ the length of head. D. XVII 13.

A. VI 9 . . . . . . . . . . . . . . . . . . . 18. lentiginosun.

II. Peetoral extending to above the origin of anal. D. XVIII 10-11.

A. VII 8. Sc. $34 \frac{5}{14}$. . . . . . . . . . . . . . 19. balteatum.

III. Pectoral extending to above the seeond or third anal spine.

D. XVIII-XIX 10-11. A. VII-VIII 8-9. Sc. $35 \frac{5-6}{14-15}$. . . 20. nicaraguense.

1. Cichlosoma eigenmanni, Meek, 1902.

Cichlosoma eigenmanni, Regan, Ann. Mag. N. H. (7) xvi. 1905, p. 225.

Hal. Southern Mexico, Rio Papaloapam (Gadow).

2. Cichlosoma nebuliferum, Günth., 1860 .

Cichlosoma nebuliferum, Regan, Ann. Mag. N. H. (7) xvi. 1905, p. 226.

IIal. Southern Mexico, Isthmus of 'lehuantepec (Sallé).

3. Cichlosoma maculicauda, Regan, 1905. (Tab. II. fig. 3.)

Cichlosoma naculicauda, Regan, Ann. Mag. N. H. (7) xvi. 1905, p. 227.

Hab. Guatemala, Rio Motagua and Lake Yzabal (Salvin); Panama, Rio Chagres (Salvin).

4. Cichlosoma fenestratum, Gïnth., 1860.

Cichlosoma fenestratum, Regan, Ann. Mag. N. H. (7) xvi. 1905, p. $22 \%$.

IIab. Southern Mexico, Chimalapa (Buller), Vera Cruz, Boca del Rio, and Rio Papaloapam (Gadow).

5. Cichlosoma sexfasciatum, Regan, 1905. (Tab. IV. figg. 2, 2 a.)

Cichlosoma sexfasciatum, Regan, Ann. Mag. N. H. (7) xvi. 1905, p. 230.

Hab. Mexico, Guapote.

This species is intermediate between $C$. fenestratum and $C$. microphthalmus. From the former it is distinguished by the shorter head, smaller eye, shorter pectoral fin, lower dorsal spines, \&c. ; from the latter by the shorter caudal peduncle and the broadly interrupted fold of the lower lip.

6. Cichlosoma bifasciatum, Steind., 1864.

Cicllosoma bifasciatum, Regan, Ann. Mag. N. H. (7) xvi. 1905, p. 228.

Ilab. Mexico. 
C. bifasciatum probably inhabits Southern Mexico, like the other species described by Dr. Steindachner in his memoir.

7. Cichlosoma guttulatum, Günth., 1864.

Cichlosoma guttulatum, Regan, Ann. Mag. N. H. (7) xri. 1905, p. 229 2

Hab. Sottherx Mexico, Rio de Sarabia (Buller ${ }^{1}$ ); Gustemala, Lakes Amatitlan and Nacasil (Salvin).

Cichlosoma zonatum, Meek (Proc. Biol. Soc. Washington, xviii. 1905, p. 245), from Tehuantepec, may be identical with $C$. guttulatum.

S. Gichlosoma microphthalmus, Günth., 1S62. (Tab. VII. fig. 2.)

Cichlosoma microphthalmus, Regan, Ann. Mlag. N. II. (7) xvi. 1905, p. 230.

Cichlosoma guentheri, Regan, t. c. p. 233.

Hab. Guatemala, Rio Motagua (Salvin).

After re-examination of the types I am unable to recognize $C$.guentheri, Pellegrin (C. oulongues, Günth., nec Casteln.), as distinct from C. microplethalmues.

9. Cichlosoma melanurum, Gïnth., 1862.

Cichlosoma melanurum, Regan, Ann. Mag. N. H. (7) xvi. 1905, p. 231.

HaZ. Guatemala, Lake Peten (Salvin).

10. Cichlosoma labridens, Pellegr., 1903.

Cichtosoma labridens, Regan, Anu. Mag. N. H. (శ) xvi. 1905, p. 443.

Hab. Mexico, Rio Panuco and its tributaries.

11. Cichlosoma gadovii, Regan, 1905. (Tab. V. figg. 2, 2 a.)

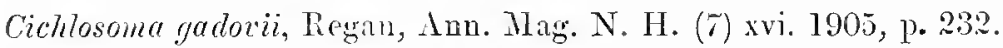

Hab. Soutifers Mexico, Motzorongo in Vera Cruz (Gadow), Oaxaca, Tehuantepec.

Dr. Meek's repetition* of the error of confusing $C$. gadovii with $C$. melanum makes it necessary for me to call attention to the more important points in which these species differ. C. melamum has been twice figured, by Günther (Trans. Zool. Soc. vi. 1869, t. 72. fig. 3) and by Steindachner, under the name Ileros nelanopogon (Denkschr. Ak. Wien, xxiii. 1s64, t. 1. fig. 3). A comparison of these figures with the one now given of $C$. gadomii will show the notable difference in marking between the two species and also that the snont is more produced and has its npper protilc less decurved in $C$. metammom. The interorbital space is much wider in $C$. gartovii than in C. melanum, its width being contained from $2 \frac{1}{4}$ to $2 \frac{2}{5}$ times in the length of the head in four specimens of the former, measuring from 130 to $240 \mathrm{~mm}$. in total lengtl, and $2 \frac{3}{5}$ to

\footnotetext{
* Proc. Biol. Soc. Wash. xriii. 1005, p. 245.
} 
times in the length of the head in four specimens of the latter species, 85 to $260 \mathrm{~mm}$. in total length. C. gadovii is subject to the same range of variation in colourmarkings as $C$. fenestratzom; in some specimens the dark cross-bars are strongly marked and the longitudinal band is scorcely visible, in others the cross-bars are faint and the longitudinal band is very strong. It is curious that Dr. Meek, who has had the privilege of collecting these fishes, shonld attempt to distinguish in this respect between C. parma (= fenestratum), with the lateral band faint or absent, and C. melanurum (=gadovii), with a conspicuous dark lateral band.

12. Cichlosoma anguliferum, Gïnth., 1862.

Cichlosoma intermedium, var, anguliferum, Regan, Amn. Mag. N. H. (7) xvi. 1905, p. 233.

Hab. Guatemala, Rio de Santa Isabel (Salvin), Rio Santa near Cahabon (Sarg).

The slight difference in colour-markings between this species and the next appears to be correlated with other slight peculiarities, so that I am inclined to provisionally recognize them as distinct. In $C$. anguliferum the interorbital space is a little wider and the dorsal spines rather higher than in $C$. intermedium, the last spine measuring rather more than $\frac{2}{5}$ the length of the head in the former and distinctly less than $\frac{2}{5}$ of the head in the latter species.

13. Cichlosoma intermedium, Günth., 1862.

Cicllosoma intermedium (part.), Regan, Ann. Mag. N. H. (7) xvi. 1905, p. 232.

Hab. Guatemala, Lake Peten (Salvin).

14. Cichlosoma pavonaceum, Garman, 1881.

Cichlosoma pavonaceum, Regan, Aun. Mag. N. H. (7) xvi. 1905, p. 234.

Hrb. Nonthern Mexıco, Monclura in Coahuila.

15. Cichlosoma sieboldii, Kner \& Steind., 1864.

Cichlosoma sieboldii, Regan, Aun. Mrag. N. H. (7) xvi. 1905, p. 235.

Hab. Panala.-Colombia.

Heros deppii, Heckel, 1840, from Mexico, may be allied to this species.

16. Cichlosoma godmani, Günth., 1862.

Cichlosona godmanni, Regan, Ann. Mag. N. H. (7) xvi. 1905, p. 235.

Hab. Guatemala, Rio Cahabon (Salvin).

17. Cichlosoma irregulare, Günth., 1862.

Cichlosoma irregulare, Regan, Ann. Mag. N. H. (7) xri. 1905, p. $236^{1}$.

Hab. Guatemala, Lake Yzabal, Rio Gerónimo, Rio Usumacinta (Salvin), Lake San Cristobal (Sarg). 
18. Cichlosoma lentiginosum, Steind., 1864.

Cichlosoma lentiginosum, Regan, Ann. Mag. N. H. (7) xvi. 1905, p. 237.

Hab. "MExico."

Probably an imhabitant of Sonthern Mexico.

19. Cichlosoma balteatum, Gill \& Bransf., 1877. (Tab. II. fig. 1.)

Cichlosoma balteatun, Regan, Ann. Mag. N. H. ( 7 ) xvi. 1905, p. 238.

Hab. Lake Nicaragua.

20. Cichlosoma nicaraguense, Günth., 1864.

Cichlosoma nicaraguense, Regan, Amn. Mag. N. H. (7) xvi. 1905, p. 238.

Hal. Lake Nicaragua.

Section 2. Anchocentrus, Gill, 1877.

Very closely allicd to Thercips, but with the anterior pair of teeth of the outer series in the upper jaw often somewhat enlarged, wilh a longer pectoral and more numerous anal spines. The gronp may be thus defined:-Body rather deep (depth $1 \frac{3}{4}$ to $2 \frac{1}{2}$ in the length, candal peduncle $\frac{1}{2}$ to $\frac{2}{3}$ as long as deep); mouth rather small, moderately protractile (maxillary not extending bejond the vertical from anterior margin of eye, promaxillary spines extending to just above the anterior margin of eye). D. XVII-XIX $7-10$, the soft fin sealy at the base. A. VIII-XII 6-9. Pectoral extending beyond the origin of anal; caudal rounded or subtruncatc.

Six species, from Southern Mexico, British Honduras, Guatemala, and Nicaragua.

$$
\text { Synopsis of the Species. }
$$

I. 6 to 8 gill-rakers on the lower part of anterior arch.

A. Maxillary extending to the vertical from anterior margin of eye.

D. XT11-XVII1 8-9. A. VIII-X 6-8. 2 or $2 \frac{1}{2}$ scalcs between latcral line and base of anterior part of soft clorsal . . . . . . . . . 21. nigrofasciatum.

D. XVII-XIX 8-10. A VIII-X $7-8$. 3. and base of anterior par of soft dorsal . . . . . . . . . . 2.2. octofasciatum.

B. Maxillary not extending to the vertical from autcrior margin of eyc.

a. Pectoral as long as or a little longer than the head. D. XVIII-

XIX 9-10. A. VIII-X 7-8 . . . . . . . . . . 23. spiturum.

b. Pectoral $\frac{4}{5}$ the length of head.

D. XVIII-XIX 9-10. A. IX 9 . . . . . . . . . . . . . 24. immaculatum.

D. XVIII-XIX $7-8$. A. XI-XII $7-8$. . . . . . . . . . . . . 25. spinosissimum.

II. 15 gill-rakers on the lower part of the anterior arch. D. XVI 8-9.
A. X-XI 8-10
26. centrarchus.

21. Cichlosoma nigrofasciatum, Günth., 1869.

Cichlosoma nigrofasciatum, Regan, Ann. Mag. N. H. (7) xvi. 1905, p. 75.

Mab. Guatenala, Lakes Aniatitlan and Atitlan (Salvin). 
22. Cichlosoma octofasciatum, Regan, 1903.

Cicklosoma octofasciatum, Regan, Ann. Mag. N. H. (7) xvi. 1905, p. 331.

Hab. Southern Mexico, Rio de Sarabia (Buller); Britrsh Honduras (Robertson).

The systematic position of this species is rather doubtful, as the dentition of some specimens is very like that of the more generalized members of the subgenus Parapetenia. Other characters seem to indicate relationship with $C$. nigrofasciatum.

23. Cichlosoma spilurum, Günth., 1862.

Cichlosoma spilurum, Regan, Ann. Mag. N. H. (7) svi. 1905, p. 75.

Hab. Guatemala, Rio Motagua and Lake Yzabal (Salvin).

24. Cichlosoma immaculatum, Pellegr., 1904.

Cichlosoma immaculatum, Regan, Ann. Mag. N. H. (7) xvi. 190亏̃, p. 77.

Hab. Guatemala, Rio Polochic.

25. Cichlosoma spinosissimum, Vaill. \& Pellegr., 1902.

Cichlosoma spinosissimum, Regan, Aun. Mag. N. H. (7) xvi. 1905, p. 76.

Hab. Guatemala, Rio Polochic.

26. Cichlosoma centrarchus, Gill \& Bransf., 1877. (Tab. IV. figg. 1, 1 a.) Cichlosoma centrarchus, Regan, Ann. Mag. N. H. (7) xvi. 1905, p. 77 .

Hab. Lake Nicaragua.

Section 3. Astatieros, Pellegr., 1904.

'Teeth of the outer series usually rather more numerous and less strougly enlarged anteriorly than in Theraps, but in the more specialized forms redueed in number and with the anterior pair in the upper jaw and the two anterior pairs in the lower strongly cnlarged. The maxillary never extends beyond the vertical from the anterior edge of the eye ; the priemaxillary spines measure from a little less than $\frac{2}{5}$ to slightly more than $\frac{1}{2}$ the length of head; the upper profile of the snont is straight and oblique. The body is rather deep (depth $1 \frac{1}{2}$ to $2 \frac{1}{3}$ in the length). The dorsal fin has XIV-XV1I 10-15 rays and is more or less scaly at tho base posteriorly; the anal has V-VIII 8-10 rays; the pectoral is usually elongate (in $C$. heterodontum and $C$. altifrons it extends to above the origin of the anal, in the other species it is longer); the caudal is subtruneate, rounded, or slightly emarginate with rounded lobes. The gillrakers are usually more numerous than in most other species of the genus (usually 11 to 13 on the lower part of the anterior arch, but only 9 or 10 in C. vitrinellum, 9 in C. lolochilus, 8 in C. exythroum).

Eleven species from Southern Mexico and Central America, one ranging into Colombia.

\section{Synopsis of the Species.}

I. Lips normal; anterior teeth not strongly enlarged.

A. Fourth to sixth dorsal spines longer than the rest.

D. XVI 10-11. A. VI 8-9. 11 or 12 gill-rakers on the lower part of anterior arch. Pectoral extending to above the middle of anal . . . . . . . . . 2\%. robertsoni. Pectoral extending to the posterior end of anal . . . . . . . . 28. longimanus. 
B. Dorsal spines subeqnal from the fiftli or sixtlı or increasing in length throughont.

1. D. XIV-XV 12-15. A. V-V1 8-9. 11 gill-rakers on the lower part of anterior areh; snout not longer than postorbital part of head.

Pectoral as long as the head ; depth of body $1 \underset{2}{1}$ in its length ; last dorsal

spine $s_{3}^{3}$ the length of head; caudal romiled . . . . . . . . . . .99. macracunthas.

Pectoral a little shorter than the head; depth of body 2 in its length; last

dorsal spine

suhtruncate . . . . . . . . . . . . . . . .30. heterodontum.

2. ก. YV1 11. A. V 8-9. 19 gill-rakcrs on the lower part of anterior arch; snont longer than postorbital part of head; pectoral cxtending nea ly to above origin of anal. . . . . 31. altifions.

3. D. XVI-XVII 11-1:. A. VII 8-9.

a. Pectoral extending to abore the last anal spine; 12 or 13 gillrakers on the lowcr part of anterior arch; snout longer than postorloital part of head . . . . . . . . . . . . 32. rostratum

b. Pectoral extending to above the third or fonth anal spine. 12 gill-rakers on the lower part of anterior arch; caudal slightly cmarginate, with ronnded lobes . . . . . . . . 33. nectrgerififermm. 9 or 10 gill-rakers on the lower part of anterior arch; candal rounded. . . . . . . . . . . 31. citrinclltum.

II. Lips exceptionally thick; antcrior pair of tecth in the upper jaw strongly cularged: two anterior pairs of tecth in the lower jaw cularged and subequal.

D. XVII 11-12. A. VH-VIII 8-9. Pectoral cxtending to abore the third to fifth ana spincs.

A. Lips subnormal, searcely produced medianly. . . . . . .35. erytlerezem.

B. Each lip produced medianly as a long flesly Hap.

Length of hear nearly 3 in the length of the fish ; 9 gill-rakcrs on the lower part of anterior arch . . . . . . . . . . . . 36. lobochitus.

Leunth of head 2! to $2:$ in the length of the fish; 11 or 12 gill-rakers on the lower part of anterior arch . . . . . . . . . . . . . 37. labiutum.

27. Cichlnsoma robertsoni, Regan, 1905. (Tab. III. fig. 1.)

richlosoma robertsoni, Regan, Ann. Mag. N. H. (7) xri. 1905, p. 239.

Ilrb. Britisi Moxduras, Stann Creek (Robertson).

28. Cichlosoma longimanus, Gïnth., 1869.

Cichlosmana lonyimanus, liegan, Ann. Mag. N. H. (б) xvi. 130.5, 1’. 240.

Jrab. Lake Nicaliagua (Salvin).

29. Cichlosoma macracanthus, Gïnth., 1864. ('Tab. I. tig. 1.)

Cirhlessomec macracantleus (part.), Regan, Anm. Mag. N. H. (7) xvi. 1905, p. :41.

Ineb. Guatemala, I uamuchal and Chiapam (Salim). 
30. Cichlosoma heterodontum, Vaill. \& Pellegr., 1902. Cichlosoma heterodontus, Regan, Ann. Mag. N. H. (7) xvi. 1905, p. 241.

Hab. Southern Mexico, Tequixistlan in Oaxaca (Gadow), Tehuantepec.

Dr. Meek * considers me to be in error in placing his $C$. evermanni in the synonymy of $C$. heterodontum, and would distinguish between $C$. evermanni, with all the teeth conical and the fold of the lower lip continuous, but freer at the sides than in front, and $C$. heterodontum, with some of the teeth worn and ending in a flat circular surface and the fold of the lower lip interrupted. The examination of a series of specimens of the closely allied $C$. macracanthus has shown me that both conditions of the dentition and of the lower lip are to be found in that species. Three small specimens of $C$. heterodontum were collected by Dr. Gadow at Tequixistlan. The largest $(125 \mathrm{~mm}$.) has some of the teeth worn and the fold of the lower lip continnous. The others (53 and $76 \mathrm{~mm}$.), formerly referred by me to $C$. macracanthus, have conical teeth, but the fold of the lower lip is interrupted.

31. Cichlosoma altifrons, Kner \& Steind., 1863.

Cichlosoma altifrons, Regan, Ann. Mag. N. H. (7) xri. 1905, p. 242.

Hab. Panama.-Colombia.

32. Cichlosoma rostratum, Gill \& Bransf., 1877. (Tab. VII. fig. 1.)

Cichlosoma rostratum, Regan, Ann. Mag. N. H. (7) xvi. 1905, p. 243.

Hab. Lake Nicaragua.

33. Cichlosoma margaritiferum, Günth., 1862.

Cichlosoma margaritiferum, Regan, Ann. Mag. N. H. (7) xvi. 1905, p. 316.

Hab. Guatemala (Salvin).

34. Cichlosoma citrinellum, Günth., 1864.

Cichlosoma citrinellum, Regan, Ann. Mag. N. H. (7) xvi. 1905, p. 316.

Hab. Lakes Managua (Dow) and Nicaragua (Salvin).

35. Cichlosoma erythræum, Günth., 1869.

Cichlosoma erythreum, Regan, Ann. Mag. N. H. (7) sri. 1905, p. 318.

IIab. Lake Managea (Dow).

36. Cichlosoma lobochilus, Günth., 1869.

Cichlosoma lobochilus, Regan, Ann. Mag. N. H. (f) xvi. 1905, p. 318.

IIal. Lake MaNagua (Dow).

* Proc. Biol. Soc. Washington, sviii. 1905, p. 244.

biol. Centr.-AMer., Pisces, October 1906. 
37. Cichlosoma labiatum, Günth., 1864.

Cichlosoma labiatum, Regan, Ann. Mag. N. H. (7) xvi. 1905, p. 319.

Hab. Lakes Managua and Nicaragua (Dow).

Section 4. Thorichirhs, Meek, 1904.

Very similar to Astatheros in form and deutition, but with the dorsal and anal fius entirely scaleless aud the caudal truncate or slightly emarginate, usually with pointed lobes. Dersal XV-XVII 8-I2. Aual VIIX 6-9. 9 to 12 gill-rakers on the lower part of the anterior arch. The coloration of the three spccies of this group may be described thus:--About six dark cross-bars, the third bearing a blackish blotch on or below the lateral line; suboperculum usually blackish; head and anterior part of body with blue spots; vertical fius dusky, usually with light spots.

\section{Synopsis of the Species.}

Pectoral extending to above origin of anal . . . . . . . . . . . . . . . 38. callolepis. Pectoral extending to above middle anal spines . . . . . . . . . . . . 39. aureum.

Pectoral extending to first branched ray of anal . . . . . . . . . . . 40. affine.

38. Cichlosoma callolepis, Regan, 1904. (Tab. II. fig. 2.)

Cichlosoma callolepis, Regan, Ann. Mag. N. H. (7) xvi. 1905, p. 321.

Hab. Mexico, San Domingo de Guzman (Buller).

39. Cichlosoma aureum, Günth., 1862.

Cichlosoma aureum, Regan, Ann. Mag. N. H. (7) xvi. 1905, p. 320.

Hab. Southern Mexico, Rio Papaloapam (Gadow, Meek), San Domingo de Guzman and Rio de Sarabia(Buller); Guatemala, Lake Yzabal and Rio Motagua (Salvin).

40. Cichlosoma affine, Günth., 1862.

Cichlosoma affine, Rcgan, Ann. Mag. N. H. (7) xvi. 1905, p. 321.

Hab. Guntemala, Lake Peten (Salvin).

Section 5. Parapetenia, Regan, 1905.

The anterior pair of teeth in the upper jaw and the two on cach side of the anterior pair in the lewer are more or less strongly enlarged and canine-like. The mouth is usually larger, more oblique and more protractile than in other groups of Cichlosoma, the length of the lower jaw or of the premaxillary spincs, from the anterior edge of the upper jaw, measuring from $\frac{2}{5}$ to a little more than $\frac{3}{5}$ the length of the head. The upper profile of the snout is straight; the fold of the lower lip is continuous or subcontinuous. The dorsal fiu has XV-XVIII 8-13 rays and pesteriorly has a sealy sheath at the base and a short series of scales on each intcradial mcmbrano; the acal has IV-IX $7-10$ rays; the pecteral is shorter than the head; the caudal is rounded.

In addition to the thirteen species from Mexico and Central America, there are two, the most generalized of the group, C. tetracauthus and $C$. adspersum, from Cuba and 
Barbados respectively, two from Western Ecuador, C. festce and C. ornatum, allied to C. urophthalmus or C. istlanum, and two, C. kraussi from Colombia and C. spectabile from the Amazon, more specialized than any in the great protractility of the mouth and apparently allied to C. managuense.

\section{Synopsis of the Mexican and Central-American Species.}

I. D. XV-XVI 10-13. A. V 7-10. Pectoral $\frac{3}{5}-\frac{3}{4}$ the length of the head. Prremaxillary spines $\frac{2}{5}$ to $\frac{1}{2}$ the length of head, extending to above anterior part of eye; maxillary not extending to helow the eye ; canines moderate.

A. Snout nearly as long as the postorbital part of head (in the adult); candal peduncle as long as deep.

1. Length of head $2 \frac{3}{4}$ (young) to 3 (adult) in the length of the fish; jaws equal anteriorly. Interorbital width $3 \frac{1}{4}$ to $3 \frac{1}{2}$ in the length of head. A dark spot below the origin of the lateral line, another on the middle of the side, a third at the base of caudal . . . . . . . . . . . . . . . . . . . . Interorbital wiath 4 in the length of head. An interrupted dark longitudinal band from operculum to the base of caudal . . . . . . . . . .

2. Length of head $2 \frac{1}{2}$ (young) to $2 \frac{3}{4}$ (adult) in the length of the fish ; lower jaw slightly projecting; coloration as in C. steindachneri . 43. bartoni.

B. Snout shorter than the postorbital part of bead (in the adult).

Depth of body 2 to $2 \frac{1}{3}$ in the length; caudal peduncle $\frac{2}{3}$ as long as deep; lower jaw slightly projecting. . . . . . . . . . . . . 44. beani.

Depth of body $2 \frac{1}{2}$ to $2 \frac{4}{5}$ in the length ; caudal peduncle as long as deep; lower jaw projecting . . . . . . . . . . . . . . . . . 4 45. mento.

II. D. XV-XVII 10-12. A. VI 8-9. Pectoral $\frac{4}{5}$ to $\frac{5}{6}$ the length of head. Præmaxillary spines nearly $\frac{1}{2}$ the length of head, not extending to above middle of eye; maxillary extending to the vertical from anterior margin of eye; canines moderate . . . . . . . . . . 46. urophthalmus.

III. D. XVI-XVIII 9-12. A. VI-IX 7-I0. Præmaxillary spines $\frac{1}{2}$ or slightly more than ! the length of head, extending to above the middle of orbit; maxillary extending to below anterior margin or anterior $\frac{1}{4}$ of eye ; canines strong.

A. Last dorsal spine $\frac{2}{5}$ to $\frac{1}{2}$ the length of head. D. XVI-XVII 9-12.

Snout shorter than postorbital part of head (in the adult). A. VI-VIII 8-9.

A dark spot above the origin of the lateral line, another on the middle of the side, a third at the base of the caudal . . . . . . . . . . Snout as long as postorbital part of head (in the adult). A. VIII-IX 7-9. An interrupted longitudinal band from eye to base of caudal . . . . 48. salvini.

B. Last dorsal spine $\frac{2}{5}$ the length of head. D. XVIII 10. A. VIIVIII 8-9 . . . . . . . . . . . . . . . . . . . 49. multifasciatum.

C. Last dorsal spine $\frac{1}{3}$ the length of head. D. XVII-XVIII 9-Il. A. VII-VIII 8-9.

Depth of preorbital $\frac{1}{2}$ to $\frac{3}{5}$ the diameter of eye (in specimens of 120 to $130 \mathrm{~mm}$.

in total length); caudal peduncle $\frac{3}{5}$ as long as deep . . . . . . . 50. friedrichstahli. 
Depth of preorbital $\frac{2}{3}$ the diameter of eye (in a specimen of $115 \mathrm{~mm}$.) or equal to it (in the adult fish); caudal peduuele $\frac{2}{3}$ to $\frac{4}{5}$ as long as deep . 51. motaguense.

IV. D. XVIII 10-12. A. VI-VII 8-10. Premaxillary spines $\frac{3}{5}$ or slightly more than $\frac{3}{5}$ the length of head, extending to above posterior edge of orbit; maxillary extending to below anterior $\frac{1}{3}$ or middle of eye ; eanines strong; last dorsal spine $\frac{1}{3}$ the length of head.

D. XVIII 10. A. VII 8. Maxillary extending to below middle of eye; depth of præorbital $\frac{2}{5}$ to $\frac{1}{2}$ the diameter of eye (in specimens of 187 to $195 \mathrm{~mm}$.) . . . . . . . . . . . . . . . . . . . . 52. managuense.

D. XVIII 12. A. VI 9-10. Maxillary extending to below anterior $\frac{1}{3}$ of eye ; depth of prrorbital $\frac{2}{3}$ to $\frac{3}{4}$ the diameter of eye (in speeimens of 140 to $14 \mathrm{~mm}$.) . . . . . . . . . . . . . . . 53. dovii.

41. Cichlosoma istlanum, Jord. \& Snyder, 1899.

Cichlosoma istlanum, Regan, Ann. Mag. N. H. (7) xvi. 1905, p. 326.

Hab. Nexico, Rio Balsas and its tributaries.

42. Cichlosoma steindachneri, Jord. \& Snyder, 1899.

Cichlosoma steindachneri, Regan, Aun. Mag. N. H. (7) xvi. 190丂, p. 441.

Hab. Mexico, Rio Panuco and its tributaries.

43. Cichlosoma bartoni, Bean, 1892.

Cichlosoma bartoni, Regan, Aun. Mag. N. H. (7) xvi. 1905, p. 445

Hab. Mexico, Rio Panuco and its tributaries.

44. Cichlosoma beani, Jord., 18s8. ('Tab. VI. fig. 1.)

Cichlosoma beani, Regan, Ann. Mag. N. H. (7) xvi. 1905, p. 328.

Hab. Mexico, rivers of Sinaloa and Jalisco.

45. Cichlosoma mento, Vaill. \& Pellegr., 1902.

Cichlosoma mento, Regan, Ann. Mag. N. H. (7) xvi. 1905, p. 329.

Hal. Southern Mexico, Rio Negro.

46. Cichlosoma urophthalmus, Günth., 1862.

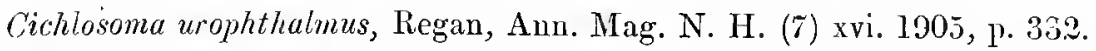

Hal. Mexico, Yucatan; British Honduras; Guatemala, Lake Peten (Salvin).

47. Cichlosoma trimaculatum, Günth., 1869.

Cichlosomen trimaculatum, Regan, Ann. Mag. N. H. (7) xvi. 1905, p. 333.

Hab. Southern Mexico, Oaxaca and Tehuantepcc; Guatemala, IIuamuchal aud Chiapam (Salvin). 
From Dr. Meek's * description of adult specimens of his C. mojarra, founded on a small example with malformed spinous dorsal, it is evident that this species is identical with C. trimaculatum, and not with the closely allied $C$. salvini, as I at first supposed.

48. Cichlosoma salvini, Günth., 1864.

Cichlosoma salvini, Regan, Ann. Mag. N. H. (7) xvi. 1905, p. 334.

Hab. Southern Mexico; British Honduras (Robertson); Guatemala, Lake Peten and Rio de Santa Isabel (Salvin), Cahabon (Sarg).

49. Cichlosoma multifasciatum, Regan, 1905. (Tab. III. fig. 3.)

Cichlosoma multifasciatum, Regan, Ann. Mag. N. H. (7) xvi. 1905, p. 335.

Hab. British Honduras, Stann Creek (Robertson); Guatenala, Lake Peten (Salvin).

50. Cichlosoma friedrichstahli, Heck., 1840. (Tab. III. tig. 2.)

Cichlosoma friedrichstalli, Regan, Ann. Mag. N. H. (7) xvi. 1905, p. 336.

Hab. Guatemala, Lake Peten (Salvin).

51. Cichlosoma motaguense, Günth., 1869.

Cichlosoma motaguense, Regan, Ann. Mag. N. H. (7) xvi. 1905̃, p. 336.

Hab. Guatemala, Rio Motagua (Salvin).

52. Cichlosoma managuense, Günth., 1869.

Cichlosoma managuense, Regan, Ann. Mag. N. H. (7) xvi. 1905, p. 337.

Hab. Lakes Managua (Dow) and Nicaragua.

53. Cichlosoma dovii, Günth., 1864.

Cicllosoma dovii, Regan, Ann. Mag. N. H. (7) xvi. 1905, p. 338.

Hab. Lake Nicaragda (Salvin).

\section{PETENIA, Günth., $1 \varepsilon 62$.}

Petenia, Regan, Ann. Mag. Nat. Hist. (7) xvi. 1905, p. 433.

The single species is allied to Cichlosoma dovii and $C$. managuense, but has the mouth larger and the maxillary more exposed, whilst the præmaxillary processes are as long as the head and extend nearly to the origin of the dorsal fin.

I. Petenia splendida, Günth., 1862.

Petenia splendida, Regan, Ann. Mag. N. H. (7) xri. 1905, p. 433.

D. XV-XVI 12-13. A. V 8-10. Sc. 40-45 $\frac{6-7}{16-17}$.

Hab. Guatemala, Lake Peten (Salvin).

* Proc. Biol. Soc. Washington, xviii. 1905, p. 244. 


\section{HERICHTHYS, Baird \& Girard, 1854.}

Herichthys, Regan, Ann. Mag. Nat. Hist. (7) xvi. 1905, p. 434.

Differs from Cichlosoma only in the dentition, the enlarged outer series of teeth being compressed. The four species inhabit Mexico and Central America, one ranging into Texas, the northern limit of the family.

\section{Synopsis of the Species.}

I. D. XV-XVII 10-12. A. V (VI 7) 8-9. Caudal peduncle ${ }_{5}^{3}$ as long as deep . . . . . . . . . . . . . . . . . . . . 1. cyanoguttatus.

II. D. XVI-XVII 13. A. V 10. Caudal peduncle as long, or nearly as long, as deep.

Last dorsal spine more than $\frac{1}{2}$ the length of head; diameter of eye $3 \frac{3}{4}$ in the length of head (in a specimen of $182 \mathrm{~mm}$.) . . . . . . . . .

Last dorsal spine less than $\frac{1}{2}$ the length of head; diameter of eye 4 in the length of head (in a specimen of $126 \mathrm{~mm}$.) . . . . . . . . .

2. bocourti.

\begin{tabular}{l} 
III. D. XVI-XVIII 11-12. A. VI-VII 9-10. Caudal peduncle $\frac{1}{2}$ to $\frac{2}{3}$ as \\
long as deep \\
\hline
\end{tabular}

\begin{tabular}{l} 
III. D. XVI-XVIII 11-12. A. VI-VII 9-10. Caudal peduncle $\frac{1}{2}$ to $\frac{2}{3}$ as \\
long as deep \\
\hline
\end{tabular}

3. underwoodi.

4. geddesi.

1. Herichthys cyanoguttatus, Baird \& Girard, 1854.

Herichthys cyanoguttatus, Regan, Ann. Mag. N. H. (7) xvi. 1905, p. 434.

Ifal. North-Eastern Mexıco, Nuevo Leon, Tamaulipas, and San Luis Potosi, extending into Texas.

2. Herichthys bocourti, Vaill. \& Pellegrin, 1902.

Hericlithys bocourti, Regan, Ann. Mag. N. H. (7) xvi. 1905, p. 435.

Hab. Guatemala, Lake [Yzabal] Isabel.

\section{Herichthys underwoodi, sp. n. (Tab, III. fig. 5.)}

Depth of body $2 \frac{2}{5}$ in the length, length of head $3 \frac{1}{3}$. Snont nearly as long as postorbital part of head. Diameter of eyc 4 in the length of head, interorbital width $2 \frac{3}{5}$. Depth of præorbital slightly more than the diameter of eje. Jaws equal auteriorly; maxillary extending to between nostril and eye; fold of the lower lip not continuous; cheek with 5 series of scales; 8 gill-rakers on the lower part of anterior arch. Scales $32 \frac{5}{13}, 3 \frac{1}{2}$ between lateral line and anterior part of soft dorsal. Dorsal XVII 13, commeneing above the extremity of operculum, the spines subequal from the fourth to the fourtcenth, thence increasing in length to the last, which is less than $\frac{1}{2}$ the length of head; soft fin, when laid back, extending a little beyond the base of caudal. Anal V 10. Ventrals extending to the vent. Candal ronnded. Caudal pednncle as long as decp. Body with 6 dark cross-bars; vertical fins with small dark spots.

Hab. Costa Rica (C. F. Underwood).

A single specimen, $126 \mathrm{~mm}$. in total length.

4. Herichthys geddesi, Regan, 1905. (Tab. III. fig. 4.)

Herichthys geddesi, liegan, Ann. Mag. N. H. (7) xvi. 1905, p. 436.

Hab. Soutinern Mexico (Geddes). 


\section{PARANEETROPLUS, Regan, 1905.}

Paraneetroplus, Regan, Ann. Mag. Nat. Hist. (7) xvi. 1905, p. 436.

The single species is apparently allied to Cichlosoma neluliferum and to Neetroplus nematopus. All the teeth are compressed, with pointed or rounded apices.

1. Paraneetroplus bulleri, Regan, 1905. (Tab. VI. fig. 2.)

Paraneetroplus bulleri, Regan, Ann. Mag. N. H. (7) xvi. 1905, p. 436.

D XVIII 12. A. VI 9. Sc. $34 \frac{5 \frac{1}{2}}{14}$. Mouth small, with the lower jaw shorter than the upper.

Hab. Mexico, Rio de Sarabia (Buller).

7. NEETROPLUS, Günth., 1869.

Neetroplus, Regan, Ann. Mag. N. H. (7) xvi. 1905, p. 437.

Very close to Paraneetroplus, but with truncate incisor-like teeth. A single species from Nicaragua.

1. Neetroplus nematopus, Günth., 1869.

Neetroplus nematopus, Regan, Ann. Mag. N. H. (7) xvi. 1905, p. 437.

D. XIX 10. A. VIII 7. Sc. $33 \frac{6}{13}$. Mouth small, with the jaws nearly equal anteriorly.

Hab. Lakes Managua (Dow) and Nicaragua.

8. HERÓTILAPIA, Pellegr., 1904.

Herotilapia, Regan, Ann. Mag. N. H. (7) xvi. 1905, p. 438.

The species is evidently closely allied to Cichlosoma nigrofasciatum, but the teeth are compressed and tricuspid, except the median ones of the outer series, which are truncate incisors.

1. Herotilapia multispinosa, Günth., 1869.

Herotilapia multispinosa, Regan, Ann. Mag. N. H. (7) xvi. 1905, p. 438.

D. XVIII 9. A. XI 8. Sc. $28 \frac{\frac{42}{2}}{12}$.

Hab. Lake Managua (Dow).

\section{Fam. 6. SCI正NID无.}

The Sciænidæ are a large family, principally tropical and subtropical shore-fishes; many of them enter rivers freely and a few are entirely fluviatile. Some of the features which distinguish them from other Perciform fishes are: (1) the dorsal fin, which is either deeply notched or completely divided into two, the anterior spinous 
portion being usually considerably shorter than the posterior soft-rayed one; (2) the presence of only one or two anal spines; and (3) the toothless palate.

One permanently fluviatile species (Haploidonotus grunniens) is found in the rivers of Mexico and Central America, but whether any of the Sciænid shore-fishes of this region ascend rivers above the influence of the tides is uncertain *.

\section{HAPLOIDONOTUS, Rafin., 1819.}

Aplodinotus, Jord. \& Everm. Bull. U.S. Nat. Mus. xlvii. 1898, p. 1484.

Body rather deep, compressed. Nouth subterminal; no barbels; præmaxillaries protractile; maxillary concealed by the preorbital; no supramaxillary; jaws with bands of small pointed teeth; palate toothless; lower pharyngeals large, completely united, with molariform teeth; præoperculum weakly denticulated. Scales of moderate size, oiliated; lateral line curved anteriorls, continued nearly to the end of the caudal fin. A single dorsal, scaly at the base, with $X 29-32$ rays; anal with II 7 rays; caudal doubly truncate; pectoral asymmetrical, pointed; rentrals each of a spine and 5 branched rays, inserted a little behind the base of the pectorals, without scaly axillary processes.

\section{Haploidonotus grunniens, Rafin., 1819.}

Corvina oscula, Günth. Cat. Fish. ii. p. 297 (1860).

Aplodinotus grunniens, Jord. \& Everm. Bull. U.S. Nat. Mus. xlvii. 1898, p. 1484.

Depth of bod $52 \frac{1}{2}$ to $2 \frac{1}{5}$ in the length, length of head $3 \frac{1}{2}$ to $3 \frac{3}{4}$. Back elevated, the ventral profile being nearly straight. Snout short, obtuse ; maxillary extending to below posterior part of eye, the diameter of which is about 5 in the length of head and $I_{\frac{1}{2}}$ in the interorbital width. Scales 56-62 $\frac{8-10}{13-16}$. Dorsal X 29-32; spines moderately strong, the third highest, $\frac{1}{2}$ the length of head and nearly as long as the longest branehed rays. Anal II 7 ; second spine strong, about as long as the longest dorsal spine, shorter than the anterior branched rays. Pectoral as long as the head. Silvery, back darker; vertical fins dusky.

Hab. Rivers and lakes of North America, from the Great Lakes to Chiapas (in Mexico recorded from Matamoros in Tamaulipas and the Rio Usumacinta).

This species, here described from Winnipeg examples of from 250 to $300 \mathrm{~mm}$., attains a weight of 50 or 60 pounds.

\section{Fam. 7. PERCID挦.}

The Percidre are a large family inhabiting the fresh waters of North America and Western Eurasia. The majority of the American species are the small fishes known as "darters," a few of which occur in Northern Mexico. These belong to two very closely allied genera, Percina and Etheostoma, which may be distinguished from other Perciform fishes by the following diagnosis:-

Body more or less clongate and compressed. Mouth small or moderate; præmaxillaries not protractile, except at the sides; maxillary exposed, but slipping nnder the procorbital for the whole length of its upper edge: villiform tecth in the jaws and nsually on the palate. Scales small, dentieulated. Two dorsals, with

* In the British Museum are examples of Bairtiella icistiu, Jord. \& Gilb., and Cynoscion xanthulus, Jord. \& Gilb., collected by Horr Forrer in the Iiio Presidio, but probably near tho mouth of the river. 
VI-XVII 8-17 rays. Anal short, with I-II 6-12 rays. Pectorals symmetrical, rounded. Tentrals below or behind the base of the pectorals, each with a moderate or feeble spine and 5 branched rays; m scaly axillary process.

The work of Boulenger and of Jordan and Evermann renders a full account unnecessary, but I have examined the examples in the British Museum collection.

Synopsis of the Species of Mexican Percidix.

I. Dorsal XIII-XVII 12-17; lateral line eomplete . . . . . . . Percina caprodes.

II. Dorsal IX-XII 9-13; lateral line incomplete.

A. Lateral line forming a curve above the pectoral. Aual II 6-8 . Etheostoma fusiforme.

B. Lateral line nearly straight.

a. Anal II 6-8.

Caudal peduncle a little longer than deep . . . . . . . . . . . E. pottsii.

Caudal peduncle nearly twice as long as deep . . . . . . . . . . E. lepidum.

b. Anal I 7-8 . . . . . . . . . . . . . . . . . E. australe.

III. Dorsal VI 10 . . . . . . . . . . . . . E. laterale.

\section{PERCINA, Haldeman, 1842.}

Percina, Bouleng. Cat. Fish. i. p. 56 (1895).

\section{Percina caprodes, Rafin., 1818.}

Percina caprodes, Bouleng. Cat. Fish. i. p. 57 (1895); Jord. \& Everm. Bull. U.S. Nat. Mus. xlvii. 1896, p. 1026.

Depth of body 5 to $6 \frac{1}{2}$ in the length, length of head 4 to $4 \frac{3}{4}$. Snout projecting beyond the month, which is

inferior. Dorsal XIII-XVII 12-17. Anal II 9-12. Scales $90-95 \frac{8-10}{14-16^{\circ}}$ Lateral line complete. Olivaceous, with numerous dark vertical bars, usually alternately long and short.

Hab. North America, Great Lakes to the Rio Grande.

This is the largest of all the Darters, attaining a length of $200 \mathrm{~mm}$.

\section{ETHEOSTOMA, Rafin., 1819.}

Etheostoma, Boulerig. Cat. Fish. i. p. 64 (1895).

\section{Etheostoma fusiforme, Girard, 1854.}

Etheostoma fusiforme, Bouleng. Cat. Fish. i. p. 75 (1895).

Boleichthys fusiformis, Jord. \& Everm. Bull. U.S. Nat. Mus. slvii. 1896, p. 1101.

Depth of body 4 to 6 in the length, length of head $3 \frac{1}{2}$ to 4 . Dorsal IX-X 9-12. Anal II 6-8. Seales $43-60 \begin{gathered}3-4 \\ 12-13\end{gathered}$ and cross-bars.

Hab. North America, Massachusetts to the Rio Grande.

biol. Centr.-AMer., Pisces, February 1907. 
2. Etheostoma pottsii, Girard, 1859.

Etheostoma pottsii, Bouleng. Cat. Fish. i. p.74 (1895) ; Jord. \& Everm. Bull. U.S. Nat. Mus. xlvii. 1896, p. 1083.

Depth of body $3 \frac{1}{2}$ to 4 in the longth, length of head $3 \frac{1}{3}$ to $3 \frac{2}{3}$. Dorsal IX-XI 10-12. Anal II 7 . Scales $44-\overline{0} 0 \frac{5}{9-11}$. Caudal pedunclo a little longer than deep. Olive, barred and marbled with brownish.

IIab. Mexico, Chilunahua and Durango.

3. Etheostoma lepidum, Baird \& Girard, 1853.

Etheostoma lepidum, Bouleng. Cat. Fish. i. p. 73 (1895) ; Jord. \& Everm. Bull. U.S. Nat. Mus. xlvii. 1896, p. 1089.

Nepth of body $4 \frac{2}{3}$ in the length, length of head $4 \frac{1}{1}$. Dorsal IX-X 10-13. Anal II 6-8. Scales $48-54 \frac{5-7}{11}$.

Caudal peduncle vearly twice as long as deep. Olire, with some more or less distinct dark vertical bars.

Mab. Norti Auerica, Texas.-Mexico, Chihuahua.

4. Etheostoma australe, Jorcian, $18 s 8$.

Etheostoma australe, Bouleng. Cat. Fish. i. p. 88 (1895) ; Jord. \& Everm. Bull. U.S. Nat. Mus. xlvii. 1896, p. 1081.

Depth of body $4 \frac{1}{4}-4 \frac{2}{3}$ in the length, length of head $3 \frac{1}{2}$ to $3 \frac{3}{4}$. Dorsal X-XIJ 9-11. Anal I 7-8. Scales $58-66 \frac{6-7}{10-12}$. Olive, with about 10 strongly-marked dark rertical hars.

Hrab. Mexico, Rio Conchos in Chihuahua.

5. Etheostoma laterale, Girard, 1859.

Etheostoma laterale, Bouleng. Cat. Fish. i. p. 87 (1895).

Aluarius lateralis, Jord. \& Lverm. Bull. U.S. Nat. Mus. xlvii. 1896, p. 1099.

body stender, elongate. Dorsal VI 10. Anal 8. Scales fery small. Browuish, spotted with black; it narrow bfackish lateral stripe, which extends round the suout; first dorsal with a black spot on its upper posterior cdge; caudal barred.

lab. Rio Ginane.

\section{Fam. 8. CENTRARCHID正.}

This family comprises the Indo-Pacific genus Kuhlia and the allied Edelia and Vronoperca from the fresh waters of Australia, and about thirty species, which may be grouped into eight or nine genera, from the fresh waters of North America. Six species range into Northern Mexico, but only one of them extends further south than the southern tributaries of the Rio Girande.

'These may be distinguished from other Perch-like fishes of Mexico by the following combination of characters :-

"A single dorsal fin, with $\mathrm{X}$-XI 10-13 rays, the middle spines the longest; anal with III 8-12 rays; ventrals below or a little belime tho basc of pectorals, close together, cach with I 5 rars, without scaly axillary process. Lateral liuo concurreut with the dorsal protilc. Head without spines or serra." 
With the exception of Micropterns salmonoides, a characteristic feature is the prolongation of the operculum as a blackish membranous flap.

In view of the recent work on this group of Boulenger and Jordan and Evermann, a full account would be superfluous. I have, however, examined the specimens in the British Museum, and hare prepared a synopsis of the Mexican species.

\section{Synopsis of the Mexican Species of Centrarchidx.}

I. Supramaxillary bone well developed.

Dorsal X 12-13. Anal III 10-11. Scales 65-70 $\frac{i-8}{17-20}$. Depth of body 3 to $3 \frac{1}{2}$ in the length . . . . . . . . . . . . Micropterus salmonoides.

Dorsal X-XI 10-11. Anal III 8-9. Scales 45-55 $\frac{6-7}{15-18}$. Depth of body 2 to $2 \frac{1}{2}$ in the length . . . . . . . . . . . . Apomotis cyanellus.

II. Supramaxillary bone absent or rudimentary.

A. Pectoral much shorter than the head, not extending to above the anal. Dorsal $\times$ 10-12. Anal III 8-10.

Scales $36-45 \frac{5-6}{14-16^{6}}$. Deptli of body $1 \frac{3}{4}-21$ in the length.

Longest dorsal spine abont $\frac{1}{3}$ the length of head . . . . . Lepomis megalotis.

Scales $35-38 \frac{6-7}{13-15}$. Depth of body $2 \frac{1}{2}$ in the length. Longest dorsal spiue nearly $\frac{1}{2}$ the length of head . . . . . . . L. haplognathus.

B. Pectoral as long as or a little longer than the head, extending to above the anal spines. Dorsal X 11-12. Anal III 11-12.

Seales $43-52 \frac{7-8}{15-18}$. . . . . . . . . . . . . . . . Eupomotis pallidus.

Scales $34-40 \frac{4-5}{13-15} \cdot$. . . . . . . . . . . . . . . E. heros.

\section{MICROPTERUS, Lacep., 1802.}

Micropterus, Bouleng. Cat. Fish. i. p. 14 (1895).

\section{Micropterus salmonoides, Lacep., 1802.}

Micropterus salmonoides, Bouleng. Cat. Fish. i. p. 16 (1895) ; Jord. \& Everm. Bull. U.S. Nat.

Mus. xlvii. 1896, p. 1012.

Ilab. North America, east of the Rocky Mountains, from the Red River and the Great Lakes to Tamanlipas.

The "Large-mouthed Black Bass" is at once distinguished from other Mexican Centrarchidæ by the larger mouth, the more elongate body, and the absence of a membranous prolongation of the operculum. 
2. APOMO'TIS, Rafin., 1819.

Apomotis, Bouleng. Cat. Fish. i. p. 18 (1895).

1. Apomotis cyanellus, Rafinesque, 1819 .

Apomotis cyanellus, Bouleng. Cat. Fish. i. p. 21 (1895); Jord. \& Everm. Bull. U.S. Nat. Mus. xlvii. 1896, p. 996.

Hab. North Averica, east of the Rocky Momntains, from the Great Lakes to the Rio Grande and its tributaries.

\section{LEPOMIS, Rafin., 1819.}

Lepomis, Bouleng. Cat. Fish. i. p. 23 (1895).

1. Lepomis megalotis, Rafinesque, 1820.

Lepomis megalotis, Bouleng. Cat. Fish. i. p. 26 (1895); Jord. \& Everm. Bull. U.S. Nat. Mus. xlvii. 1896, p. 1002.

Lepidopomus occidentalis, Meek, Pbl. Columbiau Mus. Zool. v. 1904, p. 192, t. 12.

Mab. Nortir Aurerict, east of the Rocky Mountains, from the Great Lakes to the Rio Grande and its tributaries.

\section{Lepomis haplognathus, Cope, 1885 .}

Eupomotis haplognathus, Bonleng. Cat. Fish. i. p. 372 (1895).

Lepomis haplognathus, Jord. \& Everm. Bull. U.S. Nat. Mus. xlvii. 1896, p. 1004.

Lepidopomus haplognathus, Meek, Pbl. Columbian Mus. Zool. v. 190丸, p. 192.

Hab. Mexico, Monterey.

This species, described by Cope and re-described by Meek from specimens taken at Monterey, may be identical with $I_{\text {. }}$ garmani. Forbes, from Illinois, which is probably not distinct from $L$. miniatus, Jord., ranging from 'Texas to Florida.

4. EUPOMOTIS, Gill \& Jord., 1877.

Eupomotis, Bonleng. Cat. Fish. i. p. 28 (1895).

1. Eupomotis pallidus, Mitchill, I815.

Eupomotis pallidus, Bouleng. Cat. Fish. i. p. 23 (1895).

Lepomis pallidns, Jord. \& Everm. Bull. U.S. Nat. Ans. xlvii. 1896, p. ]00.5.

IIab. North Auerica, cast of the Rocky Mountains, from the Great Lakes to the Rio Grande and its tributarics.

๖. Eupomotis heros, Baird \& Girard, 1854.

Eupomotis heros, Bouleng. Cat. Fish. i. p. 32 (1895) ; Jurd. \& Everm. Bull. U.S. Nat. Mus. xlvii. 1896 , p. 1007 .

Hab. Norti America, Southern Indiana to Florida and the Rio Grande and its tributaries. 


\section{Fam. 9. LIOGNATHID然.}

The Liognathidæ comprise the four genera Gerres, Pentaprion, Liognathus, and Gazza. The three last-named appear to be exclusively marine and are confined to the tropical Indo-Pacific. Gerres is found in all tropical seas, and most of the species appear to freely enter fresh water.

\section{GERRES, Cuv., 1829 .}

Gerres, Güntl. Cat. Fish. iv. p. 252 (1862).

Eucinostomus, Ulcema, Xystcema, and Gerres, Jord. \& Everm. Bull. U.S. Nat. Mus. xlvii. 1898. pp. 1367, 1371, 1372, and 1373.

Body eompressed; scales large or moderate, cycloid or finely ctenoid. Lateral line eomplete. Mouth moderate, very protractile; maxillary exposed; jaws equal anteriorly; bands of small villiform teeth in jaws; palate toothless. Præorbital and præoperculum entire or finely serrated. A single dorsal with IX 10 rays, with a scaly sheath at the base; second or third dorsal spine the longest; anal with II-III 7-9 rays; candal forked; pectoral asymmetrical, pointed; ventrals a little behind the base of pectorals. with I 5 rays; a scaly process at base of spine of eaeh ventral fin.

IIab. Tropical seas, entering rivers.

The American species of Gerres number seventeen, and although only a small proportion of these have been recorded from rivers or lakes in Mexico and Central America, we may feel quite sure that most of them are to be met with there. It is rather a difficult matter to know how to deal with such a group in a work on freshwater fishes, but I have thought it more useful to prepare a synopsis of all the American species, based on an examination of the available material, rather than to give descriptions of the few definitely known to occur in the fresh waters of Mexico and Central America.

I. Præoperculum entire.

\section{Synopsis of the Species.}

\section{A. Anal III 7.}

1. Second anal spine $\frac{1}{3}-\frac{1}{2}$ the length of head; second dorsal spine a little longer than third; depth of body $21-2 \frac{1}{2}$ in the length.

5 or $5 \frac{1}{2}$ scales between lateral line and middle of dorsal fin . . . . . . 1. cinereus.

4t scales between lateral line and middle of dorsal fin . . . . . . . . 2. simillimus.

2. Second anal spine from less than $\frac{1}{4}$ to slightly more than $\frac{1}{3}$ the length of head; second dorsal spine a little shorter than third.

$a$. Præmaxillary processes (measured from anterior edge of upper jaw to their posterior extremities) more than $\frac{1}{2}$ the length of liead.

Snout a little shorter than eye; maxillary extending to below anterior margin

of eye; depth of body $2 \frac{1}{3}-2 \frac{2}{3}$ in the length; 7 gill-rakers on the lower part of anterior arch . . . . . . . . . . . . . . 3. gula. 
Snout as long as eye; maxillary extending to below anterior $\frac{1}{4}$ of eye; depth of

body $29-3$ in the length; 8 gill-rakers on the lowcr part of anterior arch . 4. harengulus.

$b$. Premaxillary processes $\frac{1}{2}$ the length of head; $\tau$ gill-ralier's on the lower part of anterior arch.

1)eptls of body $2 \frac{1}{2}-2 \frac{ \pm}{3}$ in the length . . . . . . . . . . . . . . 5. califormiensis.

nepth of body $3-3 \frac{\mathrm{z}}{\mathrm{s}}$ in the length . . . . . . . . . . . . . . . 6. pseudogula.

B. Anal II 8. . . . . . . . . . . . . . . . . . . . . . . lefroyi.

II. Præoperculum finely scriated.

A. Preorbital entire; no conspicuons dark longitudinal lines along the series of scales.

1. Anal III 8.

a. Second dorsal spine from $\frac{4}{5}$ to as long as the head.

Iaxillary extending nearly to below middle of eye (in specimens of $220 \mathrm{~mm}$.) ;

4 scales between pectoral and ventral . . . . . . . . . . . . . 8. peruvianus.

Maxillary extending to below anterior $\frac{1}{3}$ of eye (in a specimen of $220 \mathrm{~mm}$.) ;

3 scales between pectoral and rentral . . . . . . . . . . . . 9. olithostumus.

b. Second dorsal spine $\frac{1}{2}$ the length of head . . . . . . . . . 10. aureolus.

2. Anal II 9 . . . . . . . . . . . . . . . . . . . . 11. rhombeus.

B. Præorbital finely serrated; conspicuous dark longitudinal lines along the series of scales.

1. Pectoral extending to, or nearly to, origin of anal.

a. Second anal spine as long as longcst dorsal spine.

a. Anal III 8.

4 scales between lateral line and middle of dorsal fin ; 15 gill-rakers on the

lower part of anterior arch . . . . . . . . . . . . . . . . 12. lineatus.

3 seales between lateral line and middle of dorsal fin; 12 gill-rakers on the

lower part of anterior areh . . . . . . . . . . . . . . . . 13. a villaris.

B. Anal $1 \mathrm{II} 7$. . . . . . . . . . . . . . . . . 14. patao.

b. Second anal spine ${ }_{5}^{4}-\frac{7}{8}$ as long as longest dorsal spine. Anal III 8. 15. plumieri.

2. Pectoral not extending to origin of anal. Anal IJI 8.

Second anal spine $\frac{4}{5}$ as long as longest dorsal spine; pectoral $\frac{3}{4}-\frac{1}{5}$ the length

of head . . . . . . . . . . . . . . . . . . . . . 16. brevimamus.

second anal spine ${ }_{x}^{5}$ as long as longest dorsal spine; pectoral as long as head . 17. mexicanus.

1. Gerres cinerens, Walbaum, 1792.

Tystema cintreum (part.), Jord. \& Everm. Bull. U.S. Nat. Mus. xlvii. 1898, p. 137., and 1900, fig. 556.

Hab. Atlantic Coasts from Florida to Brazil ; freshwater ponds of Barbados.

2. Gerres simillimus, sp. n. (Tab. V111. fig. 2.)

rystema cinerenm (part.), Jord. \& Everm. l. e.

lepth of body $2-3-2 \frac{1}{2}$ in the length, length of bead 3 to $3 \frac{1}{4}$. Snout as long as or louger than eye, the diameter of which is more than $\frac{1}{4}$ the length of head; interorlital width $2 \frac{3}{4}$ to 3 in the length of head. Maxillary extending to below anterior $\frac{1}{4}$ of oye. J'reorbital and properenlum ontire. 8 gill-raliers on the lower lart of tho unterior arch. $410-43$ seales in a longitudinal series, 4 botween lateral line and 
middle of dorsal fin. Dorsal IX 10 ; second spine longest, $\frac{2}{3}$ the length of head. Anal III 7 ; second spine not longer than third, about $\frac{2}{5}$ the length of head. Pectoral longer than the hend. Caudal deeply forked. Silvery, back brownish; about 10 narrow bluish vertical bars on the upper part of the side: dorsal and candal fins dusky.

Hab. Pacific Coast from Lower California to Panama:

Rio Presidio, Mexico.

This species differs slightly from its Atlantic representative $(G$. cinereus) in the fewer scales, larger head, longer maxillary, and longer second anal spine, whilst the bars on the sides are usually more numerous.

3. Gerres gula, Cuv. \& Val., 1830.

Eucinostomus gula, Jord. \& Everm. t. c. p. 1370.

Hab. Atlantic Coast from Carolina to Brazil.

The top of the hear is covered with scales to the level of the nostrils except for a small rounded or oval naked area completely surrounded by scales, overlying the præmaxillary spines.

4. Gerres harengulus, Goode \& Bean, 1879.

Eucinostomus harengulus, Jord. \& Everm. t. c. p. 1368.

$H a b$. Atlantic Coast from Florida to Bahia.

5. Gerres californiensis, Gill, 1862.

Eucinostomus dowi, Jord. \& Everm. t. c. p. 1367.

Eucinostomus californiensis, Jord. \& Everm. t. c. p. 1369.

Hab. Pacific Coast from California to Panama:

Rio Mascota, Mexico (Buller).

6. Gerres psendogula, Poey, 1875 .

Eucinostomus pseudogula, Jord. \& Everm. t. c. p. 1368.

Hab. Atlantic Coast from the Bermudas to Brazil.

7. Gerres lefroyi, Goode, 1874.

Ulama lefroyi, Jord. \& Everm. t. c. p. 1371.

Eucinostomus meeki, Eigenm. Bull. U.S. Fish. Comm. xxii. 1902, p. 229, fig. 10 (1904).

Hab. Atlantic Coast from the Bermudas to Cuba; rivers of Cuba.

8. Gerres peruvianus, Cuv. \& Val., 1830.

Gerres peruvianus, Jord. \& Everm. t. c. p. 1376.

Hab. Pacific Coast from Mexico to Peru; Rio Guayas, Ecuador. 
9. Gerres olithostomus, Goode \& Bean, 188:.

Gerres alithostomus, Jord. \& Evcrm. 1. c., and 1900, fig. $55 \pi$.

Hab. Atlantic Coast from Florida to Brazil; Indian River, Florida.

10. Gerres aureolus, Jord. \& Gilb., 1852.

Cerres aureolus, Jord. \& Everm. t. c. p. 1375.

IIab. Pacific Coast of Panama.

11. Gerres rhombeus, Cuv. \& Val., 1830.

Geres rhombers, Jord. \& Evcrm. t. c. p. 1374.

Hab. Atlantic Coast from Cuba to Brazil ; Rio Magdalena, Colombia.

12. Gerres lineatus, IIumboldt.

Gerres lineatus (part.), Jord. \& Everm. t. c. p. 1877.

Hab. Pacific Coast of Mexico: freshwater lake at Acapulco.

13. Gerres axillaris, Günth., 1864.

Gerres lineatus (part.), Jord. \& Everm. l. c.

Hab. Brackish-water lakes at Chiapam, Guatemala (Salvin).

14. Gerres pata0, Poey, 1868.

Gerres brasilianus (part.), Jord. \& Everm. t. c. p. 1378.

IIab. Atlantic Coast from Cuba to Bahia.

15. Gerres plumieri, Cuv. \& Val., 1830.

Gerres brasilianus (part.), Jord. \& Everm. 1. c.

Gerres embry.r, Jord. \& Everm. t. c. p. 1379.

Gerres plumieri, Jord. \& Evcrm. 1. c.

Ilal. Atlantic Coast from Florida to Brazil:

Indian River, Florida; Lake Yzabal, Guatemala (Salvin); Rio Magdalena, Colombia.

As in other species of the genus, the dorsal and anal spines become relatively shorter during growth. 'Thus in specimens of $140 \mathrm{~mm}$. the second dorsal spine is as long as or a little longer than the head, in one of $185 \mathrm{~mm}$. it is $\frac{4}{5}$ the length of the head. Gerres rmbryx, Jord. \& Starks, is based on examples of $300 \mathrm{~mm}$. with the second dorsal spinc $\ddot{3}$ the length of head. Gerres brasilianus, Cuv. \& Val., was described as in every way similar to $G$. plumieri, except for the shorter dorsil spines. 


\section{Gerres brevimanus, Günth., 1864 .}

Gerres brevimanus, Jord. \& Everm. t. c. p. $137 \%$.

Ilab. Brackish-water lakes at Chiapam, Guatemala (Salin); Pacific Coast of Panama.

17. Gerres mexicanus, Steind., 1863.

Gerres mexicanus, Jord. \& Everm. t. c. p. 1380.

Ifal. Rio 'Teapa, Mexico.

\section{Fam. 10. POMADASID现.}

A large and important group of marine fishes, chietly from tropical seas. The species of the widely distributed genus Pomalasis are numerous, but only a few ascend rivers. About thirty-five members of this genus are found on the coast of Tropical America, and sis of these are known to enter rivers freely and must be considered here.

\section{POMADASIS, Lacep., 1803.}

Pristipoma, Günth. Cat. Fish. i. p. 286 (1859).

Body compressed; scales small or of moderate size, ctenoid. Lateral line complete, usually curved. Mouth rather small or of moderate size, protractile; cntire lengtl of upper edore of maxillary slipping under the præorbital; jaws equal anteriorly or the lower somewhat the shorter; bauds ot small villiform teeth in the jaws; palate toothless. I median pit or groove bellind the symphysis of the lower jaw. Præoperculnm serrated; serra on lower limb not directed torwards. A single dorsal, with X-XIV 10-1o rays, with a more or less distinct scaly sheath at the base; soft fin not densely corered with small scales. Anal with III 7-I3 rays. Caudal truncate or forked. Pectoral asymmetrical, pointed; rentrals below or a little behind the base of the pectorals, with I 5 rays; a scaly process at the base of spine of each ventral fin.

IIab. Tropical and subtropical seas, a few species entering rivers.

\section{Synopsis of the Species found in the Rivers of Mexico and Central America.}

Sicales above the lateral line in series parallel to the lateral line. Dorsal XI-XIII 1I-I7. Anal II 6-9*.

I. A series of small scales on the membrane behind each branched ray of the dorsal fin.

Second anal spine not longer than third . . . . . . . . . . . . . 1. leuciscus.

Second anal spine longer than third. . . . . . . . . . . . . . . 2. macracanthus.

* Other species which present these features and which may prove to be fluviatile are $P$. niticlus, $P$. axillaris, and $P$. panamensis from the Pacific Coast, and $P$. curvinceformis from the Atlantic. $P$. panamensis is related to $P$. crocro, the others to $P$. leuciscus. The genns Conoclon, with a species on each coast, is very close to Pomadasis of the t5po of $P$. branicki. It is distinguished by the enlarged outer teeth and the strongly serratel præopercle, with antrorse serræ below the angle.

biol. centr.-AMer., Pisces, February 190 i. 
II. Dorsal fin sealeless, except at the base; second anal spine longer than third.

A. Maxillary not extending beyond the vertieal from anterior margin of eye.

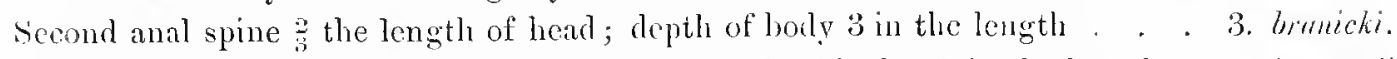
Second anal spine ${ }_{5}^{5}$ to $\frac{7}{6}$ the length of head; deptlo of body $3 \frac{1}{2}$ in the leagth . 4. buncurdi.

B. Maxillary extending to below anterior purt of eye.

$60-i 0$ scales in a longitudinal series. . . . . . . . . . . . . . 5. buyemus.

$54-62$ seales in a longitudiual series. . . . . . . . . . . . . . . c. crocro.

\section{Pomadasis leuciscus.}

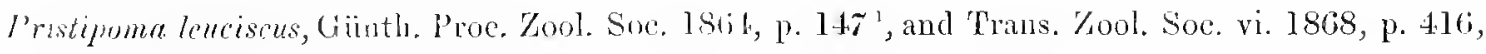
t. 66. fig. $3^{2}$.

Pomadusis leuciscus, Jord \& Giib. Proc. U.S. Nat. Mus. 1881, 1, 388 "; Jorl. \& Fesler, Rep. U.S. Fish. Comm. 189:3, p. $195^{\circ}$.

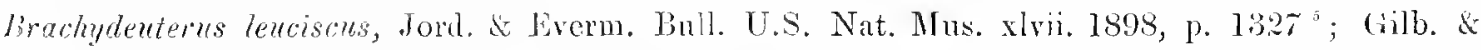
Starkis, Mlem. Calif. Ac. Sci, iv. 1901, 11. 109 ${ }^{\circ}$.

Pepth of body 3 iu tho length, length of head s. Snowt a little longer than ege, the diameter of which is

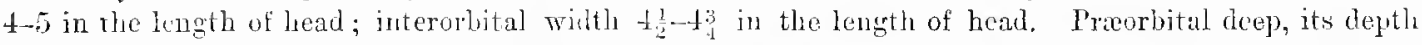
greater than the liameter of eje. Maxillarg not quite reaching the vertical from the anterior margin of ege. 11 or 12 gill-rakers on the lower part of anterior arch. $50-56$ scales in a longitudinal series. $\because$ between lateral lino and midale of dorsal fin. Jorsal XII 14-15; third or fourth spine Jongent, $\frac{1}{3}$ or less than $\frac{1}{3}$ the length of head. Anal III $7-8$ : second spine not longer thim third, $\frac{1}{1}-\frac{1}{3}$ the length of hear. Fectoral $3-\frac{1}{4}$ the length of head. Candal emaroinate. Silcery, back darker; indistinct dark longitudinal lines on the side; edge of opercular membrane blackish; often a blackisln blotch in the axil of pectoral; dorsal and caudal fins dusky.

Ilub. Pacific Coast from California to Peru, entering rivers:

Lower California5.-Mexico, Mazatlan5; Guatemali, San José and Chiapam (Salvin $\left.{ }^{12}\right)$; Panama ${ }^{56}\left(\right.$ Dow $\left.^{2}\right)$. - Northern Peru ${ }^{5}$.

Here described from four specimens, $260-300 \mathrm{~mm}$. in total length, from Panama and Chiapam.

\section{Pomadasis macracanthus.}

Pristipoma marracanthem, Giäth. Proc. Zool. Soc. 1861 1, p. 146', and Trans. Zool. Soce vi. 1866 , p. 4.16, t. 64. fig. $l^{2}$.

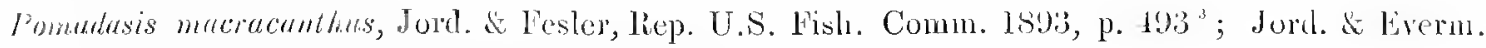
Bull. U.S. Nat. Mus. xlvii, 1698, p. 193:2'.

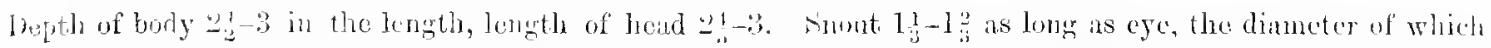

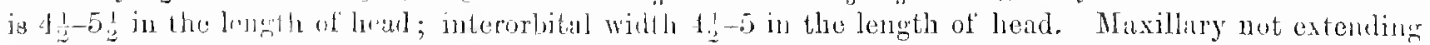
to below the eyo. 15 w 16 gill-rakers on the lower part of anterior areh. Ht-f! scales in a longitudinal

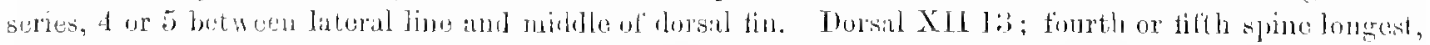

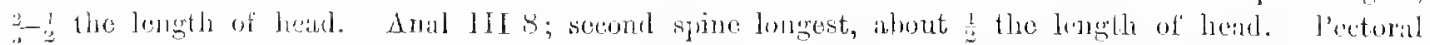
ats long, or nearly as long, as the heal. Caublal slightly emarginate. Caudal pedunclo alout $1 !$ as lom as deep. Back dark; lower part of side silvery; sometimes $\ddot{3}$ or 4 dark cross-bars on the sile; firis dusky. 
Hab. Pacific Coast of Tropical America, entering rivers:

Mexico, Rio Presidio (Forrer); Guatemala, Chiapam ${ }^{124}$ (Salvin); Panamat.

Here described from six specimens, 220-340 $\mathrm{mm}$. in total length, including the types of the species.

\section{Pomadasis branicki.}

P'ristipoma branicki, Steind. Denksehr. Ak. Wien, xii. p. 28 (1879)'.

Pomadasis branicki, Jord. \& Feslcr, Rep. U.S. Fish. Comm. 1893, p. 493” Jord. \& Everm. Bull.

U.S. Nat. Mus. xlvii. 1898, p. $1334^{3}$.

Depth of hody 3 in the length, leugth of head 3 . Snout as long as eye, the diameter of which is $3 \frac{1}{2}$ in the length of liead; intcrorbital width 4 in the length of head. Maxillary not extending to below the eye. I2 gill-rakers on the lomer part of anterior arch. 50 scales in a longitudinal series, $4 \frac{1}{4}$ between lateral line and middle of dorsal fin. Dorsal XIII 12; fourth spine longest, $\frac{3}{5}$ the lonith of head. Anal III 7 ; second spine longest, $\frac{2}{3}$ the length of head. Pectoral a little shorter thas head. Caudal truncate. Silvery, back dirker; vertical fin dusky; suft part of dorsal with 3 serios of spots.

Hab. Pacific Coasts of Tropical America, entering rivers:

Mexico, Mazatlan ${ }^{3}$, Chiapas $^{3}$; Panama ${ }^{3}$.--Peru ${ }^{1}$.

Here described from a specimen from Mazatlan, $165 \mathrm{~mm}$. in total length.

\section{Pomadasis boucardi.}

? Pristipoma ramosum, Poey, Mem. Cuba, ii. p. 186 (1860) '.

Pristipoma boucardi, Steind. Sitzl). Ak. Wien, lx. 1869, p. 120, t. $1^{2}$.

Pomadasis ramosus, Jord. \& Fesler, Rep. U.S. Fish. Comm. 1893, p. $494^{3}$; Jord. \& Everm. Bull.

U.S. Nat. Mrus. xlvii. 1898, p. 133»".

I'omadtsis templei, Meek, Pbl. Columbian Mus. Zool. v. 1901, p. 201, t. 14 ".

Depth of body $3 \frac{1}{2}$ in the length, length of head $3 \frac{1}{3}$. Snont as long as eye, the diameter of which is $3 \frac{2}{3}$ in the length of head; interorbital width $4 \frac{1}{2}-5$ in the length of head. MLaxillary extending to or nearly to the rertical from the anterior margin ol eye. Il gill-rakers on the lower part of anterior arch. $52-55$ scales in a longitudinal serios, $\mathbf{f}$ between lateral line and middte of dorsal fin. Dorsal XIII 12 ; fourth or fitth spine longest, $\frac{1}{2}-\frac{3}{5}$ the length of head. Anal III 6 ; second spine longest, $\frac{5}{6}-\frac{7}{8}$ the length ef head. Pectoral $\frac{3}{4}$ the length of head. Caudal rery slightly emarginate. Caudal peduncie $I_{4}^{3}$ as long an deep. Back dark; lower part of side silvery, with a more or less distinct longitudnal stripe; dorsal and cundal fins dusky.

IIab. Atlantic Coasts of 'Tropical America, entering rivers:

Gulf of Mexico ${ }^{2}$; Mexico, Valles ${ }^{5}$, Perez ${ }^{5}$, and the Rio Tonto (Gadow) in Vera Cruz.-Cuba ${ }^{1}$; Haiti ${ }^{4}$.

Here described from two specimens, 170 and $175 \mathrm{~mm}$. in total length, from the Rio 'Tonto, Southern Mexico.

\section{Pomadasis bayanus.}

Pristipoma humile (non Bowd.), Kner \& Steind. Abl. Bayer. Ak. x. 1866, p. 3, t. 1. fig. $1^{1}$. Pomadasis humilis, Jord. \& Fesler, Rep. U.S. Fish. Comm. 1893, p. $492^{2}$. 
Pomadasis bayanus, Jord. \& Everm. Bull. U.S. Nat. Nus. xlvii. 1898, p. 1331 ${ }^{3}$; Meek, Pbl. Columbiau Mus. Zool. v. 1904, p. $201^{4}$.

Pristipoma labraciforme, Bouleng. Boll. Mus. Toriuo, xiv. 1899, no. 335. p. 3 3.

Depth of body $3 \frac{1}{4}-4$ in the length, length of head $2 \frac{1}{\overline{5}}-3 \frac{1}{4}$. Sinout $I \frac{1}{4}-1 \frac{2}{3}$ as long as eje, the diameter of which is $4 \frac{1}{4}-5 \frac{1}{2}$ in the length of head; interorbital wilth $4 \frac{1}{2}-5$ in the length of head. NEaxillary extending a little beyond anterior margin of pupil. 12 or 13 gill-rakers on the lower part of anterior areh. 60-70 scales in a longitudinal series, 7 or 8 betreen middle of dorsal fin and lateral line. Dorsal XIII 1:2: fourth or fifth spine longest, a little more than $\frac{1}{2}$ the length of heid. Laal III 7 , second spine longest, $\frac{2-t}{5}$ the length of head. Pectoral $\frac{2}{5}-\frac{2}{3}$ the lentroth of he:ul. Candal very slightly emarginate. Caudal peduncle $1 \frac{1}{3}-1 \frac{3}{4}$ as long as deep. Silverg, back darker; dorsal and eaudal fins dusky.

IIul. Pacific Coast of Tropical America, entering rivers:

Lower California ${ }^{4}$-Mexico, Rio Maseota in Jaliseo (buller); Panama, Rio Bayano ${ }^{13}$-_Ecuador, St. Hclena Biy ${ }^{5}$, Rio Durango (Rosenber.g).

Here described from specimens measuring from 160 to $260 \mathrm{~mm}$. in total length.

\section{Pomadasis crocro.}

Pristipoma crocro, Cuv. \& Val. Hist. Nat. Poiss. v. p. 26њ (1830) '; Günth. Cat. Fish. i. p. 296;

$(1859)^{2}$, and Trans. Zool. Soc. vi. 1868, p. $386^{3}$.

Pristipoma cultriferum, Poey, Mem. Cuba, ii. p. 185 (1860)'.

Pomadasys approximans, Bean \& Dresel, Proc. U.S. Nat. Mlus. 1881, p. $160^{5}$.

I'omadasis cracro, Jord. \& Fesler, Rep. U.S. Fish. Comm. 1893, p. $493^{\circ}$; Jord. \& Everm. Bull.

U.S. Nat. Mus. xlvii. 1898, p. $1333^{7}$.

Pumadasys starri, Meek, Pbl. Columbian Mus., Zool. v. 1901 1, p. 200, t. $13^{\circledR}$.

Depth of body $3 \frac{1}{4}-3 \frac{3}{4}$ in the length, length of head $3-3 \frac{1}{3}$. Snout 1 1 $-1 \frac{1}{2}$ as long as eye, the diamecter of which is $4-5$ in the length of head; interortitul width $4 \frac{1}{2}-5$ in the leugth of head. Slaxilhary oxtending to betow anterior $\frac{1}{3}$ of eye. 11 or 12 gill-rakers on the lower part of anterior arch. 54-6:- seales in a longitudinal series, 6 or 7 between lateral line and middle of dorsal fin. Iorsal XIII 11-12; hifth g pine longest, $\frac{1}{2}$ the length of hend or less. Anal III 7 ; second spine longest, $\frac{1}{2}-\frac{\pi}{3}$ the length of head. Pectoral $\frac{2}{3}$ the length of licad. Caudal very slightly emarginate. Candal pedurcle atrout $1 \frac{1}{2}$ as long as deep. liack dark, sides silvery, sometimes with $\ddot{z}$ or 3 dark lougitudinal strifles; dorsal and candul fins dusky.

Hab. Atlantic Coasts of Tropical America, entering rivers:

Mexico ${ }^{2}$, Perez in Vera Cruz ${ }^{8}$; Gnatemala, Rio Motagua (Salvin $\left.{ }^{3}\right)$-_Cuba ${ }^{4}$; Jamaica"; Martilique ${ }^{1}$; Brazile ${ }^{7}$.

Here described from specimens measuring from 190 to $280 \mathrm{~mm}$. in total length.

\section{Fam. 11. CENTROPOMIDE.}

The Centropomidix, or Contropomina (if they be regarded as a subfanily of the Serranida), are a natural and sharply-defined group, represented on the coasts and in the rivers of 'Tropical Ancrica by the genus Centropomes and including also the Old-World genera Lates and Psammoperca, found in the rivers of Tropical Africa and wa the coasts and in the rivers of Soutl-eastern Asia and Northern Anstralia. 


\section{CENTROPOMUS, Lacep., 1802.}

Centropomus, Bouleng. Cat. Fish. i. p. 366 (1895); Jord. \& Everm. Bull. U.S. Nat. Mus. xlvii. 1896, p. $111 \%$.

Body compressed; scales small or of moderate size, finely ctenoid. Lateral line nearly straight, continued to the end of the caudal fin. Mouth rather largc, protractile; maxillary exposed; lower jaw projecting: bands of villiform teeth with obtuse crowns in jaws and on vomer aud palatines. Præorbital and supraclavicle serrated. Preoperculum with a ridgo parallel to its free cdge, bearing 1 or 2 spines at the angle : edge of prooperculum serrated, with enlarged serre or spines at the angle; suboperculnm produced into a long flap. Two dorsals, with VIII, I 9-11 rays; the first spine very small, the second short, the third or fourth the longest; anal short, with IIT 6-7 rays; caudal forked; pectoral asymmetrical, obtnsely pointed; ventrals behind base of pectorals, with I 5 rays; a scaly process at the base of the spine of each ventral fin.

Hab. Coasts and rivers of Tropical America.

I am glad to have the opportunity of attempting a revision of this interesting and difficult genus, and, after examination of all the specimens in the British Museum collection, I have arrived at the conclusion that none of the species occur on both the Pacific and Atlantic Coasts.

Although marine, nearly all the species are known to ascend rivers for considerable distances, so that they must be included in the fresh-water fauna.

\section{Synopsis of the Species.}

I. Anal with 7 branched rays; opercular flap not extending to the vertical from origin of dorsal: second and third anal spines of equal length, or the second slightly the shorter.

$66-72$ scales in a longitudinal series, $8 \frac{1}{2}$ between middle of second dorsal and

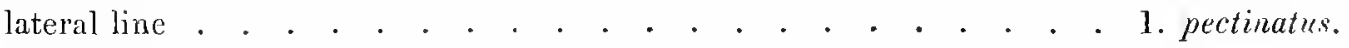

$56-65$ scales in a longitudinal series, $6 \frac{1}{2}$ to $\tau_{\frac{1}{2}}$ between middle of second dorsal and lateral line . . . . . . . . . . . . . . . 2. medius.

II. Anal with 6 (exceptionally 7 ) branched rays.

A. Opercular flap extending to the vertieal from origin of dorsal ; $75-88$ scales in a longitudinal series; second anal spine a little longer than the third. 3. parallelus.

B. Opercular flap not exteuding to the vertical from origin of dorsal; $65-80$ scales in a longitudinal series.

1. Third dorsal spine usually the longest, about $\frac{1}{2}$ the length of head ; $65-75$ scales in a longritudinal series, $7 \frac{2}{2}$ to $8 \frac{1}{2}$ between middle of second dorsal and lateral line.

Second anal spine usually slightly longer than the third, $\frac{1}{7}-\frac{1}{5}$ the length of the fish ( 1 in specimens of $295-330 \mathrm{~mm}$.) ; vent at more than $\frac{2}{3}$ of the distance from hase of ventral spine to origin of anal. . . . Second anal spine not longer than the thild, nearly $\frac{1}{7}$ the length of the fish (in specimens of $320-345 \mathrm{~mm}$.) ; vent at less than $\frac{2}{3}$ of the distance from base of ventral spine to origin of anal . . . . . .

4. undecimalis.

$$
\text { 5. viridis. }
$$

2. Third or fourth dorsal spine the longest, $\frac{}{5}$ the length of head; 73-80 scales in a longitudinal series, 9 or 10 between middle of second dorsal and lateral line; second anal spine not longer than the third . . . 6. nigrescens. 
C. Operenlar flap extending to or beyond the vertical from origin of dorsal; $48-60$ scales in a longitudinal serics.

1. 17-19 gill-rakels, including 2 to 4 rulliments, on the lower part of anterior arch ; 5 to $6 \frac{1}{2}$ scales betwecn middle of second dorsal and lateral line.

Third dorsal spine longer than fourth; sceomel anal spine about $\frac{1}{5}$ the length of the fish (in spccimens of $300 \mathrm{mu}$.) . . . . . . . \% robalito.

Third and foutl dorsal spines subequal ; seenut anal spine about $\frac{1}{4}$ the leugth of the tish (in specimens of nearly $300 \mathrm{~mm}$.) . . . . . .

2. 13-15 gitl-rakers, including 2 or 3 rudiments, on the lower part of anterior arch; 7 to $8 \frac{1}{2}$ scales betwecn middle of second dorsal and lateral line.

Third anal spine $\frac{4}{5}$ as long as second, which is $\frac{2}{7}-\frac{1}{3}$ the length of the fish (in specimens of $210-260 \mathrm{~mm}$.) . . . . . . . . . 9. armatus.

Thind anal spine $\frac{t}{y}$ as long as sccond, which is $\frac{1}{4}$ the length of the fish (in a specimen of $170 \mathrm{~mm}$.) . . . . . . . . . . . . 10. altus.

Third anal spine nearly as long as second, which is less than $\frac{1}{3}$ the lengtl of the fish (in a specimen of $260 \mathrm{~mm}$.) . . . . . . . 11. unionensis.

The length of the fish is measured from the tip of the snout to the base of the caudal fin, that of the head from the tip of the snout to the extremity of the opercular flap, which appears to be a true prolongation of the suboperculum and distinct from the branchiostegal membrane; the projecting lower jaw is not inchuded in either case. The scales are counted in a longitudinal series abore the lateral line from the supraclavicle to the base of the caudal fin, not including the scales covering the basal part of the fin.

In using the descriptions the size of the specimens described must be taken into account. Young specimens have the head proportionately longer, eye larger, snout and maxillary shorter and vertical fins more dereloped than the adults.

In the case of $C$. migrescens the second anal spine is described as $\frac{1}{7}-\frac{1}{5}$ the length of the fish in specimens of $150-300 \mathrm{~mm}$. in total length; i.e., $\frac{1}{5}$ in the smalle st example and $\frac{1}{7}$ in the largest. C.mdecimalis also is describerl as having the second anal spine $\frac{1}{7}-\frac{1}{5}$ the lcugth of the fish, but this is in specimens of $230-600 \mathrm{~mm}$. in total length, the spine being longer in this species than in C. nigrescens, when examples of the same size are comparerl

\section{Centropomus pectinatus.}

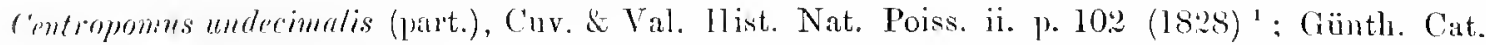
Fi.lı. i. 1. 79) $(1859)^{2}$.

('entropemus pectimatus, Pocy, New. Cuba, ii. p. 121 (1860) ${ }^{3}$, and Repert. ii. p. 280 (1868) '; Vaill. \& Boc. Miss. Se. Hex., Poiss. 1) 25 (1874) ${ }^{5}$; Bonleng. Cat. Fish. i. p. $368(1895)^{6}$;

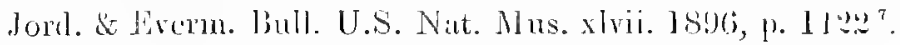

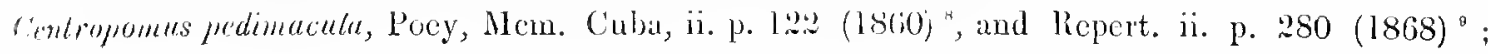


Vaill. \& Boc. Miss. Sci. Mex, Poiss. p. $29^{10}$; Steind. Denkschr. Ak. Wien, xxxix. 1878, p. $22^{11}$.

Centropomus cuvieri, Bocourt, Anı. Sc. Nat. (5) is. 1868, p. $91^{12}$; Vaill. \& Boc. Miss. Sci. Mex., Poiss. p. 26, t. 1 ter. fig. $1^{13}$.

Centropomus pedinacula (part.), Jord. \& Everm. t. c. p. $1119^{14}$.

Depth of body about $3 \frac{2}{3}$ in the longth, leugth of head $2 \frac{5}{6}$. Snout $1 \frac{1}{4}-1 \frac{1}{3}$ as long as eye, the diameler of which is $t-4 \frac{1}{3}$ in the length of head; interorbital width $6 \frac{1}{2}$ in the length of head. Maxillary extending to, below anterior $\frac{1}{3}$ of eye, its greatest width $\frac{1}{2}$ the diameter of eye or less. Prieorbital acutely serrated. præoperculum acutely serrated, with 2 or 3 cnlarged serrie at the angle; præopercular ridge with 2 serri. at the angle. Opereular flap not reaching the rertical from origin of dorsal. 16 or 17 gill-rakers, including. I or 2 rudiments, on the lower part of anterior arch. 66-72 seales in a longiturlinal series, $8 \frac{1}{2}$ between middle of second dorsal and lateral line. Dorsal VIII, I 10; third spine a little longer thinn the fourth, a little more than $\frac{1}{2}$ the length of hoad. Anal III 7 ; second and third spines of equall length or the second slightly the shorter, $\frac{1}{4}$ or $\frac{2}{7}$ the length of the fish. Pectoral a little more than $\frac{1}{2}$ the lenytlit of head. Ventrals extending beyond the vent, which is nearly equidistant from base of inner sentral ray and origin of anal. Caudal perduncle $1 \frac{2}{3}-1 \frac{1}{5}$ as long as deep. Silvery, back brownish ; lateral liwe with or without brownish jigment; spinous dorsal and membrane between second and third ansl spiness dusks; ventrals dusky at the tips.

Hab. Atiantic Coasts of Tropical America, entering rivers:

Cuba $^{34}$; San Domingo ${ }^{6} 1213$; Jamaica ${ }^{14}$; Pernambuco ${ }^{6}$.

Here described from two specimens, 160 and $230 \mathrm{~mm}$. in total length, from San Domingo and Pernambuco.

In this species the number of scales in a longitudinal series has been stated by various authors at from 48 to 78 . These discrepancies are no doubt due to different methods of counting. There are about 50 scales in the lateral line. I count 66 and 72 in a longitudinal series just above the lateral line, from supraclavicle to base of caudal fin, excluding the scales covering the base of the fin. In the same two specimens Boulenger has counted 70 and 75 scales.

\section{Centropomus medius.}

Centropomus medus, Günth. Proc. Zool. Soc. 1864, p. 144', and Trans. Zool. Soc. vi. 1868, p. $406^{2}$; Vaill. \& Boc. Miss. Sc. Mex., Poiss. p. $30(187-1)^{3}$.

Centropomus grandoculatus, Evcrm. \& Jenkins, Proc. U.S. Nat. Mus. xi. 1888, p. $139^{4}$; Jorl at Everm. Bull. U.S. Nat. Mus. xlvii. 18\%6, p. 1120".

Centropomus pedimacula (non Poey), Jord. Proc. U.S. Nat. M [us. viii. 1885, p. $376^{\circ}$; Boulenr. Cat. Fish. i. p. 371 (1895) ?

Centropomus pedimacula (part.), Jord. \& Evern. t. c. p. $1119^{\sharp}$; Gill. \& Starks, Mem. Calif. Ac. Sci. iv. 1904, p. $90^{3}$.

Depth of body $3 \frac{1}{3}-1$ in the length, length of head $23-3$. Snout $1 \frac{1}{3}-1 \frac{2}{3}$ as long as eye, the diameter of which is $4 \frac{1}{2}-6$ in the length of head; interurhital width $6-7$ in the length of hear. Maxillary extending to below anterior $\frac{1}{4}$ or $\frac{1}{3}$ of eye, its greatest wilth $\frac{1}{2}-\frac{8}{1}$ the diameter of eye. Praorbital acutely serrated posteriorly; prooperculum acutely scrrated, with 2 or 3 enlarged serre at the angle; proopercular ridgt with 1 or 2 weak spines at the auglo. Opercular flap not reaching the vcrtical from origin of dorsal. 16 or 17 gill-rakers, including $]$ or 2 rudiments, on the lower part of anterior arch. 56-65 scales in it longitudinal series, $6 \frac{1}{2}-7 \frac{1}{2}$ between middle of second dorsal and lateral line. Dorsal VIII, I 10 ; third 
spine the longest, $\frac{1}{2}-\frac{3}{5}$ the length of head. Anal 1 II 7 ; second and third spines of cqual length or the second slightly the shorter, $\frac{1}{5}-\frac{1}{4}$ the length of the fish. Pectoral $\frac{1}{2}$ or a little moro than $\frac{1}{2}$ the leugth of head. Ventrials extending to or beyond the rent, which is nearly equilistant from base of inner ventral ras and origin of anal. Candal peduncle $1 \frac{1}{2}-1 \frac{2}{3}$ as $\log g$ as decp. Nilrery, back darker ; lateral line black: spinous dorsal and membrane between second and third anal spines blackish; rentrals dusky at the tips.

Hab. Pacific Coasts of Tropical America, entering rivers:

Mexico, Guaymas ${ }^{4}$, Mazatlans, San Juan Lagoon ${ }^{5}$; Guatemala, Chiapam ${ }^{1} \geq 7$ (Salvin); Panama ${ }^{9}$.

Here described from seven specimens, $200-360 \mathrm{~mm}$. in total length, from Chiapam and Panama.

C. medius is the Pacific Coast representative of $C$. pectinatus, from which it scarcely deserves to be specifically separated. The scales are less numerous and less crowded anteriorly above the lateral line, the paired ridges on the bead are weaker and further apart, and the fin-spines usually more slender than in $C$. pectinatus. The black lateral line also appears to be a characteristic feature of the Pacific Conast form.

\section{Centropomus parallelus.}

Centropomus undecimalis (part.), Günth. Cat. Fish. i. p. 79 (1859) ${ }^{\perp}$.

Centropomus parallelus, Poer, Mcm. Cuha, ii. p. 120 (1860) ${ }^{2}$, and Repert. ii. p. 280 (I868) ${ }^{3}$;

Güntlı. Trans. Zool. Soc. vi. 1868, p. $40{ }^{\circ}$; Vaill. \& Boc. Miss. Sc. Mex., Poiss. p. 22

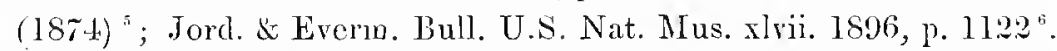

Centropomus aphendiculatus (part.), Gïnth. T'ans. Zool. Soc. vi. 1868, p. $406^{7}$.

Centropoinus mexicanus, Bocourt, Ann. Se. Nat. (5) ix. 1868, p. $90^{*}$; Vaill. \& Boe. o. e. p. 23,

t. 1. fig. $2^{\circ}$; Jord. \& Everm. t. c. p. $1121^{10}$; Meek, Pbl. Columbian Mus. Zool. v. 190t, p. $199^{12}$.

(entropomus paralletus (part.), Bouleng. Cat. Fish. i. p. 369 (1895) ${ }^{12}$.

rentropomus galbi, Fowler, Proc. Ae. Philad. 1906, p. 423, fig. $1^{13}$.

Ceniropomus leringi, Fowler, t. c. p. 425 , fig. $2^{14}$.

1)epth of body about $3 \frac{1}{2}$ in the length, length of head $23-23$. Snout $1 \frac{1}{4}-\left[\frac{1}{2}\right.$ as loug as eye, the diameter of which is $4 \frac{2}{3}-6$ in the length of head; interorlital width $7 \frac{1}{2}$ in the lemgth of head. Maxillary extending to helow middle of eye, its greatest width $\frac{1}{2}-\frac{3}{5}$ the diameter of eye. Praenrlital acutely serrated; prxolerculum acutely serrated, with 2 or 3 enlilrged serre at the angle; preopercular ridge with 2 spines at the angle. Operculir flap extending to the vertical from the origin of dorsal. 14 gill-rakers, including 2 or 3 rudiments, on the lower part of anterior areh. $75-88$ stales in a longitudinal series, 8-11 between middle of second dorsal and lateral lino. loorsal Vill, I 10; thirl or fourth spine longest. $\frac{1}{2}$ the length of head. Anal III 6 ; second spine a little longer than third, about 4 the length of the tish. I'cctoral a little more than $\frac{1}{2}$ the length of head. Ventrals about reaching the rent, which is situated very slightitly neater to the wripin of anal than to the base of the inner ventral rays. Caludal pedmele about $1 \frac{1}{2}$ as long as deep. Silvery, back darker; lateral line usially more or less blackish; dorsal fins dusky.

I/ab. Atlantic Coasts of Tropical America, entering rivers:

Mexico, Oaxaca ${ }^{89}$, San Francisco ${ }^{11}$, Boca del Rio ${ }^{11}$, El Hule ${ }^{11}$, Perez ${ }^{11}$, and the Rio Tonto (Gadow) in Vera Cruz; Panama, Rio Clagres (Salvin ${ }^{4}$ ).Surinam $^{14}$; Braril, Permambuco ${ }^{12}$, Bahia ${ }^{412}$; Cuba ${ }^{23}$; Haiti ${ }^{42} 13$; Jamaica ${ }^{42}$. 
Here described from five specimens, 200-300 mm. in total length, from Pernambuco, the Rio Chagres, and the Rio Tonto, Southern Mexico.

\section{Centropomus undecimalis.}

Sciana undecimalis, Bloch, Ausl. Fische, vi. p. 60, t. 203 (1792) '.

Platycephalus undecimalis, Schneid., Bloch's Syst. Jchthyol, i. p. $59(1801)^{2}$.

Centropomus undecimradiatus, Lacep. Hist. Nat. Poiss. iv. p. 268 (180:2) ${ }^{3}$.

Perca loubina, Lacep. t. c. p. $418^{+}$.

Sphyrana aureoviridis, Lacep. o. c. v. p. 327, t. 9. fig. $2(1803)^{\circ}$.

Centropomus undecimalis (part.), Cuv. \& Val. Hist. Nat. Poiss. ii. p. 102, t. 14 (1828) ${ }^{\circ}$; Günth.

Cat. Fish. i.p. 79 (1859) ${ }^{7}$; Boulenger, Cat. Fish. i. p. 367 (1895) ${ }^{8}$; Gilb. \& Starks, Mem.

Calif. Ac. Sci. iv. 1904, p. $89^{9}$.

Centropomus undecimalis, Guichen. in Ramon de la Sagra's Hist. Cuba, Poiss. p. 9 (1853) '";

Vaill. \& Boc. Miss. Sc. Mcx., Poiss. p. 17, t. 2. fig. 1 (1874) " ; Steiud. Denkschr. Ak.

Wien, xxxix. 1878, p. $21^{12}$; Jord. \& Gilb. Syn. Fish. N. A. p. 528 (1882) ${ }^{13}$; Everm. \&

Kendall, Bull. U.S. Fish. Comm. 1892, t. 37 (1894) ${ }^{14}$; Jord. \& Everm. Bull. U.S. Nat. Mus. xlvii. 1896, p. $1118^{15}$.

Centropomus appendiculatus, Poey, Mem. Cuba, ii. p. 119 (1860) ${ }^{16}$, and Repert. ii. p. 280 (1868) ${ }^{17}$.

Centropomus appendiculatus (part.), Günth. Trans. Zool. Soc. vi. 1868, p. $406^{18}$.

Centropomus parallelus (part.), Bonleng. t. c. p. $369^{19}$.

? Centropomus constantinus, Jord. \& Everm. t. c. p. $1125^{20}$.

Centropomus argenteus, Regan, Ann. Mag. Nat. Hist. (7) xiii. 1904, p. $260^{21}$.

Depth of body $3 \frac{3}{4}-4 \frac{1}{2}$ in the length, length of head $2 \frac{2}{3}-2 \frac{4}{5}$. Snout $1 \frac{3}{5}-2$ as long as eye, the diameter of which is $6-8 \frac{1}{2}$ in the length of head; interorbital width $8-9$ in the length of head. Maxillary extending to below middle or posterior edge of eye, its greatest width $\frac{1}{2}-\frac{4}{5}$ the dianeter of eye. Præorbital weakly serrated; præoperculum acutely serrated, the serræe enlarged at the angle; I or 2 feeble spines at angle of præopercular ridge. Opercular flap not reaching the vertical from origin of dorsal. 8 or 9 welldeveloped gill-rakers and a few rudiments on the lower part of anterior arch. $67-75$ scales in a longitudinal series, $7 \frac{1}{2}-8 \frac{1}{2}$ between middle of sceond dorsal and lateral line. Dorsal VIII, I 10; third spine usually the longest, about $\frac{1}{2}$ the length of head. Anal III 6 ; second and third spines subequal in length, the second sometimes slightly the longer, $\frac{1}{5} \frac{1}{7}$ the length of the fish. Pectoral $\frac{1}{2}$ or a little more than $\frac{1}{2}$ the length of head. Ventrals not reaching vent, which is situated at more than $\frac{2}{3}$ of the distance from base of ventral spine to origin of anal. Caudal peduncle $1 \frac{3}{4}-2$ as long as deep. silvery or golden, back greenish; lateral line usually blackish; spinous dorsal dusky.

Hab. Atlantic Coasts of Tropical America, ascending rivers:

Mexico ${ }^{78}$; British Honduras, Belize ${ }^{11}$; Panama, Rio Chagres (Salvin 78 18). Cuba ${ }^{10151617}$; Haiti ${ }^{611}$; Jamaica ${ }^{1278}$; Porto Rico ${ }^{11}$; Martinique ${ }^{5}$; Barbados ${ }^{1921}$; British Guiana ${ }^{1921}$; Cayenne ${ }^{4}$; Bahia ${ }^{20}$; Rio Janeiro.

Here described from six specimens, 230-600 $\mathrm{mm}$. in total length, from Jamaica, Mexico, the Rio Chagres, and Rio Janeiro. The small examples from Barbados and Guiana, referred by Boulenger to $C$. parallelus and described by me under the name of $C$. argenteus, prove to be young individuals of this species. 


\section{Centroponus viridis.}

Centroponens rividis, Lockington, Proc. Calif. Ae. Sci. viii. 187t, p. $110^{1}$; Jord. \& Everm. Bull. U.S. Nat. Mrus. xlvii. 1896, p. $1118 "$.

Centropomus undecimalis (part.), Gilb. \& Starks, Mem. Calif. Ac. Sci. iv. 1904, p. $89^{3}$.

Mepth of boly $4 \frac{1}{4}-4 \frac{1}{3}$ in the length, length of head $2 \frac{3}{6}-3$. Snout $2-2 \frac{1}{4}$ as long as cye, the diameter of which is $S$ in the length of head, interorbital width $7-\tau \frac{1}{2}$. Maxillary extending beyond middle of eye, its greatest width the diameter of eye. Procorbital wcakly scrrated; preoperculum acutely serrated, the serre enlarged at the angle; 1 or 2 feeble spines at angle of præopercular ridge. Opercular flap not reaching rhe rertical from origin of dorsal. S or 9 well-dereloped gill-rakers and a few rudiments on the lower part of anterior arch. $65-70$ seales in a longitudinal series, 8 or $8 \frac{1}{2}$ between midale of second dorsal and lateral line. Dorsal TIIl, I 9 ; third spine longest, $\frac{1}{2}$ the length of head. Anal III 6 ; second and thisd spines subequal in length, nearly $\frac{1}{T}$ tho length of the fish. Pectoral $\frac{1}{2}$ the length of head. Tentrals not reaching rent, which is situated at about $\frac{5}{8}$ of the distance from base of ventral spine to oricin of anal. Caudal peduncle 2 as long as deep. Silvery or golden, back greenish; latcral line blackish : spinons dorsal dusky.

Hab. Pacitic Coasts of Tropical America:

Lower California, Asuncion I. 1.-.-Nazatlan 2 ; Panama 23.

Here described from two specimens, 350 and $380 \mathrm{~mm}$. in total length, from Panama and Nazatlan.

As in its Atlantic representative, $C$. undecimalis, the air-bladder lias a pair of anterior appendages. From C. mlecimalis, with which it has been confused, this species is seen to differ, when specimens of the same size are compared, in the somewhat smaller eye, broader interorbital region, broader maxillary, shorter anal spines, and more anteriorly placed rent. Moreover, the two specimens here described agree in having 9 branclied rays in the dorsal fin, whilst all I have seen of C. undecimalis have 10.

The principal differences are shown by the following measurenents (in millimetres) of the two specimens of $C$. viridis and the two of $C$. undecimalis which come nearest to them in size :-

\begin{tabular}{|c|c|c|c|c|}
\hline \multirow[b]{2}{*}{ Length, to base of caudis } & \multicolumn{2}{|c|}{ C. viridls. } & \multicolumn{2}{|c|}{ C. undecimatis. } \\
\hline & 320 & 345 & 295 & 330 \\
\hline Inter rbitul wilth ... & 14 & 17 & 12 & 12 \\
\hline Lengtl of second anal spine & 45 & 49 & $\therefore 1$ & 54 \\
\hline Distance from base of rentral spine to rent & 70 & 80 & 70 & Ss \\
\hline ,. rent to origiu of anal. & 40 & 4.5 & 30 & 32 \\
\hline
\end{tabular}

\section{Centropomus nigrescens.}

Centropmuns migrescens, Günth. Proe. Zool. Soc. 1864, p. 144', and Trans. Zool. Soc. vi. 1868, 1. $407^{\prime \prime}$; Vaill. \& Boc. Mliss. Sci. Mex., Poiss. p. 20, t. 1 bis, fig. 1 (1874) ${ }^{3}$; Bouleng. Cat.

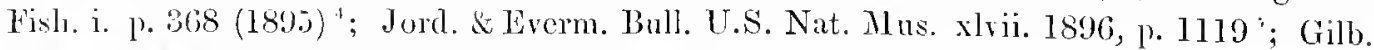

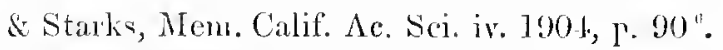

Centropoums undecimalis (part.), Bouleng. t. e. p. $367^{\top}$.

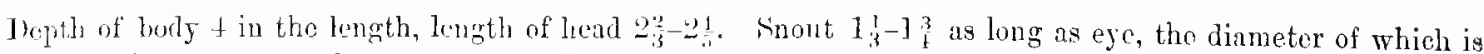

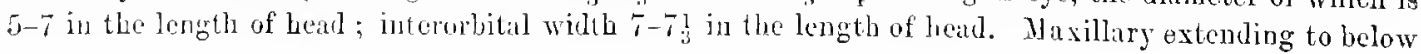


middle of eye or beyond, its gratest width $\frac{1}{2}-\frac{2}{3}$ the diameter of eye. Proorbital wealily serrated; prooperculum acutely serrated, the serre enlarged at the angle; 1 or 2 fecble spines at angle of preopercular ridge. Opercular flap not reaching the vertical from origin of dorsal. 8 or 9 well-developed gill-rakers and a few rudiments on the lower part of anterior arcb. $73-80$ scales in a longitudinal serics, 9 or $J 0$ between middle of second dorsal and lateral line. Dorsal VIII, I I0; third or fourth spine longest, $\frac{2}{5}$ the length of head. Anal III 6 ; second and third spines subequal in length, $\frac{1}{\bar{y}}-\frac{1}{7}$ the length of the fish. Pectoral $\frac{1}{2}$ or a little more than $\frac{1}{2}$ the length of head. Ventrals not reaching rent, which is situated at about $\frac{2}{3}$ of the distance from hase of rentral spine to origin of anal. Candal peduncle $1 \frac{3}{4}-2$ as long as deep. Silvery, back brownish; lateral line blackish; spinous dorsal usually blackish; otber fins usually more or less dusky.

Hab. Pacific Coasts of Tropical America, entering rivers:

Mexico, Mazatlan 45, Rio Presidio ${ }^{4}$ (Forrer), Rio Mascota ${ }^{7}$ (Buller); Guatemala, Chiapam ${ }^{12}$ (Salvin); Panama ${ }^{6}$.

Here described from three specimens, $150-300 \mathrm{~mm}$. in total length, from the Rio Presidio, the Rio Mascota, and Chiapam.

This species is very closely allicd to C. viridis, but the anterior processes of the airbladder are wanting, whilst the third dorsal spine is shorter, the scales are somewhat smaller, and the rent is placed a little further back. There appear to be constantly 10 branched rays in the second dorsal fin.

\section{Centropomus robalito.}

Centropomus armatus (non Gill), Günth. Trans. Zool. Soc. vi. 1868, p. 408 '.

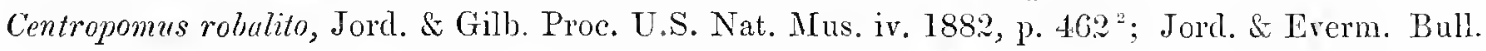
U.S. Nat. Mus. xlvii. 1896, p. $1123^{ \pm}$; Gilb. \& Starks, Mem. Calif. Ac. Sci. iv. 1904, p. 94, t. 13. fig. $25^{4}$.

Centropomus ensiferus (part.), Bouleng. Cat. Fish. i. p. 369 (1895) ${ }^{5}$.

Dejth of body $3 \frac{1}{4}-3 \frac{3}{4}$ in the length, length of head $2 \frac{9}{5}-2 \frac{3}{5}$. Snout $1 \frac{1}{2}-2$ as long as eje, the diameter of which is $6-7 \frac{1}{2}$ in the length of bead; interorbital width $S$ in the length of head. Naxillary cxtending to below middle of eje, or nearly, its greatest width $\frac{3}{5}-\frac{4}{5}$ the diameter of eye. Præorbital acutely serrated posteriorly ; preoperculum acutely serrated, with 1 or 2 cularged serræe at the angle; preopercular ridge with $I$ or 2 spines at the angle. Opercular flap extending a little beyond the rertical from origin of dorsal. 3.7-19 gill-rakers, including 2 or 3 rudiments, on the lower part of anterior arch. $45-54$ scales in a longitudinal series, $5-6 \frac{1}{2}$ between midale of second dorsal and lateral line. Worsal VIII, I ]0; spines of moderate strength, the third the longest, about $\frac{1}{2}$ the leugth of lear. Anal III 6 ; third spinc. $\frac{3}{4}-\frac{5}{6}$ as long as sceond, which is from $\frac{1}{5}$ to a littlo more than $\frac{1}{4}$ the length of the fish. Pectoral $\frac{a}{5}$ as lon: as head. Tentrals extending about to the rent, which is situated at $\frac{3}{5}$ of the distance from base of rentral spine to origin of anal. Ciudal peduncle $i \frac{1}{5}-1 \frac{1}{2}$ as long as deep. Nilvery or golden, back brownish; lateral line not blackish; spinous dorsal and membrane between second and third anai spines usually blackish.

II $\iota$. Pacific Coasts of Tropical America, entering rivers:

Mexico, Rio Presidio ${ }^{5}$ (Forrev), Mazatlan ${ }^{23}$, Acapulco ${ }^{23}$; Guatemala, Chia$\operatorname{pam}^{15}$ (Salvin); Panama ${ }^{34}$.

Here described from nine specimens, $180-300 \mathrm{~mm}$. in total length, from Panama, Chiapam, Mazatlan, and the Rio Presidio. 


\section{Centropomus ensiferus.}

'entropomus undecimalis (part.), Günth. Cat. Fish. i. p. 79 (1859) '.

Centropomus ensiferus, Pocy, Mem. Cuba, ii. p. 122, t. 12. fig. I (1860) ${ }^{2}$; Günth. Trans. Zool. Soc.

vi. 1868, p. $408^{3}$; Vaill. \& Boc. Nliss. Sci. Mex., Poiss. p. $33(1874)^{4}$; Steind. Denkschr.

Ak. Wien, xxxix. 1878, p. $21^{5}$; Jord. Proc. U.S. Nat. Mus. ix. 1886, p. $39^{B}$; Jord. \&

Everm. Bull. U.S. Nat. Mus. xlvii. 1896, p. $1125^{7}$.

Centropomus affinis, Steind. Sitzb. Ak. Wien, xlis. i. 1864, p. 200, t. 1. fig. $1^{8}$; Vaill. \& Boc. Miss.

Sci. Mex., Poiss. p. 31, t. 1. fig. 1 '.

r'entropomus scaber, Bocourt, Ann. Sc. Nat. (5) ix. 1868, p. $90^{10}$.

Centropomus ensiferus (part.), Boulcng. Cat. Fish. i. p. 370 (1895) ${ }^{\prime \prime}$.

Depth of body $3 \frac{1}{3}-4$ in the length, length of head $2 \frac{1}{2}-2 \frac{3}{4}$. Snout $1 \frac{1}{2}-2$ as long as eye, the diameter of which is 6-8 in the length of head; interorbital width about 8 in the length of head. Maxillary extending to helow anterior $\frac{1}{3}$ or mearly to middle of eye, its greatest width $\frac{1}{2}-\frac{2}{3}$ the diameter of eje. Præorbital sharply serrated posteriorly; Iræoperculum acutely serrated, the serræe enlarged at the angle; præopercular ridge with 1 or 2 spines at the angle. Opercular flap extending to or a little beyond the vertical from origin of dorsal. 17-19 gill-rakers, including 3 or 4 rudiments, on the lawer part of onterior arch. 52-58 scales in a longitudinal series, $5 \frac{1}{2}-6 \frac{1}{2}$ between middle of second dorsal and lateral line. Dorsal VII1, I 10 ; spines moderately strong, the third or fourth the longest, $\frac{2}{5}-\frac{1}{2}$ the length of head. Anal 1II 6: third spine $\frac{3}{4}-\frac{1}{5}$ as long as the second, which is $\frac{1}{4}-\frac{2}{7}$ the length of the fish. Pectoral $\frac{3}{\overline{5}}$ the length of bead. Ventrals extending nearly to the vent, which is situated at $\frac{3}{5}$ of the distance from base of rentral spine to origin of anal. Candal peduncle $1 \frac{1}{3}-1 \frac{1}{5}$ as long as deep. Silvery, back brownish ; lateral line not blackish; spinous dorsal and membrane between second and third anal spines usnally blackisb.

Hab. Atlantic Coasts of Tropical America, entering rivers:

British Honduras, Belize ${ }^{131011}$ (Salvin).-Cuba ${ }^{2}$; Jamaica ${ }^{1}$; Trinidad ; British Guiana ${ }^{1811}$; Rio Janeiro ${ }^{8}$; Cajutuba ${ }^{8}$.

Here described from five specimens from Belize, Trinidad, and Jamaica, 200-280 mm. in total length.

\section{Centropomus armatus.}

Centropomus armatus, Gill, Proc. Ac. Plilad. 1863, p. $163^{1}$; Jord. \& Everm. Bull. U.S. Nat. Mus. slvii. 1896, p. $1123^{2}$; Gilb. \& Starks, Mem. Calif. Ac. Sci. iv. 1904, p. 92, t. 13. fig. $26^{3}$.

Centropomus brevis, Günth. Proc. Zool. Soc. 1864, p. $145^{4}$.

Centropomus ensiferus (part.), Bouleng. Cat. Fish. i. p. 369 (1895) '.

Centropomus atridorsalis, Regan, Aun. Mag. N. H. (7) xii. 1903, p. $627^{\circ}$.

Depth of body $3-4$ in the length, length of head $2 \frac{2}{3}-2$. Snout $1 \frac{1}{2}-2$ as long as eye, the diameter of which is $6-7 \frac{1}{2}$ in the length of head; interorbital width 7 in the length of head. MIaxillary extending to below middle of eyo or beyond, its greatest wilth $\frac{3}{5}-\frac{1}{5}$ tho diameter of ejo. Præorhital strongly serrated posteriorly; præoperculum acutely seriated, with 2 or 3 strongly enlarged serre at the angle; praopercular ridge with 1 or 2 spines at the angle. Operenlar flap extonding a little beyond the vertical from origin of dorsal. 13-15 gill-rakors, including 22 or 3 rudiments, on tho lower part of anterior arch. $50-50$ scales in a longitudinal scries, $7-8 \frac{1}{2}$ between middle of second dorsal and lateral line. Dorsal VIII, I 10 ; spines strong, the third often slightly longer than the fourth, $\frac{2}{5}-\frac{1}{2}$ the length of head. Anal IIJ 6 (exceptionally 7 ); third spine $\frac{2}{3}-\frac{1}{5}$ as long as the second, which is $\frac{2}{7}-\frac{1}{3}$ the length of the fish. Pectoral $\frac{2}{3}$ the length of hear. Ventrals extending to tho vent, which is situaled at about $\frac{2}{3}$ of the dislance from base of ventral spiue to origin of anal. Caudil peduncle $1 \frac{1}{3}-1 \frac{2}{3}$ as long as decp. Silvery, 
hack darker; lateral line usually more or less blackish; spinons dorsal and membrane between second and third anal spines blackish.

Hab. Pacific Coasts of Tropical America, entering rivers:

Panama 1235 ; Rio Vauqueria, Ecuador ${ }^{6}$.

Here described from four specimens from Panama, 210-260 mm. in total length.

Centropomus brevis is founded on a young example of C. armatus; and C. atri. dorsalis was described from a small specimen of this species from the Rio Vauqueria, N.W. Ecuador, with the exceptional number of seven branched rays in the anal fin.

\section{Centropomus altus, sp. n. (Tab. VIII. fig 1.).}

Centropomus armatus (non Gill), Vaill. \& Boc. Miss. Sci. Mex., Poiss. p. 34, t. 1 ter, fig. 3 (1874) '. Centropomus ensiferus (jart.), Bouleng. Cat. Fish. i. p. $369(1895)^{2}$.

Depth of body 3 in the length, length of head $2 \frac{1}{2}$. Snout $1 \frac{1}{2}$ as long as eye, the diameter of which is 6 in the length of head and equal to the interorhital width. Maxillary extending to below middle of eye, its greatest width $\frac{2}{3}$ the diameter of eje. Preorbital acutely serrated posteriorly. Posterior edge of præopercle acutely serrated; two strong spines at the angle; lower edge with only 4 or 5 distinct serrie. Subopercular flap extending a little beyond the vertical from origin of dorsal. 14 gill-rakers, including 3 rudiments, on the lower part of anterior arch. 50-52 scales in a longitudinal series, 7 or 8 between middle of second dorsal and lateral line. Dorsal VIII, I 9-10; spines moderately strong, the third or fourth the longest, a little more than $\frac{2}{5}$ the length of head. Anal III 6 ; third spine $\frac{4}{5}$ the length of the second, which is $\frac{1}{4}$ the length of the fish. Pectoral $\frac{3}{5}$ the length of head. Ventrals extending a little beyond the vent, which is situated at $\frac{3}{5}$ the distance from base of rentral spine to origin of anal. Caudal peduncle $1 \frac{1}{2}$ as long as deep. Silvery, back brownish; lateral line not blackish; vertical fins more or less dusky.

\section{Hab. Atlantic Coast of Panama, Colon (Boucard ${ }^{2}$ ).}

The description is based on a single specimen, $170 \mathrm{~mm}$. in total length. 'Two others, of 85 and $95 \mathrm{~mm}$, agree with it in all essential characters, but have, of course, a shorter snout, larger eye, more elevated spinous dorsal and longer anal spines. The number of scales and fin-rays in these is included in the description.

C. altus is the Atlantic representative of $C$. unionensis, from which it differs especially in the deeper body, the more strongly armed præoperculum, and the longer second anal spine, projecting further beyond the third.

\section{Centropomus unionensis.}

Centropomus unionensis, Bocourt, Ann. Sc. Nat. (5) ix. 1868, p. $90^{1}$; Vaill. \& Boc. Miss. Sc. Mex., Poiss. p. 37, t. l. fig. 3 (1874) ${ }^{2}$; Stcind. Sitzb. Ak. Wien, lxxiv. i. 1876, p. $49^{3}$; Bouleng. Cat. Fish. i. p. $370(1895)^{4}$; Jord. \& Evernı. Bull. U.S. Nat. Mus. xlvii. 1896, p. 1122 ${ }^{5}$; Gilb. Starks, Mem. Calif. Ac. Sci. iv. 1904, p. 90, t. 13. fig. $27^{\circ}$.

Depth of body $3 \frac{1}{2}$ in the length, length of head $2 \frac{3}{5}$. Snout $1 \frac{3}{4}$ as long as eye, the diameter of which is 7 in the length of head; interortital width 6 in the length of head. Maxillary extending to below the middle of eye, its greatest width $\frac{2}{3}$ the diameter of eje. Præorbital feebly serrated posterinrly. Posterior edge of præopercle feebly serrated; two moderately strong spines at the angle; lower edge with a few serre. Opercular flap extending slightly beyond the vertical from the origin of dorsal. 14 gill-rakers, including 3 rudiments, on the lower part of the anterior arch. 52 scales in a longitudinal serics, $\tau_{\frac{1}{2}}$ between mirldle 
of second dursal and latcral line. Dorsal TIII, I 9: spines of moderate strength, the third and fourth the longest, a little more than $\frac{2}{i}$ the length of head. Anil JII 6 ; second spine slightly longer than the third, less than $\frac{1}{5}$ the length of the fish. Pectoral nearly the rent, which is situated at $\frac{3}{3}$ of the distance l'rom base of rentral spine to origin of anal. Caudal peduncle $1 \frac{1}{2}$ as long as decp. Silvery, back brownislı; lateral lino not blackish ; sjinous dorsal blackish, other fins palo.

IIal. Pacific Coasts of Central America:

$$
\text { Salvador, La Union }{ }^{12} \text {; Panama } 56 .
$$

The above description is based on a single specimen, $260 \mathrm{~mm}$. in total length, from Panama.

\section{Sub-order II. LOPHOBRANCHII.}

This sub-order comprises a number of marine fishes, mostly of small size and peculiar appearance. A few "Pipe-fishes" of the genera Syngnathus and Doryichthys are known to occur in the fresh waters of Mexico and Central America. They may be casily recognized by the long slender body enclosed in bony rings, the tubiform snout, and the small, terminal, toothless mouth.

\section{Fam. SYNGNATHIDZE.}

Lophobranchii with small gill-openings, a single dorsal tin without spines, and no ventral fins.

\section{SYNGNATHUS, Linn.}

Syngnatlues, Güntlı. Cat. Fislı. viii. p. 155 (1870).

Siphrostrma, Jord. \& Everm. Mull. U.S. Nat. Mus. xlvii. 1896, p. 761.

lectoral fins present; caudal fin present; males with an cgg-pouch under the tail.

Of the numerous American species of this widely distributed tropical genus only three appear to have been definitely recorded from fresh waters.

\section{Syngnathus spicifer, Riipp.}

Syngnathus spicifer, Günth. Cat. Fish. viii. p. $172(1870)$.

liody-rings 15-10 (abdominal) $+38-42$ (caudal). Dorsal rays 23-27. Origin of dorsal separated by 1 or 2

caudal rings from the ring containing the vent. Alulomen with dark vertical bars at the edges of the riugss.

IIab. 'Tropical Indo-Pacific.

I have compared three specimens in the British Museum from Tehuantepec with others from Zanzibar and the Philippines and I cannot detect any differences. 


\section{Syngnathus auliscus, Swain.}

Siphostomus auliscus, Jord. \& Everm. Bull. U.S. Nat. MIus. xlvii. 1896, p. 767.

Body-rings $15+3 \bar{\imath}-38$. Dorsal rays 29-30. Origin of dorsal on the riug containing the vent or the one behind it.

Hab. Pacific Coast from California to Panama.

This species has been recorded by Gilbert and Starks (Mem. Calif. Ac. Sci. iv. 1904, p. 57) from the Rio Grande, at Miraflores, near Panama.

3. Syngnathus starksi, Jord. \& Culv.

Siphostoma starksi, Jord. \& Everm. Bull. U.S. Nat. Mus. xlvii. 1896, p. $r$ rl.

Body-rings $11+37-38$. Dorsal rays 38.

Hab. Mexico, Rio Presidio in Sinaloa.

\section{DORYICHTHYS, Kaup.}

Doryichthys, Günth. Cat. Fish. viii. p. 179 (18r0).

Doryrhamphus, Jord. \& Ererm. Bull. U.S. Nat. Mus. xlvii. 1896, p. 7\%3.

Pectoral fins present; caudal fin present; males with an egg-pouch under the abdomen.

Hab. Tropical seas.

Of three American species, two have been recolded from fresh waters.

\section{Doryichthys lineatus, Kaup.}

Doryichthys lineatus, Giinth. Cat. Fish. viii. p. 183 (1870).

Doryrhamphus lineatus, Jord. \& Everm. Bull. U.S. Nat. Mus. xlvii. 1896, p. 783.

Siphostoma brevicaudum, Meek, Pbl. Columbian MLus. Zool. v. 1904, p. 163, fig. 51.

Bodr-rings 19-22+23-27. Dorsal rays 42-41, the fin originating in adranee of the vent. Snout $1 \frac{1}{2}$ as long as the rest of head.

Hab. Tropical Atlantic.

Recorded by Meek from Boca del Rio in Vera Cruz, Mexico.

2. Doryichthys brachyurus, Bleek.

Doryichthys brachyurus, Günth. Cat. Fish. viii. p. 184 (1870).

Body-rings $21-23+19-24$. Dorsal rays $36-42$, the fin originating abore the vent. Snout $1 \frac{2}{5}-1 \frac{1}{\overline{5}}$ as long as rest of head.

Hab. Tropical Indo-Pacific.

Specimens from Tehuantepec in the British Museum, which I have compared with the type of the species from the East-Indian Archipelago. 


\section{Sub-order III. PERCESOCES.}

The Fishes of this sub-order differ from the Acanthopterygii in the abdominal position of the ventral fins, the pelvic bones not being directly attached to the clavicles. In all the American species there are two well-separated dorsal fins, the first of which is formed of from 3 to 9 spines, the second of a spine and 7 to 15 articulated rays. The anal fin is wholly or partly opposed to the second dorsal and has from 1 to 3 spines. The ventral fins are inserted well behind the base of the pectorals; each consists of a spine and 5 branched rays. The candal fin is forked.

Each of the four families is marine and widely distributed. The majority of the species are shore-fishes which frequent the mouths of rivers and sometimes ascend into fresh water. The Atherinidæ and Mugilidæ include a number of permanently fluviatile forms.

Synopsis of the American Families of the Sub-order Percesoces.

I. Lateral line usually absent, never eomplete; peetoral fins placed high.

Anterior dorsal of 3 to 8 slender spines; a single anal spine; vertebræ 32 to 60 . . . . . . . . . . . . . . . 1. Atrerinid

Anterior dorsal of 3 to 5 pungent spines; 2 or 3 anal spines; vertebræ

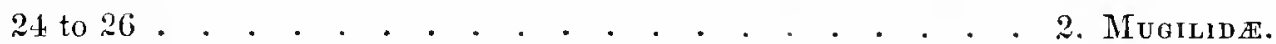

II. Isateral line present, eomplete; peetoral fins plaeed low. Pectoral fin normal . . . . . . . . . . . . . . 3. SPHYRAnide Peetoral fin with a detaehed lower portion eomposed of free filamentous rays . . . . . . . . . . . . . . . . . . 4. Polyneurde.

\section{Fam. 1. ATHERINID FE.}

The Atherinidæ occur on the coasts of most tropical and temperate seas; a considerable number of them enter or permanently inbabit fresh waters. Those found in the rivers and lakes of Mexico and Central America have the following features in common:-Body elongate, more or less compressed. Lateral line usually absent, never complete. 'Two well-separated dorsal fins, the first formed of 3 to 6 slender spines, the second of a short spine and 7 to 13 articulated rays. Anal with one spine and 12 to 25 articulated rays. Pectorals placed high ; ventrals abdominal, each with one spine and 5 branched rays. Caudal forked. Præmaxillaries protractile; jaws with two or more series of conical teeth; palate toothless, or a few teeth on the vomer. A silvcry lateral longitudinal band or stripe always prescnt. 


\section{Synopsis of the Genera found in the Fresh. Waters of Mexico and Central America.}

I. Body completely scaled; head scaly; maxillary not extending beyond the vertical from the anterior margin of eye.

Origin of spinous dorsal in advance of the anal . . . . . . . . 1. Chirostoma.

Origin of spinous dorsal posterior to that of the anal . . . . . . 2. Thyrin.

II. Head and anterior part of body naked . . . . . . . . 3. Xenatherina.

\section{CHIRostomA, Swains., 1839.}

Lethostole, Chirostoma, Kirtlandia, and Menidia, Jord. \& Everm. Bull. U.S. Nat. Mus. xlvii. 1896, pp. 792, 794, \& 796.

About fifteen species from the coasts of Tropical and Subtropical America, some of them entering rivers, and about as many fresh-water species from the Rio Lerma System and the Valley of Mexico.

Synopsis of the Mexican and Central-American Fresh-water Species.

I. Length of head $3 \frac{1}{2}$ to $4 \frac{1}{2}$ in the length of the fish. Jaws equal anteriorly or the lower projecting. Length of lower jaw less than $\frac{1}{2}$ the length of head.

A. Anal fin with I $12-15$ rays; 45 to 57 scales in a longitudinal series;

17 or 18 gill-rakers on the lower part of the anterior arch . . . 1. Zartoni.

B. Anal fin witl I 14-17 rays.

45 to 48 scales in a longitudinal series; 20 or 21 gill-rakers on the lower

part of the anterior arch . . . . . . . . . . . . . . . .

36 to 42 scales in a longitudinal series; 11 or 12 gill-rakers on the lower

part of the anterior arch . . . . . . . . . . . 3. arge.

C. Anal fin with I 16-21 rays.

38 to 42 scales in a longitudinal series; 16 gill-rakers on the lower part of the anterior arch; last dorsal spine above the origin of anal . . . . 4. jordani.

38 to 45 scales in a longitudinal series; 15 or 16 gill-rakers on the lower part of the anterior arch; last dorsal spine in advance of the origin of anal . . . . . . . . . . . . . . . 5. breve

48 to 62 scales in a longitudinal series; 16 to 19 gill-rakers on the lower part of the anterior arch . . . . . . . . . . . . . 6. humboldtianum.

68 to 82 scales in a longitudinal series . . . . . . . . . . . . 7. estor.

44 to 51 scales in a longitudinal series; 20 to 24 gill-rakers on the lower part of the anterior arch . . . . . . . . . . . . . . 8. chapalae.

56 to 62 scales in a longitndinal series; 21 to 23 gill-rakers on the lower part of the anterior arch . . . . . . . . . . . . 9. grandoculis.

II. Length of head $3 \frac{1}{2}$ in the length of the fish. Lower jaw shorter than the upper. Anal with I 19-20 rays. 53 to 56 scales in a longitudinal series . . . . . . . . . . . . . . . . 10. promelas.

BIOL. Centr.-AMER., Pisces, May 1907. 
III. Length of head 3 to $3 \frac{1}{2} \mathrm{in}$ the length of the fish. Lower jaw projecting, $\frac{1}{2}$ or a little more than $\frac{1}{2}$ the Jength of head. Anal with I 18-24 rays. 20 to 23 gill-rakcrs on the lower part of the auterior arch.

A. Teeth small or moderate, close-set; maxillary exposed distally.

1. Lower jaw moderately projecting, $\frac{1}{2}$ the length of head; pectoral $\frac{3}{5}$ to $\frac{2}{3}$ the length of head, extending nearly to above the middle of ventrals.

50 to 60 seales in a longitudinal series . . . . . . . . . . . 11. lucius.

60 to 75 scales in a longitudinal series . . . . . . . . 12. diazi.

2. Lower jaw strongly projeeting, a little more tham $\frac{1}{2}$ the length of head; pectoral $\frac{2}{3}$ to $\frac{3}{4}$ the length of head, extending a little beyond the middle of ventrals . . . . . . . . 13. ocothene.

B. Teeth strong, set rather far apart, in two series; edge of maxillary exposed for nearly its whole length . . . . . . . 14. sphiyrena.

\section{Chirostoma bartoni. (Tab. X. fig. 2.)}

Chirostoma bartomi, Jord. \& Everm. Bull. U.S. Nat. Mus. xlvii. 1896, p. $793^{3}$; Meek, Publ. Columbian Mus., Zool. v. 1904, p. $172^{2}$.

Chirostoma attematum, Meek, l. e. fig. $55^{3}$.

Chirostoma zirahuen, Mcek, t. c. p. 174, fig. $57^{4}$.

Depth of body 5 to 6 in tho length, length of head $4 \frac{1}{4}$ to $4 \frac{1}{2}$. Snont as long as eye, the diameter of whicle is $3 \frac{1}{2}$ in the length of head and a little less than the interorbital width. Tceth small; jaws equal anteriorly or the lower very slightly projecting; maxillary not or but very slightly exposed distally, not extending to below the ere. 17 or 18 gill-rakers on the lower part of anterior arch. Scales mostly with entire edges, 45 to 57 in a longitudinal series. Dorsal IV-V, I 8-10; spinous dorsal well in adrance of anal, its origin usually nearer to tip of snout than to base of caludal. Anal I 12-15. l'ectoral $\frac{2}{3}$ to $\frac{1}{5}$ the length of head, extending to abore base or anterior part of ventrals. Caudal forlsed. Caudal peduncle 3 to 4 as long as decp.

Hal). Mexico, Rio Lerma System :

Guanajuato $^{1}$; Lake Patzcuaro ${ }^{3}$; Lake Zirahuen ${ }^{4}$; Lerma :.

Here described from several specimens, measuring up to $100 \mathrm{~mm}$. in total length.

\section{Chirostoma patzcuaro. (Tab. X. fig. 1.)}

Chirostome petzcuuro, Meck, Publ. Columbian Mus., Zool. v. 1904, p. 17t, fig. $56^{1}$.

Depth of body $5 \frac{1}{3}$ in the length, length of head $t_{\frac{1}{4}}^{\frac{1}{4}}$. Snout as long as eye, the diameter of which is $33_{i}^{\frac{3}{5}}$ in $\left.t\right\}_{12}$ length of heat and nuinly chunl to the interorlitial width. Teeth small; lower jaw vcry slightly frojecting; masillury very slightly exposed distally, not extending to below the eyo. 20 gill-rakers on the lower purt of the anterior arch. Seales mostly with contire edges, 45 in a longitudinal series. Iorsal $\mathrm{V}$, I 10; spinous dorsal in adfaneo of anal, its origin slightly nearer to tip of snout than to thase of caudal. Lual I 15. l'ectoral s the length of head, extending a little beyond the baye of centrals Candal forked. Caudal peduncle $2 \frac{1}{2}$ as lung as deep.

Ilab. Mexico, Rio Lerma System:

Lake Patzcuaro?.

Here described from a single specimen from Lake Patzcuaro (Jeete), measuring 
$90 \mathrm{~mm}$. in total length. Dr. Meek's type has V, I 10 dorsal rays, I 17 anal rays, and $4 \mathrm{~S}$ scales in a longitudinal series.

\section{Chirostoma arge.}

Esluparsum arge, Jord. \& Snyd. Bull. U.S. Fish. Comm. xix. 1899, p. 133, fig. 12 (1901)'; Jord. \& Everm. Bull. U.S. Nat. Mus. xlvii. 1900, p. $3158^{2}$.

Chirostoma arge, Meek, Publ. Columbian Mus., Zool. v. 1904, p. 171, fig. $54^{3}$.

Depth of body $4 \frac{1}{2}$ to 5 in the length, length of head $4 \frac{1}{3}$ to $4 \frac{2}{3}$. Snout as long as eye, tho diameter of which is $3 \frac{1}{2}$ in the length of head and nearly equal to the interorbital width. Teeth small ; lower jaw very slightly projecting; maxillary rery slightly exposed distally, extending to the vertical from the anterior margin of eyc. 11 or 12 gill-rakers on the lower part of the anterior arch. Seales with entire edges, 36 to 42 in a longitudinal series. Dorsal III-IV, I $8-9$; spinous dorsal in advance of anal, its origin nearly equidistant from tip of snout and base of eaudal. Anal I 11-17. Pectoral about $\frac{3}{4}$ the length of head, extending to or a little beyond the base of ventrals. Caudal forked. Caudal peduncle 2 to $2 \frac{1}{2}$ as long as deep.

Hab. Mexico, Rio Lerma System:

Aguas Calientes ${ }^{13}$; Lagos ${ }^{3}$.

Here described from several specimens, measuring up to $70 \mathrm{~mm}$. in total length, from Aguas Calientes (Jordan) and Lagos (Meek).

\section{Chirostoma jordani.}

Chirostoma jordani, Woolman, Bull. U.S. Fish. Comm. xiv. p. 62, t. $2(1895)^{1}$; Jord. \& Everm.

Bull. U.S. Nat. Mus. xlvii. 1896, p. $793^{2}$; Meek, Publ. Columbian Mus., Zool. v. 1904, p. 169 , fig. $52^{3}$.

Chirostoma mezquital, Meek, t. c. p. 170, fig. $53^{4}$.

Depth of body 4 to 5 in the length, length of head $+\frac{1}{3}$ to $+\frac{1}{2}$. Snout shorter than eye, the liameter of which is 3 to $3 \frac{1}{2}$ in the length of head; interorbital width about 3 in the length of head. Teeth small; lower jaw very slightly projecting; maxillary not exposed, not quite reaching the rertical from the anterior margin of eye. 16 gill-rakers on the lower part of anterior arch. Scales with entire edges, 38 to 42 in a longitudinal series. Dorsal III-IV, I S-10; origin of spinous dorsal nearly equidistant from tip of snout and base of caudal; last dorsal spine inserted above the origin of anal. Anal I 16-19. Pectoral a little shorter than the head, extending to above the middle of ventrals. Caudal pedunclo twice as long as deep.

Hab. Mexico, Rio Mezquital and Rio Lerma Systems, Valley of Mexico:

Durango ${ }^{4}$; Aguas Calientes ${ }^{3}$; Lagos ${ }^{3}$; Salamanca ${ }^{1}$; Lake Chapala ${ }^{2}{ }^{3}$; Acambaro ${ }^{3}$; Lake Cuitzeo ${ }^{3}$; Texcoco $^{3}$; Chalco $^{3}$; City of Mexico ${ }^{13}$; Yautepec ${ }^{3}$.

Here described from specimens from Salamanca (Woolman) and Acambaro (Meek), measuring up to $65 \mathrm{~mm}$. in total length.

5. Chirostoma breve. (Tab. X. fig. 3.)

Chirostoma breve, Steind. Denkschr. Ak. Wieu, lxii. 1895, p. 526, t. 2. fig. $2^{2}$.

Chirostoma labarce, Meek, Publ. Columbian Mus., Zool. v. 1904, p. $173^{2}$.

Depth of body 4 to $4 \frac{1}{2}$ in the length, length of head 4 to $4 \frac{1}{3}$. Snout as long as or a little longer than the eje, 
the diameter of which is $3 \frac{2}{3}$ to 4 in the length of head; intrrorvital width 3 to $3 \frac{1}{3}$ in the length of head Teeth small ; lower jaw slightly projecting; maxillary slightly exposed distally, not quite reaching the vertical from the auterior margin of eye. 15 or 16 gill-rakers on the lower part of the anterior arch. Scales with crenate edges, (38) 40 to 45 in a longitudinal series. Dorsal ILI-V, I 9-II; origin of spinous dorsal usually neirer to base of eaudal than to tip of snout; last dorsal spine inserted a little in adrance of the origin of anal, which is below the membrane connecting the spine to the back. Anal I 17-20 (21). Pectoral $\frac{3}{4}$ to $\frac{4}{5}$ the length of head, cxtending a little boyond the base of ventrals, Caudal forked. Caudal peduncle 2 to $2 \frac{2}{2}$ as long as deep.

Ilab. Mexico, Rio Lerma System and the Valley of Mexico:

Lake Chapala $^{2}$; Lake Cuitzeo ${ }^{1}$; Xochimilco.

Here described from four specimens from Xochimilco (Meeh'), measuring up to $100 \mathrm{~mm}$. in total length.

\section{Chirostoma humboldtianum.}

Atherina humboldtiana, Cur. \& Val. Hist. Nat. Poiss. x. p. 479, t. 306 (1835)?

Atherina vomerina, Cuv. \& Val. t. c. p. $481^{2}$ 。

Atherinichthys humboldlii, Güinth. Cat. Fish. iii. p. 104 (1861) ${ }^{3}$.

('hirostoma hemholdtiantm, Steind. Denkschr. Ak. Wiell, lxii. 1895, p. 522, t. 1. figr. 1": Jord. \& Everm. Bull. U.S. Nat. Mus, xlvii. 1896, p. $793^{5}$; Jord. \& Suyd. Bull. U.S. Fish. Comm. xix. 1899, p. 134 ${ }^{\mathrm{c}}$; Meek, Publ. Cohumbian Mus., Zool. v. 1904, p. $175^{\top}$.

Depth of body 4 to $5 \frac{1}{2}$ in the length, length of head $3 \frac{3}{5}$ to 4 . Snout from as long to twice as long as the eye. the diameter of which is $3 \frac{2}{3}$ to $5 \frac{2}{3}$ in the length of head; interorbital width $3 \frac{1}{\frac{1}{3}}$ to $3 \frac{3}{4}$ in the length of hearl. 'Teeth rather small; jaws equal anteriorly or the lower a little projecting; jower jaw less than $\frac{1}{2}$ the length of head; maxillary exposed distally; extending nearly to the vertical from the anterior nuargin of eye. It to 19 gill-rikers on the lower part of the anterior arch. Sicales mith edges usually: crenate; 48 to 62 in a longitudinal series. Dorsal IV-YI, I 10-13; spinous dorsis iu advance of anal, its origin usually a little nearer to base of caudal than to tip of snout. Anal I 17-20. Pectoral $\frac{2}{3}$ to $\frac{1}{2}$ the length of head, extending to abose antcrior part or middle of ventrals. Caudal forked. Caudai peduncle 2 to $2 \frac{2}{3}$ as long as deep.

Hal. Mexico, Rio Lerma System and the Valley of Mexico:

Lake Juanacatlan ${ }^{7}$ (Buller) ; Lake Ayotla (Buller); Lake Patzcuaro ${ }^{7}$; City of Mexico ${ }^{7}$ (Doorman); Texcoco ${ }^{4}$; Lake Chatco ${ }^{67}$ (Jordan); Xochimilco ${ }^{7}$ (Meeh, Gadow).

Here described from a large serics of specimens, measuring up to $240 \mathrm{~mm}$. in total length. Dr. P. Pappenheim has very kindly examined the type of the species on my behalf and has sent me a photograph of it, which leares no doubt that the species above describer is the true C. lumboldticunm.

\section{Chirostoma estor.}

Chrostoma estar, Jord. Jroc. U.S. Nat. Mus. 1879, p. 298 ; Steind. Denkschr. Ak. Wien, lxii. 1895, p. 523, t. 1. fig. $2^{2}$; Meck, Publ. Columbian Mus., Zool. v. 1904, p. $180^{3}$.

Lethostole estor, Jord. \& Everm. 13ll. U.S. Nat. Mus. xlvii. 1896, 1). $799^{4}$.

Tregth of horly about 5 in tho length, length of head $3 \frac{1}{2}$ to 4 . Snout $1 \frac{1}{3}$ to 2 as long as eye, the diameter of which is 4 to $5 \frac{1}{2}$ in the length of locad; iuterorbital width 4 in the length of leend. Teeth small: 
anterior teeth sometimes moderately strong; luwer jaw projecting, less than half the length of head; maxillary exposed distally, extending nearly to the vertical from the anterior margin of eye. 20 or 21 . gill-raters on the lower part of the anterior arch. Scales with crenate edges, 68 to 82 in a longitudinal series. Dorsal IV - T, I $10-12$; spinous dorsal in adranee of anal, its origin usually a little nearer to base of caudal than to tip of snout. Aual I 17-20. Pectoral $\frac{3}{5}$ the length of head, extending to abore the base of ventrals. Caudal forked. Caudal peduucle $2 \frac{1}{2}$ to 3 as long as deep.

Hab. Mexico, Rio Lerma System and the Valley of Mexico:

Lake Chapala ${ }^{2}$; Lake Patzcuaro ${ }^{2}$; Lake Zirahuen (Meek); Xochimilcho ${ }^{3}$.

Here described from six specimens, measuring up to $220 \mathrm{~mm}$. in total length, from Lakes Patzcuaro (Merico MTus.) and Zirahuen (Meek).

\section{Chirostoma chapalæ.}

Chirostoma chicupale, Jord. \& Suyd. Bull. U.S. Fish. Comm. xix. 1899, p. 135, fig. 13 (1901) '; Jord. \& Everm. Bull. U.S. Nat. Mus. xlvii. 1900, p. $3159^{2}$; Meek, Publ. Columbian Mrus, Zool. v. 1904, p. 176, fig. $58^{3}$.

Depth of hody $4 \frac{1}{2}$ to $5 \frac{1}{2}$ in the length, length of head $3 \frac{4}{3}$ to $4 \frac{1}{2}$. Snout as long as eye, the diameter of which is $3 \frac{1}{3}$ to $3 \frac{2}{3}$ in the length of head and nearly equal to the interorbital width. Teeth small ; lower jaw very slightly projecting; maxillaxy rery slightly exposed distally, not extending to below the eye. 20 to 24 gill-rakers on the lower part of anterior arch. Scales with crenate edges, 44 to 51 in it longitudinal series. Dorsal III-T, I 10-11; origin of spinons dorsal nearly equidistant from tip of snout and base of caudal; last dorsal spine inserted above the origin of anal. Anal I 18-21. Peetoral $\frac{4}{5}$ or $\frac{5}{6}$ the length of head, extending to above the middle of the rentrals. Caudal forked. Caudal peduncle 2 to $2 \frac{1}{2}$ as long as deep.

Hab. Mexico, Rio Lerma System :

Lake Chapala ${ }^{1} 3$.

Here described from several specimens from Lake Chapala, measuring up to $125 \mathrm{~mm}$. in total length.

\section{Chirostoma grandoculis.}

Chirostome grandoculis, Steind. Denkschr. Ak. Wien, lxii. 1895, p. 525, t. 2. fig. $1^{1}$; Jord. \& Everm. Bull. U.S. Nat. Mus. xlvii. 1900, p. $3159^{2}$; Meek, Publ. Columbian Mus., Zool. r. 1904, p. 176, fig. $58^{3}$.

Depth of body about 5 in the length, length of head 4 to $4 \frac{1}{4}$. Snout as long as or shorter than eye, the diameter of whieh is $3 \frac{1}{5}$ to $3 \frac{1}{2}$ in the length of head and equal to the interorbital width. Teeth small : lower jaw very slightly projecting; maxillary very slightly exposed distally, not exiending to below the cye. 21 to 23 gill-rakers on the lower part of the anterior arch. Seales with erenate edges, $56-62$ in a longitudinal series. Dorsal V-VI, I 10-11; spinous dorsal usually entirely in advance of anal, its origin ahout equidistant from tip of snout and base of eandal. Anal I 17-20. Pcetoral 3 the length of heal, extending to above the anterior part or middle of ventrals. Caudal forked. Candal jedunele $2 \frac{1}{2}$ to 3 as long as deep.

Ilał. Mrxico, Rio Lerma System:

Lake Chapala ${ }^{3}$; Lake Patzcuaro ${ }^{13}$.

Here described from four specimens, measuring up to $11 \mathrm{~m} \mathrm{~mm}$. in total length, from Lake Patzcuaro (Meek). 


\section{Chirostoma promelas.}

Chirostoma promelas, Jord. \& Snyd. Bull. U.S. Fish. Comm. xix. 1899, p. 136, fig. 1 $1 t^{2}$; Jord. \& Everm. Bull. U.S. Nat. Mus. xlvii. 1900, p. $3160^{2}$; Meek, Publ. Columbian Mus., Zool. v. 1904 , p. $177^{3}$.

Allied to C. lucius, but with the lower jaw sherter than the upper. Dorsal IV, I 11. Anal I 19-20. Scales with crenate edges, 53 to 56 in a longitudiual series.

Hal. Mexico, Rio Lerma System:

Lake Chapala ${ }^{13}$.

\section{Chirostoma lucius.}

Chirostoma lucius (part.), Bouleng. Aun. Mag. Nat. Hist. (7) v. 1900, p. $54^{1}$.

Chirostoma crystaltinum, Jord. \& Snyd. Bull. U.S. Fish. Comm. xix. 1899, p. 139, figs. 16 \& 17

$(1900)^{2}$; Jord. \& Everm. Bull. U.S. Nat. Mus. xlvii. 1900, p. $3162^{3}$.

Chirostoma lucius, Meek, Publ. Columbian Mus., Zool. v. 1904, p. 178, fig. 60 `.

Depth of body 4 in the length, length of head $3 \frac{1}{3}$. Snout $1 \frac{3}{4}$ as long as eye, the diameter of which is $5 \frac{1}{2}$ in the length of the head; intererbital width 4 in the length of head. Teeth rather small; lower jaw projecting, $\frac{1}{2}$ the length of head; maxillary expesed distally, extending te the vertical from the autcrier margin of eye; 20 gill-rakers on the lower part of the anterior arch. Scales with crenate edges, 52 in a longitudinal series. Dorsal VI, I 11 ; spineus dorsal in advance of the anal, its origin nearer to base of caudal than to tip of snont. Anal I 20. Pectoral $\frac{3}{5}$ the length of hearl, extendiug nearly to above the middle of rentrals. Caudal forked. Caudal peduncle twice as long as deej.

Hab. Mexico, Rio Lerma System :

Guadalajara $^{2}$; Lake Chapala ${ }^{2}$ (Buller).

Here described from the type of the species, measuring $200 \mathrm{~mm}$. in total length. Jordan and Snyder give the following numbers for C. crystallinum:-Dorsal IV $-V$, 1 11-13. Anal I 18-24. 56 to 60 scales in a longitudinal series.

\section{Chirostoma diazi.}

Chirostoma diazi, Jord. \& Suyd. Bull. U.S. Fish. Comm. xix. 1899, p. 13\%, fig. 15 (1900) '; Jord. \&

Everm. Bull. U.S. Nat. Mus. xlvii. 1900, p. $3161^{2}$.

Chirostoma sphyrana, Meck, Publ. Columbian Mus., Zool. v. 1904, p. 177, fig. $59^{3}$.

Closely allied to the preceding species, but with smaller scales ( 60 to 75 in a longitudinal serics); dorsal scales very small and irregular, 21 to 27 in a series between the two dorsal fins. Dorsal IV-V, I 11-12. Anal I 20-22.

Hab. Mexico, Rio Lerma System:

Lake Chapala .

13. Chirostoma ocotlane. ('Tab. IX. fig. 1.)

Chirostoma hucius (part.), Bonleng. Anu. Mag. Nat. Hist. (7) v. 1900, p. $54^{1}$.

Chirostoma acottane, Jord. \& Sinyd. Bull. U.S. Fish. Comm. xix. 1899, p. 140, fig. 18 (1901) ${ }^{2}$; Jord. \& Everm. Bull. U.S. Nat. Mus. xlvii. 1900, p. $3163^{3}$; Meek, Publ. Cohumbian Mus., Zool. v. 1904, 1'. 180, fig. 62! 
Depth of body 5 in the length, length of head $3 \frac{1}{4}$ to $3 \frac{1}{2}$. Snout $1 \frac{1}{4}$ to $1 \frac{2}{3}$ as long as $e y e$, the diameter of which is 4 to 5 in the length of head; interorbital width $4 \frac{2}{3}$ to 5 in the length of head. Teeth ratber small; lower jaw strongly projecting, a little more than $\frac{1}{2}$ the length of head; maxillary cxposed distally, extending to the vertical from the anterior margin of eye. 21 to 23 gill-rakers on the lower part of anterior arch. Scales with crenate edges, 53 to 62 in a longitudinal series. Dorsal V-VI, I 11-13; spinous dorsal in advance of anal, its origiu nearer to base of caudal than to tip of snout. Anal I $20-22$. Pectoral $\frac{2}{3}$ to $\frac{3}{4}$ the length of head, extending beyond the middle of the rentrals. Candal forked. Candal peduncle twice as loug as deep.

Hab. Mexico, Rio Lerma System :

Lake Chapala ${ }^{24}$ (Buller, Jordan).

Here described from several specimens, measuring up to $215 \mathrm{~mm}$. in total length.

14. Chirostoma sphyræna. (Tab. IX. fig. 2.)

Chirostoma sphyrena, Bouleng. Ann. Mag. Nat. Hist. (7) v. 1900, p. $55^{1}$; Meek, Publ. Columbiau Mus., Zool. v. 1904, p. 178, fig. $59^{2}$.

Chirostoma lerme, Jord. \& Snyd. t. c. p. 142, fig. $19^{3}$; Jord. \& Everm. t. c. p. $3163^{4}$; Meek, t. c. p. 179 , fig. $61^{5}$.

Depth of body $5 \frac{2}{3}$ in the length, length of head $3 \frac{1}{5}$. Snout $2 \frac{1}{3}$ as long as $\theta y e$, the diameter of which is 6 in the length of head; iuterorbital width $4 \frac{2}{3}$ in the length of head. Tceth strong, in two series; lower jaw projecting, $\frac{1}{2}$ the length of head; maxillary extending nearly to the rertical from the anterior margin of eye, its edge exposed for nearly its whole length. 22 gill-rakers on the lower part of the anterior areh. Scales with crenate edges, 65 in a longitudinal series. Dorsal V, I 11 ; spinous dorsal in advance of anal, its origin nearer to base of caudal than to tip of snout. Anal I 21. Pcctoral vearly $\frac{2}{3}$ the length of head, extending to above the middle of ventrals. Caudal forked. Caudal peduncle twico as long as deep.

Ha乙. Mexico, Rio Lerma System:

Lake Chapala 1235 (Buller").

Here described from the type, a specimen measuring $230 \mathrm{~mm}$. in total length. Jordan and Snyder give the foliowing numbers for C. lerme:-Dorsal IV-V, 10-12. Anal 19-22. 54-5S scales in a longitudinal series.

\section{THYRINA, Jord. \& Culv., 1895.}

Thyrina, Jord. \& Everm. Bull. U.S. Nat. Mus. xlvii. 1896, p. 803.

Melaniris, Meek, Publ. Columbian Mus., Zool. v. 1904, p. 183.

Two species described by Günther, T. guatemalensis and T. pachylepis, are intermediate between Chirostoma and Atherinella, Steind., resembling the latter in the posterior situation of the spinous dorsal fin and in the long falcate pectoral. The abdominal region is more or less compressed, but not more so than in many species of Chirostoma, and there is no trace of the ventral keel which characterizes Atherinella. Melaniris was based on specimens preserred in formalin, with the iris turned black. 


\section{Thyrina guatemalensis.}

Atherinichthys guatemalensis, Güntl. Proc. Zool. Soc. 1864, p. I51 ' ${ }^{2}$, and Trans. Zool. Soc. vi. 1869, p. $443^{2}$.

Thyrina evermanni, Jord. \& Culv. Proc. Calif. Ac. Sci. (2) v. 1895, p. $419^{3}$; Jord. \& Everm.

Bull. U.S. Nat. Mus. xlvii. 1896, p. $804^{1}{ }^{1}$; Mcek, Publ. Columbian Mus., Zool. v. 1904, p. $184^{5}$.

Thyrina crystallina, Jord. \& Culv. t. c. p. 420 "; Jord. \& Everm. l. c. " ; Meck, l. c. ".

Menidia guatemalensis, Jord. \& Everm. t. c. p. 801 ".

Nelaniris balsanus, Meek, t. c. p. 183, fig. $64^{20}$.

Depth of body 4 to 5 in the length, length of head $4 \frac{1}{4}$ to 43 . Snout shorter than eje, the diameter of which is $2 \frac{2}{3}$ to 3 in the length of head; interorbital width $2 \frac{1}{2}$ in the length of head. Teeth in bands, the outermost series enlarged; jaws equal anteriorly; maxillary not exposed, extending nearly to below the eye. 16 or 17 gill-rakers on the lower part of the anterior arch. Scales with eutire edges, 39 to 42 in a longitudinal series. Dorsal III-IT, I $7-9$; origin of spinous dorsal above sixth ray of anal. Anal I 19-25, ending below or a little behind the end of the second dorsal. Pectoral falcate, longer than the head, extending beyond the midile of ventrals. Caudal forked, the lower lobe somewhat the longer. Caudal peduncle $1 \frac{i}{2}$ to 2 as $\operatorname{long}_{\mathrm{g}}$ as deep.

Hab. Pacific Coast Rivers and Lakes of Mexico and Central America, perhaps entering the sea:

Rio Presidio ${ }^{36}$ and Rio Balsas ${ }^{10}$ in Mexico; Huamuchal 12 in Guatemala.

Here described from the types of the species from Huamuehal (Salcin), and co-types of T. evermanni and T. crystallina from the Rio Presidio and of H. balsanus from the Rio Balsas, several specimens measuring up to $55 \mathrm{~mm}$. in total length. Estuarine specimens hare the pectoral fins longer and more aeute than those from inland localities. T. pachylepis, from the Coast of Panama, is elosely allied, but has laciniate scales. Gill and Bransford (Proc. Ac. Philad. 1877, p. 187) record T. guatemalensis from Lake Nicaragua, but this identification must be regarled as probably incorrect.

\section{XENATHERINA, gen. nor.}

The very aberrant little Atherine described by Meek under the name of IIcnidia lisa may be regarded as the type of a genus distinct from Chirostoma, characterized by the mouth extending to below the eye and by the peculiar disposition of the scales.

\section{Xenatherina lisa.}

Menidia lisa, Meek, Publ. Columbian Mus., Zool, v. I90t, p. 18:, fig. 63 '.

Depth of body 5 in the length, length of head 4. Snout sliorter than eye, the diameter of which is $2 \frac{1}{4}$ to $2 \frac{1}{2}$ in the length of lead and greater than the interorbital width. Teeth small; month oblique; jaws equal anteriorly : maxillary extonding to below anterior $\frac{1}{4}$ of eyc. lis gill-rakers on the lower part of the anterior arch. Tosterior pirt of body covered with scales, which are continued forwarl as a scaly band along the middle of the side; anterior jart of borly ualied, except tor a dorsal strip and a ventral patch 
of small scales. Dorsal III-V, I 8-9; origin of spinous dorsal above or a littlo behind that of the anal. Anal I 19-21. Pectoral asymmetrical, pointed, $\frac{1}{5}$ the length of head, extending to above the middle of ventrals. Caudal forked. Caudal peduncle twice as long as deep.

Hal. Mexico, Rio Papaloapam:

Refugio ${ }^{1}$, El Hule ${ }^{1}$.

Here described from five specimens, measuring up to $55 \mathrm{~mm}$. in total length, from Refugio (Meek).

\section{Fam. 2. IIUGILID正.}

The Mugilidæe are closely related to the Atherinidæe and have the same wide distribution. Most of the species of Mugil and allied genera with ciliiform teeth are marine, but freely enter fresh water. Agonostomus and Joturus comprise tropical fresh-water fishes, especially abundant in mountain-streams.

The Mexican and Central-American Mugilidæ have the following features in common:-Body elongate, more or less compressed, covered with rather large scales, which extend on to the upper surface of the head. Lateral line usually absent, never complete. Two well-separated dorsal fins, the first formed of 4 rather strong spines, the second of a spine and 7 to 10 articulated rays. Anal with 2 or 3 spines and 7 to 11 articulated rays. Pectorals placed high; ventrals abdominal, each with one spine and j branched rays. Caudal forked. Præmaxillaries protractile; jaws with teeth, which may be either well-developed or vestigial; palate with or without teeth. Coloration silvery, the back greenish or olivaceous; sometimes dark longitudinal stripes along the series of scales.

\section{Synopsis of the Mexican and Central-American Genera.}

I. Bands of small fixed teeth in the jaws and on the palate.

Teeth in the jars pointed . . . . . . . . . . . . . . . . . 1. Agonostomus.

Teeth in the jaws incisor-like, with serrated edges . . . . . . . . . . . 2. Jonurus.

II. Teetl in the jaws small, in one or more series; palate toothless.

A. Teeth ciliiform, in one or a few series; lips not very thick; rami of lower jaw meeting at an angle which is not very aeute.

Three anal spines . . . . . . . . . . . . . . . . 3. MugrL.

Two anal spines . . . . . . . . . . . . . . . . 4. Querimana.

B. Teeth in several oblique series; lips thick; rami of lower jaw meeting at all aeute angle . . . . . . . . . . 5. Сhжnourgil.

I have given full descriptions of the Mexican and Central-American species of the genera Agonostomus and Joturus, which appear to be true fresh-water tishes, and for purposes of comparison I have included in my account of the former genus two species, $A$. percoides and $A$. microps, which are at present known only from specimens in the biol. Centr.-AMER., Pisces, May 1907. 
British Museum from the IVest Indies and Venezuela. Of the marine genera Mugil, Querimana, and Chanomugil only a synopsis is given, but they are included because the species of the first-named, at least, ascend rivers for considerable distances.

\section{AGONOSTOMUS, Bennett, 1830.}

Agonostomus, Jord. \& Everm. Bull. U.S. Nat. Mus. xlvii. 1896, p. 818.

Neomugil, Vaill. Bull. Soe. Plilom. iv. 1894, p. 72.

Mouth subterminal, with lateral eleft; bauds of small pointed teeth in the jaws and on the romer and palatines; two anal spines.

Hat. Tropical rivers near the sea, most of the species being American.

\section{Synopsis of the American Species.}

I. Maxillary not extending beyond the anterior $\frac{1}{3}$ of eye (in the adult).

A. Snout subconical, the upper lip only moderately thick, even in the adult . . . . . . . . . . . . . . . . 1. monticula.

B. Snout truneated anteriorly, the upper lip thick.

Pectoral from less than $\frac{3}{4}$ (adult) to $\frac{4}{5}$ (young) the length of head; length of lower jaw $2 \frac{1}{2}$ (adult) to $2 \frac{9}{4}$ (young) in the length of head . . . . . . 2. nasutus.

Pectoral $\frac{3}{5}$ (adult) or $\frac{2}{3}$ (young) the length of head; length of lower jaw $2 \frac{1}{3}$ (adult) to $2 \frac{1}{2}$ (young) in the length of head . . . . . . . . . 3. salvini.

II. Maxillary extcuding to below middle of eye (in the adult).

A. Snout subconical, the upper lip only moderately thiek, even in the adult . . . . . . . . . . . . . . 4 percoides.

B. Snout truncated anteriorly, the upper lip thick.

Pectoral extending to the rertical from the origin of spinons dorsal (adult) or beyond (young); first clorsal spine as long as the longest rays of the second dorsal . . . . . . . . . . . . . . . . . . . . 5. macracanthus.

Pectoral nearly reaehing the vertical from the origin of spiuous dorsal in the young, but not in the adult; first dorsal spine shorter than the longest rays of the second dorsal. . . . . . . . . . . . 6. microps.

\section{Agonostomus monticola.}

Mugil monticola, Bancroft, Cuvier's Animal Kingdom (ed. Griffiths), p. 367, t. 36 (1836) '. Agonostoma monticola, Giinth. Cat. Fish. iii. p. 464 (1861) ${ }^{2}$.

Agonostomms monticole, Jord. \& Evcrm. Bull. U.S. Nat. Mus. xlvii. 1896, p. 819, and 1900, fig. $3.17^{\text {: }}$

Dopth of body $3 \frac{1}{2}$ to $4 \frac{1}{3}$ in the length, leugth of head $3 \frac{2}{3}$ to $4 \frac{1}{3}$. Snout from as long to $1 \frac{3}{3}$ as long as eye, the diameter of which is $3 \frac{1}{2}$ to $5 \frac{1}{3}$ in the length of head; interorbital width $2 \frac{3}{6}$ to 3 in the length of head. Snout subconieal, the uper lip not very thick; mouth subterminal; maxillary extending to below anterior edge or anterior $\frac{1}{4}$ of eye; about 20 gill-rakers on the lowor part of the anterior areh. 38 to 44 scales in a longitudinal series, 12 to 14 in a transverse series from spinons dorsal to vent, 20 to 22 round the caudal peduacle. Dorsal IV, I 8; origin of spinous dorsal usually nearer to tip of snout than 

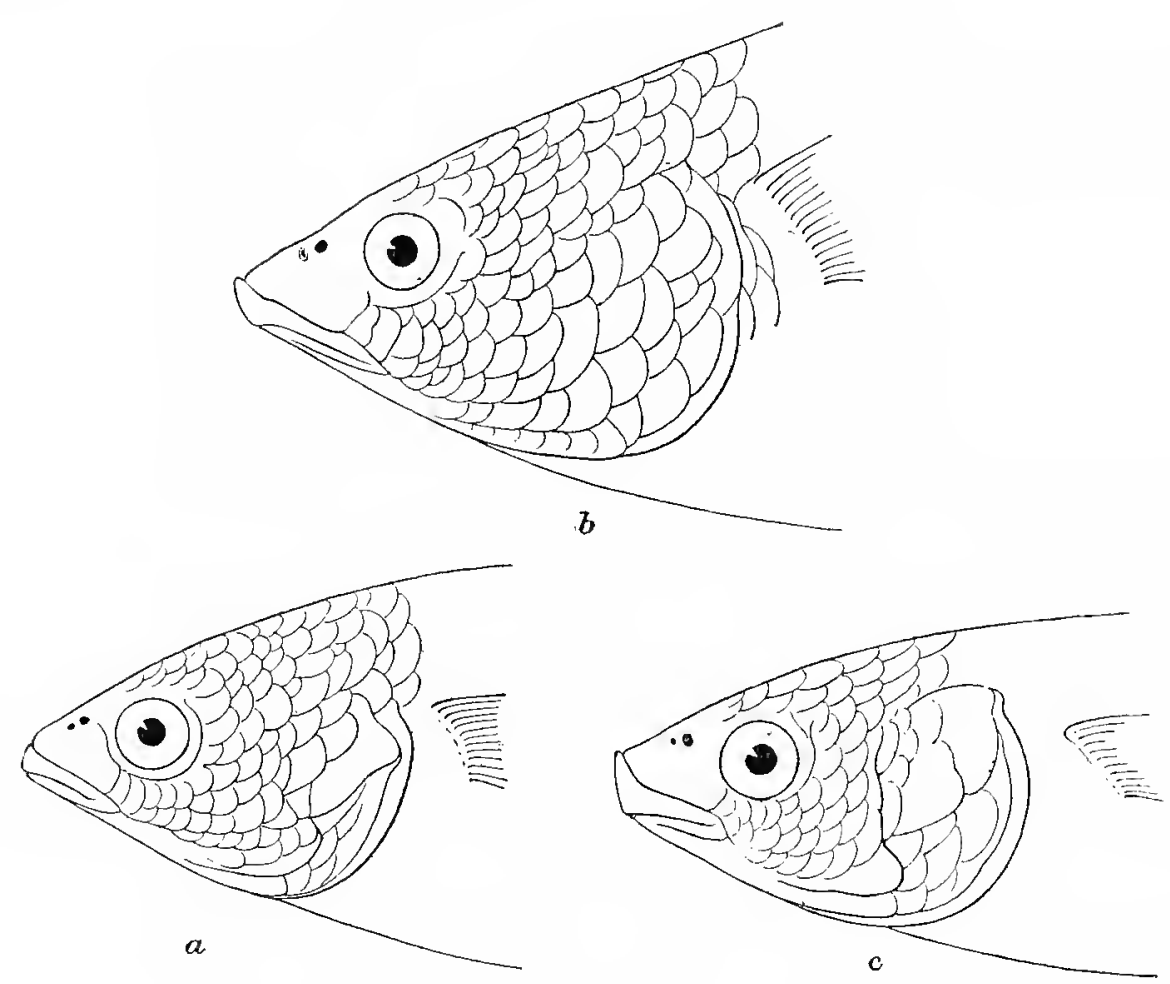

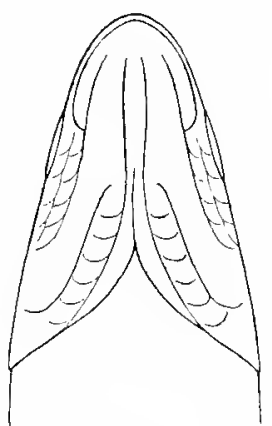

$\alpha$

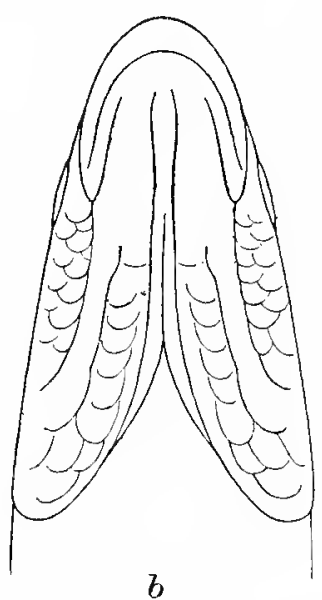

$b$

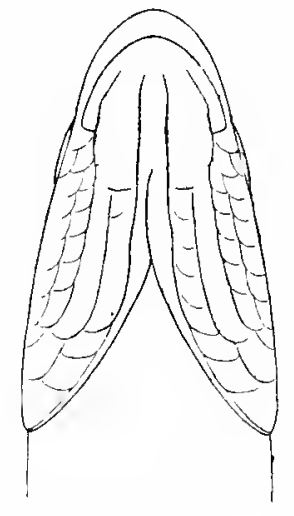

Heads of Agonostomus monticola (a), A. salvini (b), and A. nasutus (c), from the side and from below.

to base of caudal; spines moderate, the first, in the adult, about $\frac{1}{2}$ the length of head or of the distance between the origins of the dorsal fins. Anal II 10. Pectoral about $\frac{2}{3}$ the length of head, in the adult not extending to below the spinous dorsal; rentrals originating below the middle of pectorals, in the adult extending about $\frac{1}{2}$ of the distance from their base to tho origin of anal. Candal forked. Caudal peduncle $1 \frac{1}{2}$ to 2 as long as deep. Silvery, back darker; scales $\pi$ ith dark cdges, wbich often expand into irregular spots.

Hab. Mexico and Central America ${ }^{2}$.- West Indies ${ }^{12 .}$ 
Specimens in the British Museum, measuring up to $250 \mathrm{~mm}$. in total length, from the Rio Presidio in Sinaloa, the Rio Mascota in Jalisco (Buller), and Vera Cruz (Meek) appear to belong to the same species as others from Cuba, Jamaica, Barbados, and Trinidad.

2. Agonostomus nasutus. (Tab. X. fig. 4.)

Agonostoma nusutum, Günth. Cat. Hish. iii. p. 463 (1S61) ${ }^{1}$; and Trans. Zool. Soc. vi. 1868, p. 444 , t. 70 . fig. $2^{2}$.

Neonngil digueti, Vaill. Bull. Soc. Philom. iv. 189t, p. $73^{3}$.

Agonostomus nasutus, Jord. \& Ever'm. Bull. U.S. Nat. Mus. xlvii. 1896, p. $820^{4}$.

Depth of bady $3 \frac{1}{3}$ to $4 \frac{1}{3}$ in the length, length of head 4 to $4 \frac{1}{3}$. Snout from as long to $1 \frac{2}{3}$ as long as cye, the diameter ot which is 4 to $5 \frac{2}{3}$ in the length of head; interorbital width $2 \frac{2}{3}$ to $2:$ in the length of head. Snout rertically truncuted, the upper lip thick interiorly, its depth $\frac{1}{2}$ the leagth of snout; mouth subterminal; maxillary extending to below anterior elge or anterior $\frac{1}{7}$ of eye; lower jaw broally rounded, its length $2 \frac{1}{2}$ (adult) or $2 \frac{3}{4}$ (young) in the length of heal ; length of groore between lower li and ramus of lower jaw (measured from its anterior cxtremity to tho end of the maxillary) echnal to the diameter of eje (adult) or less (young). 18 to 20 gill-rakers on the lower part of the anterior areh. 41 to 43 scales in a longitudinal series, 12 to 14 in a transrorse serics from spinons dorsal to in front of rent, 21 or 22 round the candal peduncle. Forsal IV, I \& (exceptionally $\tau$ ): origin of spinous dorsal a little nearer to tip of snout than to base of caudal; syines modurate, the first from less than $\frac{1}{2}$ (adult) to $\frac{2}{5}$ (young) the length of hoad, shorter than the longest rays of the second dorsal, which haus the free edge concare. Anal II 10. Pectoral from less than $\frac{3}{4}$ (adult) in $\frac{1}{. \prime}$ (goung) the length of head, extending to below the spinous dorsal in the young, but not in the adnlt; ventrals originating bolow the middle of the pectoral, extending abont $\frac{1}{2}$ of the distance from their base to the origin of anal. Candul forked. Caudal peduncle $1 \frac{2}{3}$ to 2 as long as deep. Silrery, back darker; seales with dark edges; a blackish spot on the base of pectoral; a more or less distinct silvery lateral band.

Hab. Lower California, Mexico, and Cextral Auerica.

Specimens in the British Musem from Lower California (Dignet ${ }^{3}$ ) ; Mexico, Motzorongo (Meek); Guatemala, Rio San Gerónimo (Owen²), Rio Motagna $\left(\right.$ Salvin $\left.^{2}\right)$; Costa Rica, Juan Viñas (Underwood).

Professor Vaillant has very kindly sent me two specimens of Neomugil digneti, one of which is now figured (Tab. X. fig. 4).

3. Agonostomus salvini. ('Tab. Xl. fig. 2.)

Agonostomus salvini, Regan, Amm. Mag. Nat. Hist. (i) xix. 1907, 1). $60^{1}$.

Depith of hody $: \frac{1}{3}$ to $4 \frac{1}{1}$ in the length, length of hearl 4 . Snont $1 \frac{1}{3}$ to 2 as long as cyc, the diameter of which is 43 to $6 \frac{1}{2}$ in the longth of head; interorbital width 2 等 103 in the length of head. Snout rertically or obliquely truncated, the upper lip ratler thick anteriorly, its depth $\frac{p}{\bar{\sigma}}$ the length of snout; month subterminal; maxillary extending to betow anterior $\frac{1}{4}$ or anterior $\frac{1}{3}$ of eye; lower jaw erenly rounded, its length $2 \frac{1}{3}$ (adult) or $2 \frac{1}{2}$ (young) in the length of head; length of groore between lower lip and ramus of lower jaw (measured from its anterior extremity to the end of the maxillary) equal to the diameter of eye (young) or $1 \frac{2}{2}$ the diamoter of cye (adult). $15-20$ gill-rakers on tho lower part of the anterior areh. 38 to 40 scales in a longitndinal series, 12 or 13 in a transwerse scrics frou spinons dorsal to in front of rent, 21 or 22 round the caulal peduncle. Dorsal IV, I S ; origin of spinous dorsal cepuidistant from tip of snout and base of catulal or a litile nearer the former; spines moderate, $\frac{2}{3}$ (adult) or $\frac{1}{2}$ (young) of the 
length of head or of the distance between the origins of the dorsal fins and shorter than the longest rays of the second dorsal, which has the free edge a little concare. Anal II 10. Pectoral $\frac{2}{3}$ the length of head (young) or less (adnlt), not extending to below the spinous dorsal; ventrals oririnating below the middle of pectoral, extending nearly $\frac{1}{2}$ of the distance from their base to the origin of aual. Caudal moderately notched. Caudal peduncle 2 as long as deep. Silvery or golden, the back olivaceous.

Hab. Guatemala, Nacasil (Salvin).

Three specimens, 150 to $270 \mathrm{~mm}$. in total length.

The species is closely allied to $A$. nasutus, which has the upper lip thicker, eye a little larger, lower jaw a little shorter, pectorals longer, \&c.

\section{Agonostomus percoides.}

Agonostoma percoides (part.), Günth. Cat. Fish. iii. p. 161 (1861).

This species is represented in the British Museum by the type, from San Domingo, and by two examples from Trinidad. These are the only specimens known.

\section{Agonostomus macracanthus. (Tab. XI. fig. 1.)}

Agonostomus macracanthus, Regan, Ann. Mag. Nat. Hist. ( $/$ ) xix. 1907, p. $65^{3}$.

Depth of body $3 \frac{2}{3}$ to 4 in the length, length of head $3 \frac{3}{3}$ to $3 \frac{2}{3}$. Snout $1 \frac{1}{3}$ to $1 \frac{2}{3}$ as long as eje, the diameter of which is $4 \frac{3}{4}$ to $5 \frac{2}{3}$ in the length of head; interorbital width $2 \frac{2}{3}$ in the length of head. Snont vertically truncated, the upper lip thick anteriorly; mouth subterminal : muxillary extending to below middle of eye, or nearly. 20 gill-rakers on the lower part of anterior arch. 41 to 43 seales in a longitudinal series, 14 in a transverse series from spinous dorsal to in front of rent, 20 or 21 round the caudal peduncle. Dorsal IV, I 8 ; origin of spinous dorsal a little nearcr to tip of snout than to base of caudal; spincs strong, the first $\frac{1}{2}$ to $\frac{3}{5}$ the length of head or $\frac{2}{3}$ to $\frac{3}{4}$ the distance between the origins of the dorsal fins and as long as the longest rays of the scoond dorsal, which has the free edge concare. Anal II 10. Pectoral $\frac{2}{3}$ the length of head, extending to the rertical from the origin of the spinous dorsal or a little beyond; ventrals originating below the middle of the pectorals, extending their base to the origin of anal. Caudal forked. Caudal peduncle $1 \frac{2}{3}$ as long as deep. Silvery; back darker; scales with dark edges; a more or less distinct dark lateral band ending in a lark spot at the base of caudal and with a silvery band above it; dorsal and caudal tins a little dusky.

Hab. Guatearala, Rio Guacalate (Salvin $\left.{ }^{1}\right)$.

Two specimens, 145 and $210 \mathrm{~mm}$. in total length.

These were referred by Günther to A. microps, a species which differs in many respects, notably in the shorter paired fins and lower spinous dorsal.

\section{Agonostomus microps.}

Agonostoma microps, Günth. Cat. Fish. iii. p. 462 (1861), and Trans. Zool. Soc. vi. 1839, t. 70. fig. 1.

Agonostoma percoides (part.), Günth. Cat. Fish. iii. p. 464 .

This species has erroneously been referred to the Central-American fauna; it is represented in the British Nuseum by a number of specimens from St. Vincent, Dominica, and Venezuela, and is not known to occur elsewhere. 


\section{JOTURUS, Poey, 1861.}

Joturus, Jord. \& Ererm. Bull. U.S. Nat. Mus. xlvii. 1896, p. 820.

Mouth rather small, inferior, with short lateral cleft; jaws with bands of small incisor-like teeth with serrated edges, the band in the lower jaw interrupted at the symphysis; very small teeth on vomer, palatines, and pterygoids. Thrce anal spines.

A single species.

\section{Joturus pichardi.}

Joturus pichardi, Poey, Mem. ii. p. 263 (1861) ${ }^{\text {; }}$; Jord. \& Everm. Bull. U.S. Nat. Mus. xlvii. 1896, p. 821, and 1900, fig. $348^{2}$; Meek, Publ. Columbian Mns., Zool. v. 1904, p. $188^{3}$.

Agonostoma gloliceps, Günth. Ann. Mag. Nat. Hist. (4) xiv. 1874, p. $370^{4}$.

Joturus stipes, Jord. \& Gilb. Proc. U.S. Nat. Mus. 1882, p. $373^{5}$.

Depth of body $3 \frac{1}{2}$ in the length, length of head $4 \frac{3}{5}$. Profile decurved from origin of dorsal to mouth, the snout obtuse, longer than the eye, the diameter of which is $5 \frac{1}{2}$ in tho length of head. Interorbital region rery eonvex, its width $\frac{1}{2}$ the length of head. Præorbital serrated posteriorly. 43 scales in a longitudinal series. Dorsal IV, I 9 ; origin of spinous dorsal much nearer tip of snout than base of eaudal ; first spiue rather more than $\frac{3}{\overline{0}}$ the length of hend. Anal II 11, the first articulated ray simple. Pectoral a little shorter than the head, extending to below the spinous dorsal. Caudal forked. Olivaceous, without markings.

Hab. Southern Mexico to Panama.—Cuba:

Mexico, Misantla in Vera Cruz ${ }^{4}$; Costa Rica ${ }^{2}$; Panama ${ }^{5}$; Cuba ${ }^{1}$.

Here described from the type of $A$. gloliceps, a specimen $240 \mathrm{~mm}$. in length. The species is said to attain a length of $600 \mathrm{~mm}$., and to live only in mountain-torrents and at the foot of waterfalls.

\section{MUGIL, Linn.}

Mugil, Jord. \& Everm. Bull. U.S. Nat. Mus. xlvii. 1896, p. 809.

Jouth rather small, transverse, subterminal; rami of lower jaw forming an angle; lower jaw with a more or less distinct symphysial prominence; teeth very small, ciliiform, in one or a few series. Three anal spines.

A large number of species of "Grey Mullet" are known from the coasts of tropical and temperate countries, entering fresh waters.

\section{Synopsis of the Mexican and Central-American Species.}

Adipose cyelid well developed. Dorsal IV, I 7-9. Anal III 7-9.

I. Second dorsal nalicd, except for a series of small seales behind each ray; aual rays usually III 8.

38 to 43 scales in a longitudinal series . . . . . . . . . . . 1. cephalus.

32 to 36 seales in a longitudinal series . . . . . . . . . . . 2. brasiliensis. 
II. Second dorsal covered with small seales.

A. Anal rays usually III 9 .

1. 42 to 46 scales in a longitudinal series.

Second dorsal spine longer than first . . . . . . . . . . . . 3. incilis.

Second dorsal spine not longer than first . . . . . . . . . . . 4. thoburni.

2. 36 to 39 scales in a longitudinal series.

Peetoral $\frac{2}{3}$ to $\frac{3}{4}$ the length of head, extending nearly to the vertical from the origin of the spinous dorsal in the young, but not in the adult . . . . . 5. curema.

Peetoral from $\frac{4}{5}$ to as long as the head, extending to below the spinous dorsal, even in the adult . . . . . . . . . . . . . . . 6. hospes.

B. Anal rays usually III 8 ; 32 to 36 scales in a longitudinal series . . 7. trichodon.

1. Mrugil cephalus, Linn.

Mugil cephalus, Jord. \& Everm. Bull. U.S. Nat. Mus. xlvii. 1896, p. 811, and 1900, fig. $3 \pm 3$.

Hab. Japan; Sandwich Islands; Pacific Coast of America from California to Chile; Atlantic Coast of America from Cape Cod to Brazil ; Atlantic Coast of Europe and Africa from the Loire to the Congo.

2. Mugil brasiliensis, Agass., 1829.

Mugil brasiliensis, Jord. \& Everm. Bull. U.S. Nat. Mus. xlvii. 1896, 1. 810.

Hab. Atlantic Coast from Cuba to Patagonia.

3. MIugil incilis, Hancock, 1830.

Mugil incilis, Jord. \& Everm. Bull. U.S. Nat. Mus. xlvii. 1896, p. 812.

$H a b$. Atlantic Coast from Panama to Brazil.

4. MIugil thoburni, Jord. \& Starks, 1896.

Mugil thoburni, Jord. \& Everm. Bull. U.S. Nat. Mus. xlvii. 1896, p. 812.

Hab. Pacific Coast from Guatemala to Ecuador and the Galapagos Islands.

5. Mugil curema, Cuv. \& Val., 1836.

Mugil curema, Mugil gaimardianus, and Mugil setosus, Jord. \& Everm. Bull. U.S. Nat. Mus. xlvii. 1896, pp. 813, 814, and 815 .

Mugil curema, Jord. \& Everm. t. c. 1900, fig. 344 .

Hab. Pacific and Atlantic Coasts from the United States to Chile and Brazil; Cape Verde Islands.

The examination of a large series of examples (including one received from Dr. Jordan as MLugil setosus) has shown me that the length of the pectoral fin compared to that of the head varies but little according to the size of the individual, but if its length be compared with its distance from the spinous dorsal it appears to be longer in youngr 
specimens than in adults. Thus in small examples the pectoral fin nearly or quite reaches the vertical from the origin of the spinous dorsal, but in large ones it extends only $\frac{2}{3}$ of the distance from its base to the spinous dorsal.

In young examples also the adipose eyelid is thinner and more transparent, the tceth are more evident, and the mandibulary angle is more acute than in the adults. Poey's description of Mugil gaimardianus (Ann. Lye. N. York, xi. 1876, p. 64, t. 8 . figs. 1-3) was based on an example $225 \mathrm{~mm}$. in length which was compared with one of $M$. curema of $325 \mathrm{~mm}$. The supposed speeific differences are mostly very trivial and due to individual rariation (e. g., $M$. gaimardianus was said to have the body less deep, the depth $5 \frac{1}{5}$ in the length as compared with 5 in $M$. curema); other differences, $i . e$. the shorter snout, stronger teeth, and shorter distance between tip of pectoral and spinous dorsal in $M$. gaimardianus, are due to the different size of the specimens compared. The characters assigned to MI. setosus (Gilbert, Proc. U.S. Nat. Mus. 1891, p. 549) are those of young specimens of $M I$. curema.

6. IMugil hospes, Jord. \& Culver, 1895.

Mugil hospes, Jord. \& Everm. Bull. U.S. Nat. MIus, xlvii. 1896, p. 814, and 1900, fig. 345.

Hab. Pacific Coast from Sinaloa to Panama.

7. Wingil trichodon, Poey, 1870.

Mugil trichodon, Jord. \& Everm. Bull. U.S. Nat. Mus. xlvii. 1896, p. 816.

Hab. Atlantic Coast from Florida to Brazil.

4. QUERIMANA, Jori. \& Gilb., 18\$2.

Querimana, Jord. \& Everm. Bull. U.S. Nat. Mus. xlvii. 1896, p. 817.

This genus differs from Mrugil principally in having 2 anal spines instearl of 3 . It comprises "Grey Mullets" of small size, whieh have not been recorded as entering fresh waters.

\section{Querimana harengus, Gïnth., 1861.}

Querimana harengus, Jord. \& Everm. Bull. U.S. Nat. Mlus. xlvii. 1896, p. 817.

Dorsal IV, I S. Anal II 9-10. 38 scales in a longitudinal series.

IIab. Pacific Coast from Mazatlan to Peru.

2. Querimana gyrans, Jord. \& Gilb., $18 \$ 4$.

Querimana gyrans, Jord. \& Everm. Bull. U.S. Nat. Mus. xlvii. 1896, p. 818.

Dorsal IV, I 7-S. Anal II 7-8. 28 or 29 scales in a longitudinal series.

IIab. Southern Atlantic Coasts of the United States. 


\section{CHÆNOMUGIL, Gill, 1863.}

Chenomugil, Jord. \& Everm. Bull. U.S. Nat. Mus. xlvii. 1896, p. 816.

Mouth rather small, subterminal or iuferior; rami of lower jaw forming an angle; teeth small, movable, in sereral oblique series; palate toothless.

This genus comprises two species, one American, the other from the Sandwich Islands.

\section{Chænomugil proboscideus, Günth., 1861.}

Chanomugil proboscideus, Jord. \& Everm. Bull. U.S. Nat. Mus. xlvii, 1896, p. 816.

Lips very thick; mandibular angle very acute; no adipose eyelid. Dorsal IV, I 8. Anal III 10. 38 to 41 scales in a longitudinal series.

Ilab. Pacific Coast from Mazatlan to Panama.

"Common in rock pools" (Jordan \& Evermann); not recorded from fresh waters.

\section{Fam. 3. SPHYRENID量*}

The single genus Sphyrcena comprises about twenty species, pike-like carnivorous marine fishes, with large mouth and strong dentition, often growing to a considerable size.

There appear to be no records of any of the American species occurring in the fresh waters of Mexico and Central America, but one of them, S. guachancho, Cuv. \& Val., has been recorded from the Congo $\begin{aligned} & \text { t. } \\ & \text {. }\end{aligned}$

\section{Fam. 4. POLYNEMID尼}

This family comprises three genera with about thirty species, tropical shore fishes which often enter rivers. They are easily recognizable on account of the peculiar structure of the pectoral fin, which has a detached lower portion composed of free filamentous rays. Pentanemus quinquarius, Linn., from the Tropical Atlantic, with the præoperculum entire and the anal fin much longer than the second dorsal, is known to ascend West African rivers and has been recorded from Cuba; it is perhaps to be met with in the rivers of the Atlantic slope of Tropical America.

The fishes of the genus Polynemus, Linn., have the præoperculum serrate and the anal fin about as long as the second dorsal. Two species are found on the Pacific Coast, ranging from California to Ecuador, viz., P. approximans, Lay \& Bennett, with 5 or 6 pectoral filaments, and $P$. opercularis, Gill, with 8 or 9 pectoral filaments.

* Jord. \& Everm. Bull. U.S. Nat. Mus. xlvii. 1896, p. 822.

$\uparrow$ Bouleng. Les Poissons du Bassin du Congo, p. 364 (1901).

$\ddagger$ Jord. \& Everm. Bull. U.S. Nat. Mus. xlrii. 1896, p. 828 .

BIOL. Centr.-AMer., Pisces, May 1907. 
HAPLONII.

There are examples of the former species, collected by Herr Forrer at Presidio, in the British Museum collection. Atlantic coast species are P. virginicus, Linn., and $P$. octonemus, Girard, the former usnally with $T$ pectoral filaments, the latter usually with 8 .

\section{Sub-order IV. HAPLOMI.}

The Haplomi are represented in the fresh waters of Mexico and Central America by two families, Scombresocide and Cyprinodontidæ, which may be distinguished from other soft-rayed fishes with abdominal ventral fins by the following combination of characters:- "Jaws toothed; præmaxillaries wholly or in great part excluding the maxillaries from the upper border of the mouth. Gill-membranes free from the isthmus. Body scaly; lateral line either absent or placed very low. Fins without spinous rays; a single dorsal; no adipose fin; ventral fins, if present, 5 - to 7-rayed, abdominal in position."

The two families may be distinguished thus:-

Lateral line present, running along the edge of the lower surfaee of the

body . . . . . . . . . . . . . . . . . . 1. Scombresocida.

No lateral line . . . . . . . . . . . . . . . . 2. Cyprinodontidie.

\section{Fam. 1. SCOMBRESOCID压.}

The Scombresocide are marine Fishes of the tropical and temperate seas. Some of the species of Belone and Hemirhamphus enter rivers, and a few permanently fluviatile forms are now usually referred to distinct genera.

\section{BELONE, Cuv., 1817.}

Belone, Günth. Cat. Fish. vi. p. 234 (1866).

Tylosurus (Cocco), Jord. \& Everm. Bull. U.S. Nat. Mus. xlvii. 1896, p. 708.

Jody slender, elongate. Mouth with wide litteral cleft, hoth jaws beinr much prolonged; jaws with small pointed teeth in bands and with a series of onlarged, wide-set, conical tceth; palate toothless. Scales small. Iorsal and anal fins opposite each other and posterior $i_{1}$ position; caudal lunate or forked; pectorals asymmetrical, placed light ; ventrals 6-rayed, inscrted posteriorly.

Many species from tropical and temperate seas; of eighteen American forms, two have been recorded from fresh-watcr localities in Mexico and Central America.

1. Belone marina, Walbanm, 1792.

Tylosurns marinus, Jord. \& Evcrm. Bull. U.S. Nat. Mus. xlvii. 1896, p. 714; Meek, Publ. Columbian Mus., Zool. v. 1904, p. 160. 
Snout twice as long as rest of head. Diametor of eye $2 \frac{1}{2}$ in length of postorbital part of head. Dorsal 15. Anal 17. Caudal peduncle somewhat depressed, the lateral line forming a slight keel. Silvery, back greenish; a bluish-silvery lateral stripe.

Total length $1000 \mathrm{~mm}$.

IIab. Atlantic Coast from Cape Cod to Southern Mexico, entering rivers.

2. Belone scapularis, Jord. \& Gilb., 1881.

Tylosurus scapularis, Jord. \& Everm. Bull. U.S. Nat. MIus. xlvii. 1896, p. 711 ; Gilb. \& Starks, Mem. Calif. Ac. Sci. iv. 1904, p. 51.

Snout twice as long as rest of head. Diameter of eye $3 \frac{1}{2}$ to 4 in leugth of postorbital part of head. Dorsal 14.

Anal 15. Caudal peduncle not depressed. Silvery, back greeuish; a bluish-silvery lateral stripe; a dark hotch above the pectoral.

Total length $450 \mathrm{~mm}$.

ILa\}. Pacific Coast of Panama, entering rivers.

\section{Fam. 2. CYPRINODONTID正.}

Head and body covered with cycloid scales * no lateral line. Head depressed or moderately compressed, usually flat above; body more or less elongate, compressed posteriorly. Mouth protractile, bordered above by the promaxillaries only; jaws with teeth; palate toothless $\uparrow$. A single dorsal fin; pectoral fins placed low or moderately high; rentrals abdominal, of 5 to 7 rays; caudal usually rounded or truncate.

'This family comprises over two hundred species which may be referred to about twenty-five genera, from the fresh waters of America, Africa, and Southern and Eastern Eurasia. Most of the species are American, several of them entering the sea. Some species attain a length of $200 \mathrm{~mm}$., but the majority do not grow to more than half that length.

\section{Synopsis of the Mexican and Central-American Genera.}

I. Oviparous. Males with the anal fin unmodified. Rami of the lower jaw firmly united.

(Crprinodontine.)

A. Teeth conical.

1. Eyes with free margins.

Teeth in ljands, with an outer series of more or less strongly

enlarged teeth. . . . . . . . . . . . 1. Fundulus.

Teeth in a single series . . . . . . . . . . 2. Lucania.

2. Margins of eyes not free; teetl in bands, with an outer series of enlarged teeth . . . . . . . . . . . 3. Rivulus.

B. Teeth trieuspid, in a single series . . . . . . . 4. Cyprinodon.

* The edges of the scales bear a series of prickles in the males of some species of Cyprinodon.

+ Vomerine teeth are present in some Asiatic and African species.

L 2 
II. Viviparous. Males with the anterior 5 or 6 anal rays short, stiff, and subequal, separated by a shallow notch from the rest of the fin. (Characodontine.)

A. Rami of the lower jaw firmly united; teeth fixed.

Teeth of the outer scries conical . . . . . . . . . 5. Zoogonemicus.

Teeth of the outer series usually spear-shaped, sometimes with the apices truncate or even notched . . . . . . . . 6. Linnurgus.

Teeth of the outer series all distinetly bicuspid . . . . . . 7. Characodon.

13. Rami of the lower jaw weakly comnected; teeth of the outer series movable, bicuspid . . . . . . . . . . . . 8. Goodea.

If!. Viviparous. Males with the anal fin advanced and modified into an intromittent organ, some of the anterior rays being enlarged and produeed. Eyes normal. (Pacilinx.)

A. Mouth large, with wide lateral cleft; teeth in bands, slender, pointed, depressible. . . . . . . . . . . . . 9. Beloxesox.

13. Mouth rather swall, with short lateral cleft; rami of lower jaw firmly united; teeth in bauds, with an outer series of enlarged, fixed teeth.

Teeth of the outer series conical . . . . . . . . . 10. Ganrusia.

Teeth of the outer series clisel-shaped . . . . . . . . 11. Glaridentirs.

C. Mouth small, transverse; rami of lower jaw weakly connected; tecth unicuspid.

1. Teeth in a single series . . . . . . . . . . . 12. Grrardinus.

2. Teeth in bands, with an outer series of larger teeth.

Dorsal fin with 8-11 rays, higher but not much longer in the males than

in the females; eaudal rounded or subtruncate in both sexes . . . 13. Poecina.

Dorsal fin with 12 to 16 rays, higher and considerably longer in the males

than in the females; caudal rounded or subtrmncate, sometimes with

the lower angle a little produeed in the males . . . . . . . . 14. Mollenisia.

Dursal fin with 11 to 15 rays, higher but not much longer in the males

than in the females : lower rays of the caudal, in the males, produced

to form a long pointed appendage . . . . . . . . . . . 15. Xiphophorus.

IV. Viviparous. Males with the anal fin modified into a conical scaly intromittent organ with terminal orifiee. Eye transversely divided into two parts. (Aviblepsin.e.) . . . . . . . . 16. Anableps.

\section{FUNDULUS, Lacep., 1803.}

Hoploctirius (part.) and Fundulus, Güntl. Cat. Fish. vi. pp. 310 \& 318 (1860).

Fundulws and Adinia (part.), Jord. \& Everm. Bull. U.S. Nat. Mus. xlvii. 1896, pp. 633 \& 660.

()viparans. Nonth rather small, with shout lateral cleft; rami of the lower jaw firmly united ; teeth pointed, in bands, with an outer series of more or less strongly enlarged, curred, conical teeth. Eyes with frec margins.

This genus comprises a large number of species, mostly North American, some of which are marine. A fow forms occur in the rivers of Mexico and Central America, and the genus is also represented in Africa and Southern Europe. In my synopsis of the species I include some which have been described from the coast of Lower 
California and which probably enter the rivers of Sinaloa, and others which are not yet known to extend further south than the Rio Grande.

\section{Synopsis of the Mexican and Central-American Species.}

I. Origin of anal fin below or behind that of the dorsal. (Fundulus.)

A. 30 to 40 scales in a longitudinal series.

1. Dorsal 12-14. Anal 13-17. Oviduct not produced into a tube attached to the anal fin. a. 32 to 35 seales in a longitudinal series.

Interorbital width more than $\frac{1}{2}$ the length of head; snout not longer than cye. 1. pachycephalus.

Intcrorbital width $\frac{1}{2}$ the length of head or a little less; snout not shorter

than eye . . . . . . . . . . . . . . . . . 2. punctatus.

b. 36 to 39 scales in a longitudinal series . . . . . . . 3. labialis.

2. Dorsal 10-13. Anal 10-12. Females with the oviduct produced into a tube or sheath attached to the anterior anal rays. (? F. vinctus.)

a. 31 to 34 scales in a longitudinal series.

Interorbital width $\frac{1}{2}$ the length of head, which is $3 \frac{3}{4}$ in the length of the fish

(in specimens of $65 \mathrm{~mm}$.) . . . . . . . . . . . . . . . . 4. vinctus.

Interorbital width $\frac{2}{5}$ the length of head, which is $3 \frac{2}{5}$ in the length of the fish

(in specimens of $70 \mathrm{~mm}$.) . . . . . . . . . . . . . . . . 5. pallidus.

Interorbital width $\frac{1}{3}$ the length of head, which is 3 in the length of the fish

(in specimens of $100 \mathrm{~mm}$.) . . . . . . . . . . . . 6. similis.

b. 35 to 39 seales in a longitudinal series.

Anal fin cleep, when laid back extending to or nearly to the base of caudal . 7. heteroclitus.

Anal fin of moderate depth, when laid back not nearly reaching the caudal . 8. grandis.

B. 44 to 60 scales in a longitudinal series.

Dorsal 13. Anal 11. 44 seales in a longitudinal series . . . . . . . 9. adinit.

Dorsal 15. Anal 13. 47 scales in a longitudinal series . . . . . . . 10. extensus.

Dorsal 14-15. Anal 13-14. 60 scales in a longitudinal scries . . . . . 11. zebrinus.

II. Origin of anal fin far in advance of that of the dorsal. (Zrgonectes.). 12. dovii.

\section{Fundulus pachycephalus.}

Fundulus pachycephalus, Günth. Cat. Fish. vi. p. 321 (1866) ', and Trans. Zool. Soc. vi. 1868, p. 483 , t. 84 . fig. $6^{2}$.

Adinia pachycephala, Jord. \& Everm. Bull. U.S. Nat. Mus. xlvii. 1896, p. $660^{3}$.

Depth of body 3 to $3 \frac{2}{3}$ in the length, leugth of head $3 \frac{1}{4}$ to $3 \frac{1}{2}$. Snout nearly as long as or shorter than eye, the diameter of which is $3 \frac{1}{2}$ to $3 \frac{3}{4}$ in the length of head; interorbital width more than $\frac{1}{2}$ the length of head. Lower jaw slightly projecting. 32 to 35 scales in a longitudinal series. Dorsal 12 to 14 ; origin nearer to base of caudal than to head. Anal $13-15$; origin below or a little behind that of the dorsal; no tube attached to the anterior rays. Pectoral $\frac{3}{5}$ to $\frac{2}{3}$ the length of head. Caudal subtruncate. Brownish, each scale with an indistinct darker spot; an indistinct dark lateral band on the posterior part of the body; vertical fins dusky, the dorsal with a few spots, the anal with a pale margin.

Hab. Guatemala, Lake Atitlan ${ }^{12}$ (Salvin).

Here described from the types, four females measuring up to $72 \mathrm{~mm}$. in total length. 


\section{Fundulus punctatus.}

Fundulus penctatus, Gïntl. Cat. Fish. vi. p. 320 (1866)', and Trans. Zool. Soc. vi. 1868, p. 482, t. 84. fig. $5^{2}$; Jord. \& Everm. Bull. U.S. Nat. Mns. xlvii. 1896, p. $63 \sigma^{3}$.

Fundulus gratemalensis, Günth. t. c. p. 321 ', and l. c. t. 94. figs. $3 \& 4^{5}$.

Adinia gratemalensis, Jord. \& Everm. t. c. p. $660^{\circ}$.

Fundulus oaxace, Mcck, Publ. Columbian Mlus., Zool. v. 1904, p. 104, fig. 28 7.

Depth of body $3 \frac{1}{2}$ to $4 \mathrm{in}$ the length, length of head $3 \frac{1}{2}$ to 4 . Suout as long as or a little lowger than eje, the diameter of which is 4 to $4 \frac{1}{3}$ in the leugth of head; interorbital width abont $\frac{1}{2}$ the length of head. Jaws equal anteriorly, or the lower jaw slightly projecting. 32 to 35 scales in a longitudinal scries. Dorsal 1.2-14; origin nearer to base of eaudal than to head. Anal 13-16; origin below or a little behind that of the dorsal; fin deeper in females than in males, but not reaching the base of candal when litid back: no tube attaehed to the anterior anal rays. Pectoral $\frac{3}{3}$ to $\frac{2}{5}$ the length of head. Caudal subtrunciate. Brownish or olivaceous, each scale nsually with a darker spot: spots expecially well definerh in males on the posterior part of the body; females usually with a dark longitudinal baud or a series of short vertical bars on the postcrior part of the body; vertical fins usually dusky, the dorsal often with a series of spots near the base, the anal often with a pale margin.

IIal. Mexico, San Domingo de Guzman (Buller), Totolopam (Gadow), Tequesixtlan (Gadow), and Oaxaca ' (Meek); Guatemala, Chiapam 12, Rio Guacalate ${ }^{25}$, Lalies Dueñas ${ }^{45}$, Nacasil, and Amatitlan ${ }^{45}$ (Sulvin); Honduras. - Western ECUADOR 45 .

Here described from a large series of specimens measuring up to $100 \mathrm{~mm}$. in total length, including the types of the species and of $F$. guatemalensis.

\section{Fundulus labialis.}

Fundulus labialis, Günth. Cat. Fish. vi. p. $319(1866)^{1}$, and Trans. Zool. Soc. vi. 1868, p. 481, t. 84. figs. 1 \& $2^{2}$; Jord. \& Evcrm. Bull. U.S. Nat. Nus. xlvii. 1896, p. 64t ${ }^{3}$.

Tepth of borly $3 \frac{1}{2}$ to $+\frac{1}{2}$ in the length. length of hear 4 to $4 \frac{1}{3}$. Suout as long as or a little longer than eye, the diameter of which is $t$ to $+\frac{1}{4}$ in the length of head; interorbital wilth $\frac{1}{2}$ the length of head or a little less. Jaws equal anteriorly; upper lip rather broad. $31 ;$ to 39 scales in a longitudinal series. Dorsal 1:3-14; origin nearer to hase of cauclal than to hoad. Anal 15-17; origin below that of the dorsal ; fin much deeper in females than in males, when laid back exteuding to the base of cindal; no tube attached to the anterior anal rays. Pectoral nearly $\frac{3}{4}$ the length of head. Caudal subtruncate. Olivaceous: edges of scales nsually darker; vertical fus dusky, the dorsal and anal with broad yellow margins, which are especially well lefined in tho wales.

Irrl. Guatemala, Rio San Gerónimo ${ }^{12}$, Rio Chisoy, and Lake Yzabal ${ }^{2}$ (Salvin).

Here describerl from several specimens, including the types of the species, measuring up to $120 \mathrm{~mm}$. in total length.

\section{Fundulus vinctus.}

Findulus vinclus, Jord. \& Gilb. Proc. U.S. Nat. Mus. 1882, p. 355 '; Jord. \& Everm. Bull. U.S. Nat. Mus. xlvii. 1896, p. $1337^{2}$.

IIal. Lower Calffornin, Cape St. Lucas or lagoons near La Pizz ${ }^{12}$. 


\section{Fundulus pallidus.}

Fundulus pallidus, Everm. Bull. U.S. Fish. Comm. xi. 1891, p. 84, t. 35. fig. 2 (1892) ' ; Jord. \& Everm. Bull. U.S. Nat. Mus. xlvii. 1896, p. $638^{2}$.

Fundulus similis (non Baird \& Girard), Mleek, Publ. Columbian Mus., Zool. v. 1904, p. $105^{3}$.

Depth of body $3 \frac{2}{3}$ to $4 \frac{1}{3}$ in the length, length of head 3 to $3 \frac{2}{5}$. Snout as long as or shorter than eye, the diameter of which is 3 to $3 \frac{1}{2}$ in the length of head; interorbital width $2 \frac{1}{2}$ in the length of head. Jaws equal anteriorly. 31 to 31 scales in a longitudinal scries. Dorsal 10-12; origin equidistant from beul and base of candal. Anal 11-12; origin below or a little behind that of the dorsal; females witl a short tube attached to the basal part of the anterior anal rays. Pectorul $\frac{2}{3}$ the length of head. Caudal subtruncate. Sides with a series of blackish vertical bars, which are broader and less sharply defined in the males than in the females; an oblong black median spot on the back in front of the dorsal fin.

Hab. North Americh, Galveston in 'Texas.-Mexico, Linares ${ }^{3}$ and Victoria ${ }^{3}$ (Meek) in Tamaulipas.

Here described from four specimens measuring up to $70 \mathrm{~mm}$. in total length.

\section{Fundulus similis.}

Hydrargyra similis, Girard, U.S. \& Mex. Bound. Surrey, Fish. p. 68, t. 35. figs. 1-8 (1859) '.

Fundulus similis, Jord. \& Everm. Bull. U.S. Nat. Mus. xlvii. 1896, p. $638^{2}$.

Hab. Rio Grande to Florida, entering the sea 2.

\section{Fundulus heteroclitus.}

Cobitis heteroclitus, Linn. Syst. Nat. p. 500 (1766) '.

Fundulus heteroclitus, Jord. \& Everm. Bull. U.S. Nat. Mus, xlvii. 1896, p. $640^{2}$.

Hab. Rio Grande to Maine, entering the sea 2.

\section{Fundulus grandis.}

Fundulus grandis, Girard, U.S. \& Mex. Bound. Survey, Fish. p. 69, t. 36 (1859) ?.

Fundulus heteruclitus grandis, Jord. \& Everm. Bull. U.S. Nat. Mus. xlvii. 1896, p. C+1 ².

Ifab. Rio Grande to Florida, entering the sea 2

Dr. Meek (Publ. Colnmbian Mus., Zool. v. 1904, p. 107) describes this species as having 40 to 46 scales in a longitudinal series. Specimens which I have examined, and which certainly belong to $F$. grandis as clescribed and figured by Girard, have 36 to $3 S$ scales in a longitudinal series. In females of this species the length of the tube attached to the anal fin is about $\frac{1}{2}$ the depth of the tin, in F. heteroclitus about $\frac{2}{3}$.

\section{Fundulus adinia.}

Fundulus adinia, Jord. \& Gilb. Synopsis, p. $335(1883)^{\text {I }}$; Jord. \& Everm. Bull. U.S. Nat. Mus. xlvii. 1896, p. $6 \pm 5^{2}$.

Hab. Rio Grande at Brownsville ${ }^{1}$. 


\section{Fundulus extensus.}

Funtulus extensus, Jord. \& Gilb. Proc. U.S. Nat. Mus. 1882, p. 355 ' ; Jord. \& Everm. Bull. U.S. Nat. Mus. xlvii. 1896, p. $646^{2}$.

IIal. Lowfr California, Cape St. Lucas or lagoons near Ia Paz 2.

\section{Fundulus zebrinus.}

Fundulus zebrinus, Jord. \& Gilb. Synopsis, p. 891 (1883) '; Jord. \& Everm. Bull. U.S. Nat. Mns. xlvii. 1896, p. $646^{2}$.

Ilab. Rio Grande to Kansas?

\section{Fundulus dovii.}

Haplochilus dovii, Güntl. Cat. Fish. vi. p. 316 (1866) ${ }^{\prime}$, and Trans. Zool. Soc. vi. 1868, p. 48I, t. 82. fig. $5^{2}$.

Fundulus dovii, Jord. \& Everm. Bull. U.S. Nat. Nus. xlvii. 1896, p. $650^{3}$.

Depth of body $4 \frac{1}{2}-5$ in the length, length of head $3 \frac{2}{5}$. Snout as long as the postorbital parts of hearl.

Diameter of eye $4 \frac{1}{2}$ in the length of head and $1 \frac{3}{4}$ in the interorbital width. Lower jaw i little shorter. than the upper; teeth of the outer scries in the lower jaw implanted horizontally. 30 scales in a longitudinal series. Dorsal 8. Anal 13-14, originating at a point equidistant from base of pectoral and base of caudal or a littlo nearer the latter, terminating below the origin of dorsal. Pectoral $\frac{?}{5}$ the length of head, extending to the base of rentrals, which reach the vent. Candal rounded. Oliraceous, witls indistinct darker rertical bars; vertical fins with serics of spots.

Hab. Costa Rica I 2, Punta Arenas (Dow).

Two specimens, types of the species, $150 \mathrm{~mm}$. in totai length.

This is the southern representative of the subgenus Zygonectes, Agass., and is close to the North-American Fundulus (Zygonectes) notatus, Rafin.

\section{LUCAN1A, Girard, 1859.}

Lucania, Jord. \& Everm. Bull. U.S. Nat. Mus. xlvii. 1896, p. 663.

Uviparous. Houth rather small, with short lateral clett; rami of the lower jaw firmly united; tecth conical, in a single series.

Four species from the Atlantic Coasts and rivers of the United States, one extending southwards to Tamaulipas.

\section{Lucania venusta.}

Limia venusta, Girard, U.S. \& Mex. Bound. Surv., Fish. p. 71, t. 39. figs. 20-23 (1859) ${ }^{\text {. }}$.

Lucunia venustu, Girard, Proc. Ac. Philad. 1859, p. $118^{2}$; Günth. Cat. Fish. vi. p. $310(1866)^{2}$;

Jord. \& Everm. Bull. U.S. Nat. Mus. xlvii. 1896, p. $665^{1}$; Meek, Publ. Columbian Mus.,

Zool. v. 1904, p. $109^{\circ}$.

Lucania affinis, Girard, l. c. ${ }^{6}$.

bepth of body 3 to $3 \frac{1}{2}$ in the length, length of head $3 \frac{1}{3}$ to $3 \frac{2}{3}$. Snout shorter than cye, the diamoter of which is 3 in tho length of head; interorlital width $2 \frac{1}{2}$ in the length of head. Lower jaw slightly projecting. 
25 or 26 scales in a longitudinal series. Dorsal 11-13; origin equidistant from tip of snout and base of caudal. Anal 9-11; origin below middle of dorsal. Pectoral $\frac{3}{4}$ the length of head. Caudal rounded. Olivaceous; edges of seales darker; a silvery lateral stripe; fins plain ( $q$ ) or a dark spot at anterior edge of dorsal ( $\left.\sigma^{*}\right)$.

Hab. Coasts and rivers from Florida to Tamaulipas:

Pensacola in Florida ${ }^{4}$; Indianola in Texas ${ }^{1}$; Matamoros in Tamaulipas ${ }^{6}$.

Here described from specimens from Florida, measuring up to $60 \mathrm{~mm}$. in total length.

3. RIVULUS, Poey, 1860.

Rivulus, Günth. Cat. Fish. vi. p. 327 (1866) ; Jord. \& Everm. Bull. U.S. Nat. Mus. xlvii. 1896, p. 662.

Cynodonichthys, Meek, Publ. Columbian Mus, Zool. v. 1904, p. 101.

Oriparous. Mouth rather small, with short lateral cleft; rami of the 1 wer jaw firmly united; teeth pointed, in bands, with an outer series of enlarged, curred, conical teeth. Margins of ejes not free.

This genus comprises four species from Mexico and Central America, two from Cuba, and about eight from South America*. The head is rather broad and the body is somewhat elongate, subcylindrical anteriorly and compressed posteriorly. The snout is short, and the lower jaw projects a little beyond the upper; the lateral gape of the mouth is short, horizontal, and about on a level with the middle of the eye; a vertical cleft in front of the eye marks the posterior edge of the broad lower lip. The teeth of the outer series are rather few and strong, and do not extend on to the sides of the jaws; one or two of the lateral teeth of this series may be longer than the others. The rather short dorsal fin is placed further back than the longer anal. The pectorals are obtuse and are placed very low; the ventrals are small; the caudal is rounded or subtruncate.

Synopsis of the Mexican and Central-American Species.

I. Origin of dorsal over posterior part of anal, which ends below the middle of the dorsal.

Dorsal 9. Anal 12. 42 scales in a longitudinal series . . . . . . . 1. flabellicauda.

Dorsal 8. Anal 11. 38 scales in a longitudinal series . . . . . . . 2. tenuis.

Dorsal 8. Anal 11. 35 scales in a longitudinal series . . . . . . . 3. godmani.

II. Origin of dorsal over middle of anal, which ends a little in advance of the

end of the dorsal. Dorsal 9. Anal 11. 32 scales in a longitudinal scries. 4. isthmensis.

1. Rivulus flabellicauda. (Tab. X. fig. 6.)

Rivulus flabellicauda, Regan, Ann. Mag. Nat. Hist. (7) xix. 1907, p. 6t'.

Depth of body $4 \frac{2}{3}$ in the length, length of head $3 \frac{4}{5}$. Snout shorter than eye, the diametcr of which is 4 in the longth of head; interorbital width $2 \frac{1}{3}$ in the length of headt. 42 scales in a longitudinal series.

* Haplachilus harti, Bouleng., from Trinidad, and $H$. peruanus, Regan, from Peru, belong to this genus.

$\dagger$ In this species and in $R$. opercularis the interorbital width is less than the interocular width.

Biol. Centr.-Amer., Pisces, May 1907. 
Dorsal 9; origin abore posterior part of anal, which onds below the middle of the dorsal. Anal 12: origin equidistant from opereulum and base of caudal. Pectoral $\frac{2}{3}$ the length of head. Caudal subtruncate. Bromnish; cdges of scales darkor; vertical fins with some small ditrker spots; an ocellus on the upper half of the base of the caudul fin.

Hab. Costa Rica, Juan Viñas (Underwood ), San José (Biolley).

Two specimens, the type, $70 \mathrm{~mm}$. in total length, and a much smaller example not included in the description.

\section{Rivulus tenuis.}

Cynodonichthys tenuis, Meek, Publ. Columbian MIus., Zool. v. 1904, p. 101, fig. $2 \tau^{\prime}$.

Allied to $R$. godmuni, but with smaller seales and a smaller eye (diameter $3 \frac{2}{3}$ in the length of head in a slecimen of $40 \mathrm{~mm}$.).

Hal. Mexico, Ei Hule in Oaxaca ${ }^{1}$.

3. Rivulus godmani. (Tab. X. fig. 5.)

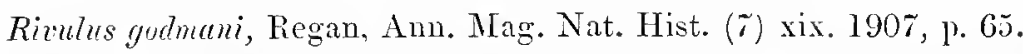

Depth of body $+\frac{1}{2}$ to 5 in the length, length of head $3 \frac{3}{4}$. Snout shorter than eje, the diameter of whieh is :3 in the length of head and a little less than the juterorljital width. 35 scales in a loigitudinal series. Dorsal 8; origin above posterior part of anal, which ends below the midlle of the dorsal. Anal 11 ; origin equidistant from operculum and base of caudal. Pectoral $\frac{2}{3}$ the leugth of head. Caudal subtruncate or rounded. Oliraccous, with a more or less distinct darker spot on each scale; opereulum blackish; rertical fins dusky, the caudal with a narrow light edge, and below with a blackish intramarginal stripe; caudal ocellus sometines present.

Hab. Gtatemala (Godman).

Two specimens, $40 \mathrm{~mm}$. in total length.

\section{Rivulus isthmensis,}

Rivulus isthmensis, Garman, Mem. Mus. Comp. Zool. xix. 189j, p. $140^{1}$.

Hal. Costa Rich, Rio San José 1 .

\section{CYPRINODON, Lacep., IS03.}

Cypminolon, Jord. \& Everm. 13ull. U.S. Nat. Mus. xlvii. 1896, p. $6 r 0$.

Oriparous. Mouth small, with short laterul clett; rami of the lower jaw firmly united; tecth incisor-like, tricusid, in a single series.

About eight species comprise this genus, which ranges from the United States to Brazil. In these the gill-openings are restricted from above, commencing only a little above the level of the pectoral tins. The Old-IVorld genus or subgenus Lebias differs only in the greater freedom of the operculum.

A few forms enter the sea and others are sometimes found in salt springs; they are very variable and difficult to distinguish; specimens withont ventral fins are not uncommon. 
Only two well-established species, $C$. macularius and $C$. bovinus, have been recorded from Mexico, but two others known to occur in the Rio Grande system are probably to be met with in its southern tributaries and are therefore included here. In all these the origin of the dorsal fin is about in the middle of the length of the fish (without the caudal fin), and the anal commences below the posterior part of the dorsal.

\section{Synopsis of the Mexican and Central-American Species*.}

I. Longest dorsal rays, in the male, only a little more than $\frac{1}{2}$ the lengtlı of head, less than the length of base of the fin . . . . . . . . . . 1. elegans.

II. Longest dorsal rays, in the male, from $\frac{2}{3}$ to as long as the head, not shorter than the base of the fin.

A. Longest anal rays eonsiderably shorter than those of the dorsal.

Diameter of eye $3 \frac{1}{2}$ to 4 in the length of head (in specimens measuring up to $60 \mathrm{~mm}$.) ; pectoral $\frac{3}{4}$ the length of head . . . . . . . . . 2. bovinus.

Diameter of eye 3 to $3 \frac{1}{2}$ in the length of head (in specimens measuring up to $70 \mathrm{~mm}$.) ; pectoral as long or nearly as long as the head. . . . 3. variegatus.

B. Longest anal rays seareely shorter than those of the dorsal . . . . . . 4. macularius.

\section{Cyprinodon elegans.}

Cyprinodon elegans, Baird \& Girard, Proc. Ac. Philad. 1853, p. $389^{1}$; Girard, U.S. Mex. Bonnd. Surv., Fish. p. 66, t. 37. figs. 1-7 (1859) ${ }^{2}$; Jord. \& Everm. Bull. U.S. Nat. Mus. xlvii. 1896, p. $675^{3}$.

Depth of bod $2 \frac{2}{3}$ in the length, length of head $3 \frac{1}{3}$. Snout as long as eye, the diameter of which is $3 \frac{1}{2}$ in the leugth of head; interorbitul width 23 in the length of head. 26 seales in a longitudinal series. Dorsal 11; longest rays less than the length of base of the fin, scarcely more than $\frac{1}{2}$ the leugth of head, shorter than the longest anal rays. Anal 11. Pectoral $\frac{3}{t}$ the length of head. Caudal snbtruncate. Least depth of caudal peduncle $1 \frac{2}{\partial}$ in its length, $\frac{2}{3}$ the length of head. Dark brownish above, yellowish beneath; upper parts with irregular dark spots; a dark band along the middle of the side; fins pale; basal half of dorsal with small dark spots; candal with a narrow blackish posterior edge.

Hab. Camanche Springs, Rio Grande ${ }^{2}$.

Here clescribed from a single specimen, a male, measuring $50 \mathrm{~mm}$. in total length, received from the Smithsonian Institution.

\section{Cyprinodon bovinus.}

Cyprinodon bocinus, Baird \& Girard, Proc. Ac. Philad. 1853, p. $389^{2}$; Girard, U.S. \& Mex. Bound. Surv., Fish. p. 6\%, t. 37. figs. 12-18 (1859) ${ }^{2}$; Jord. \& Everm. Bull. U.S. Nat. Mus. xhrii. 1896, p. $673^{3}$.

* C. carpio, Gïnth., from Florida, apparently does not extend further south. It is recognizable by the largo eye (diameter $\frac{1}{3}$ the length of head in specimens of $80 \mathrm{~mm}$.) and by the humeral scale, which is not enlarged.

C. marte, Steind., from the coast of Colombia, may occur in Central America; it appears to hare a more slender body than the species described here. 


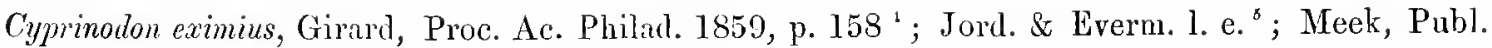
Columbian Mus., Zool. v. 1904, p. $125^{\circ}$.

Cyprinodon latifasciatus, Garm. Bull. Mus. Comp. Zool. vii. 1881, p. $92^{\top}$, and Mem. Mus. Comp. Zool. xix. 1895, p. $22^{4}$; Jorrl. \& Everm. t. c. p. $676^{9}$; Mcek, l. c. ${ }^{10}$.

Cyprinodon elegans, Mcek, t. c. p. 125 ".

Depth of body 2 to $2 \frac{2}{3}$ in the length, length of heal 3 to $: 3 \frac{1}{2}$. Snout about as long as eye, the diameter of which is $3 \frac{1}{2}$ to $t$ in the length of head; interorbital width $2 \frac{1}{4}$ to $2 \frac{1}{2}$ in the length of head. 26 or 27 scales in a longitulinal series. Dorsal 9-11; longest rays equal to the base of the fin or $\frac{2}{3}$ the length of hearl $(\pi)$ or less than the base of the fin and $\frac{1}{2}$ the length of head ( 9 ). Anal 9-11; longest rays shorter than those of the dorsal. Pectoral $\frac{3}{7}$ the length of head. Candal truncate or subtruncate. Least depth of caudal peduncle $\frac{2}{3}$ the lengtl of head. Coloration very variable, the males sometimes spotted or barrcd, sometimes unitornly blackish : fomales spotted, the spots sometimes forming crossbars, sometimes a longitudinal lateril band; vertical fins pale or dusky; caudal, in the males, usually spotted and with a blackish posterior edge; temales with a dark spot on the posterior part of the dorsal.

Hab. Rio Grande System and sonthrvards to Durango:

Leon Spring in Texas ${ }^{12}$; Colonia Juarez, Guzman, Santa Maria and Miñaca in Chihuahua ${ }^{11}$; Rio Carmen and Rio Sauz in Chihnahua ${ }^{\circ}$; Rio Conchos in Chibuahua ${ }^{5}$; Rio Chihuahua ${ }^{4}$; Parras in Coahuila ${ }^{7}$; Labor and Durango in Durango ${ }^{10}$.

Here described from specimens measuring up to $60 \mathrm{~mm}$. in total length from the Rio Conchos (Woolman), determined as C. eximius and C. elegans by Dr. Jordan, the Rio Sauz (Metk), and Labor (Mcek).

\section{Cyprinodon variegatus.}

Cyprinodon variegatus, Lacep. Hist. Nat. Poiss. v. p. 486 (1803) ${ }^{1}$; Günth. Cat. Fish. vi. p. 305

(1866) ${ }^{2}$; Garman, Mem. Mus. Comp. Zool. xix. 1895, p. 20³ ; Jord. \& Everm. Bull. U.S.

Nat. Mus, xivii. 1896, p. $672^{4}$.

Esox orimus, Mitchell, Trans. Phil. Soc. N. York, i. 1815, p. 441, t. 4. fig. $7^{5}$.

Lebias rlomboidalis, Val. in Humboldt's Obs. Zool. ii. p. 100 (1817) ${ }^{6}$.

Lebias ellipsoiten, Le Sueur, Journ. Ac. Philad. ii. 18:21, p. 5, t. 2. figs. 1-3 ${ }^{7}$.

Cyyminodon giblosus, Baird \& Girarl, Proc. Ac. Philad. 1853, p. $390^{4}$; Girarl, U.S. Mex. Bound.

Surv., Fish. p. 67, t. 37 . figs. $1-7^{\circ}$.

Trifarcias riverandi, Poey, Mcm. ii. p. 306 (1861 $)^{10}$.

Depth of body 2 to $2 \frac{1}{2}$ in the length, length of head $3 \frac{1}{2}$. Snout a little shorter than eyc, the diameter of which is $3-3: \frac{1}{2}$ in the length of heal ; interortuital width $2 \frac{1}{2}$ to $2 \frac{3}{4}$ in the length of head. 26 or 27 seales in a longitudinal serics. Dorsal 10-11; longest rays equal to tiee base of the fin and nearly as long as

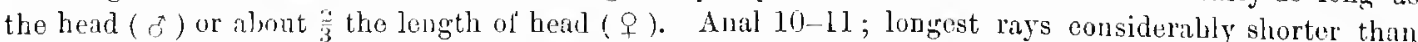
those of the dorsal. I'ectoral nearly as louts as the hasd. Caudal truncato. Least depth of candal peduncle $\frac{2}{3}$ the leneth of head. bioly with more or less distinct dark verticul bars; caudal lin, in malces, with a dark posterior edge; females with a dark spot on the posterior part of the dorsal.

IIab. Cape Cod to the Rio Grande and Cuba, entering the sea:

New York ${ }^{5}$; Carolina $^{1}$; Florida $^{7}$; Louisiana ${ }^{6}$; Indianola in Texas ${ }^{8} 9$; Cuba ${ }^{10}$. 
Here described from specimens from Florida, measuring up to $70 \mathrm{~mm}$. in total length.

\section{Cyprinodon macularius.}

Cyprinodon macularius, Baird \& Girard, Proe. Ac. Philad. 1853, p. $389^{\prime}$; Girard, U.S. \& Mex.

Bound. Surv., Fish. p. 68, t. 37. figs. 8-11 (1859) ${ }^{2}$; Garm. Mem. Mus. Comp. Zool. xix.

1895, p. $24^{3}$; Gilb. N. Amer. Fauna, no. 7, p. 232 (1893) ' ; Jord. \& Everm. Bull. U.S.

Nat. Mus. xlvii. 1896, p. $674^{5}$; Gilb. \& Scofield, Proc. U.S. Nat. Mus. 1898, p. $498^{\circ}$;

Meek, Publ. Columbian Mus., Zool. v. 1904, p. 126 ${ }^{\tau}$.

Cyprinodon californiensis, Girard, Proc. Ac. Philad. 1859, p. 157 .

Cyprinodon nevadensis, Eigenm. Proc. Calif. Ae. Sei. (2) i. 1889, p. $270^{\prime}$.

Depth of body $2 \frac{1}{4}$ to $2 \frac{1}{2}$ in the length, length of head 3 . Snout a little shorter than eye, the diameter of which is 3 to $3 \frac{1}{2}$ in the length of head; intererbital width $2 \frac{1}{2}$ in the length of head. 25 or 26 scales in a longitudinal series. Dorsal 10-11; longest rays equal to the base of the fin ( $\delta$ ) or a little less ( 9 ), $\frac{2}{3}(\delta)$ or $\frac{1}{2}(q)$ the length of head, scarcely longer than the longest anal rays. Anal 10-11. Pectoral $\frac{4}{3}$ the length of head. Caudal subtruneate. Least depth ef candal peduncle $\frac{2}{3}$ the length of head. Body with irregular dark cross-bars and an interrupted lateral band, these markings scarcely distinct in males; the caudal fin and sometimes the dorsal and anal with a narrow dark edge (in the males), the dorsal with a small dark spot on the posterior rays (in the females).

Hab. Colorado and Nevada to Sonora and Lower California:

$$
\text { Colorado; Nevada }{ }^{49} \text {; California }{ }^{489} \text {; Arizona }{ }^{12} \text {; Sonora }{ }^{56} \text {. }
$$

Here described from five specimens from Colorado (Eigenmann) and Lower California, measuring up to $60 \mathrm{~mm}$. in total length.

\section{ZOOGONETICUS, Meek, 1902.}

Zoogoneticus, Meek, Publ. Columbian Mus., Zool. v. 1904, p. 109.

Viriparous. Anal tin of the male with the anterior five or six rays short, stiff, and subequal, separated by a more or less distinct notch from the rest of the fin. Mouth rather small, with short lateral eleft; rami of the lower jaw firmly united; minute teeth in bands, with an outer series of enlarged, fixed, conical teeth.

This genus comprises four species, from the Rio Lerma System and the Valley of Mexico. It is very closely related to Funcluli of the type of F. punctatus, F. pachycephalus, \&c.

$$
\text { Synopsis of the Species. }
$$

I. 28 to 30 scales in a longitudinal series.

Dorsal 13-16; origin about equidistant from tip of snout and posterior end of caudal fin. Anal 13-15 . . . . . . . . . . . . . 1. cuitzeoensis.

Dorsal 17 ; origin nearer to end of eaudal than to tip of snout. Anal 13 2. dugesii.

II. 32 to 34 scales in a longitudinal series . . . . . . . . . . . . 3. dia $z i$.

III. 36 to 39 scales in a longitudinal series . . . . . . . . . . 4. robustus. 


\section{Zoogoneticus cuitzeoensis.}

Platypecilus quitzeoensis, B. A. Bean, Proc. U.S. Nat. Mus. 1898, p. 540, fig. 1 '.

Zoogoneticus critzeoensis, Meck, Publ. Columbian Mus., Zool. v. 1904, p. 111, fig. $99^{2}$.

Depth of body $2 \frac{1}{3}$ to $3 \frac{1}{2}$ in the length, length of head $3 \frac{1}{4}-3 \frac{3}{4}$. Snont as long as or shorter than the eye, the diameter of which is 3 to $3 \frac{1}{2}$ in the length of head; interorbital width $2 \frac{2}{3}$ to 3 in the length of head. Lower jaw projeeting. 25 to 30 scutes in a longitudinal series. Dorsal 13-16: origin equidistant from eye or operenlum and baso of caudal. Anal 13-15; urigin a little behind that of the dorsal. Pectoral $\frac{3}{3}$ to $\frac{3}{4}$ the length of head. Caudal rounded. Males nearly uniformly coloured, with the rertical fins dusky, the dorsal and anal with pale edges. Females with a series of dark spots or bars on the lower half of the posterior part of the body; a pair of dark spots at the base of the candal ; fins pale, immaculate.

Hab. Mexico, Rio Lerma System :

Lake Chapala ${ }^{2}$; Lakie Cuitzeo ${ }^{1}$.

Here described from specimens from Lake Chapala (Meek), measuring up to $65 \mathrm{~mm}$. in total length.

\section{Zoogoneticus dugesii.}

Fundulus dugesii, Bean, Proc. U.S. Nat. Mns. 1887, p. 373, t. 20. fig. $5^{\text {'. }}$

Aitinia dugesii, Jord. \& Everm. Bull. U.S. Nat. Mus, xlvii. 1896, p. 661 ².

Zoogoneticus dugesii, Mrcek, Publ. Columbian MIus., Zool. v. 1904, p. 111, fig. $30^{3}$.

Hab. Mexico, Rio Lerma System:

Lagos $^{3}$; Guanajuato ${ }^{1}$; Lake Patzcuaro ${ }^{3}$.

This species should be easily distingnished by the coloration, the body being crossed by well-defined vertical bars, and by the short and deep candal peduncle.

\section{Zoogoneticus diazi.}

Zoogoneticus diazi, Meck, Publ. Columbian Mius., Zool. v. 1904, p. 11t, fig. $32^{1}$.

Zoogoneticus miniatus, Mcck, t. c. p. 115, fig. $33^{2}$.

Depth of body $3-3 \frac{1}{2}$ in the length, length of head $3 \frac{1}{3}$ to $3 \frac{2}{3}$. Snout ncarly as long as or shorter than eye, the diameter of which is $2 \frac{3}{4}$ to $3 \frac{2}{3}$ in the length of head; interorbital midth $2 \%$ to 3 in the length of head. Lomer jaw a little projecting. 32 to 34 scales in a longitudinal series. "Dorsal 16-18; origin equidistant from heal and base of eandal ( o ) or a little nearer the former (o). Anal 12-15; origin below or a little behind that of the dursal. Pectoral $\frac{3}{5}$ the lenth of head. Caudal sultruneate. $\Lambda$ lateral series of irregular dark spots or vertical bars; fins immaculate.

Mab. Mexico, Rio Lerma System and Valley of Mexico:

Lalie Patzcuaro ${ }^{1}$; Lake Zirahuen ${ }^{1}$; Lake Chalco ${ }^{2}$.

Here described from specimens from Lake Patzcuaro (Meek) measuring up to $80 \mathrm{~mm}$. in total length.

\section{Zoogoneticus robustus.}

Fundulus rolustus, Bean, Proc. U.S. Nat. Mus. 1892, p. 285, t. 44. fig. $2^{1}$; Jord. \& Everm. Bull. U.S. Nat. Mus, xlvii. 1896, p. 6.1². 
Zoogoneticus robustus, Meek, Publ. Columbian Mus., Zool, iii. 1902, p. $92^{3}$, and v. 1904, p. 113, fig. $31^{4}$.

Zoogoneticus maculatus, Regan, Amn. Mag. N. H. (7) xiii. 1904, p. $256^{5}$.

Depth of body 3 to $3 \frac{3}{4}$ in the length, length of head 3 to $3 \frac{1}{3}$. Snout as long as or longer than eye, the diameter of which is 4 to 5 in the length of head; interorbital width $2 \frac{1}{\%}$ to $2 \frac{2}{3}$ in the length of head. Lower jaw projecting. 36 to 39 scales in a longitudinal series. Dorsal $13-14$; origin nearly equidistant from preoperculum and base of candal. Anal $1+-16$; origin a little behind that of the dorsal. Pectoral $\frac{3}{5}$ to $\frac{2}{3}$ the length of head. Caudal suhtruncate. Body usually with irregular dark spots; fins immaculate.

Hab. Mexico, Rio Lerma System :

Guanajuato ${ }^{1}$; Rio Grande de Santiago ${ }^{5}$ (Buller) ; Lake Chapala ${ }^{4}{ }^{4}$; Lake Cuitzeo $^{34}$; Lake Patzcuaro ${ }^{34}$; Zirahuen ${ }^{34}$.

Here described from several specimens from the Rio Grande de Santiago, Lake Chapala, and Lake Patzcuaro, measuring up to $145 \mathrm{~mm}$. in total length.

\section{LIMNURGUS, Günth., 1866.}

Limnurgus, Günth. Cat. Fish. vi. p. 309 (1866).

Girardinichthys, Jord. \& Everm. Bull. U.S. Nat. MIus. xlvii. 1896, p. 666.

Viriparous. Anal fin of the male with the anterior five or six rays short, stiff, and subequal, separated by a more or less distinct notch from the rest of the fin. Mouth small, with short lateral cleft; rami of the lower jaw firmly united; minute teeth in bands, with an outer series of enlarged fixed teeth which are usually spear-shaped, but may have their apices truncate or even notched.

A single species from the Valley of Mexico.

\section{Limnurgus innominatus. (Tab. XII. fig. 1.)}

Lucania sp., Girard, Proc. Ac. Philad. 1859, p. $118^{1}$.

Girardinichtlys innominatus, Bleek. Cyprin. p. $48+(1860)^{2}$; Jord. \& Everm. Bull. U.S. Nat. Mus. xlvii. 1896, p. $666^{3}$; Meek, Publ. Columbian Mus., Zool. v. 1904, p. $116^{4}$.

Limnurgus variegatus, Günth. Cat. Fish. vi. p. 309 (1866) ${ }^{\text {s. }}$

Characodon geddesi, Regan, Anu. Mag. N. H. (7) xiii. 1904, p. $257^{\circ}$.

Depth of body $2 \frac{1}{3}$ to $3 \frac{1}{3}$ in the length, leugth of head $3 \frac{3}{4}$ to 4 . Snout as long as eye, the diamcter of which is 4 to $4 \frac{1}{4}$ in the length of head; interorbital width $2 \frac{1}{5}$ to $2 \frac{2}{5}$ in the length of head. 39 to 43 scales in a longitudinal series. Dorsal 18-23; origin equidistant from eye $\left(\sigma^{\pi}\right)$ or operculum $(q)$ and base of caudal. Anal 20-26; origin a little behind that of the dorsal. Pectoral $\frac{2}{3}$ tho length of head. Caudal subtruncate. Body with irregular dark spots or narrow vertical bars.

Hab. Mexico, Valley of Mexico:

City of Mexico ${ }^{1}$; Lake Chalco ${ }^{4}$ (Meek̂); Lake Tezcoco ${ }^{6}$ (Geddes) ; Xochimilco ${ }^{4}$.

Here described from several specimens, measuring up to $75 \mathrm{~mm}$. in total length. 


\section{CHARACODON, Günth., 1866.}

Characodon, Giinth. Cat. Fish. vj. p. 308 (1866) ; Jord. \& Everm. Bull. U.S. Nat. Mus. xlvii. 1896, p. $66 \%$.

Characodin and Chapalichthys, Mcek, Publ. Columbian Mus., Zool. v. 1904, pp. 118 \& 123.

Tiviparons. Anal fin of the male with the anterior five or six rajs short, stiff, and subequal, separated by a more or less distinct notch from the rest of the fin. Mouth rather small, with short lateral cleft; rami of lower jaw firmly nnited; minute teeth in bands, with an outer series of enlarged, fixed, bicuspid teeth.

\section{Hab. Mexico and Lower California.}

\section{Synopsis of the Species.}

1. Dorsal and anal fins each with more than 25 rays . . . . . . . . 1. multiradiatus.

II. Dorsal and anal fins each with less than 20 rays.

A. 32 to 36 scales in a longitudinal series.

Origin of anal below middle of dorsal; orjgiu of dorsal equidistant from tip of snout and base of caudal or a little nearer the latter . . . . . . . 2. encaustus.

Origin of anal below anterior part of dorsal ; origin of dorsal about equidistant from tip of snont and posterior end of caudal tin . . . . . . . . . 3. variatus.

Origin of anal a little in advance of that of thc dorsal, which is equiclistant from posterior part of head and posterior end of caudal fin . . . . . . 4. lateralis. B. 50 to 55 scales in a longitudinal series . . . . . . . . . . . 5. furcidens.

\section{Characodon multiradiatus. ('lab. XII. figg. 3, 4.)}

Characodon multiradiatas, Mcek, P’ubl. Columbian Mus., Zool. v. 1904, p. $119^{1}$.

Jepth of body $2 \frac{2}{3}$ to $3 \frac{1}{3}$ in the length, length of head $3 \frac{3}{4}$ to 4 . Snout a little shorter than eye, tho diamcter of which is 3 to $3 \frac{1}{3}$ in the length of head : interorbital width 2 to $2 \frac{1}{3}$ in the length at head. About to scales in a longitudinal series*. Dorsal 28-33; origin nearer to tip of snout than to baso of caudal ( $\delta$ ) or nearer to the caudal $(q)$. Aual $20-32$; origin below the anterior part of the dorsal. Pectoral $\ddot{3}$ to $\frac{3}{4}$ the length of head. Caudal subtruncate. Olivaceaus, with irregular dark eross-bars; rertical tius, in the males, with blackish edges.

Hab. Mexico, Rio Lerma System, Lerma ${ }^{1}$.

Here described from four specimens, measuring up to $45 \mathrm{~mm}$. in total length, from Lerma (Meeh).

\section{Characodon encaustus.}

Charucordon encaustus, Jord. \& Suyd. Bull. U.S. Fish. Comm. xix. 1899, p. 126, fig. 7 (1900) '. Chapalichtitys encaustus, Meek, Publ. Columbian Mus., Zool. v. 1904, p. 123, fig. $36^{2}$.

Tepth of body 3 to $: 3 \frac{2}{3}$ in the length, length of head $3 \frac{1}{3}$ to 4 . Snout as long as or shorter than eye, tho diameter of which is 3 to $3 \frac{1}{2}$ in the length of hend; interorbital width $2 \frac{1}{2}$ to 3 in the length of head.

* When the scales are regularly arranged I count not more than 40 in a longitudiual scries. Sometimes they are irregular, two scales from scries above and below meoting to oxolude a scale from contact with what shonld be the next one in its lon ritudinal scries; in one specimen this occurs to such an extent that more than 45 may be counted from abovo the pectoral to the caudal. 
33 to 36 scales in a longitudinal series. Dorsal 15-18; origiu equidistant from tip of snout and base of caudal or a little nearer the latter. Anal 15-17; origin below the middle of dorsal. Pectoral nearly $\frac{3}{4}$ the length of head, extending bejond the base of ventral. Caudal truncate. Olivaceous; a series of 7 to 10 dark brown spots or short vertical bars along the middle of the side.

\section{Hab. Mexico, Lake Chapala 12.}

Here described from several specimens, measuring up to $75 \mathrm{~mm}$. in total length.

\section{Characodon variatus.}

Characodon variatus, Bean, Proc. U.S. Nat. Mus. 1887, p. 370, t. 20. fig. $1^{1}$; Jord. \& Everm. Bull. U.S. Nat. Mus. xlvii. 1896, p. $669^{2}$; Meek, Publ. Columbian Mus., Zool. v. 1904, p. $120^{3}$. Characodon ferrugineus, Bean, t. c. p. 372 , t. 20. figs. $3 \& 4{ }^{4}$.

Characodon eiseni, Rutter, Proc. Calif. Ac. Sci. (2) vi. 1896, p. $266^{5}$; Jord. \& Evcrm. t. c. 1898 , p. $2831^{6}$; Meek, t. c. p. $119^{7}$.

Depth of hody about 3 in the length, length of head $3 \frac{1}{4}$ to $3 \frac{1}{2}$. Snout as long as eye, tho diameter of which is $3 \frac{1}{2}$ to 4 in the length of head; interorbital width $2 \frac{1}{2}$ in th3 length of bead. 32 to 35 seales in a longitudinal series. Dorsal 12-14; origin equidistant from tip of snout and end of caudal fin. Anal 14-17; origin behind that of the dorsal. Pectoral $\frac{3}{5}$ to $\frac{3}{4}$ the length of head. Candal subtruncate. Males with a bleckish longitudinal band; dersal and caudal fins blackish, with a narrow light edge. Females with the lateral band broken up into a series of spots or bars; body with numerons irregular spots; fins pale.

Hab. Mexico, Rio Lerma System :

Aguas Calientes ${ }^{3}$; Tepic $^{5}$; Lagos $^{3}$; Guanajuato $^{14}$; Ocotlan $^{3}$; Celaya $^{3}$; Salamanca ${ }^{3}$; Huingo ${ }^{3}$.

Here described from a number of specimens, measuring up to $75 \mathrm{~mm}$. in total length, from Aguas Calientes (Jordan, Meek) and Salamanca (Woolman).

\section{Characodon lateralis.}

Characodon lateralis, Günth. Cat. Fisl. vi. p. 308 (1866) ${ }^{1}$, and Trans. Zool. Soc. vi. 1868, p. 480, t. 82. fig. $2^{2}$; Garm. Mem. Mus. Comp. Zool. xix. 1895, p. $36^{3}$; Meek, Publ. Columbian Mus., Zool. v. 1904, p. $121^{ \pm}$.

Characodon garmani *, Jord. \& Everm. Bull. U.S. Nat. Mus. xlvii. 1898, p. $2831^{5}$; Meek, 1. c. ".

Depth of body $2 \frac{1}{2}$ to 3 in the length, length of head 3 to $3 \frac{1}{3}$. Snout as long as or shorter than eye, the diameter of which is $3 \frac{1}{2}$ to $4 \frac{1}{4}$ in the length of head; interorbital width 2 to $2 \frac{1}{4}$ in the length of head. 32 to 35 seales in a longitudinal series. Dorsal 11-14; origin equidistant from preoperculum or operoulum and end of eaudal. Anal 13-16; origin a little in advance of that of the dorsal. Pectoral $\frac{3}{5}$ the length of head. Caudal rounded or subtruncate. Jales dark brownish, with a more or less distinet blackish lateral band; vertical fins each with a blackish intramarginal band. Females olivaceous, with the dark lateral band more or less broken up into spots or bars.

* Jordan \& Evermann (Bull. U.S. Nat. Mus. xlvii. 1898, p. 2831) proposed the name Characodon garmani for the specimens from Parras, Coahuila, described by Garman (Mem. Mus. Comp. Zool. xix. 1895, p. 36) under the name Characodon latevalis. Garman's description appears about equally applicable to C. lateralis and $C$. variatus, species which he does not recognize as distinct from each other. Specimens collected by Dr. Meek at Durango and sent as $C$. garmani are identical with $C$. lateralis.

Biol. Centr.-AMER., Pisces, July 1907. 
Hab. Mexico, Coahuila, Durango, and Jalisco :

Parras in Coahuila ${ }^{3}$; Durango and Labor in Durango ${ }^{6}$; Jalisco ${ }^{4}$.

Here described from sereral specimens, measuring up to $05 \mathrm{~mm}$. in total length, the types of the species (described as from Central America, without particulars as to the exact locality) and a series from Durango (Meek).

5. Characodon furcidens. (Tab. XII. fig. 2.)

Characodon furcidens, Jord. \& Gilb. Proc. U.S. Nat. M[us. 1882, p. 354' ; Jord. \& Everm. Bull. U.S. Nat. Mus. xlvii. 1892, p. $670^{2}$.

Depth of body $3 \frac{1}{2}$ in the length, length of head 4. Snout as long as eje, the diameter of which is $3 \frac{1}{2}$ in the length of head: interorbital width 2 in the length of head. 53 scales in a longitudinal series. Dorsal 16; origin equidistant from base of pectoral and base of candal. Anal 12; origin posterior to that of the dorsal. Pectoral $\frac{2}{3}$ the length of head. Caudal truncate. Brownish above, yellowish below ; upper part of the body with traces of darker spots.

Hab. Lower California and Jalisco :

Cape San Lucas or lagoons near La Paz ${ }^{1}$; Rio de Mascota in Jalisco (Buller); Colima ${ }^{2}$.

Here described from a specimen of $80 \mathrm{~mm}$. from the Rio de Mascota (Buller).

\section{GOODEA, Jord., 1879.}

Goodea, Jord. \& Everm. Bull. U.S. Nat. Mus. xlvii. 1896, p. 685.

Xenendum, Jord. \& Snyd. Bull. U.S. Fish. Comm. xix. 1899, p. 1:2 (1900).

Goodea and Skiffia, Meck, Publ. Columbian Mus., Zool. v. 1901, pp. 136 and 141.

Viviparous. Anal fin of the male with the anterior five or six rays short, stiff, and subequal, separated by a more or less distinct notch from the rest of the fin. Mouth small, transverse; rami of lower jaw weakly connected ; minute teeth in bands, with an onter series of larger, morable, bicuspid teeth.

Hab. Mexico.

\section{Synopsis of the Species.}

I. Origin of anal well in advance of that of the dorsal; 38 to 15 scales in a longitudinal series. . . . . . . . . . . . . . 1. toweri.

II. Origin of anal below or slightly in advance of that of the dorsal.

39 to 44 scales in a longitudinal series . . . . . . . . . . . . 2. atripinnis.

34 to 38 seales in a longitudiual series . . . . . . . . . . . . 3. calientis.

III. Origin of anal a little bchind that of the dorsal; 32 scales in a longitudinal series . . . . . . . . . . . . . . . 4. bilineata.

IV. Origin of anal considerably behind that of the dorsal.

A. 48 to 55 scales in a longitudinal scries . . . . . . . . . . 5. whitii.

B. 32 to 38 scales in a longitudinal series.

Dorsal with 12-15 rays . . . . . . . . . . . . . 6. lerme.

Dorsal with $16-18$ rays . . . . . . . . . . . . . . 7. multipunctata. 


\section{Goodea toweri.}

Goodea toweri, Meek, Publ. Columbian Mus., Zool. v. 1904, p. 138, fig. $411^{1}$.

Depth of body 2 to $2 \frac{1}{3}$ in the length, length of head $3 \frac{3}{4}$. Snout shorter than eye, the diameter of which is $2 \frac{3}{4}$ in the length of head; interorbital width equal to the distance from posterior margin of pupil to free edge of operculnm. 38 to $42(45)$ scales in a longitudinal series. Dorsal 11-12; origin equidistant from preeoperculum or operculum and postcrior ead of caudal. Anal 12-13; origin in advance of that of the dorsal. Pcctoral $\frac{3}{4}$ the length of head. Caudal truncate. Brownish above, lighter below; fins plain.

Hab. Mexico, Upper tributaries of the Rio Panuco:

Rio Verde in San Luis Potosi ${ }^{1}$.

Here described from two specimens of $70 \mathrm{~mm}$. from the Rio Verde (Meek).

\section{Goodea atripinnis.}

Goodea atripinnis, Jord. Proc. U.S. Nat. Mus. 1879, p. $299^{1}$; Jord. \& Everm. Bull. U.S. Nat. Mus. xlvii. 1896, p. $685^{2}$, and 1900, fig. 301.

Characodon luitpoldi, Steind. Denkschr. Ak. Wien, lxii. 1895, p. 528, t. 2. fig. $3^{3}$.

Goodea luitpoldi, Meek, Publ. Columbiau Mus., Zool. v. 1904, p. 139, fig. $42^{ \pm}$.

Xenendum xaliscone, Jord. \& Snyd. Bull. U.S. Fish. Comm. xix. 1899, p. 128, fig. 9 (1900) ${ }^{5}$.

Depth of body 3 to $3 \frac{2}{3}$ in the length, length of head 4 to 5 . Snout as long as eye, the diameter of which is $3 \frac{1}{2}$ to 4 in the length of head; interorbital width equal to the distance from middle of eye to free edge of operculum. 39 to 44 scales in a longitudinal series. Dorsal 13-15; origin equidistant from eye and posterior end of caudal fin. Anal 15-16; origin below or a little in advance of that of the dorsal. Pectoral a little shorter than the head. Caudal rounded or subtruncate. Caudal peduncle $1 \frac{1}{3}-1 \frac{2}{3}$ as long as deep. Brownish; rertical fins dusky.

Hab. Mexico, Rio Lerma System :

Leon in Guanajuato $^{1}$; Lake Chapala ${ }^{45}$; Lake Patzcuaro ${ }^{3}$.

Here described from five specimens, measuring up to $180 \mathrm{~mm}$. in total length, from Lakes Chapala (Buller) and Patzcuaro (Meek).

\section{Goodea calientis.}

Nenendum caliente, Jord. \& Snyd. Bull. U.S. Fish. Comm. xix. 1899, p. 127, fig. 8 '.

Goodea atripinnis, Meek, Publ. Columbian Mus., Zool. v. 1904, p. 140, fig. 43".

Depth of body $2 \frac{2}{3}$ to $3 \frac{1}{3}$ in the length, length of head 4 . Snout about as long as eye, the diameter of which is $3 \frac{1}{2}$ to $4 \frac{1}{2}$ in the length of head ; interorbital width equal to the distance from posterior margin of pupil to free edge of operculum. 34 to 38 scales in a longitudinal series. Dorsal 13-15; origin equidistant from operculum and posterior end of caudal fin. Anal 15-16; origin below or a little in advance of that of the dorsal. Pectoral a little shorter than the head. Caudal rounded or subtruncate. Caudal peduncle as long as or a littlo longer than deep. Brownish; young with irregular darker spots ; fins plain.

Hab. Mexico, Rio Lerma and upper tributaries of the Rio Panuco:

Aguas Calientes ${ }^{12}$; Lagos $^{2}$; Celaya ${ }^{2}$; Acambaro ${ }^{2}$; San Juan del Rio²; Huingo $^{2}$; Lake Patzcuaro ${ }^{2}$.

Here described from a number of specimens from Aguas Calientes (Jordan, Meek), San Juan del Rio (Meek), Huingo (Meek), and Patzcuaro (Mexico Mus.). 


\section{Goodea bilineata.}

Characodon bilineatus, Bean, Proc. U.S. Nat. Mns. 1887, p. 371, t. 20. fig. $2^{2}$.

Skiffia bilineatu, Meek, Publ. Columbian Mus., Zool. v. 1904, p. 144, fig. 45 .

Hab. Mexico, Rio Lerma System :

Leon in Guanajuato ${ }^{1}$; Huingo ${ }^{2}$.

This species agrees with G. multipunctata in the number of scales and fin-rays, but has the clorsal fin placed further back, whilst the markings are quite different.

\section{Goodea whitii.}

Goodea whitei, Meek, Publ. Columbian Mus., Zool. v. 1904, p. 137, fig. $40^{3}$.

Depth of body 3 to 4 in the length, length of head 4 . Snout as long as or shorter than eye, the diameter of which is 3 to $3 \frac{1}{2}$ in the length of head; interorbital width equal to the distance from posterior margin of pupil to free edge of operculum. 48 to 55 scales in a longitudinal series. Dorsal 14-17; origin equidistant from tip of snout and posterior end of eaudal fin. Anal 12-14; origin posterior to that of the dorsal. Pectoral about $\frac{3}{4}$ the length of head. Candal truncate, the upper angle sometimes a little produced. Brownish abore, yellowish below ; each scale of the upper part of the body with a dark spot: usnally a blackish lateral stripe; vertical fins dusky, more or less distinctly spotted, sometimes with a pale edge and dark intramarginal stripe.

Hat. Mexico, upper tributaries of the Rio Balsas:

Yantepec ${ }^{1}$; Cuautla ${ }^{1}$.

Here described from several specimens, measuring up to $90 \mathrm{~mm}$. in total length, from Yautepec and Cuautla (Meek).

\section{Goodea lermæ.}

skiffic lerma, Mcek, Publ. Columbian Mus., Zool. v. 1904, p. 14:2, t. 8 '.

skiffu rarieguta, Meek, t. c. p. 143 , fig. $44^{2}$.

Depth of bouly $2 \frac{2}{3}$ to $3 \frac{1}{3}$ in tho length, length of head 4 . Snout shorter than eye, the diameter of which is 3 in the length of head; interorbital width equal to or a little more than the postorbital part of head. 34 to 38 scales in a longitudinal series. Dorsal 12-15; origin eqnidistant from snont and base of caudal (o) or nearer the latter ( $q$ ). Anal 13-15; origin posterior to that of the dorsal. Pectoral $\frac{2}{3}-\frac{1}{3}$ the length of head. Caudal truneate. Males dark brownish; females olivaceous, with irregular darker spots; sometimes an indistinct dark lateral stripo and a spot or bar at the base of caudal; fins plain.

Hab. Mexico, Rio Lerma System and Valley of Mexico:

Celaya $^{1}$; Lake Patzcuaro ${ }^{1}$; Lake Zirahuen ${ }^{2}$; Lake Chalco ${ }^{2}$.

Here described from a number of specimens, measuring up to $65 \mathrm{~mm}$. in total length, from Lakes Patzcuaro and Zirahuen (Meek). I am unable to detect any differences between the examples from these two lakes, sent as $S$. leime and $S$. variegata respectively.

7. Goodea multipunctata. ('Tab. XII. figg. 5, 6.)

Xenendum multipunctutum, Pellegr. Bull. Mus. Paris, 1901, p. $205^{1}$.

Skiffic multipunctata, Meck, Publ. Columbian Mus., Zool. v. 1904, p. 141 2.

Depth of body $2 \frac{2}{3}$ to $2 \frac{4}{5}$ in the length, length of head 4. Snout shorter thau eye, the diameter of which is 3 
in the length of head; interorbital width equal to or a little longer than the postorbital part of head. 32 to 35 scales in a longitudinal series. Dorsal 16-18; origin equidistant from snout and base of caudal $\left(\sigma^{*}\right)$ or ncarer the latter ( 9 ). Anal 14-16; origin posterior to that of the dorsal. Pectoral $\frac{3}{4}-\frac{4}{5}$ the length of head. Caudal truncate or subtruncate. Olivaceous; a dark spot on each scale of the upper and posterior parts of the body; a dark vertical bar at the base of the caudal fin; dorsal and caudal fins with dark spots.

Hab. Mexico, Rio Lerma System :

Jalisco $^{1}$; Lake Chapala ${ }^{2}$.

Here described from four specimens, measuring up to $50 \mathrm{~mm}$. in total length, from Ocotlan (Meek).

\section{BELONESOX, Kner, 1860.}

Belonesox, Günth. Cat. Fish. vi. p. 333 (1866) ; Jord. \& Everm. Bull. U.S. Nat. Mus. xlvii. 1896, p. 684 .

Viviparous. Anal fin, in the male, advanced and modificd into an intromittent organ. Mouth large, with extended lateral cleft; teeth in bands, slender, pointed, depressible.

This genus comprises a single species, quite unlike any other member of the family.

\section{Belonesox belizanus.}

Belonesox belizanus, Kner, Sitzungsb. Ak. Wien, xl. 1860, p. 419, fig. ' ; Günth. Cat. Fish. vi. p. 333

$(1866)^{2}$; Jord. \& Everm. Bull. U.S. Nat. Mus. xlvii. 1896, p. 684 ${ }^{3}$; Meek, Publ. Columbian Mus., Zool. v. 1904, p. $135^{4}$.

Depth of body 4 to 6 in the length, length of head nearly 3 . Snout $2 \frac{1}{2}$ to $3 \frac{1}{4}$ as long as eye, the diameter of which is 5 to 6 in the length of head. Lower jaw more than $\frac{1}{2}$ the length of head. 55 to 65 scales in a longitudinal series. Dorsal 9-10. Anal 10-12, in advance of the dorsal. Candal rounded. A small dark spat on each scale of the upper part of the body; a blackish spot at the base of the caudal.

IIab. Mexico, Boca del Rio ${ }^{4}$, Otopa ${ }^{4}$, El Hule ${ }^{4}$, Obispo ${ }^{4}$, and Perez ${ }^{4}$ in Vera Cruz; British Honduras, Belize ${ }^{1}$; Guatemala, Lake Peten ${ }^{2}$.

Here described from eight specimens, measuring up to $200 \mathrm{~mm}$. in total length, from Perez (Meek), Lake Peten (Salvin), and Belize. 'The largest males measure $90 \mathrm{~mm}$.

\section{GAMBUSIA, Poey, 1855.}

Pseudoxiphophorus and Gambusia, Güntlı. Cat. Fish. vi. pp. 332 aud 333 (1866) ; Jord. \& Everm. Bull. U.S. Nat. Mus. xlvii. 1896, p. 678.

Viviparous. Anal fin, in the male, advanced and modified into an intromittent organ. Mouth small or moderate; rami of lower jaw firmly united; small teeth iu bands, with an outer scries of more or less enlarged, conical, fixed teeth.

This genus comprises ten species from the Southern United States, Mexico, and Central America, and three or four from Cuba and Jamaica. 
Synopsis of the Mexican and Central-Americàn Species.

I. Dorsal fin with 7 to 12 rays, its origin posterior to that of the anal. (Gambusia.)

A. Anal fin similar to the dorsal, rounded or obtuse, the middle rays the longest. (? G. tridentiger.)

1. End of anal below anterior part or middle of dorsal (q); no dark cross-bars on the body.

Diameter of eye 3 to $3 \frac{1}{2}$ in the length of head (in specimcns measuring up to $70 \mathrm{~mm}$.)

Diameter of eye $2 \frac{1}{3}$ to 23 in the length of head (in specimens measuring up to

$50 \mathrm{~mm}$.)

1. gracilis.

2. End of anal nearly below origin of dorsal.

4. or 5 narrow blackish cross-hars on each side . . . . . . . . . . 3. fasciata.

7 or 8 brownish vertical bars on the posterior part of the body . . . . . 4. tridentiger.

B. Anal fin dissimilar to the dorsal, pointed, the anterior rays the longest.

1. Pectoral mearly as long as the head, extending to the origin of anal . 5. nicaraguensis.

2. Pectoral shorter than the head, not rcaching the anal.

a. Dorsal with 8 or 9 rays.

Length of head 4 to $4 \frac{1}{2}$ in the length of the fish (in specimens of 25 to $50 \mathrm{~mm}$.) ;

29 to 31 scales in a longitudinal series . . . . . . . . . 6. infans.

Length of head $3 \frac{1}{2}$ to $3 \frac{3}{4}$ in the length of the fish (in specimens measuring up

to $45 \mathrm{~mm}$.) ; 28 scales in a longitudinal serics . . . . . . . . . 7. episcopi.

b. Dorsal with 10 to 12 rays . . . . . . . . . . . 8. annectens.

II. Dorsal fin with 11 to 17 rays, its origin in advance of that of the anal. (Pseudoxiphophorus.)

A. Origin of anal below or a little in advance of middle of dorsal; no dark spot above the pectoral.

Dorsal with 12 to 14 rays, its origin equidistant from tip of snont and base or anterior part of caudal . . . . . . . . . . . . . . 9. terrabensis.

B. Origin of anal bclow antcrior part of dorsal; a dark spot above the pectoral.

Dorsal with 11 to 13 rays, its origin equidistant from tip of snont and middle

or posterior part of caudal. . . . . . . . . . . . . . . 10. jonesii.

Dorsal with 13 to 17 rays, its origin abont equidistant from tip of snout and

base of candal .. . . . . . . . . . . . . . . . 11. bimaculata.

\section{Gambusia gracilis*.}

Xiphophorus gracilis, Heck. Sitzungsb. Ak. Wicn, i. 1848, p. 300, t. 9. figs. 3-4 ${ }^{\text {}}$.

Gambusia affinis, Jord. \& Evern. Bull. U.S. Nat. Mns. xlvii. 1896, p. $680^{2}$; Mcck, Pnbl. Columbiaı

Mins., Zool. v. 1904, p. $130^{3}$.

Gambusia nobilis, Jord. \& Everm. t. c. p. $682^{1}$.

Gambusia gracilis, Jord. \& Everm. t. c. p. $683^{5}$.

Depth of body 3 to 4 in the length, length of head $3 \frac{1}{2}$ to 4 . Snout as long or nearly as long as ese, the diameter of which is $: 3-3 \frac{1}{2}$ in the length of head. Intcrorbital width about equal to the distance from

* For the extensive synonymy of this speeies, see Jord. \& Everm. p1. 681-683, and Garm. Mem. Mus. Comp. Zool. xix. 1895, ip. 82-85 (G. hollroolii, patruelis, and gracilis). 
middle of eye to free edge of operculum. 29 to 31 scales in a longitudinal series. Dorsal 8-9 ; origin usually nearer to posterior end of caudal fin than to tip of snout; free edge of the fin convex. Anal 9-10, similar to the dorsal, ending below or a little in advance of the middle of the dorsal. Pectoral $\frac{3-5}{4}-\frac{5}{6}$ the length of bead. Caudal rounded or subtruncate. Least depth of caudal peduncle about $\frac{2}{3}$ the length of head. Olivaceous; edges of scales darker; often a dark longitudinal band from upper part of eye to base of caudal.

Hab. Streams of the Atlantic Slope from Illinois to Vera Cruz:

In Mexico recorded from Rio Chihuahua and Rio Conchos in Chihuahua ${ }^{3}$; Monclova in Coahuila ${ }^{3}$; Monterey and Rio San Diego in Nuevo Leon ${ }^{3}$; Matamoros, Rio Soto la Marina, and Rio Panuco in Tamaulipas ${ }^{3}$; Orizaba ${ }^{1}$ and Vera Cruz.

Here described from specimens measuring up to $70 \mathrm{~mm}$. in total length.

\section{Gambusia bonita.}

Gambusia bonita, Meek, Publ. Columbian Mus., Zool. v. 1904, p. 132, fig. $39^{2}$.

Depth of body $3 \frac{1}{3}$ to $3 \frac{2}{3}$ in the length, length of head $3 \frac{1}{2}$ to $3 \frac{3}{4}$. Snout shorter than eye, the diameter of which is $2 \frac{1}{3}$ to $2 \frac{3}{4}$ in the length of head. Interorbital width equal to the distance from posterior margin of pupil to free edge of operculum. 29 to 31 scales in a longitudinal series. Dorsal $8-10$; origin a little nearer to posterior end of caudal fin than to tip of snout; middle rays longest. Anal 10-11, similar to the dorsal, ending below the anterior rays of dorsal. Pectoral $\frac{4}{5}$ the length of head. Caudal rounded or subtruncate. Least depth of caudal peduncle $\frac{2}{3}$ the length of head. Olivaccous; scales of upper part of body with dark edges.

Hal. Mexico, Rio Papaloapam :

$$
\text { Refugio }{ }^{1} \text {, Motzorongo }{ }^{1 .}
$$

Here described from five specimens, measuring up to $50 \mathrm{~mm}$. in total length, from Refugio, received from Dr. Meek.

\section{Gambusia fasciata.}

Gambusia fasciata, Meek, Publ. Columbian Mus., Zool. v. 1904, p. 129, fig. $37^{1}$.

Depth of body $3 \frac{1}{2}$ to $3 \frac{3}{4}$ in the length, length of head + to $+\frac{1}{3}$. Snout a little shorter than eye, the diameter of which is 3 to $3 \frac{1}{3}$ in the length of head. Interorbital width equal to the distance from middle of eye to free edge of operculum. 32 scales in a longitudinal series. Dorsal 8 ; origin considerably nearer to end of caudal than to tip of snout; middle rays longest. Anal 9-10, similar to the dorsal, ending below the origin of dorsal. Pectoral $\frac{1}{5}$ the length of head. Caudal subtruncate. Least depth of caudal peduncle $\frac{2}{3}$ the length of head. 4 or 5 narrow rertical or slightly oblique blackish hars on each side; a small blackish spot on the anterior dorsal rays, another on the anal.

Hab. Mexico, Oaxaca, Tequesixtlan (Gadow), San Gerónimo 1, Tehuantepec ${ }^{1}$.

Here described from six specimens, measuring up to $55 \mathrm{~mm}$. in total length.

\section{Gambusia tridentiger.}

Gambusia tridentiger, Garm. Mem. Mus. Comp. Zool. xix. 1895, p. $89^{2}$.

Inner teeth tricuspid. 28 to 30 scales in a longitudinal series. Dorsal 7-8; origin abont equidistant from occiput and end of candal, nearly ahove the last ray of anal. Anal 10. 7 or 8 brownish rertical bars, separated by pale interspaces of equal width, on the posterior part of the body.

Hat. Isthmus of Panama ${ }^{1}$. 


\section{Gambusia nicaraguensis.}

Gambusia nicaraguensis, Günth. Cat. Fish. vi. p. 336 (1866) ${ }^{2}$, and Traus. Zool. Soe. vi. 1868, p. 483, t. 82. fig. $3^{2}$; Jord. \& Everm. Bull. U.S. Nat. Mus. xlvii. 1896, p. $682^{3}$.

Paragambusia nicaraguensis, Meek, Publ. Columbian Mus., Zool. v. 1904, p. $133^{4}$.

Depth of body $2 \frac{2}{3}$ to $3 \frac{1}{2}$ in the length, length of head $3 \frac{1}{2}$ to $3 \frac{3}{4}$. Snout shorter than eyc, the diameter of which

is $2 \frac{1}{2}$ to 3 in the length of head. Intcrorbital width abont equal to the distance from middle of eye to free edge of operculum. 28 to 30 scules in a longitudinal series. Dorsal 7-8; origin nearer to posterior end of eauclal fin than to tip of snout; free edge of the fin straight. Anal 10-11, pointed, with concare free edge, ending below the origin of dorsal. Pectoral noarly as long as the head. Caudal rounded. Least deptl of caudal peduncle $\frac{2}{3}$ to $\frac{3}{4}$ the length of head. Olivaceous: a small dark spot at the base of each scale on the upper part of the body; dorsal and eandal with scries of small dark spots.

Hab. Southern Mexico and Central America:

Mexico, Boca del Rio ${ }^{4}$, Otopa ${ }^{4}$, El Hule ${ }^{4}$, Obispo ${ }^{4}$, and Perez ${ }^{4}$ in Vera Cruz; Nicaragua, Lake Nicaragua ${ }^{2}$ (Dow).

Here described from several specimens measuring up to $55 \mathrm{~mm}$. in total length, the types of the species from Lake Nicaragua and examples from El Hule, received from Dr. Meek.

\section{Gambusia infans.}

Gambusia infans, Woolman, Bull. U.S. Fish. Comm. 1894, p. 62, t. 2. fig. $3^{1}$; Jord. \& Everm. Bull. U.S. Nat. Mus. xlvii. 1896, p. $680^{2}$; Meek, Publ. Columbian Mus., Zool. v. 1904, p. 131, fig. $38^{3}$.

Gambusia gracilis, Meek, t. c. p. $130^{4}$.

Depth of body $3 \frac{1}{4}$ to $3: \frac{1}{4}$ in the length, length of head 4 to $4 \frac{1}{2}$. Snout nearly as long as or shorter than eje, the diameter of which is 3 to $3 \frac{1}{2}$ in the length of head. Interorbital width about equal to the distance from middle of eye to free edgo of operculum. 29 to 31 seales in a longitudinal series. Dorsal 8-9; origin usually nearer to posterior ond of caudal than to tip of snout; free edge of fin slightly conrex. Anal 9-10, pointed, ending below anterior rays of dorsal. Pectoral $\frac{4}{5}$ the length of head. Caudal rounded or subtruncate. Least depth of caudal peduncle $\frac{2}{3}$ to $\frac{3}{4}$ the length of head. Oliraceous; scales with narrow dark edges; often a durk stripe from operculum to caudal.

Hab. Mexico, Rio Lerma and Rio Balsas:

Salamanca ${ }^{1}$; Celaya ${ }^{3}$; Ocotlan ${ }^{3}$; La Barca ${ }^{3}$; Huingo ${ }^{3}$; Yautepec ${ }^{4}$; Cuautla ${ }^{4}$; Puente de Ixtla ${ }^{4}$; Jojutla ${ }^{4}$; Chietla ${ }^{4}$; Balsas ${ }^{4}$.

Here described from several specimens, measuring up to $50 \mathrm{~mm}$. in total length, from Salamanca (Woolman), Celaya and Puente de Ixtla (Meek). A male of $25 \mathrm{~mm}$. is marked with dark vertical bars.

\section{Gambusia episcopi.}

Ganbusia episcopi, Steind. Sitzungsb. Ak. Wien, lxxvii. 1878, p. 387, t. 2. figs. 3 \& 4².

Hab. Panama ${ }^{1}$. 
8. Gambusia annectens. (Tab. XIV. figg. 5, 6.)

Gambusia annectens, Regan, Ann. Mag. N. H. (7) xix. 1907, p. 259.

Depth of body 3 to $3 \frac{1}{2}$ in tho length, length of head $3 \frac{1}{2}$ to $3 \frac{3}{4}$. Snout as long as or shorter than eye, the diameter of which is 3 to $3 \frac{3}{3}$ in the length of head; interorbital width equal to the distance from middle or posterior part of eye to free edge of operculum. 28 to 31 scales in a longitudinal series. Dorsal 10-12; origin equidistant from tip of snout and middle or posterior part of caudal; free edge of the fin convex. Anal 9-10, peinted, originating a little in advance of the dorsal. Pectoral about $\frac{3}{4}$ the length of head. Caudal rounded or subtruncate. Least depth of caudal peduncle about $\frac{2}{3}$ the length of head. Scales with dark edges, forming series of spots on the lower part of the side: often a series of short dark vertical bars along the middle of the side; a series of dalk spots on the lower part of the dorsal fin.

IIal. Costa Rica, Carrillo and Juan Viñas (Underwood), Irazu (Rogers).

Numerous specimens, measuring up to $70 \mathrm{~mm}$. in total length.

This species is very close to G. episcopi, Steind., from Panama, which has only $S$ or 9 dorsal rays and also differs in having a blackish spot on the anal fin. It is also close to G. terrabensis, Regan, and $G$. jonesii, Günther, and with them forms a series from G. episcopi to G. (Pseudoriphophoms) bimaculata, Heck., so that the genus Psendoaiphophorus can no longer be maintained.

9. Gambusia terrabensis. (Tab. XII. fig. 7.)

Gambusia terrabensis, Regan, Ann. Mag. N. H. (7) xix. 1907, p. 260.

Depth of body $3 \frac{1}{4}$ to $3 \frac{1}{2}$ in the length, length of head $3 \frac{1}{2}$ to $3 \frac{1}{3}$. Snout shorter than eye, the diameter of which is 3 to $3 \frac{1}{3}$ in the longth of head; interorbital width equal to the distance from posterior margin of pupil to free edge of olerculum. 29 to 31 scales in a longitudinal series. Dorsal 12-14; origin equidistant from tip of snout and base of caudal or a little nearer the latter. Anal y-10; origin belaw or a little in adrance of the middle of dorsal. Pectoral nearly $\frac{3}{4}$ the length of head. Caudal subtruncate. Least depth of caudal pednncle nearly $\frac{2}{3}$ the length of head. Scales of the upper part of the body with dark edges; an interrupted dark lateral stripe; dorsal tin with a basul series of vertically expanded blackish spots and with a second series of smaller spots; anal dark at the base and also distally; josterior part of caudal dusky.

Hab. Costa Rica, Rio Graude de Terraba, Pacific Slope (Pittier).

Six specimens, mensuring up to $48 \mathrm{~mm}$. in total length.

\section{Gambusia jonesii. (Tab. XII. fig. 8.)}

Mollienisia jonesii, Gïnth. Amn. Mag. N. H. (4) xiv. 1874, p. 371 '; Garm. Mem. Mus. Comp. Zool. xix. 1895, p. $52^{2}$; Jurd. \& Everm. Bull. U.S. Nat. MIus. xlvii. 1896, p. $698^{3}$.

Pseuloxiphophorus binaculates (non Heck.), Jord. \& Everm. t. c. p. 678*.

Pseudoxiphophorus pauciradiatus, Regan, Ann. Mag. N. H. (7) xiii. 1904, p. 256 ${ }^{5}$, and (T) xri. 1905, p. $362^{5}$.

Tery closely allied to $G$. limaculula. Dorsal 11-13; origin of dorsal equidistant from tip of snout and middle or posterior part of caudal. Longest anal ray $\frac{3}{3}$ to $\frac{2}{3}$ the length of head. Seales witl durk edges, especially superiorly; a dark spot on the operculum, another above the root of the pectoral, and a third on the upper part of the basc of the caulal; dorsal with about 3 series of small dark spots : anal and caudal with an oblong dark siot on each interradial meml rane.

hiol. Centr.-AMER., Pisces, July 1007. 
Ilab. Mexico, Mountain Lakes and Streams of Central Tera Cruz:

Like Alcohuaca, near Huamantla, 8000 feet $^{1}$ (Joncs); Orizaba ${ }^{4}{ }^{6}$ (Troolman, Garlow).

Of the numerous examples, measuring up to $85 \mathrm{~mm}$. in total length, which I have examined, the majority liave 12 dorsal rays, in striking contrast to G. bimaculata, in which the usual number is 14 or 15.

\section{Gambusia bimaculata. (Tab XIV. fig. 4.)}

Tiphophorws bimuculatus, Ileek. Sitzungsb. Ak. Wien, i. 1818, p. 296, t. 9. figs. I-2 '. Pecilioides bimaculatus, Steind. Sitzungsh. Ak. Wieı, xlviii. 1863, p. 176, t. 4. fig. $2^{2}$.

Pseudoxiphophorus reticulatus, Trosch. in Müller's Reise Mexieo, iii. Append. p. 104 (1865) ${ }^{3}$; Günth. Cat. Fish. vi. p. 333 (1866) ${ }^{4}$; Jord. \& Everm. Bull. U.S. Nat. Mus. xlvii. 1896, p. 678 ${ }^{\overline{5}}$.

Pseudoxipleppliorus bimaculatus, Troseh. I. e." ; Günth. t. e. p. 332 ${ }^{7}$; Garm. Mem. Mus. Comp.

Zool. xix. 1895, p. 81 " Meek, 1’ubl. Columbian Mus., Zool. v. 1904, p. 127".

Pseudoxiphophorus bimaculatus, var. t.eniatus, Regan, Ann. Mag. N. H. (7) xvi. 1905, p. 362 ${ }^{10}$.

Depth of body 3 to 4 in the length, length of head $3 \frac{1}{3}$ to 4 . Suout as long as or a little slorter than eye, the diameter of which is 3 to $: 3$ in the length of head. Interorbital width equal to the distance from middle or posterior part of ore to free edge of operculum. 28-331 scales in a longitudinal series. Dorsal 13-17; origin about equidistant from tip of snout and base of caudal. Anal 9-11, below the anterior dorsal rays, poiuted, the longest ray from $\frac{2}{3}$ to as loug as the head. Pectoral $\frac{2}{3}$ to $\frac{4}{5}$ the length of head. Caudial rounded. Least depth of caudal peduncle $\frac{8}{3}$ to $\frac{3}{4}$ the leugth of head. Olivaceous or brownish; some or all of tho scales with dark outlines; a dark spot abovo the pectoral, another on the upper part of the base of caudal; dorsal with series of small dark spots; anal and caudal dusky.

Ilal. Soutriens Mexico, Tepeaca, San Domingo de Guzman ${ }^{10}$ (Buller), Jalapa 9 , Xico", Orizaba ${ }^{15}$, Cordova (Boucurd), Motzorongo", El Hule?, Obispo ?, Perez ${ }^{9}$, Sanborn 9, Rio 'lonto (Gadow); Britisil Honduras, Stann Creek (Robertson); Guarimala (Godman).

A very variable species in form, coloration, and number of fin-rays. Specimens from San Domingo de Guzman (var. temiatus) have 16 or 17 dorsal rays and the dark edges of the mid-lateral series of scales so broad as to form a dark longitudinal band; one of these is figured (Tab. XIV. fig. 4). Examples from other localities appear "also to have peculiarities which may prove to be distinctive. The numerous specimens examined measure up to $90 \mathrm{~mm}$. in total length.

\section{GLARIDICITHYS, Garman, 1896.}

Glaridichtlugs, Garman, Am. Nat. xxx. 1896, p. 232.

Vinimarous. Anal fin, in the male, adranced and modified into a long intromittent organ. Month small or monerate; rami of lower jaw firmly united; small teeth in bands, with an outer series of cnlarged, chisel-shaped, fixed teeth. Dorsal fin short, with 8 to 11 rajs.

'This genus comprises three species, respectively from Northern Mexico, Cuba, and Brazil. 


\section{Glaridichthys latidens.}

Glaridodon latidens, Garm. Mem. Mus. Comp. Zool. xix. 1895, p. $42^{\perp}$.

Glaridichthys latidens, Meek, Publ. Columbian Mirs., Zool. v. 1904, p. 134².

Depth of body nearly equal to length of head, which is more than $\frac{1}{4}$ of the length of the fish. Snout shorter than eye, the diamcter of which is 3 in the length of head. 28 to 30 scales in a longitudinal series. Dorsal 8; origin a little nearer to posterior end of caudal than to tip of snout and abore the middle of the anal. Anal 10. Caudal rounded or subtruncate. Olivaceous ; sides with narrow brownish rertical bars, which are more distinct posteriorly.

Hal. Mexico, Chihuahua 1.

\section{GIRARDINUS, Poey, 1855.}

Girardinus, Garman, Mem. Mus. Comp. Zool. xix. 1895, p. 45.

Viviparous. Anal fin, in the male, advanced and modified into a long intromittent organ. Mouth small, transverse ; rami of lower jaw weakly connected; teeth unicuspid, morable, in a siugle series.

Mal. Carolina to Guatemala; West Indies.

'The three Mexican and Central-American forms are very closely allied and should perhaps be regarded as races or subspecies of Girardinus pleurospilus. The following description applies to all :-

Depth of body $3 \frac{1}{4}$ to $3 \frac{3}{4}$ in the length, length of head $3 \frac{3}{4}$ to $4 \frac{1}{2}$. Snout nearly as long as or shorter than ere, the diameter of which is 3 to $3 \frac{1}{3}$ in the length of head. Interorbital width equal to the distance frum middle or posterior part of eyo to free edge of opereulum. 27 to 30 scales in a longitudiual series. Dorsal 7-9; origin equidistant from tip of snout and end of caudal or a little nearer the latter $(q)$. Anal 8-10; origin in advance of that of the dorsal. Dorsal and anal fins eaeh with an acute anterior angle and nearly straight free edge. Pectoral as long as or a little shorter than the head. Caudal rounded or subtruncate. Least depth of caudal peduncle $\frac{3}{\overline{3}}$ to $\frac{3}{4}$ the length of head.

\section{Girardinus presidionis.}

Pacilia presidionis, Jord. \& Culver, Prof. Calif. Ac. Sci. (2) v. 1895, p. 413, t. $29^{2}$; Jord. \& Everm. Bull. U.S. Nat. Mus. xlvii. 1896, p. $697^{2}$; Meek, Publ. Columbian Mus., Zool. v. 1904, p. $152^{3}$.

A series of narrow dark vertical bars, variable in number, along the side of the body; one or two of the bars sometimes represented by oval spots.

Hal. Mexico, Rio Presidio in Sinaloa 123.

Ten examples, measuring up to $70 \mathrm{~mm}$. in total length. In these I am unable to detect any trace of an inner series of teeth, even with the aid of a binocular microscope.

\section{Girardinus lutzi.}

Heterandria lutzi, Meek, Publ. Columbian MLs., Zool. v. 1904, p. 148, fig. $4 \tau^{2}$. Heterandria pleurospilus, Meek, l. c. .

A series of dark spots along the middle of the side, usually more than eight in number, and esch usually smaller than the eye. A few spots sometimes expanded rertically; posterior spots sometimes broken up, forming two or eren three irregular series. 
Hab. Southerx Mexico, Otopa ${ }^{1}$, Motzorongo ${ }^{1}$, Venta Salada ${ }^{1}$, El Hule ${ }^{1}$, Perez ${ }^{1}$, and Cuicatlan ${ }^{1}$ in Vera Cruz, Oaxaca ${ }^{1}$, Tequesixtlan (Gadow), San Gerónimo ${ }^{2}$ and Tehuantepec in Oaxaca.

Numerous examples, measuring up to $80 \mathrm{~mm}$. in total length.

\section{Girardinus pleurospilus.}

Girardinus pleurospilus, Günth. Cat. Fish. vi. p. $355(1866)^{1}$, and Trans. Zool. Soc. vi. 1868, p. 486 , t. 87 . fig. $1^{2}$.

Heterandria pleurospilus, Jord. \& Everm. Bull. U.S. Nat. MTus. xlvii. 1896, p. $688^{3}$.

A series of from four to eight rounded dark spots, each about as large as the eye, along the middle of the side.

Hab. Guatemala, Lake of Dueñas ${ }^{12}$, Lake Nacasil (Salvin).

Numerous examples, measuring up to $60 \mathrm{~mm}$. in total length.

\section{PGECILIA, Schneider, 1801.}

Pecilia, Günth. Cat. Fish. vi. p. 339 (1866) ; Jord. \& Everm. Bull. U.S. Nat. Mus. xlvii. 1896, p. 690 .

Viriparous. Anal fin, in the male, adraneed and modified into an intromittent organ of moderate length. Mouth small, transserse; rami of lower jaw weakly connected; minute teeth in bands, with an outer series of nore or less enlarged, enrved, unicuspid, movable tceth. Dorsal fin with 8 to 11 rays, higher but not much longer in the males than in the females. Caudal rounded or subtruncate in both sexes.

Mab. Mexico and Central America to Brazil; West Indies.

$P$. elongat a is known to enter the sea, and probably $P$. sphenops, which is abundant in brackish water, does so also.

Dr. Garman, in his monograph of the Cyprinodonts (Mem. Mus. Comp. Zool. xix. 1895), proposed a considerable reduction in the number of Mexican and CentralAmerican species of this genus. He placed $P$. couchiana, Girard, $P$. mexicana, Steind., P. thermalis, Steind., P. petenensis, Günth., P. dovii, Günth., P. spilurus, Günth., and $P$. butleri, Jord., in the synonymy of $P$. sphenops, Cuv. \& Val., and $P$. elongata, Günth., P. boncardi, Steind., and P. chisoyensis, Günth., in the synonymy of $P$. gillii, Kner \& Steind.

After examination of a large number of specimens I have reached the conclusion that $P$. couchiana, $P$. petenensis, $P$. spilurus, and $P$. elongate are very distinct and easily definable species. The others enumerated appear to be merely forms of one widely distributed and variable form, $P$. sphenops. 


\section{Synopsis of the species*.}

I. Origin of anal in advance of that of the dorsal.

Dorsal 8. Anal 7. 26 scales in a longitndinal scries . . . . . . . . . 1. spilurus.

Uorsal 7-9. Anal 9-11. 27 to 30 scales in a longitudinal serics . . . . . 2. occidentulis.

Dorsal 9-10. Anal 8-9. 30 to 33 scales in a longitudinal series . . . . . 3. elongata.

II. Origin of anal below or behind that of the dorsal.

A. Origin of anal below or a little behind that of the dorsal; origin of dorsal equidistant from tip of snout and middle or posterior part of caudal; 26 to 30 scales in a longitudinal series.

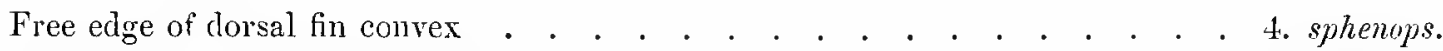

Free edge of dorsal fin straight . . . . . . . . . . . . . . . . . . 5. salvatoris.

B. Origin of anal below fourth or fifth dorsal ray; origin of dorsal equidistant from tip of snout and base of caudal; 28 to 30 scales in a longitudinal series . . . . . . . . . . . . . 6. petenensis.

C. Origin of anal bclow the middle of dorsal; origin of dorsal equidistant from tip of snout and anterior part of caudal ; 23 to 27 scales in a longitudinal series.

Depth of body about $2 \frac{3}{4}$ in the length, length of head about 4 (in speeimens of

$50 \mathrm{~mm}$.) . . . . . . . . . . . . . . . . . . . . 7. conchiana.

Depth of body 2 to $2 \frac{2}{3}$ in the length, length of head $3 \frac{1}{3}$ to $3 \frac{2}{3}$ (in specimens of

$60 \mathrm{~mm}$.) . . . . . . . . . . . . . . . . . . 8. maculata.

\section{Pœcilia spilurus.}

Precilia spilurus, Gunth. Cat. Fish. vi. p. 345 (1866) ${ }^{2}$; Jord. \& Evern. Bull. U.S. Nat. Mrrs. slvii. 1896 , p. $69 \pi^{2}$.

Depth of body $3 \frac{1}{4}$ in the length, length of head 4 . Snout a little shorter than eye, the diameter of which is $3 \frac{1}{3}$ in the length of head. Interorbital width equal to the distance from posterior margin of pupil to free edge of operculnm. 26 scales in a longitudinal series. Dorsal s; origin about equidistant from tip of snout and posterior end of caudal. Anal 7 ; origin iu advance of that of the dorsal ( ( ). Least depth of eaudal peduncle the length of head. A blackish spot on each side of the upper part of the tail, at the base of the caudal fin.

\section{Hab. Central America (Sallé ${ }^{1}$ ).}

Here described from the type, the only specimen known, $60 \mathrm{~mm}$. in total length.

\section{Pœcilia occidentalis.}

Heterandria occidentalis, Baird \& Girard, Proc. Ac. Philad. 1853, p. $390^{1}$; Jord. \& Everm. Bull.

U.S. Nat. Mus. xlvii. 1896, p. $689^{2}$.

Girardinus occidentalis, Girard, U.S. Mcx. Bound. Surv., Fishes, p. 73, t. 39. figg. 16-19 ${ }^{3}$ and Proe. Ac. Philad. 1859, p. 119 ".

Girardinus sonorensis, Girard, Proc. Ac. Philad. 3858, p. $120^{5}$.

* This synopsis is based on female specimens only. The males of some of the species have not jet been described. 
Pecilza occidentalis, Garm. Mem. Mus. Comp. Zool. xix. 1895, p. $71^{6}$; Rutter, Proc. Calif. Ac. Sci. (2) vi. 1896, pp. $261^{7}$ and $267^{8}$; Meek, Pulsl. Columbian Mus., Zool. v. 1904, p. $150^{\circ}$.

IIab. Pacific Coast Rivers from Arizona to Jalisco:

Rio Santa Cruz in Arizona ${ }^{134}$; Rio Sonora $^{7}$ and Rio Yaqui ${ }^{4}$ in Sonora; Tepic in Jaliscos.

\section{Pœcilia elongata.}

Pacilia elongata, Günth. Cat. Fislı. vi. p. $34: 2^{3}$ (1860), and Trans. Zool. Soc. vi. 1869, p. 484, t. 85. fig. $2^{2}$; Jord. \& Ererm. Bull. U.S. Nat. Mus. xlvii. 1896, p. $60 \sigma^{3}$; Gilb. \& Starlss, Mem. Calif. Ac. Sci. iv. 1904, p. 54t.

Depth of body $3 \frac{1}{2}$ to 4 in the length, leugth of head about 4 . Snout as long as or a little shorter than eye, the diameter of whieh is $3 \frac{1}{2}$ to $3 \frac{3}{4}$ in the leugth of head. Interorbital width nearly equal to the distance from the posterior edge of pupil to the free edge of operenlum. 30 to 33 seales in a longitudinal series. Dorsal 9-10; anterior angle acute, free edge straight, oblique; origin nearly equidistant from tip of snout and posterior edge of eaudal (․). Anal 8-9; origin a little in adrance of that of the dorsal. lectoral as lovg as the head. Caudal ronded. Least depth of eaudal peduncle $\frac{2}{3}$ to $\frac{3}{4}$ tho length of head $(q)$. Olivaceous, with indistiuct narrow cross-bars.

IIab. PaNaina 124.

Here described from several specimens, including the types, all females, measuring up to $1 \fallingdotseq 0 \mathrm{~mm}$. in total length.

Pecilia cuneata, Garman (Mem. Mus. Comp. Zool. xix. 1895, p. 62), from 'Turbo, is described as baving 28 to 29 scales in a longitudinal series, but is otherwise very similar to $P$. elongata, with which it may prove to be identical.

\section{Pœcilia sphenops. (Tab. XIII. figg. 1-7.)}

Pacilia sphenops, Cuv. \& Val. Hist. Nat. Poiss. xriii. p. 130, t. 526 (1816) '; Gïnth. Cat. Fislı. vi. p. 643 (1866) "; Garman, Mem. Mus. Comp. Zool. 1895, p. 59 ; Jord. \& Evcrm. Bull. U.S. Nat. Mus. xlvii. 1896, p. $694^{4}$; Meek, Publ. Cohmmbian Mus., Zool. v. 1904, p. 153, fig. $49^{5}$.

Pucilia mexicana, Steind. Sitzungsb. Ak. Wien, xlviii. 1863, p. I78, t. 4. fig. $1^{6}$; Günth. t. c. p. $340^{7}$; Jord. \& Everm. t. c. p. $692^{*}$.

Precilia thermalis, Steind. t. c. p. 181, t. 4. fig. $3^{9}$.

Xiphophorus gillii, Kner \& Steind. Abhandl. Bayer. Ak. x. 1864, p. 28, t. 4. fig. $1^{10}$.

"Gombusia modesta, Trosch. in Müller's Reise Mexico, iii. Appent. p. 105 (1865)".

?Gambusia plumbea, Trosch. t. c. p. $106^{12}$.

Procilia chisoyensis, Günth. t. c. p. $342^{13}$; Jord. \& Everm. t. c. p. $693^{11}$.

Parcilia dorii, Giünth. t. c. p. $314^{15}$; Jord. \& Everm. t. c. p. $695^{15}$.

P'recilia gillii, Gü̈nth. Trans. Zool. Soc. vi. 1869, p. $485^{17}$.

Platypocilus mentalis, Gill, Proc. Ac. Philad. 1876, p. $335^{14}$.

P'xecilia vandepalli, Van Lidth de Jeude, Notes Leyden Mus. ix. 1887, 1). $438{ }^{19}$; Jord. \& Everm. t. c. p. $696^{20}$.

Procilia vandepolli arubensis, Van Lidth de Jende, 1. c. ${ }^{21}$; Jord. \& Everm. 1. c. ${ }^{22}$.

Precilia boucardii, Steind. Sitzungsb. Ak. Wien, lxxvii. 1878, p. 386, t. 3. figs. $2 \& 3{ }^{23}$; Jord. \& Everm. t. c. p. $695^{*}$; Gilb. \& Starks, Mem. Calif. Ac. Sci. (2) iv. 1901, p. $51:$ 
Precilia butleri, Jord. Proc. U.S. Nat. Mus. 1888, p. $330^{26}$; Jord. \& Evcrm. t. c. p. $691^{27}$; Meek, t. c. p. $151^{24}$.

Precilia limantouri, Jord. \& Snyd. Bull. U.S. Fish. Comm. 1900, p. 129, fig. $10^{29}$; Jord. \& Everm. t. c. p. $3153(1900)^{30}$.

Platypocilus nelsoni, Meek, t. c. p. 147, fig. $46^{31}$.

Precilia latipunctata, Mcek, t. c. p. 151, fig. $48^{32}$.

Depth of body $2 \frac{2}{3}$ to $3 \frac{1}{2}$ in the length, length of head $3 \frac{1}{2}$ (young) to $4 \frac{1}{2}$. Snout as long as or shorter than eye, the diameter of which is 3 (young) to $3 \frac{3}{5}$ in the length of head. Interorbital width equal to the distance from middle or posterior part of eye to free edge of operculum. 26 to 29 scales in a longitudinal serics. Dorsal 8-11; origin equidistant from tip of snout and middle or posterior part of caudal (q); free edge of the fin more or less conrex, the rajs usually increasing in length to the middle ones and rajidly decreasing posteriorly. Anal 8-10, acutely pointed; origin below or a little behind that of the dorsal (우). Pectoral as long as or a little shorter than head. Caudal rounded or subtruncate. Least depth of caudal pedunele from $\frac{2}{3}(q)$ to as long as the head $\left(\delta^{*}\right)$. Olivaceous, edges of scales sometimes darker; sides often with narrow dark vertical bars, especially in males; series of dark spots, one on eaeh scale of the side of the body, often present, espocially in females; dorsal and eaudal sometimes blackish, with or without pale margins, sometimes pale, usually with several series of small dark spots, which may be absent in females.

II $九$. Mexico and Central America, extending to Colombia and the Leeward Islands:

Mexico, Rio San Juan in Nuevo Lenn ${ }^{5}$, Rio Conchos ${ }^{5}$, Rio Soto Marina ${ }^{5}$ and Rio Forlon 52032 in Tamanlipas, Rio Presidio 2030 in Sinaloa (Forrer), Los Menores in Jalisco (Buller), Rio Verde ${ }^{5}$ in San Luis Potosi, Vera Cruz ${ }^{25}$, Boca del Rio $^{5}$ and Rio Papaloapam ${ }^{5}$ in Vera Cruz, Orizaba ${ }^{6}$, Puebla (Boucard), Rio Balsas in Guerrero ${ }^{51}$, Tehnantepec ${ }^{5}$, Tequesixtian (Garlow), and San Gerónimo ${ }^{5}$ in Oaxaca, La Esperanza in Chiapas ${ }^{9}$; Guatemals, Rio Chisoy ${ }^{13}$, Chiapam, Huamuchal, and Lakes Dueñas, Nacasil, and Amatitlan (Salvin); Nicaragua, Lake Nicaragua ${ }^{15}$ (Dow) ; Cos'ra Rica, San José (Biolley); Parama ${ }^{18}$, Panama ${ }^{25}$, Colon ${ }^{23}$, and Rio Chagres ${ }^{10}$.-Colombia ; Curaçoa ${ }^{10}$; Aruba ${ }^{21}$.

I have examined a large series of specimens, representing the whole range of the species, measuring up to $100 \mathrm{~mm}$. in total length, including the types of $P$. chisoyensis and $P$. dovii and examples of $P$. butleri, $P$. limantouri, and $P$. latipunctata received from their describers. Of the last-named I have compared one specimen, from Forlon, received from Dr. Meek, with several from the same locality determined by him as Precilia sphienops. The lateral series of spots supposed to be characteristic of $P$. latipunctata is merely a phase of the peculiar and usually irregular blackish markings which are found on individual specimens of so many Cyprinodont species.

The specimens figured on Tab. XIII. are:-

1. One of the types of P. latipunctata, from Forlon.

2. A female from San José, Costa Rica.

3. A spotted variety from Tequesixtlan.

4. A female from Puente de Ixtla.

5. A male from Vera Cruz (typical P. sphenops).

6. A male from Puebla.

7. A female from Lake Amatitlan (typical P. mexicana). 


\section{Pœcilia salvatoris. (Tab. XIV. figg. 2, 3.)}

Pecilia thermalis (non Steind.), Giinth. Cat. Fish. vi. p. 341 (1866) ${ }^{1}$; Jord. \& Everm. Bull. U.S.

Nat. Mus. xlvii. 1896, p. $693^{2}$.

Parcilia salvatoris, Regan, Ann. Mag. Nat. Hist. (7) xix. 1907, p. $65^{3}$.

Depth of body $3 \frac{1}{7}$ to $3 \frac{3}{7}$ in the length, length of bead about $3 \frac{3}{4}$. Snout shorter than eye, the diameter of which is $3 \frac{1}{4}$ in the length of head. Interorbital width equal to the distance from anterior part or middle of ese to free edge of operculum. 27 to 30 scales in a longitudinal series. Dorsal 10-11; origin equidistant from tip of snout and middle or posterior part of caudal ( $(9)$; anterior angle rectangular, free edge of the fin straight, the rays gradually decreasing in length from the first branched ray backwards ( 9 ). Anal S-9; origin below or a little behind that of the dorsal. Pectoral a little shorter than the head. Caudal subtruncate. Lcast depth of caudal peduncle from $\frac{3}{5}(q)$ to $\frac{4}{5}$ ( $\delta$ ) the length of head. Olivaceous; males with more or less distinct cross-bars; dorsal fin, in the males, with 2 series of rertically expanded blackish spots, which may or may not be present in the females; caudal, in the males, with oblong spots.

Hab. Saltador $\left(\right.$ Dow $\left.^{1}{ }^{3}\right)$.

Here described from several specimens, measuring up to $55 \mathrm{~mm}$. in total length.

\section{Pœcilia petenensis.}

Pecilia petenensis, Giinth. Cat, Fish. vi. p. 342 (1866) ', and Trans. Zool. Soc. vi. 1868, p. 484, t. 85. figs. $3 \& t^{2}$; Jord, \& Everm. Bull. U.S. Nat. Mus. xlvii. 1896, p. $694^{3}$.

Depth of body $3 \frac{1}{3}(\delta)$ to $f \frac{1}{2}(f)$ in the length, length of head $4 \frac{2}{5}$ to $4 \frac{4}{5}$. Snout as long as eye, the diameter of which is $: 3 \frac{1}{3}$ to $3 \frac{1}{2}$ in the length of head. Interorbital width equal to the distance from the middle or posterior part of oye to the free edge of operculum. 28 to 30 scales in a longitudiual series. Dorsal 10-11; anterior angle rectangular, free edge straight ( $q$ ); origin equidistaut from tip of snout aud base of caudal ( $q)$. Anal 8-9, acutely pointed; origin below the fourth or fifth dorsal ras ( $q$ ). Pectoral as long as the head. Caudal rounded. Least depth of caudal peduncle nearly equal to the length of head $(\delta)$ or about $\frac{3}{7}$ the length of head ( $\left.q\right)$. Greenish; scales on the npper part of the body with dark edges; dorsal and caudal blickish ( $\delta$ ) or with small dark spots ( $q$ ).

Ilab. Guatemala, Lake Peten (Salvin $\left.{ }^{1} \stackrel{2}{)}\right)$.

Here described from the types, five specimens measuring up to $150 \mathrm{~mm}$. in total lengtl.

7. Pœcilia couchiana. (Tab. XIV. fig. 1.)

Limis couchiona, Girard, Proc. Ac. Philad. 1859, p. $116^{1}$.

Precilia couchii, Günth. Cat. Fish. vi. p. 347 (1866) ${ }^{2}$.

Pacilia couchiana, Jord. \& Evcrm. Bull. U.S. Nat. Mus. xlvii. 1896, p. 695 ; Meek, Publ. Columbian

Mlus., Zool. v. 1904, p. 152 !

Depth of body ahout $2 \frac{3}{4}$ in the length, length of head about 4 . Snout a little shorter than eye, the diameter of which is 3 in the length of head. Interorbital width equal to the distance from anterior part of eye to frce cdge of oporculum. 24 to 27 scales in a longitudinal series. Dorsal $9-11$; origin equidistant from tip of snout and anterior part of candal $(q)$; free edge of fin nearly straight, the branched rays subegual (9.). Anal $7-8$, pointed, opposite to the posterior half of the dorsal ( $q$ ). Pectorul nearly as lom as the licad. Caudal romided or subtruncate. Least depth of caudal pednucle $\frac{3}{4}$ to $\frac{1}{5}$ the length of head. Upper half of boty dark brownish or blackish, the colour especially dark at the edges of the scales: lower part of borly usually yellowish and sharply eplarated from the darter uprer part, at the lower edgo of which there may bo a blackish longitudinal band. 


\section{IIab. Mexico, Rio San Juan at Monterey, Nuevo Leon ${ }^{14}$.}

Here described from several specimens, measuring up to $50 \mathrm{~mm}$. in total length.

\section{Pœcilia maculata.}

Platypocilus maculatus, Günth. Cat. Fish. vi. p. 3\%) (1856) ${ }^{1}$; Garman, Mem. Mus. Comp. Zool. xix. 1895, p. $48^{2}$; Jord. \& Everm. Bull. U.S. Nat. Mus. xlvii. 1896, p. $686^{3}$; Meek, Pulbl. Columbian Mus., Zool. v. 1904, p. 145, t. $9^{1}$.

Platypxcilus variatus, Meek, t. c. p. 146, t. $10^{5}$.

Depth of hody 2 to $2 \frac{2}{3}$ in the length, length of head $3 \frac{1}{3}$ to $3 \frac{2}{3}$. Snent sherter than eye, the diameter of which is 3 in the length of head. Interorbital width equal to the distance from middle of eye to free edge of operculum. 23 to 26 scales in a longitudinal series. Dorsal 9-11; origin equidistant from sneut and anterier part of caudal ; free edge of the fin semewhat conver. Anal 8-9, pointed, oppesite the posterior half of the dorsal ( $q$ ). Pecteral a little sherter than the head. Candal reunded. Least depth of caudal peduncle from $\frac{3}{4}$ te as long as the head. Olivaceous, semetimes with black blotches; often a dark spot or crescent or a pair of spets at the base of the caudal.

IIab. Atlantic Coast Streams of Mexico :

Rio Soto la Marina (Garza Valdez, Santa Engracia, Victoria) ${ }^{5}$; Rio Panuco (Forlon, Rascon, Valles) ${ }^{5}$; Rio Papaloapam (El Hule, Obispo, Perez) ${ }^{4}$.

Here described from eight specimens, measuring up to $60 \mathrm{~mm}$. in total length, including the types of the species.

\section{I4. MOLLIENISIA, Le Sueur, 1821.}

Mollienisia, Jord. \& Everm. Bull. U.S. Nat. Mus. xlvii. 1896, p. 698.

Sicarcely generically distinct from Pocitia. Dersal fin lenger, of 12 te 16 rays, in adult males not only higher but considerably longer than in females.

Hab. Carolina to Guatemala.

\section{MIollienisia latipinna.}

Mollienisia latipinna, Le Sueur, Journ. Ac. Philad. ii. 1821, p. 3, t. $3^{1}$; Günth. Cat. Fish. vi. p. $348(1866)^{2}$; Garm. Mem. Mus. Comp. Zool. xix. 1895, p. 50, t. $12^{9}$; Jord. \& Everm. Bull. U.S. Nat. Mus. xlvii. 1896, p. $699^{4}$; Meek, Publ. Columbian Mus., Zool. v. 1904, p. $155^{5}$.

Pacilia multilineata, Le Sueur, t. c. p. 4, t. $]^{6}$.

Pucilia lineolata, Girard, U.S. Mex. Bound. Surv., Fishes, p. 70 , t. 35. figs. 9-11 (1859) ${ }^{7}$.

Limia poecilioides, Girard, t. c. p. 70, t. 38. figs. 8-11 ${ }^{\text {. }}$.

Limia formosa, Girard, Proc. Ac. Philad. 1859, p. $115^{9}$.

Limia matamorensis, Girard, t. c. p. $116^{10}$.

Mollienisia formosa, Günth. t. c. p. $349^{11}$; Jord. \& Everm. 1. c. $^{12}$; Meek, l. c. ${ }^{13}$.

Dcpth of hedj $2 \frac{1}{2}$ to 3 in the length, length of head $3 \frac{1}{2}$ to 4.26 to 28 scales in a lengitudinal series.

Dersal 13-16, in adult males very elevated and eccupying the greater part of the longth of the back. Anal 9-10. Caudal rounded in both sexes. Each scale on the side of the body with a dark spet, which may form continuous longitudinal stripes; dersal, in the female, with series of small dark spets, in the male with an obleng or oval spot on each interradial membrane, forming a serics aleng the middle of BIol. Centr.-Amer., Pisces, July 1907. 
the fin, below which are longitudinal stripes and above which are numerous smaller spots; caudal with series of small spots.

Mab. South Carolina to Tamaulipas :

Pensacola in Florida; New Orleans ${ }^{16}$; Indianola $^{8}$ and Brownsville ${ }^{7}$ in Texas ; Matamoros ${ }^{10}$, Palo Alto ${ }^{9}$, La Vega ${ }^{5}$, and Tampico ${ }^{5}$ in Tamaulipas.

Here described from several specimens, measuring up to $75 \mathrm{~nm}$. in total length, from New Orleans, Pensacola, and Tampico. Garman's plate illustrates strikingly the differences between the sexes and the changes during growth in this species, which attains a length of $100 \mathrm{~mm}$.

\section{Mollienisia petenensis.}

Mollienisia petenensis, Günth. Cat. Fisl. vi. p. 348 (1866) ${ }^{1}$, and Trans. Zool. Soc. vi. 1868, p. 485, t. 86. figs. $1-3^{2}$; Jord. \& Everm. Bull. U.S. Nat. Mus. xlvii. 1896, p. $700^{3}$.

Wepth of body $2 \frac{3}{4}$ to 3 in the length, length of head 4. 28 to 30 scales in a longitudinal series. Dorsal 15-16. Anal 9. Caudal rounded or sultruneate, in the males with the lower angle pointed and slightly produeed. Males $\pi$ ith a small dark spot on eaeh seale of the upper and posterior parts of the body and with the lower edge of the caudal blackish; dorsal fin eoloured as in M. latipinna.

Ilab. Guatemala, Lake Peten (Salvin) ${ }^{1} 2$.

Here described from the types, six specimens, measuring up to $130 \mathrm{~mm}$. in total length. This species is very close to the preceding, but it attains a larger size and is distinguished by the form of the caudal in the males, which suggests relationship with Xiphophorus.

\section{XIPHOPHORUS, Heck., 1848.}

Xiphophorus, Jord. \& Everm. Bull. U.S. Nat. Mus. xlvii. 1896, p. 701.

Sicarcely generically distinet from Pacilia and Mollienisia. Dorsal with 11 to 15 rays, higher but not much longer in the males than in the females. Males with the lower rays of the eandal fon produced to form a long pointed appendage.

\section{Hab. Tamaulipas to British Honduras.}

The five closely allied species of this genus agree in the following features:- Snout as long as or a little shorter than eye, the diameter of which is 3 to $3 \frac{1}{3}$ in the length of head, interorbital width $1 \frac{3}{5}$ to $1 \frac{4}{5}$. Origin of dorsal about equidistant from tip of snout and base of caudal, well in advance of that of the anal (q). Pectoral nearly as long as the head. Caudal appendage of the males palc, with black edges.

\section{Synopsis of the Species.}

I. Anal with 6 to 8 rays . . . . . . . . . . . . . . . . . 1. montezumce.

II. Anal with 8 to 10 rays.

A. Depth of body $3-1$ in the length.

1. Lcast depth of caudal peduncle not greater than the distance from anterior margin of eye to free edge of opereulum . . . . . . 2. helleri. 
2. Least depth of caudal peduncle greater tlian the distance from anterior margin of eye to free edge of opereulum.

A blaekish lateral stripe . . . . . . . . . . . . . . 3. strigatus.

No well-marked lateral stripe . . . . . . . . . . . 4. guentheri.

B. Depth of body $2 \frac{1}{2}-2 \frac{2}{3}$ in the length . . . . . . . . . . . . 5. brevis.

\section{Xiphophorus montezumæ.}

Xiphophorus montezuma, Jord. \& Snyder, Bull. U.S. Fish. Comm. 1900, p. 131, fig. 11 ' ; Jord. \& Everm. Bull. U.S. Nat. Mus. xlvii. 1900, p. $3156^{\circ}$; Meek, Publ. Columbian Mus., Zool. v. 1904, p. 158, fig. $50^{3}$.

Depth of body about 3 in the length, length of head about 4. 27 to 29 scales in a longitudinal scries.

Dorsal 11-13. Anal 6-8. Yellowish ; seales of upper part of body with dark edges; a more or less distinct dark stripe from eye to base of caudal.

Hab. Mexico, Rio Panuco System, Rascon 123.

Here described from a number of specimens from Rascon, measuring up to $60 \mathrm{~mm}$. in total length.

\section{Xiphophorus helleri.}

Xiphophorus helleri, Heck. Sitzungsb. Ak. Wien, i. 1818, p. 291, t. $8^{1}$.

Xiphophorus jalape, Meek, Publ. Columbian Mus., Zool. iii. 1902, p. 107², and v. 1904, p. 136, t. $11^{3}$.

Depth of body 3 (q) to $4(\delta)$ in the length, length of head about 4. 27 to 29 scales in a longitudinal

series. Dorsal 11-13. Anal 8-10. Dorsal rays, in the males, subequal from about the third to the ninth or tenth, thence increasing in length to the last. Least depth of caudal peduncle nearly equal to the distance from anterior margin of eye to free edge of operculum. Olivaceous; a well-defined blackish lateral stripe from eye to base of caudal; males with a second stripe from axil of pectoral to the lower edge of the caudal peduncle.

Hab. Mexico, Mountain Streams of Central Vera Cruz: Jalapa ${ }^{2} 3$, Orizaba ${ }^{1}$.

Here described from several specimens from Jalapa, measuring up to $70 \mathrm{~mm}$. in total length. Heckel's figures are not good, but the lower stripe distinctive of the males of this form is clearly shown.

\section{Xiphophorus strigatus. (Tab. XIV. fig. T.)}

Xiphophorus helleri (part.), Giinth. Cat. Fish. vi. p. 319 (1866) ' ${ }^{2}$ and Trans. Zool. Soc. vi. 1868, p. 485 , t. 87 . fig. $6^{2}$; Garman, Mem. Mus. Comp. Zool. xix. 1895, p. 68, t. 4. fig. 14, and t. 8. fig. $4^{3}$; Jord. \& Ererm. Bull. U.S. Nat. Mus. xlvii. 1896, p. $701^{4}$.

Xiphophorus hetleri (non Heck.), Meek, Publ. Columbian Mus., Zool. v. 1904, p. $157^{5}$. Xiphophorus strigatus, Regan, Ann. Mag. Nat. Hist. (7) xix. 1907, p. $65^{\circ}$.

Depth of body about $3 \frac{1}{2}$ in the length, length of head $4 \frac{1}{5}$ to $4 \frac{3}{5}$. 28 to 30 scales in a longitudinal series. Dorsal 12-14. Anal 9-10. Dorsal rays, in the males, subequal from the second or third to the ninth or tenth, thence increasing in length to the last. Least deptb of eaudal pedunole greater than the distance from anterior margin of eye to free edge of operculum. Olivaccous; a blackish lateral stripe from eye to base of caudal; no additional stripe in the males. 
Hab. Southern Mexico. Cordova ${ }^{156}$ (Boucard), Otopa ${ }^{5}$, Motzorongo ${ }^{5}$, Refugio 5 , El Hule ${ }^{5}$, Obispo ${ }^{5}$, Sanborn ${ }^{5}$, Oaxaca $\left(G_{\text {Gadow }}^{6}\right)$.

Several specimens, measuring up to $100 \mathrm{~mm}$. in total length.

\section{Xiphophorus guentheri.}

Xiphophorus helleri (part.), Giinth. Cat. Fish. vi. p. 349 (I866) ${ }^{1}$, and 'Trans. Zool. Soc. vi. 1868, p. 485 , t. 87 . figs. $2-5{ }^{2}$.

Xiphophorus guentheri, Jord. \& Everm. Bull. U.S. Nat. Mus. xlvii. 1896, p. $702^{3}$.

Depth of body $3-3 \frac{1}{2}$ in the length, length of head $4 \frac{1}{2}$. 28 or 29 scales in a longitudinal series. Dorsal $1: 3-14$.

Anal 9-10. Dorsal rays, in the males, increasing in longth thronghout. Least depth of caudal peduncle nearly equal to the length of head. Oliraceous, with brownish longitudinal stripes or series of spots along the rows of scales.

Hab. Guatemala, Rio Chisoy 2 (Godman and Salvin).

Here described from eight specimens, measuring up to $100 \mathrm{~mm}$. in total length. Jordan and Evermann gave a name to this form because they considered the dark irregular blotches on some of the specimens figured by Günther were a specific character. This is not the case, for in this, as in many other species of the fanily, the dark spotting or marbling is found only on some individuals.

\section{Xiphophorus brevis. (Tab. XIV. figg. 8, 9.)}

Xiphophorus brevis, Regan, Ann. Mag. Nat. Hist. (7) xix. 1907, p. $65^{1}$.

Depth of body $2 \frac{1}{2}-2 \frac{2}{3}$ in the length, length of head $3 \frac{3}{5}-3 \frac{3}{4} .27$ seales in a longitudinal series. Dorsal 13-15. Anal 9-10. Least depth of caudal peduncle nearly equal to tho length of head, equal to the distance from end of dorsal to base of caudal. Olivaceous; 3 or 4 indistinct darker longitudinal stripes at the edgos of the series of scales on the sides of the body.

IJal. British Honduras, Stann Creek (Rolertson) I.

Here described from two specimens, male and female, 70 and $75 \mathrm{~mm}$. in total length.

$$
\text { 16. ANABLEPS, Bloch, } 1795 .
$$

Anableps, Gïnth. Cat. Fish. vi. p. 337 (1866).

Viviparous. Anal fin, in the male, modified into an intromittent organ, covered with scules and with a terminal orifice. Mouth small or moderate; teeth pointed, in bands. Wyes placed bigh, each dirided into an upper and a lower portion, the former abore the level of the rest of the head. Dorsal fin short, with 8-12 rays, posterior in position; anal with 10-12 rays, in advance of the dorsal.

This remarkable genus comprises three species, two of which are restricted to the rivers of tropical South America.

\section{Anableps dovii.}

Anableps dowei, Gill, Proc. Ac. Philad. J864, p. 4.'.

Anableps dovii, Günth. Cat. Wjsh. vi. p. 338 (1866)" ; Jord. \& Everm. Bull. U.S. Nat. Mus. xlvii. 1896, p. $685^{3}$; Meek, Publ. Columbian Mus., Zool. v. 1904, p. 136 '.

Anableps dawii, Garm. Mem. Mus. Comp. Zool. xix. 1895, p. $79^{5}$. 
Depth of body about 6 in the length, length of head about 4. 60 to 68 scales in a longitudinal series. Dorsal 8-10. Anal 10-11. Caudal rounded. Browuish; a yellow longitudinal band, bordered by a. dark brownish band above and below, from axil of pectoral to base of caudal.

Hab. Southern Mexico and Central America:

Mexico, Tequesixtlan (Gadow) and Tehuantepec (Buller) in Oaxaca, Chiapas ${ }^{5}$; Guatemala, Chiapam (Salvin); Salvador.

Several specimens, up to $250 \mathrm{~mm}$. in total length.

\section{Sub-order V. APODES.}

Body elongate, eel-shaped; fins without spinous rays; no rentral fins; gill-openings small, separate (except in the marine eels of the family Synaphobranchidæ).

The Apodes are chiefly marine fishes, but the members of the genus Anguilla are fresh-water eels which go down to the sea for purposes of reproduction.

\section{Fam. 1. ANGUILLIDÆ.}

1. ANGUILLA, Shaw, 1804.

Anguilla, Günth. Cat. Fish. viii. p. 23 (1870); Jord. \& Everm. Bull. U.S. Nat. Mus. xlvii. 1896, p. 347 .

Head subconical; eye above the angle of the mouth; teeth in bands in the jaws and on the romer. Body eovered with oblong imbedded scales whieh are arranged obliquely at right angles to each other; dorsal and anal fins well-developed, confluent round the end of the tail; pectoral fins present.

The number of valid species of this widely distributed genus is probably not more than five or six. The American form appears to be nearly identical with the European eel, Anguilla vulgaris, but it is generally regarded as distinct by American ichthyologists.

\section{Anguilla chrysypa, Rafin., 1820.}

Anguilla chrysypa, Jord. \& Everm. Bull. U.S. Nat. Mus. xlvii. 1896, p. 348 ; Meek, Publ. Columbian Mus., Zool. v. 1904, p. 91.

Hab. Atlantic Coast Rivers, from Maine to Mexico; West Indies.

\section{Fam. 2. MIURENID压.}

\section{PISODONTOPHIS, Kaup, 1856.}

Pisoodonophis, Jord. \& Everm. Bull. U.S. Nat. Mus. xlvii. 1896, p. 377.

Head subconical; eye above the mouth; teeth granular, in bands in the jaws and on the romer. Body naked; tail projecting beyond the dorsal and anal fins; pectoral fin present. 
1. Pisodontophis daspilotus, Gilb., 1898.

Pisoodonophis daspilotus, Gilb. \& Starks, Micm. Calif. Ac. Sci. v. 1904, p. 36.

Hab. Paxam.

This marine species is recorded by Gilbert and Starks from a fresh-water pond at Miraflores, Panama.

\section{Sub-order VI. STMBRANCHII.}

Body elongate, eel-shaped; fins without spinous rays; no rentral fius; gill-npenings confluent to form a ventral slit.

\section{Fam. 1. SYMBRANCHID理.}

\section{SYMBRANCHUS, Bl., 1795.}

Symbranchus, Günth. Cat. Fish. viii. p. 15 (1870): Jord. \& Evcrm. Bull. U.S. Nat. Mus. xlvii. 1896, p. 342.

This genus comprises four species from India, China, Australia, and 'Tropical America.

1. Symbranchus marmoratus, Bl., 1795.

Symbranchus marmoratus, Günth. Cat. Fish. viii. p. 15 (18j0); Jord. \& Everm. Bull. U.S. Nat. Mus. xlvii. 1896, p. 342.

IIab. Southern Mexico to Brazil.

\section{Sub-order VII. OSTARIOPHYSI.}

'The nembers of this sub-order have the anterior vertebra modified and bearing a chain of small bones counecting the air-bladder with the auditory organ, but they differ so greatly in outward appearance that it is nearly impossible to give a definition based on external characters.

The principal characters of the Mexican and Central-American fishes of this suborder are shown in the following synopsis:-

\section{Synopsis of the Mexican and Central-American Families.}

I. Ventral fins prescut, abdominal in position.
A. Body protected by scries of bony plates; mouth inferior, with expanded, sucker-like lijs . . . . . . . . . . . . . . . l. Lonicanune.
B. Body naked; mouth terminal or subterminal; 4 to 8 barbels; an adipose fin. . . . . . . . . . . . . . . . 2. Silumbar. 
C. Body scaly.

Nouth toothless; gill-membranes joined to the isthmus; no adipose fin

3. CyPRINIDX.

Jaws with teeth; mouth bordercd laterally by the maxillaries; gill-membranes

free from the isthmus; 3 to $\tilde{5}$ branchiostegals; an adipose fin often

present; lateral line usually present and runuing along the middle of the

side; pectoral fins placed low . . . . . . . . . . . . . . . . Characinides.

II. No ventral fins; no dorsal; a long anal; body more or less eel-shaped. 5. Grmnoridx.

\section{Fam. 1. LORICARIID无.}

The Loricariidie are fresh-water fishes of South America, ranging from Panama to Monte Video. There are about 200 species, of which seven are known from Panama. These may be recoguized by the series of bony plates which protect the body, the restricted gill-openings, and the inferior mouth with expanded sucker-like lips. The dorsal fin is anterior in position, the anal fin is short, and the uppermost and lowest rays of the caudal and the first ray of each of the other fins are simple and often spinous.

\section{Synopsis of the Genera represented in Central America.}

I. Candal peduncle compressed or cylindrical.

A. Snout granular to its margin.

Operculum and interoperculum little, and not independently, movable . . . 1. PLecostonus.

Interoperculum freely movable, spinate . . . . . . . . . . . . . 2. Ancistrus.

B. Snout with a naked margin.

Snont without tentacles . . . . . . . . . . . . . . . 3. Ch жrostonus.

Snout with teutacles . . . . . . . . . . . . . . . . . . . 4. Xenocara.

II. Caudal peduncle strongly depressed.

Teeth not setiform; snout not much produced; an orbital notch . . . 5. Loricaria.

Teeth numerous, setiform; snout produced; no orbital uotch . . . 6. Oxyloricaria.

\section{PLECOSTOMUS, Gronow.}

Piecostomus, Regan, Trans. Zool. Soc. xvii. 1904, p. 202.

Body more or less elongate, protected on each side by 5 longitudinal series of bony scutes; upper surface of snout covered with granular plates to its margin; operculum and interoperculum little, and not independently, movable. Teeth slender, bifid, in a single series. Adipose fin usually present and supported by a movable spine.

About thirty-five species from Tropical America.

\section{Plecostomus guacari, Lacep.}

Loricaria plecostomus, Linn. Syst. Nat. i. p. 508 (1766).

Plecostomus guacari, Regan, Trans. Zool. Soc. xvii. 1904, p. 205.

Dorsal I 7. Anal I 4. 25 or 26 scutes in a longitudinal series, the anterior and superior scutes keeled. 
Supraoccipital with a median ridge and bordored posteriorly by a single scute. Dark spots on head, bods, and fins.

Hab. Panama to Paraguay.

This species, which attains a length of $350 \mathrm{~mm}$., is known to range from Venezucla to Paraguay. It has also been recorded by Kuer and Steindachner (Abhandl. Bayer. Akad. x. 1865, p. 60) from Panama. The Panama specimens are said to differ from the typical $P$. guacari in having more numerous teeth ( 40 on each side), a lower occipital keel, \&c., but the probable explanation is that Kner and Steindachner had examples of the true $P$. guacari and compared them with specimens of $P$. verres, Cuv. \& Val., a species which has not usually been distinguished from $P$. guacari, but which differs from it in the fewer teeth, higher occipital keel, \&c.

\section{ANCISTRUS, Kner.}

Ancistrus, Gill, Anu. Iyc. N. York, vi. 1858, p. 407 ; Regau, Traus. Zool. Soc. xvii. 1904, p. 221. Nimilar to Plecostomus, but operoulum and interoperculum independently movalle, the latter usually with a group of spines or bristles which can be everted.

'Thirty-one species from Tropical America.

\section{Ancistrus aspidolepis, Günth.}

Ancistrus aspidolepis, Regan, Trans. Zool. Soc. xvii. 1904, p. 230.

Dorsal I 7. Anal I 4. Scutes all strongly keeled, 25 in a longitudinal series. Interoperculum armed with a few short spines. Small dark spots or vermiculations on head, body, and fins.

Hab. Panama, Veragua.

Total length $280 \mathrm{~mm}$.

\section{CHÆTOSTOMUS, 'Tschudi.}

Chetostomus, Regan, Trans. Zool. Soc. xvii. 1904, p. 24 .

Similar to Ancistrus, but the snout with a naked margin.

Fifteen species, chiefly from the Andes of Peru, Ecuador, and Colombia, but extending into Venezuela and Panama.

\section{Chætostomus fischeri, Steind.}

(hetostomus fischeri, Steind. Denkschr. Ak. Wien, xli. 1879, p. 164, t. 4. fig. 9.

Dorsal I 8. Anal I 5. 23 to 24 sentes in a longitudinal series, none of them keeled. Interoperculum armed with 1 or 2 short spines. Head and anterior part of body with little yellowish spots; fins spotted or clouded with blackish.

Ifab. Panama, Rio Mamoni.

Total length $275 \mathrm{~mm}$. 


\section{XENOCARA, Regan.}

Xenocara, Regan, Trans. Zool. Soc. xvii. 1901, p. 20i1.

Similar to Ancistrus, hot the snout with a naked margin, which is usually broader in males than in femaless and bears fleshy tentacle-like processes, which are more dereloped in the males.

'Twelve species from Tropical America.

\section{Xenocara chagresi, Eigerım.}

Tenocara chayresi, Regan, Trans. Zool. Soc. xvii. 1904, p. 256, t. 14. fig. 7.

Dorsal I 7. Anal I 3-4. 2t scutes in a longitudinal series, none of then keeled. Interoperculum armers with about 10 spines. Olivaceous; a dark spot at the base of the first interradial membrune of the dorsal.

Mab. Panama, Rio Chagres.

Total length $175 \mathrm{~mm}$.

\section{LORICARIA, Linn.}

Loricaria, Regan, Trains. Zool. Soc. xvii. 1904, p. 270.

Body clongate, protected by bony scutes : caudal peduncle depressed, with paired dorsal and ventral series of scutes and postcriorly with a single lateral series of scutes on each side. Suout pointed or rounded. Teeth bifid, in a single series. An orbital notch. No adipose fin.

Forty-two species from Panama and South America.

\section{Loricaria uracantha, Kner \& Steind.}

Loricaria uracantha, Kncr \& Steind. Abhandl. Bayer. Ak. x. 1865, p. 56, t. 6. fig. 3 : Regan, Trans. Zool. Soc. xvii. 1904, p. 278.

Loricaria lima, Kner \& Steind. t. c. p. 58.

Loricaria bransfordi, Gill, Proc. Ac. Philad. 1876, p. 338.

Lips papillose, with short marginal fringes. Snout pointed. Maies with bristles on the sides of the head, the oecipital region and nuehal scutes, and the pectoral fins. 28 scutes in a longitudinal series. Abdomen covered with 3 or 4 series of plates between the lateral series. Upper caudal ray stroug, stout, spinous.

Hal. Panama.

'Total length $180 \mathrm{~mm}$.

\section{Loricaria variegata, Steind.}

Loricaria variegata, Steind. Denkschr. Ak. Wien, xli. 1879, p. 165, t. 3; Regan, Trans. Zool. Soc. xvii. 1904, p. 293.

Lips with filiform papillæ and long marginal fringes. Snout obtuse. 30 to 32 scutes in a longitudinai series. Abdomen naked exeept for the kateral series of plates and a meliau strip of smaller plates. Uppermost caudal ray elongate. Head, body, and dorsal, caudal, and pectoral fins with numerous dark oblong spots.

Ilab. Paxama, Rio Mamoni.

BIOL. Centr.-AMER, Pisces, July $190 \pi$. 


\section{OXYLORICARIA, Bleek.}

Oryloricaria, Regan, Trans. Zool. Soe. xvii. 1904, p. 297.

Differs from Loricaric in the numerous, setiform teeth and the absence of an orbital noteh.

Seven species from Panama and South America.

\section{0xyloricaria panamensis, Eigenm.}

Loricaria aurea, Steind. Denksehr. Ak. Wien, Kxií. 1902, p. 138, t. 5. fig. 1. Oxyloricaria pananensis, Regan, Traus. Zool. Soe. xvii. 1904, p. 301.

Body slender, elongate; snout produced as a rostrum.

Mlab. Panama.-Colombia, Rio Magdalena.

\section{Fam. 2. SILURID无.}

This is one of the largest families of fishes, comprising over 1000 species, and is nearly cosmopolitan. The Mexican and Central-American Siluridie may be recognized by the naked body, the presence of two to four pairs of barbels, the short anteriorly placed dorsal fin, the first ray of which is a more or less strong spine, the presence of an adipose fin, and the spiny outer ray of the pectoral fins.

In Mexico and Central America there are about sixty species, comprising (1) marine Cat-fishes of the genera Arius, Galeichthys, and Alurichthys, most of the species of which seem to enter fresh-waters; (2) fishes of the South-American fresh-water genera Rhamdia, Pimelodus, and Conorhynchus; and (3) the North-American fresh-water types, Amiurus and Leptops.

\section{Synopsis of the Mexican and Central-American Genera.}

I. Nostri]s chose together ; teeth on the palate; no nasal barbels; ventral fins with 6 rays.

A. Teetl on the palate villiform.
Four barbel
1. Elurich'sirs.
Six barbels
2. GaLEICHTIIS.
B. Teeth on the palate granular or obtusely eonical; six barbels . . . 3. Arus.

II. Nostrils well separated; palate toothless.

A. No nasal barbels; barbels 6 ; ventral fins with 6 rays.

1. Adipose fin long; jaws with well-rleveloped teeth.

Dorsal fin-spine slender, flexible; oeeipital proeess not nearly reaching the dorsal fin . . . . . . . . . . . . . . . . 4. Runnnis.

Dorsal fin-spine pungent; oecipital process extending to shield at base of spinc of dorsal fir . . . . . . . . . . . . . . 5. Praleulus.

2. Adipose fin rather short, shorter than the anal; teeth in the jaws fecble or abscut. . . . . . . . . . . . . . . . 6. Cuxinurncinus. 
B. Posterior nostril with a barbel; barbels 8; ventral fins with 8 or 9 rays.

Præmaxillary band of teeth of equal breadth throughout, or sometimes very

slightly produced backwards at the sides; lower jaw not projecting . . 7. Amrukus.

Præmaxillary band of teetl with a well-developed posterior extension on each side; lower jaw somewhat projeeting . . . . . . . . . 8. Leptops.

\section{ELURICH'THYS, Baird \& Girard, 1854.}

Alurichthys, Günth. Cat. Fish. v. p. 177 (1861).

Felichthys (Swainson), Jord. \& Everm. Bull. U.S. Nat. Mus. xlvii. 1896, p. 116.

Body elongate. Mouth terminal or subterminal; jaws with villiform teeth in bands; vomerine and palatine tecth; nostrils close together, the posterior with a flap; a pair of maxillary and a pair of mental barbels. Parieto-occipital with a process which extends posteriorly to the small basal shield of the dorsal spine. Dorsal fin with a strong spine and $\boldsymbol{\tau}$ branched rays; adipose fin short; anal moderate or rather long: rentral fins 6-raycd; caudal deeply forked.

Eight species from the Coasts and Rivers of America.

It seems most useful to deal here with the whole genus and not to omit the two species (A. bahiensis and $A$. bagre) which are not known to range so far north as Central America, but which may do so.

\section{Synopsis of the Species.}

I. Occipital process of nearly equal breadth throughout, with convex lateral edges*; spine of dorsal fin uot bearing a filameut; about 14 gill-rakers on the lower part of the anterior arch.

A. Vomerine patches of teeth separate, nearly equal in length and breadth to the palatine patches; occipital process not broader than long; aual of 26 or 27 rays . . . . . . . . . . . . . 1. panamensis.

B. Vomerine patches of teeth united, considerably broader than the palatine patches; occipital process broader than long.

Breadth of occipital process $\frac{2}{5}$ or nearly $\frac{2}{5}$ the length of head ; anal of 28 rays, produced anteriorly, the longest ray, when laid back, reaching beyond the end of the base of the fin . . . . . . . . . . . . 2. scutatus.

Breadth of occipital process $\frac{1}{3}$ the length of liead; anal of 29 or 30 rays, the longest, when laid back, not reaching the end of the base of the fin . . 3. isthmensis.

II. Occipital process narrowed posteriorly, with concave or straight lateral edges; spine of dorsal fin bearing a long filameutous ray; not more than 10 gill-rakers on the lower part of the anterior arch.

A. Distance from tip of snout to origin of dorsal nearly $\frac{1}{3}$ the length of the fish (to basc of caudal).

1. Pectoral spine $\frac{3}{3}$ to $\frac{3}{4}$ as long as the head.

Anal of 22 to 24 rays, the longest nearly as long as or shorter than the base of the fin; dorsal filament not reaching the adipose fin . . . . . 4. marinus.

* In the species of this section the occipital process has the appearance of a separate nuchal shield. 
2. Pretoral spine nearly as long as the liead.

Anal of 19 to 21 rays, the longest as long as or a little longer than the base of the fin ; dorsal filament extending to the adipose fin . . . . . .

Anal of 24 to 26 rays, the longest a little shorter than the base of the fin; dorsal filament extending to the candal . . . . . . . . 6. filamentosus.

B. Distance from tip of snout to origin of forsal $\frac{1}{4}$ to $\frac{a}{7}$ the length of the fislı; longest anal ray much shorter than the hase of the fin.

Inal of $:-7$ to 31 rays; vomerine patehes of teetl united, about as large as the palatine patches, with which they are continuous . . . . . . . 7. pinnimaculatus.

Anal of 31 to 35 rays; vomerine patches of teetli separated, much shorter than than the palatine patches, with which they are subcontinuous . . . 8. bagre.

\section{Ellurichthys panamensis.}

Alurichthys panamensis, Gill, Proc. Ae. Plitad. 1863, p. 172.

Alurichth!s nuchalis, Günth. Cat. Fish. v. p. 179 (186t), and Trans. Zool. Soc. vi. 1868, p. t76, t. 81 . fig. 2.

Elurichthys panamensis (part.), Steind. Sitzmugh. Ak. Wien, lxxii. 18;6, p. 564, t. 2. figs. 3 \& 4. Frfichthys panamensis, Jord. Everm. Bull. U.S. Nit. Mus. xlvii. 1896, p. 117.

Felichthys panamensis (part.), Gilb. \& Starks, Mem. Calif. Ac. Sci. iv. 1904, p. 20.

1) $\mathrm{p}^{\text {th }}$ of body a little less than the length of bead, which is 4 in the length of the fish. Irreadih of head $1 \frac{1}{3}$ in its length; snout a little longer than eye, the diameter of which is 4 in the length of leend. Jower jaw a little shorter than the upper; vomerine patches of teeth separate, equal in length and brearth to the palatine patches; maxillary barbel extending to the ventral fin. 14 gill-rakers on the lower part of the anterior areb. Head coverel with skin; profile nearly strajght from snout to dorsal fin; occipital process uncorered by skin, pitted, of nearly equal breadth throughout, the lateral edges somewhat convex, the posterior edge a little cmarginate; two halves of the process meeting in the middle line at an angle which is rather more than a right angle: hreadth of process equal to (or a little less than) its length and to the length of head. Dorsil $I T$, the spine not bearing a long filanent. Anal $26(27)$, somewliat wroluced anteriorly, the longest rays, when laid lack, just reaching the end of the base of the fin. l'ectoral spine bearing a long tilament; veutrals not reaching the anal. Caudal deeply forked. Caudal peduncle twice as long as decp. Silvery, back b]nish.

\section{Mrell. Pacific Coast of Paxima (l)ow).}

One specimen, type of A. muchatis, $220 \mathrm{~mm}$ in len:th.

๖. Elurichthys scutatus, sp. n. (Tab. XV. fig. 2 and Tab. XIX. fig 2.)

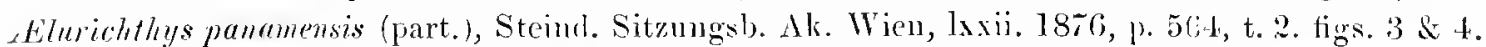
felichthys pantmensis (part.), Gilb. Starlss, Mem. Calif. Ac. Sci. iv. 1904, p. 20.

Deph of body a little less than the length of beid, which is $t$ to $t \frac{1}{4}$ in the length of the firls. Breadth of lucad $1 \frac{1}{4}$ in its length; snont longer than eye. the dianeter of which is $+\frac{1}{2}$ to $5 \mathrm{in}$ the length of the hend. lower jaw a litte shorter thin the ulper ; vomerino patches of teeth united, cousiderably broader

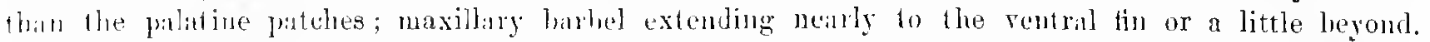
14 gill-rakess on the lower part of the anterior anch. Head and vecipital puocess covered with smooth

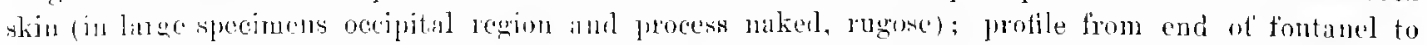
origin of dowal enrox; orciptal process shaped nearly as in the precteding species, but enusiderably brialce than long (the breadth $\stackrel{2}{\circ}$ or nearly $\stackrel{3}{*}$ the length of head) and with the two halves forming a more 
acute angle. Dorsal $I T$, the spine not bearing a long filament. Anal 28 , considerably produced anteriorly, the longest rays, when laid back, cxtending beyond the end of the basc of the fin. Pectoral spine bearing a long filament; rentrals reaching the anal. Candil deeply lorked. Cuudal peduncle $1 \frac{3}{4}$ as long as deep. Silvery, back hluish; rettical fins more or less dusky.

Ilab. Pacific Coast of Paxama (Jorlan).-N.W. Ecuadur (Rosenlerg).

Two specimens, 220 and $280 \mathrm{~mm}$. in length.

Probably both this and the preceding species extend northwards tn Lower California, but it is impossible to say to which the northern records should apply.

3. Ellurichthys isthmensis, sp. 11. (Tab. XV. fig. 1 and Tab. XIX. fig. 1.)

Depth of borly nearly equal to the length of head. which is $t$ to $4 \frac{1}{4}$ in the length of the fish. Breadth of bearl $1 \frac{1}{3}$ in its length; snout longer than eye, the diameter of which is $4 \frac{1}{2}$ to $4 \frac{2}{3}$ in the length of head. Lower jaw searccly shorter than the upper; vomerine patches of teeth united, considerably broader thin the palatine patches; maxillary barbel extending nearly to the ventral fiu. 14 gill-rakers ou the lower part of the anterior arch. Head covered with skin: upper profile of head straight or slightly convex; occipital process shaped nearly as in the preceding species, uncovered by skin, pitted, broader than lon:r, its breadth $\frac{1}{3}$ the length of head. Dorsal I 7 , the spine not bcaring a long filament. Anal 29-31,. slightly produced anteriorly, the longest rays, when laid back, not nearly reaching the end of the base ot the fin. Pectoral spine bearing a long filament; rentrals not reaching the anal. Caudal deeply forked. Caudal peluncle $1 \frac{\pi}{5}$ as long as deep. Silvery, back bluish.

Hal. Atlantic Coast of Panina, Colon (Boucard).

Two specimens, 190 and $210 \mathrm{~mm}$. in total length.

\section{4. \#lurichthys marinus.}

Eluriclthys marinus (Mitchill, 1815), Girard, Rep. U.S. Mex. Bound., Fishes, p. 31, t. It (1859); (Günth. Cat. Fish. v. p. 178 (1864).

Felichthys marinus, Jord. \& Everm. Bull. U.S. Nat. Mus. xhvii. 1896, p. 118.

Distance from tip of snont to origin of dorsal about $\frac{1}{3}$ the length of the fish. Occipital process narrowed posteriorly, with straight or concare lateral edges. Maxillary barbel extending to pectoral (adult) or ventral (young); vomerine and palatine teeth forming a continuous or subcontinuous band; about 8 gill-rakers on the lower part of the anterior arch. Dorsal $I 7$; filomentous ray usually not reaching the adipose fin. Anal 20-24; longest ray nearly as long as or shorter than the base of the fill. Pectoral spine $\frac{3}{5}$ to $\frac{3}{4}$ the length of head. Silcery, back bluish.

IIab. North America, Atlantic Consts and Rivers from Cape Cod to Texas; probably occurring in Northern Mexico.

Here described from three specimens, 180 to $400 \mathrm{~mm}$. in total length.

\section{5. Ælurichthys bahiensis.}

Galeichtlyys lahiensis, Casteln. Anim. Amér. Sud, Poiss. p. 3\%, t. 18. fig. 1 (185.5).

Elurichthys longispinis (part.), Günth. Cat. Fish. v. p. 178 (1864).

Felichthys Lahiensis, Jord. \& Ererm. Bull. U.S. Nat. MIus. xlvii. 1896, p. 118.

Uistance from tip of snout to origin of dorsal ahout $\frac{1}{3}$ the length of the fish. Occipital process narrowed posteriorly, with straight or concare lateral edges. Mlaxillary barbel nearly reaching ventrn fin; vomerine and palative teeth forming a continuous or subcontinuous band; 6 gill-ralsers on the lower 
part of the anterior arch. Dorsal I 7 ; filamentons ray extending to the adipose fin. Anal 19-21; longest ray as loug as or a little louger than the base of the fin. Pectoral spine nearly as long as the head. Silvery, back bluish.

Mab. South America, Brazil.

Here described from two specimens, 300 and $400 \mathrm{~mm}$. in total length.

\section{Wlurichthys filamentosus.}

Silurus bagre (non Linn.), Bloch, Ausl. Fische, t. 365 (1793) ${ }^{1}$.

Felichthys filamentosus, Swainson, Nat. Hist. Fish. ii. p. 305 (1839) ${ }^{2}$; Jorl. \& Everm. Bull. U.S.

Nat. Mus. xlvii. 1896, p. $118^{\text {? }}$.

Alurichthys longispinis (part.), Günth. Cat. Fish. v. p. 178 (186t) ${ }^{4}$.

Distance from tip of snout to origin of dorsal $\frac{1}{3}$ the length of the fish. Occipital process narrowed posteriorls, with slightly concare lateral edges. Maxillary barbel extending to ventral fin; romerine and palatine teeth forming a narrow band which is interrupted in the middle; 7 gill-rakers on the lower part of the anterior arch. Dorsal I 7 ; filamentous ray extending to the candal fin. Anal 24-26; longest ray a little sborter than the base of the fin. Pectoral spine nearly as long as the head. Silvery, back bluish.

Ifub. Atlantic Coasts and Rivers of Central America:

Gulf of Mexico ${ }^{4}$; Lake Nicaragua ${ }^{3}$.

Here described from a specimen $220 \mathrm{~mm}$. in total length.

\section{7. Ællurichthys pinnimaculatus.}

? Galeichthys eydouxii, Cuv. \& Val. Hist. Nat. Poiss. xv. p. 43 (18t.0) ?.

Elurichthys pimimaculatus, Steind. Sitzungsh. Ak. Wien, lxxii. 1876, p. 565, t. $8^{2}$.

Felichthys pinnimaculatus, Jord. \& Everm. Bull. U.S. Nat. 11 us. xlvii. 1896, p. $117^{3}$.

1)istance from tip of snout to origin of dorsal fin $\frac{1}{4}$ to $\frac{2}{7}$ the length of the fish. Occipital process narrowed posteriorly, with straight or coucave lateral edges. Maxillary barbel extending to, or nearly to, the anal fin; tecth on the palate forming a continnous or subcontinuous band, the romerine and palatine patches subcqual; 2 gill-rakers and a fow rudiments on the lower part of tho anterior arch. Dorsal I 7 : filamentous ray extending to adipose fin or even to the caudal. Anal $27-3 \mathrm{I}$; longest ray about $\frac{1}{2}$ the length of base of the fin (more in the adult, less in the young). Pectoral spine $\frac{2}{3}$ to $\frac{3}{4}$ the length of heal. Silrery, back bluish; a blackish spot on the anterior part of the anal and sometimes one on the candal and on each of the paired fins.

Ilab. Pacific Coast from Mexico to Ecuador:

Altata $^{2}$ and Mazatlan in Sinaloa $\left(\operatorname{Tordan}^{3}\right)$; Costa Rica ${ }^{2}$; Panama $\left(J_{\text {ordan }}{ }^{3}\right)$; Guayaquil 1 .

Here described from three specimens, 250 to $500 \mathrm{~mm}$. in total length.

\section{Elurichthys bagre.}

silurus bagre, Linn. Syst. Nat. p. 505 (1766).

Elurichthys yronovii (Cuv. \& Val.), Günth. Cat. Fish. v. p. 178 (1864).

Felichthys bayre, Jord. \& Everm. Bull. U.S. Nat. Mus. xlvii. 1896, p. 117. 
Distance frem tip of snout to origin of dersal fin $3 \frac{1}{2}$ to 4 in the length of the fish. Occipital process narrewed pesteriorly, with straight or cencave lateral edges. Maxillary barbel extending beyond the origin of anal fin; vomerine patches of teeth separate, much smaller than the palatine patches, with which they are subcontinuous; 4 gill-rakers and a few rudiments on tho lewer part of the anterier arch. Dorsal I7; filamenteus ray extending te the adipose fin. Anal 30-35; longest ray less than $\frac{1}{2}$ the length of base of the fin. Pectoral spine $\frac{3}{4}$ the length of head. Silvery, back bluish.

Hab. Atlantic Coast of South America; West Indies.

Here described from three specimens, the largest $350 \mathrm{~mm}$. in total length.

\section{GALEICHTHYS, Cuv. \& Val., 1840.}

Galeichthys and Arius (part.), Cuv. \& Val. Hist. Nat. Poiss. xv. pp. 28 \& 52 (18+0); Güinth. Cat. Fish. v. pp. $138 \& 174$ (1864).

Scicedichthys (Bleek.), Selenaspis (Bleek.), Netuma (Bleek.), and Galeichthys, Jord.\& Evcrm. Bull. U.S. Nat. Mus. xlvii. 1900, pp. 2757, 2760, 2764, \& 2770.

Bedy elengate. Mouth terminal or subterminal; jans with rilliform teeth in bands; rilliform teeth on tho palate; nostrils close together, the posterior with a flap; a pair of maxillary and two pairs of mental barbels. Parieto-eccipital produced into a precess which extends to the basal shield of the dorsal spine. Dorsal fin with a strong spine and 7 branched rays; adipese fin short or of medcrate length; anal of moderato length ; ventral fins 6-rayed; caudal deeply forked.

A large number of species from the consts of tropical and sub-tropical countries. most of them entering rivers freely.

\section{Synopsis of the Mexican and Central-American Species.}

I. Teeth present on vomer, palatines, and pterygoids, sometimes in separate patches, but in the adnlt usually forming a eontinuous band, the large subtriangular palato-pterygoid patehes connected anteriorly by a transverse vomerine strip.

A. A transverse membranous fold on the snout, connecting the posterior nostrils; dorsal shield large, saddle-shaped . . . . . . . . 1. dovii.

B. No membranous fold comnecting the posterior nostrils.

1. Dorsal shield subpentagonal, large, its length in the middle line

$\frac{1}{6} \mathrm{or}^{2} \frac{1}{7}$ of the distance from snout to origin of dorsal fin . . . 2. troscheli.

2. Dorsal shield subcreseentie, considerably smaller than in G. troscheli.

a. Fontanel produced posteriorly into a feeble groove which does not extend to the parieto-occipital; adipose fin a little longer than the dorsal tin.

Width of mouth $\frac{1}{2}$ the width of head . . . . . . . . . . . . . 3. planiceps.

Widtl of mouth $\frac{2}{3}$ the width of head . . . . . . . . . . . . . . 4. kessleri.

し. Fontanel produced posteriorly into a well-dereloped groove which extends to the parieto-occipital; adipose fin shorter than the dorsal fin . . . . . . . . . . . . . . . . 5. platypogon.

II. Teeth present on palatines and usually on the vomer, but nut on the pterygoids, the vomerine patehes separate or subcontinuous, and contiuuous or subcontinuous with ur separate from the palatine patehes, which may be rounded, oval, club-shaped, or ublong.

A. Fontanel not produced backwards into a groove; oceipital process not lunger than broad; inner edge of pectoral spine modcrately or strongly serrated; aual of 16 to 20 rays. 
1. Vomerine patches of teeth continuous with the larger club-sliaped palatine patches; maxillary barbel extending to operculum or nearly to base of pectoral.

Wridth of mouth slightly more than $\frac{1}{2}$ the width of head . . . . . . 6. assimilis.

Width of mouth nearly $\frac{2}{3}$ the width of head . . . . . . . . . . . gratemalensis.

2. Vomerine patclies of teeth oblong or oval, continuons or subcontinuous with the palatine patches, which are only a little larger than the vomerine ones and of similiar form; maxillary barbel extending beyoud the base of pectoral . . . . . . . . .

8. carulescens.

B. Fontanel produced backwards into a feeble groove which iones not reach the parieto-occipital; occipital process twice as long as broad; inner edge of pectoral spine weakly serrated; anal of 21 or 22 rays . 9. Tentiginosus.

C. Fontanel prorluced backwards into a groove which nearly or quite reaches the parictooccipital; inner edge of pectoral spine weakly or moderately serrated; anal fin of 14 to 20 rays.

1. Occipital process subtriangular, much broader than long; 9 to $1: 2$ gill-rakers on the lower part of the anterior arch; adipose fin shorter than the dorsal.

Occipital process rounded postcriorly; premaxillary band of tecth $4 \frac{1}{2}$ times

as long as broad . . . . . . . . . . . . . . . . . 10. guentheri.

Occipital process with straight sides and truncate apex ; promaxillary band of

teeth 5 to 6 times as long as broad . . . . . . . . . . . . .1. seemuni.

2. Occipital process as long as broad; 6 gill-rakers on the lower part of the anterior arch; adipose fin a little longer than the dorsal . . 12. longicephalus.

3. Occipital process 3 times as long as broad; 10 glll-rakers on the lower part of the anterior arch; adipose fin as long as the dorsal . 13. peruciunus.

\section{Galeichthys dovii.}

Leptarins dowi, Gill, Proc. Ac. Philad. 1863, 1). 1\%0'.

Arius alatus, Steind. Sitzungsb. Ak. Wien, lxiii. 18\%6, p. 569, t. $6^{2}$.

Selenaspis dowi, Jord. \& Everm. Bull. U.S. Nat. Mus. xlvii. 1900, p. $2761^{3}$.

Hab. Pacific Coast from Panama to Fcuador :

Panama 123 ; Ecuador ${ }^{3}$.

This is the Pacific representative of G. her zeryii, Bl., from Guiana and Brazil.

\section{Galeichthys troscheli.}

siades troscheli, Gill, Proc. Ac. Plitad. 1863, p. 1rl ${ }^{2}$.

Arins troscheli, Günth. Cat. Fish. v. p. $150(1864)^{2}$.

Arius braudtii, Steind. Sitzungab. $\Lambda \mathrm{k}$. Wien, lxxii. 1876, p. $5 \pi \mathrm{l}$, t. $3^{3}$.

Scicedichthys troscheti, Jord. \& Everm. Bull. U.S. Nat. Mus. xhii. 1900, p. 2rã'.

1)epth of body 5 in the length, length of hoad $3_{4}^{3}$. Brcadth of head $1 \frac{1}{b}$ to $1 \frac{1}{6}$ in its length, diameter of eye 7 to $8 \frac{1}{2}$. Fontanel not jroduced backwirds into a distinct groove; occipital process with a weak licel, broader than $\operatorname{long}$, the sides straight, the posterior erge emarginate; dorsal shicld sub-pentagonal, emarginate posteriorly, about as broad as long, its length in the median line $\frac{1}{6}$ to $\frac{1}{7}$ of the distance from tip of snont to origin of dorsal fin. Width of month $\frac{3}{3}$ to $\frac{2}{3}$ the wilth of head; pricmaxillary hand of 
tecth about 6 times as long as broad; teeth on the palate villiform, in the adult forming a continuous band, the rather narrow romerine strip connecting the large subtriangular palato-pterygoid patches. Maxillary barbel about reaching the base of pectoral. 10 gill-rakers on the lower part of the anterior arch. Dorsal I 7 ; spine about $\frac{2}{3}$ the length of head; adiposo fin about as long as the dorsal. Anal 17-18. Pectoral spine about $\frac{2}{3}$ the length of head, with tuberculated or weakly serrated edges.

Hab. Pacific Coast of Mexico and Central America, from Mazatlan to Panama:

Mazatlan ${ }^{4}$ and Altata ${ }^{3}$ in Sinaloa; Panama ${ }^{1} 34$.

Here described from two specimens from Mazatlan and Panama (Jordan), 260 and $420 \mathrm{~mm}$. in total length.

\section{Galeichthys planiceps.}

Arius planiceps, Steind. Sitzungsb. Ak. Wien, lxxii. 1876, p. 576, t. $4{ }^{1}$.

Netuma planiceps, Jord. \& Everm. Bull. U.S. Nat. Mus. xlvii. 1900, p. $2766^{2}$; Gilb. \& Starks, Mem.

Calif. Ac. Sci. iv. 1904, p. $27^{3}$.

Netuma oscula (Jord. \& Gilb.), Jord. \& Evcrm. t. c. p. $2768^{4}$; Gilb. \& Starks, t. c. p. $28^{5}$.

Depth of body about 5 in the length, length of head $3 \frac{3}{\overline{3}}$ to $4 \frac{1}{\bar{\nu}}$. Brealth of head $1 \frac{1}{\overline{3}}$ to $1 \frac{1}{4}$ in the length, diameter of eye $6 \frac{1}{2}$ to 8 . Fontanel produced backwards into a feeble groove, which does not extend to the parieto-occipital; occipital process with a keel, longer than broad, truncated posteriorly, and with the sides straight; dorsal shield small, subcrescentic. Width of mouth $\frac{1}{2}$ the width of head; prosmaxillary band of teeth $3 \frac{3}{4}$ to $4 \frac{1}{2}$ times as long as broad; teeth on the palate villiform, the vomerine patches continuous or subcontinuous with each other and with the large subtriangular palato-pterygoid patches. Maxillary barbel nearly reaching the base of pectoral. 9 or 10 gill-rakers on the lower part of the auterior arıh. Dorsal I 7 ; spine $\frac{2}{3}$ to $\frac{4}{5}$ the length of head; adipose fin a little longer than the dorsal. Anal 18-19. Pectoral spine $\frac{3}{5}$ to $\frac{4}{5}$ the length of head, with tuberculated or weakly serrated edges.

Hab. Pacific Coast of Mexico and Central America :

Altata in Sinaloa ${ }^{1}$; Panama ${ }^{12345}$.

Here described from four specimens from Panama (Jordan), 220 to $250 \mathrm{~mm}$. in total length.

\section{Galeichthys kessleri.}

Arius kessleri, Steind. Sitzungsb. Ak. Wien, lxxii. 1876, p. 574, t. $5{ }^{2}$.

Netuma kessleri, Jord. \& Everm. Bull. U.S. Nat. Mus. xlvii. 1900, p. $2765^{2}$; Gilb. \& Starks, Mem.

Calif. Ac. Sci. iv. 1904, p. $26^{3}$.

Netuma elattura (Jord. \& Gilb.), Jord. \& Everm. t. c. p. $2769^{ \pm}$.

Depth of body $5 \frac{1}{3}$ in the length, length of head $3 \frac{2}{5}$. Breadth of hcad $1 \frac{1}{4}$ in its length, diameter of eye $7 \frac{1}{2}$. Fontanel produced backwards into a feeble groove, which does not reach the parieto-occipital ; occipital process with a keel, rather broader than long, subtriangular, posteriorly rounded, and with the sides slightly concave; dorsal shield small, subcrescentic. Width of mouth nearly $\frac{2}{3}$ the width of head; premaxillary band of tceth 6 times as long as broad; vomerine, palatine, and pterygoid patches of teeth present, separate or subcontinuous. Maxillary barbel reaching basal part of pectoral. 8 gill-rakers on the lower part of the antorior arch. Dorsal I 7 ; spine $\frac{3}{3}$ the length of head; adipose fin a littlo longer than the dorsal. Anal 19. Pectoral spino $\frac{3}{3}$ the length of head, weakly serrated.

BIol. Centr.-AMer., Pisces, Juty 1907. 
Hal. Pacific Coast of Mexico and Central America :

Altata in Sinaloa ${ }^{1}$; Panama ${ }^{1234}$.

Here described from a single specimen from Panama (Dow), $2 S 0 \mathrm{~mm}$. in total length.

Tetuma insculpta, Jord. \& Gilb. (Jord. \& Everm. Bull. U.S. Nat. Mus. xlvii. 1900, p. 2765), from Panama, is evidently very closely allied to G. Kessleri and may be identical with it.

5. Galeichthys platypogon. (Tab. XVII. fig. 1 and Tab. XIX. fig. 5.)

Arius platypogon, Günth. Cat. Fish. v. p. 14 r (1861) ${ }^{2}$; Steind. Sitzungsb. Ak. Wicn, lxxii. 18i6, p. $567^{2}$.

Netuma platy/pogon, Jord. \& Everm. Bull. U.S. Nat. Mus. xlvii. 1900, p. 2r6r ${ }^{3}$; Gilb. \& Starks, Mem. Calif. Ac. Sci. iv. 190t, p. $28^{*}$.

Depth of body 5 to $6 \mathrm{in}$ the length, length of luead $3 \frac{3}{4}$ to $4 \frac{1}{4}$. Breadth of head about $1 \frac{1}{4}$ in its length, diameter of eye 5 to 6 . Fontanel produced backwards into a groove which reaches the parieto-oceipital; vecipital process with a keel, usually longer than broad, subtriangular, with straight sides and truncated apex; dorsal shield small, subcrescentic. Width of mouth $\frac{3}{5}$ the width of head; præmaxillary band of teeth 4 to 5 times as long as broad; vomerine, palatine, and pterggoid patches of teeth sometimos separate, sometimes forming a continuous band, the rather narrow romerine strip connecting the large subtriangular palato-pterygoid patches. Maxillary barbel extending to base or middle of pectoral. About 10 gillrakers on the lower part of the anterior arch. Dorsal 17 ; spine about $\frac{3}{4}$ the length of head; adipose tin shorter than the dorsal. Anal 18. Pectoral spine $\frac{3}{4}$ to $\frac{4}{5}$ the length of head, weakly serrated.

Hab. Pacific Coast from Lower California to Peru :

Lower California ${ }^{2}$; Mazatlan in Mexico ${ }^{3}$; San José in Guatemala ${ }^{1}$; Panama ${ }^{4}$; Peru ${ }^{2}$.

Here described from the types of the species from San José (Godman \& Salvin), and a specimen from Mazatlan (Jordan), tive examples measuring from 150 to $240 \mathrm{~mm}$. in toital length.

6. Galeichthys assimilis. ('Tab. XVI. fig. 2 and Tab. XIX. fig. 4.) Arius assimilis, Günth. Cat. Fish. v. p. $140(186 t)^{2}$.

Dejth of body 5 in the length, length of head $3 \frac{2}{3}$. Breadth of head $1 \frac{1}{3}$ in its length, diameter of eje 7 . Fontanel not produced backwards into a groove; occipital process with a feeble keel, broader tlian long, subtriangnlar, with truncated apex and straight sirles; dorsal shield subcreseentic, larger than in related species, its length in the middle line equal to the breadth of the posterior extremity of the occipital process. Wilth of mouth slightly more than $\frac{1}{2}$ the width of head; premaxillary band of teoth 5 times as long as broad; vomerine patches of teeth separate, continuous with the larger elub-shiped palatine patches. Masillary barbel nearly reaching the base of pectoral. 11 gill-raliers on the lower part of the interior arch. Dorsal I 7 ; spine $\frac{3}{5}$ the length of head; adipose fin nearly as long as the dursal. Anal 19. l'ectoral spine $\frac{5}{7}$ the lengih of head, with the inner odge rather strongly serrated.

Hab. Guatemala, Lake Yzabal ${ }^{1}$ (Godman \& Salvin).

IIere described from the type, a specimen measuring $300 \mathrm{~mm}$. in total length. 


\section{Galeichthys guatemalensis.}

Arius guatemalensis, Güinth. Cat. Fish. v. p. 14j (1864) ${ }^{2}$.

Galeichthys yuatemalensis, Jord. \& Everm. Bull. U.S. Nat. Mus. xlvii. 1900, p. 27\%9².

Galeichthys azureus (Jord. \& Williams), Jord. \& Everm. t. c. p. 2775, fig. $55^{3}$.

Depth of body 6 in the length, length of hoad $3 \frac{1}{2}$. Broadth of head $1 \frac{1}{3}$ in its Icngth, diameter of eye $6 \frac{1}{2}$. Fontanel not produced backward into a groove; occipital process weakly keeled, considerably broader than long, with apex truncated and sides somerwhat concave. Width of mouth ncarly $\frac{2}{3}$ the width of head; præmaxillary band of teeth $5 \frac{1}{2}$ times as long as broad; vomerine patches of teeth separate, continuous with the largor club-shaped palatine patches. Haxillary barbel extending to opercnlum. 11 gill-rakers on the lower part of the anterior arch. Dorsal I 7 ; spine $\frac{1}{2}$ the length of head; adipese fin shorter than the dorsal. Anal 19. Pectoral spine nearly $\frac{2}{3}$ the length of head, with strongly serrated inner edge.

Hab. Pacific coast of Mexico and Central America :

$$
\text { Mazatlan }{ }^{3} \text {; Guatemala }{ }^{1} \text {. }
$$

Here described from the type, a specimen measuring $260 \mathrm{~mm}$. in total length. Günther's specimen (b), from Chiapam, belongs to G. carulescens.

8. Galeichthys cærulescens. (Tab. XVII. fig. 2 and Tab. XIX. fig. 6.)

Arius ccerulescens, Günth. Cat. Fish. v. p. 149 (1864) '.

Galeichthys cerulescens, Jord. \& Everm. Bull. U.S. Nat. Mus. xlvii. 1900, p. 27\%6².

Depth of body 5 to 6 in the Jength, length of head $3 \frac{1}{2}$ to 4 . Breadth of head $1 \frac{1}{4}$ to $1 \frac{1}{3}$ in its length, diameter of eye 6 to 8 . Fontanel not prodnced backwards into a groere; occipital process not or but feebly keeled, subtriangular, as hroad as or a little broader than long, with apex truncated or subtruneated and sides nearly straight; dorsal shield small, subcrescentic. Width of mouth $\frac{2}{5}$ to $\frac{2}{3}$ the width of head; premaxillary band of teeth 6 times as long as bread; vomerine patches of teeth oblong or oval, separate, continuous or subcontinuous with the palatine patches, which are ouly a little larger than the romerine ones and of similar form. Maxillary barbel extending to basal part or middle of pectoral. 12 or 13 gill-rakers on the lower part of the anterior arch. Dorsal I 7 ; spine $\frac{1}{2}$ (adult) or $\frac{2}{3}$ (young) the length of head; adipose fin as long as or a little shorter than the dorsal. Anal 16-18. Pectoral spine $\frac{3}{5}$ to $\frac{2}{3}$ the length of hcad, with the inner edge moderately or rather strongly serrated.

Hal. Pacific Coast of Mexico and Guatemala:

Rio Presidio in Mexico (Forrer); Huamachal ${ }^{1}$ and Chiapam in Guatemala (Salvin).

Here described from six specimens, including the type of the species, measuring from 160 to $280 \mathrm{~mm}$. in total length.

\section{Galeichthys lentiginosus.}

Galeichthys lentiginosus (Eigenm. \& Eigenm.), Jord. \& Everm. Bull. U.S. Nat. Mus. xlvii. 1900, p. $2771^{1}$; Gilb. \& Starks, Mcm. Calif. Ac. Sci. iv. 1904, p. $20^{2}$.

Galeichthys xenauchen (Gilb.), Jord. \& Evern. t. c. p. $2777^{3}$; Gilb. \& Starks, t. c. p. 24, t. 4. fig. $7^{*}$.

Depth of body 5 to 6 in the length, length of head 4 . Breadth of head $1 \frac{1}{\ddagger}$ in the length, diameter of eye 8 to 9. Fontanel produced backwards into a fecble greore which does not reach the parieto-occipital; occipital process with a fooble keel, twice as long as broad, scarcely narrowed posteriorly, with straight 
sides; dorsal shield small, subcrescentic. Width of mouth $\frac{1}{2}$ the width of head; premaxillary band of teeth 5 times as long as broad; romerine patches of teeth rounded or quadrangular, separate or subcontinnous, contimnous with the linger rounded or elliptical palatine patches. Maxilliry barbel extending to basal part of pectoral. 4 gill-ratzers on the lower part of the anterior arch. Dorsal I 7 ; spine nearly $\frac{2}{3}$ the length of head, adiprose fiu louger than the dorsal. Anal 21-22. Pectoral spine $\frac{3}{5}$ to $\frac{2}{3}$ the length of head, weakly serrated.

Hal. Panama $123 \pm$ (Jordan).

Here described from two specimens, 270 and $280 \mathrm{~mm}$. in total length.

10. Galeichthys guentheri, sp. n. (Tab. XVI. fig. 1 and Tab. XIX. fig. 3.) Arius milberti (non Cuv. \& Val.), Gïntl. Cat. Fish. v. p. 155 (186t) ${ }^{1}$.

Depth of body $5 \frac{1}{2}$ in the length, length of head $3 \frac{1}{2}$ to $3 \frac{3}{4}$. Breadth of head $1 \frac{1}{3}$ in its length, diameter of cye 6 to $6 \frac{1}{2}$. Fontanel produced into a groove which nearly or quite reaches the parieto-occipital; occipital process keeled, much broader than long, subtriangular, with rounded apex; dorsal shield small, subcrescentic. Width of month $\frac{1}{2}$ to $\frac{3}{5}$ the width of head; præmaxillary band of teeth $4 \frac{1}{2}$ times as long as broad; romerine patches of teeth rery small, well separated, separate from or continuous with the oral palatine patches. Naxillary barbel extending to operculum. 9 or 10 gill-rakers on the lower part of the anterior arch. Dorsal I 7 ; spine $\frac{3}{5}$ the length of head; adipose fin shorter than the dorsal. Anal 17-1S. Pectoral spine $\frac{2}{\overline{7}}$ to $\frac{2}{3}$ the length of head, weakly serrated.

HaZ. Gulf of Mexico (Haslar Coll.) '

Two specimens, 240 and $260 \mathrm{~mm}$. in total length.

Galeichthys felis, Linn. (Arius milberti, Cuv. \& Val., Arins equestris, Girard), which is known to range from Cape Cod to Texas, is closely allied to G. guentheri, but differs in several respects, notably in having the occipital process as long as broad and in the longer barbels. I have examined a specimen from New Orleans.

\section{Galeichthys seemani.}

Arius seemani, Günth. Cat. Fish. v. p. 117 (1864) ${ }^{1}$.

Galeichthys seenami, Jord. \& Evcrm. Bull. U.S. Nat. Mus. xlvii. 1900, p. 27\%2².

Galeichthys jordani (Eigenm. \& Eigenm.), Jord. \& Everm. t. c. p. 2rz山 ${ }^{3}$; Gilb. \& Starks, Mem. Calif. Ac. Sci. iv. 1904, p. 22*.

Galeichthys gilberti (Jord. \& Williams), Jord. \& Everm. t. c. p. 2773, fig. 54".

Galeichthys eigenmanni, Gilb. \& Starks, t. c. p. 21, t. 4. fig. $8^{\circ}$.

Depth of body $5-5 \frac{1}{3}$ in the length, length of had $3 \frac{1}{2}$ to 4 . Breadth of head $1 \frac{1}{1}$ to $1 \frac{1}{2}$ in its length, dianueter of eje $5 \frac{1}{2}$ to $7 \frac{1}{2}$. Fontancl produced into a groove which nearly or quite reaches the parieto-occipital; occipital process keelcd, wnch broader than long, subtriangular, the apex trumeated, the sides straight; dorsal shield small, sulicrescentic. Width of mouth $\frac{1}{2}$ to $\frac{3}{5}$ the width of head; promaxillary band of teeth 5 to 6 times as long as broad; romeriue patches of teoth quadrangular, ronnded or orate, separatc or subcontinuous, subcontinuons or continuous with the larger oral or club-shaped palatine patches. Jaxillary barbel extending to opercle or base of pectoral. 10 to 12 gill-rakers on the lowcr part of the anterior arch. Dorsal 17 ; spine $\frac{3}{5}$ to the length of head; adipose fin shorter than the dorsal. Anal 16-20. Pectoral spine weakly or moderately serrated, $\frac{3}{\overline{3}}$ to $\frac{2}{3}$ the length of head.

IIal. Pacific Coast from Mexico to Ecuador:

Mazatlan (Jordan)5 ${ }^{5}$ Panama (Jorden) 2346 ; Ecuador (Festa). 
Here described from eight specimens, 220 to $330 \mathrm{~mm}$. in total length, including the type of the species and co-types of G. gilberti and G. eigenmami.

\section{Galeichthys longicephalus.}

Galeichtlyys dasycephalus (non Günth.), Jord. \& Everm. Bull. U.S. Nat. Mus. xlvii. 1900, p. 2780 ${ }^{\text {; }}$; Gilb. \& Starks, Mem. Calif. Ac. Sci. iv. 1904, p. $25^{2}$.

Gateichthys longicephalus (Eigenm. \& Eigenm.), Jord. \& Everm. t. c. p. 2781 ${ }^{3}$; Gilb. \& Starks, 1. c. ${ }^{4}$.

Depth of body $5 \frac{1}{2}$ in the length, length of head 4. Breadth of head $1 \frac{1}{3}$ in its length, diameter of eye $6 \frac{1}{2}$. Foutanel produced into a greove which reaches the parieto-occipital; occipital process strongly keeled, as long as broad, with truncated apex and slightly concave sides. Width of mouth $\frac{1}{2}$ the width of head: premaxillary band of teeth 4 times as long as broad; vomerine patches of teeth small, well separated, continuous with the rather small oblong or oral palatine patches. Maxillary barbel extending to the basal part of the pectoral. 6 gill-rakers on the lower part of the anterior arch. Dorsal 17 ; spine $\frac{1}{3}$ the length of head; arlipose fin a little longer than the dorsal. Anal 19. Pectoral spine $\frac{2}{3}$ the length of head, with the inner edge weakly serrated.

Mab. Panama (Jordan 1234 ).

Here described from a specimen of $250 \mathrm{~mm}$.

\section{Galeichthys peruvianus.}

Galeichthys peruvianus, Lütk. Vid. Medd. 1874, p. $205^{1}$; Steind. Sitzungsb. Ak. Wien, lxxii. 1876, p. 584" ; Eigenm. \& Eigenm. Occ. Papers Calif. Ac. Sci. i. 1890, p. $51^{3}$; Jord. \& Everm. Bull. U.S. Nat. Mns. xlvii. 1896, p. $122^{4}$.

Apparently allied to the preceding species, which it resemblcs in the arrangement of the teeth on the palate, but well distinguished by the longer occipital process, the narrower præmaxillary band of teeth ( 8 times as long as broad), and the shorter anal fin, with 14 to 16 rays:

Hab. Pacific Coast from Mexico to Peru:

Altata in Sinaloa ${ }^{2}$; Panama ${ }^{2}$; Callao ${ }^{123}$.

\section{ARIUS, Cuv. \& Va]., 1840.}

Arius (part.), Cuv. \& Val. Hist. Nat. Poiss. xv. p. 52 (18t0); Günth. Cat. Fish. v. p. 174 (1864). Tachysurus*, Eigenm. \& Eigenm. Occ. Papers Calif. Ac. Sci. i. 1890, p. 4:2 ; Jord. \& Everm. Bull.

U.S. Nat. Mus, xlvii. 1900, p. 2782.

Cathorops (Jord. \& Gill s.), Jord. \& Everm. t. c. 1896, p. 133.

Like Galeichthys, from which it differs only in having the teeth on the palate granular or obtusely conical instead of villiform, this genus comprises a considerable number of species from the coasts of tropical and subtropical countries, most of which enter fresh water.

* Lacepide (Hist. Nat. P'oiss. v. p. 151, 1803) founded the genus Tachysums on a Chinese painting of a fresh-water fish which may have belonged to Galeichthlys or Arius or may not have been at all closely related to thom. The generic diagnosis consists of (1) characters which are common to Avius, Pimelodus, and other genera, and of (2) others which might certainly bo held to define the genus Tachysurus if they could be relied 


\section{Synopsis of the Mexican and Central-American Species.}

I. Middle of eye above the level of the angle of the mouth; 9 to 12 gill-rakers on the lower part of the anterior arch.

A. Anal fin of 19 to 24 rays.

1. Occipital process not much broader than long.

$a$. Teeth on the palate in two rather small, well-separated patches.

Diametcr of eye 6 in the length of head (in specimens of 180 to $200 \mathrm{~mm}$.) ; maxillary barbcl extcnding to basal part of pectoral ; dorsal spine $\frac{3}{5}$ the length of head; pectoral spine $\frac{3}{5}$ the length of head, its inner edge very strongly serrated. . . . . . . . . . . . . . . . . . .

Diametcr of eye 4 to 5 in the length of head (in specimens of about 180 to $220 \mathrm{~mm}$.) ; maxillary barbel extending about to base of pectoral ; dorsal spine $\frac{3}{4}$ to $\frac{7}{8}$ the length of head; pectoral spine $\frac{2}{3}$ the length of head .

1. melanopus.

b. Teeth on the palate in two rather large narrowly separated patches; diameter of eye 6 to $7 \frac{1}{2}$ in the length of head (in specimens of 196 to $260 \mathrm{~mm}$.) ; maxillary barbel extending to basal part or middle of pectoral; dorsal and pectoral spines $\frac{2}{3}$ to $\frac{3}{4}$ the length of head, the latter with the inner edge moderately serrated . . . . . . . . . . . . .

2. Occipital process much broader than long. . . . . . . 4. evermanni.

B. Anal fin of 27 rays . . . . . . . . . . . . . 5. multiradiatus.

II. Mildle of eye about on a level with the angle of the mouth; 30 gillrakers on the lower part of the anterior arch; anal fin of 22 or 23 rays . . . . . . . . . . . . . .

6. hypophthalmus.

1. Arius melanopus. (Tab. XVIII. fig. I and Tab. XIX. fig. 7.)

Arius melanopus, Günth. Cat. Fisl., v. p. 172 (1861) ${ }^{1}$.

Tachysurus melanopus, Jord. \& Everm. Bull. U.S. Nat. Mus, xlvii. 1900, p. $2784^{2}$.

Galeichthys aqua-dulce, Meek, Publ. Columbian Mus., Zool. v. 1904, p. 9, t. $4^{3}$.

Depth of body 5 to $5 \frac{1}{2}$ in the length, length of head $3 \frac{3}{4}$ to $4 \frac{1}{3}$. Breadth of head $1 \frac{1}{3}$ in its length, diameter of

on, viz., a single nasal opening on each side and a rayed adipose dorsal. Cuvier and Valencicnnes (xr.p. 163, 1540) placed Lacepide's fish in the genus Pimelodus and made the following remarts:- " $\mathrm{M}$. de Lacépède a cru devoir faire un genre à part de ce peisson, à cause de quelques traits que l'on roit sur l'adipeuse, ot qüil a rerardés, dit-il, comme des rayons; .... . il le nomme tachisure ì cause de l'agilité de sa qucue, longue et déliée, et comme on peut en juger par la copie, assez mauvaise d'ailleurs, qu’il doune de sa figure chinoise, les proportions do cette partie ne diffèrent pas boaueoup de ce qu'elle est dans les espices du groupe actuel. Il nous pârait donc que le genre Taclisure ne peut être conserré."

I have thought it necessary to give iu detail the roasons why I use Arius instead of Tachysurus, as tho latter is now generally used by American ichthyologists, although I am at a loss to imagine how they have determined that a fish known unly frow a Chinese painting had granular or obtusely conical teeth on the palate. 
eye 6. Fontanel produced into a feeble groove which nearly reaches the parieto-occipital; occipital process keeled, subtriangular, about as broad as long, with sides slightly concave and apex more or less emarginate; dorsal shield small, subcrescentic. Width of mouth $\frac{1}{2}$ the width of head; præmaxillary band of teeth $3 \frac{1}{2}$ to 4 times as long as broad; teeth on the palate obtusely conical, in 2 rather small well-separated subovate patches; maxillary barbel extending to basal part of pectoral. 11 gill-rakers on the lower part of the anterior arch. Dorsal I 7 ; spine $\frac{3}{5}$ the length of head; adipose fin shorter than the dorsal. Anal 19-21. Pectoral spine $\frac{3}{5}$ the length of head, with the inner edge very strongly serrated. Inner surface of the paired fins blackish.

Hal. Mexico, Rio Papaloapam ${ }^{3}$; Guatemala, Rio Motagua ${ }^{1}$ (Salvin).

Here described from the types of the species, three specimens measuring from 180 to $200 \mathrm{~mm}$. in total length.

This is the only member of the genus known from the Atlantic slope of Mexico and Central America.

\section{Arius liropus.}

Tachysurus liropus (Bristol), Jord. \& Everm. Bull. U.S. Nat. Mus. xlvii. 1900, p. 2781 ${ }^{2}$.

Hab. Mexico, San Juan Lagoon in Sonora ${ }^{1}$.

3. Arius fuerthii. (Tab. XVIII. fig. 2 and Tab. XIX. fig. 8.)

Arius fürthii, Steind. Sitzungsb. Ak. Wien, lxxii. 1876, p. 579.

Tachysurus furthii, Jord. \& Evcrm. Bull. U.S. Nat. Mus. xlvii. 1900, p. $2787^{2}$; Gilb. \& Starks,

Mem. Calif. Ac. Sci. iv. 1904, p. $32^{3}$.

Tachysurus steindachneri, Gilb. \& Starks, t. c. p. 29, t. 5. fig. $9^{4}$.

Dopth of body 5 in the length, length of head $3 \frac{3}{4}$ to 4 . Breadth of head $1 \frac{1}{3}$ in its length, diamcter of eye 6

to $7 \frac{1}{2}$. Fontanel produced into a groove which does not reach the parieto-occipital; occipital process with or without a weak keel, usually broader than long, with straight or concave sides and truncate or emarginate apex; dorsal shield small, subcrescentic. Width of month $\frac{1}{2}$ the width of head; præmaxillary band of teeth 4 times as long as broad; teeth on the palate obtusely conical, in 2 rather large subovate patches whieh are not very widely separated anteriorly ; maxillary barbel extending to the basal part or middle of pectoral. 10 or 11 gill-rakers on the lower part of the anterior arch. Dorsal I 7 ; spine $\frac{2}{3}$ to $\frac{3}{4}$ the length of head; adipose fin shorter than the dorsal. Anal 20-24. Pectoral spine $\frac{2}{3}$ to $\frac{3}{4}$ the length of head, with the inner edge moderately serrated.

Hab. Pavala 1234 (Boucard, Jordan).

Here described from five specimens, 190 to $260 \mathrm{~mm}$. in total length.

\section{Arius evermanni.}

Tachysurus evermanni, Gilb. \& Starks, Mem. Calif. Ac. Sci. iv. 1904, p. 32, t. 5. fig. $10^{1}$.

Hab. Panama ${ }^{1}$.

Very closely allied to $A$. fuerthii, but apparently distinguished by the shorter and broader occipital process.

The species is based on a single specimen of $250 \mathrm{~mm}$. 


\section{Arius multiradiatus.}

Arius multiradiatus, Günth. Cat. Fish. v. p. 173 (1864) ${ }^{2}$.

Tachysurus multiradiatus, Jord. \& Everm. Bull. U.S. Nat. Mns. xlvii. 1896, p. $132^{2}$.

Tachysurus emmelane (Gilb.), Jord. \& Everm. Bull. U.S. Nat. Mus. xlvii. 1900, p. $2786^{3}$; Gilb. \&

Starks, Mem. Calif. Ac. Sei. iv. 1904, p. 31, t. $6^{+}$.

Depth of body 5 in the length, length of head $3 \frac{1}{2}$. Breadth of lead $1 \frac{2}{5}$ in its length, diameter of eye 7 .

Fontanel produced into a groove which nearly reaehes the parieto-occipital; occipital process without distinct keel, broader than long, with concave sides and slightly emarginate apex; dorsal shield small, suberescentic. Width of mouth $\frac{1}{2}$ the width of head; premaxillary baud of teeth 4 times as long as broad; teeth on the palate obtusely conioal, in two small, well-separated, subovate patches ; maxillary barbel extending to basal part of pectoral. 11 gill-rakers on the lower part of anterior arch. Dorsal I 7 ; spine $\frac{2}{3}$ the length of head; adipose fin shorter than the dorsal. Anal 27. Pectoral spine $\frac{3}{5}$ the length of head, with the inner edge rather strongly serrated.

\section{IIab. Panama 134 (Boncard).}

Here described from a specimen measuriug $230 \mathrm{~mm}$, in total length.

\section{Arius hypophthalmus.}

Arius hypophthalmus, Steind. Sitzungsb. Ak. Wien, lxxii. 1876, p. 581, t. $10^{2}$.

Tachisurus gulosus, Eigenm. \& Eigenm. Oce. Papers Calif. Ac. Sci. i. 1890, p. $93^{2}$.

Cathorops hypophthalmus, Jord. \& Everm. Bull. U.S. Nat. Nus. xlvii. 1896, p. $133^{3}$.

Cathorops gulosus, Jord. \& Everm. 1. c. ".

Hal. Paxama 1234.

\section{RHAMDIA, Bleek., 1858.}

Rhamdia, Jord. \& Everm, Bull. U.S. Nat. Mus. xlvii. 1896, p. 149.

Body elongate. Snout not greatly produced; mouth terminal or subterminal; jaws with rilliform teeth in bands; palate toothless; nostrils remote from each other; no nasal barbels; barbels 6 ; occipital process not extending to the dorsal fin. Dorsal fin with a slender flexible spine and 5 to 8 branched rays; adipose fin long; anal short or of moderate length ; ventral fins 6-rayed.

Numerous species, from Mexico to the La Plata.

\section{Synopsis of the Mexican and Central-American Species*.}

I. Caudal fin deeply notehed, the middle rays not more than $\frac{1}{2}$ the length of the longest.

A. Width of mouth $\frac{2}{5}$ to $\frac{1}{2}$ the width of head; peetoral spine $\frac{1}{2}$ to $\frac{1}{5}$ the leagth of head. Occipital process as broad as long, extending $\frac{1}{3}$ of the distance from its base to the origin of dorsal; body rather deep (depth $4 \frac{1}{3}$ to 5 in the length) . . 1. parryi. Occipital process much longer than broad, extending ${ }_{3}^{3}$ of the distance from its base to the origin of dorsal; body rather slender (depth about 6 in the length); first branched ray of dorsal the longest . . . . . . . 2. motaguensis.

* The original description of P. brachypterus, Cope (Trans. Am. I'lil. Soc. 1866, p. 404), from Orizaba, is insufficient, but Fowler's re-description of the type (in Meck, Publ. Columbiau Mus., Zool. v. 1904, p. 21) shows that this species is probably not distinct from $P$. gratcnulensis. 
B. Width of mouth $\frac{3}{5}$ to $\frac{3}{4}$ the width of head.

1. Occipital process extending $\frac{1}{2}$ of the distance from its base to the origin of dorsal.

a. Breadth of head $1 \frac{1}{2}$ in its length, interorbital width 4. . . . 3. nicaraguensis.

b. Breadth of head $1 \frac{1}{5}$ to $1 \frac{2}{5}$ in its length, interorloital width $23 \frac{3}{5}$ to $3 \frac{1}{4}$.

a. Pectoral spine $\frac{1}{3}$ the length of hoad; least depth of caudal peduncle 3 in the length of head . . . . . . . . . .

3. Pectoral spine $\frac{2}{5}$ to $\frac{1}{2}$ the lengtl of head ; least depth of caudal peduncle $1 \frac{3}{4}$ to $2 \frac{1}{2}$ in the lerigth of head.

* Length of snout $2 \frac{3}{5}$ to $2 \frac{3}{4}$ in the length of head, which is $4 \frac{1}{2}$ to $4 \frac{3}{4}$ in the length of the fish (in specimens measuring up to $280 \mathrm{~mm}$.) . . . . . . . . . . . . . . .

** Length of snout $2 \frac{3}{4}$ to 3 in the lengtl of head (in specimens

5. wagneri. measuring up to $280 \mathrm{~mm}$.).

Breadth of head $1 \frac{1}{5}$ in its length, which is $4 \frac{3}{5}$ in the length of the fish ; least depth of caudal peduncle $1 \frac{3}{4}$ in the length of head . . . . . . .

Breadth of head $1 \frac{1}{3}$ to $1 \frac{2}{5}$ in its length, which is $3 \frac{4}{5}$ to $4 \frac{2}{5}$ in the length of the fish ; least depth of caudal peduncle 2 to $2 \frac{1}{2}$ in the length of head' . . . 7. guatemalensis.

2. Occipital process extending $\frac{2}{5}$ of the distance from its base to the origin of dorsal ; interorbital width $2 \frac{2}{3}$ to $3 \frac{1}{3}$ in the length of head.

Maxillary barbel extending to origin of adlipose fin; pectoral spine $\frac{2}{5}$ to $\frac{1}{2}$ the length of head . . . . . . . . . . . . . . . . . .

Maxillary barbel extending to middle of dorsal fiu; pectoral spine $\frac{1}{3}$ the length of head . . . . . . . . . . . . . . . . . . 9. microptera.

3. Occipital process extending ${ }_{3}^{1}$ of the distance from its base to the origin of dorsal; interorbital width 4 in the leugth of head . . 10. managuensis.

II. Caudal fin with a moderately deep notch, but the middle rays more than $\frac{1}{2}$ as long as the longest.

A. Occipital process extending $\frac{2}{7}$ of the distance from its base to the origin of dorsal; pectoral spine $\frac{2}{5}$ to $\frac{1}{2}$ the length of head.

Pectoral spine with a finely serrated inner edge and a series of antrorse denticnlations on the outer edge; maxillary barbel reaching origin of adipose fin (in a specimen of $105 \mathrm{~mm}$.); anal of 10 rays . . . . . . . . 11. heteracantha.

Pectoral spine with serrated inner and entire outer edge; maxillary barbel reaching middle of base of dorsal fin (in a specimen of $115 \mathrm{~mm}$.) ; anal of 13 rays . . . . . . . . . . . . . . . . . 12. hypsehura.

B. Occipital process slender, extending $\frac{1}{4}$ of the distance from its base to the origin of dorsal; pectoral spine nearly $\frac{2}{\overline{5}}$ the length of head; naxillary barbel extending to basal part of pectoral (in specimens measuring up to $190 \mathrm{~mm}$.) . . . . . . . . . . . 13. brachycephala.

C. Occipital process short, triangular, extending $\frac{1}{5}$ or $\frac{1}{6}$ of the distance from its base to the origin of dorsal; pectoral spine from less than $\frac{1}{3}$ to nearly $\frac{2}{5}$ the length of hear.

1. Humeral process not reaching middle of pectoral spine; length of adipose fiu $3 \frac{2}{3}$ to $4 \frac{1}{4}$ in the length of the fish; anal of 11 or 12 rays. 14 . underwoodi.

niol. Cextr.-Anier., Pisces, November 1907. 
2. Humeral process extending beyond middle of pectoral spine.

Adipose fin $\ddot{7}$ the lengtlı of the fish; anal of 12 rays . . . . . . . . 15. salvini.

Adipose fiu $\frac{1}{3}$ the length of the fish ; anal of $15 \mathrm{rags}$. . . . . . . 16. polycaulus.

III. Caudal fin slightly notched, nearly truncate.

Maxillary barbel cxtending to middle of pectoral fin ; adipose fin $\frac{p}{j}$ the

length of the fish . . . . . . . . . . . . . 37. rogersi.

Maxillary barbel cxteuding to ventral fin; adipose fin $\ddot{\tilde{\sigma}}$ the lengtlı of the fish . . . . . . . . . . . . . . 18. laticauda.

\section{Rhamdia parryi.}

Rhamdia parryi, Eigenm. Proc. Calif. Acad. Sci. (2) i. 1888, p. $130^{1}$; Jord. \& Everm. Bull. U.S. Nat. Mus. xlvii. 1896, p. $153^{2}$.

Depth of body $4 \frac{1}{3}$ to 5 in the length, length of head $4 \frac{1}{3}$ to $4 \frac{1}{2}$. Breadth of head $1 \frac{1}{4}$ in its length. Diamcter of eye 5 in the length of head, 2 in the length of snout, $1 \frac{1}{2}$ in the interorbitil width. Lower jaw shorter than the upper: width of mouth $2 \frac{2}{3}$ to 3 in the length of head (about $\frac{2}{3}$ to $\frac{1}{3}$ the width of head). Maxillary barbel extending to or beyond the dorsal fin. Hoad covered with smooth skin; occipital proeess as broad as long, extending $\frac{1}{3}$ of the distance from its base to the origin of dorsal. Dorsal I 6 ; spine slender. Length of adipose fin 3 to $3 \frac{1}{2}$ in the lougth of the fish. Anal 12-14. Peetoral spine slightly more than $\frac{1}{2}$ the length of head. Lower eaudal lobe rounded. Brownish; a blackish lateral stripe.

IIab. Mexico, Rio Zanalenco in Chiapas ${ }^{1}$.

Apparently allied to $R$. motagnensis.

2. Rhamdia motaguensis. (Tab. XX. fig. 1.)

Pimelodus motagnensis, Günth. Cat. Fish. v. p. 127 (1864) '.

Rhamdia motaguensis, Jord. \& Evelm. Bull. U.S. Nat. Mus. xlvii. 1896, p. 151 ?

Depth of body $5 \% \frac{1}{3}$ to $6 \frac{1}{3}$ in the length, length of head $5 \frac{1}{4}$ to $5 \frac{1}{3}$. Breadth of head $1 \frac{1}{4}$ to $1 \frac{1}{3}$ in its length, length of snout $2 \frac{1}{2}$ to 23 , diameter of eye 5 to 6 , interorbital width 3 to $3 \frac{1}{3}$. Lower jaw shorter than the ulper; width of snout $\frac{1}{3}$ the width of head. Naxillary barbel extending to middle of dorsal (adult) or noarly to arlipose fin (young). Hoad covered with smooth skin; occipital process extending $\frac{3}{5}$ of the distance from its hase to the origin of dorsal. 8 or 9 gill-rakers on the lower part of the anterior arch. Torsal I 6: spine slender; first branched ray the longest. Length of adipose fin $3 \frac{1}{3}$ in the length of the tish. Anal 1: Humeral process not extending to middlo of peetoral spine, which is about $\frac{3}{4}$ the length of the fin and $\frac{1}{2}$ to $\frac{3}{5}$ the length of head. Ventrals inserted behind the last dorsal ray, cxtending $\frac{3}{2}$ to $\frac{2}{3}$ of the distance from their base to tho origin of anal. Candal deeply notehed. Least depth of eaudal peduncle $1 \frac{2}{3}$ in the length of head and $1 \frac{4}{5}$ to 2 in the distance from anal to base of caudal. brownish; dorsal dusliy, with a pale band near the base.

Mlal. Britisi Hondumas, Stamn Creek (Robertson); Gudmemala, Rio Motagua ${ }^{1}$ (Salvin).

Here described from two specimens, the type, $210 \mathrm{~mm}$. in total length, and one of $130 \mathrm{~mm}$, from Stann Creek.

3. Rhamdia nicaraguensis. ('Iab. XX. fig. 2.)

Pirueloches nicaraguensis, Güntl. Cat. Fish. v. p. 125 (1864) '.

Rhandia nicaraguensis, Jord. \& Everm. Bull. U.S. Nat. Mus. xlvii. 1896, p. $152 ?$. 
Depth of body 7 in the length, length of head $4 \frac{1}{2}$. Breadth of head $1 \frac{1}{2}$ in its length, length of snont 22 , diameter of eye $5 \frac{2}{3}$, interorbital widtl 4 . Jaws nearly equal anteriorly; width of mouth $\frac{2}{3}$ the width of head. Maxillary harbel extending to origin of adipose fin *. Head covered with smooth skin; occipital process extending $\frac{1}{2}$ of the distance from its hase to the origin of dorsal. 11 gill-rakers on the lower part of the anterior arch. 'Dorsal I 6 ; spine slender, fin rounded. Length of adipose fin $2 \frac{2}{3}$ in the length of the fish. Anal 13. Humeral process extending slightly beyond the middle of the pectoral spine, which is about $\frac{2}{3}$ the length of the fin and nearly $\frac{1}{2}$ the length of head. Tentrals inserted behind the last dorsal ray, extending $\frac{2}{3}$ of the distance from their base to the origin of anal. Caudal deeply notched. Least depth of eaudal peduncle $2 \frac{2}{3}$ in the length of head and $2 \frac{1}{4}$ in the distance from the anal to the base of caudal. Brownish.

\section{Hal. Lake Nicaragua ${ }^{1}$ (Dow).}

Here described from the type, measuring $190 \mathrm{~mm}$. in total length.

\section{Rhamdia boucardi. (Tab. XX. fig. 3.)}

? Rhamdia depressa, Barbour \& Cole, Bull. Mus. Comp. Zool. l. 1906, p. 155, t. $1^{2} \dagger$.

Pimelodus boucardi, Regan, Ann. Mag. Nat. Hist. (7) xix. 1907, p. $258^{2}$.

Depth of body $6 \frac{1}{2}$ in the length, length of head 4 . Breadth of head $1 \frac{1}{3}$ in its length, length of snout $2 \frac{3}{4}$. diameter of eye 6 , interorbital width 3 . Lower jaw nearly as long as the upper; width of mouth $\frac{2}{3}$ the width of head. Maxillary barbel extending to origin of adipose fin. Head eovered with smooth skin ; occipital process rather strong, extending $\frac{1}{2}$ the distance from its base to the origin of dorsal. 12 or 13 gill-rakers on the lower part of the anterior arch. Dorsal I 6, the spine slender, the fin rounded. Adipose fin $\frac{1}{3}$ the length of the fish. Anal 1t: when laid back nearly reaching the vertical from the end of adipose fin. Pectoral spine with serrated inner edge, abont $\frac{3}{5}$ the length of the fin and $\frac{1}{3}$ the length of head; humeral process long, nearly reaching the middle of the fin. Tentrals originating vearly below the last dorsal ray, extending more than $\frac{2}{3}$ of the distance from their base to the origin of anal. Caudal deeply notched, the lohes rounded, the lower the larger. Least depth of eandal pedunele 3 in the length of head, and $2 \frac{1}{3}$ in the distance from anal to base of eaudal. Blackish.

\section{Hab. Mexico, Yucatan ${ }^{1}$ (Boucard).}

Here described from the type, a specimen measuring $190 \mathrm{~mm}$. in total length.

\section{Rhamdia wagneri.}

Pimelodus cinerascens (nou Güntlı.), Kner \& Steind. Ablandl. Bạern. Akad. x. 1865, p. 19 ?

Pimelodus wagneri, Günth. Trans. Zool. Soc. vi. 1868, p. 4ĩ ".

Rhamdia bransfordi, Gill, Proc. Ac. Philad. 18\%6, p. $33 \pi^{3}$.

Rhamdia wagneri, Jord. \& Everm. Bull. U.S. Nat. Mus, xlvii. 1896, p. $151^{4}$.

leyth of body abont 6 in the length, length of. head $4 \frac{1}{2}$ to $t_{4}^{3}$. Breadth of head $1 \frac{1}{4}$ to $1 \frac{1}{3}$ in its length, length of snout $2 \frac{3}{3}$ to $2 \frac{3}{4}$, liameter of eye 6 to 7 , interorbital width $2 \frac{3}{5}$ to 3 . Lower jaw nearly as long as the upper; width of mouth about $\frac{2}{3}$ the width of head. Maxillary barbel extending abont to the origin of adipose fin. Head covered with smooth skin; occipital process extending $\frac{1}{2}$ of the distance from its base to the origin of dorsal. 7 to 9 gill-rakers on the lorrer part of anterior arch. Dorsal I 6 ; spine slender. fin rounded. Length of adipose fin $2 \frac{3}{5}$ to 3 in the length of the fish. Anal 10-12, when laid back nearly reaching the rertical from end of adipose fin. Humeral process extendiug about to the middle of

* As described by Günther. Both barbels are now broken off in the type, the longest reaching the middle of the dorsal.

$\uparrow$ Rhamdia depressa is probably the same as $R$. boucurti, but the description is insufficient and the figure bad. 
lectoral spine, which has the inner erge serrated and measures $\frac{2}{3}$ to $\frac{3}{1}$ of the length of the fin or about $\frac{1}{2}$ the length of head. Teutrals inserted behind the linst ray of dorsal, extending $\frac{3}{\hat{o}}$ to $\frac{3}{4}$ of the distance fiom their base to the origin of anal. Candil deeply notched, the lower lobe rounded. Least depth of candal pedunclo abont $\frac{1}{2}$ the length of head or of the distance from anal to base of caudal. Brownish; usually a blackish lateral stripe; fins dusky, tho dorsal with a pale band near the buse.

Hab. Costa Rica, Shilures (II. Pittier); Panama ${ }^{3}$.-W Western Ecuador (Rosenlerg).

Here described from four specimens, measuring 200 to $280 \mathrm{~mm}$. in total leugth. Probably records of this species from Sunthem Mexico refer to R. guatemalensis.

\section{Rhamdia petenensis. (Tab. XXII. fig. 1.)}

Pimelodes petenensis, Günth. Cat. Fish. v. p. 126 (1864) ? ${ }^{\text {? }}$

Rhamdia petenensis, Jord. \& Evern. Bull. U.S. Nat. Mus. xlvii. 1896, p. $153^{2}$.

Depth of body $5 \frac{1}{2}$ in tho length, length of head $4 \frac{3}{5}$. Breadth of bead $1 \frac{1}{5}$ in the length, length of snout $2 \frac{1}{5}$, diameter of eye $5 \frac{1}{2}$, interorbital width 3 . Jaws nearly equal anteriorly; width of mouth $\frac{2}{3}$ the width of head. Maxillary barbel extending to origin of adipose fin. Head covered with smocth skin; occipital process extending abont $\frac{1}{2}$ of the distance from its base to the origin of dorsal. 8 gill-rakers on the lower part of anterior arch. Dorsal I 6 ; spine slender, fin rounded. Longth of adipose fin 2.11 in the length of the fish. Anal 12. Humeral process extending to middle of pectoral spine, which is $\frac{2}{3}$ to $\frac{3}{7}$ the length of the fin and nearly $\frac{1}{2}$ the longth of head. Ventrals inserted behind the last dorsal ray, extending $\frac{3}{\bar{n}}$ of the distance from their base to the origin of anal. Caudal decply notched. Least depth of caudal pedunclo $1 \frac{3}{4}$ in the length of bead and $1 \frac{1}{2}$ in the distance from anal to baso of caudal. Lrownish; an indistinct dark luteral stripe; dorsal dusliy, with a palo band near the base.

\section{Ilal. Guatemala, Lake Peten ${ }^{1}$ (Salvin).}

Here described from the type, a specimen measuring $200 \mathrm{~mm}$. in total length.

\section{Rhamdia guatemalensis.}

Pimelorlus guatemalensis, Gïnth. Cat. Fish. v. p. 122 (1864) ${ }^{\perp}$.

Rlamdia guatemalensis, Jord. \& Everm. Bull. U.S. Nat. Mus. xlvii. 1896, p. 15:22.

Rhambla oaxace, Meck, Publ. Columbian Mus., Zool. r. 190 t, p. 20, t. $5^{3}$.

Depthol borly $5 \frac{1}{3}$ to $6 \frac{1}{2}$ in the length, length of head $3 \frac{1}{1}$ to $4 \frac{2}{3}$. Breadth of head $1 \frac{1}{3}$ to $1 \frac{2}{\%}$ in its length, Icngth

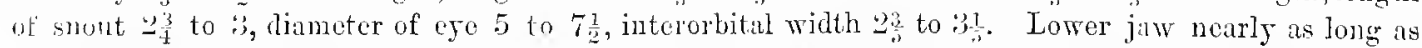

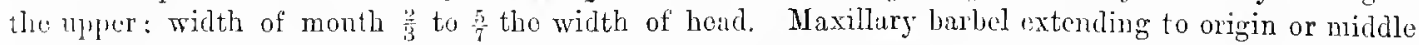
of ardiuso fin. Hoad corered with smooth skin; occipital process extending uearly $\frac{1}{2}$ the distance from its bisse to the origin of dursal. 5 to 7 gill-rakers on the lower part of anterior arch. Dorsal 16 ; spine slender, fin ronded. Length of alipose fin 22 to 3 in the leugth of the fish. Anal 11-13, when laid lark reaching the rentical from the end of adipose fin. Humeral process extending about to middle of pectoral spine, which has the inner elge serrated and measures from less than $\frac{2}{3}$ to more than $\frac{3}{4}$ the lengtl of the fin, or $\frac{2}{i,}$ to $\frac{1}{2}$ the length of hend. Ventrals inserted belind tho vertical from last ray of arsal, estending $\frac{3}{b}$ to the distance from their base to the origin of anal. Caudal deeply noteber, the lower lobe rounded. Least depth of caudal pedunclo 2 to $2 \frac{1}{2}$ in tho longth of liead or $1 \frac{1}{2}$ to 2 in the distince from anal to base of caudal. Brownish; usually a blackish latoral stripe; fins usually more or lees dusky, the dorsa] with an indistinct pale band near the baso.

Hab. Surtiens Mexico, Rio Blanco ${ }^{3}$, Rio Papaloapam ", Tequesixtlan in Oaxacar (Grentow); Britisir Hoxduras, Stann Creek (Robertson); Guatemala, Huamuchal ${ }^{1}$ (S'celvin). 
Here described from a large series of specimens, including the types of the species, measuring from 95 to $280 \mathrm{~mm}$. in total length.

Pimelodus baronis-mülleri, Trosch., 1865 (Rhamdia baronis-mulleri, Jord. \& Everm. Bull. U.S. Nat. Mus. xlvii. 1896, p. 151), is probably identical with P. guatemalensis.

\section{S. Rhamdia godmani. (Tab. XXI. fig. 1.)}

Pimelodus godmani, Günth. Cat. Fish. v. p. 124 (1864)?

Rhandia godmani, Jord. \& Everm. Bull. U.S. Nat. Mus. xlvii. 1896, p. 15:2.

? Rhandia sacrificii, Barbour \& Cole, Bull. Mus. Comp. Zool. 1. 1906, p. 150̈, t. $2^{3}$.

Depth of body about 6 in the length, length of head 4 to $4 \frac{1}{2}$. Breadth of head $1 \frac{1}{4}-1 \frac{1}{2}$ in its length, length of snout $2 \frac{2}{5}$ to $2 \frac{4}{5}$, diameter of eye $5 \frac{1}{2}$ to 7 , interorbital width $2 \frac{2}{3}$ to $3 \frac{1}{3}$. Lower jaw a little shorter than the upper; width of mouth about $\frac{2}{3}$ the width of head. Maxillary barbel extending about to origin of adipose fin. Head corered with smooth skin; occipital procoss extending about $\frac{2}{5}$ of the distance from its base to the origin of dorsal. 7 to 9 gill-rakers on the lower part of the anterior arch. Dorsal I 6 (exceptionally I 5); spine slender, fin rounded. Length of adipose fun $2 \frac{1}{2}$ to 3 in the length of the fish. Anal 11-13. Humeral process not extending beyond the middle of pectoral spine, which is $\frac{3}{5}$ to $\frac{3}{4}$ the length of the fin and $\frac{2}{5}$ to $\frac{1}{2}$ the length of head. Ventrals inserted behind the last dorsal ray, extending $\frac{3}{5}$ to $\frac{3}{4}$ of the distance from their base to the origin of anal. Caudal deeply notched. Least depth of caudal peduncle 2 to $2 \frac{1}{2}$ in the length of head or $1 \frac{2}{\overline{5}}$ to 2 in the distance from anal to base of caudal. Brownish; dorsal dusky, with a pale band.

Hab. Mexico ${ }^{1}$ (Sallé), Yucatan ${ }^{3}$; Gustexala, Baja Vera Paz ${ }^{1}$ (Godman \& Salvin), Rio Motagua ${ }^{1}$ (Salvin).

Here described from eight specimens, including the types of the species, measuring from 150 to $270 \mathrm{~mm}$. in total length.

\section{Rhamdia microptera. (Tab. XXIII. fig. 3.)}

Pimelodus micropterus, Günth. Cat. Fish. v. p. 124 (1864) ${ }^{2}$.

Rhamdia microptera, Jord. \& Everm. Bull. U.S. Nat. Mus. xlvii. 1896, p. 153 ².

Depth of body $6 \frac{1}{2}$ in the length, length of head $4 \frac{1}{2}$. Breadth of head $1 \frac{1}{3}$ in tho length, length of snout $2 \frac{4}{5}$, diameter of eje 6 , interorbital width 3. Jaws nearly equal anteriorly ; width of mouth rather more than $\frac{2}{3}$ the width of head. Maxillary barbol extending to middle of dorsal fin. Head covered with smooth skin; occipital process extending $\frac{2}{\overline{3}}$ of the distance from its base to the origin of dorsal. 7 gillrakers on the lower part of the anterior arch. Dorsal I 6; spine slender, fin rounded. Length of adipose fin $2 \frac{3}{4}$ in the length of the fish. Anal 13. Humeral process extending nearly to tip of pectoral spine, which is $\frac{3}{5}$ the length of the fin and $\frac{1}{3}$ the length of head. Ventrals inserted behind the last dorsal ray, extending $\frac{1}{2}$ of the distance from their base to the origin of anal. Caudal deeply notched. Least depth of caudal peduncle $2 \frac{1}{5}$ in the length of head and $1 \frac{4}{\overline{5}}$ in the distanco from anal to base of caudal. Dark greyish; fins dusky.

Hab. Guatemala, Rio San Gerónimo ${ }^{1}$ (Godman \& Salvin).

Here described from the type, a specimen measuring $170 \mathrm{~mm}$. in total length.

10. Rhamdia managuensis. (Tab. XXI. fig. 2.)

Pimelodus managuensis, Günth. Trans. Zool. Soe. vi. 1868, t. $474^{1}$. Rhamdia managuensis, Jord. \& Everm. Bull. U.S. Nat. Mus. xlvii. 1896, p. Iรั3 2. 
Depth of body 6 in the length, length of head 5. Breadth of head $1 \frac{2}{5}$ in its length, length of snout $2 \frac{3}{5}$, diameter of eye $5 \frac{1}{3}$, interorbital width 4 . Lower jaw nearly as long as the upper; width of mouth $\frac{2}{3}$ the width of head. Naxillary barbel extending nearly to the posterior end of pectoral fin. Head covered with smooth skin; occipital process extending $\frac{1}{3}$ of the distance from its base to the origin of dorsal. 9 to 11 gill-rakers on the lower part of anterior arch. Dorsal I 6 ; spine slender, fin rounded. Length of adipose fin $2 \frac{3}{5}$ in the length of the fish. Anal 1t, when laid back not nearly reaching the vertical from the end of adipose fin. Humeral process extending a little beyond the middle of pectoral spine, which has the imner edge serrated and measures $\frac{2}{3}$ the length of the fin or $\frac{2}{5}$ the length of head. Vontrals inserted behind the last ray of dorsal, extending $\frac{2}{3}$ of the distance from their base to the origin of anal. Candal deeply notched, the lower lobe rounded. Least depth of candal peduncle $2 \frac{1}{2}$ in the length of head and $2 \frac{3}{4}$ in the distance from anal to base of candal. Bromnish.

Ilab. Nicaragua, Lake Managua ${ }^{1}$ (Dow).

Here described from the type, a specimen measuring $210 \mathrm{~mm}$. in total length.

\section{Rhamdia heteracantha, sp. n.}

Depth of body $5 \frac{2}{3}$ in the length, length of head $4 \frac{1}{3}$. Brcadti of head $1 \frac{1}{3}$ in its length, length of snout, $2 \frac{3}{\cdots}$, diameter of eye $5 \frac{2}{3}$, interorbital width 3 . Lower jaw scarcely shorter than the upper; width of mouth $\frac{3}{5}$ the width of head. Naxillary barbel extending to origin of adipose fin. Head corered witl smooth skin; oecipital process triangular, extending about $\frac{2}{7}$ of the distance from its base to the origin of dorsal. 7 gill-rakers on the lower part of the anterior arch. Dorsal $I 6$; spine slender, fin rounded. Length of adipose fin nearly 3 in the length of the fish. Aual 10. Humeral process extendiug noarly to middle of pectoral spine, which has the inner edge finely scrrated and a series of antrorse denticulations on the outer edge and measures $\frac{2}{3}$ the length of the fin and $\frac{2}{5}$ to $\frac{1}{3}$ the length of head. Tentrals inserted behind the last ray of dorsal, extending $\frac{3}{4}$ of the distance from their base to the origin of anal. Caudal moderately notched. Least dejth of caudal peduncle $2 \frac{1}{5}$ in the length of head and $1 \frac{2}{4}$ in the distance from anal to base of caudal. Brownish.

\section{IIab. Costa Rica, Juan Viñas (Underwood).}

A single specimen, measuring $105 \mathrm{~mm}$. in total length.

\section{Rhamdia hypselura. (Tab. XXI. fig. 3.)}

Pimelodus hypselurus, Guinth. Cat. Fish. v. p. 126 (1861) '.

Rhandia hypseturus, Jord. \& Everm. Bull. U.S. Nat. Mus. xlvii. 1896, p. 152².

1)epth of horly about $5 \frac{1}{2}$ in the length, length of head $4 \frac{12}{3}$. Breadth of head $1 \frac{1}{4}$ in its length, length of snout $y$, diameter of eye $5 \frac{1}{3}$, interorbital width 3. Lower jaw shorter than the upper; width of mouth slightly more than $\frac{3}{i}$ the width of head. Maxillary barbel extending to niddle of dorsal fin. Head eorered with smooth skin; occijital process extending $\frac{2}{7}$ of the distance from its base to the origin of dorsal. 9 gill-rakers on the Iower part of the anterior arch. Dorsal I 6 ; spine slender, fin rounded. Length of adipose fin $3 \frac{1}{2}$ in the length of the fish. Anal 13. Humeral process extending to middlo of pectoral spine, which is $\frac{2}{3}$ the length of the fin and $\frac{1}{2}$ the length of head. Tentrals inserted behind the last dorsal ray, exteuding $\frac{2}{3}$ of the distance from their base to the origin of anal. Caudal moderately notched. Least dejth of candal peduncle $1 \frac{2}{5}$ in the longth of head and $1 \frac{1}{2}$ in the distance from anal to base of candal. Dark greyish.

Llub. Mexico ${ }^{1}$ (Parmazki).

IIcre described from the type, a specimen measuring $115 \mathrm{~mm}$. in total length. 
13. Rhamdia brachycephala. (Tab. XXII. fig. 2.)

Pimelorlus brachycephalus, Regan, Ann. Mag. N. H. (7) xix. 1907, p. 258 '.

Depth of body $5 \frac{1}{2}$ to $6 \frac{1}{2}$ in the length, length of head $5 \frac{1}{3}$ to $5 \frac{1}{\overline{5}}$. Breadth of head $1 \frac{1}{5}$ in its length, length of snout $2 \frac{2}{3}$ to 3 , diameter of eye 5 to 6 , interorbital width 3 to $3 \frac{1}{2}$. Lower jaw a little shorter than the upper; width of mouth $\frac{1}{2}$ to $\frac{2}{5}$ the width of head. Waxillary barbel extending to the basal part of pectoral. Head covered with smooth skin; occipital process slender, extending about $\frac{1}{1}$ of the distance from its base to the origin of dorsal. 6 to 8 gill-raliers on the lower part of the anterior areh. Dorsal $I 6$, the spines slender, the fin rounded. Length of adipose fin $3 \frac{1}{4}$ to $3 \frac{3}{4}$ in the length of the fish. Anal 12-1:3, when laid back sometimes reaching the vertical from end of adipose fin. Pectoral spine with serrated inner edge, about $\frac{3}{\bar{\partial}}$ the length of the fin and $\frac{2}{5}$ the length of head; humeral process extending to or beyond the middle of the spine. Ventrals originating behind the dorsal, extending $\frac{1}{2}$ to $\frac{3}{5}$ the distance from their base to the origin of anal. Caudal moderately notched, the lower lobe rounded and rather shorter than the upper. Teast depth of eardal peduncle $\frac{2}{3}$ or more than $\frac{2}{3}$ the length of head, $1 \frac{2}{5}$ to $1 \frac{4}{3}$ in the distance from anal to base of caudal. Brownish.

Hab. Guatemala, Rio Nacasil ${ }^{1}$ (Salvin).

Here described from the types, six specimens, measuring up to $190 \mathrm{~mm}$. in total length.

\section{Rhamdia underwoodi, sp. n. (Tab. XXIII. fig. 4.)}

Depth of body $5 \frac{1}{2}$ to 6 in the length, length of head $4 \frac{2}{3}$ to 5 . Breadth of head $1 \frac{1}{5}$ to $1 \frac{1}{4}$ in its length, length of snont $2 \frac{2}{3}$ to $2 \frac{4}{5}$, diameter of eye 6 to 7 , interorbital width 3 . Lower jaw searcely shorter than the upper; width of mouth $\frac{1}{2}$ to $\frac{3}{5}$ the width of head. Maxillary barbel extending to posterior end of pectoral fin. Head eorered with smooth skin; occipital process extending $\frac{1}{5}$ or $\frac{1}{6}$ of the distance from its base to the origin of dorsal. 7 or 8 gill-rakers on the lower part of the anterior arch. Dorsal I 6 (exoeptionally I 7) ; spine slender, fin rounded. Length of adipose fin $3 \frac{2}{3}$ to $t_{4}^{\frac{1}{4}}$ in the length of the fish. Anal 11-12. Humeral process short, not extending to middle of pectoral spine, which has the inner edge serrated and measures about $\frac{3}{5}$ the length of the fin and $\frac{1}{3}$ to $\frac{2}{5}$ the length of the head. Ventrals inserted behind the last ray of the dorsal, extending $\frac{1}{2}$ to $\frac{2}{3}$ of the distance from their base to the origin of anal. Caudal moderately notched. Least depth of caudal peduncle $1 \frac{3}{1}$ to 2 in the length of head and $1 \frac{1}{2}$ to $1 \frac{3}{12}$ in the distance from anal to base of caudal. Blackish grey.

Hab. Costa Rica, Juan Viñas (Underwood).

Four specimens, the largest $100 \mathrm{~mm}$. in total length.

15. Rhamdia salvini. ('Tab. XXIII. fig. 2.)

Pinelodus salvini, Günth. Cat. Fish. v. p. 130 (186t) ${ }^{1}$.

Rhamdia salvini, Jord. \& Everm. Bull. U.S. Nat. Mus. xlvii. 1896, p. 152.

Depth of body $6 \frac{1}{3}$ in the length, length of head $5 \frac{2}{3}$. Breadth of head $1 \frac{1}{1}$ in its length, length of snout $2 \frac{1}{2}$, diameter of eye 6 , interorbital width $3 \frac{1}{4}$. Jaws nearly equal anteriorly; width of month $\frac{3}{5}$ the width of head. Maxillary barbel extending a little bejond middle of pectoral. Head eorered with smooth skin; occipital process short, triangular, extending $\frac{1}{5}$ of the distanco from its base to the origin of dorsal. $\tau$ gill-rakers on the lower part of anterior arch. Dorsal I 6 ; spine slender, fin rounded. Length of adipose fin $3 \frac{1}{2}$ in the length of the fish. Anal 12. Humeral process extending bejoud the middle of the pectoral spine, which is about $\frac{1}{2}$ the length of the fin and $\frac{1}{3}$ the longth of head. Tentrals inserted behind the last dorsal ray, extending $\frac{3}{\bar{n}}$ of the distance from their base to the origin of anal. Caudal moderately notohed. Least depth of caudal peduncle $1 \frac{2}{3}$ in the length of head and 2 in the distance from aval to base of caudal. Brownish. 


\section{Hab. Guatemala, Rio San Gerónimo ${ }^{1}$ (Salvin).}

Here described from the type, a specimen measuring $135 \mathrm{~mm}$. in total length.

\section{Rhamdia polycaulus. (Tab. XXII. fig. 3.)}

Pimelodus polycaulus, Giinth. Cat. Fish. v. p. 131 (186t) ’.

Rhandia polycaulus, Jord. \& Everm. Bull. U.S. Nat. Mus. xlvii. 1896, p. $153^{2}$.

Iepth of body $5 \frac{2}{3}$ in the length, length of head $5 \frac{1}{3}$. Breadth of head $1 \frac{1}{1}$ in its length, length of snout $2 \frac{1}{5}$, diameter of eye 5 , interorbital width $3 \frac{1}{5}$. Lower jaw shorter than the upper; width of mouth $\frac{3}{5}$ the width of head. Maxillary barbel extending to posterior ond of pectoral. Head covered with smooth skin; occipital process short, triangular, extending $\frac{1}{5}$ of the distance from its base to the origin of dorsal. 6 gill-rakers on the lower part of anterior arch. Dorsal $I 6$; spine slender, fin rounded, last ray elcft to the base. Length of adjpose fin $2 \frac{5}{6 i}$ in the length of the fish. Anal 15. Humeral process extending nearly to end of pectoral spine, which is less than $\frac{1}{2}$ the length of the fin and $\frac{1}{3}$ the length of head. Ventrals inserted behind the last dorsal ray, extending $\frac{2}{3}$ of the distance from their base to the origin of anal. Caudal moderately notched. Least depth of caudal peduncle $1 \frac{4}{5}$ in the length of head or in the distance from anal to base of candal. Brownish.

\section{Ilab. Guatemala, Rio San Gerónimo ${ }^{1}$ (Salvin).}

Here described from the type, a specimen measuring $115 \mathrm{~mm}$. in total length.

\section{Rhamdia rogersi. (Tab. XXIII. fig. 1.)}

Pimelodus rogersi, Regan, Amm. Mag. N. H. (7) xix. 190\%, p. $259^{1}$.

Dey,th of body 6 in the length, length of head 5 . Breadth of head $1 \frac{1}{\text { in }}$ in length, length of snout 3 , diameter of eye 6 , interorbital width 3 . Lower jaw shorter than the upper; width of mouth $\frac{3}{\overline{3}}$ the width of head. Maxillary barbel extending to middle of pectoral fin. Head coyered with smooth slin ; occipital process short, slcnder, extending about $\frac{1}{5}$ of the distance from its basc to the origin of dorsal. 7 gill-rakers on the lower part of anterior arch. Dorsal I 6 ; spine slender, fin rounded. Length of adipose fin about $4 \frac{1}{2}$ in the length of the fish. Anal 12-14, when laid back nearly reaching the vertical from the end of adipose fin. Humeral process extcnding about to the middlo of pectoral spine, which has the immer edge scrrated and measures nearly $\frac{2}{3}$ the length of the fin or nearly $\frac{2}{5}$ the lengtl of head. Tentrals originating behind the last ray of dorsal, extcnding $\frac{1}{2}$ the distance from their base to the origin of anal. Candal slightly notched. Least depth of caudal peduncle about $1 \frac{2}{3}$ in the length of head or $1 \frac{1}{2}$ to 2 in the distance from anal to base of caudal. Brownish.

Hal. Costa Rich, Irazu ${ }^{1}$ (Rogers).

Here described from the types, four specimens measuring up to $130 \mathrm{~mm}$, in total length.

\section{Rhamdia laticauda.}

Pimelodus laticaudus (Heck. MS.), Kuer, Sitzungsb. Ak. Wien, xxvi. 1857, p. 420 ${ }^{1}$; Günth. Cat. Fish. v. p. 127 (1864) 2 .

Rhamdia laticauda, Jord. \& Everm. Bull. U.S. Nat. Mus. xlvii. 1896, p. $152^{3}$.

Evidently allicd to the preceding, differing at least in the longer barbels and the lunger adipose fin.

\section{IIal. Mexico ${ }^{1}$.}

'Total length about $220 \mathrm{~mm}$. 


\section{PIMELODUS, Lacep., 1803.}

Pimelodella and Pimelodus, Jord. \& Everm. Bull. U.S. Nat. Mus. xlvii. 1896, pp. 153 \& 154.

Occipital process extending to shield at base of dorsal spine; dorsal spine pungent ; in other respects simailar to Rhandia.

Numerous species, ranging from Panama to La Plata.

Synopsis of the Mexican and Central-American Species.

I. Head covered with smooth skin; maxillary barbel about reaching origin of adipose fin. Occipital process twice as long as broad; adipose fin about $\frac{2}{7}$ the length of the

fish . . . . . . . . . . . . . . . . . . . . 1. chagresi. Occipital process 3 times as long as broad; adipose fin $\frac{1}{3}$ the length of the fish . . 2. modestus.

II. Head naked, rugose; maxillary barbel extending to caudal fin . . . . 3. maculatus.

\section{Pimelodus chagresi.}

Pimelodus chagresi, Steind. Sitzungsb. Ak. Wien, lxii. 1876, p. 584 ${ }^{1}$.

Hab. Panama, Rio Chagres.

\section{Pimelodus modestus.}

Pimelodus modestus, Günth. Proc. Zool. Soc. 1860, p. $239^{1}$, and Cat. Fish. v. p. 117 (1864) ${ }^{2}$.

Hah. ? Panama.-Western Ectador ${ }^{12}$.

P. modestus has been recorded from the Rio Chagres by Kner and Steindachner (Abhandl. Bayer. Ak. x. 1865, p. 49), but it is not improbable that this record refers to the preceding species, which appears to differ from it only in the characters given in the key.

\section{Pimelodus maculatus.}

Pimelodus clarias, Steind. Denkschr. Ak. Wien, xli. 1879, p. $162^{2}$.

Pimelodus maculatus, Jord. \& Everm. Bull. U.S. Nat. Mus. xlvii. 1896, p. 155 .

Hab. Panama, Rio Mamoni ${ }^{1}$.

Steindachner's description of specimens from the Rio Mamoni, Panama, is not sufficiently detailed to show whether they should be referred to one of the SouthAmerican species which have been placed together under the names P. clccrias, L., or P. maculatus, Lacep. The specimens in the British Museum which come nearest to them geographically are from Colombia, but these are certainly distinct from the Mamoni River form.

Biol. Centr.-Amer., Pisces, November 1907. 
6. CONORHYNCHUS, Bleek., $1863 \%$

Conorlyncluse, Günth. Cat. Fish. v. p. 135 (1864).

Tecth feeble or absent: adipose fin rather short; in other respects similar to Pinclodus.

Three species, ranging from Mexico to Brazil.

\section{Conorhynchus nelsoni.}

Conorhynchus nelsoni, Everm. \& Goldsborough, Bull. U.S. Fish. Comm. xxi. p. I40, fig. 1 (1902).

Snout long, conical; posterior part of head naked, rugose; barbcls short. Dorsal I 6. Anal 17. Caudal forked.

Irab. Mexico, Rio Usumacinta in Chiapas.

\section{AMIURUS, Rafin., 18:0.}

Ictalurus, Amiurus, Tillurius, and Istlarius, Jord. \& Everm. Bull. U.S. Nat. Mus. xlvii. 189(i1900, pp. 133, 135, 29799, \& 3138.

Body clongate; mouth terminal or sulbterminal; jaws with villiform teeth in bands, the premaxillary band of teeth of nearly equal breadth throughont, sometimes with a slight posterior extension on each side; palate toothless; nostrils remote from each other, the posterior with a barbel; barbels eight. Dorsal fin with a spine and 6 branched rays; adipose fin short; anal of moderate longth or rather elongate: rentrals 8- or 9-rayed.

About 20 species from North and Central America and one from China.

Synopsis of the Hevican and Central-American Species.

I. Candal fin forked or ileeply emarginate.

A. Occipital process notcher at the apex for the reception of the anterior point of the second interneural. (Ionuturess.)

Anal with 28 to 32 rays; pectoral spine about $\frac{1}{2}$ the length of head, its inner edge with 9-1:2 serra; maxillary barbel extending to base of pectoral; silvery, back darker . . . . . . . . . . . . . . . . . . . . . .

Anal with 25 to 80 rays; pectoral spine nearly $\frac{2}{3}$ the length of head, its imer edge with 10 or 11 serre; maxillary barbcl cxtending uearly to middle of pectoral; silvery, luack darker, sides usually with small, round, dark spots. 2. punctatus.

B. Occipital process pointed or truncated posteriorly, not or scarcely reaching the second interncural. (liauspor.)

1. Pectoral spine witl inncr edgc distinctly serrated.

Anal with 32 to 37 rays; pectoral spine about $\frac{1}{2}$ thie lcugth of head, its inner cdge with 5 or 6 strong serræ; maxillary barbel cxtending to basal part or mildle (young) of pectoral . . . . . . . . . . . . . . .

Inal with 24 to 29 ray's p pectoral spine albont $;$ the length of head, its inner cdge with 7 to 9 serrie; maxillary luarbel extending to middle of pectoral . 1. meridionalis. Anal with 19 to with 10 to 12 rather slort projections, some of which are bifid; maxillary

barbel extending ncarly to nirldle of pectoral . . . . . . . . . 5. pricei.

\footnotetext{
* I'reoccuy,ied in Colooptora (Motsolaulsky, 1860).
}

3. furcalus.

4. lupus. 
Anal with 21 rays; peetoral spine $\frac{2}{5}$ the leugth of head, its inner edge with 5 strong serræ; maxillary barbel extending to basal part of pectoral . . 6. meeki.

2. Pectoral spine with inner edge entire or very indistinctly serrated.

Anal with 26 rays; pectoral spinc a little less than $\frac{1}{2}$ the length of head;

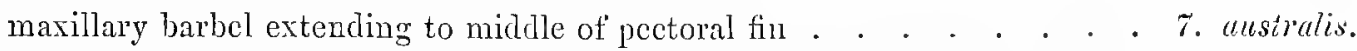

Anal with 20 or 21 rays; pectoral spine a little less than $\frac{1}{2}$ the leugth of head; maxillary barbel extending to loasal part of pectoral; middle candal rays $\frac{2}{3}$ as long as the longest rays . . . . . . . . . . . . . . . .

Anal with 20 to 24 rays ; pectoral spine about $\frac{1}{2}$ the length of head ; maxillary barbel extending to basal part of pectoral; middle caudal rays not more than $\frac{1}{2}$ as long as the longest . . . . . . . . . . . . . . .

Anal with 24 to 26 rays; pectoral spine $\frac{1}{3}$ the length of head; maxillary barbel extending to basal part of pectoral fin . . . . . . . . 10. balsanus.

II. Caudal fin subtrumeate. (AxruRus.)

Anal with 24 to 27 rays . . . . . . . . . . . . . . 11. natalis.

\section{Amiurus meridionalis.}

Amiurus meridionalis, Günth. Cat. Fish. v. p. 102 (1864) ', and Trans. Zool. Soc. vi. 1868, p. 473, t. 81. fig. $1^{2}$.

Ictalurus meridionalis, Jord. \& Everm. Bull. U.S. Nat. Mus. xlvii. 1896, p. $135^{3}$.

Ichthycalurus meridionalis, Meek, Publ. Columbian Mus., Zool. v. 1904, p. $11^{4}$.

Hab. Mexico, Rio Otopa in Vera Cruz ${ }^{4}$; Guntemala, Rio Usumacinta ${ }^{2}$ and Rio Chisoy (Salvin).

The largest of four specimens in the British Museum measures $340 \mathrm{~mm}$. in total length.

\section{Amiurus punctatus.}

Ictalurus punctatus (Rafinesque), Jord. \& Everm. Bull. U.S. Nat. Mus. xlvii. 1896, p. $135^{1}$. Ichthyalurus punctatus, Meek, Publ. Columbian Mus., Zool. v. 1904, p. $135^{2}$.

Hab. Great Lakes to Tamaulipas 12.

I have examined specimens from Arliansas and the Ohio River; the species is said to attain to a weight of twenty-íve pounds.

\section{Amiurus furcatus.}

Ictalurus furcatus (Le Sueur), Jord. \& Everm. Bull. U.S. Nat. MIus. xlvii. 1896, p. 134'. Ichthycelurus furcatus, Meck, Publ. Columbian Mus., Zool. v. 1904, p. $10^{2}$.

Hab. Iowa and Ohio to Tamaulipas ${ }^{1} 2$.

This species is said to attain a weight of forty pounds. I bave examined a few small specimens, including one of the types of $A$. affinis, Baird \& Girard, and 
specimens collected at Juarez, Rio Grande, by Mr. A. J. Woolman, who determined them as A. punctatus. In these the occipital process is not notched posteriorly and scarcely reaches the second interneural, but whether this is the case in the adult fish I cannot say.

\section{Amiurus lupus.}

Amiurus lupus (Girard), Jord. \& Everm. Bull. U.S. Nat. Mus. xlvii. 1896, p. 137' ; Mcck, Publ. Columbian Mus., Zool. v. 190t, p. $1 t^{2}$.

Hab. North America, Texas '.-Mexrco, Nuevo Leon ${ }^{2}$ and Tamaulipas 2.

I have examined four specimens from the Rio Soto Marina (Heek), the largest measuring $150 \mathrm{~mm}$; the species attains to a length of $450 \mathrm{~mm}$.

\section{Amiurus pricei.}

lillarius pricei, Rutter, Proc. Calif. Ac. Sci. (2) vi. 1896, p. $257^{1}$; Jord. \& Everm. Bull. U.S. Nat. Mus. xlvii. 1900, p. $2799^{2}$.

11ab. Upper tributaries of the Rio Yaqui in Sonora and Southern Arizona ${ }^{12 .}$

I have examined one of the types, a specimen measuring $240 \mathrm{~mm}$. in total length.

\section{Amiurus meeki, sp. n. (Tab. XXIII. fig. 5.)}

Amiurus pricei (non Rutter), Meek, Publ. Columbiau Mus., Zool. v. 1904, p. $16^{2}$.

Depth of body 5 in tho length, length of head 4. Snout $1 \frac{2}{3}$ as long as ejo, the diameter of which is 5 in the length of head; interorbital width $3 \frac{1}{3}$ in the length of head. Mouth subterminal; maxillary barbel extending to basal part of peetoral. 11 gill-rakers on the lower part of the anterior arch. Occipital process obtusely pointed, not quite reaehing the seeond internasal. Dorsal I 6 ; spine short, $\frac{2}{3}$ the length of head. Anal 21, the free edge convex, the middle rays the lengest. Pectoral spine $\frac{2}{5}$ the length of head, its inner edge with 5 strong serræ; humeral process extending beyond the middlo of pectoral spino. Caudal deeply emarginate, the middle rays $\frac{2}{3}$ as long as the longest, the lobes rounded. A few indistinet small round dark sprots on the sides; candal with a dark edge.

Hab. Mexico, Miñaca in Chihuahna (Meek ${ }^{1}$ ). (Also recorded by Meek from Lerdo and Durango in Durango.)

A single specimen, $105 \mathrm{~mm}$. in total length.

\section{Amiurus australis.}

Amiurus australis, Meek, Publ. Columbian Mus., Zool. v. 1904, p. $13^{1}$.

Hab. Mexico, Rio Forlon in Tamaulipas ${ }^{1}$, Rio Blanco in Vera Cruz ${ }^{1}$.

\section{Amiurus mexicanus.}

Amiurus mexicanus, Mcck, Publ. Columbian Mus., Zool. v. 1904, p. 15 '.

Hab. Mexico, Rio Verde in San Luis Potosi ${ }^{1}$ 


\section{Amiurus dugesi.}

Amiurus dugesi, Bean, Proc. U.S. Nat. Mus. 1879, p. $304^{2}$; Jord. \& Everm. Bull. U.S. Nat. Mus. xlvii. 1896, p. $138^{2}$; Meek, Publ. Columbian Mus., Zool. v. 1904, p. $15^{3}$.

Hab. Mexico, Rio Lerma System ${ }^{2} 3$.

I have examined a number of specimens in the British Museum from Lake Chapala (Jordan, Meek) measuring up to $200 \mathrm{~mm}$. in total length. A specimen from Salarnanca (Woolman) appears to belong to the same species, but has the dorsal and pectoral spines shorter, less than $\frac{1}{2}$ the length of head.

\section{Amiurus balsanus.}

Istlarius balsanus, Jord. \& Snyder, Bull. U.S. Fish. Comm. xix. 1899, p. 118 (1900) ' ; Jord. \& Everm. Bull. U.S. Nat. Mus. xlvii. 1900, p. $3138^{2}$; Meek, Publ. Columbian Mus., Zool. v. 1904, p. 17, fig. $2^{3}$.

Hab. Mexico, Rio Balsas ${ }^{1} 2$.

The præmaxillary band of teeth has a slight posterior projection on each side, but this is scarcely sufficient justification for placing this species in a different genus from A. dugesii, to which it is closely allied. I have examined three specimens (Jordan, Meek), the largest $180 \mathrm{~mm}$. in total length. The species attains a length of $900 \mathrm{~mm}$.

\section{Amiurus natalis.}

Amiurus natalis (Le Sueur), Jord. \& Everm. Bull. U.S. Nat. Mus. slvii. 1896, p. $139^{1}$; Meek, Publ. Columbian Mus., Zool. v. 1904, p. $16^{2}$.

Hab. Nortil America, Great Lakes to the Rio Grande ${ }^{12}$.

\section{LEPTOPS, Rafinesque, 1820.}

Leptops, Jord. \& Everm. Bull. U.S. Nat. Mus. xlvii. 1896, p. 142.

Præmaxillary band of teeth with a well-developed pointed posterior extension on each side; dorsal fin with a spine and 7 branchod rays; in other respects similar to Amiurus.

A single species from North America and Northern Mexico.

\section{Leptops olivaris.}

Leptops olivaris (Rafinesque), Jord. \& Everm. Bull. U.S. Nat. Mus. xlvii. 1896, p. $143^{1}$; Meek, Publ. Columbian Mus., Zool. v. 1904, p. 18 ".

Body slender; head depressed; lower jaw a little projecting. Dorsal I 7. Anal 13-16. Caudal truncate.

Peetoral spine with the inner edge serrated and with the outer edge roughened or serrated. Yellowish, marbled with brownish.

Hab. North America, Mississippi System and Southern United States ${ }^{2}$.- Mexico, Chihuahua 12.

This species is an important food-fish, and is said to attain a weight of fifty to seventy-five pounds. 


\section{Fam. 3. CYPRINID庒.}

Fresh-water fishes of North America, Eurasia, and Africa. The species are very numerous, about 1400 being known. The American Cyprinide extend southwards to the Rio Balsas in Southern Mexico and the Rio Usumacinta in Guatemala. The Mexican and Central-American representatives are scaly fishes, with the mouth toothless, with the gill-membranes joined to the isthmus and with 3 branchiostegals. There are no spinous fin-rays, the single dorsal fin is not followed by an adipose fin and the rentral fins are abdominal, $T$ - to 12 -rayed. The upper pharyngeals are toothless and the lower pharyngeals are falciform, each with 1 to 3 series of teeth.

Synopsis of the Gencra representerl in Mcaico and Central Ancerica*.

I. Month bordered above by the premaxillaries and the maxillaries; lips fleslly, papillose or plieated; pharyngeal tecth in a single series, 6 or more in number on eaeh sids. [C.тоттомик..]

A. Dorsal fin long, of 20 to 35 rays. . . . . . . . . . 1. Ictionus.

B. Dorsal fin short, of 8 to 16 rays.

1. Body nomally shaped; no nuehal hump.

Seales moderate, 40 to 50 in a longitudinal series; jaws without carti-

laginous slieaths . . . . . . . . . . . . . . . 2. Moxostoma.

Scales small, 60 to 100 in a longitudinal series; jaws with more or less

distinct cartilaginons sheaths . . . . . . . . . . 3. CA Tostovus.

2. Nuehal region with an elevated sharp-edgcd hump, the interneural spines being enlarged and expanded; seales small . . 4. Xrraucnen.

11. Nouth bordered above by the premaxillaries; lips not papillose nor plieated; pharyngeal teeth in 1 to 3 series, 3 to 6 in number in the main row on each side. [Cyprinins.]

A. No barbels.

1. Abdomen behind the rentral fins eompressed to for'm a keel; ancl fin more or less elongate . . . . . . . . . . 5. Abramis.

2. Abrlomen not eompressed to an edge.

a. Anterior 2 or 3 rays of dorsal fin simple, graduated and closely connected, the first not enlarged nor separated by a membrane from the seeond.

$\alpha$. Air-bladder eompletely surrounded by convolutions of the very long intestine . . . . . . . . . . . . 6. Campostoma.

B. Air-bladder not surrounded by the intestine.

* Pliaryngeal teeth subeonieal or more or less compressed and hooked, 4 to 6 in the main row on each side.

+ Gill-ralicrs comparatively few and short.

* A revision of the Americun Cyprinidie would probably show that several of the genera here recognized are untenable. For the present I have thought it best to agree as far as possible with the current American nomenclature for the fishes of this family. 
§ Intestinc elongate, with several convolutions; pharyngeal teeth compressed, scarcely hooked, with broad grinding-surface, in a single scries, 4-4.

Seales large, less than 60 in a longitudinal series . . . . . . . . 7. Hrbognarhus.

Scales small, 60 or more in a longitudinal series . . . . . . . . 8. Algansea.

$\S \S$ Intestine comparatively short; pharyngeal teeth subeonical, scareely hoohed, wide apart, in 2 series,

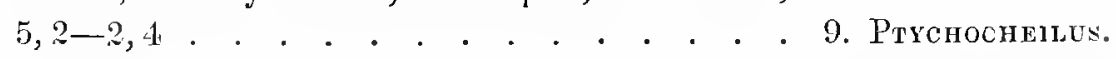

$\S \S \S$ Intestine comparatively short; pliaryngcal teeth compressed and looked, without or with narrow grinding-surface, not set wide apart.

$\ddagger$ Pharyngeal teeth in 2 series, $4-6,1-2-2-1,4-6$. 10. Leucrscus.

$\ddagger \ddagger$ Pharyngeal teeth nsually in a single series, $4-4$; sometimes a sccond series of 1 or 2 small teeth.

Lips normal ; scales rather large, 45 to 50 in a longitudinal series; ventral

fins 10-rayed . . . . . . . . . . . . . . . . 11. Falcula.

Lips normal ; scales rather large, 30 to 60 in a longitudinal series; ventral

fins 8-rayed . . . . . . . . . . . . . . . . 12. Notropis.

Lips normal ; scales small, 85 to 95 in a longitudinal series . . . . . 13. Evarra.

Lower lip forming a fleshy lobe on each side . . . . . . . . . 14. Phenacobius.

† Gill-rakers very long, slender, and numerous . . 15. XYstrosus.

** Pharyngeal teeth cylindrical, with obtusely convex apices,

in a single series, 3 in number on each side . . . . 16. STrpopon.

b. First dorsal ray more or less enlargcd and spinous or surrounded by thick skin, separated by a membrane from the second ray.

Jars without hard sheaths . . . . . . . . . . . . . . 17. Pinephales.

Jaws with hard sheaths, forming cutting-plates . . . . . . . 18. Cochlognathus.

B. A small barlyel at or near the end of each maxillary.

1. Mouth terminal, oblique.

Seales rather large, 45 to 50 in a longitudinal series . . . . . . 19. Yuriria.

Scales smaller, 55 to 75 in a longitudinal series . . . . . . . . . 20. Couesius.

2. Mouth subterminal or inferior.

a. Premaxillaries protractile.

Scales large, less than 60 in a longitudinal series . . . . . . . . . 21. Hrвopsis.

Seales smaller, 60 to $90 \mathrm{in}$ a longitudinal series . . . . . . . . 22. Agosia.

b. Præmaxillaries not protractile . . . . . . . . 23. Rнилichtнys.

1. ICTIOBUS, Rafin., 1820.

Ictiobus and Carpiodes (Rafin.), Jord. \& Everm. Bull. U.S. Nat. Mus. xlvii. 1896, pp. 163, 165.

This genus is at once distinguished from other Mexican Catostominæ by the elongate dorsal fin. It comprises about ten species, ranging from the region of the Great Lakes to Guatemala. 
Synopsis of the Mexican and Central-American Species.

I. Deptl of body $2 \frac{3}{4}$ to $3 \%$ in the length; pectoral fin not extending to the ventral.

A. Dorsal fin of 28 to 31 rays . . . . . . . . . . . . . . . 1. meridionalis.

B. Dorsal fin of 23 to 26 rays.

1. Origin of ventrals below aloout the seventh dorsal ray.

Depth of body $2 \frac{3}{4}$ to $3 \frac{1}{3}$ in the length ; caudal peduncle as long as deep . . . 2. microstomus.

Depth of body $3 \frac{1}{4}$ to $3 \frac{2}{3}$ in the length; caudal peduncle longer than deep . . 3. elongatus.

2. Origin of ventrals below about the third dorsal ray . . . . 4. labiosus.

I1. Depth of body about $2 \frac{5}{5}$ in the length; pectoral extending to or a little

beyond the base of ventral . . . . . . . . . . . . 5. tumidus.

1. Ictiobus meridionalis. (Tab. XXIV. fig. 1.)

scterognathus meridionalis, Günth. Cat. Fish. vii. p. 23 (1868) ${ }^{2}$.

Ictiobus meridionalis, Jord. \& Everm. Bull. U.S. Nat. Mus. xlvii. 1896, p. 164 ${ }^{2}$

Carpiodes meridionalis, Meek, Publ. Columbian Mus., Zool. v. 1904, p. $26^{3}$.

1)epth of body $2 \frac{3}{4}$ to $3 \frac{1}{3}$ in tho leugth, length of head 4 to $4 \frac{1}{2}$. Diameter of eye $1 \frac{1}{2}$ in the length of suout and $5 \frac{1}{2}$ in the length of head; interorbital width 2 to $2 \frac{1}{4}$ in the length of head. Snout obtuse, more or less projecting beyond the mouth, which has plicated lips. 36 to 40 scales in a longitndinal series, 7 or 8 in a transverse serics from origin of dorsal fin to lateral line, 5 or 6 between lateral line and base of ventral. Dorsal 28-31, the 3 anterior rajs simple, the fin elevated anterierly, the longest ray shorter than the head. Anal 10, the 3 anterior rays simple, the fin, when laid back, extending to the caudal. Peetoral extending $\frac{2}{3}$ to $\frac{5}{6}$ of the distance from its base to the origin of the ventral, which is bolow tho fourth to sixth rays of the dorsal. Caudal emarginate. Caudal peduncle nearly as long as decp. Silvery, back brownish.

Hab. Mexico, Perez in Vera $\operatorname{Cruz}^{3}$ (Meek); Guatemala, Rio Usumacinta (Salvin) ${ }^{1}$.

I Iere described from the types, four specimens, 200 to $250 \mathrm{~mm}$. in total length, with which I have compared two small specimens from Perez. This species is said to attain a length of over $600 \mathrm{~mm}$.

\section{Ictiobus microstomus.}

Carpiodes microstomus, Meek, Publ. Columbian Mus., Zool. v. 1904, p. 27, fig. 4'.

Ilab. Mexico, Rio Conchos in Chihuahua ${ }^{1}$.

Four small specimens from the Rio Conchos (Meek) differ from I. meridionalis especially in the shorter dorsal fin.

\section{Ictiobus elongatus.}

Cirpriodes elongatus, Mcek, Publ. Columbian Mus., Zool. v. 1904, p. 28, fig. 5 '.

Ilab. Mexico, Rio San Juan, Rio Conchos, and Rio Soto Marina in Tamaulipas ! 


\section{Ictiobus labiosus.}

Carpiodes labiosus, Meek, Publ. Columbian Mus., Zool. v. 1904, p. 29, fig. $6{ }^{2}$.

IIab. Mexico, Valles in San Luis Potosi ${ }^{1 .}$

\section{Ictiobus tumidus.}

Ictiobus tumidus, Girard, U.S. \& Mex. Bound. Surv., Fish. p. 34, t. 19. figs. 1-4 (1859) '. Carpiodes velifer (part.), Jord. \& Everm. Bull. U.S. Nat. Mus. xlvii. 1896, p. $167^{2}$. Carpiodes tumidus, Meek, Publ. Columbian Mus., Zool. v. 1904, p. $27^{3}$.

Haל. Texas and North-eastern Mexico:

Texas ${ }^{2}$, Rio Grande at Fort Brown ${ }^{1}$; Rio Soto Marina and Rio Forlon in Tamaulipas ${ }^{3}$.

Differs from I. meridionalis especially in having the bocly deeper, the pectoral fin longer, and the dorsal rather more elevated anteriorly and perhaps with fewer rays.

Girard described and figured his fish as having 29 rays, and Meek gives the number as 24. The former seems often to have given 1 or 2 in excess of the actual number, whilst the latter would sometimes count the 3 anterior simple rays as one.

\section{MOXOSTOMA, Rafin., 1820.}

Morostoma, Jord. \& Everm. Bull. U.S. Nat. Mus. xlvii. 1896, p. 187.

The distinctive characters of this genus are the short dorsal fin, large scales, complete lateral line, small inferior protractile mouth, jaws without cartilaginous sheaths and compressed pharyngeal teeth.

There are about 24 species from the United States east of the Rocky Mountains and from Mexico.

\section{Synopsis of the Mexican Species.}

I. Posterior edge of lower lip straight, transverse; dorsal fin of 2 simple and 10 or 11 branched rays.

A. Pectoral as long as the head, nearly or quite reaching the ventral . . 1. congestum.

B. Pectoral shorter than the head, not rcaching the rentral.

Width of mouth $\frac{1}{3}$ the width of head; interorbital width $2 \frac{1}{4}$ to $2 \frac{1}{3}$ in the length of head, which is $4 \frac{1}{2}$ to $4 \frac{3}{4}$ in the length of the fish (in specimens of 130 to $150 \mathrm{~mm}$. ) ; pharyngeal teeth $10-10$. . . . . . . . . . . . 2. austrinum.

Width of mouth $\frac{2}{5}$ to $\frac{1}{2}$ the width of head; interorbital width $2 \frac{1}{2}$ to $2 \frac{3}{4}$ in the length of head, which is 4 to $4 \frac{1}{3}$ in the length of the fish (in specimens of 105 to $150 \mathrm{~mm}$.) ; pharyngeal teeth $6-6$. . . . . . . . . . . . 3. mascotre.

II. Posterior edge of lower lip notched; dorsal fin of 2 simple and 12 branched rays. . . . . . . . . . . . . . . . . . . . . . 


\section{Moxostoma congestum.}

Ptychostomus congestus, Girard, Rep. U.S. \& MIex. Bound. Surv., Fish. p. 36, t. 21. figs. 5-8 (1859) '.

Ptychostomus albidus, Girard, t. e. p. 36, t. 19. figs. 5-8?

Moxostoma congestum, Jord. \& Everm. Bull. U.S. Nat. Mus. xlvii. 1896, p. 192, and 1900 , fig. $91^{3}$.

Mỹostoma congestum, Meek, Publ. Columbiau Mus., Zool. v. 1904, p. 34:

Depth of body 4 in the length, length of head 4 to $4 \frac{1}{3}$. Diamoter of cye $t$ to $4 \frac{1}{2}$ in the length of head, length of snout $2 \frac{3}{4}$, interorbital width 2 to 21 . Snout truncated anteriorly. Lips plicated; lower lip with a straight transrerse posterior edge; width of month $\frac{1}{3}$ to $\frac{2}{5}$ the widlh of head. 44 to 46 seales in a longitudinal series, 6 or 7 in a transserse series from origin of dorsal fin to lateral line, 5 or 6 from lateral line to base of ventral fin. Dorsal 12, the 2 anterior rays simple; origin nearer to tip of snout than to base of caudal ; free edge straight or slightly eoneare; longest ray longer than the base of the fin. Anal 8, the 2 anterior rays simple, the fin, when laid backs, extending to the basal prart of the caudal. Pectoral as long as tho head, ncarly or quite reaching the rentral, which is inserted below the anterior part of the dorsal. Candal emarginate. Candal peduncle $1 \frac{1}{2}$ as long as deep. Brownish above, yellowish below; dorsal dusky, other fins pale.

Hab. Rio Grande System ; Rivers of Texas and Tamaulipas:

R. Lampasas ${ }^{3}$ and R. Salado ${ }^{3}$ in Texas; R. Conchos in Chihuahua ${ }^{4}$; R. San Juan in Nuero Leon ${ }^{24} ; R$. Conchos and R. Soto Marina in Tamaulipas ${ }^{4}$.

Here described from two spccimens, 120 and $160 \mathrm{~mm}$. in total length, from the Rio Soto Marina (Meek). 'The species attains a length of $350 \mathrm{~mm}$.

\section{Moxostoma austrinum.}

Myxostoma austrina, Bean, Proc. U.S. Nat. Mus. 1879, p. 302 '

Moxostoma austrinum, Jord. \& Everm. Bull. U.S. Nat. Mus. xlvii. 1896, p. $192^{2}$.

Myzostona austrinum, Meek, Publ. Columbian Mus., Zool. v. 190 1, p. $35^{3}$.

About 10 pharyngeal tecth on each side. Depth of body $4 \frac{1}{3}$ in the length, length of head $4 \frac{1}{2}$ to $4 \frac{3}{4}$. Diameter of eje $5 \frac{1}{4}$ to $5 \frac{1}{2}$ in the length of head, length of snout $2 \frac{1}{5}$, interorbital width $2 \frac{1}{4}$ to $2 \frac{1}{3}$. Suout truncated anteriorly. Lips plieated; lower lip with a straight transverse posterior edge; width of mouth $\frac{1}{3}$ the width of head. 47 to 50 seales in a longitudinal series, 7 in a transverso series from origin of dorsal fin to lateral line, 6 from lateral line to base of rentral fin. Dorsal 12 , the 2 anterior rays simple; origin nearer to tip of snout than to baso of eaudal; free edge straight or slightly coucare; longest raj a little longer than the hase of the fin. Anal 8 , with the 2 anterior rays simple, the fin, when laid back, extending nearly to the base of eaudal. F'ectoral a little shorter thau the heal, extending rather more than $\frac{2}{3}$ of the distauce from its base to the origin of the rentral, which is below the middle of the dorsal. Caudal emarginate. Candal peduucle $1 \frac{3}{4}$ as long as deep. Brownish abose, yellowish below; dorsal dusky, lower fins pale yellowish.

Hal. Mexico, Rio Mezquital and Rio Lerma Systems:

Durango ${ }^{3}$; Aguas Calientes and Ataquiza in $\mathrm{Jalisco}^{3}$; Salamanca in Guanajuato $^{2}$; Lake Chapala ${ }^{3}$; Morelia in Michoacan ${ }^{\text {. }}$.

Here described from two specimens from Aguas Calientes (Jordan), 130 and $150 \mathrm{~mm}$. in total length. The species grows to the same size as the preceding one. 


\section{Moxostoma mascotæ, sp. n. (Tab. XXIV. fig. 2.)}

Pharyngeal teeth comparatively fow and strong, about 6 on each side. Depth of body 4 to $4 \frac{1}{2}$ in the length, length of head 4 to $4 \frac{1}{3}$. Diameter of eye 5 to 6 in the length of head, length of snout $2 \frac{1}{2}$ to $2 \frac{3}{4}$, interorbital width $2 \frac{1}{2}$ to $2 \frac{3}{4}$. Snout truncated anteriorly. Lips plicated; lower lip with a straight transverse posterior edge ; width of mouth $\frac{2}{5}$ to $\frac{1}{2}$ the width of head. 43 to 48 scales in a longitudinal series, 6 or 7 in a transverse scries from origin of dorsal fin to latcral line, 5 or 6 from lateral line to luase of rentral. Dorsal 12-13, the 2 anterior rass simple; origin equidistant from tip of snout and base of caudal or a littlo nearer the former; free edge of the fin straight or slightly concave; longest ray as long as or a little longer than the base of the fin. Anal 8, the 2 anterior rays simplo, the fin, when laid back, extending nearly to the caudal. Pectoral shorter than the head, extending $\frac{3}{5}$ to $\frac{3}{4}$ of the distance from its base to the origin of the ventral, which is a little in advance of the middle of the dorsal. Caudal emarginate. Caudal peduncle $1 \frac{1}{2}$ to $1 \frac{3}{4}$ as long as deep. Brownish above, yellowish below; fins pale zellowish.

\section{Ilab. Mexico, Rio Mascota in Jalisco (Buller).}

Here described from seven specimens, 105 to $150 \mathrm{~mm}$. in total length, taken near the source of the river, at a height of 4000 feet.

\section{Moxostoma parvidens, sp. n. (Tab. XXIV. fig. 3.)}

Pharyngeal teeth small, 14 on each side. Depth of body $3 \frac{2}{3}$ to 4 in the length, length of head 4 to $4 \frac{1}{4}$. Diamcter of eye $3 \frac{1}{2}$ to $3 \frac{2}{3}$ in the length of head, length of snout 3 to $3 \frac{1}{4}$, interorbital width $2 \frac{1}{2}$. Snout truncated anteriorly. Lips plicated; lower lip with the posterior edge notched, $\mathbf{V}$-shaped, the two halres of the $\mathbf{V}$ meeting at an obtuse angle; width of mouth nearly $\frac{1}{3}$ the width of hoad. 41 to 43 scales in a longitudinal scries, 6 in a transverse series from origin of dorsal fin to lateral line, 5 from lateral line to base of ventral. Dorsal 14 , the 2 anterior rays simple; origin nearer to tip of snout than to the base of caudal; free edge of the fin nearly straight; longest ray as long as or shorter than the base of the fin. Aual 8, the 2 anterior rays simple, the fin, when laid back, extending to the base of caudal. Pectoral a little shorter than the head, extending $\frac{3}{4}$ of the distance from its base to the origin of ventral, which is below the middle of the dorsal. Caudal emarginate. Caudal peduncle as long as dcep. Silvery, back brownish; dorsal dusky; other fins pale.

Hab. Mexico, Rio Grande at Juarez (Woolman).

Two specimens, 90 and $120 \mathrm{~mm}$. in total length.

\section{CATOSTOMUS, Le Sueur, 1817.}

Partosteus (Cope, 1876) and Catostomus, Jord. \& Everm. Bull. U.S. Nat. Mus. xlvii. 1896, pp. 169 and 173.

The distinctive characters of this genus are the short dorsal fin, small scales, complete lateral live, moderate inferior protractile mouth, jaws with cartilaginous sheaths and compressed pharyngeal teeth.

There are about 25 species from North America and one from Eastern Siberia.

\section{Catostomus plebeius.}

Minomus plebeius, Girard, Rep. U.S. \& Mex. Bound. Surv., Fish. p. 38, t. 22. figs. 1-4 (1859) ${ }^{\text {. }}$ ? Acomus guzmaniensis, Girard, t. c. p. 39, t. 23. figs. 1-10².

Catostomus nebuliferus, Garm. Bull. Mus. Comp. Zool. viii. 1881, p. $89^{3}$. 
Pantosteus plebeius, Jord. \& Everm. Bull. U.S. Nat. M[us. xlvii. 1896, p. 170"; Meek, Publ. Columbian Mus., Zool. v. 1904, p. $30^{5}$.

Catostomus conchos, Meek, t. c. p. 33, t. $\tau^{\circ}$.

Depth of body 4 to 5 in the length, length of head $+\frac{1}{3}$ to $4 \frac{2}{3}$. Diameter of eye 5 to 6 in the length of head, length of snout $2 \frac{1}{2}$, interorbital width $2 \frac{1}{i,}$ to $2 \frac{1}{3}$. Snout obtuse. Lips papillose; lower lip decply ineised; width of mouth $\frac{2}{3}$ the width of head. 80 to 95 scales in a longitudinal series. Dorsal 10-11, the 2 anterior rays simple; origin nearly equidistant from tip of snout and base of caudal; free cdge straight; longest ray longer than the base of the fin. $\Lambda$ nal 8 , the 2 auterior rays simple, the fin, when laid back, extending to the base of eandal. Pectoral shorter than the head, extending $\frac{1}{2}$ to $\frac{3}{4}$ of the distanco from its base to the origin of ventral, which is nearly below the middle of the dorsal. Caudal emarginate. Brownish, mottled with darker.

Hab. Mexico, Chihnahua and Durango:

Rio Casas Grandes ${ }^{25}$, Rio Santa Maria ${ }^{5}$, Rio Carmen ${ }^{5}$, Rio Sauz ${ }^{5}$ and Rio Conchos ${ }^{56}$ in Chihuahua; Rio Nazas ${ }^{3}$ and Rio Mezquital ${ }^{5}$ in Durango.

Here described from seven specimens, the largest $150 \mathrm{~mm}$. in total length, from the R. Casas Grandes and the R. Nazas (Heek). The species attains a length of $450 \mathrm{~mm}$.

From Girard's figure I should have thought that C. guzmaniensis was a distinct species, differing in having a longer dorsal fin with 13 rays and in coloration, the back and sides being dark, with an orange lateral band. I place it in the synonymy on the authority of Dr. Meek, who states that this is the coloration of adult males.

\section{Catostomus bernardini.}

Catostomus bernardini, Girard, Rep. U.S. \& Mex. Bound. Surv., Fish. p. 40, t. 23. figs. 1-5 $(1859)^{2}$; Jord \& Ercrm. Bull. U.S. Nat. Mus. xlvii. 1896, p. 178' ${ }^{2}$; Meck, Publ. Columbian Mus., Zool. v. 1904, p. $32^{3}$.

Catostomus sonorensis, Mcck, l. c. ".

Jiffers from the preceding especially in the larger scales, 65 to 75 in a longitudinal series.

Hab. Mexico, Sonora 1234.

4. XYRAUCHEN, Eigenm. \& Kirsch, $18 S 8$.

Xyrauchen, Jord. \& Everm. Bull. U.S. Nat. Mus. xlvii. 1896, p. 184.

This genus differs from Catostomes in having a sharp-edged hump behind the occiput, produced by the remarkable development of the expanded plate-like anterior interneural bones. It comprises two species from the Colorado River System, one of which has been recorded from Horseshoe Bend, on the border of Sonora.

\section{Xyrauchen cypho, Lockington, $18 s 0$.}

Xyrauchen cypho, Jord. \& Evcrm. Bull. U.S. Nat. Mus. xlvii. 1896, p. 181' ; Meek, Publ. Columbian Mus., Zool. v. 1904, p. $33^{2}$.

Ifab. Colorado River ${ }^{1}$. 


\section{ABRAMIS, Cuv., 1817.}

Abramis, Jord. \& Everm. Bull. U.S. Nat. Mus. xlvii. 1896, p. 249.

Rody ovate, compressed; abdomen behind the ventral fins compressed to form a keel. Ifouth small, protractile; no barbels. Pharyngeal teeth compressed, hooked, in a single series, 5-5. Scales rather large; lateral line complete, decurred. Dorsal fin short, posterior to the rentrals; anal more or less elongate.

Eight species in Europe and Western Asia and one in North America.

\section{Abramis chrysoleucus, Mitchell, 1814.}

Abramis clrysolencus, Jord. \& Everm. Bull. U.S. Nat. Mus. xlvii. 1896, p. $250^{1}$; Meel, Pabl. Columbiarl Mus., Zool. v. 1904, p. $57^{2}$.

IIab. Dakota and Nova Scotia to the Rio Graude ${ }^{1}$.

6. CAMPOSTOMA, Agass., 1855.

Campostoma, Jord. \& Everm. Bull. U.S. Nat. Mus. xlvii. 1896, p. 204.

This genus differs from Hybognathus in having the air-bladder completely surrounded by the convolutions of the very long intestine.

Two species from the United States and Mexico.

\section{Campostoma ornatum.}

Campostoma ornatum, Girard, U.S. \& Mex. Bound. Surv., Fish. p. 40, t. 25. figs. 1-4 (1859)';

Günth. Cat. Fish. vii. p. 183 (1868) ${ }^{2}$; Jord. \& Everm. Bull. U.S. Nat. Mus. xlvii. 1896,

p. $205^{3}$; Meek, Publ. Columbiau Mus., Zool. v. 1904, p. 41 '.

Camposta pricei, Jord. \& Everm. 1. e.5.

Depth of body 4 to 5 in the length, length of head $3 \frac{1}{2}$ to 4 . Diameter of eye $4 \frac{3}{4}$ to $5 \frac{1}{2}$ in the length of head, length of snout 3 to $3 \frac{1}{4}$, interorbital width 4 to $4 \frac{1}{3}$. 70 to 75 scales in a longitudial series. Dorsal $9-10$, with 7 or 8 branched rays ; origin equidistant from tip of suout and base of caudal or a little: nearer the latter ; free edge straight or slightly convex; longest ray considerably longer than the base of the fin. Anal 8, with 6 branched rays. Pectoral $\frac{3}{5}$ to $\frac{4}{5}$ the length of head or of the distance from its base to the origin of ventrals, which is nearly below that of the dorsal. Caudal emarginate. Candal peduncle nearly twice as long as deep. Sides with dark mottlings; yuung with a dark lateral band cnding in a eaudal spot; a black band on the basal part of the dorsal fin; ventrals and anal sometimes similarly banded.

Hab. Southern Arizona and Northern Mexico:

Rucker Cañon, a tributary of the Rio Yaqui in Southern Arizona ${ }^{5}$; Rio Casas Grandes ${ }^{4}$ and Rio Conchos ${ }^{14}$ in Chihuahua; Rio Nazas in Durango ${ }^{4}$.

Here described from several specimens, 75 to $110 \mathrm{~mm}$. in total length, from Chihuahua (Woolman) and San Andres (Meek). 


\section{Campostoma anomalum.}

Campostuma anomalum (Rafin., 1820), Jord. \& Everm. Bull. U.S. Nat. Mus. xlvii. 1896, p. 205 '

Meek, Publ. Columbian Mlus., Zool. v. 1904, p. $42^{2}$.

Campostoma formulosum, Girard, U.S. \& Mcr. Bound. Surv., Fish. p. 4l, t. 25. figs. 5-8 (1859) ${ }^{3}$;

Jord. \& Everm. t. c. p. $206^{\prime}$; Meck, l. c. ${ }^{5}$.

Campostoma nasutum, Girard, t. c. p. 42, t. 25. figs. 9-12:

Closely allicd to the preceding, but with much larger scales, 46 to 53 in a longitudinal series.

Hab. Mississippi System and southwards to the Rio Grande; in Mexico recorded from the Rio San Juan in Nuevo Leon ${ }^{35}$.

I have compared a specimen from Ohio with Girard's figures.

\section{HYBOGNATHUS, Agass., 1855.}

Hybogmathus, Jord. \& Everm. Bull. U.S. Nat. MIus. xlvii. 1896, pp. 211 and 242.

Body elongate, more or less compressed. Mouth protractile, small, horizontal, terminal or subterminal; no barbels. Pharyngeal tecth compresscd, scarcely or slightly hooked, with broad grinding-surface, in a single scries, $4-4$. Scales large. Lateral line complete. Dorsal fin short, about in the middle of the length of the fish; anal short. Intestine elongate, with several convolutions.

About eight species, small herbirorous fishes, chiefly of the Mississippi and Rio Grande Systems.

\section{Hybognathus episcopus.}

Dionda episcopa, Girard, Proc. Ac. Philad. 1856, p. $17 \sigma^{2}$.

Dionda melanops, Girard, t. c. p. $178^{2}$, and U.S. \& Mcx. Bound. Surv., Fish. p. 44, t. 26. figs. $17-20(1859)^{3}$.

Dionda couchi, Girard, 1. c.', and t. c. p. 44, t. 26. figs. 1-1.

Hybognathus punctifer, Garm. Bull. Mus. Comp. Zool. viii. 1881, p. $89^{\circ}$.

Hybognathus civitis, Cope, Trans. Am. Pliil. Soc. 1884, p. $167^{\text {? }}$.

Hybognathus episcopus, Jord. \& Everm. Bull. U.S. Nat. Mus. xlvii. 1896, p. $214^{9}$; Meek, Publ.

Columbian Mus., Zool. v. 1904, p. $49^{3}$.

Hyboynathus melanops, Jord. \& Everm. t. c. p. $216^{10}$.

Notropis rasconis, Jord. \& Snyd. Bull. U.S. Fish. Comm. xix. 1899, p. 121, fig. (1900) ${ }^{11}$.

Hybognathus rasconis, Mcek, t. c. p. 50, fig. $10^{12}$.

Depth of body 3 to 4 in the length, length of head 4 to $4 \frac{1}{2}$. Snout as long as eye, the diametcr of which is 3 to $3 \frac{1}{2}$ in the length of hoad; interorbital width $2 \frac{\pi}{2}$ to $2 \frac{2}{3}$ in the length of bead. Mouth snall, subterminal. Dorsal 8-9, with 6 or 7 brauched rays; origin nearly equidistant from tip of snout and base of caudal. Anal 8. Pectorals sluorter than the head, not renching the rentrals, which are inserted below or a little in arlsance of the origin of dorsal. 35 to $\$ 4$ scales in a longitudinal series, 6 or 7 in a transverse series from origin of dorsal to lateral line, 4 or 5 betwecn lateral line and base of rentral. Lateral line completc. Caudal peduncle ncarly iwice as long as deep. A more or less distinct darlí latcral stripe ending in a ciudal spot.

Hab. Southern 'Texas and Northern Mexico:

Camanche Spring, Iiio Grande ${ }^{1}$, Brownsrille, Texas ${ }^{10}$; Rio Conchos in Chihuahua $^{910}$ (Meck); Buena Vista ${ }^{2}{ }^{3}$, Parras ${ }^{6}$, and Saltillo ${ }^{6}$ in Coaluula; Rio 
San Juan in Nuevo Leon ${ }^{4579}$ (Meek); Durango in Durango ${ }^{9}$; Rio Verde in San Luis Potosi 1112 (Meek).

Here described from several specimens, measuring up to $70 \mathrm{~mm}$. in total length.

S. ALGANSEA, Girard, 1856.

Algansea, Jord. \& Everm. Bull. U.S. Nat. Mus. xlvii. 1896, p. 211.

This genus differs from Hybognathus in the larger and more oblique mouth and in the smaller scales. It comprises four species from the Rio Lerma System (including the Valley of Mexico and the upper tributaries of the Panuco).

\section{Synopsis of the Species.}

I. 10 to 12 gill-rakers on the lower part of the anterior arch; 67 to 76 scales in a longitudinal series.

12 to 14 seales between lateral line and base of ventral fin . . . . . . 1. tincella.

8 to 11 seales between lateral line and base of ventral fin . . . . . . 2. affinis.

II. 13 or 14 gill-rakers on the lower part of the anterior arch; 60 to 66 seales in a longitudinal series, 7 or 8 between lateral line and base of ventral fin. 3. stigmatura.

III. 15 to 17 gill-rakers on the lower part of the anterior areh; 76 to 86 seales in a longitudinal series. . . . . . . . . . . . . 4. dugesi.

\section{Algansea tincella.}

Leuciscus tincella, Cuv. \& Val. Hist. Nat. Poiss. xvii. p. $323(1844)^{1}$; Günth. Cat. Fish. vii. p. $244(1868)^{2}$.

Alyansea tincella, Girard, U.S. \& Mex. Bound. Surv., Fish. p. 46, t. 27. figs. 1-4 (1859) ${ }^{3}$; Jord. \& Everm. Bull. U.S. Nat. Mus. xlvii. 1896, p. 45 !

Algansea tincella (part.), Meck, Publ. Columbian Mus., Zool. v. 1904, p. $44^{5}$.

Depth of body $3 \frac{1}{2}$ to $4 \frac{1}{4}$ in the length, length of head $3 \frac{1}{2}$ to 4 . Snout considerably longer than eyc, the diameter of which is $5 \frac{1}{2}$ to 7 in the length of head; interorbital width $2 \frac{2}{3}$ to 3 in the length of head. 10 to 12 gill-rakers on the lower part of the anterior arch. 70 to 76 scales in a longitudinal series, 14 to 16 in a transrerse series from dorsal fin to lateral line, 12 to 14 between lateral line and base of rentral fin. Dorsal 9 , with 7 branched rays; origin a little nearer to base of caudal than to tip of snout; free edge straight or slightly convex; longest ray $\frac{1}{2}$ to $\frac{3}{4}$ the length of head. Anal 8 , witli 6 branched rays, when laid back not reaching the caudal fin. Pectoral $\frac{3}{5}$ to $\frac{4}{5}$ the length of head, not extending to the ventrals, which are inserted neariy below the origin of dorsal. Silvcry; back brownish; fins pale.

Hað. Valley of Mexico ${ }^{135}$.

Here described from four specimens, 100 to $150 \mathrm{~mm}$. in total length, from Mexico (Mexico Muss.) and Chalco (Meek).

2. Algansea affinis, sp. n. (Tab. XXV. fig. 1.)

Algansea tincella (part.), Meek, Publ. Columbian Mus., Zool. v. 1904, p. $44^{1}$.

Depth of body nearly equal to the length of head, which is 4 to $4 \frac{1}{2}$ in the length of the fish. Snout longer 
than eye, the diameter of which is $4 \frac{1}{3}$ to 5 in the length of head; intcrorbital width $2 \frac{2}{3}$ to 3 in the length of head. 10 gill-rakers on the lower part of the anterior areh. 65 to 76 scales in a longitudinal series, 13 to $16 \mathrm{in}$ a transverse serjes from dorsal fin to lateral line, $S$ to 11 between latcral line and base of rentral fin. Dorsal 9, with 7 branched rars; orjoin equidistant from tip of snont and base of caudal or slightly nearer the latter; free edge straight; longest ray $\frac{2}{3}$ the length of head. Anal 8, with 6 branched rays. Pectoral $\frac{2}{3}$ the length of head, not reaching the vcntrals, which are inserted below the origin of the dorsal. Traces of a dark lateral band ending in a eandil spot.

Ilab. Mexico, Rio Lerma and upper tributaries of the Rio Panuco ${ }^{1}$.

Here described from several specimens, 90 to $120 \mathrm{~mm}$. in total leugth, from Aguas (alientes (Jordan), Salamanca (Hoolman), and San Juan del Rio (Meek).

This species has a shortcr head and larger eye than A. tincella, but is especially distinguished by the fewer scales between the lateral line and the ventral fin.

\section{Algansea stigmatura, sp. n. (Tab. XXV. fig. 2.)}

bepth of body 4 to $4 \frac{1}{2}$ in the length, length of head $3 \frac{1}{2}$ to 4 . Snout as long as ese, the diameter of which is 4 in the length of head; intcrorbital width $2 \frac{3}{4}$ to 3 in the length of licad. 13 or 14 gill-rakers on the lower part of the anterior arch. 60 to 60 scales in a longitudinal series, 13 to 15 in a transrerse seric's from origin of dorsal to lateral line, 7 or 8 between lateral line and base of rentral fin. Dorsal 9 , with 7 branched rays; origin equidistant from tip of snont and base of candal; free edge straight; longest ray $\frac{3}{4}$ the length of head. Anal 8. P'ectoral $\frac{2}{3}$ the length of head, not reaching the ventrais, which are inserted nearly below the origin of dorsal. Silvery; a dark candal spot.

Ilal. Mexico, Rio Grande de Santiago.

Four specimens, 55 to $75 \mathrm{~mm}$. in total length, collected by Dr. A. C. Buller.

\section{Algansea dugesi.}

Alyansea dugesi, Bean, Proc. U.S. Nat. Mus. 1892, p. 283, t. 41. fig. $1^{1}$; Jord. \& Everm. Bull. U.S. Nat. Mus. xlvii. 1896, p. $212^{2}$, and 1900, fig. $98^{3}$; Mleek, Publ. Columbian Mrus., Zool. v. 1904, p. 45, firg. $8^{1}$.

Algansea lacustris, Stcind. Denkischr. Ak. Wien, Ixii. 1895, p. 526, t. 3. fig. $1^{5}$; Meek, t. c. p. 4. ${ }^{5}$. Alyansea tarascorum, Steind. t. c. p. 527, t. 3. fig. $2^{7}$.

? Algansea rubescens, Meek, t. c. p. 46 , fig. $9^{\circ}$.

Deptlo of body nearly equal to the length of head, which is $3 \frac{2}{\overline{3}}$ to 4 in the length of the fish. Snout longer than eye, the dianeter of which is $4 \frac{1}{2}$ to 6 in the length of head: interorbital width 3 in the length of head. 15 to 17 gill-rakers on the lower part of the anterior arch. 76 to 86 scales in a longitudinal scries, 18 to 21 between dorsal fin and lateral line, 12 to 15 between lateral line aud root of ventral. Dorsal 9, with 7 branched rays; origin cyuidistaut from tip of snout and base of caudal or a little nearer the latter; free edge straight; longest ray $\frac{1}{2}$ to $\frac{2}{3}$ the length of head. Anal 8 , with $(6$ branched rays. Pectornl $\frac{g}{5}$ to $\frac{2}{3}$ the length of head, not reaching ile ventrals, which are inserted nearly blow the origin of dorsal. Silvery, back darker; young with a dark spot at the base of cuudal.

IIab. Mexico, Rio Lerma System:

Lake Yuriria in Guanajuato ${ }^{1}$; Lake Chapala in Jalisco ${ }^{8}$; Lake Patzcuaro in Michoacan 4567 .

Here described from three sjecimens, I00 to $200 \mathrm{~mm}$. in total length, from 
L. Patzcuaro (Mexico Mus., Meek). These evidently correspond to Steindachner's A. lacustris and A.tarascorum. Meek gives 85 to 100 scales in a longitudinal series for $A$. lacustris, but my lower counts agree with those of Steindachner. I have examined the type of $A$. dugesi in the U.S. National Museum at Washington. I count 84 scales in a longitudinal series, 18 between dorsal fin and lateral line, 14 from lateral line to root of ventral fin.

A. rubescens is said to differ from $A$. dugesi in the more numerous gill-rakers, 22 or 23 on the first arch; in the specimens described above $I$ count 19 to $22(4-5+15-17)$.

\section{PTYCHOCHEIL.US, Agass., 1855.}

Ptychocheilus, Jord. \& Everm. Bull. U.S. Nat. Mus. xlvii. 1896, p. 224.

This genus differs from Leuciscus in the large subterminal horizontal mouth extending to below the eye and in the subconical pharyngeal teeth set wide apart on the long, slender, lower pharyngeal bones. It comprises three species, large fishes from the Pacific Coast streams of the United States and Northern Mexico.

\section{Ptychocheilus lucius, Girard, 1856.}

Ptychocheilus lucius, Jord. \& Everm. Bull. U.S. Nat. Mus. xlvii. 1896, p. 224; Meek, Publ. Columbian Mus., Zool. v. 1904, p. 52.

Hab. Colorado River and Northern Sonora.

This species is said to reach a length of five feet and a weight of eighty pounds.

\section{LEUCISCUS, Cuv., 1817.}

Gila (Baird \& Girard) and Leuciscus, Jord. \& Everm. Bull. U.S. Nat. Mus. xlvii. 1896, pp. 226 and 228 .

Body orate or elongate, more or less compressed. Mouth protractile, terminal or subterminal, small or moderate, usually more or less oblique; no barbels. Pharyngeal teeth compressed, hookcd, in two series, 1-2, 4-6-6-4, 1-2. Dorsal fin short; anal short or of moderate length.

A large number of species from Europe, Asia, and North America.

Synopsis of the Mexican Species.

85 to 90 scales in a longitudinal series . . . . . . . . . . . . . . 1. elegans.

60 to 75 scales in a longitudinal series . . . . . . . . . . . 2. nigrescens.

\section{Leuciscus elegans.}

Gila elegans, Baird \& Girard, Proc. Ac. Philad. 1853, p. $369^{1}$; Jord. \& Everm. Bull. U.S. Nat. Mus. xlvii. 1896, p. $226^{2}$; Meek, Publ. Columbian Mus., Zool. v. 1904, p. $53^{3}$.

? Gila minace, Meek, t. c. p. 54, fig. $11^{*}$.

biol. Centr.-Amer., Pisces, November 1907. 
Hab. Colorado and Gila Rivers ${ }^{123}$, headwaters of the Rio Yaqui, at Minaca in Chihuahua ${ }^{4}$.

The species attains a length of $300 \mathrm{~mm}$. or more. Some of the distinctive characters assigned to $G$. minace by Dr. Meek are evidently due to the small size of the specimen described.

\section{Leuciscus nigrescens.}

Gila pulchella (non Leuciscus pulchellus, Storer), Baird \& Girard, Proc. Ac. Philad. 1854, p. $29^{2}$. Tigoma pulchella, Girard, Proc. Ac. Philad. 1856, p. 206², and U.S. \& Mex. Bound. Surv., Fish. p. 62 , t. 34. figs. $5-8(1859)^{3}$.

Tigoma nigrescens, Girard, t. c. p. $207^{4}$, and t.c. p. 64 , t. 32 . figs. $1-4^{5}$.

Tigoma pulchra, Girard, l. c. ${ }^{6}$, and t. c. p. $65^{7}$.

Tigoma conspersa, Garm. Bull. Mus. Comp. Zool. viii. 1881, p. 91 ".

Cheonda modesta, Garm. t. c. p. $92^{9}$.

Cheonda nigrescens, Garm. 1. c. ${ }^{10}$.

Leuciscus nigrescens, Jord. \& Evcrm. Bull. U.S. Nat. Mus. xlvii. 1896, p. $233^{11}$; Meek, Publ. Columbian Mlus., Zool. v. 1904, p. $55^{12}$.

Depth of body $3 \frac{1}{3}$ to $4 \frac{1}{3}$ in the length, length of head $3 \frac{1}{3}$ to 4 . Snout longer than eye, the diameter of which is $4 \frac{1}{2}$ (young) to $5 \frac{1}{2}$ in the length of head; interorbital width 3 in the length of head. Mouth terminal, oblique. Dorsal 10, with 8 branched rays; origin above the insertion of the innermost ray of the rentral. Anal 9. 60 to 75 seales in a longitudinal series, 15 to 18 in a transverse series from origin of dorsal to lateral line, 8 to 10 between lateral line and base of rentral. Lateral line complete. Silvery, back darker; a dark lateral stripe ending in a caudal spot present in the young.

Hab. Mexico, Chihuahua, Coahuila, and Durango:

Rio Grande ${ }^{11}$; Rio Casas Grandes (Meek) ${ }^{1} 235$ 12, Rio Santa Maria ${ }^{12}$, Rio Carmen ${ }^{12}$ and Rio Conchos (Woolman) ${ }^{6712}$ in Chihuahua; Parras ${ }^{10}$ and Saltillo ${ }^{9}$ in Coahuila; Rio Nazas ${ }^{8} 12$ and Durango (Meek) ${ }^{12}$ in Durango.

Here described from several specimens measuring up to $150 \mathrm{~mm}$. in total length.

\section{FALCULA, Jord. \& Snyd., 1900.}

Fulcula, Jord. \& Snyd. Bull. U.S. Fish. Comm. xix. 1899, p. $12 \pm$ (1900).

Although the single species of this genus does not appear to be specially closely related to the small fishes which are comprised in Notropis, it is difficult to find characters by which to separate it from them generically. Until a study of the anatomy makes its relationships clear, the external character of the larger number of rays (10 instead of 8 ) in the ventral fins may be used.

\section{Falcula chapalæ.}

Falcula chapale, Jord. \& Snyd. Bull. U.S. Fish. Comm. xix. 1899, p. 125, fig. (1900) ${ }^{1}$; Meek, Publ. Columbian Mus., Zool. v. 1904, p. 58, fig. 122.

Depth of body nearly equal to the length of head, which is $t$ in the length of the fish. Snout longer than 
eye, the diameter of which is 5 to 6 in the length of head; interorbital width $3 \frac{1}{3}$ to $3 \frac{2}{3}$ in the leugth of head. Mouth terminal, oblique. Dorsal 10, with 7 branched rays; origin equidistant from tip of snout. and base of eaudal or a little nearer the former; longest ray $\frac{2}{3}$ to $\frac{3}{4}$ the length of head. Anal 10. Ventrals inserted below or in advance of the origin of dorsal. 45 to 50 seales in a longitudinal series, 8 in a transverse series from origin of dorsal to lateral line, 4 or 5 between lateral line and base of ventral. Silvery, back darker; fins pale.

Hab. Mexico, Rio Lerma System :

Lake Chapala ${ }^{2}$ (Buller); Ojo de Agua, Michoacan (Mexico Mus.).

Here described from four specimens, 130 to $190 \mathrm{~mm}$. in total length.

\section{NOTROPIS, Rafin., 1818.}

Notropis, Jord. \& Everm. Bull. U.S. Nat. Mus. xlvii. 1896, p. 25 t.

This genus differs from Leuciscus in the smaller number of pharyngeal teeth, in one or two series, $4,0-2-0-2,4$.

The scales are large (30 to 60 in a longitudinal series), and the ventral fins are S-rayed.

A large number of species of small fishes from the United States east of the Rocky Mountains and from Mexico.

\section{Synopsis of the Mexican Species.}

I. Mouth subterminal, the lower jaw included.

35 to 39 scales in a longitudinal series . . . . . . . . . . . . 1. boucardi.

42 scales in a longitudinal series . . . . . . . . . . . . . 2. orca.

48 to 54 scales in a longitudinal series . . . . . . . . . . 3. nazas.

54 to 60 scales in a longitudinal series . . . . . . . . . . . . 4. sallcei.

II. Mouth terminal, oblique, with the jaws equal anteriorly.

A. 32 to 40 scales in a longitudinal series.

1. Lateral line complete or absent on a few scales posteriorly.

a. Caudal peduncle $2 \frac{1}{2}$ as long as deep. . . . . . . . . . 5. chihuahua.

$b$. Caudal peduncle not more than twice as loug as deep.

a. Diameter of eye $2 \frac{1}{2}$ (young) to $3 \frac{1}{2}$ (adult) in the length of head;

32 to 36 scales in a longitudinal series . . . . . . . . .

$\beta$. Diameter of eye $3 \frac{1}{2}$ to 5 in the length of head; 34 to 40 scales

in a longitudinal series.

Males with several dark cross-bars; anal fin of 8 or 9 rays . . . . . . . 7. ornatus.

Males with a dark vertical bar behind the head; anal fin of 9 or 10 rays;

length of head $3 \frac{2}{3}$ to 4 in the length of the fish . . . . . . . . . . 8. lutrensis.

Males with a dark vertical bar behind the head; anal fin of 10 to 12 rays;

length of head 4 to $4 \frac{1}{2}$ in the length of the fish . . . . . . . 9. garmani.

2. Lateral line incomplete, not continucd beyond the ventral fins.

38 scales in a longitudinal series . . . . . . . . . . . . . 10. santamarire.

32 to 35 scales in a longitudinal series . . . . . . . . . . . . . 11. calientis.

$\mathrm{X} 2$ 
B. 40 to 50 scales in a longitudinal series.

Diameter of eye 3 to $3 \frac{1}{2}$ in the length of head (in specimens measnring up to $55 \mathrm{~mm}$.); caudal deeply notched, the middle rays $\frac{1}{2}$ as long as the longest . . . . . . . . . . . . . . . . . . . . . 12. formosus.

Diameter of eye 4 to 5 in the length of head (in specimens measuring up to $80 \mathrm{~mm}$.); caudal moderately notched, the middle rays $\frac{3}{4}$ as long as the longest . . . . . . . . . . . . . . . . . . 13. azlecus.

1. Notropis boucardi. (Tab. XXV. figg. 4, 5.)

Moniana nitida (non Alburnus nitidus, Kirtland), Girard, Proc. Ac. Philad. 1856, p. 21 ' . Leuciscus boucardi, Günth. Cat. Fish. vii. p. 485 (1868) ${ }^{2}$.

Graodus nigroteniatus, Günth. 1. c. ${ }^{3}$.

Rutilus boucardi, Jord. \& Everm. Bull. U.S. Nat. Mus. xlvii. 1896, p. 247".

Notropis nigrotceniatus, Jord. \& Everm. t. c. p. $264^{\bar{*}}$.

Notropis braytoni, Jord. \& Everm. 1. c. ${ }^{6}$; Meek, Publ. Columbian Mus., Zool. v. 1904, p. $65^{\top}$.

Notropis boucardi, Meek, t. c. p. $67^{9}$.

Depth of body $3 \frac{1}{2}$ to $4 \frac{1}{2}$ in the length, length of head $3 \frac{2}{3}$ to $4 \frac{1}{2}$. Diameter of eye $3 \frac{1}{2}$ to $4 \frac{1}{2}$ in the length of head. Month little oblique; lowor jaw included within the upper; snout obtuse. Dorsal 9, with 7 branched rays. Aual 8-10, with 6 to 10 branched rays. Tentrals inserted nearly below the origin of dorsal, which is about equidistaut from tip of snout and base of caudal. 35 to 39 scales in a longitudinal series, 6 or 7 in a transverse series from origin of dorsal fin to lateral line, 3 or 4 between lateral line and base of rentral fin. Lateral lins eomplete. Caudal peduncle abont trice as long as deep. Usually a dark lateral stripe ending in a caudal spot.

Hab. Mexico, rivers of Nnero Leon and Tamaulipas and northern tribntaries of the Rio Balsas :

Cadereita $^{7}$ and Rio San $\mathrm{Juan}^{7}$ (Meek) in Nuevo Leon; Rio Conchos ${ }^{7}$ and Rio Soto Marina ${ }^{7}$ (Meek) in Tamaulipas; Yautepec ${ }^{s}$, Cuautla ${ }^{\&}$, Cuernavaca ${ }^{2}$ (Boucurd), Atlixco ${ }^{3} 8$, Puente de Ixtla ${ }^{8}$ (Meek), Matamoros ${ }^{8}$, Jojutla ${ }^{8}$ and Chietla ${ }^{8}$.

Here described from a series of specimens measuring up to $100 \mathrm{~mm}$. in total length. The examples figured are the types of Leuciscus boucardi (fig. 4) and Graodus nigrotceniatus (fig. 5).

\section{Notropis orca.}

Notrayis orca, Woolman, Bull. U.S. Fish. Comm. xiv. 1894, p. $56^{1}$; Jord.\& Everm. Bull. U.S. Nat.

Mus. xlvii. 1896, p. $289^{2}$.

Hab. Rio Grande at EI Paso, Texas.

\section{Notropis nazas.}

Nototropis nazas, Mcck, Publ. Columbian Mus., Kool. v. 1904, p. 70, fig. 19 '.

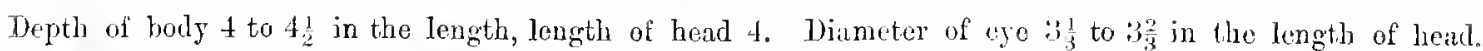
Montle little oblique; lower jaw included within the upper; snont rather pointed. Dorsal 9, with 7 hranched rays. Anals. Teutruls inscrted in alsance of the origin of dorsal, which is a little nearer to the base of candal than to the tip of snout. to to 54 seales in a longitudinal series, 9 or 10 in it 
transverse series from origin of dorsal to lateral line, 5 between lateral line and root of ventral fin. Lateral line complete. Caudal pcduncle 3 times as long as deep. A narrow dark lateral stripe ending in :s small caudal spot.

\section{Hab. Mexico, Rio Nazas in Durango ${ }^{1}$ (Meek).}

Here described from seven specimens, measuring up to $70 \mathrm{~mm}$. in total length.

\section{Notropis sallæi. (Tab. XXV. fig. 3.)}

Ceratichthys sallai, Günth. Cat. Fish. vii. p. $48 \pm(1868)^{1}$.

Zophendum australe, Jord. Proc. U.S. Nat. Mus. 1870, p. $300^{2}$.

Algansea sallaei, Jord. \& Everm. Bull. U.S. Nat. Mus. xlvii. 1896, p. $212^{3}$.

Azlecula mexicana, Mcek, Publ. Columbian Mus., Zool. v. 1904, p. 61, fig. $15^{4}$.

Depth of body $3 \frac{1}{2}$ in the length, length of head 4 . Diameter of eye 5 in the length of head. Month terminal; snout rather obtuse. Dorsal 9 , with 7 branched rays; origin nearer to base of caudal than to tip of snout; longest ray $\frac{1}{2}$ or a little more than $\frac{1}{2}$ the length of head; free edge straight or convex. Anal 8-9, with 6 or 7 branched rays. Pectoral $\frac{2}{3}$ the longth of head, not reaching the vontrals, which are inserterl slightly in adrance of the origin of dorsal. 56 to 60 scales in a longitudinal series, 8 or 9 in a transrerse series from dorsal fin to lateral line, 6 or 7 between lateral line and base of ventral fin. Lateral lines complete. Caudal peduncle about twice as long as deep. Brownish, with silvery stripes along the series of scales.

Hab. Mexico, Rio Lerma and upper tributaries of the Rio Balsas and the Rio Panuco: Lake Tupataro in Guanajuato ${ }^{2}$; Rio San Juan in Hidalgo ${ }^{4}$; Cuernavaca in Morelos ${ }^{1}$.

Here described from the types, three specimens of 70 to $85 \mathrm{~mm}$., from Cuernavaca (Boucard), with which I have compared several smaller specimens from San Juan del Rio (Meek), received as A. mexicana.

\section{Notropis chihuahua.}

Notropis chihuahua, Woolman, Am. Nat. 1892, p. $260^{\text {' }}$; Jord. \& Everm. Bull. U.S. Nat. Mus. xlvii. 1896, p. $265^{2}$.

Nototropis robustus, Meek, Publ. Columbian Mus., Zool. v. 1904, p. 66, fig. $17^{3}$.

Nototropis chihuahua, Meek, t. c. p. 67, fig. $18^{4}$.

Depth of body nearly equal to the length of head, which is 4 in the length of the fish. Diameter of eye $3 \frac{1}{3}$ to $3 \frac{2}{3}$ in the length of head. Mouth terminal, slightly oblique; jaws equal anteriorly; snout obtuse. Dorsal 9-10, with 7 branched rays. Anal 8-9, with 6 or 7 branched rays. Ventrals insertecl below or a little in advance of the origin of dorsal, which is nearly equidistant from tip of snout and base of caudal. 33 to 38 seales in a longitudinal series, 6 to 8 in a transverse series from origin of dorsal to lateral line, 4 or 5 between lateral line and base of ventral fin. Lateral line complete. Candal peduncle about $2 \frac{1}{2}$ as long as deep. A dark lateral stripe usually cuding in a caudal spot; small dark spots on the upper half of the body in the adult.

Hab. Mexico, Rio Conchos in Chihuahua 1234.

Here described from several specimens, measuring up to $70 \mathrm{~mm}$. in total length.

Notropis santarosalice, Meek (Publ. Columbian Mus., Zool. v. 1904, p. 75, fig. 22), is based on a specimen of about $45 \mathrm{~mm}$., which may be a young example of $N$. chithualinu. 


\section{Notropis macrostomus.}

Cyprinella macrostoma, Girard, Proc. Ac. Philad. 1856, p. 198', and U.S. \& Mex. Bound. Surr.,

Fish. p. 54, t. 31. figs. 5-8 (1859)".

Notropis macrostomus, Jord. \& Everm. Bull. U.S. Nat. Mus. xlvii. 1896, p. 2r4; ${ }^{3}$; Meek, Publ.

Columbian Mus., Zoul. v. 190t, p. 724.

Notropis forlonensis, Meek, t. c. p. 70, fig. $20^{\prime}$.

1)epth of body nearly equal to the length of heal. which is $3 \frac{2}{5}$ to $3 \frac{1}{5}$ in the length of the fish. Diameter of ege $2 \frac{1}{2}$ to $2 \frac{3}{4}$ (Joung) in the length of head. Mouth terminal, oblirjue: snout pointed. Dorsal 8-9, with ij or 7 branched rays; origin equidistant from tip of snout and base of candal. Anal 8-9. Ventrals inserted below or a little in advance of the origin of dorsal. 32 to 36 scales in a longitudinal series, 6 in a transterse series from origin of dorsal to lateral line, 3 betreen lateral line and base of rentral. Lateral line complete. Caudal peduncle nearly twice as long as deep. A dark lateral stripe.

Herb. 'Texas, Devil's River ${ }^{1}$-_Mexico, Rio San Juan in Nuevo Leon ${ }^{24}$; Rio Forlon in Tamaulipas" (Meeh).

Here described from three specimens, measuring up to $45 \mathrm{~mm}$. in total length, received as $N$. forlonensis; these are only to be distinguished from small examples of $N$. lutrensis by the larger eye, and appear to be the young of the species described ind figured by Girard.

\section{Notropis ornatus.}

ridoma ornata, Girard, U.S. \& Mcx. Bound. Surv., Fish. p. 53, t. 29. figs. 22-25 (1859) '.

Notropis ornatus, Jord. \& Everm. Bull. U.S. Nat. Mus. xlvii. 1896, p. $270^{2}$; Meek, Publ. Columbian

Mus., Zool. v. I904, p. $68^{3}$.

Depth of body 3 (adult) to $3 \frac{1}{2}$ (Joung) in the length, length of head $3 \frac{3}{y}$ to 4 . Diameter of eye $3 \frac{1}{2}$ to $4 \frac{1}{2}$ in the length of head. Mouth terminal, oblique; jaws equal antcriorly; snout obtuse. Dorsal 9, with 7 branched rays. Anal 8-9, with (; or 7 branched rays. Ventrals inserted a little in adrance of the origin of dorsal, which is equidistant from tip of snout and base of caudal or a little nearer the latter. 36 to 40 scales in a lougitudinal series, 6 to 8 in a transverse series from origin of dorsal to lateral line, $3 \frac{1}{2}$ to $4 \frac{1}{2}$ between lateral line and base of ventral fin. Latoral line complete. Caudal peduncle twice as long as deep. Males with bluckish eross-bars and with the fins dark with pale edges; females and young with a lateral stripe and with the fins pale.

Ifrl. Mexico, rivers of Chihuahua and Durango:

Chihuahua ${ }^{23}$ (Meek); San Andres ${ }^{3}$, Jimenez ${ }^{3}$, and Miñaca ${ }^{3}$ in Chihuahua; Santiago Papasquiaro ${ }^{3}$ (Meek) and Durango in Durango ${ }^{3}$.

Here described from specimens measuring up to $70 \mathrm{~mm}$. in total length.

\section{Notropis Iutrensis.}

Lenciscus lutrensis, Baird \& Girard, Proc. Ac. Philad. 1853, p. 391 '.

Moriana couchi, Girard, U.S. \& Mcx. Bound. Surv, Fish. p. 57, t. 30. figs. 21-24 (1859) ².

Nomiana rutila, Girard, 1. c. t. 30. figs. I-1 ${ }^{3}$.

Notropis lutrensis, Jord, \& Everm. Bull. U.S. Nat. Mus. xlvii. 1396, p. 271 '; Mcek, Publ.

Columbian Mus., Zool. v. 190 t, p. 72.

1y.j, th of body $5 \%$ to $: \frac{1}{2}$ in the length, leugth of head $3 \%$ to 4 . Diameter of eye 4 to 5 in the length of head. Jouth terrainal, oblique; jaws cogual anteriorly; snout rather obtuse. Dorsal 9, with 7 hrnnched rars. 
Anal 9-10. Ventrals inserted a little before the origin of dorsal, which is equidistant from the tip of snout and base of caudal or a little nearer the latter. 34 to 38 scales in a longitudinal series, 6 to 8 in a transverse series from origin of dorsal to lateral line, 3 or 4 between lateral line and root of rentral. Lateral line usually complete. Caudal peduncle $1 \frac{2}{3}$ to 2 as long as deep. A dark vertical bar behind the head; a lateral stripe on the posterior part of the body.

Hab. South Dakota to Northern Mexico:

In Mexico recorded from the Rio Santa Maria ${ }^{5}$, Rio Carmen 5 (Mcel), Rio Sauz $^{5}$ (Meek), and Rio Conchos ${ }^{5}$ (Meek) in Chihuahua; Rio San Juan in Nuevo Leon ${ }^{235}$; Rio Conchos in Tamaulipas 5.

Here described from several specimens, measuring up to $70 \mathrm{~mm}$. in total length.

\section{Notropis garmani.}

Cyprinella rubripinna (non Argyreus rulripinnis, Heck.), Garm. Bull. Mus. Comp. Zool. viii. 1881, p. $91^{1}$.

Notropis garmani, Jord. Cat. Fish. N. Am. p. 813 (1885) ${ }^{2}$; Jord. \& Everm. Bull. U.S. Nat. Mus. xlvii. 1896, p. $281^{3}$; Meek, Publ. Columbian Mus., Zool. v. 1904, p. $73^{4}$.

Very similar to $N$. lutrensis, but with the head smaller ( + to $+\frac{1}{2}$ in the length of the fish) and the anal fin usually longer (of 10 to 12 rays).

Hab. Mexico, Rio Nazas:

Lerdo (Meek) and Santiago Papasquiaro in Durango ${ }^{4}$; Parras in Coahuila ${ }^{4}$.

I have examined four specimens, measuring up to $70 \mathrm{~mm}$. in total length.

\section{Notropis santamariæ.}

Notropis santamarie, Everm. \& Goldsborough, Bull, U.S. Fish. Comm. xxi. 1902, p. 147, fig. ' Meek, Publ. Columbian Mus., Zool. v. 1904, p. 74, fig. 21 '.

Very close to $N$. lutrensis and perhaps not really distinct, but the lateral line incomplete, terminating below the origin of the dorsal fin, and only 2 scales between the lateral line and the base of the rentrul fin.

Ilab. Mexico, Lago de Santa Maria in Chihuahua.

\section{Notropis calientis.}

Notropis calientis, Jord. \& Snyd. Bull. U.S. Fish. Comm. xix. 1899, p. 129, fig. $(1900)^{1}$; Meck, Publ. Columbian Mus., Zool. v. 1904, p. 65, fig. $16^{2}$.

Nepth of body $3 \frac{1}{4}$ to $3 \frac{2}{3}$ in the length of the fish, length of head $: 3 \frac{3}{4}$ to 4 . Diameter of cye 4 in the length of head. Mouth terminal, oblique ; jaws equal anteriorly; snout obtuse. Dorsal 9, witl 7 branched rays. Anal $7-8$, with 5 or 6 branched rays. Ventrals inserted below or a little in advance of the origin of dorsal, which is nearly equidistant from tip of snout and base of caudal. 32 to 35 scales in a longitudinal series, 6 or 7 in a transverse series from origin of dorsal to lateral line, 3 or 4 betwuen lateral line and base of ventral fin. Lateral line ineomplete, not extending further back than the vertical from the origin of the dorsal fin. Caudal peduncle twice as long as deep. A dark lateral striju.

Hab. Mexico, Rio Lerma System :

Aguas Calientes $^{12}$, Ocotlan ${ }^{2}$, Acambaro ${ }^{2}$.

Here described from eight specimens, measuring up to $50 \mathrm{~mm}$. in total lelloth, from Aguas Calientes (Meck). 


\section{Notropis formosus.}

Moniana formosa, Girard, U.S. \& Mex. Bound. Surv., Fish. p. 58, t. 30. figs. 5-9 (I859) ${ }^{\text {. }}$

Notropis formosus, Jord. \& Evernı. Bull. U.S. Nat. Mus. xlvii. 1896, p. 271 ${ }^{2}$; Meek, Publ.

Columbian Mus., Zool. v. 1904, p. $74^{3}$.

Depth of body 3 to 4 in the length, Jength of head $3 \frac{2}{3}$ to 4 . Diameter of eye 3 to $3 \frac{1}{2}$ in the length of head.

Iouth terminal, oblique; jaws equal anteriorly; snout rather pointed. Dorsal 9 , with 7 branched rays, its origin equidistant from tip of snont and base of caudal or a little nearer the latter. Anal 8-9. Ventrals inserted in advance of the origin of dorsal. 40 to 50 scales in a longitudinal series, 8 to 10 in a transverse series from origin of dorsal to lateral line, 4 to 6 between lateral line and base of ventral. Lateral line usually complete. Caudal peducle abont twice as long as deep. A lateral stripe on the posterior part of the body.

Hab. Mexico, Rio Casas Grandes in Chihuahua:

$$
\text { Rio Mimbres }{ }^{1} \text {; Colonia Juarez }{ }^{3} \text { (Meek). }
$$

Here described from several specimens, measuring up to $55 \mathrm{~mm}$. in total length.

\section{Notropis aztecus.}

Codoma vittata (non Leuciscus vittatus, De Kay), Girard, U.S. \& Mex. Bound. Surv., Fish. p. 53, t. 29. figs. 18-21 (1859) ".

Notropis aztecus, Woolm. Bull. U.S. Fish. Comm. xiv. 189t, p. 63, t. $2^{2}$; Jord. \& Everm. Bull. U.S. Nat. Mus. xlvii. 1896, p. $258^{3}$.

Aztecula lerme, Everm. \& Goldsborough, Bull. U.S. Fish. Comm. xxi. 1902, p. 147, fig. $3^{3}$; Meek,

Publ. Columbiau MIus, Zool. v. 1904, p. 60, fig. $14^{5}$.

Aztecula vittata, Meek, t. c. p. 59, fig. $13^{\circ}$.

1)epth of body $3 \frac{1}{2}$ to 4 in the length, length of head 4 to $4 \frac{1}{4}$. Diameter of eje 4 to 5 in the length of head. Mouth terminal, obilique: jaws equal anteriorly; snout obtuse, decurved. Dorsal 9, with 7 branched rays : origin a little wearer to base of caudal than to tip of snout; longest ray $\frac{1}{2}$ or a little more than $\frac{1}{2}$ the length of head; free edge straight or convex. Anal 8. Pectoral shorter than the head, not reaching the ventrals, which are inserted a little in advauce of the origin of dorsal. 43 to 50 seales in a longitudinal series, 7 or $S$ in a transrerse series from dorsal fin to latcral line, 4 or 5 between lateral line aud base of veutral fin. Latcral line complete. Caudal peduncle nearly twice as long as deep. Young with a dark lateral band ending in a caudal spot.

IIal. Mexico, Rio Lerma System, Valley of Mexico, and upper tributaries of the Rio Balsas :

Lerma $^{45}$ (Meck), Texcoco ${ }^{6}$ (Meek), Chalco ${ }^{6}$, and Xochimilco (Gadow) in Mexico ${ }^{23}$; Puebla in Puebla ${ }^{6}$.

Here described from six specimens, measuring from 45 to $80 \mathrm{~mm}$. in total length.

\section{EVARRA, Woolman, 1894.}

Evarra, Jord. \& Everm. Bull. U.S. Nat. Mus. xlvii. 1896, p. 304.

Allied to Notropis and evidently derived from a type similar to $N$. aztecus, but distinguished by the smaller scales, the more clongate and less compressed body, and the broader isthmus, the gill-openings not extending forward below to the level of the posterior edge of the preoperculum.

'Two species from the Valley of Mexico. 


\section{Evarra eigenmanni.}

Evarra eigenmanni, Woolman, Bull. U.S. Fish. Comm. 1894, p. $64^{2}$; Jord. \& Everm. Bull. U.S.

Nat. Mus. xlvii. 1896, p. $304^{2}$; Meek, Publ. Columbian Mus., Zool. v. 1904, p. $7 \tau$, fig. $23^{3}$.

Depth of body $5 \frac{1}{3}$ in the length, length of head $4 \frac{1}{4}$. Diameter of eye $4 \frac{2}{3}$ in the length of head. Snout obtuse ; mouth small. Dorsal 9 , with 7 branched rars; origin nearer to base of caudal than to tip of snout. Anal 8. Ventrals inserted in advance of the origin of dorsal. 85 scales in a longitudinal series, 15 in a transterse series from origin of dorsal to lateral line, 9 between lateral line and base of ventral. Lateral line complete. Silvery, back darker; an indistinct lateral stripe ending in a small caudal spot.

Hab. Valley of Mexico:

City of Mexico ${ }^{12}$ (Woolman); Tlahuac ${ }^{3}$.

Here described from the type, $60 \mathrm{~mm}$. in total length.

\section{Evarra tlahuacensis.}

Evarra tlahuacensis, Meek, Publ. Columbian Mus., Zool. v. 1904, p. 78, fig. $24{ }^{2}$.

Differs from the preceding in the smaller scales ( 95 in a longitudinal series) and the longer anal fin (of 14 rays).

Hab. Valley of Mexico, Tlahuac ${ }^{1}$.

\section{PHENACOBIUS, Cope, 1867.}

Phenacobius, Jord. \& Everm. Bull. U.S. Nat. Mus. xlvii. 1896, p. 302.

Body elongate, little compressed. Mouth protractile, inferior: lower lip produced into a fleshy lobe on each side; no barbels. Pharyngeal teeth compressed, hooked, in a single series, 4-4. Scales small or moderate (40 to 60 in a longitndinal series); lateral line complete. Dorsal and anal fins short.

'This genus comprises five species, small fishes of the Eastern United States and the Mississippi System, one extending south to the Rio Grande.

\section{Phenacobius scopifer, Cope, 1870.}

Phenacobius scopifer, Jord. \& Everm. Bull. U.S. Nat. Mus. xlvii. 1896, p. $303^{1}$; Meek, Publ. Columbian Mus., Zool. v. 1904, p. $76^{2}$.

Hab. Illinois to the Rio Grande ${ }^{2}$.

15. XYstROSUS, Jord. \& Snyd., 1900.

Xystrosus, Jord. \& Snyd. Bull. U.S. Fish. Comm. xix. 1899, p. 123 (1900).

This genus appears to be nearest to Falcula, but is at once distinguished by the numerous rery long and slender gill-rakers.

A single species from Lake Chapala.

\section{Xystrosus popoche.}

Xystrosus popoche, Jord. \& Suyd. Bull. U.S. Fish. Comm. xix. 1899, p. 123, fig. (1900) ${ }^{1}$; Meek, Publ. Columbian Mus., Zool. v. 1904, p. 43, fig. $7^{2}$.

Depth of body 4 to $4 \frac{1}{2}$ in the lengtb, length of head $3 \frac{1}{2}$. Mouth rather large, terminal, oblique; gill-rakers Biol. Centr.-AMER., Pisces, February 1908. 
rery long, slender, and numerous. 60 to 70 scales in a longitudinal series. Dorsul 9-10, with 7 branched rays; origin equidistant from tip of snont and base of eaudal and above the insertion of the ventrals. Anal 8-10, with 6 or 7 branched rays. Silvery, back darker; fins plain.

IHub. Nexrco, Lake Chapala in Jalisco ${ }^{12}$ (Buller, Meek).

1 have examined three specimens, 200 to $230 \mathrm{~mm}$. in total length.

\section{STYPODON, Garm., 1881.}

Stypodon, Jord. \& Everm. Bull. U.S. Nat. Mrus. xlvii. 1896, p. 220.

Body oblong, compressed. Nouth small, protractilo; no barbels. Pharyngeal tceth cylindrical, with convex apices, in a single series, $3-3$. Seales large (35 in a longitudinal series); lateral line complete, decurred. Dorsal and anal fins short.

A single species from Coahuila.

\section{Stypodon signifer.}

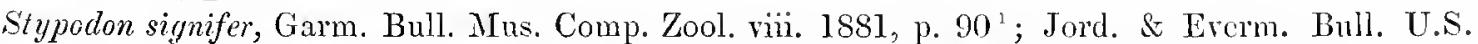
Nat. Mus. xlvii. 1896, p. $220^{2}$; Meek, Prbl. Columbian M[us., Zool. v. 1904, p. $5 \mathrm{l}^{3}$.

Hab. Mexico, Lake Parras in Coahuila ${ }^{1}$.

17. PINEPHALES, Rafin., 1820.

Pimephales, Jord. \& Everm. Bull. U.S. Nat. Mus. xlvii. 1896, p. 216.

Body more or less elongate, moderately compressed. Nouth small, inferior, protractile; no barbcls. Pharyngeal teeth with oblique grinding-surface, ustally not hooked, in a single series, 4-4. Scales moderate. Dorsal and anal fins short, the former with the first ray more or less spinons (in adult males covered by a thick skin) and separated from the second by a membrane. Intestine elongate.

Three or four species from the United States and Northern Mexico.

\section{Pimephales confertus.}

Hyborhynchus confertus, Girard, Proc. Ac. Philad. 1856, p. 179'.

Pimephales promelas conjertus, Jord. \& Everm. Bull. U.S. Nat. Mus. xlvii. 1896, p. 217"2.

Pimelocephales conferlus, Meek, Publ. Columbian Mus., Zool. v. 190t, p. $50^{3}$.

Dent th of hody $3 \frac{1}{\frac{1}{2}}$ to $3 \frac{3}{4}$ in the length, length of head $3 \frac{2}{3}$ to 4 . Snout oltuse; diameter of eye $3 \frac{1}{\frac{1}{2}}$ to $3 \frac{3}{4}$ in the length of head. Dorsal 10, with 8 brauched rays. Anal 8 . 50 to 55 scules in at longitudinal series, 8 between lateral line and base of ventral. A dark lateral stripe ; males dark with pale vertical bars.

Hab. South-western 'Texas and Northern Mexico:

Rio Pecos ${ }^{1}$ and Brownsville ${ }^{3}$ in Texas; Rio Casas Grandes ${ }^{3}$, Rio Santa Maria ${ }^{3}$, Rio Conchos ${ }^{3}$ (Meek) and Miñaca ${ }^{3}$ in Chihuahna.

Here described from six specimens, measuring up to $60 \mathrm{~mm}$. in total length.

18. COCHLOGNATHUS, Baird \& Girard, 1854.

Cachlognathus, Jord. \& Everm. Bull. U.S. Nat. Mus. xlvii. 1890, p. 251.

Differs from Pinephales especially in tho structure of the jaws, cach of which is provided with a hard entting- 
plate. The pharyngeal teeth are more strongly hooked than in Pimeplucles, and the intestine is shorter.

Two species from Texas and the Rio Grande.

\section{Cochlognathus ornatus.}

Cochlognathus ornatus, Baird \& Girard, Proc. Ac. Philad. 1854, p. $158^{1}$; Girard, Bull.U.S. \& Mex. Bound. Surv., Fish. p. 46, t. 25. figs. 12-17 (1859) ${ }^{\circ}$ Jord. \& Everm. Bull. U.S. Nat. Mus. xlvii. 1896, p. $252^{3}$.

Hal. Rio Grande at Brownsville 123.

\section{YURIRIA, Jord. \& Everm., 1896.}

Yuriria, Jord. \& Everm. Bull. U.S. Nat. Mus. xlvii. 1896, p. 315.

Body elongate, compressed. Mouth protractile, terminal, oblique; a small barbel at the end of each maxillary. Pharyngeal teeth compressed, hooked, in a single series, 4-4. Gill-openings separated by a narrow isthmus. Scales large. Dorsal and anal fins short, the former about in the middle of the length of the fish; rentral fins 10-rayed.

A single species from the Rio Lerma System.

\section{Yuriria alta.}

Hudsonius altus, Jord. Proc. U.S. Nat. Mus. 1879, p. $301^{1}$.

Hybopsis altus, Jord. \& Everm. Bull. U.S. Nat. Mus. xlvii. 1896, p. $321^{2}$, and 1900, fig. $138^{3}$; Meek, Publ. Columbian Mus., Zool. v. 1904, p. 81 *.

Depth of body about $t$ in the length, length of head $3 \frac{2}{3}$ to $t$. Snout longer than eje, the diameter of which is $4 \frac{1}{3}$ to 5 in the length of head; interorbital width 3 in the length of head. Dorsal 9, with 7 branched rays; origin nearly equidistant from tip of snout and base of candal; longest ray $\frac{2}{3}$ to $\frac{4}{5}$ the length of head; free edge straight or slightly concare. Anal 9 . Pectorals nearly or quite reaching the rentrals, which are inserted below the origin of dorsal. t5 to 50 scales in a longitudinal series, 8 to 10 in a transverse series from origin of dorsal to lateral line, $t$ or 5 between lateral line and base of ventral. Lateral line complete, slightly decurved. Caudal peduncle $1 \frac{2}{3}$ to 2 as long as deep. Silvery, back darker ; fins pale.

Hab. Mexico, Rio Lerma System :

Aguas Calientes ${ }^{4}$ (Jordan, Meek), Lagos ${ }^{4}$, Celaya ${ }^{4}$ (Meek), Acambaro ${ }^{4}$, Lago de Tupataro ${ }^{1}$, Salamanca ${ }^{2}$ (Woolman); Rio Cuitzeo ${ }^{4}$; Ojo de Agua, Michoacan (Mexico Mus.).

Here described from several specimens, measuring up to $130 \mathrm{~mm}$. in total length.

20. COUESIUS, Jord., 1878.

Couesius, Jord. \& Everm. Bull. U.S. Nat. Mus. xlvii. 1896, p. 323.

Very similar to the preceding genus, but the body less compressed, the barbel not quite terminal, the pharyngeal teeth in two series, $2,4-4,2$, and the scales smaller.

Five species from North America, including one from Northern Mexico. 


\section{Conesius adustus.}

Couesius adustus, Woolman, Bull. U.S. Fish. Comm. xiv. 1894, p. $57^{1}$; Jord. \& Everm. Bull. U.S. Nat. Mus. xlvii. 1896, p. $325^{2}$; Meek, Publ. Columbian Mus., Zool. v. 1904, p. $82^{3}$.

Mab. Mexico, Rio Conchos in Chihuahua ${ }^{12}$.

\section{HYBOPSIS, Agass., 1854.}

Hybopsis (part.), Jord. \& Everm. Bull. U.S. Nat. Mus. xlvii. 1896, p. 314.

Differs from Furiria in haring the body less compressed, the snout obtuse, the mouth horizontal aud subterminal or inferior, the isthmus wider, and the rentral fins 7-or S-rased.

About fifteen species from the United States, from the Great Lakes to the Rio Grande and its southern tributaries.

\section{Hybopsis æstivalis.}

Golio estivalis, Girard, Proc. Ac. Philad. 1856, p. $189^{1}$, and U.S. \& Mex. Bound. Surv., Fish. p. 49, t. 5 \%. figs. $17-29(1859)^{2}$.

Hybopsis estivalis, Jorl. \& Everm. Bull. U.S. Nat. Mus. xlvii. 1896, p. $316^{3}$; Meck, Publ. Columbian 1lus., Zool. v. 1904, p. 81 !.

Depth of body 4 to 5 in the length, length of head 4 . Snout as long as postorbital part of head; diameter of eye 4 in the length of hear. Dursal 9 , with 7 branched rays; origin nearer to tip of snout than to base of caudal; longest ray shorter thin the head; free edge concave. Anil 8-9. Pectorals sometimcs nearly reaching the ventrals, which are inserted below the origin or anterior part of dorsal. 33 to 36 scales in a longitudinal series, 5 or 6 in a transverse series from origin of dorsal to lateral line, $3 \frac{1}{2}$ or 4 betreen lateral line and base of rentral. Caudal peduncle twice as long as deep. Upper part of body with small dark spots; a dusky stripe on each caudal lobe.

Hab. Mexico, Rio San Juan in Nuevo Leon ${ }^{124}$; Rio Conchos in Tamaulipas ${ }^{4}$ (Meek).

Here described from six specimens, measuring up to $65 \mathrm{~mm}$. in total length.

\section{Hybopsis sterletus.}

Ceratichthys sterletus, Cope, in Whecler's Surv., Zool. v. p. 65.2, t. 27. fig. 3 (1876).

Depth of body $5 \frac{1}{2}$ in the length, length of head 4. Snout nearly as loug as postorbital part of head ; diameter of eye $4 \frac{1}{3}$ in the length of head. Dorsal 9, with 7 brancbed rays ; origin nearer to tip of snout than to base of caudal; longest ray nearly as long as the head; frce edge concave. Anal 1). Pectorals extending to the ventrals, which are inserted bolow the origin of dorsal and reach the anal. 38 scales iu a longitudinal series, $5 \frac{1}{2}$ in a transverse series from origin of dorsal to lateral line, $t$ between lateral line and base of ventral. Caudal peduncle twice as long as deep. Coloration uniform; fins palc.

Hab. Rio Grande:

San 1ldefonso ${ }^{1}$; Juarez (Woolman).

Here described from a single specimen of $40 \mathrm{~mm}$. 


\section{AGOSIA, Girard, 1856.}

Agosia, Jord. \& Everm. Bull. U.S. Nat. Mus, xlvii. 1896, p. 308.

Differs from Hybopsis in the smaller seales, 60 to 90 in a longitudinal series, and in the more posterior position of the dorsal fin, which is often partly above the anal.

About ten species, small fishes of the mountain streams of Western North America, two of which have been recorded from Northern Mexico.

\section{Agosia oscula.}

Argyreus osculus, Girard, Proc. Ac. Philad. 1856, p. $186^{1}$, and U.S. Mex. Bound. Surv., Fish. p. 47 , t. 27. figs. 9-12 (1859) ${ }^{2}$.

Argyreus notabilis, Girard, 1. c. ${ }^{3}$, and t. c. p. 47, t. 27. figs. 5-8 4 .

Agosia oscula, Jord. \& Everm. Bull. U.S. Nat. Mus. xlvii. 1896, p. $309^{5}$; Meek, Publ. Columbian Mus., Zool. v. 1904, p. $80^{\circ}$.

Hab. Gila River in Arizona:

Recorded in Mexico from the Rio Santa Cruz ${ }^{34}$ in Northern Sonora, a tributary of the Gila.

\section{Agosia chrysogaster.}

Agosia chrysogaster, Girard, Proc. Ac. Philad. 1856, p. 187 ${ }^{\prime}$, and U.S. \& Mex. Bound. Surv., Fish. p. 49, t. 28. figs. 5-8 (1859) ${ }^{2}$; Jord. \& Everm. Bull. U.S. Nat. Mus. xlvii. 1896, p. $313^{3}$; Meek, Publ. Columbian Mus., Zool. v. 1904, p. $80^{4}$.

Hal. Gila River in Arizona; Sonora and Western Chihuahua:

Rio Santa Cruz ${ }^{1}$, Hermosillo ${ }^{4}$ and Rucker Cañon ${ }^{4}$ in Sonora; Sierra Madre in Chihuahna ${ }^{4}$.

\section{RHINICHTHYS, Agass., 1850.}

Rhinichthys, Jord. \& Everm. Bull. U.S. Nat. Mus. xlvii. 1896, p. 305.

Body elongate, littlo compressed. Mouth non-protractilo, subterminal or inferior; a small barbel at the end of each maxillary. Pharyngeal teeth compressed, hooked, in two series, 2, 4-4, 2 or 1. Gill-openings separated by a bread istbmus. Scales small. Dorsal and anal fins shert, the former about in the middle of the length of the fish; rentral fins 7 -or S-rayed.

Three or four species from mountain-streams of North America, including one from Chihuahua.

\section{Rhinichthys simus.}

Rhinichthys simus, Garm. Science Obscrver, 1881, p. $61^{\text {' }}$; Jord. \& Everm. Bull. U.S. Nat. Mus.

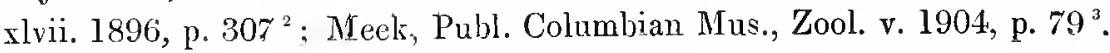

Depth of body 4 to $4 \frac{3}{4}$ in the length, length of head about 4 . Suout obtuse; mouth inferior; diameter of eye 5 to 6 in the length of head. Dorsal 8-9, with 6 or 7 branched rays; origin above innermost ray of pentrals and nearly equidistant from tip of snout and base of caudal. Anal 8.50 to 62 scales in a longitudinal series, 12 to 14 in a transverse series from origin of dorsal to latcral line, 8 to 10 between 
lateral line and base of rentral. Caudal peduucle nearly twice as long as deep. Brownish ; young with a dark lateral band.

IIab. Tributaries of the Rio Grande in Northern Mexico:

Santa Rosalia in Chihnahua ${ }^{3}$; Coahuila ${ }^{1}$; Montemorelos in Nuevo Leon ${ }^{3}$ (Ileek).

Here described from two specimens, 60 and $85 \mathrm{~mm}$. in total length.

\section{Fam. 4. CHARACINID正.}

The Characinidæe comprise about 500 species from the fresh-waters of Mexico and South America and 100 from Africa. The family is in many ways the most generalized of the Ostariophysi, but is closely related to the Cyprinidæ. In the Mexican and Central-American species the body is scaly, the maxillary enters the gape of the mouth, the branchiostegals number 3 to 5 and the gill-membranes are free from the isthmus. An adipose dorsal fin is often present and the jaws are nsually toothed.

\section{Synopsis of the Mexican and Central-American Genera.}

I. Teeth well dereloped in both jaws.

A. No adipose fin ; anal fin sliort, of 10-12 rays; body rather elongate; mouth large; teeth conical . . . . . . . . 1. Hoplias.

B. An adipose fin.

1. Anal fin short, of 10-12 rays; body rather elongate.

Nouth moderate; teeth in jaws compressed, cuspidate; palate toothless ; dorsal fin in the middle of the length of the fish . . . . . . . .

Nouth large, the snout produced, the jaws with small conical teeth in a single series ; palate toothed; dorsal fin posterior in position . . 3. Luclocharax.

2. Anal fin rather long, of 20 to 40 rays ; teetl compressed, euspidate.

a. Teeth of the outer serics in both jaws subequal, without canines.

a. Body oblong or ovate; abdomen in front of the ventral fins rounded.

A pair of conical teeth behind the middle of the serics in the lower jaw ; præmaxillary teeth in 3 or $t$ series . . . . . . . . . . . 4. Brrcon.

No pair of conical teeth in the lower jaw; premaxillary teeth in 2 series . 5. Tetragonoprerus.

No pair of conical teeth in the lower jaw; pricmaxillary teeth in a single series . . . . . . . . . . . . . . . . .

B. Budy deep; abdomen in front of veutral fins compressed to a sharp edge . . . . . . . . . . . .

b. Some of the anterior teeth enlitrod, caninc-like; snout somewhat produeed . . . . . . . . . . . 8. Bканоснавах.

3. Anal fin very loug, of 45 to 55 rays; tceth conical . . . . 9. Rebondes.

II. Jaws toothless; anal fin short . . . . . . . . . . 10. Cunnumus. 


\section{HOPLIAS.}

Macrodon (non Schinz), Müll. \& Trosch. Hor. Ichthyol. iii. p. 6 (1815); Günth. Cat. Fish. v. p. 281

(1864) ; Jord. \& Everm. Bull. U.S. Nat. Mus. xlvii. 1896, p. 330.

Hoplias, Gill, Proc. U.S. Nat. Mus. xxvi. 1903, p. 1016.

This genus comprises two species only, viz. H. microlepis from l'anama and Western Ecuador, and the widely-distributed South-American $I I$. tratir $\alpha$, Spix, which ranges from the Magdalena to the La Plata and which differs from its congener in having a broader head and somewhat larger scales.

\section{Hoplias microlepis. ('Tab. XXVI. fig. 1.)}

Macrodon microlepis, Günth. Cat. Fish. v. p. $282(1864)^{1}{ }^{1}$.

Depth of body $3 \frac{3}{4}$ to 5 in the length, length of head $3 \frac{1}{3}$ to $3 \frac{1}{2}$. Snout longer than eye, the diameter of which is 6 to 8 in the length of head; interarbital width $3 \frac{1}{2}$ to $3 \frac{1}{5}$ in the length of head. Mouth wide, the maxillary extending beyond the vertieal from the posterior edge of cye; tecth aeutely conical, in a single serics in the jaws, with some strong canines; teeth on the palatines in bands and on the romer in two separate patehes. $\$ 2$ to 45 scales in a longitudinal series, 6 between middle of dorsal and lateral line, 5 or 6 between lateral line and root of ventral fin, 11 aeross the baek of the tail from one lateral line to the other. Dorsal 13-14, nearly in the middle of tho length of the fish; edge straight or slightly convex. Anal 10-11, rounded. Pectorals and ventrals of moderate length, rounded. Caudal rounded. Olivaecons, marbled with browuish, the marking sometimes forming a longitudinal band and rertical bars; fins with dark undulating stripes or series of spots.

Hab. Panama, Rio Chagres ${ }^{1}$ (Dow, Salvin).-Western Ecuador (Festa).

Here described from several specimens, including the types of the species, measuring up to $300 \mathrm{~mm}$. in total length.

\section{PIABUCTNA.}

Piabucina, Cuv. \& Val. Hist. Nat. Poiss. xxii. p. 161 (1849); Güntlı. Cat, 1ish. v. p. 311 (1864); Jord. \& Everm. Bull. U.S. Nat. Mus. xlvii. 1896, p. 332.

This genus resembles Itoplias in general form, in the structure and position of the fins, except that the caudal is emarginate instead of rounded, and in the absence of a fontanel in the cranial roof.

About six species are known, from Panama, Ecuador, Colombia, Venezuela, and Guiana.

\section{Piabucina panamensis.}

Piabucina panamensis, Gill, Proc. Ac. Philad. 1876, p. 336'; Jord. \& Everm. Bull. U.S. Nat. Mus. x]vii. 1896 , p. $333^{2}$.

Depth of body 4 in the length. Dorsal 10. Anal 12. 30 scales in a longitudinal series, $\Delta$ dark longi. tudinal band on the middle of the side; a dark spot on the base of the dorsal fin.

IIab. Panama, Rio Tripoli 1.

This species may be identical with P. enyflivinoides, C. \& V., from Voneznela. 


\section{Piabucina festæ.}

Piabucina feste, Bonleng. Boll. Mus. Torin. xiv. 1899, No. 346, p. $1^{1}$; Jord. \& Everm. Bull. U.S. Nat. Mus. xlvii. 1900, p. $3145^{2}$.

Depth of body 4 in the length. Dorsal 9. Anal 11. $2 S$ scales in a longitudinal series. Deep olire-brown abore, whitish below ; fins gregish.

Hab. Panama, Rio Sabina.

Length of the type, $160 \mathrm{~mm}$.

\section{LUCIOCHARAX.}

Luciocharax, Steind. Denkschr. Ak. Wien, xxxix. 1878, p. 67; Jord. \& Everm. Bull. U.S. Nat. Mus. xlvii. 1896, p. 339.

A single species from Panama and Colombia.

\section{Luciocharax insculptus.}

Luciocharax insculptus, Steind. Denlischr. Ak. Wien, xxxix. 1878, p. 6r, t. 13. fig. $2^{1}$, and xli. 1879, p. $169^{2}$; Jord. \& Everm. Bull. U.S. Nat. Mus. xlvii. 1896, p. $339^{3}$.

Deptl of body 6 in the length, length of head 3. Dorsal 10. Aval 1:. 4 scales in a longitudinal serics. Silrery, back greyish; a dark spot at the base of eadal.

Mab. Panama, Rio Mamoni ?.-C'olombia, Rio Magdilena ${ }^{2}$

Total length $300 \mathrm{~mm}$.

\section{BRYCON.}

Erycon, Müll. \& Trosch. Hor. Ichthyol. i. p. 15 (1845); Güıth. Cat. Fish. v. p. 333 (1864); Jord. \& Everm. Bull. U.S. Nat. Mus. xlvii. 1896, p. 337.

Chalcinopsis, Kner, Sitzungsb. Bayer. Ak. 1863, p. 226 ; Günth. t. c. p. 336.

Numerous species from Central and South America.

\section{Brycon guatemalensis, sp. $\mathrm{n}$.}

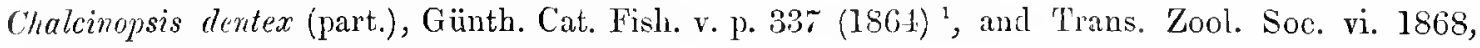
P. 478, t. 82. fig. $1^{2}$.

Depth of body $2 \frac{3}{4}$ to $3 \frac{2}{3}$ in the length, length of head $4 \frac{1}{4}$ to $4 \frac{3}{4}$. Snout longer than eye, the diameter of which is $4 \frac{1}{3}$ to $5 \frac{1}{2}$ in the length of head: interorbital width 2 to $2 \frac{3}{7}$ in the length of head. Maxillary extending nearly to below middle of eye; lower jaw a little shorter than the ujper; premaxillary teeth in 4 series. 13 to 15 gill-rakers on the lower part of the anterior arch. 52 to 56 scales in a longitudinal series, 10 between dorsal fin and lateral line, 5 or 6 betwecen lateral line and root of rentral. 1)orsal 11; origin behind the ventrals; free edge straight or convex; longest ray as long as or shorter than the head. Anal 34-36, of 4 simple and 30 to 32 branched ruys; origin below the middlo of dorsal; anterior part of fin deep and convex, middle part cmarginate. Pectoral als long als or shorter than heatl, sometimes reaching the rentrals, which do not extend to the anal. Caudal lorked. Silsery; some of the scales with blackish edges, forning vertical strcalis; posterior odge of gill-openingr blickish; a more ur less distinct blackish spot on the candal pedunclo; anal usually dark-edged. 
Hab. Guatemala, Rio Chisoy, Rio Usumacinta ${ }^{2}$, Rio Motagua I 2 and Lake Yzabal 12 (Godman \& Salvin).

Six specimens, measuring up to $400 \mathrm{~mm}$. in total length.

The types of Brycon dentex, from Western Ecuador, have 18 gill-rakers on the lower part of the anterior arch, 47 to 50 scales in a longitudinal series, the lower jaw shorter, the eye larger and the interorbital region narrower than in $B$. gucatematensis, and the body uniformly silvery.

Gill (Proc. Ac. Philad. 1877, p. 188) has recorded B. dentex from Lake Nicaragua, but judging from Meek's description (Publ. Columbian Mus., Zool. vii. 1907, p. 109) the Nicaraguan species is not Bryeon dentex and may prove to be distinct from B. guatemalensis.

\section{Brycon striatulus.}

Chalcinopsis striatulus, Kner, Sitzgsb. Bayer. Ak. 1863, p. $226^{1}$; Günth. Cat. Fish. v. p. 337 (1864) ${ }^{2}$. Chalcinopsis chagrensis, Kner, l. c. p. $338^{3}$.

Depth of body $2 \frac{3}{4}$ to $3 \frac{1}{2}$ in the length, length of head $4 \frac{1}{4}$ to $4 \frac{1}{2}$. Snont a little longer than eye, the diameter of which is 4 to $4 \frac{2}{3}$ in the length of head; interorbital width $2 \frac{1}{3}$ to $2 \frac{3}{4}$ in the length of head. Maxillary extending nearly to below middle of eye; lower jaw a little shorter than the upper; premaxillary tceth in 4 series. 13 or 14 gill-rakers on the lower part of the anterior arch. 70 to 77 scales in a longitudinal series (exclusive of 4 or 5 on the basal part of the eaudal), 12 to 15 between dorsal fin and lateral line, 8 or 9 between lateral line and root of ventral fin. Dorsal 11-12 ; origin behind the ventrals: free edge nearly straight; longest ray shorter than the head. Anal 33-39, of 3 or 4 simple and 30 to 35 branched rays; anterior part deep and convex, free edge emarginate. Peetoral noarly as long as or shorter than head, sometimes reaching the ventrals, which may extend to the anal. Caudal forked. Coloration as in the preceding species.

Hab. Costa Rica, Juan Viñas and El Pozo del Rio Grande (Underwood); Panana, Rio Chagres ${ }^{13}$.

Here described from several specimens, measuring up to $230 \mathrm{~mm}$. in total length.

\section{TETRAGONOPTERUS.}

Tetragonoplerus, Cuv. Règne Anim. ii. p. 166 (1817); Güntl. Cat. Fish. v. p. 317 (1864); Jord. \& Everm. Bull. U.S. Nat. Mus. xlvii. 1896, p. 333.

This genus comprises a large number of species from South America and a few from Mexico and Central America.

\section{Synopsis of the Mexican and Centrat-American Species.}

I. Interoribital width 29 to 3 in the length of head; 10 to 15 gill-rakers on the lower part of the anterior arch.

Anal 25-33 (3-1/22-29); maxillary extending to below anterior edge or anterior part of eye; diameter of eye 3 to $3 \frac{1}{2}$ in the length of head (in specimens of 65 to $120 \mathrm{~mm}$.) . . . . . . . . . . . . . . . 1. ceneus.

Anal 23-29 (3-4/20-25) ; maxillary extending to below anterior $\frac{1}{3}$ of eye ; diameter of eye $2 \frac{1}{2}$ to 3 in the length of head (in specimens of 65 to $130 \mathrm{~mm}$.) . . . . . . . . . . . . . . . . . 2. macrophthatmus. Biol. Centr.-Amer., Pisces, February 1908. 
Anal 20-2\% (3-4/17-24) ; maxillary extending to below anterior part or middle of eye; diameter of eye $2 \frac{3}{4}$ to $3 \frac{1}{2}$ in the length of head (in speeimens of 60 to $120 \mathrm{~mm}$.). . . . . . . . . . . . . .

3. mexicanus.

II. Interorbital width $3 \frac{1}{3}$ to $3 \frac{1}{2}$ in the length of head; $14-17$ gill-1akers on the lower part of the anterior areh . . . . . . . . 4. angustifrons.

\section{Tetragonopterus æneus.}

Tetragonopterus eneus, Giinth. Proe. Zool. Soc. 1860, p. $319^{1}$, and Cat. Fish. v. p. 326 (1864) ${ }^{2}$;

Jord. \& Everm. Bull. U.S. Nat. Mus. xlvii. 1896, p. $334^{3}$.

Tetragonopterus fasciatus (part.), Günth. Cat. Fish. v. p. 322 (1864) ${ }^{4}$.

Tetragonopterus microphthalmus (part.), Güntl. t. c. p. $324^{5}$.

Tetragonopterus panamensis, Günth. 1. c. ${ }^{6}$; Steind. Denkschr. Ak. Wien, xli. 1879, p. 166, t. 1. figs. $1 \& 2^{7}$.

Tetragonopterus humilis, Günth. t. e. p. $327^{\mathrm{s}}$.

Tetragonopterus finitimus, Boeourt, Ann. Sei. Nat. (5) ix. 1868, p. $62^{3}$; Vaill. \& Pellegr. Bull. Mus. Paris, 1903, p. 325 ${ }^{10}$.

Tetragonopterus belizianus, Boeourt, 1. c. ${ }^{11}$; Vaill. \& Pellegr. 1. e.. ${ }^{22}$.

Tetragonopterus arstedii (Kröyer, MS.), Lütken, Vid. Medd. 18г ^, p. 2:29 ${ }^{13}$.

Tetragonopterus rutilus (part.), Jord. \& Everm. l. c. ${ }^{1 *}$.

Tetragonopterus aneus (part.), Meek, Publ. Columbian Mus., Zool. v. 1904, p. $86^{15}$.

? Astyanax nasutus, Meek, Publ. Colnmbian Mlus., Zool. vii. 190\%, p. $108^{16}$.

Astyanax rutitus arstedii, Eigennam \& Ogle, Proe. U.S. Nat. Mus. xxxiii. 1907, p. $22^{17}$.

Astyanax rutilus nicaraguensis, Eigenmann \& Ogle, t. e. p. $23^{1 *}$.

Astyanax rutilus aneus, Eigenmann \& Ogle, t. c. p. $2 \Psi^{19}$.

Astyanax fischeri, Eigcnmann \& Ogle, t. c. p. $26^{20}$.

Depth of body $2 \frac{1}{4}$ to $3 \frac{1}{3}$ in the length, length of head $3 \frac{2}{3}$ to $4 \frac{1}{2}$. Snout obtuse, not longer than eye. the diameter of which is 3 to $3 \frac{1}{2}$ in the length of head; interorbital width $2 \frac{1}{2}$ to 3 in the length of head. Maxillary extending to the vertical from anterior edge of eyo or sometimes a little beyond; maxillars teeth 0 to 6. 11 to 15 gill-rakers on the lower part of the anterior arch. 32 to 40 scales in a longitudinal series, 6 to 8 in a transrerse series from dorsal fin to lateral line, 5 to 7 between lateral line and root of rentral fin. Dorsal 10-12 : origin behind the rentrals; longest ray from $\frac{2}{3}$ to as long as the head; free edge of the fin nearly straight. Anal $2.5-33$, with 3 or 4 simple and 22 to 29 branched rays; free edge usualiy slightly emarginate. Pectoral from $\frac{3}{4}$ to as long as the head, usually reaching the ventrals, whieh often extend to the origin of anal. Caudal forlied. Caudal peduncle about as long as deep. Olivaceous above, silvery below; a bluish-silvery lateral band; often a dark humeral spot; usually a blackish oblong spot on the caudal peduncle, produced on tho middle caudal rays.

Ilal). Mexico ${ }^{19}$, Rio Papaloapam ${ }^{15}$ (Buller, Garlow, Meeh), Oaxaca ${ }^{1}$ (Sallé); British Honduras ${ }^{11} 12$ (Paris Mus., Robertson); Guatemala ${ }^{19}$, Rio Motagua *, Lake Yzabal ", Huamuchal ${ }^{4}$, Rio Guacalate", and Lake Amatitlan ${ }^{5}$ s (Godman $\mathcal{d}$ Salvin), Chinautla $^{910}$; Nicaragus ${ }^{17}$, Lake Nicaragua ${ }^{18}$, Lake Managua ${ }^{16}$ and Rio San Juan ${ }^{13}$ (Copentagen Mus.) ; Costa Rica (Underwood); Panama ${ }^{6}{ }^{20}$ (Godman \&. Salvin), Rio Mamoni 7 , Rio Chagres.

Here described from a large series of specimens, measuring up to $120 \mathrm{~mm}$. in total longth, including the types of the species aud of $T$. miorophthalmus, T. panamensis, and T. Lumilis, and co-types of T. corstedii and T. belizianus. 
$T$. ceneus is very closely allied to T. rutilus, Jenyns, which ranges from Venezuela to Montevideo, and it is practically impossible to distinguish between young examples of the two species. When adult specimens are compared, however, the distance between the eye and the upper edge of the lower limb of the præopercle, just behind the articulation of the lower jaw, is seen to be considerably less in $T$. rutilus than in T. ceneus, being equal to $\frac{1}{2}$ the vertical diameter of the eye in the former and $\frac{3}{4}$ of the same in the latter species.

Steindachner had formerly given the name $T$. fischeri to the specimens which he described and figured as T. panamensis. Astyanax emperador, Eigenm. \& Ogle (Proc. U.S. Nat. Mus. xxiii. 1907, p. 26), from Panama, is said to differ fron A. fischeri in the smaller scales ( 39 to 45 instead of 34 to 37 ) in a longitudinal series.

\section{Tetragonopterus macrophthalmus, sp. n. (Tab. XXVI. fig. 4.)}

Tetragonopterus aneus (part.), Meek, Publ. Columbian Mus., Zool. v. 1904, p. $86^{1}$. Astyanax rutilus, variety?, Eigenmann \& Ogle, Proc. U.S. Nat. Mus. xxxiii. 1907, p. $23^{2}$.

Depth of body $2 \frac{1}{3}$ to $3 \frac{1}{4}$ in the length, leugth of head $3 \frac{1}{5}$ to $4 \frac{2}{5}$. Suout obtuse, decnrved, $\frac{1}{2}$ to $\frac{3}{4}$ as long as eye, the diameter of which is $2 \frac{1}{2}$ to 3 in the length of head; interorbital width $2 \frac{2}{3}$ to 3 in the length of head. Maxillary extending nearly to the vertieal from anterior edge of pupil ; 0 to 4 maxillary teeth. 10 to 12 gill-rakers on the lower part of the anterior areh. 34 to 40 seales in a longitudinal series, 6 to 8 in a transverse series from dorsal fin to lateral line, 5 or 6 between lateral line and base of ventral. Dorsal 10-12 ; origin behind the base of ventrals; longest ray as long as the head; free edge of the fin nearly straight. Anal 23-29, of 3 or 4 simple and 20 to 25 branehed rays; free edge usually emarginate. Pectoral about as long as the head, usually reaching the ventrals, whieh nearly or quite reach the origin of anal. Candal forked. Caudal peduncle longer than deep. Coloration as in the preceding species.

Hab. Mexico (Sallé), Motzorongo ${ }^{2}$ in Vera Cruz ${ }^{12}$ (Meek, Gadow).

Several specimens, measuring up to $130 \mathrm{~mm}$. in total length.

Meek's description is evidently based on examples of this species, but he also had the true $T$. aneneus in his collections.

3. Tetragonopterus mexicanus. (Tab. XXVI. figg. 2, 3.)

Tetragonopterus mexicanus, Filippi, Rev. Mag. Zool. 1853, p. $166^{1}$; Steind. Sitzungsb. Ak. Wien, lx. 1869, p. 299, t. $4^{\text {}}$; Jord. \& Everm. Bull. U.S. Nat. Mus. xlvii. 1896, p. $335^{3}$; Meek, Publ. Columbian Mus., Zool. v. 1904, p. $85^{4}$.

Tetragonopterus argentatus, Baird \& Girard, Proc. Ac. Philad. 1854, p. $27^{5}$; Jord. \& Everm. t. c. p. $336^{\circ}$.

Tetragonopterus fasciatus (part.), Günth. Cat. Fish. v. p. $322(1864)^{7}$.

Tetragonopterus brevimanus, Günth, t. c. p. $325^{8}$.

Tetragonopterus petenensis (part.), Giinth. t. c. p. $326^{9}$.

Tetragonopterus cobanensis, Bocourt, Ann. Sci. Nat. (5) ix. 1868, p. $62^{10}$; Vaill. \& Pellegr. Bull.

Mus. Paris, 1903, p. $323^{12}$.

Tetragonopterus oaxacanensis, Bocourt, l. c. ${ }^{12}$; Vaill. \& Pcllegr. t. c. p. $324^{13}$.

Tetragonopterus nitidus, Bocourt, l. c. ${ }^{11}$; Vaill. \& Pellegr. 1. c. ${ }^{25}$. 
Tetragonopterus fulyens, Bocourt, l. c. ${ }^{16}$; Vaill. \& Pellcgr. l. c. ${ }^{17}$.

Teiragomopterus streetsii, Cope, Proc. Ac. Philad. 18i1, p. $21 \tau^{19}$.

Astyanat mexicanus, Eigenmann \& Ogle, Bull. U.S. Nat. Mus. xxxiii. 1907, p. $25^{11}$.

Depth of borly $2 \frac{2}{5}$ to $3 \frac{1}{3}$ in the length, length of head $3 \frac{3}{5}$ to $4 \frac{2}{5}$. Snout obtuse, nearly as long as or shorter than eye, the diameter of which is $2 \frac{3}{4}$ (young) to $3 \frac{1}{2}$ in the length of head; interorbital width $2 \frac{2}{5}$ to $2 \frac{4}{5}$ in the length of head. Maxillary extending about to the vertical from anterior edge of pupil, or sometimes nearly to below middle of eye; maxillary teeth 0 to 5 . 10 to 14 gill-rakers on the lower part of anterior arch. 33 to 39 scales in a longitudinal series, 6 to 8 in a transverse series from dorsal fin to lateral line, $4 \frac{1}{2}$ to 7 between lateral line and root of ventral fin. Dorsal 10-12; origin above or a little behind the base of last ray of ventral; longest ray $\frac{2}{3}$ to $\frac{5}{6}$ the length of head; free edge of the fin straight or slightly conrex. Anal $20-27$, with 3 or 4 simple and 17 to 24 branched rays, free edge usually slightly emarginate. Pectoral $\frac{3}{5}$ to $\frac{5}{6}$ the length of head, sometimes reaching the rentrals, which may or may not extend to the origin of anal. Candal forked. Caudal peduncle longer than deep. Olivaceous above, silvery below; a bluish-silvery lateral band; often a dark humeral blotch; an oblong blaekish spot on the candal peduncle, extending to the end of the middle caudal rays.

Hab. Texas ${ }^{19}$, Rio Grande ${ }^{5}$, Rio Nueces ${ }^{5}$ (Smithsonian Inst.), and Rio Leona ${ }^{5}$ - Mexico, Rio Conchos in Chihuahua ${ }^{5}$ (Foolman), Rio Nazas in Durango ${ }^{4}$, Rio San Juan in Nuevo Leon ${ }^{4}$, Rio Conchos, Rio Soto Marina, and Rio Forlon in Tamaulipas ${ }^{4}$ (Meek), Rio Verde in San Luis Potosi ${ }^{4}$ (Jordan, Meek), Rio Papaloapam and its

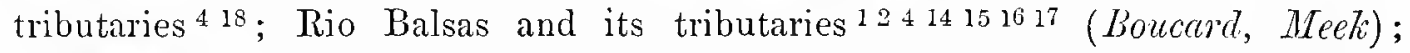
Guatenala, Rio Chisoy ${ }^{7}$, Rio San Gerónimo ${ }^{8}$, Lake Peten ${ }^{9}$ and Lake Yzabal ${ }^{8}$ (Salvin), Coban in Vera Paz ${ }^{10}$ (Paris Mus.).

Here described from a large series of specimens measuring up to $120 \mathrm{~mm}$. in total length, including the types of $T$. brevimanus (fig. 3) and T. petenensis (fig. 2), co-types of $T$. argentatus and of $T$. cobanensis, and examples collected at Cuernavaca by M. Boucard, corresponding to the $T$. nitidus and $T$. fillgens of Bocourt, which were described from specimens obtained at this place by the same collector.

\section{Tetragonopterus angustifrons, sp. n. (Tab. XXVI. fig. 5.)}

Iepth of body about 3 in the length, length of head $3 \frac{2}{3}$ to 4 . Snont subconical, $\frac{2}{3}$ as long as eye, the diameter of which is 3 in the length of head; interorbital width $3 \frac{1}{3}$ to $3 \frac{1}{2}$ in the length of head. Maxillary extending about to the vertical from anterior edge of pupil ; 3 to 5 maxillary teeth. 14 to 17 gill-ralsers on the lower part of the anterior arch. 34 to 38 scales in a lungitudinal series, 7 or $S$ in a transverse series from dorsal fin to lateral line, 6 or 7 between lateral line and base of ventrals. Dorsal 11 ; origin behind the base of ventrals; longest ray $\frac{3}{4}$ to $\frac{4}{5}$ the length of head; free edge of tiu slightly convex. Aral 26-29, of 3 or 4 simple and 23 to 26 brancbed rays; free edge slightly emarginate. Pectoral $\frac{3}{1}$ the length of head, about reaching the ventrals, which extend nearly to the anal. Caudal forked. Caudal pedunclo longer than deep. Coloration as in the proceding species.

Hab. Mexico (Sallé).

Thiree specimens, the largest $80 \mathrm{~mm}$. in total length.

\section{CHIRODON.}

Chirodon, Girard, Proc. Ac. Pliilad. vii. 1854, p. 199; Güntl. Cat. Fish. v. p. 332 (1864).

About twelve species from South America and one from Mexico. 


\section{Chirodon compressus.}

Hemigrammus compressus, Mcek, Publ. Columbian Mus., Zool. v. 1904, p. 87, fig. 25.

Depth of body $2 \frac{1}{2}$ in the length, length of head $3 \frac{1}{2}$. Snout shorter than eye, the diameter of which is $2 \frac{3}{4}$ in the length of head and greater than the interorbital width. Maxillary extending a little beyond the rertical from the anterior edge of eye; 5 maxillary teeth. About 12 gill-rakers on the lower part of the anterior arch. About 45 seales in a longitudinal series; lateral line on only 5 or 6 scales. Dorsal 10-11; origin behind the rentrals. Anal 25-27, origin below middle or posterior part of dorsal: anterior part of fin deep, pointed; free edge emarginate. Pectoral reaching the ventrals, which extend beyond the origin of anal. Caudal forked. Olivaceous; a dark spot on the basal part of the dorsal fin.

Hab. Mexico, Rio Papaloapam ${ }^{1}$ (Meek).

Here described from two specimens, $45 \mathrm{~mm}$. in total length.

\section{GASTROPELECUS.}

Gastropelecus, Pall. Spic. Zool. fasc. 8, p. 50 (1769); Günth. Cat. Fish. v. 1. 342 (1864) ; Jord. \& Everm. Bull. U.S. Nat. Mus. xlvii. 1896, p. 337.

About six species from tropical South America and one from Panama.

\section{Gastropelecus maculatus.}

Gastropelecus maculatus, Steind. Denkschr. Ak. Wien, xli. 1879, p. 168, t. 1. fig. $4^{2}$; Jord. \& Everm. Bull. U.S. Nat. Mus. xlvii. 1896, p. $338^{2}$.

Dorsal 11. Anal 36 or 37 . 31 or 32 scales in a longitudinal series.

Hab. Panama, Rio Mamoni ${ }^{1}$.

Length about $80 \mathrm{~mm}$.

\section{S. BRAMOCHARAX.}

Bramocharax, Gill, Proc. Ac. Philad. 1877, p. 189 ; Jord. \& Everm. Bull. U.S. Nat. Mus. xlvii. 1896, p. 338.

Two species from Nicaragua.

\section{Bramocharax bransfordi.}

Bramocharax bransfordi, Gill, Proc. Ac. Philad. 1877, p. $190^{1}$; Jord. \& Everm. Bull. U.S. Nat. Mus. xlvii. 1896, p. $339^{2}$; Eigenmann \& Ogle, Proc. U.S. Nat. Mus. xxxiii. 1907, p. 32, fig. 6.

Dorsal 11. Aual 28. Depth of body $2 \frac{3}{1}$ in the length.

\section{Hab. Lake Nicaragua ${ }^{1}$.}

Eigenmann and Ogle's figure of this species shows that the teeth are not conical, but notched, as in Brycon, \&c. The produced pointed snout and the canine-like. anterior teeth distinguish Bramocharax from Chirodon. 


\section{Bramocharax elongatus.}

Bramochara.s elongatus, Meek, Publ. Columbian Mus., Zool. vii. 1907, p. 110 '.

Dorsal 10. Anal 25 to 28. 41 scales in a longitudinal series. Depth of body $3 \frac{2}{5}$ to $t$ in the length.

Maxillary extending to below middle of eje.

Hab. Nicaragua, Lake Managua ${ }^{1}$.

Total length $150 \mathrm{~mm}$.

\section{RCEBOIDES.}

Raboides, Günth. Cat. Fish. v. p. 347 (1864); Jord. \& Ercrm. Bull. U.S. Nat. Mus. xlvii. 1896, p. 338.

About ten species from Central and South America.

\section{Rœboides guatemalensis.}

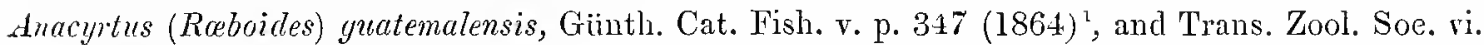
1868, p. 479, t. 82. fig. $4^{2}$.

Rerboides guatemalensis, Jord. \& Everm. Bull. U.S. Nat. Mus. xlvii. 1896, p. $339^{3}$; Meek, Publ.

Coilumbian Mus., Zool. v. 1904, p. $88^{4}$, and vii. 1907, p. $111^{5}$.

Depth of bordy $2 \frac{1}{2}$ to $2 \frac{4}{3}$ in the length, length of head about 4 . Snout as long as eye, the diameter of which is $3 \frac{1}{2}$ to $3 \frac{2}{3}$ in the length of head and equal to the interorbital width. Naxillary extending to below middle of eje; lower jaw included. Upper profile of head concave. 10 gill-ratsers on the lower part of the anterior arch. 76 to 82 scales in a longitudinal series, 17 to 19 between dorsal fin and lateral line, 20 to 22 from lateral line to origin of anal. Dorsal 11-12, rather elevated; origin above anterior part of anal. Anal $47-53$, with 3 or 4 simple and 44 to 49 branched rass, deepest anteriorly; free edge straight. Pectoral extending to, ventrals beyond the origin of anal. Caudal forked. Olivaceous: a silvery lateral stripe, sometimes bearing a dusky spot, about equidistant from head and dorsal fin and another on the caudal peduncle.

Hab. Mexico, San Gerónimo in Oaxaca ${ }^{4}$; Guatemala, Huamuchal 12 (Salvin); Nicaragua, Lake Nicaragua ${ }^{5}$; Costa Rica, Juan Viñas and El Pozo del Rio Grande (Underwood) ; Panami, Rio Chagres ${ }^{12}$ (Salvin).-Western Ecuador (Rosenberg).

\section{CURIMATUS.}

Curimatus, Cuv. \& Val. Hist. Nat. Poiss. xxii. p. 5 (1849); Günth. Cat. Fish. v. p. 288 (1864) ; Jord. \& Everm. Bull. U.S. Nat. Mus. xlvii. 1896, p. 332.

Several species from Tropical South America, one extending into Panama.

\section{Curimatus magdalenæ.}

Curimatus magdlalence, Steind. Denkschr. Ak. Wien, xxxix. 1878, p. 50 ${ }^{1}$, and xli. 1879, p. $167^{2}$; Jord. \& Everm. Bull. U.S. Nat. Mus. xlvii. 1896, p. $332^{3}$.

Dorsal 11-12. Anal 9-10. 36 to 38 seales in a longitudinal series. Depth of body $\frac{22}{3}$ in the length.

Hab. Panama, Rio Mamoni 2--Colombia, Rio Magdalena 1. 


\section{Fam. 5. GYIINOTIDE.}

This family, which has recently been monographed by Eigenmann*, comprises about 30 species from South America, one of which extends into Panama and another as far north as Guatemala.

The Gymnotidæ are highly specialized Characinids, and may be recognized by the long, more or less eel-shaped body, naked or covered with small scales, the restricted gill-openings, the anterior position of the vent, the absent dorsal and ventral fins, the very long anal, and the small or absent caudal.

\section{Synopsis of the Central-American Genera.}

Each jaw with a series of conical teeth . . . . . . . . . . . 1. Giton.

Each jaw with a pateh or band of very small villiform teeth . . . . . 2. Eigenmannia.

1. GITON, Kaup, 1S56:

Carapus (non Rafin.), Cuv. Règne Anim. p. 237 (1817); Müll. \& Trosch. Hor. Iehthyol. iii. p. 13 (1815); Güuth. Cat. Fish. viii. p. 9 (18r0).

Giton, Jord. \& Everm. Bull. U.S. Nat. Mus. xlvii. 1896, p. 340.

This genus includes only one species.

1. Giton fasciatus, Pall., 1769.

Carapus fasciatus, Günth. Cat. Fish. viii. p. $9(1870)^{2}$.

Giton fasciatus, Jord. \& Everm. Bull. U.S. Nat. Mus. xlvii. 1896, p. $340 \%$

Gymnotus carapo, Meck, Publ. Columbian Mus., Zool. vii. 1907, p. $135^{3}$.

Hab. Guatemala to La Plata ${ }^{2}{ }^{2}$; in Central America known only from the Rio Motagua (Salvin) and Lake Amatitian ${ }^{3}$.

A very variable species, sometimes uniformly coloured, more often with oblique dark cross-bands which may break up into spots.

Total length $400 \mathrm{~mm}$.

2. EIGENMANNIA, Jord. \& Everm., 1896.

Eigenmannia, Jord. \& Evcrm. Bull. U.S. Nat. Mus. xlvii. 1896, p. 341.

Four species from Tropical America.

\section{Eigenmannia humboldti, Steind., 1878.}

Sternopygus humboldti, Steind. Denkschr. Ak. Wicn, xxxix. 1878, p. 71, t. 14. fig. $3^{2}$, and xli. 1879, p. $169^{2}$.

Eigenmannia humboldti, Jord. \& Everm. Bull. U.S. Nat. Mus. xlvii. 1896, p. $341^{3}$.

Hab. Panama, Rio Mamoni 2.-Colombia, Rio Magdalena ${ }^{\text {. }}$

Total length $450 \mathrm{~mm}$.

* Proc. Washington Ac. vii. 1905. 


\section{Sub-order VIII. MALACOPTERYGII.}

This sub-order is represented in the fresh waters of Mexico and Central America by a few fishes, mostly marine types. These are soft-rayed fishes with elongate or ovate scaly body and naked head; dorsal, anal, and caudal fins are present, the pectorals are placed low and the ventrals are abdominal. The naked head, the maxillary forming part of the border of the mouth, the normal position of the lateral line (when present), and the larger number of rays in the ventral fins distinguish them externally from the Haplomi of this region. From the Characinidæ they may usually be distinguished by the larger number of branchiostegal rays.

\section{Synopsis of the Families represented in the fresh waters of Mexico}

and Central America.

I. An adipose dorsal fin . . . . . . . . . . . . . . . . . . 1. Shlmonide.

II. No adipose fin.

A. No gular plate; teeth small or absent.

No lateral line . . . . . . . . . . . . . . . . . 2. Clupeide.

Lateral line well developed . . . . . . . . . . . . . . . . 3 . Chinnide.

B. A gular plate between the rami of the lower jaw ; bands of villiform teetl in the jaws and ou the palate and tongue . . . . . . . . 4. Elopider.

\section{Fam. 1. SALMONID郡.}

The Salmonidæ are principally a circumpolar family of marine origin which are establishing themselves in fresh water in the Palæarctic and Nearctic Regions. One fresh-water genus occurs in Australia and New Zealand. There are about twenty genera, but the number of species which should be recognized is very uncertain.

\section{SALMO, Linn.}

Oncorhynchus (Suckley, 1861) and Salmo, Jord. \& Evcrm. Bull. U.S. Nat. Mus. xlvii. 1896, pp. 474 and 483 .

body elongato, more or less compressed, covered with small cycloid scales. Lateral line present. Head naked; mouth large; conical teeth in the jaws and on the palate. Dorsal fin short, in the middle of the length of the fish; an adipose fin; anal short or of moderate length; caudal forked or truncate.

The species are very variable and difficult to define; they inhabit the rivers and lakes of North America, Europe, and Asia; many of the forms are migratory, living part of their life in the sea and ascending rivers to spawu.

\section{Salmo clarkii, Richards.}

Salmo mykiss, Jord. \& Everm. Bull. U.S. Nat. Mus. xlvii. 1896, p. 487.

Sulmo clartiii, Jord. \& Everm. t. e. 1900, p. 2819.

Salmo irideus, Meck, Publ. Columalian Mus., Zool. v, 190t, p. 96. 
Hab. Streams of the Rocky Mountains and Sierra Nevada, from Kamchatka and Alaska to California and Durango.

This species embraces a number of local forms, including S. spilurus, Cope (Jord. \& Everm. t. c. p. 495, fig. 210), which inhabits the upper Rio Grande and extends southwards into Chihuahua and Durango.

A second form, S. pleuriticus, Cope (Jord. \& Everm. t. c. p. 496, fig. 211), is found in the Colorado River, and is probably the trout reported by Meek as abundant in the Rio Yaqui in Sonora.

\section{Fam. 2. CLUPEID正.}

A large and widely distributed marine family; several species are anadromous, and some are permanently fluviatile.

The Clupeidæ may be distinguished from other soft-rayed fishes of the fresh waters of Mexico and Central America by the compressed body, covered with thin cycloid scales, the naked head, the feeble dentition, and the absence of a lateral line.

Synopsis of the Genera represented in the fresh waters of Mexico and Central America.

I. Abdomen compressed to a serrated edge; mouth small or moderate; last dorsal ray elongate. Maxillary bearing one supramaxillary . . . . . . . . . . . . . 1. Dorosona. Maxillary bearing two supramaxiliaries . . . . . . . . . . . 2. Signalosa.

II. Abdomen not serrated ; mouth large, the maxillary extending baek far behind the eye ; last dorsal ray not elongate.

Teeth in the jaws evident, some more or less enlarged . . . . . . . . 3. Lycengraulis. Teeth in the jaws very small or absent . . . . . . . . . . . . 4. Anchovia.

1. DOROSOMA, Rafin., 1829.

Chatoessus (Cuv.), Günth. Cat. Fish. vii. p. 406 (1868).

Dorosoma, Jord. \& Everm. Bull. U.S. Nat. Mus. xlvii. 1896, p. 415.

Five species from the Atlantic coasts and rivers of America.

Synopsis of the Mexican and Central-American Species.

74 to 78 scales in a longitudinal series; anal of 26 to 30 rays . . . . . . . 1. chavesi.

69 to 73 scales in a lougitudinal series; anal of 36 to 38 rays . . . . . . . 2. anale.

56 to 60 scales in a longitudinal series; anal of 30 to 34 rays . . . . . . . 3. exile.

40 to 45 scales in a longitudinal series; anal of 21 to 24 rays . . . . . . . 4. petenense.

\section{Dorosoma chavesi.}

Dorosoma chavesi, Meek, Publ. Columbian Mus., Zool. vii. 1907, p. $112^{\text {'. }}$

Hab. Nicaragua, Lakes Managua and Nicaragua ${ }^{1}$

Total length $210 \mathrm{~mm}$.

BIOL. CENTr.-AMER., Pisces, February 1908. 


\section{Dorosoma anale.}

Dorosoma anale, Meek, Publ. Columbian Mus., Zool. v. 190^, p. 93, fig. 26'.

1lab. Mexico, Otopa and Rio Papaloapam in Vera Cruz ${ }^{\mathrm{I}}$.

Total length $300 \mathrm{~mm}$.

\section{Dorosoma exile.}

Dorosoma cepedianum exile (Jord. \& Gilb., 188:2), Jord. \& Everm. Bull. U.S. Nat. Mus. xlvii. 1896, p. $416^{\text {? }}$.

Dorosoma exile, Meek, Publ. Columbian Mus., Zool. v. 1904, p. 94².

Ilab. Coasts and rivers of Texas ${ }^{1}$ and Tamanlipas ${ }^{2}$.

Total length $300 \mathrm{~mm}$.

\section{Dorosoma petenense.}

Chatoessus petenensis, Günth. Cat. Fish. vii. p. 408 (1868) '.

Dorosoma petenerse, Jord. \& Everm. Bull. U.S. Nat. Mus. xlvii. 1896, p. $417^{2}$.

Depth of body $2 \frac{3}{4}$ to 3 in the length, length of head $3 \frac{1}{2}$. Jaws equal anteriorly; maxillary extending to below anterior $\frac{1}{4}$ or $\frac{1}{3}$ of eye. 40 to 43 scales in a longitudinal series. Dorsal 1t-15; origin above or slightly in adrance of the rcntrals. Anal 21-2t. Pectoral nearly reaching the ventral. Silvery, a dark humeral spot.

Hab. Guatemala, Lake Peten ${ }^{1}$ (Salvin).

Here described from the types, four specimens, 70 to $90 \mathrm{~mm}$. in total length.

2. SIGNALOSA, Everm. \& Kendall, 1838.

Signalosa, Jord. \& Everm. Bull. U.S. Nat. Mus. xlvii. 1900, p. 2809.

A single species.

\section{Signalosa mexicana.}

rhatoessus mexicanus, Giünth. Cat. Fish. vii. p. 409 (1868) ?

Dorosoma mexicanum, Jord. \& Everm. Bull. U.S. Nat. Mus. xlvii. 1896, p. $416^{2}$.

Signalosa atchafalaya, Everm. \& Kendall, Bull. U.S. Fish. Comm. 1897, p. 1.27 (1898) ${ }^{3}$; Jorr. \& Everm. t. c. 1900, p. 2809, fig. 18: ${ }^{4}$.

Signalosa mexicana, Meek, Publ. Columbian Mus., Zool. v. 1901, p. $94^{3}$.

Depth of body $2 \frac{2}{3}$ to 3 in the length, length of head 3 to $3 \frac{1}{2}$. Jaws equal anteriorly; maxillary extending to below anterior $\frac{1}{4}$ or $\frac{1}{3}$ of eye. 40 to 42 scales in a longitudinal series. Dorsal 13-14; origin immediately behind the base of the ventrals. Anal 2t-25. Pectoral extending to or a little boyond the base of ventral. Silvery, a dark humeral spot.

IIab. Atlantic Coast streams of the Southern United States and Mexico:

United States, Mississippi ${ }^{4}$ and Louisiana ${ }^{34}$; Mexico ${ }^{1}$ (Sallé), Valles in San Luis Patosi ${ }^{5}$; Rio Papaloapam in Vera Cruz ${ }^{5}$ (Meek).

Tere described from three specimens, 90 to $100 \mathrm{~mm}$. in total length, including the types of the species. S. atchafalayce is described and figured as having the origin of the dorsal above the ventrals, but it scems to be the same as S. mexicana. 


\section{LYCENGRA ULIS, Günth., 1868.}

Lycengraulis, Günth. Cat. Fish. vii. p. 399 (1868); Jord. \& Everm. Bull. U.S. Nat. Mus. xlvii. 1896, p. 451.

Two species from the coasts of Panama and South America.

\section{Lycengraulis poeyi.}

Engranlis poeyi, Kner \& Steind. Abliandl. Bayern. Ak. x. 1864, p. 23, t. 3. fig. $3^{2}$.

Stolephorus poeyi, Jord. \& Everm. Bull. U.S. Nat. Mns. xlvii. 1896, p. $445^{2}$.

Lycengraulis poeyi, Gilb. \& Starks, Mem. Calif. Ae. iv. 1904, p. $49^{3}$.

Hab. Panama ${ }^{3}$, Rio Bayano ${ }^{1}$.

Total length $20 \mathrm{Sm}$.

4. ANCHOVIA, Jord. \& Everm., 1896.

Anchovia, Jord. \& Everm. Bull. U.S. Nat. Mus. xlvii. 1896, p. 449.

A single species.

\section{Anchovia macrolepidota.}

Engraulis macrolepidotus, Kner \& Steind. Abhandl. Bayern. Ak. x. 186t, p. 21, t. 3. fig. $2^{1}$. Anchovia macrolepidota, Jord. \& Everm. Bull. U.S. Nat. Mus. xlvii. 1896, p. $449^{2}$.

Hab. Pacific Coast of Mexico and Central America, entering rivers:

Mexico, Guaymas ${ }^{2}$; Panama, Rio Bayano ${ }^{1 .}$

Total length $200 \mathrm{~mm}$.

\section{Fam. 3. CHANIDE.}

This family includes a single genus with 3 or 4 species, marine fishes of the IndoPacific.

\section{CHANOS, Lacep., 1803.}

Chanos, Günth. Cat. Fish. vii. p. 473 (1868); Jord. \& Everm. Bull. U.S. Nat. Mus. xlvii. 1896, p. 414.

Body elongate or ovate, compressed, covered with small cycloid scales. Latcral line complete, straight. Head naked; mouth small, terminal, toothless; gill-membranes broadly united; an adipose eyelid. Dorsal fin short, in the middle of the length of the fish, above the rentrals; anal fin short; caudal deeply forked.

1. Chanos salmoneus, Bl. Schin., 1801.

Chanos salmoneus, Giinth. Cat. Fish. vii. p. 473 (1868).

Chanos chanos (Forsk.), Jord. \& Everm. Bull. U.S. Nat. Mus. xlvii. 1896, p. 414, and 1900, fig. 182.

Hal. Indian and Pacific Oceans, entering rivers.

Specimens of this large silvery fish in the British Museum are from brackish lakes at Chiapam in Guatemala. 


\section{Fam. 4. ELOPID死.}

Two genera with five species, inhabiting tropical and subtropical seas.

$$
\text { 1. MEGALOPS, Lacep., } 1803 \text { * }
$$

Megalops, Günth. Cat. Fish. vii. p. 471 (1868).

Tarpon, Jord. \& Everm. Bull. U.S. Nat. Mus, xlvii. 1896, p. 409.

Body elongate, compressed, corered with large silvery cycloid scales. Lateral line present. Head naked; mouth large, terminal, the lower jaw prominent; bauds of villiform teeth in the jaws and on tho palate and tongue. A gular plate between the rami of the lower jaw. Dorsal fin short, in the middle of the length of the fish, last ray produced; anal of moderate length ; caudal forked.

Two species, one from the Indian Ocean, the other from the Atlantic coasts of America.

\section{Megalops atlanticus, Cuv. \& Val., $1 S 46$.}

Megalops thrissoides (non Bl. Schn.), Giinth. Cat. Fish. vii. p. 472 (1868).

Tarpon atlanticus, Jord. \& Everm. Bull. U.S. Nat. Mus. xlvii. 1896, p. 409, and 1900, fig. 117.

Hab. Atlantic coasts of America from Long Island to Brazil, entering rivers.

The Tarpon attains a length of $1800 \mathrm{~mm}$. It has been recorded by Gill and Bransford (Proc. Ac. Philad. 1877, p. 187) from Lake Nicaragua.

\section{Sub-order IX. GINGLYMODI.}

This sub-order includes only the genus Lepirlosteus, unique among fishes in having opisthocœlous vertebra, and distinguished from other fresh-water fishes of Mexico and Central America by the rugose skull, the hard, rhombic ganoid scales, and the abbreviate heterocercal caudal fin.

\section{Fam. 1. LEPIDOSTEIDA心.}

\section{LEPIDOSTHUS, Lacep., 1803.}

Lepidosteus, Günth. Cat. Fish. viii. p. 328 (18i0); Jord. \& Everm. Bull. U.S. Nat. Mlus, xlvii. 1896, p. 109.

Body elongate, subeylindrical, covered with bony rhombic scales arrangod in oblique series ruming duwnwards and backwards. Jaws elongate, the upper projocting beyond the lower; tecth conical, in the jaw's and on the palate. Dorsal fin short, posterior, nearly opposite the anal; pectorals placed low ; ventrals abdominal : caudal rounded.

Six or seven species of this genus may be regarded as valid. They inhabit Nortl and Central America.

* This name has been used for a genus of Staphyliuida in the Biol. Centr. $-\Delta \mathrm{m}$. (Coleopt. i. pt. 2), but it has priority in Pisces. 


\section{Synopsis of the Mexican and Central-American Species*.}

I. Snout more than twice as long as the rest of the head ; no series of enlargcd teeth on the palatines in the adult . . . . . . . . . . . . 1. osseus.

II. Snout not more than once and a half as long as the rest of the head; a series of cnlarged teeth on the palatines in the adult, as well as in the young.

58 to 60 scales in a longitudinal series; length of head 3 to $3 \frac{\text { J }}{3}$ in the length of the fish (in specimens of 300 to $500 \mathrm{~mm}$.) . . . . . . . . . . 2. trisioechus.

51 to 54 scales in a longitudinal series; length of head $3 \frac{2}{5}$ to $3 \frac{3}{5}$ in the length of the fish (in specimens of 450 to $500 \mathrm{~mm}$.) . . . . . . . . 3. tropicus.

\section{Lepidosteus osseus.}

Esox osseus, Linn. Syst. Nat. p. 313 (1758) '.

Lepidosteus osseus, Günth. Cat. Fish. viii. p. $330(1870)^{2}$; Jord. \& Everm. Bull. U.S. Nat. Mus. xlvii. 1896, p. $109^{3}$; Meek, Publ. Columbian Mus., Zool. v. 1904, p. $5^{4}$.

Snout about $2 \frac{1}{2}$ times as long as the rest of the head. Dorsal $i-8$. Aural 8-9. 58 to 62 scales in a longitudinal series.

Hab. United States from the Great Lakes to the Rio Grande ${ }^{23}$; North-eastern Mexico ${ }^{4}$.

In Mexico recorded by Meek from San Juan in Nuevo Leon, Forlon in Tamaulipas, and Valles in San Luis Potosi.

Total length $1500 \mathrm{~mm}$.

\section{Lepidosteus tristoechus.}

Esox tristoechus, Schneid. Bloch's Syst. Ichth. p. 395 (1801)'.

Lepidosteus viridis (non Gmelin), Gïnth. Cat. Fish. viii. p. 329 (1870) ².

* The three species here recognised comprise the subgenera Lepidosteus (L. osseus) and Atractosteus (L. tristocehus and L. tropicus). There is a third subgenus, Oylinclrosteus, with the dentition of Lepidosteus, but with the snout shorter and broader than in $L$. osseus, only a little longer than the rest of the head. This subgenus is usually considered to include a single species, L. platystomus, Rafin., which is said to range from the Great Lakes to Texas. Examiuation of the specimens in the British Museum Ieares no doubt that 3 or $t$ distinct species belong to this section; some of these may extend into North-eastern Mexico.

L. productus, Cope, seems to be different from L. platystomus or any of the species which I have seen. Specimens of L. platystomus from Illinois and Louisiana hare 60 to 62 scales in a longitudinal series and the width of the snout, at the lerel of the angles of the mouth, not more than $\frac{1}{3}$ the length of the upper jaw. A fish from St. Louis, received from the Museum of Comparative Zoology, closely resembles L. platystomus, and may not he specifically distinct, but has larger scales ( 55 or 56 in a longitudinal series) and corresponds in every way to L. agassizii, Dum., also described from a St. Louis specimen from the Museum of Comparative Zoology. The type of L. grayi, Agass. (600 mm. long), and a much larger specimen, also from Louisiana, differ from L. platystomus in having a much broader suout (width at the angles of the mouth $2 \frac{1}{3}$ in the length of the upper jaw). L. zadocki, Dum.y is evidently the same as L. grayi. 
Lepidostens tristoechus, Jord. \& Everm. Bull. U.S. Nat. Mus. xlvii. 1896, p. 1 Il $^{3}$; Meek, Publ. Columbian Mus., Zool. v. 1904, p. $6^{4}$.

Length of head 3 to $3 \frac{1}{3}$ in the length of the fish. Snout $1 \frac{1}{4}$ to $1 \frac{2}{5}$ as long as the rest of the head. Dorsal $7-8$. Anal 7-S. 58 to 60 scales in a longitudinal series.

Hab. Southern United States ${ }^{234}$; North-eastern Mexico ${ }^{234}$; Cuba ${ }^{123}$.

In Mexico recorded from Tampico in Tamaulipas.

Here described from three specimens, 300 to $500 \mathrm{~mm}$. in total length, from Mexico and Cuba. The species is said to attain a length of $3600 \mathrm{~mm}$.

\section{Lepidosteus tropicus.}

Atractosteus tropicus, Gill, Proc. Ac. Plilad. 1863, p. $172^{1}$; Duméril, Hist. Nat. Poiss. ii. p. 36 б $(1870)^{2}$.

Atractosteus bocourti, Duméril, t. c. t. 22. fig. $1^{3}$.

Lepidostens tropicus, Jord. \& Everm. Bull. U.S. Nat. Mus. xlvii. 1896, p. $111^{2}$; Everm. \& Goldsborough, Bull. U.S. Fish. Comm. xxi. 1902, p. 139 ${ }^{j}$; Meek, Publ. Columbian Mus., Zool. vii. 1907 , p. $104^{\circ}$.

Jength of head $3 \frac{2}{\bar{\partial}}$ to $3 \frac{2}{2}$ in the length of the fish. Suout $1 \frac{1}{\bar{\partial}}$ to $1 \frac{2}{5}$ as long as the rest of the head. Dorsal 6- 7 . Anal $6-7.51$ to 54 scales in a longitudinal series.

Hab. Mexico, Montecristo and Teapa in Tabasco ${ }^{5}$; Guatemala, Huamuchal (Salvin) and Rio Nagualate ${ }^{23}$; Nicaragua, Lakes Managua and Nicaragua ${ }^{6}$; Panama ${ }^{1}$.

Here described from two specimens, 450 and $500 \mathrm{~mm}$. in total length.

\section{Sub-class II. SELACIII.}

\section{Order I. EUSELACHII.}

\section{Sub-order I. PLEUROTREMATA.}

Sharks, with the gill-openings lateral, 5 to 7 in number on each side, the last in front of or above the pectoral fin.

\section{Fam. 1. CARCHARIIDE.}

1. CARCHARIAS, Rafin., 1810.

Carcharias, Günth. Cat. Fish. viii. p. 357 (1870).

Carcharinus (Blainv., 1816), Jord. \& Everm. Bull. U.S. Nat. Mus. xlvii. 1896, p. 33.

Numerous species from tropical and sub-tropical seas. 


\section{Carcharias nicaraguensis.}

Eulamia nicaraguensis, Gill \& Bransf. Proc. Ac. Philad. 1877, p. 190.

Carcharinus nicaraguensis, Jord. \& Everm. Bull. U.S. Nat. Mus. xlvii. 1896, p. 39.

Hab. Nicaragua, Lake Nicaragua and Rio San Juan.

This shark attains a length of $2100 \mathrm{~mm}$. It has so far only been recorded from fresh water, and does not appear to be identical with any of the marine species of the coasts of America,

\section{Sub-order II. HYPOTREMATA.}

Rays, with the gill-openings ventral, five in number on each side, below the pectoral fins.

\section{Fam. 1. PRISTID床.}

\section{PRISTIS, Latham, 1794.}

Pristis, Günth. Cat. Fish. viii. p. 436 (1870) ; Jord. \& Everm. Bull. U.S. Nat. Mus. xlvii. 1896. p. 60.

This genus comprises four or five species, "Saw-fishes," inhabiting warm seas on sandy shores and often ascending rivers. Only two species appear to occur on the coasts of Mexico and Central America *

1. Pristis pectinatus, Latham, 1794.

Pristis pectinatus, Giinth. Cat. Fish. viii. p. 4.37 (1870) ; Jord. \& Everm. Bull. U.S. Nat. Mus. xlvii. 1896, p. 60.

$2 \pm$ to 32 pairs of rostral teeth, the posterior further apart than the anterior.

Hab. Tropical seas.

2. Pristis perrotteti, Müll. \& Henle, 1838.

Pristis perrotteti, Günth. Cat. Fish. viii. p. 436 ; Jord. \& Everm. Bull. U.S. Nat. Mus. xlvii. 1896, p. 60.

Pristis zephyreus (Jord. \& Starks), Jord. \& Everm. Bull. U.S. Nat. Mus. xlvii. 1898, p. 2749.

18 to 22 pairs of rostral teeth.

Hab. Tropical seas.

This is probably the Saw-fish which has been recorded from Lake Nicaragua by Gill and Bransford (Proc. Ac. Philad. 187\%, p. 190) as Pristis antiquorum, Latham.

* Saw-fishes were seen by Mr. G. C. Champion in a fresh-water lagoon at Paso Antonio, near the Pacitic coast of Guatemala. 


\section{Sub-class III. CYCLOSTOMATA.}

\section{Order I. HYPEROAR'TII.}

\section{Fam. 1. PETR0MYZ0NIDA.}

Jampreys, with naked eel-shaped body, suctorial month, and seven gill-openings on eaclis side.

\section{LAMPETRA, Gray, 1851.}

Lampetra, Jord. \& Everm. Bull. U.S. Nat. Mus. xlvii. 1896, p. 12.

Five or six species, small Lampreys inhabiting brooks in Europe and North America.

\section{Lampetra spadicea.}

Lampeira spadicea, Bean, Proc. U.S. Nat. Mus. 1887, p. $374^{1}$; Jord. \& Everm. Bull. U.S. Nat. Mus. xlvii. 1896, p. 13, and 1900, fig. $6^{2}$; Meek, Publ. Columbian Mus., Zool. v. 190t, p. 2 , fig. 1 :

Frol. Mexico, Rio Lerma System:

Guanajuato ${ }^{2}{ }^{2}$; Lake Chapala ${ }^{3}$. 


\section{S U P P L E M E N T.}

THE following additions and corrections are chiefly necessitated by the acquisition of fresh material during the progress of this work, and by the recent publication of some papers by Dr. S. E. Meek on Central-American fishes. I am indebted to Dr. Meek for kindly sending me proof-sheets of his latest memoir (Publ. Columbian Mus., Zool. vii. 1907, pp. 133-157); in this he quotes, presumably from proofs, a paper on the fishes of the Rio Motagua (Miller, Bull. Amer. Mus. Nat. Hist. 1907, pp. 95-124) which I have not seell.

\section{ACHIRUS (p. 3).}

\section{2 (A). Achirus fischeri, Steind., 1879.}

Achirus fischeri, Jord. \& Everm. Bull. U.S. Nat. Mus. xlvii. 1898, p. 2699.

Depth of body nearly 2 in the length; right pectoral fin represented by a single ray ; 60 to 62 scales in a longitudinal series.

Hab. Panama, Rio Mamoni.

SICYDIUM (p. 10).

\section{1 (A). Sicydium altum.}

Sicydium altum, Meek, Publ. Columbian Mus., Zool. vii. 1907, p. $149^{1}$.

Horizontal teeth of lower jaw mostly concealed. Scales extending forward on the upper surface of the head nearly to the interorbital region; abdomen scaly, except for a small area just behind the ventral fins ; 92 scales in a longitudinal series. Dorsal VI, I 10. Anal I 10. Dark oliraceous, withont spots or bars ; fins without spots or vermiculations, the anal with a dark edge.

Hab. Costa RICA, Turrialba ${ }^{1}$ and El Guayabo ${ }^{1}$.

Total length $105 \mathrm{~mm}$.

\section{1 (в). Sicydium pittieri.}

Sicydium pittieri, Regan, Ann. Mag. Nat. Hist. (7) xix. 1907, p. $260^{2}$.

Horizontal teeth of lower jaw concealed or not. Scales extending forward on the upper surface of the head nearly to the interorbital region; abdomen with a median naked area or strip; 75 to 80 scales in a longitudinal series. Dorsal VI, I 10. Anal I 10. A dark spot on each scale; dorsal fins with dark vermiculations; anal with a dark edge.

Hab. Costa Rica, Rio Grande de Terraba ${ }^{1}$ (Pittier).

Here described from the types, two specimens (males), 120 and $135 \mathrm{~mm}$. in total length.

BIOL. CENTr.-ANer., Pisces, February 1908. 


\section{1 (A). Cichlosoma zonatum.}

CICHLOSOMA (p. 17).

Cichlasoma zonatum, Meek, Proc. Biol. Soc. Washington, xviii. 1905, p. 245 '.

This species was originally described as having the jaws equal anteriorly, and I suggested (cntei, p. 20) that it might be the same as C. quftulatum. Dr. Meek (Publ. Columbian Mus., Zool. vii. 1907, p. 141) has now stated that $C$. zonatum differs from $C$. guttulatum in the smaller and more inferior mouth; it is evidently allied to $C$. cigenmemi, differing in the deeper body (depth $2 \frac{1}{10} \mathrm{in}$ the length), the lower spinous dorsal (last spine $\frac{f}{5}$ the length of head), and the fewer soft rays (10 or 11) in tho dorsal fin.

Hab. Mexico, Niltepec in Oaxaca ${ }^{2}$.

Cichlosoma maculicauda (p. 19).

Thecorded from Belize by Meek (Publ. Columbian Mus., Zool. vii. 1907, p. 151).

\section{3 (A). Cichlosoma nigritum.}

Cichlasoma nigritum, Meek, Pulıl. Columbian Mus., Zool. vii. 1907, p. 128.

Apparently very similar to $C$. macelicauda, but the coloration plain dark olivaceous, without a dark spot on the caudal peduncle.

Hab. Lake Nicaragui.

Cichlosoma microphthalmus (p. 20).

'To the synonymy add :-

Cichlasoma milleri, Meck, Publ. Columbian Mus., Zool. vii. 1907, p. 142.

Meek's type is also from the Rio Motagua.

Cichlosoma pavonaceum (p. 21).

This species appears to resemble Herichthys cyanoguttatus in so many respects that it seems probable that it may prove to belong to the genus IIerichthys.

Cichlosoma sieboldii (p. 21).

Specimens of $C$. sieboldii from Costa Rica (Pittier) show that it is a Parancetroplus and is the same as the species described on p. 30 from a single badly preserved example under the name Herichthys underwoodi.

\section{2 ( $)$. Cichlosoma alfari.}

Cichlasoma alfari, Mcek, Publ. Columbian Mus., Zool. vii. 1907, p. 148.

Viffers from C. baltectume especially in the lower spinous dorsal, tho last spine ecarecly more than 3 the length of head.

IIal.COSta Rica, Turrialba. 
Cichlosoma citrinellum (p. 25).

A specimen has been received from Juan Viñas, Costa Rica (Underwood). This species is recorded from Lago de Guila and Lago de Asososca in Nicaragua by Meek (Publ. Columbian Mus., Zool. vii. 1907, p. 152).

\section{4 (A). Cichlosoma granadense.}

Cichlasoma granadense, Meek, Publ. Columbian Mus., Zool. vii. 1907, p. 121.

Apparently intermediate between $C$. citrinellum and $C$. erythroum, with the lips and dentition of the former and the low spinous dorsal fin of the latter.

Hab. Lakes Managua and Nicaragua.

35 (A). Cichlosoma dorsatum.

Cichlasoma dorsatum, Meek, Publ. Columbian Mus., Zool. vii. 1907, p. 123.

Differs from $C$. erythrceum in tho longer pectoral fin, which is a little longer than the head and extends to the soft-rayed portion of the anal fin.

Hab. Nicaragua, Lake Managua.

Cichlosoma affine (p. 26).

'This species is recorded by Barbour and Cole (Bull. Mus. Comp. Zool. 1. 1906, p. 158) from near Progreso in Yucatan.

46 (A). Cichlosoma centrale.

Cichlasoma centrale, Meek, Publ. Columbian Mus., Zool. vii. 1907, p. 94.

Apparently very similar to C. urophthalmus, but distinguished by the lower spinous dorsal (longest spine less than $\frac{2}{5}$ the length of head).

Hab. Guatemald, Caballo Blanco, Pacific slope.

46 (в). Cichlosoma tenue.

Cichlasoma tenue, Meek, Publ. Columbian Mus., Zool. vii. 1907, p. 94.

Differs from $C$. centrale in the slender body (depth $2 \frac{3}{4}$ in the length) and the more produced rertical and ventral fins.

Hab. Mexico, Achotal in Vera Cruz.

Cichlosoma trimaculatum (p. 28).

Recorded from Achotal in Vera Cruz by Meek (Proc. Biol. Soc. Washington, xviii. 1905, p. 245).

\section{7 (A). Cichlosoma mojarra.}

Cichlasoma mojarra, Meek, Publ. Columbian Mus., Zool. v. 1904, p. 217, fig. $71^{1}$; Proc. Biol. Soc.

W ashington, xviii. 1905, p. 244 ${ }^{2}$.

Hab. Mexico, San Gerónimo in Oaxaca ${ }^{12}$. 
SUPPLEMENT.

Dr. Meek (Publ. Columbian Mus., Zool. vii. 1907, p. 140) compares this species with $C$. trimaculatum, from which it is said to differ in several features, none of which are very marked.

Cichlosoma motaguense (p. 29).

Recorded from Belize by Meek (Publ. Columbian Mus., Zool. vii. 1907, p. 151).

Cichlosoma managuense (p. 29).

Recorded from Lago de Guila in Nicaragua by Meek (Publ. Columbian Mus., Zool. vii. 1907, p. 152).

\section{HERICHTHYS (p. 30).}

Examination of a large series of examples of Herichthys cycnoguttatus received recently shows that the pointed inner teeth are more or less compressed. The genera Herichthys and Paraneetroplus may nevertheless be maintained, the former including species with slender teeth, those of the outer series in the lower jaw gradually decreasing in size and becoming acutcly pointed laterally. This genus includes $H$. cyanoguttatus, $H$. bocourti, and H. gedlesi, whilst Garman's Heros pavonacens probably belongs here also.

\section{PARANEETROPLUS (p. 31).}

This genus differs from Herichthys in having broader and more strongly compressed teeth. The outer series in the lower jaw is transverse, formed of subequal teeth with rounded or obtusely pointed apices; it ceases abruptly and does not extend back on the sides. Heros sieboldii, Kner \& Stdr. (of which Herichthys underwoodi, Regan, is a synonym), from Costa Rica and Panama, belongs to this genus.

\section{NEETROPLUS (p. 31).}

\section{Neetroplus nematopus (p. 31).}

Recorded from Lago de Guila in. Nicaragua by Meek (Publ. Columbian Mus., Zool. vii. 1907, p. 153).

\section{SCIENID正 (pp. 31, 32).}

Micropogon undulatus, C. \& V. (Jord. \& Ererm. Bull. U.S. Nat. Mus. xlvii. 1898, P. 1461), is a marine species ranging from Cape Cod to Montevideo. It has been recorded from Lake Yrabal by Vaillant and Bocourt (Miss. Sci. Mex., Poiss. 1874).

$$
\text { GERRES (p. 37). }
$$

The characters of $G$. peruvianus and $G$. olithostomus have unfortunately been transposed in the synopsis of the species (p. 38). It is G.peruvianus which has the month smaller and the scales of the thoracic region larger. 
Gerres californiensis (p. 39).

Recorded from Caballo Blanco in Guatemala by Meek (Publ. Columbian Mus., Zool. vii. 1907, p. 143).

Gerres peruvianus (p. 39).

Recorded from Caballo Blanco in Guatemala by Meek (Publ. Columbian Mus., Zool. vii. 1907, p. 143).

$$
\text { POMADASIS (p. 41). }
$$

\section{Pomadasis boucardi (p. 43).}

'To the synonymy add :-

? Pomadasis grandis, Meek, Publ. Columbian Mus., Zool. vii. 1907, p. 116.

This supposed species is based on a single specimen of $345 \mathrm{~mm}$. from Lake Nicaragua, which appears to differ from $P$. boucardi, as described, only in characters due to its larger size, such as the smaller eye and shorter fin-spines.

Fam. 10 (A). LUTIANIDÆ. (To precede the Centropomidre, p. 44.)

Lutianus argentiventris, Peters, 1869 (Neomænis argentiventris, Jord. \& Everm. Bull. U.S. Nat. Mus. xlvii. 1898, p. 1260), is a marine species from the Pacific coast of tropical America. It has been recorded from fresh-water at Caballo Blanco in Guatemala by Meek (Publ. Columbian Mus., Zool. vii. 1907, p. 140).

CENTROPOMUS (p. 45).

Centropomus nigrescens (p. 50).

Recorded from Caballo Blanco in Guatemala by Meek (Publ. Columbian Mus., Zool vii. 1907, p. 140).

THYRINA (p. 63).

\section{Thyrina sardina.}

Melaniris sardina, Meek, Publ. Columbian Mus., Zool. vii. 1907, p. 114.

Hab. Lakes Managua and Nicaragua.

Dr. Meek's description shows that this species is very closely allied to T. gratematensis of the rivers of the Pacific slope, and they may yet prove to be inseparable.

\section{FUNDULUS (p. 76).}

Fundulus grandis (p. 79).

This species is recorded by Barbour and Cole (Bull. Mus. Comp. Zool, 1, 1906. p. 156) from near Progreso, Yucatan. 


\section{CYPRINODON (p. 82).}

\section{Cyprinodon bovinus (p. S3).}

This species is recorded (as Cyprinodon eximius) by Barbour and Cole (Bull. Mus. Comp. Zool. 1. 1906, p. 157) from near Progreso, Yucatan.

4(A). JORDANELLA, Goode \& Bean, 1879.

('To precede the genus Zoogoneticus, p. 85.)

Jordemella, Jord. \& Everm. Bull. U.S. Nat. Mus. xlvii. 1896, p. 677.

1)iffers from Cyprinodon in the longer dorsal fin with 15 to 18 rays, the first of which is a stout spine.

A single species.

\section{Jordanella floridæ.}

Jordanella floride, Goode \& Bean, Proc. U.S. Nat. Mus. ii. 1879, p. $117^{\prime}$; Jord. \& Everm. Bull. U.S. Nat. Mus. xlvii. 1896, p. $677^{2}$, and 1900, fig. $298^{3}$; Barbour \& Cole, Bull. Mus. Comp. Zool. l. 1906, p. $157^{4}$.

Mab. Nontin Alierici, Florida $12 .-$ Mexico, near Progreso, Yucatan 4.

GAMBUSIA (p. 93).

\section{Gambusia fasciata (p. 95).}

Recorded from Caballo Blanco, Pacific slope of Guatemala, by Meek (Publ. Columbian Mus., Zool. vii. 1907, p. 137).

\section{GIRARDINUS (p. 99).}

\section{Girardinus lutzi (p. 99).}

Recorded from the Rio Motagua in Guatemala by Meek (Publ. Columbian Mus., Zool. vii. 1907, p. 137).

$$
\text { PQECILIA (p. 100). }
$$

\section{4 (A). Pœcilia caucana.}

Girardinus caucanus, Stcind. Denkschr. Ak. Wien, xlii. 1880, p. 87, t. 6. figs. 4 \& 5 '. Pocitia tenuis, Neck, Publ. Columbian Mus., Zool. vii. 1907, p. $147^{2}$.

Pacilia sphenops, Regan (part.), autcia, p. 102, t. 13. fig. $2^{3}$.

Ifab. Costa Rica, San José ${ }^{3}$ (Biolley) and Rio Maria Aguilar 2-Colombia, Rio Cauca ${ }^{1}$.

The specimens from Costa Rica referred to $P$. splenops, one of which is figured (Tab. XIII. fig. 2), appear to differ from $P$. sphenops in the greater length of the anterior dorsal rays and in the presence of a dark spot at the base of the dorsal fin. This species seems to be the one described by Steindachner as Girarlinus crncanus. 
4 (в). Pœcilia tropica.

Platypocilus tropicus, Meek, Publ. Columbian Mus., Zool. vii. 1907, p. $146^{1}$.

This species is described as having a larger eye than $P$. spluenops (diameter $2 \frac{1}{2}$ to $2 \frac{3}{4}$ in the length of head in speeimens of 59 to $63 \mathrm{~mm}$.); other differences are not apparent.

Hab. Costa Rica, Turrialba ${ }^{1}$.

MOLLIENISIA (p. 105).

Mollienisia latipinna (p. 105).

This species is recorded by Barbour and Cole (Bull. Mus. Comp. Zool. l. 1906, p. 157) from near Progreso, Yucatan.

\section{ELURICHTHYS (p. 115).}

\section{Ælurichthys marinus (p. 117).}

This species and not Galeichthys millerti, C. \& V. (p. 124), is the Silurus felis of Linnæus, and the name should be changed to Elurichthys felis. 1 am indebted to Dr. Günther for kindly calling my attention to this (see Proc. Linn. Soc. 1898-99, p. 30).

$$
\text { RHAMDIA (p. 128). }
$$

Rhamdia parryi (p. 130).

Recorded by Meek (Publ. Columbian Mus., Zool. vii. 1907, p. 134) from Caballo Blanco in Guatemala.

5 (A). Rhamdia barbata.

Rhamdia barbata, Meek, Publ. Columbian Mus., Zool. vii. 1907, p. $106^{1}$.

Allied to R. warneri, but apparently distinguished by the longer barbels (extending beyond the middle of the adipose fin) and the longer adipose fin (length $2 \frac{1}{3}$ to $2 \frac{3}{5}$ in the length of the fivh).

Hab. Nicaragua, Lake Managua.

Rhamdia godmani (p. 133).

Recorded by Meek (Publ. Columbian Mus, Zool, vii. 190i, p. 150) from Belize.

Rhamdia brachycephala (p. 135).

Recorded by Meek (Publ. Columbian Mus, Zool. vii. 1907, p. 144) from Turrialba in Costa Rica.

\section{3 (A). Rhamdia cabreræ.}

Rhamdia cabrers, Meek, Publ. Columbian Mus., Zool. vii. 1907, p. $93^{1}$.

Apparently allied to $\mathbb{R}$. brachycephala, which it resembles in the short barbels. small occipital [rocess, \&c. 
It seems to be distinguished by the longer head ( $4 \frac{3}{5}$ in the length of the fish) and the shorter humeral process (not extending beyond the anterior $\frac{1}{3}$ of the pectoral spine).

Ilab. Guatedrala, Lake Amatitlan '.

Rhamdia rogersi (p. 136).

'To the synonymy add:

Ihhandia regani, Neek, Publ. Columbian Mus., Zool. vii. 1907, p. 144².

Costa Rica, Turrialba ${ }^{2}$ and Rio Tiribi, San José ${ }^{2}$.

CONORHYNCHUS (p. 138).

I learn from an editorial footnote that the name Conorhynchus is preoccupied. 1 propose to substitute for it the name Conorhynchichthys.

1 (A). CYCLEPTUS, Rafin., 1819. (To precede Moxostoma, p. 145.)

C'ycleptus, Jord. \& Everm. Bull. U.S. Nat. Mus. xlvii. 1896, p. 168.

Scarcely distinct from Ictiobus, but with a much shorter head (length 6 to $8 \frac{1}{2}$ in the length of the fish) and smaller scales ( 55 to 60 in a longitudinal series) than any species of that genus.

A single species.

\section{Cycleptus elongatus.}

Cutostomus elongatus, Le Sueur, Journ. Ac. Philad. i. 1817, p. $103^{1}$.

Sclerognathus elongatus, Giunth. Cat. Fish. vii. p. 23 (1868) ${ }^{2}$.

Cycleptus elongatus, Jord. \& Everm. Bull. U.S. Nat. Mus. xlvii. 1896, p. 168 ${ }^{3}$; Meek, Publ. Columbian Mus., Zool. vii. 1907, p. 154 ${ }^{4}$.

Hab. Unimed States, Mississippi System ${ }^{12}{ }^{3}$. Mexico, Rodriguez in Nuevo Lcon ${ }^{4}$. 


\section{N D E X.}

[Names in small capitals refer to Families, \&e.; those in roman type to the chief reference to each species inciuded in the work; those in italics to species incidentally mentioned, synonyms, \&c.]

\begin{tabular}{|c|c|}
\hline Page & \\
\hline$\ldots \ldots \ldots 149$ & Agonostoma globiceps \\
\hline$\ldots \ldots \ldots \ldots 142$ & - microps........... \\
\hline - chrysoleucus ........ 149 & - monticola ...... \\
\hline ANTHOPTERXGII . . . . . . & - nasutum, ... \\
\hline ARA $\ldots \ldots \ldots \ldots \ldots \ldots \quad 16$ & _ percoides ....... \\
\hline$a r a \ldots \ldots \ldots \ldots \ldots \ldots$ 15 & Agonostomus ........ \\
\hline coruleopunctata ...... 16 & Agonostomus ........... \\
\hline unirus $\ldots \ldots \ldots \ldots ., 185$ & - macracanthus ... \\
\hline - fasciatus $\ldots \ldots \ldots \ldots .3$ & — macracanthus ........ \\
\hline - fischeri...$\ldots \ldots \ldots \ldots$. 18.5 & $\longrightarrow$ microls $_{1} \quad \ldots \ldots \ldots \ldots$ \\
\hline - fousecensis $\ldots \ldots \ldots \ldots$ & — microps ......... $0.5,60$ \\
\hline - mazatlanus ......... & — monticola ........... 66 \\
\hline comus guzmaniensis . ...... 147 & - monticola ........... \\
\hline dinia...$\ldots \ldots \ldots \ldots$. & - nasutus ............ \\
\hline - dugesii ............ 86 & — nasutus $\ldots \ldots \ldots 6(6,6 \pi, 69$ \\
\hline - gratemalensis $\ldots \ldots \ldots$ 78 & — pereoides .......... 69 \\
\hline _- pachycephalet ...... & - percointes $\ldots \ldots \ldots \ldots 65,60$ \\
\hline ELURICETHX's $\ldots \ldots \ldots 115,191$ & — Salfini. \\
\hline Elurichthys ........... 114 & — salvini $\ldots \ldots \ldots \ldots 66,67$ \\
\hline - bagre ............ 118 & Agosia $\ldots \ldots \ldots \ldots \ldots \ldots 165$ \\
\hline$-\operatorname{becpre} \ldots \ldots \ldots \ldots \ldots 115,116$ & Ayosia $\ldots . .$. \\
\hline — bahiensis .......... 117 & L chrysogaster \\
\hline _bahiensis .......115, 116 & - oscula ..... \\
\hline- felis $\ldots \ldots \ldots \ldots \ldots 191$ & Allurians nitidus . \\
\hline - filamentosus .. & Algansea $\ldots$. \\
\hline - filamentosus ......... & Algansea .... \\
\hline _gronovii............ & - affinis .. \\
\hline - isthmensis ........ & — dugesi $\ldots \ldots \ldots \ldots \ldots 152$ \\
\hline - isthmensis ........... 115 & _- dugesi ....... \\
\hline - longispinis........11\%,118 & - lacustris \\
\hline - marinus. ........ 117, 191 & _u rubescens \\
\hline - marinus ......... 115 & - sallai \\
\hline - muchalis .......... & — stigmaturi . . \\
\hline _ panamensis ........ & — stigmatwa . \\
\hline - panamensis $\ldots \ldots$. & - tarcesconzun $\ldots \ldots \ldots 1,52,159$ \\
\hline - pinnimaculatus .... & — tincella ............ 151 \\
\hline - piminaculatus.... & — - tincella ..... \\
\hline - scutatus & Alvarius lateralis ..... \\
\hline - scutatus & Amblyopus brasiticnsis..... \\
\hline
\end{tabular}

Blol. Centr.-n Her, Pisces, Februaty 1908.

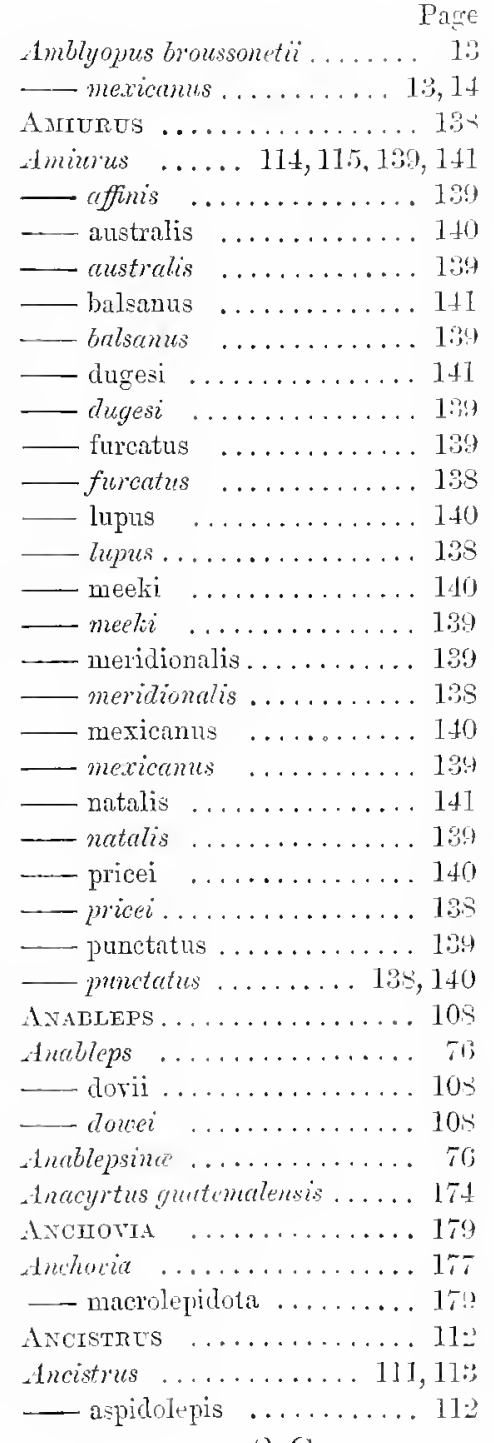

) $\mathrm{C}$ 


\begin{tabular}{|c|c|c|}
\hline Fage & It & s hypophthalmus.... \\
\hline 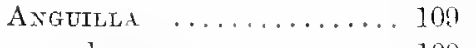 & Atractosteus tripicus & Cuthomps hypophthalmus.... \\
\hline chrestia ........... 109 & Awnous $\ldots . . . \ldots \ldots \ldots . . . .$. & Catostumina ........... \\
\hline - vulyaris........... 109 & — mericanus. & Gatostomes ............ \\
\hline ANGUILLID.E $\ldots . . . \ldots . .100$ & - nelsoni $\ldots \ldots \ldots \ldots \ldots$ & Catostomus........... 14, 148 \\
\hline dplodisotus $\ldots \ldots \ldots \ldots \ldots$. 32 & - tuidsica........... 12 & — bernardini $\ldots \ldots$ \\
\hline - gramiens ......... 32 & Antecula lemenc $\ldots \ldots \ldots$ & - conchos \\
\hline APODES . . . . . . . . . . . . . . 100 & - mericana & — elungatus ........ \\
\hline Ponotis ............. 86 & - vittati .......... & - gumaniensis....... \\
\hline _ cyanellus ........... 36 & & —- nebuliferus $\ldots . .$. \\
\hline _- cyoncllus $\ldots \ldots \ldots \ldots . .65$ & & — plebeins........ \\
\hline Archocotsus $\quad \ldots \ldots \ldots \ldots .29$ & Buritiella icistia $\ldots \ldots \ldots \ldots$ 3? & - sonorensis . .......... \\
\hline rgypreus notalitis $\ldots . . . \ldots$. 105 & BeLon & Centrarchidai \\
\hline - osculues ............ 165 & $-\operatorname{marina} . . . \ldots \ldots \ldots$ & Centrurchide........... \\
\hline - rubripinnis . ........ 159 & — scapularis.......... 75 & Centrofomide $\ldots \ldots$. \\
\hline urius $\quad \ldots \ldots \ldots \ldots \ldots \ldots 125$ & Belonesox .......... 93 & Centropomiate $\ldots \ldots \ldots$ \\
\hline vius.......... 114,119,126 & Belonesax ............. 76 & Centropomes $\ldots \ldots \ldots \ldots 45,189$ \\
\hline - alcutus ............ 120 & - belizamus .......... & Cestropomus .......... \\
\hline - assimilis $\ldots \ldots \ldots \ldots, 120$ & Lolechethys fusifurmis ....... & -affinis. \\
\hline - brandtia $\ldots \ldots \ldots \ldots .130$ & Brachydutems lencisens..... 42 & - altus . ........... \\
\hline - corulescens $\ldots . \ldots \ldots \ldots 10.9$ & Bramocharax ......... 173 & —altus ............... \\
\hline - equestris & Eramocharar & — appendiculutus........48,49 \\
\hline - evermanni $\ldots \ldots \ldots \ldots 19$ & - bransfordi $\ldots \ldots \ldots$ & nteus ........ \\
\hline - evermanni $\ldots \ldots \ldots \ldots 120$ & — elongatus ......... 174 & - armatus.......... 50 \\
\hline - fuerthii . . . . . . . . . 197 & Burcon $\ldots \ldots \ldots \ldots \ldots .168$ & - armatus.......44,51, 58 \\
\hline - fuertiri............ 120 & Birycon ........... 160,179 & — atridursulis ........ ni, 59 \\
\hline - gratemalensis ........ 123 & -- denter & _- brevis $\ldots \ldots \ldots \ldots .59,58$ \\
\hline - hypophthahmus $\ldots . . .128$ & __ guatemalensis . . . . . 168 & - constantinus $, \ldots \ldots \ldots \ldots, 49$ \\
\hline ophthalmus........ 126 & — guatematensis ....... 169 & - cuvieri $\ldots \ldots \ldots \ldots \ldots .47$ \\
\hline$e r i \ldots \ldots \ldots \ldots \ldots 121$ & — striatulus . . . . . . . 169 & -_ ensiferus $\ldots \ldots \ldots \ldots \ldots$ \\
\hline ous $\ldots \ldots \ldots \ldots \ldots 1: 7$ & & rus ........46,51,58 \\
\hline 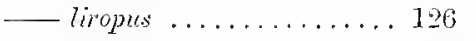 & & $i \ldots \ldots \ldots \ldots \ldots$ \\
\hline апориз $\ldots \ldots \ldots \ldots .120$ & Campostona $\quad \ldots \ldots \ldots \ldots .149$ & doculatus ......... \\
\hline$\ldots \ldots \ldots \ldots 124$ & $a \ldots \ldots \ldots \ldots \ldots 149$ & — heringi .......... \\
\hline tiradiatus $\ldots \ldots \ldots$. 12k & nlum $\quad \ldots$ & — medius ............. \\
\hline - multiradiates ........ 126 & — formulosum. ........ 150 & — medius $\ldots \ldots \ldots \ldots \ldots 45,48$ \\
\hline - planicepss ........... 121 & - nasutum $\ldots \ldots \ldots \ldots .150$ & —mcxicanus........... 48 \\
\hline - pletypoyon $\quad \ldots \ldots \ldots \ldots$ 122 & — oruatum $\ldots \ldots \ldots \ldots \ldots 149$ & cens $\ldots \ldots \ldots .50,189$ \\
\hline - secmani $\ldots \ldots \ldots \ldots .124$ & - pricei $\ldots \ldots \ldots \ldots \ldots \ldots 149$ & ens..........45,40 \\
\hline - troscheli ........... 120 & ARANGLDE $\ldots \ldots \ldots \ldots, 14$ & lus $\ldots \ldots \ldots \ldots 48$ \\
\hline Astatheros .............. 23,20 & irangince .................. & lelus .......... \\
\hline styanax enty & uretpus ............... 175 & - pect \\
\hline - fischeri........ 170,171 & — fusciutus ... & - pectinatus. ........45,48 \\
\hline - menicanus .......... 172 & Garularias $\ldots$ & -_- perdinaculla $\ldots \ldots \ldots .46,47$ \\
\hline - nasutus. ............ 170 & - nicurngruensis ...... & _- robalito........... \\
\hline$\ldots \ldots \ldots \ldots \ldots 171$ & . . . . . . . 182 & - robulito ............ 46 \\
\hline - _- ances ........... 170 & $\ldots \ldots \ldots \ldots \ldots 18$ & - scuber............. 52 \\
\hline —_- nicurnufucnsis ..... 170 & - nicuragutseris ........ 183 & - undecimalis ......... 49 \\
\hline _. arstedia ........ 170 & Garpuedes ............. 149 & - andecimatis ........ 4t, 46 \\
\hline therina humbuldtinat $\ldots . .60$ & $-\operatorname{clonugatus} \ldots \ldots \ldots$ & $48,50,50$ \\
\hline - romerint ........... 60 & _lathosus...... & _- undecimratiatus. \\
\hline hecrinellet & -.. meritionalis .... & - maionensis \\
\hline therinichtlyy gratencalensis . . Git & - mirrostomas..... & - unionensis........ \\
\hline$-7_{n+m b o l i d i i}$ & - trmintus & — riridis .. \\
\hline WRTNIDAE & $-i w^{\prime} l i f r^{\prime}$ & — viritis ..........45,51 \\
\hline$\ldots 181$ & therropss & Ceratichllygs salleri ..... \\
\hline & - gulosus & - sterlctus......... \\
\hline
\end{tabular}




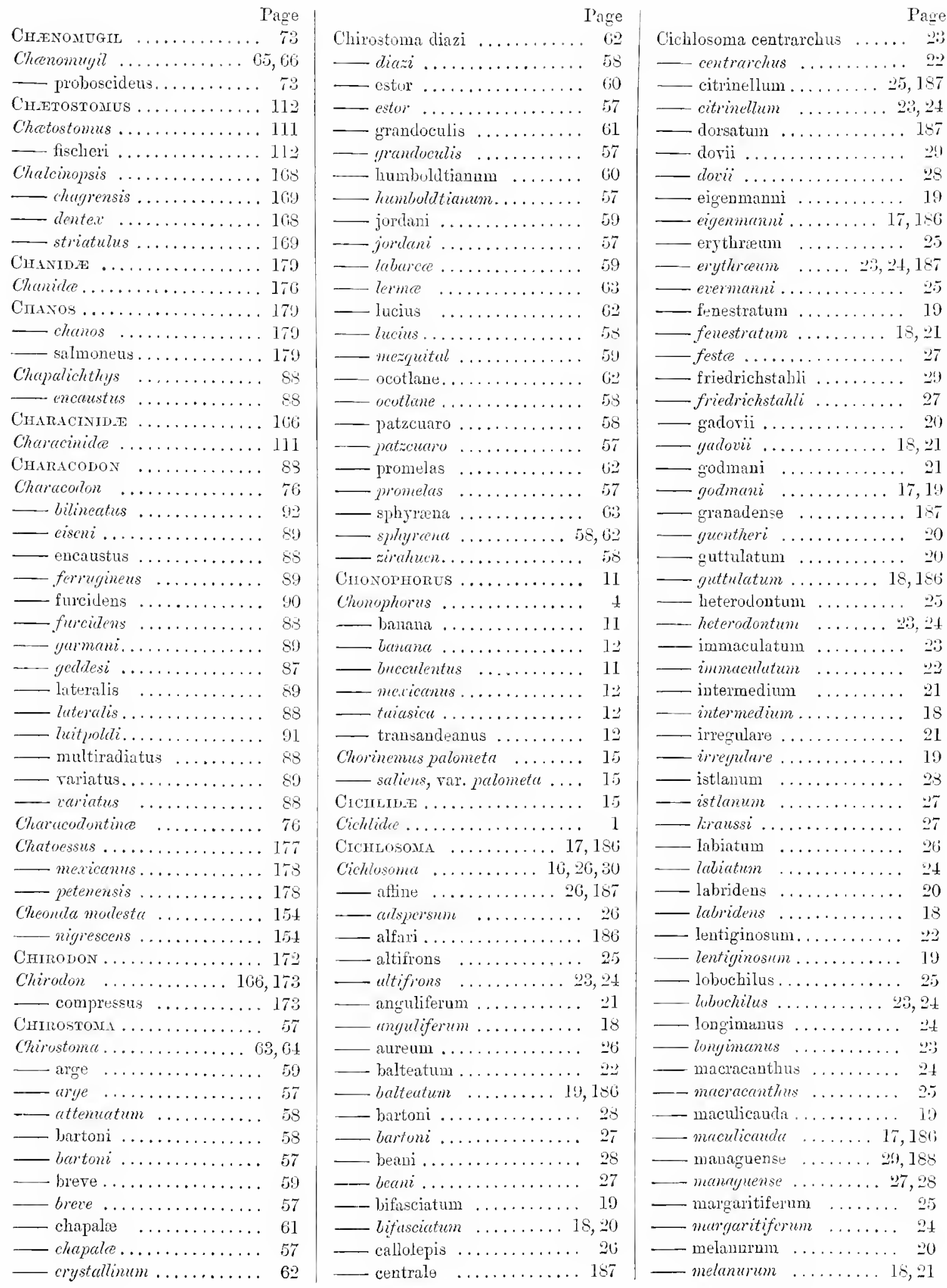




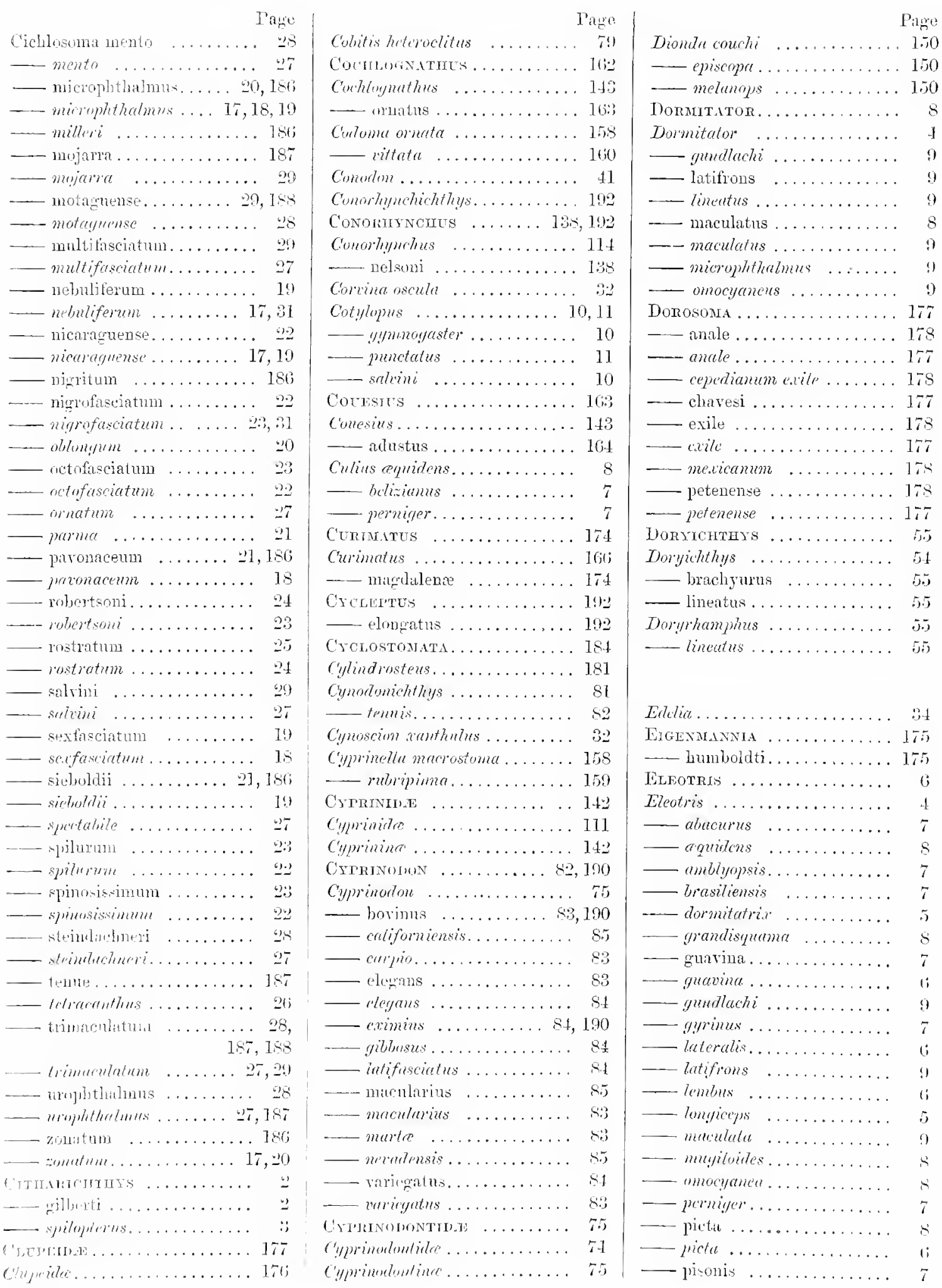




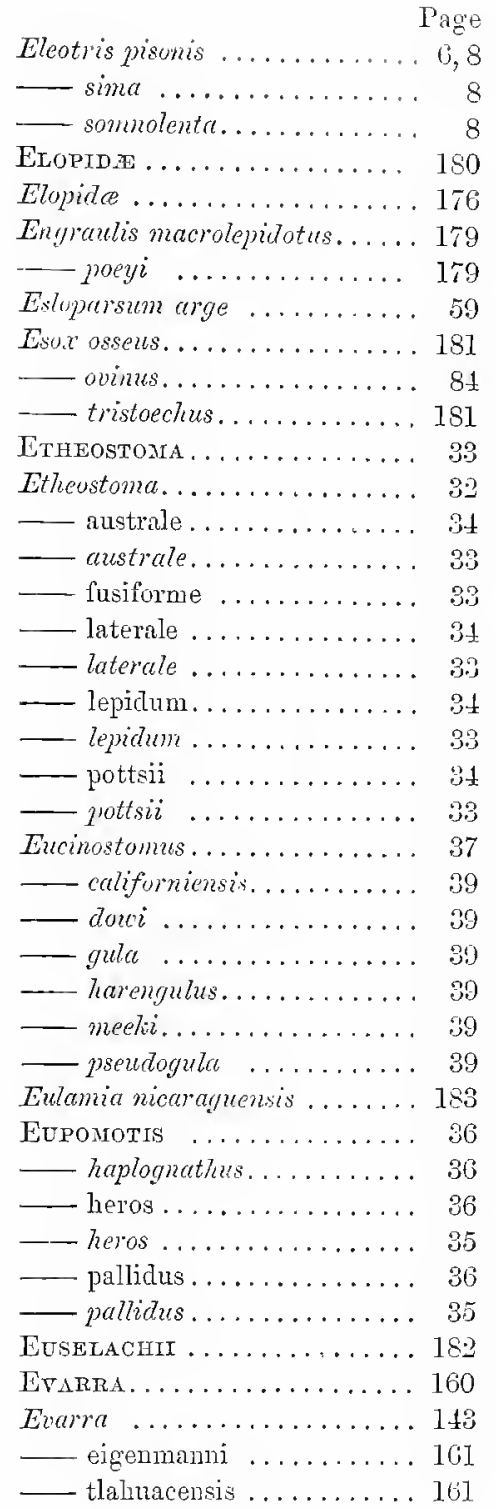

Farcula $\ldots \ldots \ldots \ldots \ldots \ldots$. 154 Falcula ............. 143, 161 - ehapale............. 154 Felichthys .............. 115 - bagre ................. 118

- bahiensis ........... 117

- flamentosus ........... 118

— marimus.............. 117

— panamensis ......... 116 _ pinnimaculatus......... 118 Fundulus .......... 76,189 Fundulus.........75,77,85 Fodinia $\ldots \ldots \ldots \ldots \ldots \ldots, 79$

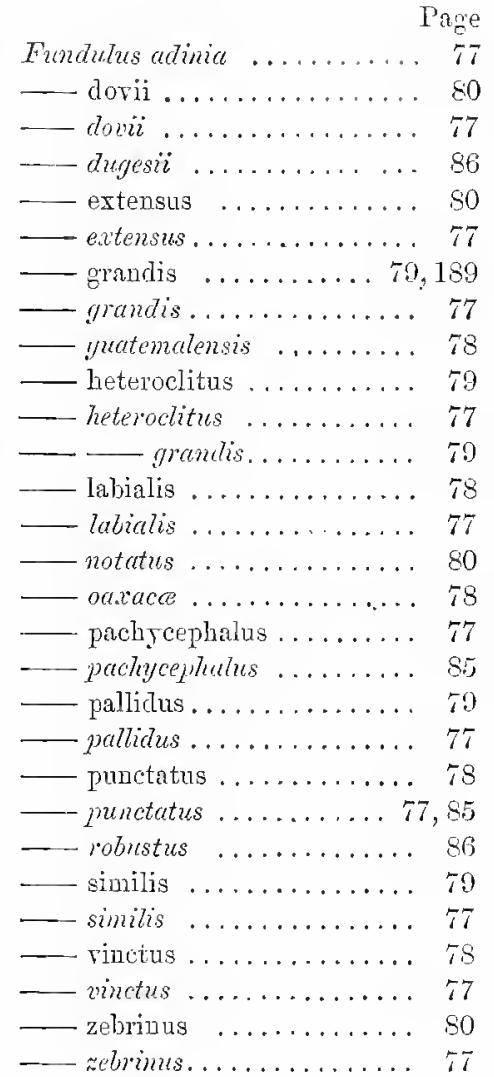

GALETCH'THYs ............ 119 Galeichthys ..........114, 125

_- aqua-dulce. . . . . . . . 126

— assimilis ........... 122

—assinilis . . ......... 120

—a artents ............ 123

_ batiensis ............ 117

— cærulescens ......... 128

- cremlescens ........... 120

- rlesyceplectus. ......... 195

- dovii ............... 120

dovii ................. 119

eigenmanni ...... 124, 125 eydouxii ........... 118 felis .............. 124 gilberti ......... 124, 125 gruatemalensis . . . . . . 128 yuatemalensis $\ldots \ldots \ldots . .120$ gnentheri ............ 124 guentheri ........... 120 -jordani ............ 124 heraberfï ........... 120

kessleri ............. 121 liessleri .........119, 122 lentiginosus ......... 123
Tage

Galeichthys lentirinosus ..... 1:0

_. longicephalus ........ 125

— longicephalus........... 1:20

- milberti. ............. 191

— perurianus $\ldots \ldots \ldots \ldots$ 125

— peruvianzus............ 120

— planiceps ........... 1:1

- planiceps ............ 11 .

— platypogon ......... 122

- plutypogon............ 119

- seemani............. 18

$-\operatorname{sem} a n i \ldots \ldots \ldots \ldots . .190$

— troscheli ............ 120

— troscheli ............ 119

—. renauchen............ 129

Ganbusia ...........

Gambusict .............. T, 94

-affinis ............ $9 t$

— annectens ............

- annectens ............ 94

_ bimaculata .......... 98

_ bimaculata $\ldots \ldots \ldots .94,97$

— bonita ............ 0.

- bonita .............. 94

- episcopi ............

—episcopi..........94, gr

— fasciata $\ldots \ldots \ldots .95,190$

- fasciata.............

— gracilis ............ of

- gracilis ............

- holbrookii ............

- - infans ............. 00

- infans ............ 9t

— jonesii $\ldots \ldots \ldots \ldots \ldots . . .97$

— jonesii ............ 44

— modestce ........... 102

—uicaraguensis $\ldots \ldots \ldots, \quad 9 t^{\circ}$

- nicarayucnsis ........ 94

- nobilis ........... $9_{4}$

- patruelis ........... 94

- plumbea............. 10.

- teniata............ gs

_ temabensis ......... 97

— tervabensis............ 94

— tridentiger ......... 0.5

- tridentiyer .......... 94

Gastropelecus ........... 173

Gastropelecus.............. 1hiti

- maculatus............ 17

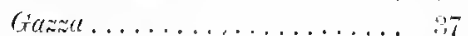

Geophagus .............

— crassilatyris ......... 1t

Gerres $\ldots \ldots \ldots \ldots \ldots .37,158$

— amreolus .......... 40

—uercolus............. 88

—axillaris.......... 40 


\begin{tabular}{|c|c|c|}
\hline Tage & Page & \\
\hline erres axilluris............. in & TOBITSOCTDA & Ilaplochitus harti \\
\hline —urasitianns .......... 40 & Cobiesncidee & - perzanus. \\
\hline - brevimanus ... & Gobiesin adustus & IlAPLOIDONOTUS... \\
\hline - Urezimanus...$\ldots \ldots$. & 正 & - grtuniens . . . . . . . . 32 \\
\hline — coliforniensis . . ..... 39, 189 & $\ldots$ & $11_{\text {AILOMI }} \ldots \ldots \ldots \ldots \ldots \ldots$ \\
\hline — califormiensis $\ldots \ldots \ldots$ is & ..... 164 & Hazstor ............ 138 \\
\hline - cinereus........... 38 & Gomiontes.............. 13 & Henigrammus compressus ... 173 \\
\hline - cinercus.......... 37,39 & Gobioides $\ldots \ldots \ldots \ldots \ldots \ldots$ & Iheminhamphus ........... \\
\hline$-e m \ln y \cdot \ldots \ldots \ldots \ldots \ldots$ & - barreto .............. 13 & IEnichiturs $\ldots \ldots \ldots \ldots, 30,188$ \\
\hline$\ldots \ldots \ldots \ldots, 89$ & sonetii .......... 1: & IItrichthys $\ldots \ldots \ldots \ldots$ \\
\hline$\ldots \ldots \ldots \ldots \ldots$ & onetii .......... 14 & - bocourti $\ldots \ldots \ldots$ \\
\hline nowlus $\ldots \ldots \ldots \ldots$ & us $\ldots \ldots \ldots \ldots \ldots \quad 14$ & —ocourti.......... \\
\hline $2 y z l u t s \quad \ldots \ldots \ldots \ldots$ & dormitor ........ & — cyanoruttatus ..... \\
\hline - lefroyi $\ldots \ldots \ldots \ldots \ldots$ & is............... & - cyannymttutus ..... 180, I88 \\
\hline - Zefroyi & tus $\ldots \ldots \ldots \ldots$ & — geddesi $\ldots \ldots \ldots \ldots \ldots .80$ \\
\hline$a s \ldots \ldots \ldots \ldots \ldots \quad 40$ & $\ldots \ldots 12$ & si ............ 188 \\
\hline$\ldots \ldots \ldots \ldots \ldots 88$ & $\ldots \ldots \ldots \ldots$ & roodi ......... 30 \\
\hline us.......... 41 & $-\operatorname{rmos} r a \ldots \ldots \ldots \ldots$ & -underwoodi ....... 186, 188 \\
\hline $8 \ldots \ldots \ldots \ldots \ldots 88$ & - banana ............ 11 & Heros deprii ......... 17, 21 \\
\hline$n s \ldots \ldots \ldots \ldots \quad 10$ & ${ }_{i} \ldots \ldots \ldots \ldots \ldots$ & $m \ldots \ldots \ldots \ldots$ \\
\hline mus $\ldots \ldots \ldots .38,188$ & epholus........ 11 & $-p c$ \\
\hline$\ldots \ldots \ldots \ldots \ldots, 40$ & eri $\ldots \ldots \ldots \ldots \ldots 12$ & $i i \ldots \ldots \ldots$ \\
\hline$\ldots \ldots \ldots \ldots \quad 38$ & $c u s \ldots \ldots \ldots \ldots, 11$ & 11ঙROT \\
\hline $4 \ldots \ldots \ldots, 1,89$ & $u s \ldots \ldots \ldots \ldots, 11$ & Herot \\
\hline (s........ 38,188 & $n s \ldots \ldots \ldots \ldots \ldots \quad 13$ & tispinosa ..... \\
\hline ri $\ldots \ldots \ldots \ldots$. 10 & $18 \ldots \ldots \ldots \ldots$. 13 & Ilcteru \\
\hline$r \quad \ldots \ldots \ldots \ldots \ldots$ ss & 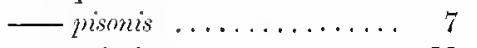 & $-o c$ \\
\hline ula $\ldots \ldots \ldots \ldots$ & $a \ldots \ldots \ldots \ldots \ldots$ & 09,100 \\
\hline guld $\ldots \ldots \ldots \ldots$ & neleanus. & 167 \\
\hline us .......... 40 & $\ldots \ldots \ldots$ & 166 \\
\hline$\ldots \ldots \ldots \ldots$ 38 & worlen & 167 \\
\hline$s \ldots \ldots \ldots \ldots, 88$ & is $\ldots \ldots \ldots \ldots$. & $-t$ \\
\hline - simillimus .......... 87 & mis .......... o & Ifuls \\
\hline veride $\ldots \ldots \ldots \ldots \ldots \ldots$ & itia $\ldots \ldots \ldots \ldots, \quad 99$ & Hxi \\
\hline$\ldots \ldots \ldots \ldots 15,9$ & itn $\ldots \ldots \ldots \ldots$. 90 & $\ldots \ldots 148,149,151$ \\
\hline$\ldots \ldots \ldots \ldots, 15,3$ & — crlientis $\ldots \ldots \ldots \ldots \ldots 91$ & $\ldots \ldots \ldots \ldots \ldots 150$ \\
\hline$\ldots \ldots \ldots \ldots 1,5,154$ & is . ............ & us $\ldots \ldots$ \\
\hline$\ldots \ldots \ldots \ldots \ldots 154$ & -1 & $-n$ \\
\hline$\ldots \ldots \ldots \ldots \ldots] \quad]=0$ & $-i c$ & ifer $\ldots \ldots \ldots \ldots$ \\
\hline$s \ldots \ldots \ldots \ldots$ st & oldi $\ldots . . . \ldots \ldots . . .91$ & $s \ldots \ldots$ \\
\hline atus $\ldots \ldots \ldots \ldots 87$ & unctatia ........ 92 & 164 \\
\hline$\ldots \ldots \ldots \ldots, 09,190$ & munetate $\ldots \ldots \ldots$ or & 149,165 \\
\hline$\ldots \ldots \ldots \ldots \ldots 76$ & - toweri...$\ldots \ldots \ldots$ & $\longrightarrow \mathrm{e}$ \\
\hline zazts $\ldots \ldots \ldots \ldots .190$ & - toweri $\ldots$ & $-a$ \\
\hline$\ldots \ldots \ldots \ldots \ldots, 9] 90$, & whitii & $-s$ \\
\hline entatis .......... 101 & -_whitii... & chens confurtus \\
\hline lus ........... 100 & cromerle & $I I y$ \\
\hline thes $\ldots \ldots \ldots$ & Ginavim & 184 \\
\hline $\operatorname{lis}_{1} \ldots \ldots \ldots \ldots, 09$ & ${ }^{2} \ldots \ldots \ldots \ldots \ldots$ & CA $\ldots \ldots \ldots$ \\
\hline - sonorensis ............ 101 & $\ldots \ldots \ldots \ldots \ldots 175$ & \\
\hline$\ldots \ldots \ldots \ldots \ldots$ I & $\ldots \ldots \ldots \ldots \ldots 1]$ & \\
\hline ......... & Grymmotus curapol .... & Ichthly \\
\hline ws $\ldots \ldots \ldots \ldots$ on & & - mer \\
\hline$\ldots \ldots \ldots \ldots \ldots \pi$ & & $-p$ \\
\hline 99 & raplortitus: & It tulut \\
\hline $9 y$ & - dovii. & - furcatus. \\
\hline
\end{tabular}




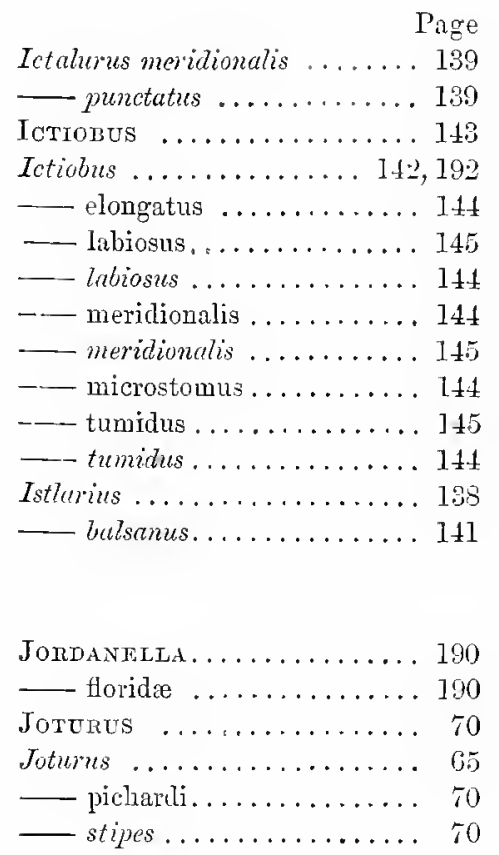

Firtlandia ............ 57 Kuthlia .............. 34

LAMPETRA............... 184 — spadicer.............. 184 Lates ................... 44 Lebius .................. 82 ellipsoidert........... 84 rhomboidalis.......... 84 Lembus maculatus ........... 5 Lepidopomus haplognatiuts ... $\quad 36$ -occidentalis .......... 36 LepidosteId . . ........... 180 Leprinosteus $\ldots \ldots \ldots \ldots . .180$ Lepidosteus ................ 181

- vgassiaii............ 181

— grayi .......................... 181

—osseus ............. 181

_platystomus .......... 181

— productus ............. 181

— tristoechus .......... 181

- tristochus .......... 182

- tropicus............ 182

— tropicus ............ 181

— viridis ............. 181

- $\approx a d o c t i \ldots \ldots \ldots \ldots \ldots, 181$

Leponis. . . . . . . . . . . . . . . . 36 —yarmani........... 36 haplognathus $\ldots \ldots \ldots \ldots \quad 36$ _haplognathes........... 35

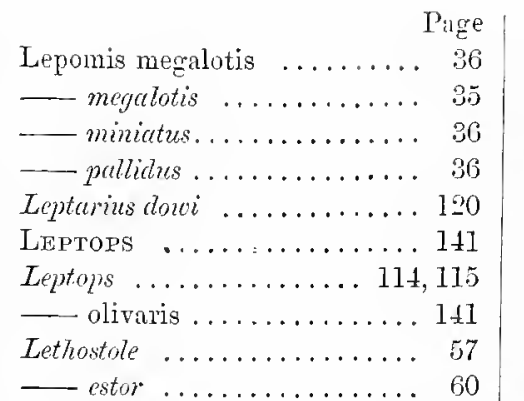

LeUCISCUS $\ldots \ldots \ldots \ldots \ldots .159$

Leuciscus $\ldots . . . . . . . .143,155$

— boucardi ............ 156

- elegans .............. 153

_. Tutrensis . . . . . . . . . 158

— nigrescens............ 154

— nigrescens . . .......... 159

— pulchellus ........... 154

- tincella ............... 15]

— vittatus ............... 160

Limia couchiana ........... 104

— formosa .............. 105

— matumorensis . ........ 10,5

— proitioides ............ 105

- venusta ............. 80

Limnurgus ............. 8

Limnurgus ................ 76

__ innominatus .......... 87

- variegatus ........... $8 \bar{t}$

LIOGNATHID E. .......... 34

Liagnathide.......... .

Lioynathus................ 37

LOPHOBRANCIIII ........... 54

LORICARIA.............., 113

Loricerice .......... 111,1]t

- area.............. 114

_uransfordi ............ 113

_— lime ............... 119

— plecostomers .......... 111

— uracantha ........... 113

— variegata ..........., 1$] 3$

LoRICARIID ${ }^{2} \quad \ldots \ldots \ldots \ldots \ldots 111$

Loricariede .............. 110

LUCANIA ............. 80

Lucania ................

-atfinis............... 80

- $s p . \ldots \ldots \ldots \ldots \ldots \ldots, 87$

— vemusta ............. 80

LUCiocharix ............ 168

Luciocharax ............ 166 — insculptus . . . . . . . . . 168

LOTIANIDLE ............ 189

Lutianus argentiventris . . . . . 189

LITCENGRAULIS. . . . . . . . . . 179

Lycengrautis ........... 177

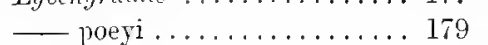

Page

Lacrodon ............... 167

— microlepis ........... 167

Madacopterygit........... 176

MEGALOPS ............ 180

— atlanticus ........... 180

- thrissoides............. 180

Helanivis .............. 63

- Galsunns............. (it

- sirdina .............. 189

Menidia................ 57

- guatemalensis ........ 64

- lisa.............. 64

Micropogon amdulutus ....... 188

Micropteros ............. 35

- salnonoides ......... 3.

Minonus plebeius .......... 147

Molimenisiat ......... $10 \bar{j}, 191$

Mollienisia .......... 70,100

— formosa ............. 105

— joilesii............ 97

- latipimna ......... 105, 191

_latipinna ........... 106

- petenensis ........... loti

Moniuna coucki ............ 158

- formosa . ............ 160

— nitida.............. 150

- rutils . . . . . . . . . . . 158

Moxosruma ............. 145

Morostoma ......... ] 42,192

- austrinum . . . . . . . . 140

- austrinumi ........... 145

— congestum.......... $146^{\circ}$

- congestum ............ 145

- mascotie $\ldots \ldots \ldots \ldots .147$

- mascote ............ 145

— parvidens ............. 147

— parridens ........... 145

MugIL ................ 70

Inegil $\ldots \ldots \ldots \ldots \ldots \ldots \ldots \ldots$

— brasiliensis........... $\pi$

- brasitiensis............ T0

— cephalus ........... 71

- ccphatus............ 70

—— curema ............ 71

- currmace............ 73

— gaimendianus ...... $71,7$.

- hospes ........... is

-hospes.............. 71

- incilis............... $\pi$

- monticolra ............ 66

— sctusus ........... 71,72

- thoburni $\ldots \ldots \ldots \ldots \ldots$. 71

- trichodon ...........

- trichodon ............. is

MUGILID.E $\ldots \ldots \ldots \ldots \ldots$ (i.

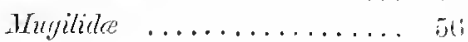




\begin{tabular}{|c|c|c|}
\hline ge & Pago & $70-7=7-5=$ \\
\hline RENIDAE & Oligoplites........... 1t,15 & Pinelodus godmani \\
\hline rostoma austrinu ........ 140 & — salions palomite ....... 15 & - gratemalensis \\
\hline$y=0$ stona austritmm $\ldots \ldots .148$ & Oncorlyynchus .. & — hypseluris. \\
\hline conyestrum & Oreaqubius.............. 10 & - luticaudus......... \\
\hline & - rasenbergiz & — maculatus......... \\
\hline & TARIOPHXSI . . . . . . . . 110 & - manuguensis...... \\
\hline$\ldots \ldots \ldots \ldots \ldots$ st & IiA $\ldots \ldots \ldots \ldots 11 t$ & - modestus \\
\hline 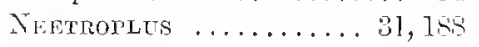 & yloricariat .............. 111 & _. motrguensis .... \\
\hline Vectroplus ............ 16 & - jamamensis .......... 114 & — microptems .... \\
\hline - nematopus ........31 & & - nicarafuensis. \\
\hline gentiventris ..... 189 & & - peterensis...... \\
\hline$\ldots \ldots \ldots \ldots, 60$ & thtosteus............. $1 \pm 7$ & —polycaulus........ \\
\hline dipneti & - plebeius............ 148 & - rogersi ....... \\
\hline$\ldots \ldots \ldots \ldots \ldots \ldots, 119$ & arayembusia micuraynensis .. & — salvini. \\
\hline 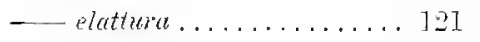 & ARANEETROPLUS.......: :1, 188 & - uagneri............ 131 \\
\hline Inte $\ldots \ldots \ldots \ldots .1232$ & $\ldots \ldots 16,180$ & 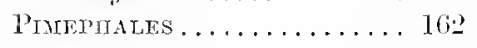 \\
\hline 一 Tiessieri ............ 121 & $\ldots \ldots .81$ & Pimephales ......... 14:3, 1603 \\
\hline - oscula & erapetenia ........... & - confertus .......... 162 \\
\hline - planictps & tilapia $\ldots \ldots \ldots \ldots 15,10$ & — promelas comfortus ..... 162 \\
\hline - plet & dranemus quinquarius ..... $7:$ & Pisolion \\
\hline chimathum & utapion & lotus. . \\
\hline$\ldots \ldots \ldots \ldots$ & $\ldots \ldots \quad 49$ & Pisoodonoph is \\
\hline - roberstus ............. 157 & SOCES .......... & — duspilotus ........ \\
\hline$\ldots \ldots \ldots \ldots 155$ & 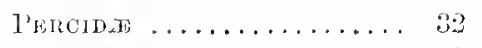 & is armilator. \\
\hline tropis .......... 14:, 1.5t, 1600 & cille .......... & - und \\
\hline artecus ........... 160 & NA $\ldots \ldots \ldots \ldots \ldots \ldots$ & es maculatus. \\
\hline$\ldots \ldots \ldots \ldots 150,160$ & I'eicina $\ldots \ldots \ldots \ldots \ldots \ldots$. & - mentais .......... \\
\hline _ boucardi ...........50 & - caprodes $\ldots . . .$. & — netsmi .......... \\
\hline 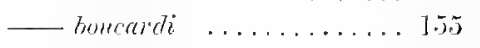 & A $\ldots \ldots \ldots \ldots$ & - quitzernsis \\
\hline - braytuni $\ldots . . . .$. & $\ldots \ldots \ldots \ldots$ & — tropicus... \\
\hline entis $\ldots \ldots \ldots \ldots$ & - splentida ........... & $-r \sigma \theta^{\circ}$ \\
\hline$s \ldots \ldots \ldots$ & $\min \ldots \ldots \ldots 18 t$ & Plef \\
\hline a.......... & $\ldots \ldots \ldots \ldots 101$ & I'lecos \\
\hline$a \ldots \ldots$ & ius $\ldots \ldots \ldots \ldots .14: 3$ & uri $\ldots \ldots \ldots$ \\
\hline$i s \ldots . . . .$. & $f(x, \ldots \ldots \ldots$. & - guecurai.......... \\
\hline sus $\ldots \ldots$. & $s \quad \ldots \ldots \ldots \ldots$ & $-w$ \\
\hline - formosus $\ldots \ldots \ldots$ & $\ldots \ldots \ldots \ldots \ldots$ & ECTIITA. \\
\hline ni........... & nitictor $\ldots . . .$. & $d_{c} \ldots \ldots \ldots$ \\
\hline$m i \ldots \ldots \ldots$ & $t o r \ldots \ldots \ldots \ldots, 0,0$ & rimatata ....... \\
\hline sis $\ldots \ldots \ldots \ldots 158$ & lis............... & . $100,1 ! 10$ \\
\hline asis $\ldots \ldots \ldots$ 155, 159 & datus............ & Irecitiu.... \\
\hline mus........... & $A \quad \ldots \ldots \ldots$ & —oncrurli .. \\
\hline umus $\ldots \ldots \ldots$. & inbuerina $\ldots . . .$. & — Butleri ...... \\
\hline$\ldots \ldots \ldots \ldots \ldots 1$ & - eivthterinoide's....... & - concaua........... 190 \\
\hline$\ldots \ldots \ldots \ldots$ & e............ & (rosis. .... . 100, 102, 103 \\
\hline - nippotenintess. & atensis . . . . . & ana . . . . . . 104 \\
\hline - oreat & Teceles confirtus & Ficant..... \\
\hline orest. & 137 & rii $\ldots \ldots$ \\
\hline _ omatus... & tes $\ldots \ldots \ldots \ldots \ldots 137$ & wila ......... \\
\hline - ornatus....... & inclentes ...... 114, 125, 120,198 & — dorï ....... 100, 10 , 103 \\
\hline -ritsonis....... & - Imeronis-mialleri ... & - "longnta .......... 102 \\
\hline — sillliei $\ldots .$. & cunrli ... & - chomeyter. \\
\hline - sallei $\ldots . .$. & brartygerydutus & — jillii. \\
\hline - sontimirite ... & - chinguesi . & - Intijuncteter. \\
\hline namire.. & - cinerastems & - limentmeri... \\
\hline malie. & - cletrits: & - lincolula \\
\hline
\end{tabular}




\begin{tabular}{|c|c|}
\hline & \\
\hline aculata ..... & Pristipoma \\
\hline - maculata $\ldots \ldots \ldots \ldots$ & - boncardi \\
\hline - mericana ..... ] 100, 102, 103 & - Uranicki \\
\hline - multilineata & - crocro \\
\hline _occidentalis .......... 301 & — cultriferum $\ldots . .$. \\
\hline - octidentalis ......... 102 & —-Tumite ......... \\
\hline - petenensis .......... 104 & — Telireciforme......... 44 \\
\hline - peteneusis........ 100,101 & —leuciscus $\ldots \ldots \ldots \ldots$ \\
\hline Iionis $\ldots \ldots \ldots \ldots .99$ & - macraranthum ........ 19 \\
\hline i. $\ldots \ldots \ldots \ldots 104$ & -ramosum ... \\
\hline ris ............. 101 & Pristers. \\
\hline ops ............. 102 & - rntiquorum \\
\hline $\begin{array}{r}\text { sphenops } \ldots \ldots \ldots 100,101 \\
103,190,191\end{array}$ & $\begin{array}{l}\text { atus. . . . . . . . } \\
\text { teti . . . . . }\end{array}$ \\
\hline 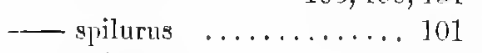 & — \\
\hline - spilurus ............ 100 & Psummoperca \\
\hline ais $\ldots \ldots \ldots \ldots \ldots 190$ & Hophorets ..... 99,94,9T \\
\hline atis ..... 100, 102, 104 & _ bimacrlatus ........997, 9 \\
\hline . . . . . . . 191 & ——, var. teoniatus..... $9 \mathrm{~s}$ \\
\hline$\ldots \ldots \ldots \ldots \ldots 102$ & - panciradiatus ........ \\
\hline Gensis . . . . . . 102 & $\longrightarrow r$ \\
\hline$\ldots \ldots \ldots, 76$ & ILUS. \\
\hline culatus $\ldots . .$. & 143 \\
\hline$\ldots \ldots \ldots \ldots$ & 158 \\
\hline$\ldots \ldots \ldots \ldots$ & ans at \\
\hline$\ldots \ldots \ldots \ldots \ldots$ & cstus $\ldots \ldots \ldots \ldots 146$ \\
\hline$n n n s \ldots \ldots \ldots \ldots$ & \\
\hline$\ldots \ldots \ldots \ldots$ & \\
\hline is $\ldots \ldots \ldots \ldots$ t3 & A. . \\
\hline$s \ldots \ldots \ldots \ldots$ & 05,60 \\
\hline$\ldots \ldots \ldots \ldots$ & $-m$ \\
\hline$\ldots \ldots \ldots \ldots \ldots, 2$ & us \\
\hline$\ldots \ldots \ldots \ldots 41,189$ & \\
\hline$\ldots \ldots \ldots \ldots \ldots t 1$ & \\
\hline$\ldots \ldots \ldots \ldots \ldots$ & 1.78 \\
\hline$\ldots \ldots \ldots \ldots \pm 2,41$ & Rhat \\
\hline 1 & -1 \\
\hline$\ldots \ldots \ldots$ & $s$-miilleri... \\
\hline$\ldots \ldots \ldots \ldots$ & $\longrightarrow 1$ \\
\hline$\ldots \ldots \ldots \ldots 41,42$ & 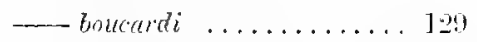 \\
\hline formis ........ 11 & ephala ..... 15: \\
\hline$\ldots \ldots \ldots \ldots \ldots t 4$ & phale .... 1:9, 192 \\
\hline$\ldots \ldots \ldots \ldots 41,42$ & ypterus $\ldots$ \\
\hline$\ldots \ldots \ldots \ldots \ldots 1 s \theta$ & $\ldots 131$ \\
\hline$\ldots \ldots \ldots \ldots \ldots 48$ & $\ldots \ldots \ldots \ldots \ldots 191$ \\
\hline $18 \ldots \ldots \ldots \ldots, 42$ & $(\ell \ldots \ldots \ldots \ldots \ldots 131$ \\
\hline$\ldots \ldots \ldots \ldots \ldots, 41$ & $\ldots \ldots \ldots 1: 9,191$ \\
\hline inthus . & $\cdot 1 \pm 9$ \\
\hline anthus .. & ualensis. \\
\hline$u s \ldots$ & $1: 8,729$ \\
\hline nensis & .. 184 \\
\hline$u_{s} \quad \ldots \ldots \ldots \ldots$ & atha ..... \\
\hline$\ldots \ldots \ldots \ldots \ldots \quad 4$ & ra $\ldots \ldots \ldots \ldots \ldots, 134$ \\
\hline moximecess ...... & 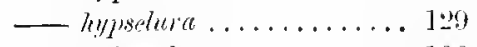 \\
\hline 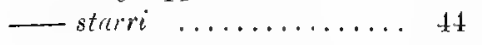 & .136 \\
\hline$\cdots \cdots \cdots$ & - Laticumber ............ \\
\hline
\end{tabular}

biol. Centr.-Amer., Pisces, February ] $90 \mathrm{~S}$.
Piure

Rham dia manaruensis. . . . . 13;

- manayuensis.......... 1:!

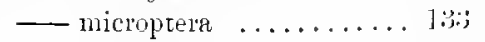

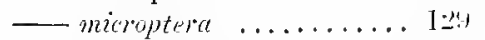

- motaguensis ........ 180

— motreguensis ....... 128, 191

- nicaraguensis ......... 1:010

— nicaraguensis $\ldots \ldots \ldots$.... $1: \vdots$

- vatuce .............. 1:3.

- paryi $\ldots \ldots \ldots \ldots 130,191$

- parryi $\ldots \ldots \ldots \ldots \ldots, 12$.

- petenensis $\ldots \ldots \ldots \ldots$. 1:2.

— petenensis ........... 1:!n

- polycaulus .......... ] 54

- polycuulus ........... 130

— regani ........... 19:

- rogersi $\ldots \ldots \ldots \ldots 130,193$

- nogersi ............ 1:3

- sacrificii $\ldots \ldots \ldots \ldots . . \ldots 1 \% ;$

— salvini ............. 19,

- salvimi ............ 130

_- underwoodi .......... 19.

—underuoodi ........... 124

- wagneri ............ 131

- wugneri. .......... 129, 191

Rhivichthrs ........... 165

Rlimirletleys ............. 14::

- simus. . . ......... 16:

Thirugobius lucculentus ..... 11

— contractus ......... 11

Rirules ................ 81

Tiverlers .............

- Habellicauda ......... 81

- godmavi ............ 8 ;

- godmani .......... 81

—isthmensis.......... 8

-_. istlmensis ........... 81 .

- operculeris .......... 81

- tenuis ............. 8

_- tenuis............. $\mathrm{sl}$

Riebotdes................ 174

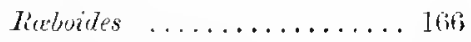

_- guatemalensis ....... 17t

Rutiles buucerdi .......... 1ist

Sumo ............... 17;

- darlii ........... 17

_. irideus ............. 17t;

— mykiss . . . . . . .

— plewriticus........... 177

— spilures........... 177

Salmoxima ............. 17t

Scindes troscheli ........... 106

Sciceslichthys ........... 11:

- trascheti............. 120

21 


\begin{tabular}{|c|c|c|}
\hline Page & Page & ge \\
\hline Gicirena maculata $\ldots . . . . . .$. & Stypndon signifar...... & Thyrina .............. \\
\hline - maderimalis ........... & NMMBRINCHIDE $\ldots .$. & - crystallima. \\
\hline 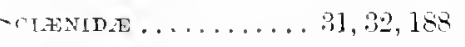 & SyMURANGHI & —evermanui........... \\
\hline$\ldots \ldots \ldots \ldots \ldots \ldots$ & Simbranchus ....... & __ guatemalensis ....... \\
\hline 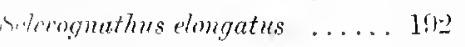 & - marmoratus ...... & - guatemulensis. ...... (0.0, ]s! \\
\hline _ meridimalis........... 144 & Svngnathila .......... 54 & - - pachylepis ......... (jis, li.t \\
\hline 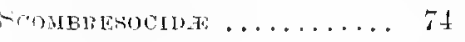 & 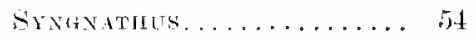 & - sardina $\ldots \ldots \ldots \ldots \ldots, \mid k\}$ \\
\hline CombMUIDEs $\ldots \ldots \ldots \ldots .14$ & - muliscus........... 5,5 & 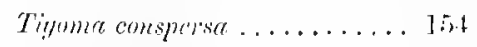 \\
\hline - alters ............ 15 & —-spiciter $\ldots \ldots \ldots \ldots \ldots .54$ & — migrescens .......... 15i \\
\hline mumitus ........... 15 & —otirksi $\ldots \ldots \ldots \ldots \ldots$ 5. & - pichellet $\ldots \ldots \ldots$ \\
\hline - pilometa ........... 15 & & 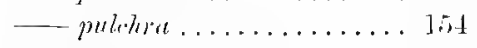 \\
\hline - palonerta $\ldots \ldots \ldots \ldots \ldots \quad 14$ & & Trifuras riveramti........ \& \\
\hline - rifulgens $\ldots \ldots \ldots \ldots \ldots$ 15 & Tnchirure & Tylusures $\ldots \ldots \ldots \ldots \ldots \ldots$ Tt \\
\hline _. suliens...$\ldots \ldots \ldots \ldots$ 15.5 & Tachisurus yolosus .... & - marinas............ 74 \\
\hline - saumus $\ldots \ldots \ldots \ldots \ldots \quad 15$ & rach!skurus & - scapuluris ... \\
\hline FELACHII . . . . . . . & Lemmetune & \\
\hline Mlenaspis .............. 110 & —orermanni... & \\
\hline - dow $\ldots \ldots \ldots \ldots \ldots \ldots$ 1: & — fiivthii ......... & \\
\hline -rovidum ........... 10, 18; & - liromus & _ lefroui \\
\hline ingdium ................ 4,11 & - melunopus. & \\
\hline- altum $\quad \ldots \ldots \ldots \ldots \ldots$, & — multiratiatns $\ldots$. & \\
\hline ogaster......... 10 & — strimdachneri.... & \\
\hline anctatum ...... 11 & 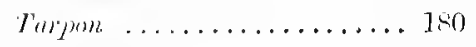 & Tillurius \\
\hline ieri & $\longrightarrow$ mlenticas .......... 1so & - pricei \\
\hline- punctntum.......... 11 & Ténjomet. & \\
\hline 一 Enlvini $\ldots \ldots \ldots \ldots \ldots, 10$ & $\ldots \ldots \ldots \ldots$ & \\
\hline hyopterne gymmongaster ..... 10 & PГERUS . . . . . 16 16! & IN. $\ldots$ \\
\hline - sulvimi .......... 10 & Tetrongonupteres $\ldots \ldots \ldots \ldots 160$ & Xenatherina .............. \\
\hline i'inatonst $\ldots \ldots \ldots \ldots \ldots$. & - mueus $\ldots \ldots \ldots \ldots \ldots$ ] & - lisn $\ldots \ldots \ldots \ldots \ldots$ \\
\hline Sirpunlana & — conens............ 100. 151 & Senenadum .............. \\
\hline - atchafalayge.... & - - angustifrons .......... IT: & - cabiente............ \\
\hline - mexicina ...... & —anumstifions .......... 170 & - multipenctetum $\ldots \ldots \ldots$ \\
\hline 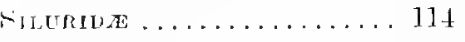 & _ - aryentutus ........ 171,172 & - maliscone...$\ldots \ldots$. \\
\hline sirurides $\ldots \ldots$. & _ beliziams ........... 170 & Xieno \\
\hline siluress bagre............ & — brerimanus $\ldots \ldots \ldots 171,172$ & Simocata \\
\hline _felis ............. 191 & —ubunessis . . . . . 171, 17: & $-\operatorname{chingtesi}$ \\
\hline siph, stoma ............ 54 & - fescriutus & Xiphophoris ..... \\
\hline - auliscus. ......... 5.j. & _finitimus & Xiphopplorus .... \\
\hline _- brevicandum .......... & — fiscreri ......... & - Limencelutuss \\
\hline - sturtisi $\ldots \ldots \ldots \ldots \ldots$ is & — friggus ........... 172 & - brevis .... \\
\hline vigfier .................. 00 & — Immilis ............. 170 & Wrenis.. \\
\hline- bilineata $\ldots \ldots$ & - m:urepluthismus ....... 171 & - gillii \\
\hline$\ldots \ldots \ldots \ldots$ & __ meroruphthatmas & - grarilis \\
\hline - mullipunctuta..... & - masicums...... & - gruentleri. \\
\hline - vuringatit ............ & — mercomus . . . . . . . . . 170 & - yuentheri .... \\
\hline vintea achiress ............... & — mirwophthaln:as ...... 170 & - heiliri ... \\
\hline - fonsecensis............. & —uifirles & - helleri \\
\hline 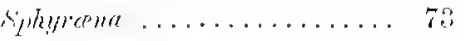 & 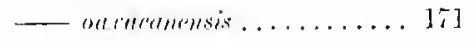 & - jaltipre \\
\hline - ampentritis & 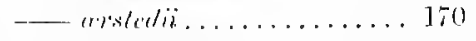 & - montezinuite. \\
\hline 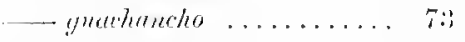 & - - pananemis .. & - montenmer \\
\hline CHYMIANADAE $\ldots .$. & — memensis .... & _- stripatus ... \\
\hline rysheyrronite: $\ldots \ldots \ldots$ & __milus & Kiraucing.... \\
\hline 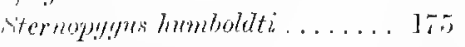 & - stepetsii & Sincunctien... \\
\hline 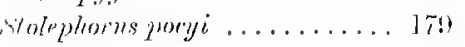 & $.17,22,2,: ;$ & - cypho \\
\hline $10 ; 0$ & Theriollethys & Xystemue \\
\hline
\end{tabular}




\begin{tabular}{|c|c|c|}
\hline Page & Taree & Proge \\
\hline Arsinosus ............. lfit & Jongonetrous ........... in & Zoogoneticus maculatus ..... ह \\
\hline 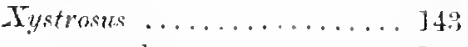 & \%ooyoneticns............. iti, 190 & — miniatus $\ldots \ldots \ldots \ldots \ldots$ sii \\
\hline popoche. & - cuitzeoensis ......... $s($ & - robustus $\ldots \ldots \ldots \ldots . . .86$ \\
\hline & - critzpoensis $\ldots \ldots \ldots \ldots$ \&.j & —roluestus.......... \\
\hline & - diazi ..... & Zxpheredmm australe ......... 15i \\
\hline Iurtia $\ldots \ldots \ldots \ldots \ldots \ldots, 149,164$ & 一 $\operatorname{diazi}_{\mathrm{d}} \ldots \ldots \ldots \ldots \ldots \ldots$ & Zygonactes ......... \\
\hline
\end{tabular}





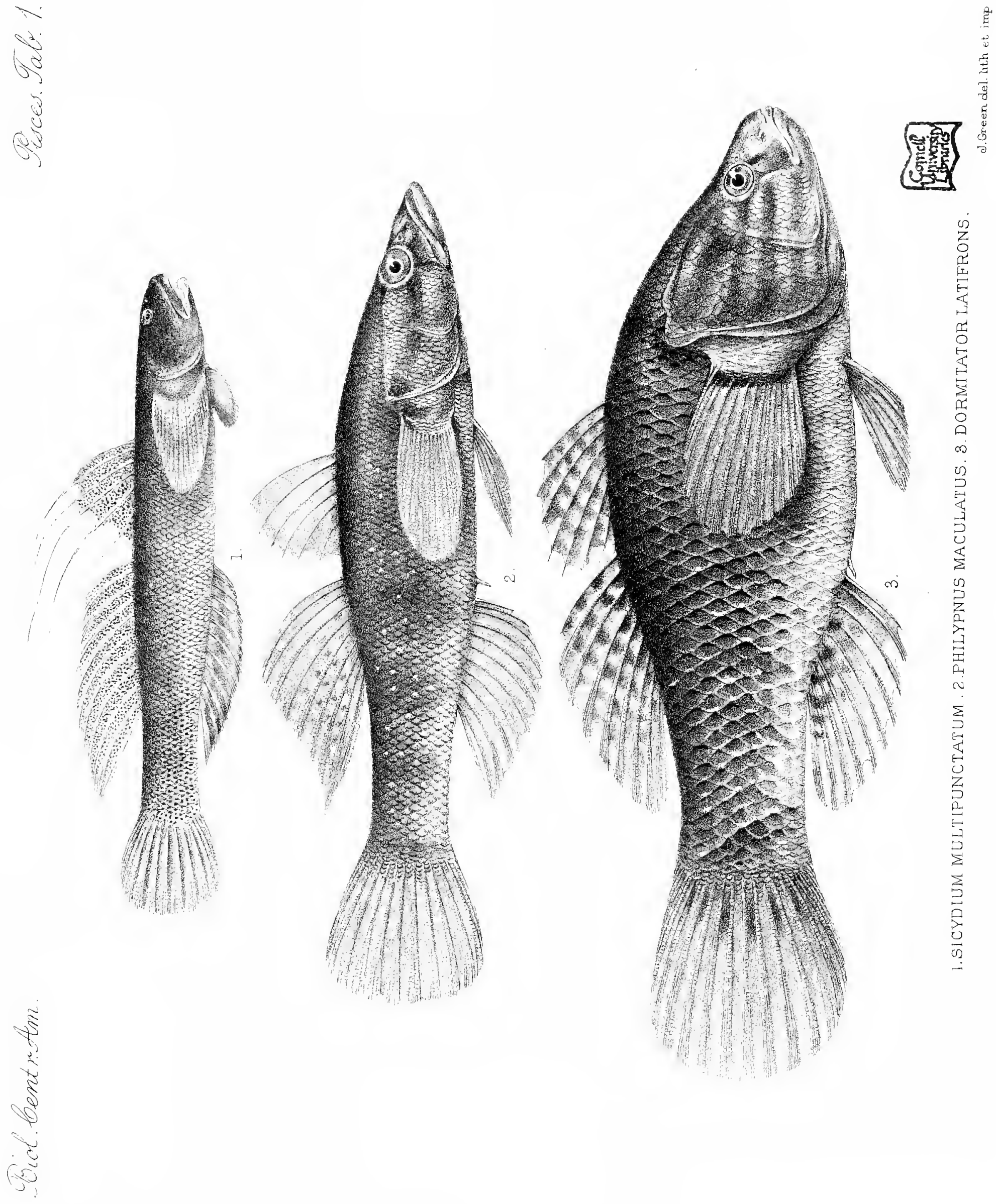




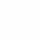



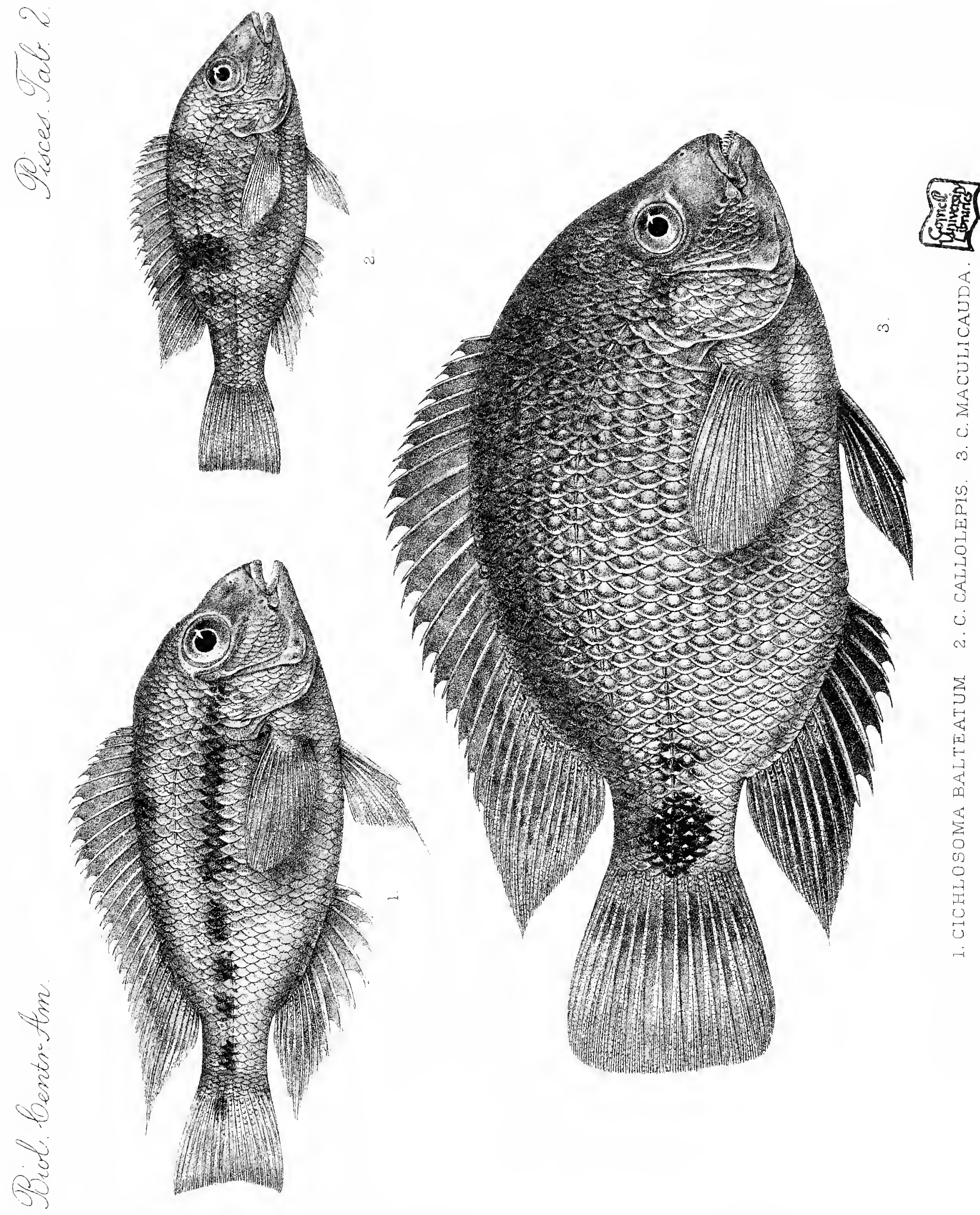

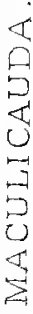

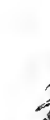




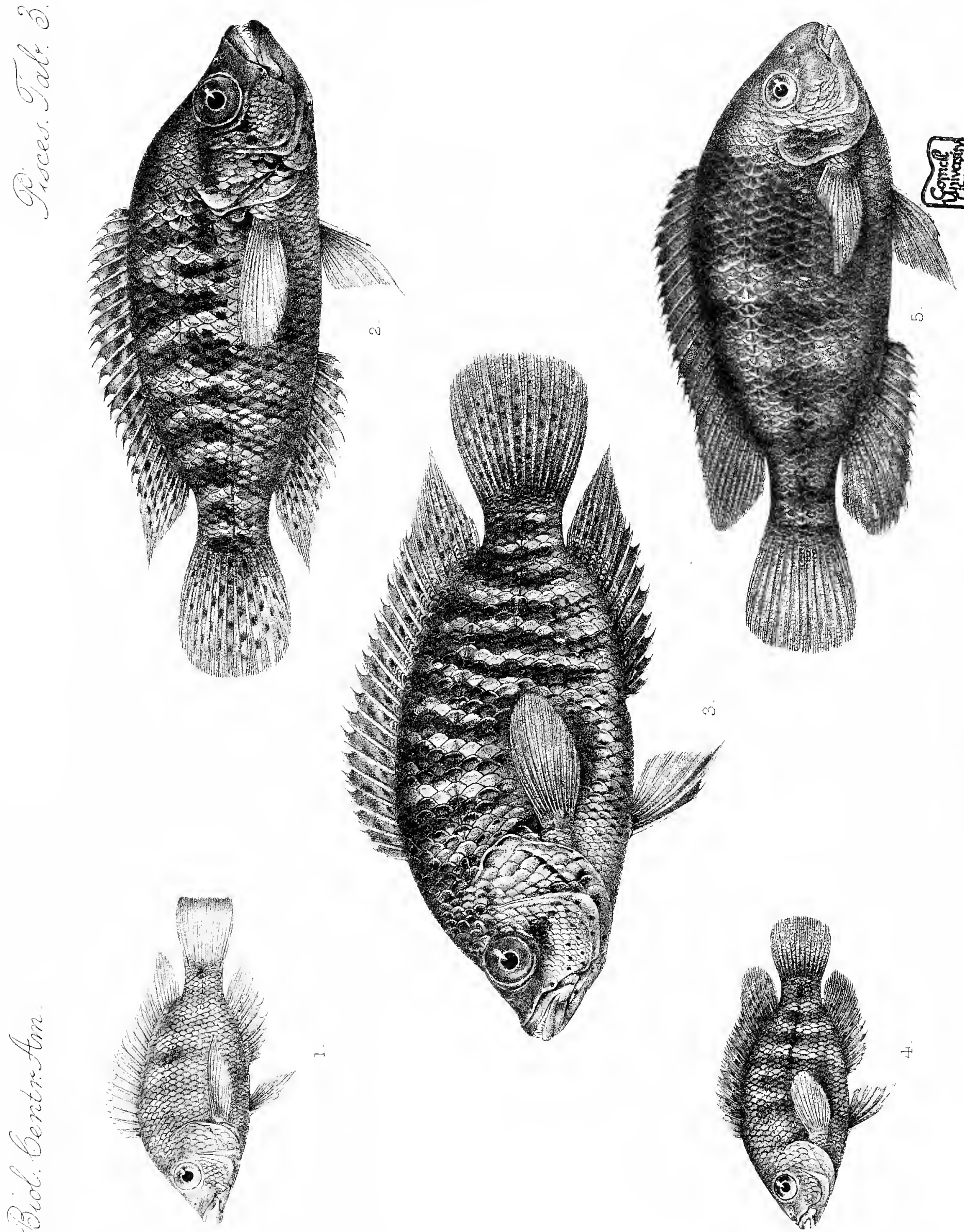

4
3
3
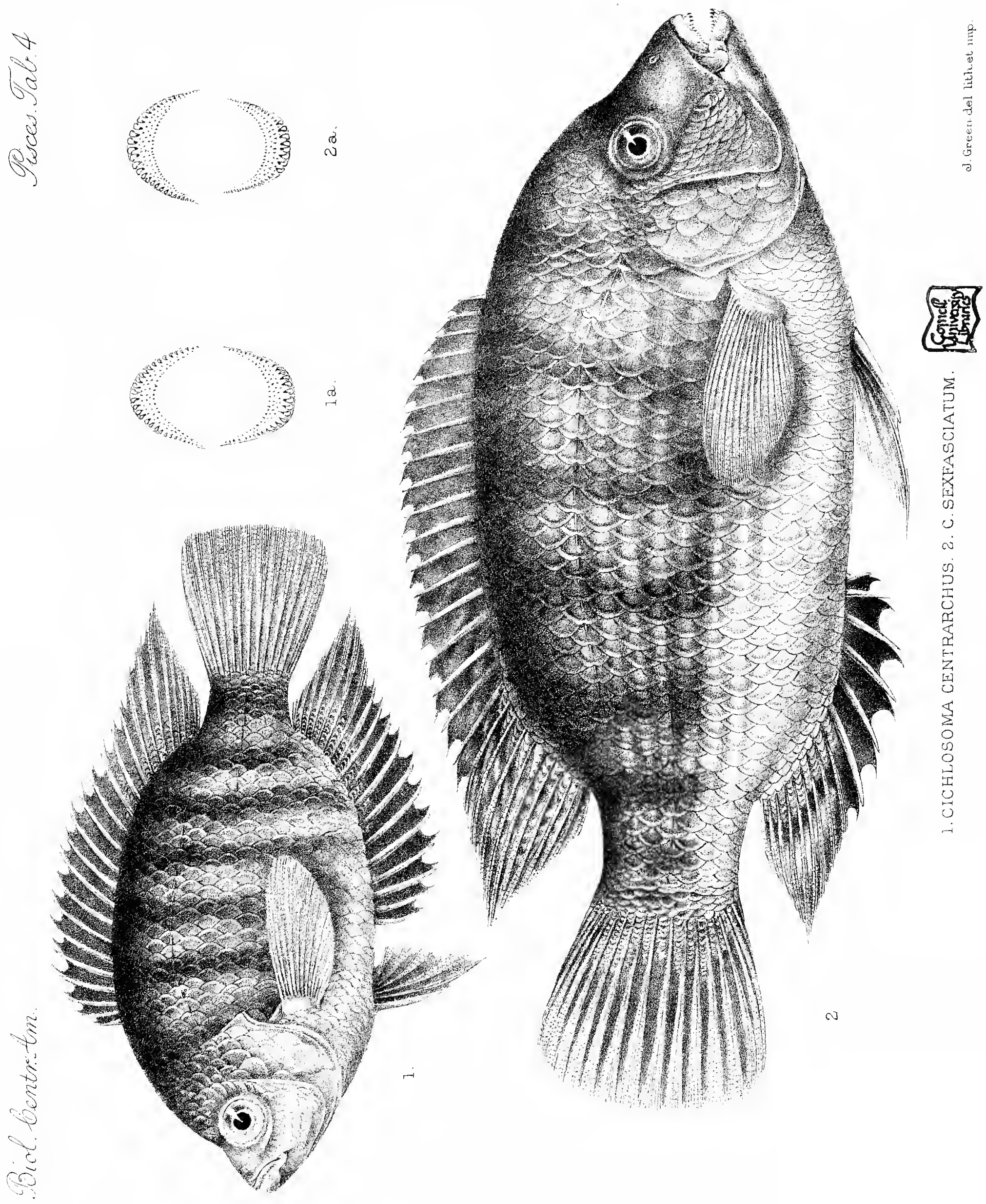

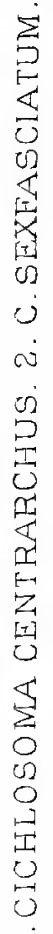





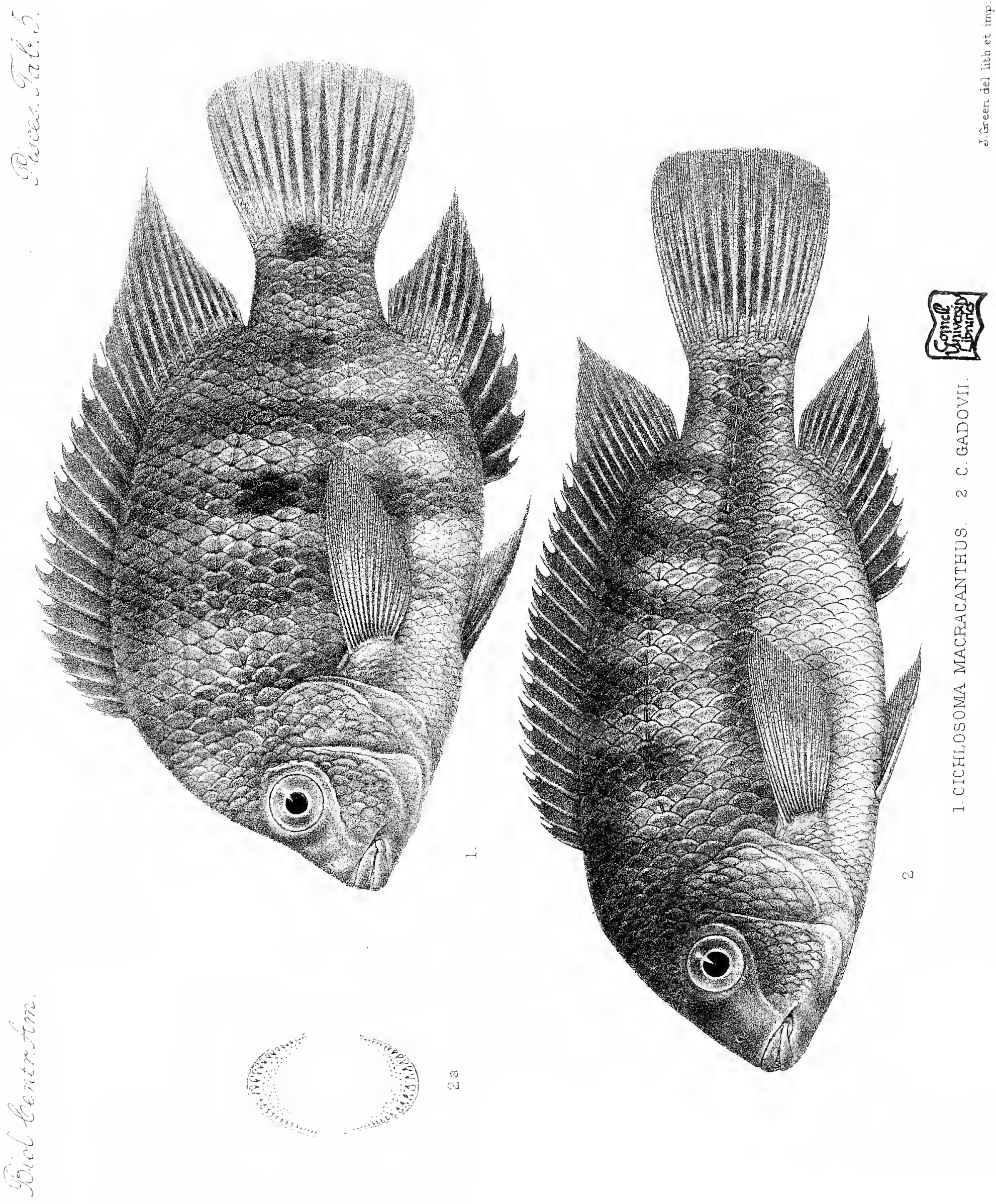





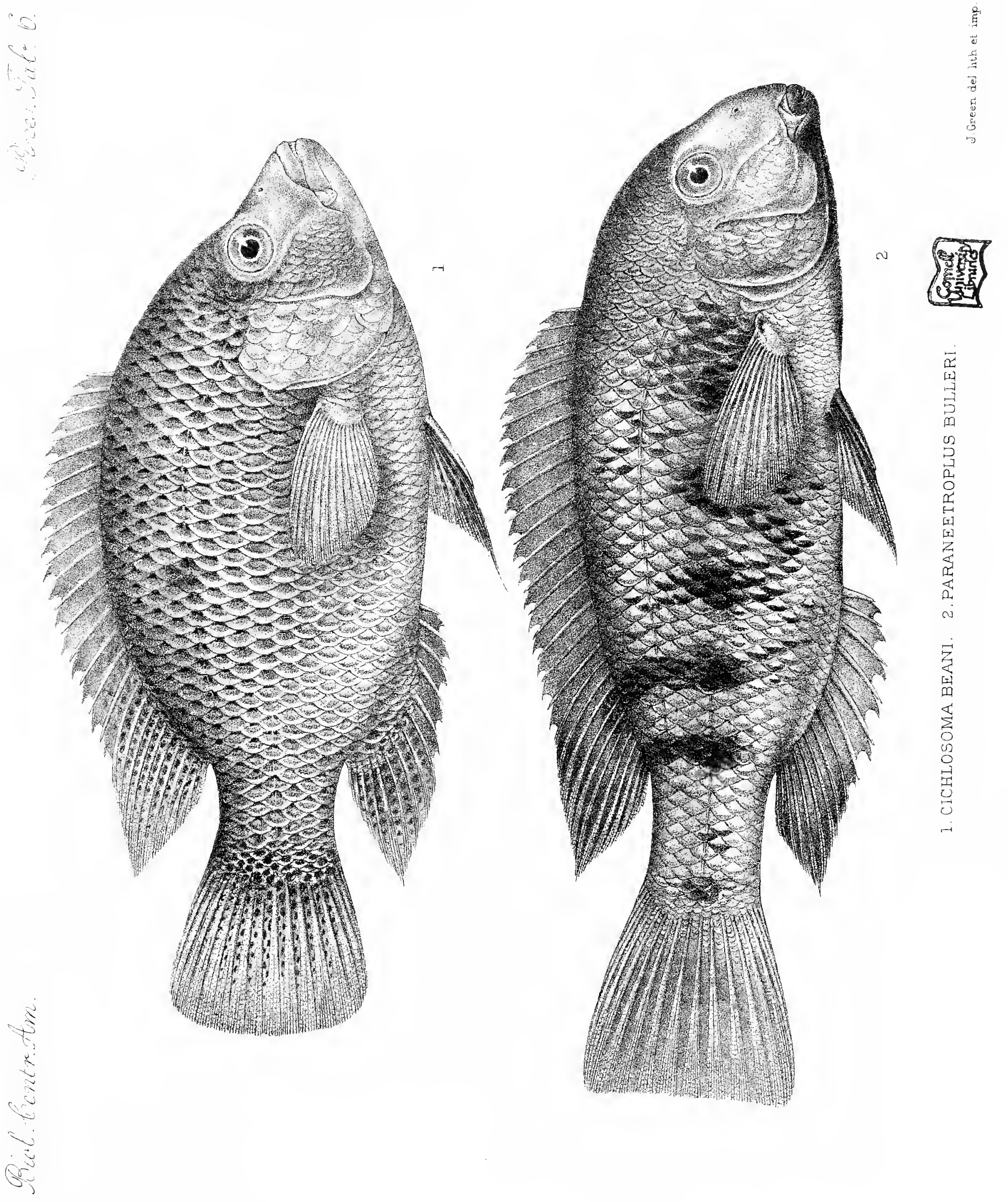





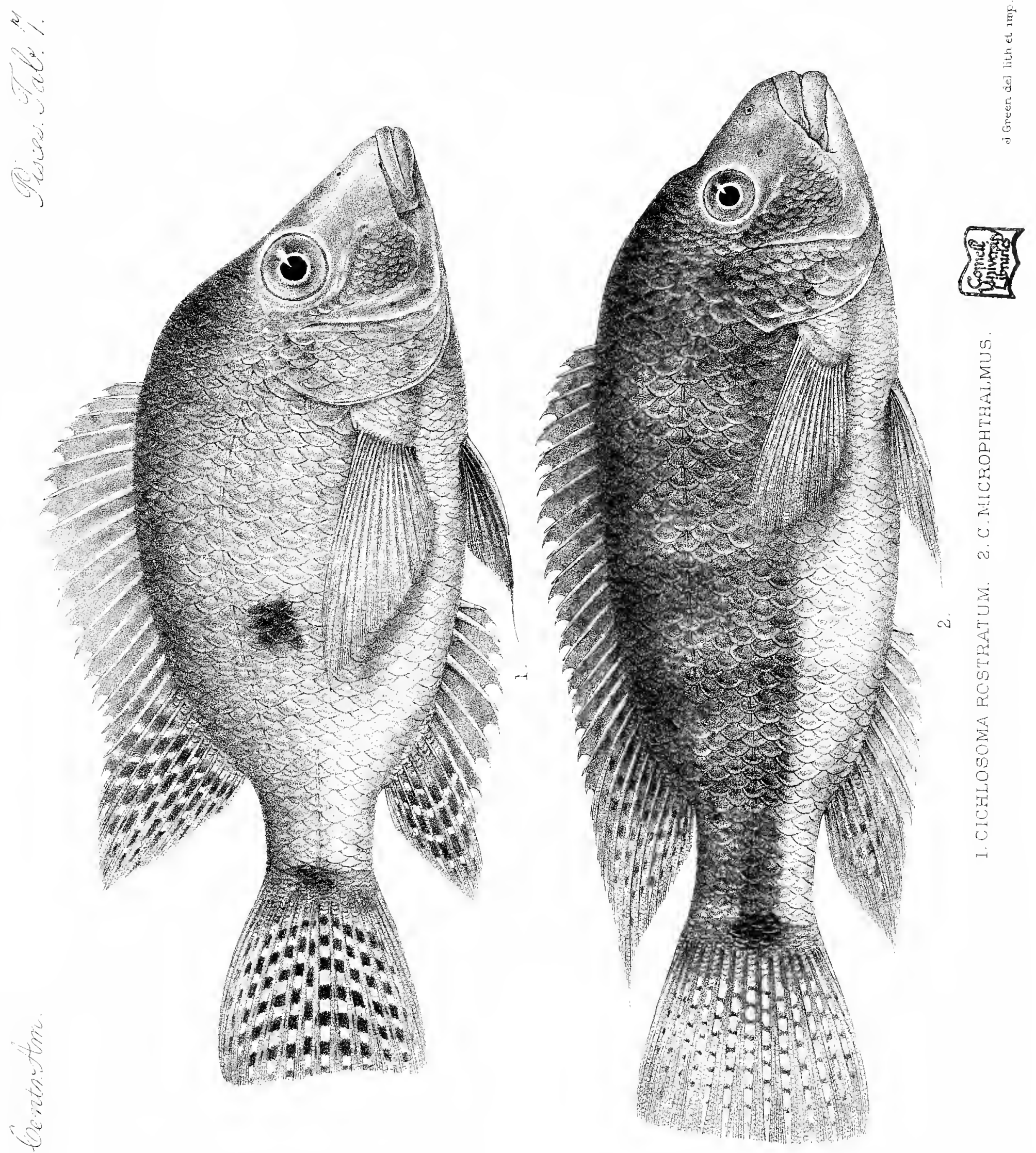





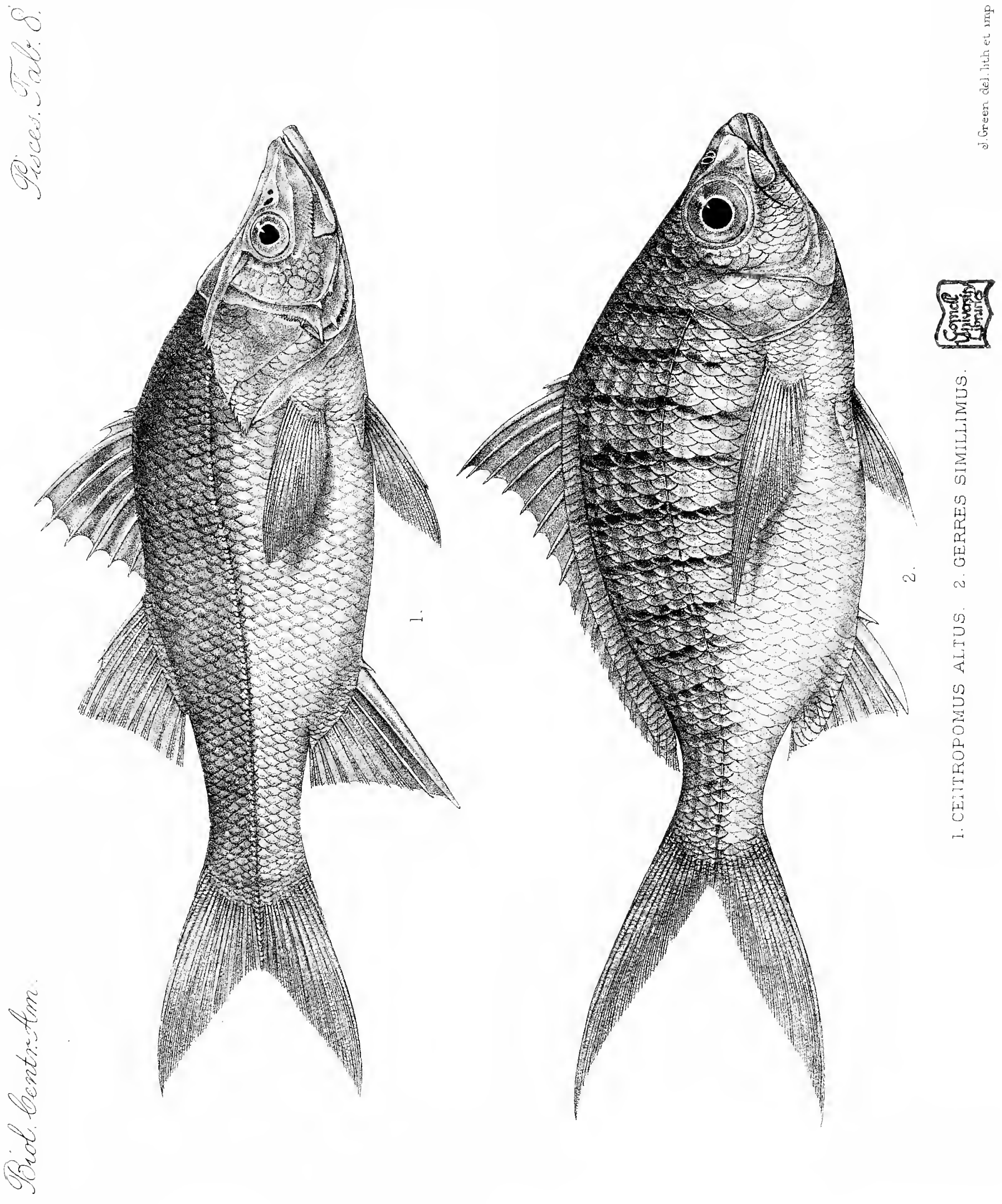




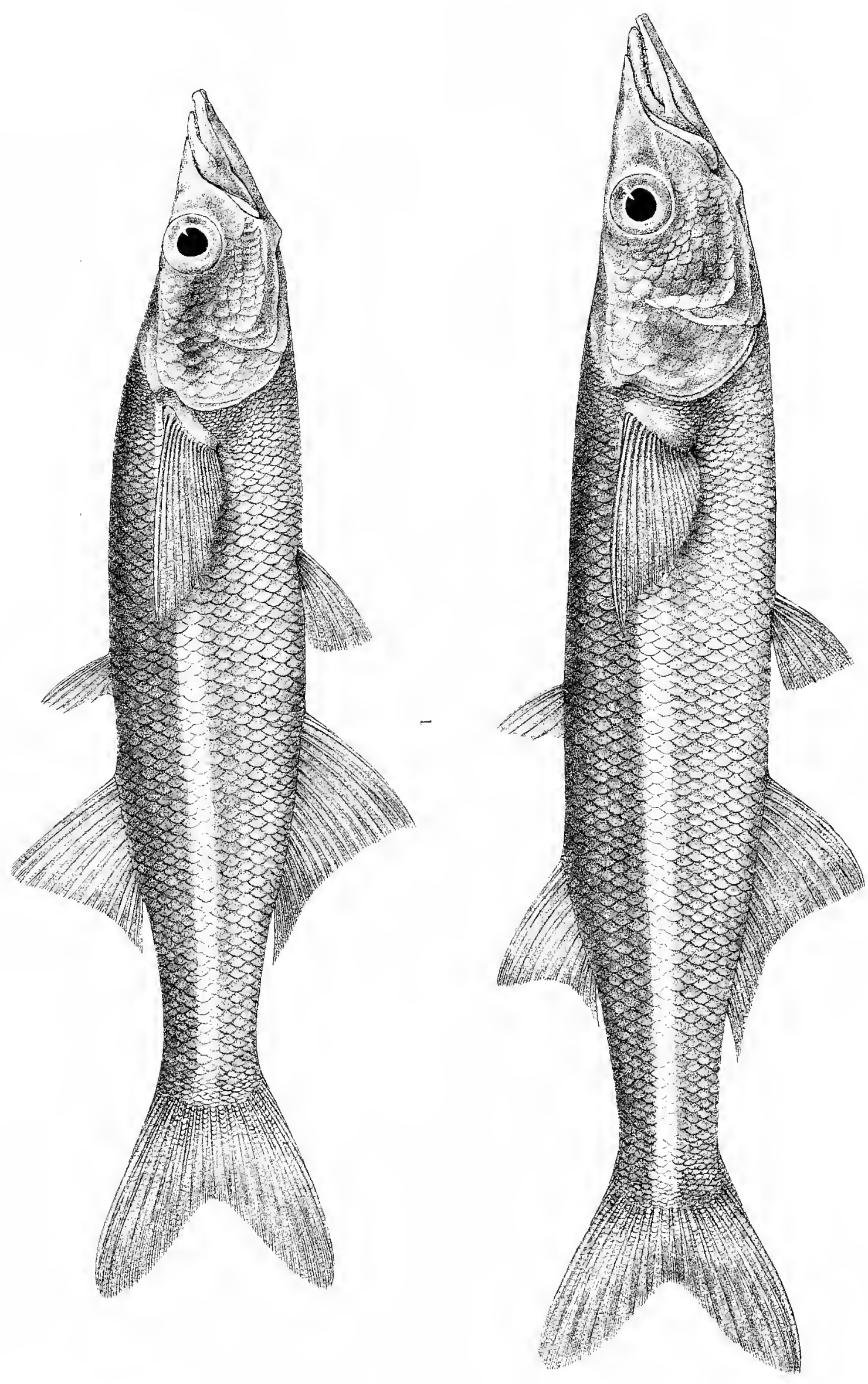

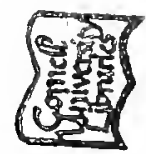

 



$$
f^{1}
$$





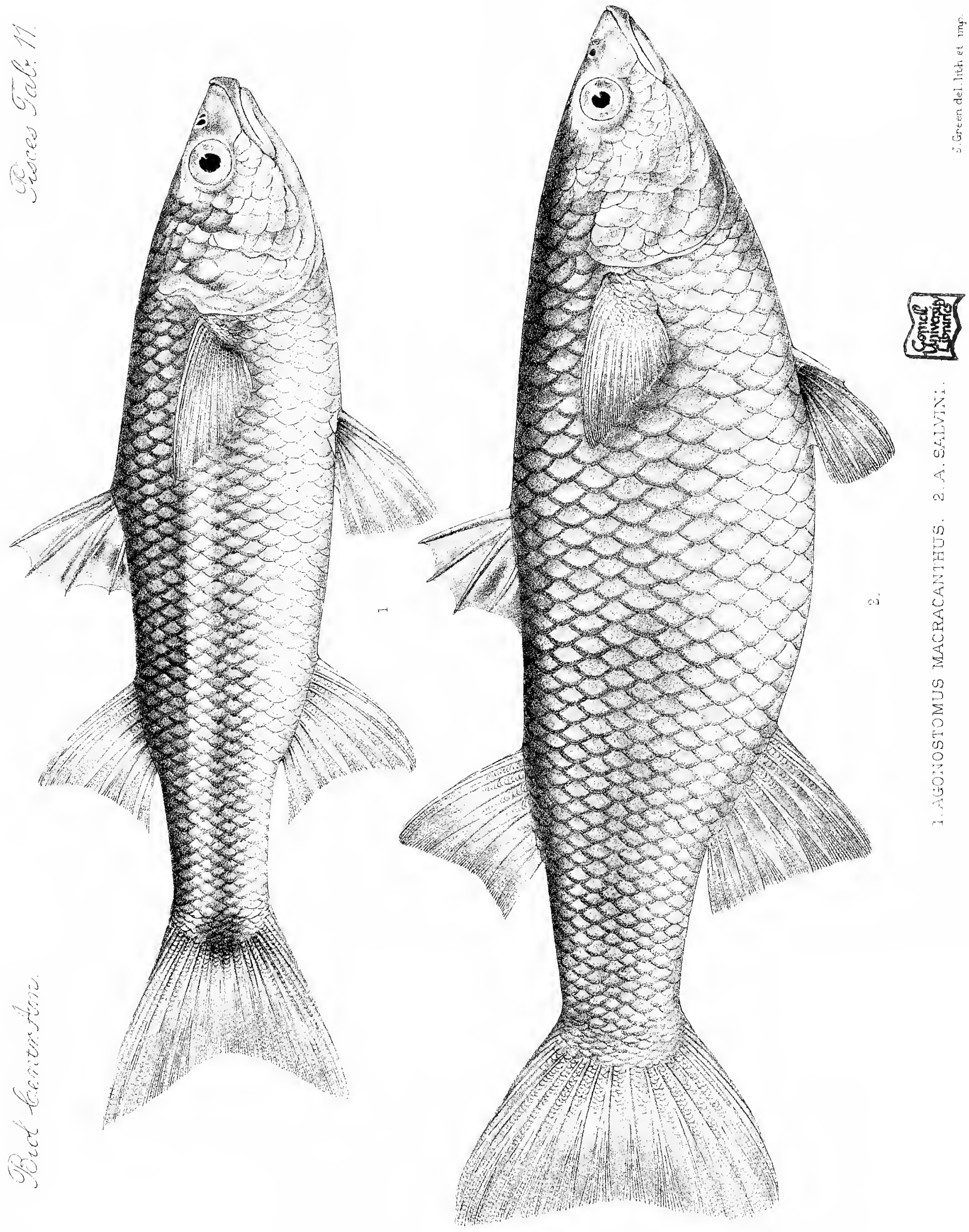





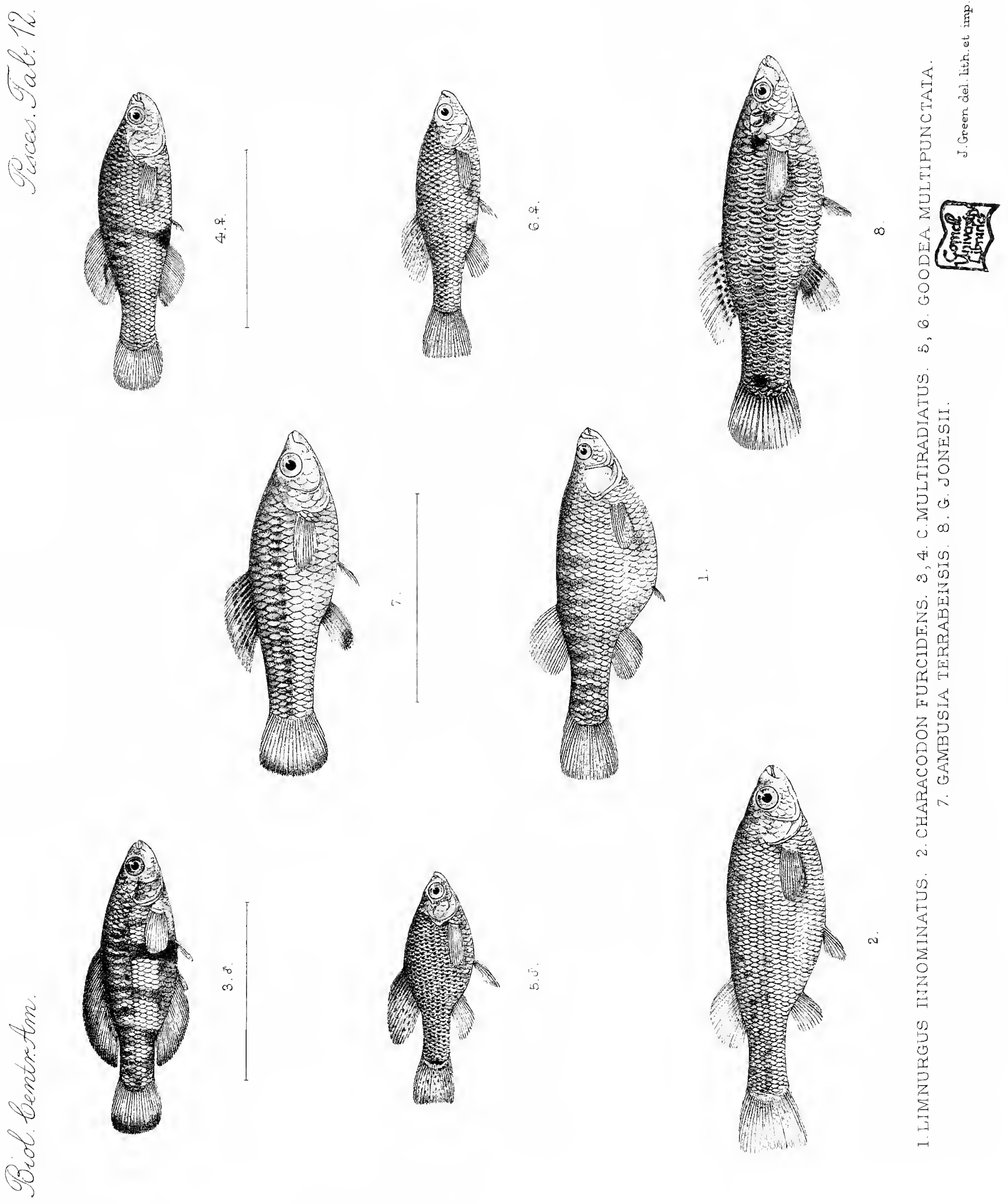





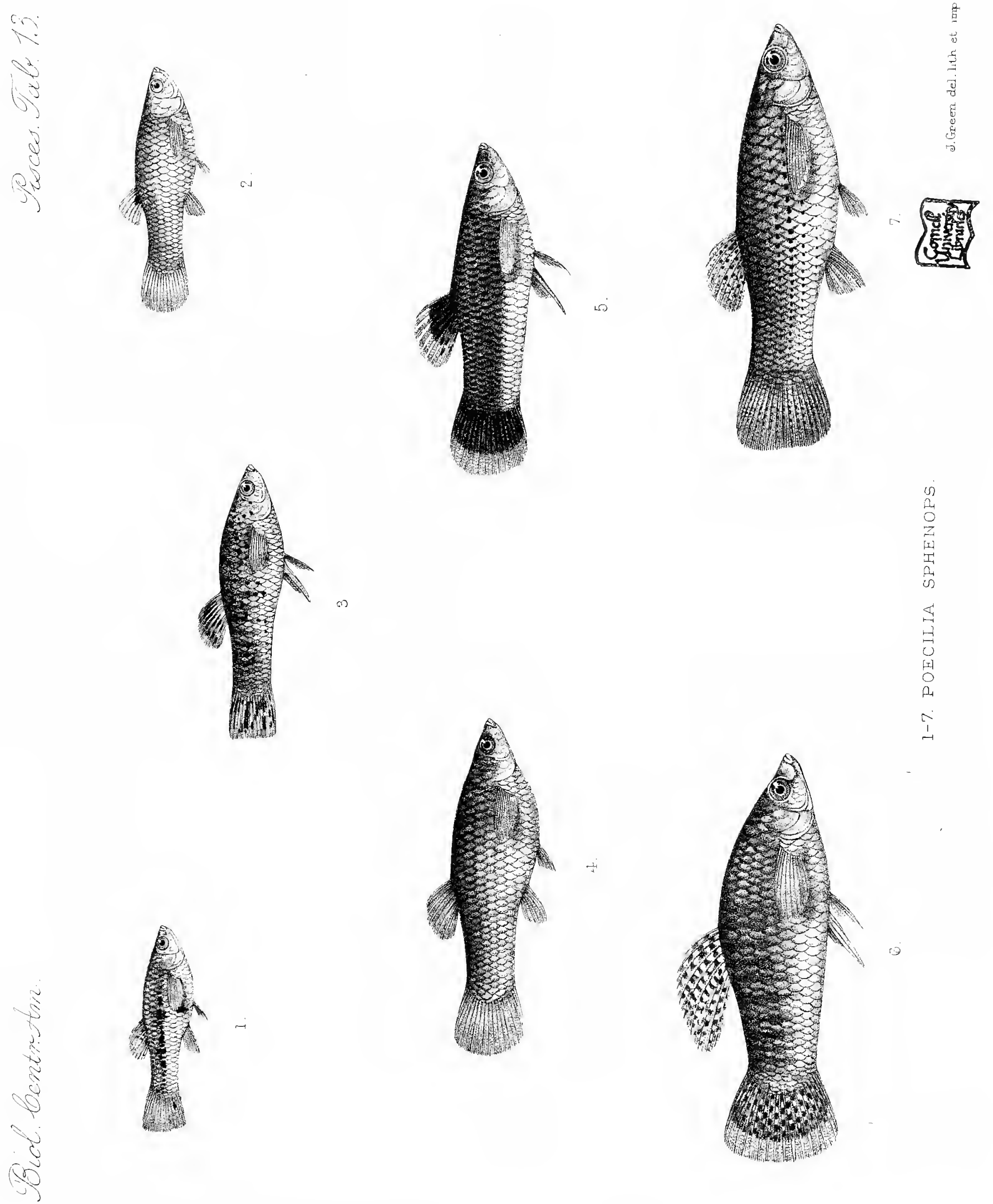





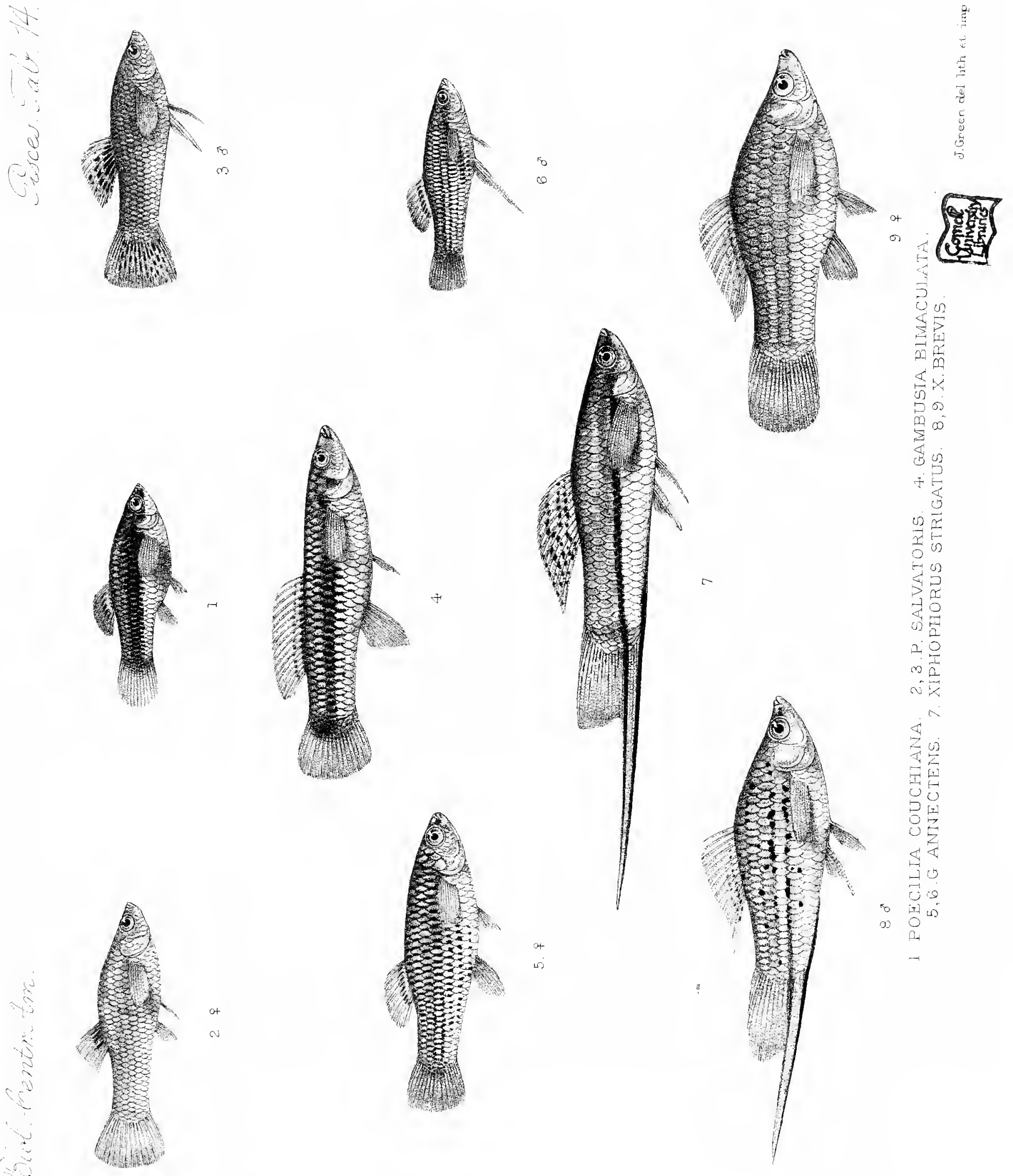





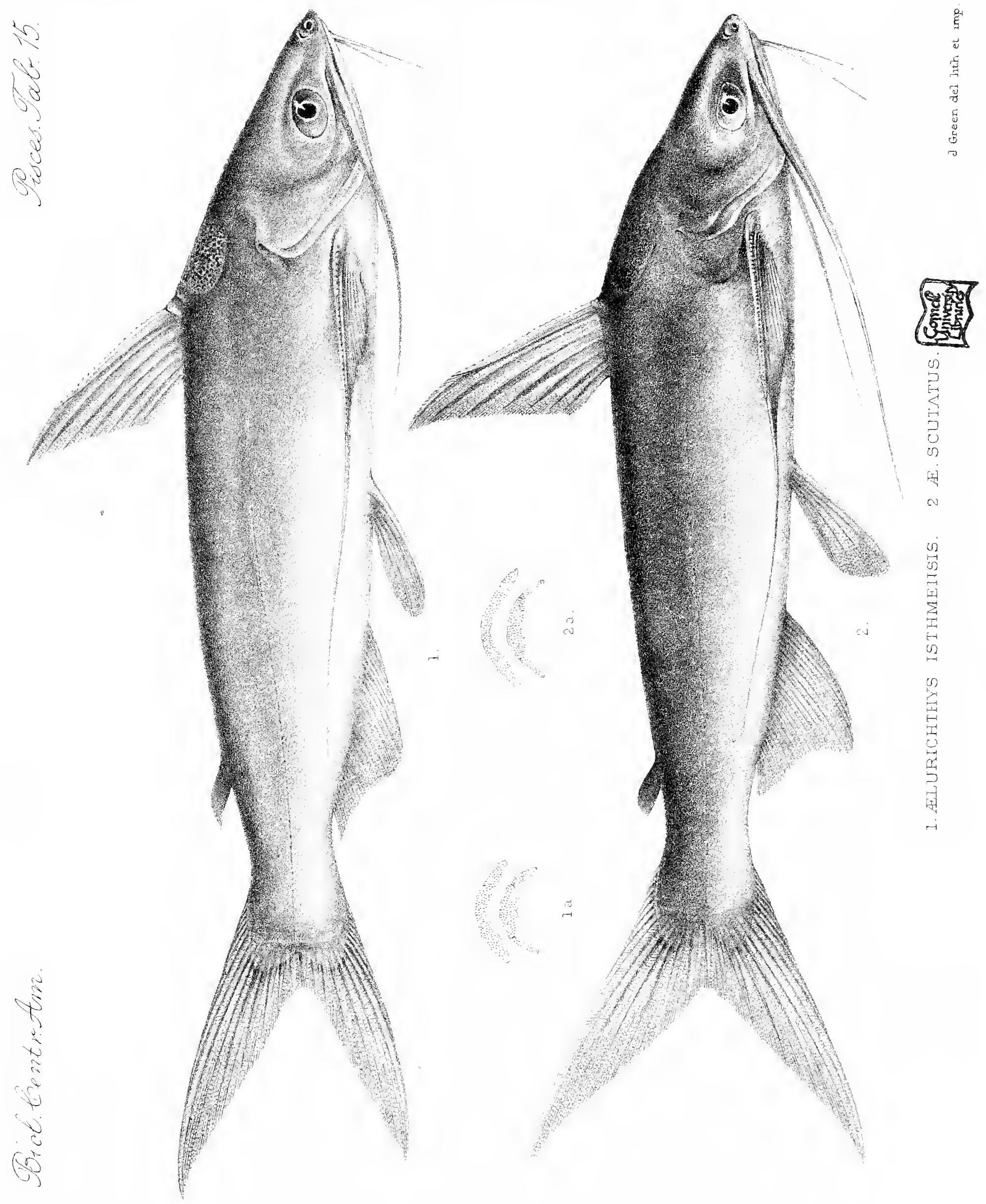





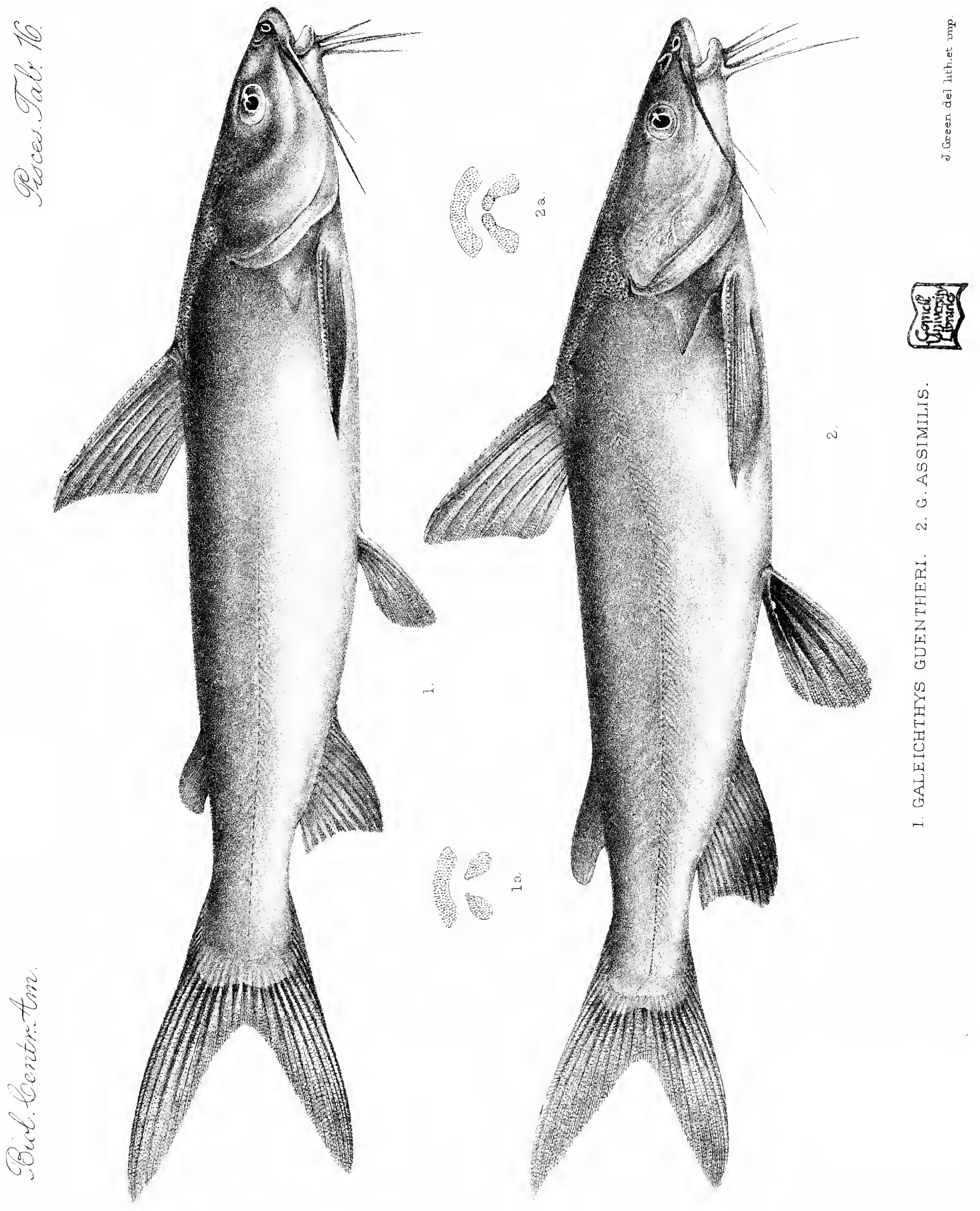





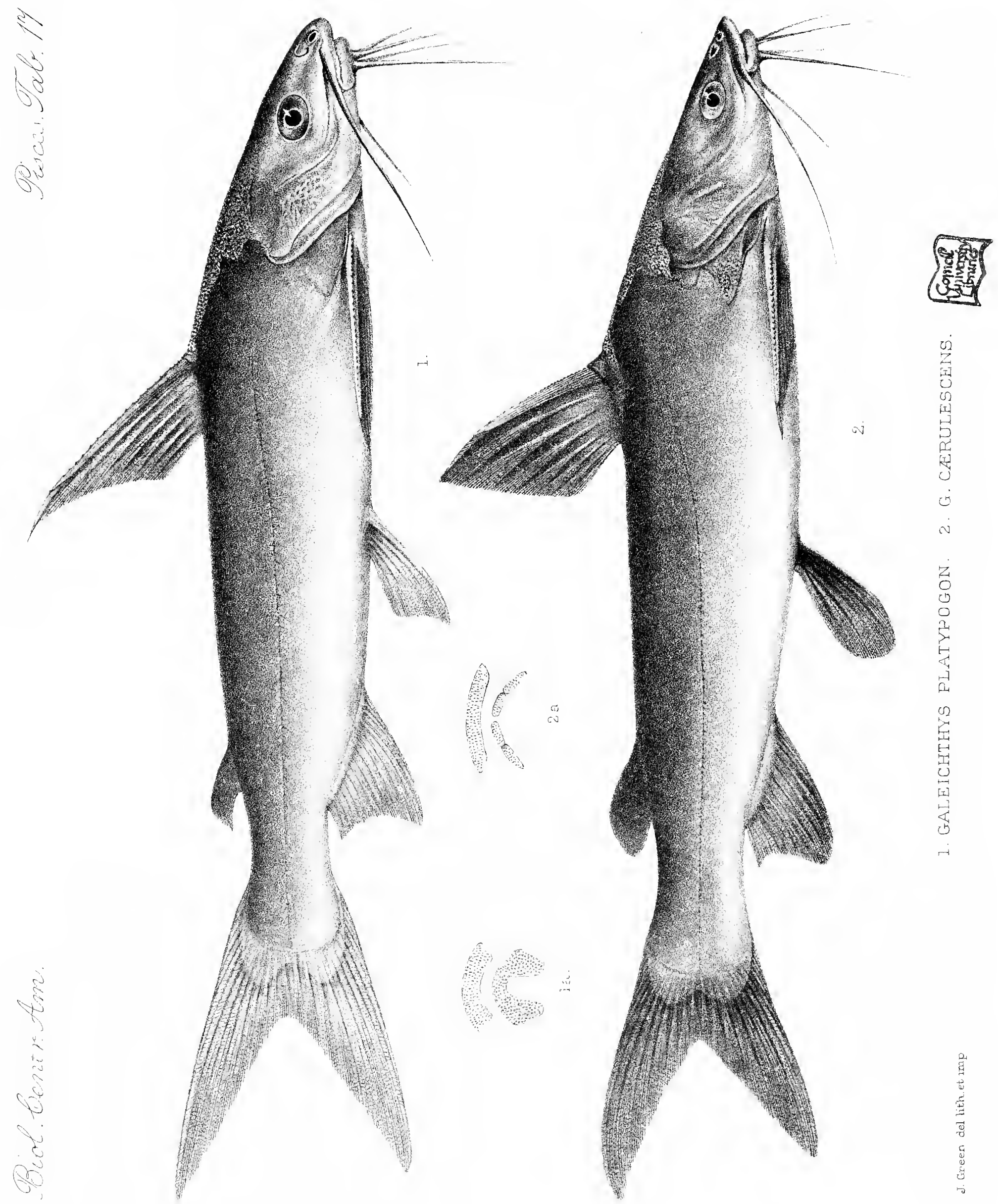





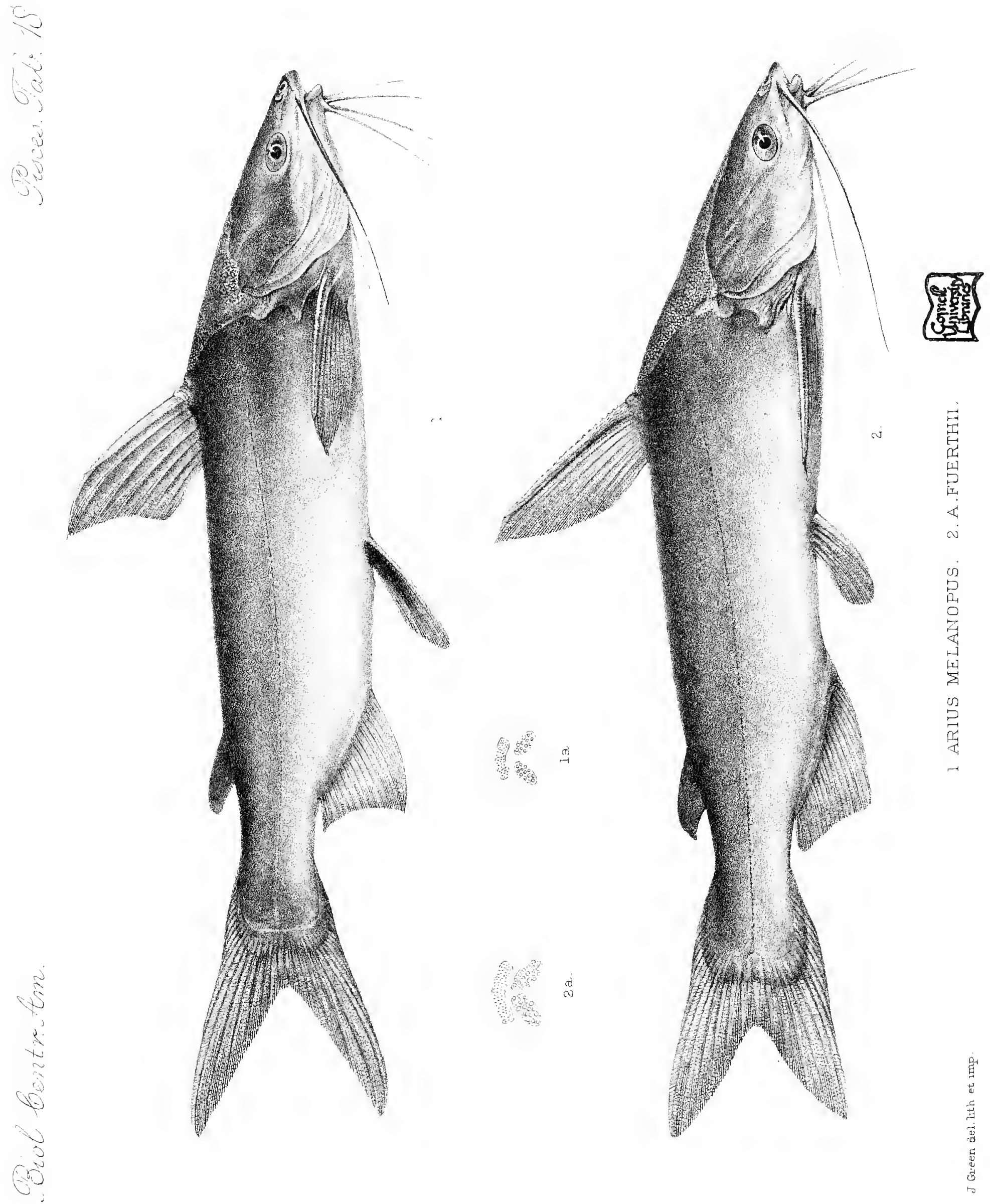




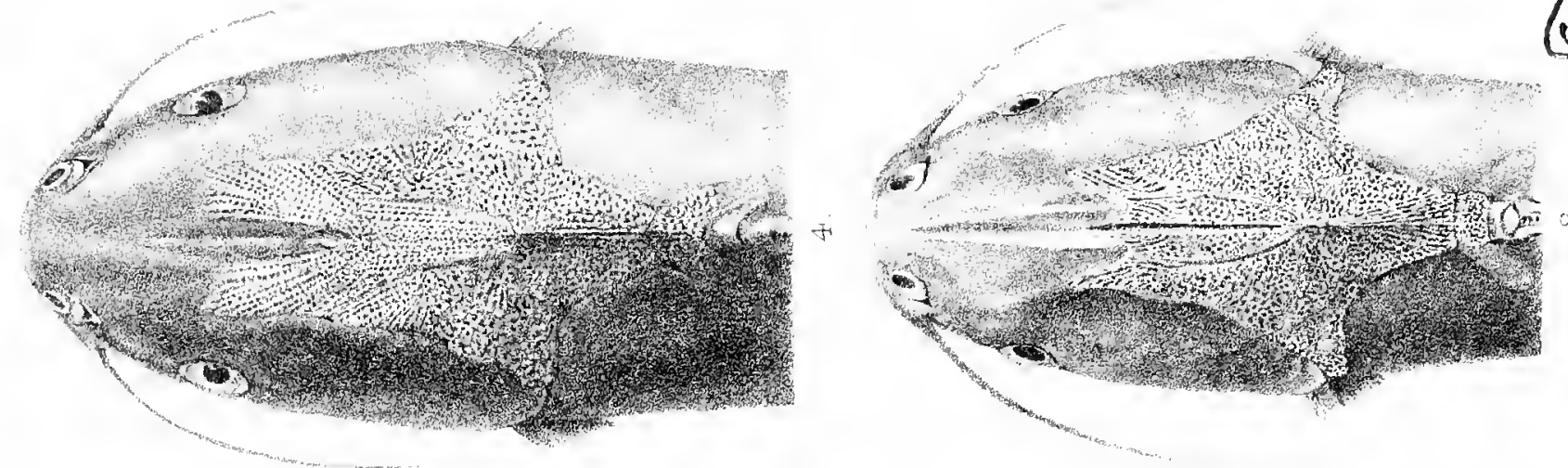

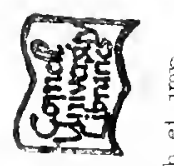
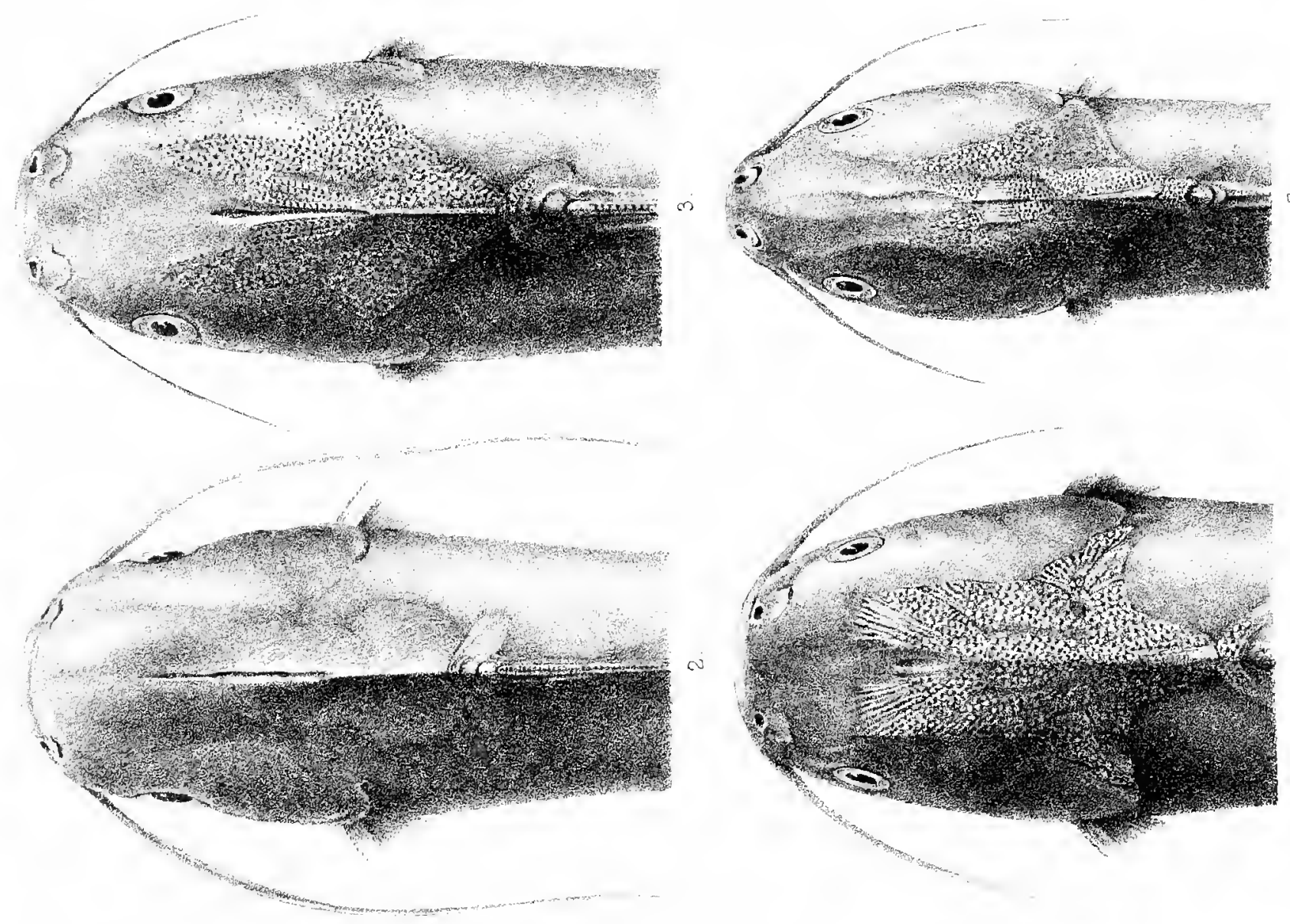

ת)

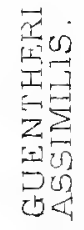

点

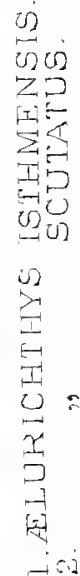

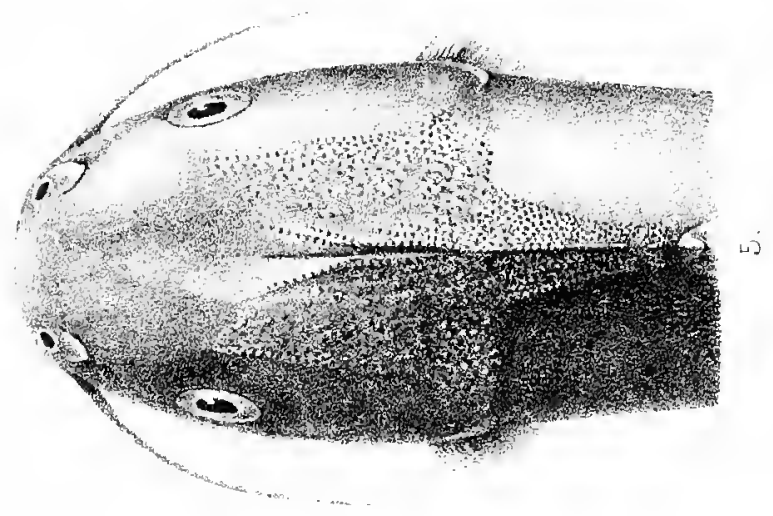





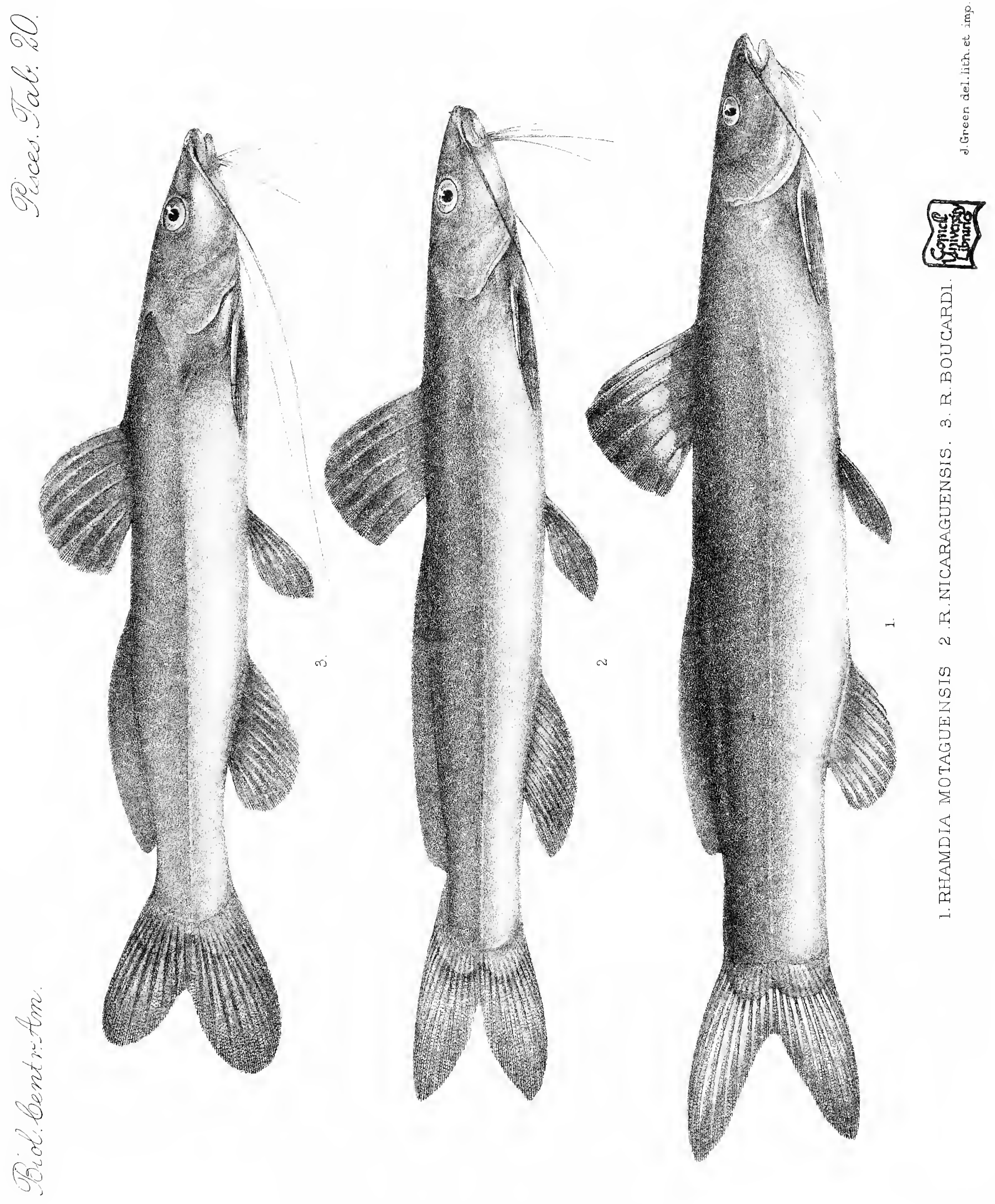





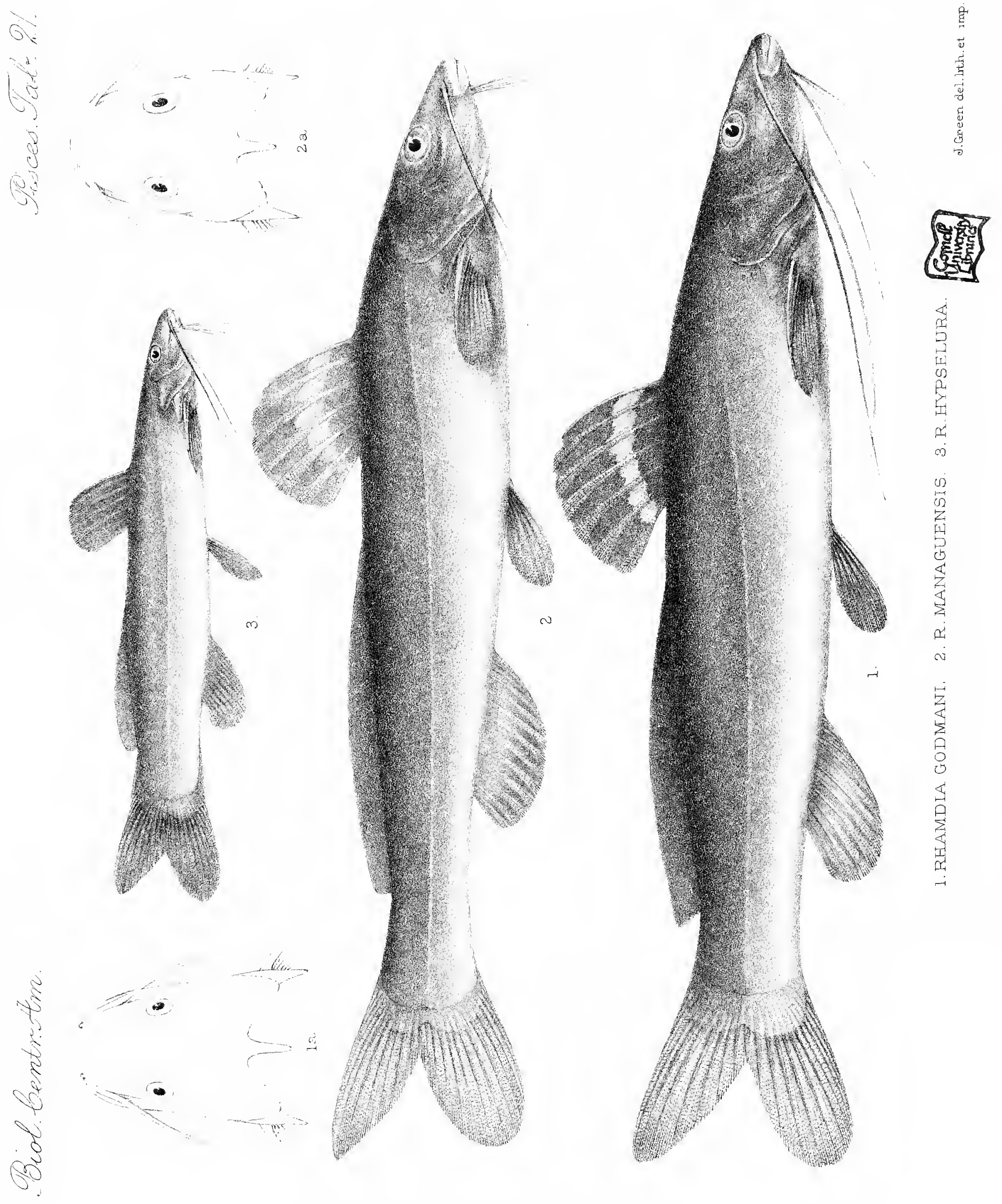




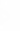



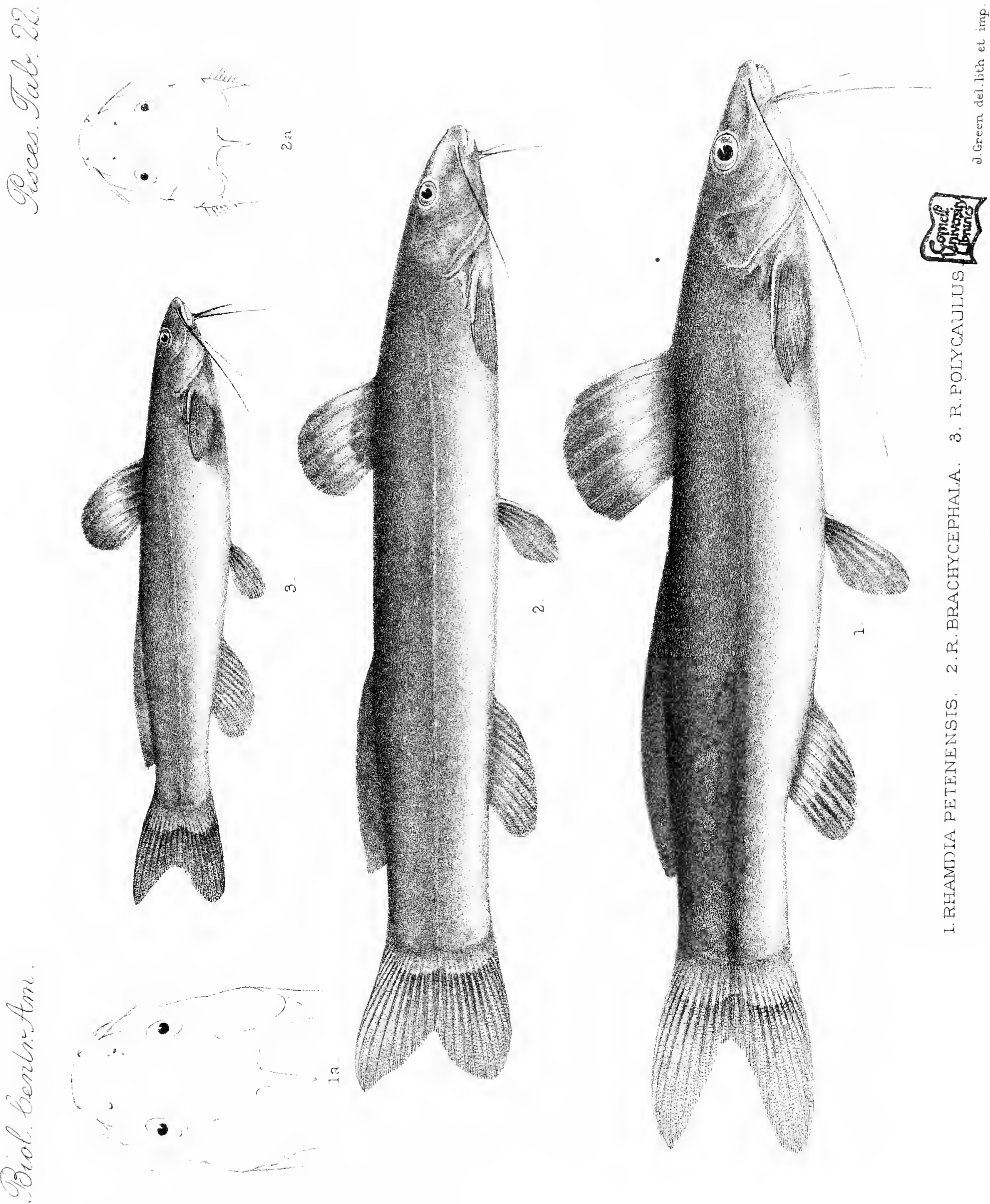



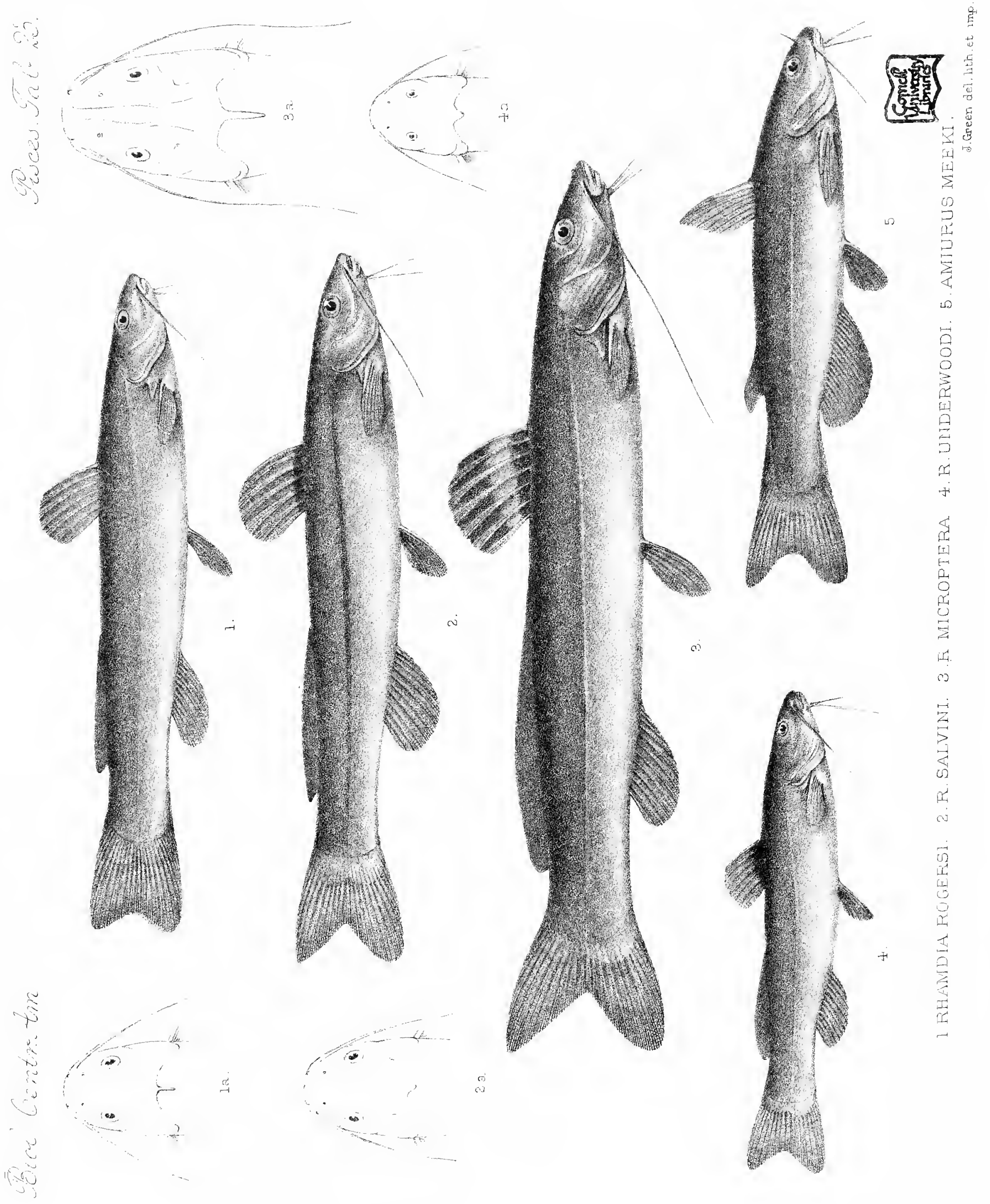





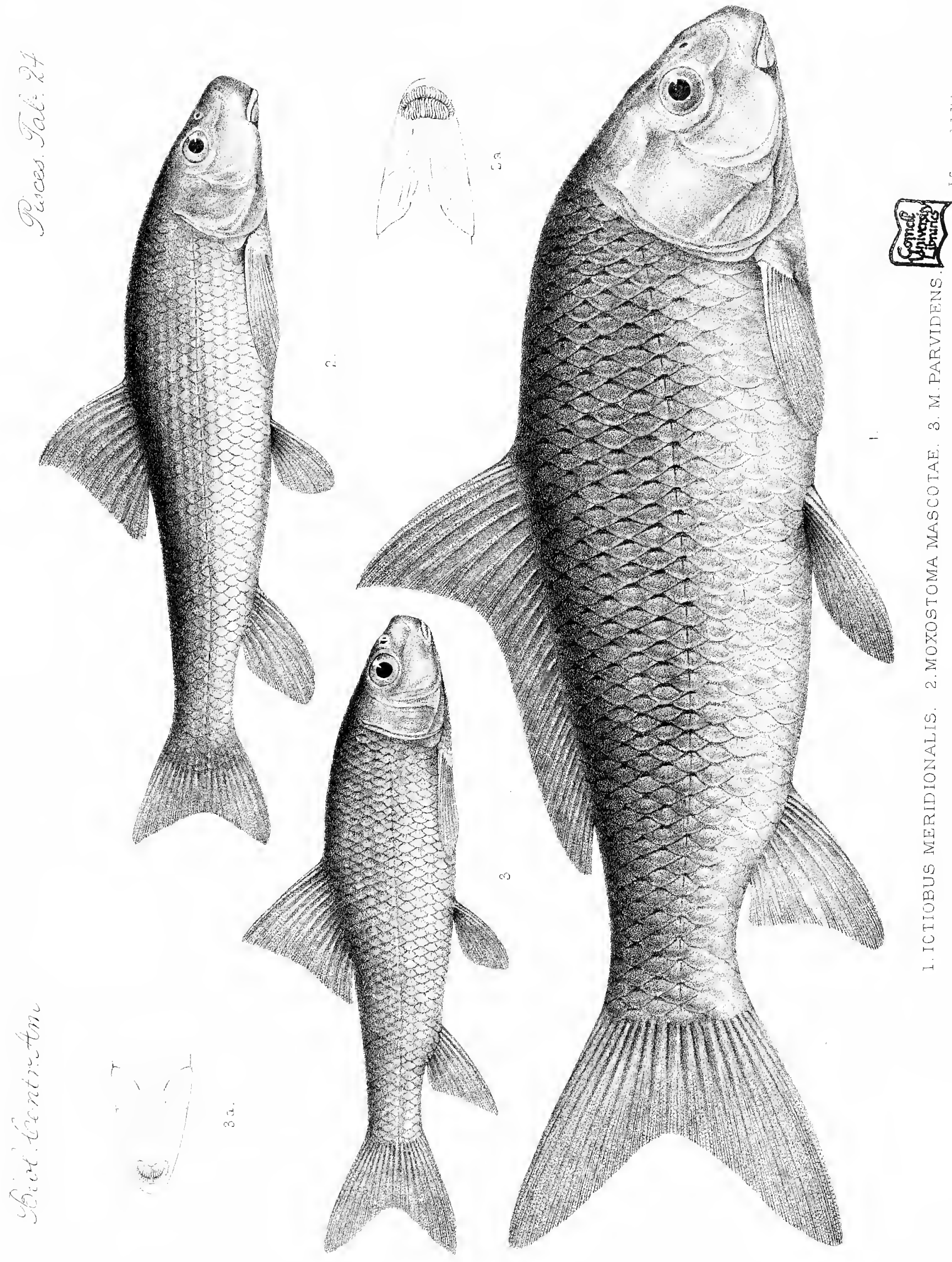





$$
+1
$$





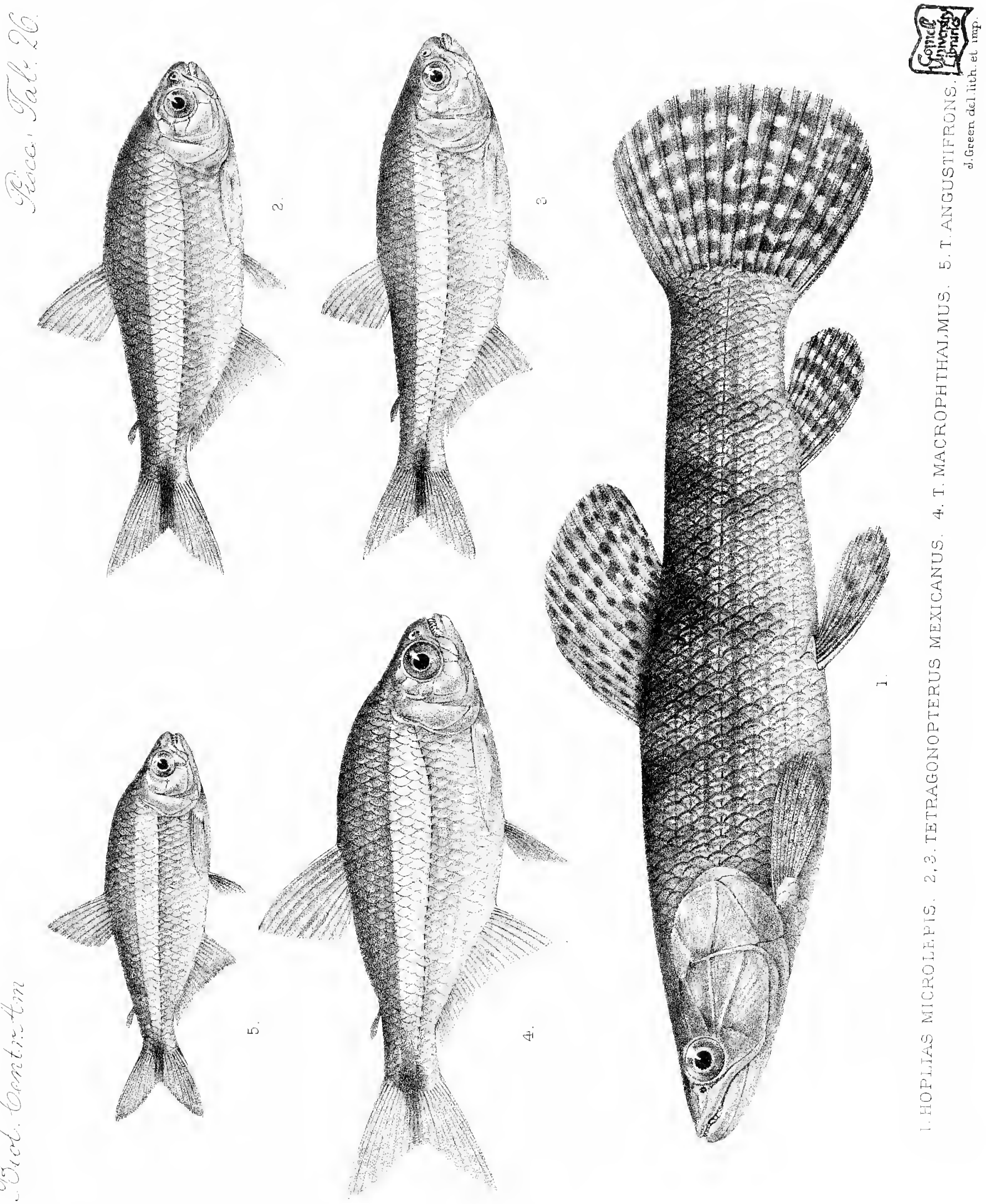






